UNIVERSIDADE DE SÃO PAULO

INSTITUTO DE GEOCIÊNCIAS

\title{
HIDRODINÂMICA E HIDROGEOQUÍMICA DA ZONA NÃO SATURADA DO AQÜÍFERO ADAMANTINA EM URÂNIA - SP
}

REGINALDO ANTONIO BERTOLO

Orientador: Prof. Dr. Ricardo César Aoki Hirata

TESE DE DOUTORAMENTO

COMISSÃO JULGADORA

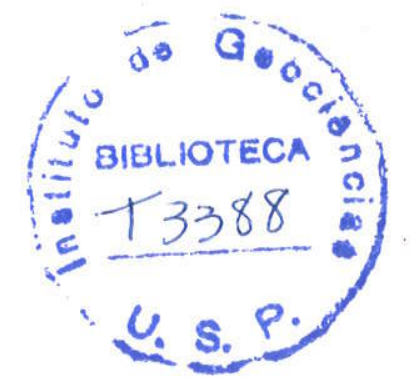

Nome

Presidente: Prof. Dr. Ricardo César Aoki Hirata

Examinadores: Prof. Dr. Chang Hung Kiang

Dr. Rodrigo César de Araújo Cunha

Prof ${ }^{\text {a. }}$ Dr $^{\text {a. }}$ Sonia Maria Barros de Oliveira

Prof. Dr. William Zamboni de Mello

\section{Assinatura}

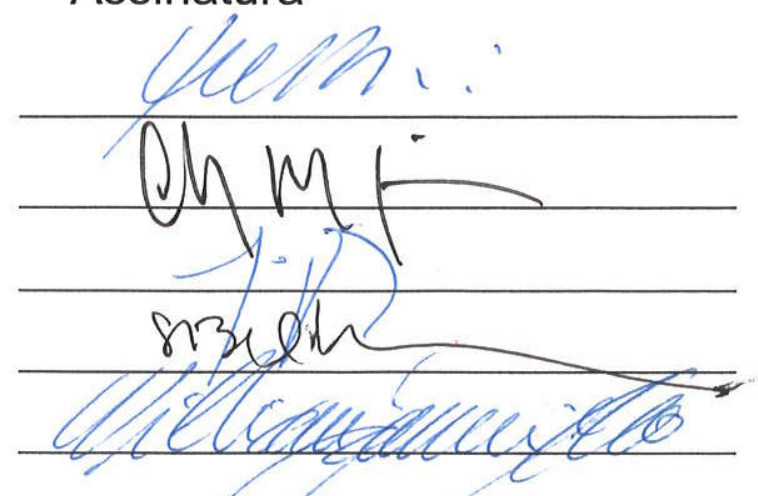




\section{UNIVERSIDADE DE SÃO PAULO INSTITUTO DE GEOCIÊNCIAS}

\section{HIDRODINÂMICA E HIDROGEOQUIIMICA DA ZONA NÃO SATURADA DO AQÜÍFERO ADAMANTINA EM URÂNIA - SP}

Reginaldo Antonio Bertolo

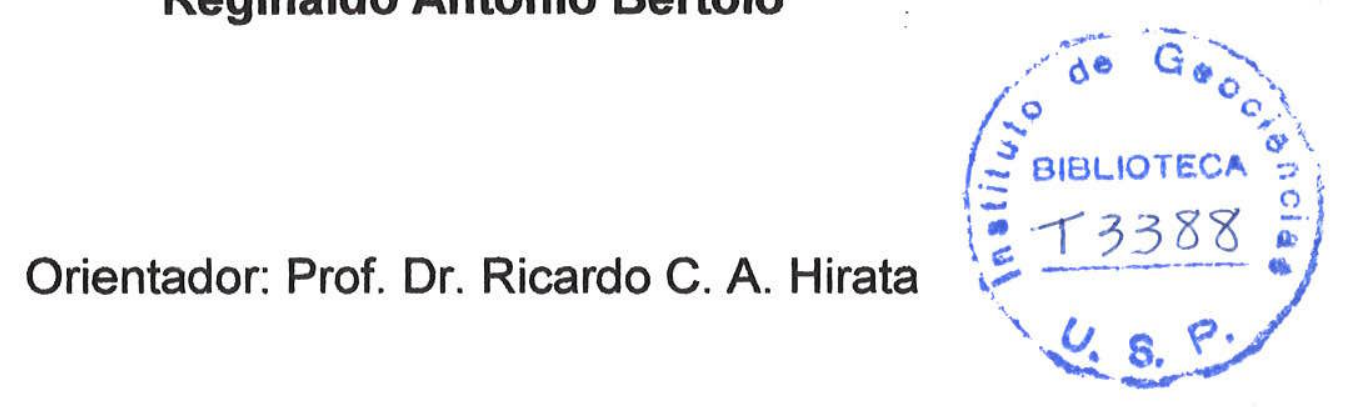

TESE DE DOUTORAMENTO

Programa de Pós Graduação em Recursos Minerais e Hidrogeologia

São Paulo

2001

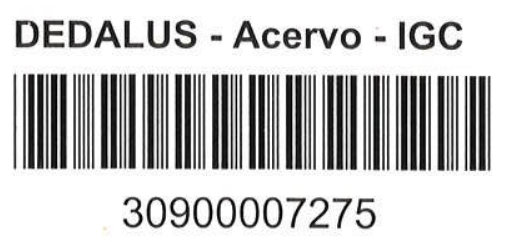


Ao Pedro, Helena e Celina, pela existência.

À Rhauna, pelo caminho.

Ao Nilo e a quem mais chegar, pela continuação. 


\section{SUMÁRIO}

1. APRESENTAÇÃO

2. REVISÃO BIBLIOGRÁFICA

2.1. Aspectos Teóricos

2.1.1. Movimento e Reservação da Água na Zona Não Saturada ................................................

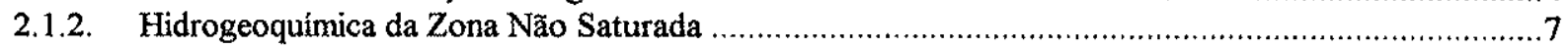

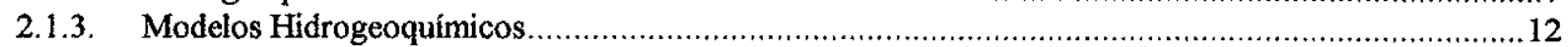

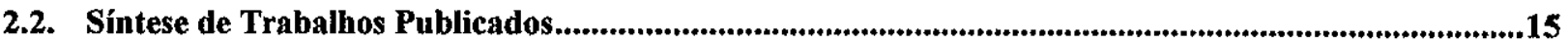

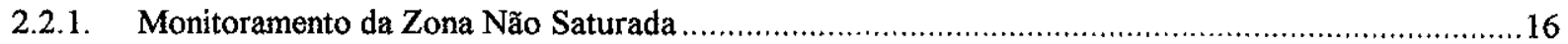

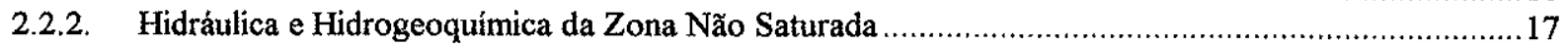

2.2.3. Modelos Matemáticos de Fluxo e Transporte da Zona Não Saturada ............................................22

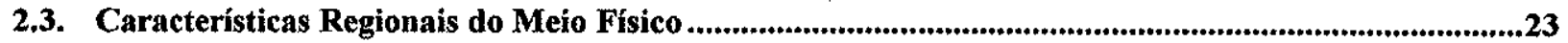

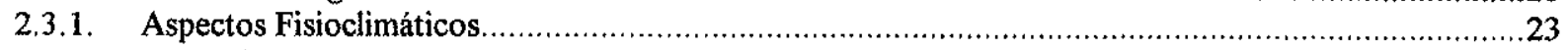

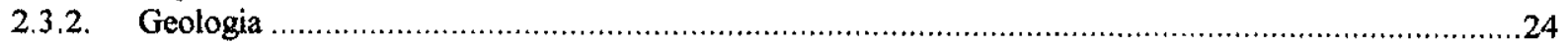

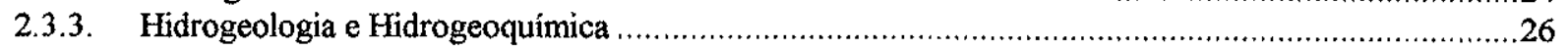

3. MATERIAL E MÉTODO

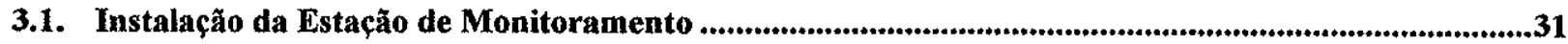

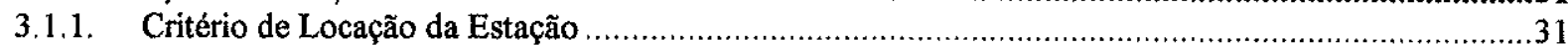

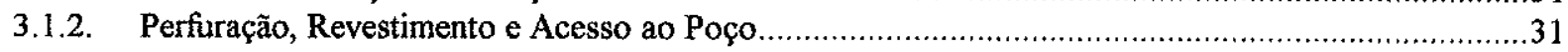

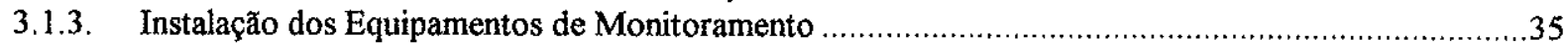

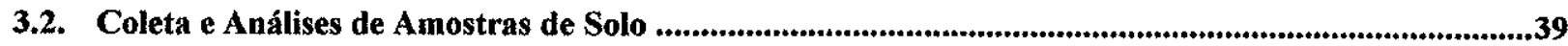

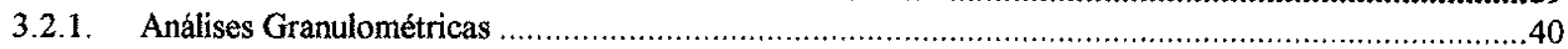

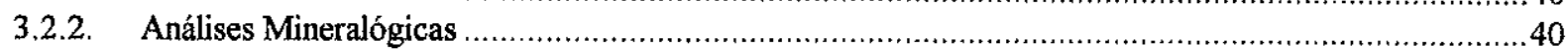

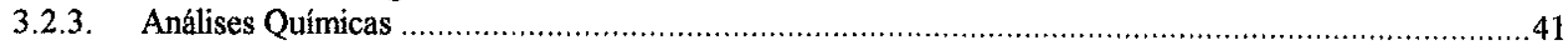

3.3. Coleta e Ensaios em Laboratório de Amostras Indeformadas de Solo .............................................45

3.4. Monitoramento do Comportamento Hidráulico das Zonas Saturada e Não Saturada .........................46 
3.5. Coleta e Análises Químicas de Amostras de Água .................................................................................46

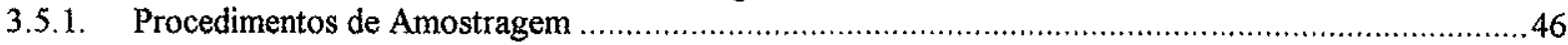

3.5.2. Análises Realizadas e Controle de Qualidade dos Resultados .......................................................48

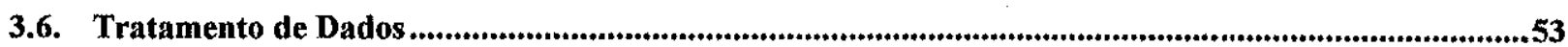

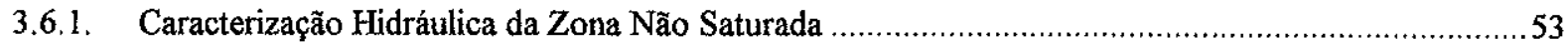

3.6.2. Caracterização Hidrogeoquímica da Zona Não Saturada e Modelagem Matemática ...........................55

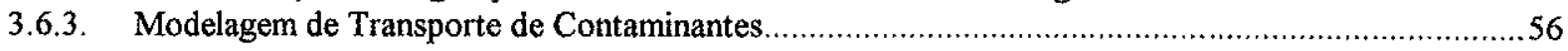

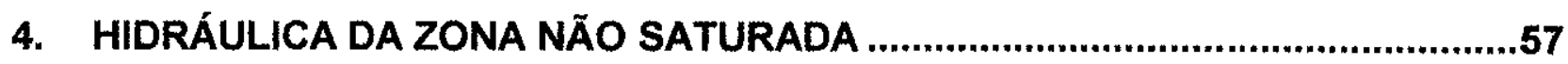

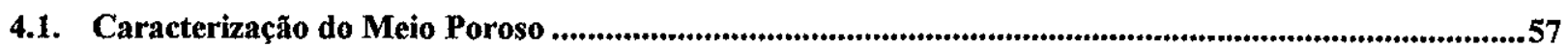

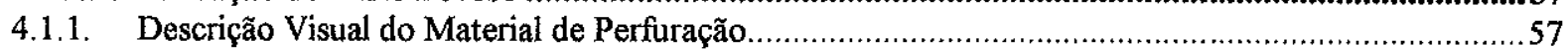

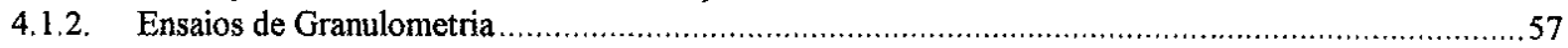

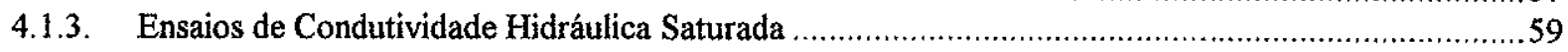

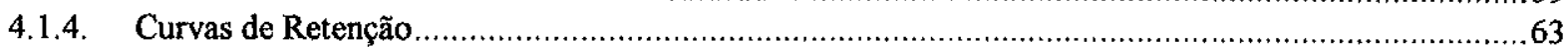

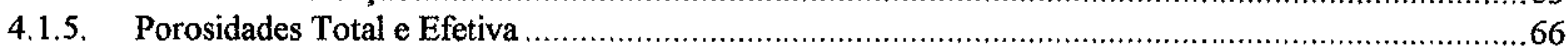

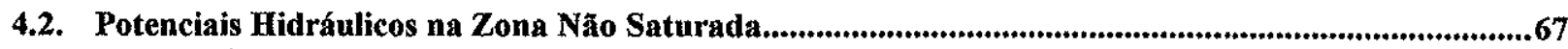

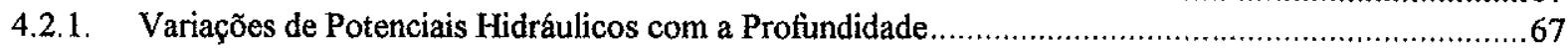

4.2.2. Variações Laterais de Potenciais Hidráulicos .................................................................................. 71

4.3. Utilização do Modelo VS2DT na Avaliação de Fluxo e Reservação de Água na Zona Não Saturada.76

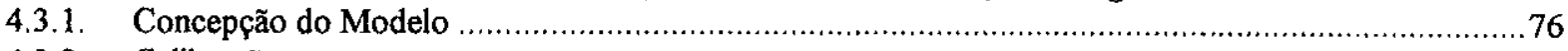

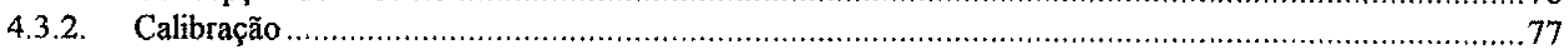

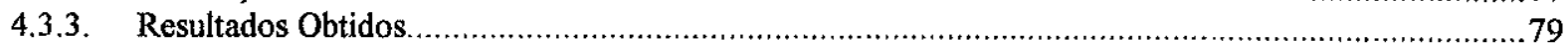

4.3.4. Variações de Umidade e de Velocidade de Fluxos na Zona Não Saturada ............................................8 84

5. HIDROGEOQUÍMICA DA ZONA NÃO SATURADA.

5.1. Mineralogia e Composição Química da Fase Sólida da Zona Não Saturada..........................................89

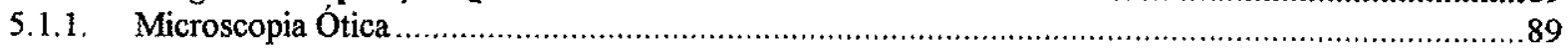

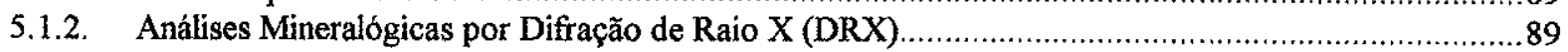

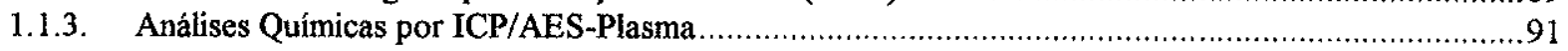

1.1.4. Análises de Capacidade de Troca de Cátions, pH e Matéria Orgânica .................................................95

1.1.5. Análises em Microscópio Eletrônico de Varredura (MEV)..........................................................100

1.1.6. Correlações entre Mineralogia e Composição Química do Solo ..........................................................102

1.2. Evolução da Composição Química da Água................................................................................104

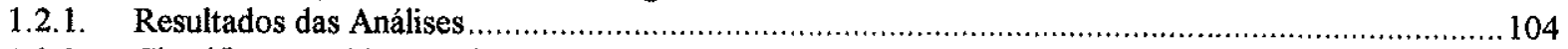

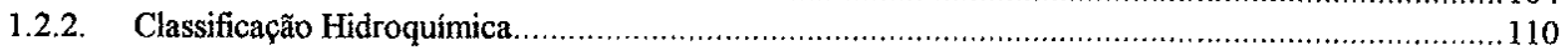

1.2.3. Variações da Composição Química com a Profundidade .................................................................112

1.2.4. Varią̧ões Laterais da Composição Química .................................................................................119

1.3. Modelo Hidrogeoquímico Conceitual ........................................................................................121

1.3.1. Cálculo de Índices de Saturação através de Modelo de Especiação …...........................................121

1.3.2. Diagramas de Estabilidade de Aluminossilicatos .........................................................................124

1.3.3. Relações entre Capacidade de Troca de Cátions e Composição Química da Água ................................127

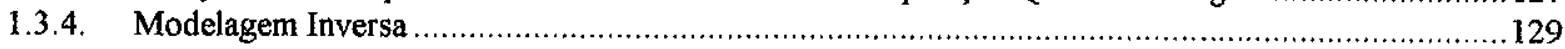

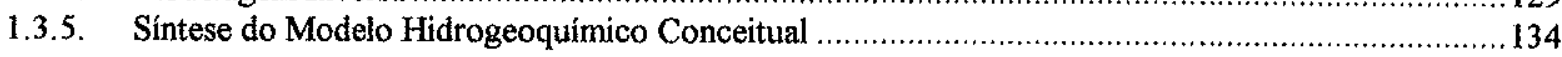

\section{SIMULAÇÕES DE TRANSPORTE DE NITRATO NA ZONA NÃO SATURADA.138}

6.1. Transporte de Contaminantes através de Fossas.

6.2. Transporte de Nitrato através de Fertilizantes. 
9. ANEXOS

9.1. ANEXO 1 - RELATÓRIO FOTOGRÁFICO.

9.2. ANEXO 2 - RESULTADOS DE ENSAIOS REALIZADOS NO SOLO

9.3. ANEXO 3 - DADOS DE MONITORAMENTO DE POTENCIAL MATRICIAL DOS

TENSIOMMETROS.

9.4. ANEXO 4 - RELATÓRIO DE DADOS DE ENTRADA DO MODELO VS2DT

9.5. ANEXO 5 - UMIDADE E CONDUTIVIDADE HIDRÁULICA NÃO SATURADA

9.6. ANEXO 6 - RESULTADOS DE ANÁLISES QUíMICAS E MINERALÓGICAS DO MATERIAL DO SOLO

9.7. ANEXO 7-RESULTADOS DE ANÁlISES QUÍMICAS DA ÁGUA .200

9.8. ANEXO 8 - ESTATISTICAS DOS RESULTADOS DE ANÁLISES QUÍMICAS DE ÁGUA.........206

9.9. ANEXO 9- RESULTADOS DE MODELAGENS HIDROQUÍMICAS 209

9.10. ANEXO 10 - DADOS DE ENTRADA DAS MODELAGENS DE TRANSPORTE 214

\section{Lista de Figuras}

Figura 1 - Localização do município de Urânia

Figura 2 - Potenciometria da cidade de Urânia e arredores (Hirata, 2000).

Figura 3 - Potenciometria da cidade de Urânia e arredores com a operação dos poços profundos da SABESP (Hirata, 2000).

Figura 4 - Localização da estação de monitoramento na área urbana de Urânia.

Figura 5 - Planta construtiva da estação de monitoramento da zona não saturada

Figura 6-Resultados dos ensaios de granulometria das amostras de solo do poço da estação de monitoramento

Figura 7 - Condutividades hidráulicas nas direções $\mathrm{Z}, \mathrm{X}$ e $\mathrm{Y}$ de amostras indeformadas de solo em função da profundidade.

Figura 8 - Condutividade hidráulica calculada a partir dos ensaios granulométricos em função da profundidade.

Figura 9-Curvas de retenção das amostras de solo de $1 \mathrm{~m}$ de profundidade 64

Figura 10-Curvas de retenção das amostras de solo de $3 \mathrm{~m}$ de profundidade 64

Figura 11 - Curvas de retenção das amostras de solo de $5 \mathrm{~m}$ de profundidade

Figura 12-Curvas de retenção das amostras de solo de $7 \mathrm{~m}$ de profundidade

Figura 13 - Curvas de retenção das amostras de solo de 9 e $9,5 \mathrm{~m}$ de profundidade

Figura 14 - Potenciais hidráulicos totais dos tensiômetros e cargas hidráulicas do poço de monitoramento ao longo do tempo

Figura 15 - Potenciais hidráulicos totais dos tensiômetros de $0,5 \mathrm{~m}$ ao longo do tempo ............ 72

Figura 16 - Potenciais hidráulicos totais dos tensiômetros de $1,0 \mathrm{~m}$ ao longo do tempo .............73

Figura 17 - Potenciais hidráulicos dos tensiômetros de T50D, T1D e T2 ao longo do tempo .... 73 
Figura 18 - Variação do potencial hidráulico em função da profundidade em três situações de tempo

Figura 19 - Potenciais matriciais calculados e reais - modelo Urânia A................................. 81

Figura 20 -. Potenciais matriciais calculados e reais - modelo Urânia B ................................. 81

Figura 21 - Potenciais matriciais calculados e reais - modelo Urânia C..................................83 83

Figura 22 - Variações de umidade do modelo Urânia A, expressas em \% de saturação e em conteúdo de umidade (vol/vol).

Figura 23 - Velocidades de fluxo de água e balanço de fluxos de entrada e saída do modelo

Urânia A.

Figura 24 - Variação temporal da umidade de saturação.

Figura 25 - Variação temporal da condutividade hidráulica não saturada................................ 88

Figura 26 - Variação da composição química das amostras de solo total com a profundidade .. 92

Figura 27 - Resultados das análises de capacidade de troca de cátions ...................................96

Figura 28 - Resultados das análises de pH e matéria orgânica do solo.......................................99

Figura 29 - Relações entre cátions adsorvidos e capacidade de troca de cátions ......................97 97

Figura 30 - Faixa de concentrações dos parâmetros químicos em relação ao desvio padrão em torno da média.

Figura 31 - Diagramas de classificação hidroquímica das cinco campanhas de amostragem ... 111

Figura 32 - Variações da composição química da água com a profundidade nas cinco campanhas de amostragem

Figura 33 - Índices de saturação em função da profundidade para alguns dos minerais mais reativos.

Figura 34 - Diagramas de estabilidade de alguns minerais dos sistemas dos sistemas $\mathrm{Na}_{2} \mathrm{O}$ $\mathrm{Al}_{2} \mathrm{O}_{3}-\mathrm{SiO}_{2}, \mathrm{CaO}-\mathrm{Al}_{2} \mathrm{O}_{3}-\mathrm{SiO}_{2}$ e $\mathrm{K}_{2} \mathrm{O}-\mathrm{Al}_{2} \mathrm{O}_{3}-\mathrm{SiO}_{2}$, a $25^{\circ} \mathrm{C}$ e $1 \mathrm{~atm}$

Figura 35 - Variações das concentrações de nitrato na zona não saturada para taxa de infiltração constante de $2,2 \mathrm{~cm} / \mathrm{dia}$.

Figura 36 - Variações das concentrações de nitrato com a profundidade para duas situações de contaminação inicial (200 e $1000 \mathrm{mg} / \mathrm{L})$

Figura 37 - Concentração efetiva de nitrato infiltrado por concentração que chega no aqüifero, de acordo com as simulações realizadas.

Figura 38 - Variações das concentrações de nitrato para concentração inicial de $200 \mathrm{mg} / \mathrm{L}$ em cinco anos de simulação

\section{Lista de Tabelas}

Tabela 1 - Algumas reações de dissolução/precipitação de minerais que podem ocorrer na zona não saturada de aqüíferos sedimentares arenosos em clima tropical ..

Tabela 2 - Medidas de capacidades de troca de cátions e de $\mathrm{pH}_{\mathrm{zpc}}$ de alguns materiais comuns 10

Tabela 3 - Resumo dos principais processos que produzem e que controlam as concentrações dos íons na água.

Tabela 4 - Análises realizadas em amostras deformadas de solo

Tabela 5 - Parâmetros químicos analisados em amostras de água, preservação, laboratório e método de análise.

Tabela 6 - Reprodutibilidade das análises de amostras de água duplicata do lisímetro L9 e do poço de monitoramento PM.

Tabela 7 - Reprodutibilidade das análises da água para avaliação de diferentes procedimentos de

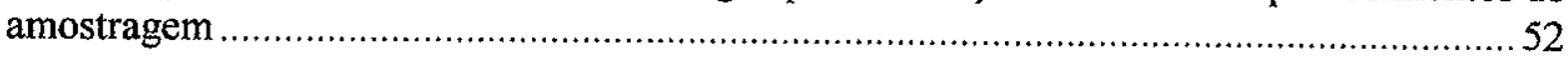

Tabela 8 - Descrição visual do material de perfuração do poço da estação de monitoramento... 57

Tabela 9 - Comparação de resultados de ensaios de granulometria por diferentes métodos....... 59 
Tabela 10 - Resultados de condutividade hidráulica em amostras indeformadas de solo e por curva de granulometria

Tabela 11 - Resultados calculados dos parâmetros da equação de van Genuchten a partir das curvas de retenção de água

Tabela 12 - Porosidades total, de retenção (capacidade de campo) e efetiva das amostras indeformadas de solo

Tabela 13 - Resultados de resíduos normalizados dos três modelos

Tabela 14 - Comparação de valores de condutividade hidráulica saturada medidas em laboratório e utilizadas nos modelos.

Tabela 15 - Resultados de análises mineralógicas por difração de raio X do solo do poço frações fina, flutuado e afundado

Tabela 16 - Composição química média das frações total, fina, afundada e flutuada das amostras de solo das profundidades de 1,6 e $9,5 \mathrm{~m}$.

Tabela 17 - Matriz de correlação das análises químicas do solo total por ICP/AES e ensaios de granulometria

Tabela 18 - Matriz de correlação entre as análises de capacidade de troca de cátions (CTC) e as análises químicas do solo total por ICP/AES.

Tabela 19 - Relação entre cátions adsorvidos sobre cátions totais no solo da zona não saturada (em \%)

Tabela 20 - Matriz de correlação entre as análises de capacidade de troca de cátions (CTC) e os ensaios de granulometria.

Tabela 21 - Matriz de correlação dos parâmetros químicos analisados na água dos lisímetros L50 a L9

Tabela 22 - Composição química teórica da água na hipótese de ocorrência de desadsorção dos cátions de base adsorvidos

Tabela 23 - Coeficientes de correlação entre cátions adsorvidos e em solução

Tabela 24 - Resultados da modelagem inversa entre os pontos L3 e L5 (agosto/99) ............... 131

Tabela 25 - Resultados da modelagem inversa entre os pontos L5 e L7 (agosto/2000).

\section{Lista de Equações}

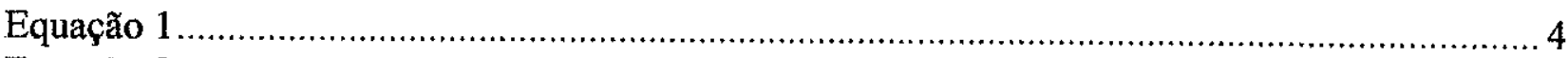

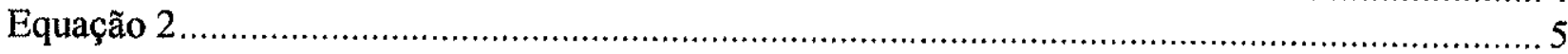

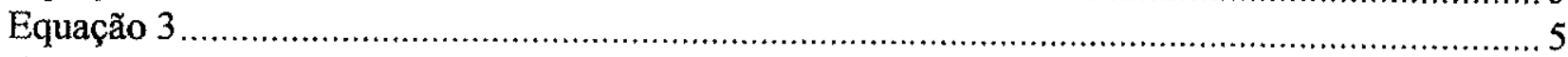

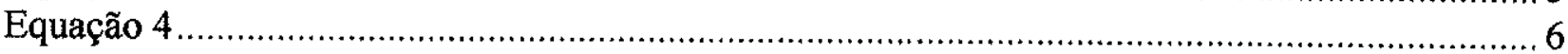

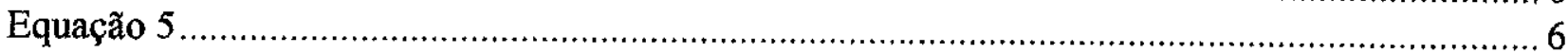

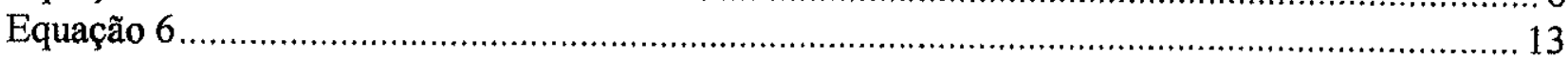

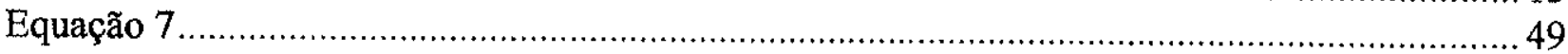

Equação 8

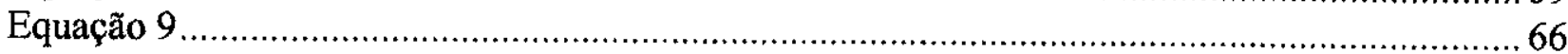

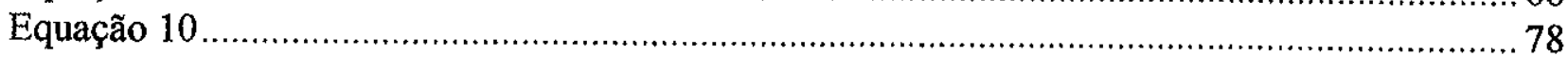

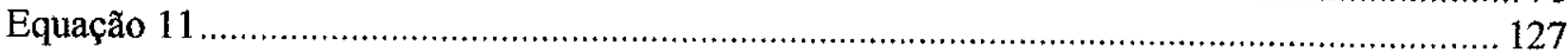

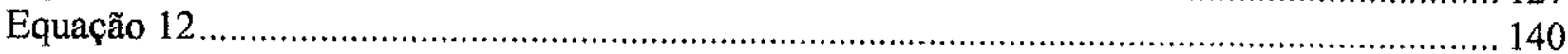




\section{Lista de Símbolos e Unidades}

$\mathrm{h}$ - potencial hidráulico (em metros de coluna d'água)

$\mathrm{Z}$ - potencial de elevação (em metros de coluna d'água)

$\psi$ - potencial matricial (em metros de coluna d'água)

$\mathrm{p}$ - potencial matricial, $\left(\mathrm{N} / \mathrm{m}^{2}\right.$ - Pascal $) ;(1 \mathrm{~mm} \mathrm{Hg}=133$ Pascal $)$

$\rho$-densidade de massa $\left(\mathrm{kg} / \mathrm{m}^{3}\right)$

$\mathrm{g}$ - aceleração da gravidade $\left(\mathrm{m} / \mathrm{s}^{2}\right)$

$\theta$ - umidade volumétrica para determinado potencial matricial (vol. água/vol. sólido)

$\theta_{\mathrm{r}}$ - umidade volumétrica de retenção (vol. água/vol. sólido)

$\theta_{\mathbf{s}}$ - umidade volumétrica de saturação (vol. água/vol. sólido)

$\alpha$-constantes empíricas relacionadas com o solo $\left(\mathrm{cm}^{-1}\right.$ de $\left.\mathrm{H}_{2} \mathrm{O}\right)$

$\mathrm{m}$ e $\mathrm{n}$ - constantes empíricas de van Genuchten relacionadas com o solo (adimensionais)

$\mathrm{K}_{(\theta)}$ - condutividade hidráulica não saturada $(\mathrm{cm} / \mathrm{s})$

$\mathrm{K}$ - condutividade hidráulica saturada $(\mathrm{cm} / \mathrm{s})$

$\omega$ - saturação efetiva (adimensional)

$\mathrm{L}$ - parâmetro empirico de van Genuchten (adimensional)

IS - índice de saturação (adimensional)

IAP - produto das atividades dos íons formadores de um mineral (adimensional)

$\mathbf{K}$ - constante de equilíbrio químico de um mineral (adimensional)

$\mathrm{K}_{\mathrm{gr}}-$ condutividade hidráulica saturada calculada por ensaio granulométrico $(\mathrm{em} \mathrm{cm} / \mathrm{s})$

A - coeficiente relacionado ao grau de arredondamento dos grãos (adimensional)

$\mathrm{d}_{10}$ - diâmetro granulométrico representativo dos $10 \%$ mais finos (em $\mathrm{mm}$ )

$\mathrm{K}_{\mathbf{x}}, \mathrm{K}_{\mathbf{y}}$ e $\mathrm{K}_{\mathbf{z}}$ - condutividade hidráulica saturada nos sentidos $\mathrm{X}$, Y e $\mathrm{Z}(\mathrm{em} \mathrm{cm} / \mathrm{s})$

$\mathbf{n}$ - porosidade total (vol./vol.)

$\rho_{\mathbf{b}}$ - densidade aparente da amostra $\left(\mathrm{em} \mathrm{g} / \mathrm{cm}^{3}\right)$

$\rho_{\mathbf{s}}$ - densidade dos sólidos $\left(\mathrm{em} \mathrm{g} / \mathrm{cm}^{3}\right)$. 


\section{Resumo}

Este trabalho objetiva investigar o comportamento hidráulico e a evolução hidrogeoquímica da água de infiltração da zona não saturada do Aqǘfero Adamantina, bem como simular o comportamento de nitrato neste meio. O método consistiu na construção de uma estação de monitoramento, na execução de vários ensaios e análises em amostras de solo, no monitoramento de potenciais matriciais, em amostragens e análises de água da zona não saturada e na execução de modelagens hidroquímicas e de fluxo e transporte de contaminantes.

A zona não saturada apresenta natureza arenosa fina e subdivide-se em três sub-zonas hidráulicas: a primeira, entre a superfície até a linha de evaporação (a $2 \mathrm{~m}$ ), sofre os efeitos das variações climáticas, com os potenciais hidráulicos respondendo rapidamente a cada pequeno evento de recarga ou evaporação; na segunda zona, entre 2 e $7 \mathrm{~m}$, as pequenas frentes de molhamento sofrem dissipação e os tensiômetros registram apenas mudanças de potenciais matriciais que se relacionam com eventos mais longos de recarga ou de secagem. A terceira zona situa-se entre $7 \mathrm{~m}$ e o nível d'água (média de 9,5 m) e caracteriza-se por apresentar valores de potenciais hidráulicos muito próximos da carga hidráulica do aqüífero freático. $O$ tempo de trânsito da água na zona não saturada, no evento de recarga do início de 2000 , foi de 3 meses.

A zona não saturada encontra-se num avançado estágio de intemperismo, sendo que a mineralogia principal é composta por quartzo e caulinita. A água é pouco mineralizada, classificada como bicarbonatada cálcica, mas com elevadas concentrações de nitrato, apresenta variações de concentrações com a profundidade, lateralmente e no tempo e encontra-se estratificada em três zonas que coincidem com as zonas hidráulicas. Foram identificados os seguintes processos hidrogeoquímicos na zona não saturada: (1) ações antropogênicas, devido à poluição por nitrato; (2) ação de evaporação até $2 \mathrm{~m}$; (3) ação de respiração vegetal até $7 \mathrm{~m},(4)$ condições propícias para a dissolução de minerais primários e formação de caulinita e de formas secundárias de sílica; e (5) condições propícias para a ocorrência de fenômenos de adsorção e troca iônica, cujas análises de capacidade de troca de cátions indicaram os minerais ferruginosos como as principais superfícies adsorventes.

As simulações de transporte de nitrato indicaram que o aqǘfero freático é vulnerável à poluição devido à infiltração de efluentes de fossas sépticas e à aplicação de fertilizantes nitrogenados no solo. 


\begin{abstract}
This thesis investigated the hydraulics and the hydrogeochemical evolution of the water infiltrating through the vadose zone of the Adamantina Aquifer. To this end, a monitoring station was constructed in the unsaturated zone, soils were sampled for several analysis and tests, pressure heads were monitored using tensiometers, soil water was sampled for chemical analysis using suction lysimeters, and both geochemical models as well as flow and transport models were utilized.

The unsaturated zone consists of a clayey fine sand and is subdivided into three hydraulic zones: the first one is limited by the soil surface and the evaporation line, situated at a depth of $2 \mathrm{~m}$. This zone is characterized by rapid changes of the hydraulic potentials due to small events of recharge or drought. The second zone is situated between 2 and $7 \mathrm{~m}$ depth, where small wetting fronts suffer dissipation, and tensiometers only register changes in pressure potentials related to longer events of recharge or drought. The third zone extends from $7 \mathrm{~m}$ to the water table (at $9.5 \mathrm{~m}$ depth) and presents values of hydraulic potentials close to the hydraulic heads of the underlying phreatic aquifer. The transit time for water in the unsaturated zone was measured as 3 months during the recharge period of the beginning of 2000 .

The unsaturated zone is in an advanced stage of weathering, characterized, mineralogically, mainly by quartz and kaolinite. Water is little mineralized and is classified as calcium bicarbonate, but with high concentrations of nitrate. Water quality changes with time, with depth and laterally, and is stratified in three zones, in accordance to the three hydraulic zones defined above. The following hydrogeochemical processes were identified in the unsaturated zone: (1) nitrate pollution due to human activities; (2) evaporation to a depth of $2 \mathrm{~m}$; (3) plant transpiration to a depth of $7 \mathrm{~m}$; (4) favorable conditions for the dissolution of the main primary minerals, with subsequent formation of kaolinite and amorphous silica; and (5) favorable conditions for adsorption and cation exchange. Cation exchange capacity analysis indicates that the ferrous minerals may provide the main adsorptive surfaces.

The transport of nitrate was simulated mathematically. The results indicate that the phreatic aquifer is vulnerable to pollution, due to the infiltration of effluents from septic tanks and the application of fertilizers at the soil surface.
\end{abstract}




\section{Agradecimentos}

Registro o meu agradecimento a várias pessoas e entidades, sem as quais a realização deste trabalho não seria possível.

Ao Prof. Dr. Ricardo C. A. Hirata, a quem devo muito de minha evolução profissional, pelo oferecimento da oportunidade da execução desta pesquisa, pelo constante acompanhamento no trabalho, pela disponibilidade sempre presente, pelo empenho em trazer pessoas de fora para discutir o trabalho e, sobretudo, pelo companheirismo que extrapola a simples orientação.

Ao Instituto de Geociências da USP, através dos departamentos de Geologia Sedimentar e Ambiental (GSA) e de Mineralogia e Geotectônica (GMG) e do Centro de Pesquisas de Águas Subterrâneas (CEPAS), pelo uso de suas dependências, de seus equipamentos e infra-estrutura e por seu apoio técnico.

À Fundação de Amparo à Pesquisa do Estado de São Paulo (FAPESP), pelo financiamento da pesquisa (processo 97/13879-6) e fornecimento de bolsa de estudo (processo 98/15340-0).

À Companhia de Saneamento Básico do Estado de São Paulo (SABESP), através de Antonio "Dalua" Rodrigues da Grella Filho (escritório de Jales) e de Sérgio Donizete Giovanini (escritório de Urânia), que cederam a área para a construção da estação de monitoramento e forneceram valioso suporte para a realização dos trabalhos de campo.

A Roberto Ramos Natividade (in memorian) e Miguel Mariano de Castro pela dedicação na construção da estação de monitoramento. A Gilmar Domingos de Assis, que além de participar da construção da estação, realizou o monitoramento dos tensiômetros e ajudou nos trabalhos de amostragem de água dos lisímetros de sucção.

À Prof . Dra. Sônia M. B. Oliveira (DGSA/IGc-USP) pelas valiosas discussões e ajuda na interpretação dos difratogramas de raio X. Ao Dr. Rodrigo César de Araújo Cunha (CETESB) e à Prof. Dra. Maria Cristina Motta de Toledo (DGSA/IGc-USP) pelas sugestões e críticas ocorridas no exame de qualificação.

Aos funcionários do IGc-USP: Ana Paula Cabanal e Magali P. F. Rizzo (Secretaria de Pós Graduação), por sempre quebrar galhos com muito bom humor; Lúcia Helena Silva (Lab. Hidrogeoquímica II - CEPAS), pelas excelentes análises químicas da água; Miltonete Soares de Araújo, Mauro Marcos Lopes, João Marcos Gouveia e Angelito Teodoro de Araújo (Seção de Transportes), pela companhia e ajuda nos trabalhos de campo; Sandra Andrade (Lab. Química e ICP-AES-GMG), pela eficiência na execução das análises químicas de solo e por me ensinar 
muitas coisas de química; e a Flávio M. S. Carvalho (Lab. Difratometria de Raios X - GMG) pela ajuda na interpretação dos difratogramas de raio $\mathrm{X}$.

À Ondrej Sracek (Universidade de Laval - Canadá) pelo auxílio na operação do modelo MinteqA2; ao companheiro Jesse Stimson (Universidade de Waterloo - Canadá), que gentilmente veio de longe para ajudar na execução da modelagem inversa com o Phreeqce e para dar sugestões na interpretação dos dados.

Ao amigo Cristiano $\mathrm{M}$. Chiessi, por passar várias horas à frente do computador fazendo as simulações, pelas discussões que provocaram inspirações e por ajudar na realização de coisas pequenas e grandes. À Marta L. N. Almodovar, pelo acompanhamento da escavação do poço da estação de monitoramento e pelo tratamento de parte das amostras de solo. À Angélica $\mathrm{S}$. Gutierrez, pela companhia e ajuda freqüentes nos trabalhos em Urânia e pelas discussões de hidroquímica. À Fabiana A. Cagnon, Jeane G. Santos e Fabíola M. Rossato pela companhia e ajuda nos trabalhos de campo. Ao Alessando Cesarino, sempre a ajudar a todos; à Cláudia L. Varnier, pelas longas discussões e pelo convívio produtivo; ao Luiz C. Ferrari, pelas dicas de estatísticas; e à Célia A. Surita, que trouxe a sua experiência em zona não saturada em várias discussões.

E finalmente à Marisa Jelen Damous, pela estrutura oferecida e por cuidar da casa e do Nilo por inúmeras vezes. 


\section{Apresentação}

A água da chuva ao infiltrar-se no solo atravessa toda a zona não saturada antes de atingir o aqüífero freático. Neste percurso, a água sofre a primeira e mais intensa modificação na sua composição química, devido às suas interações químicas com os minerais do solo, com o meio gasoso contido nos poros, com a matéria orgânica, com o meio biótico e com toda a dinâmica da infiltração.

São relativamente escassos os estudos que caracterizam e relacionam os processos hidrodinâmicos e hidrogeoquímicos da zona não saturada, sobretudo em países de clima tropical úmido. $\mathrm{O}$ entendimento mais aprofundado destes mecanismos é importante na avaliação da vulnerabilidade de um aqüífero d poluição, que pode ser definida como sendo uma interação entre o grau de acessibilidade hidráulica da zona não saturada à penetração de contaminantes e a capacidade de atenuação dos contaminantes pelos materiais da zona não saturada, como resultado de sua retenção física e reações químicas com as substâncias infiltradas (Foster \& Hirata, 1988).

Este trabalho estuda com detalhe a hidráulica e a hidrogeoquímica da água de infiltração ao longo da zona não saturada em uma estação de monitoramento localizada no manto de intemperismo do Aqüífero Adamantina, visando avaliar com maior detalhe as variáveis que atuam na zona não saturada e que definem as características químicas da água do aqüífero freático, bem como na sua vulnerabilidade à poluição.

Estudos deste tipo são importantes para o contexto do Sistema Aqüífero Bauru, por ocupar cerca de $40 \%$ do território do Estado de São Paulo e por constituir-se em um dos mananciais mais explorados de água potável, principalmente por poços rasos, do tipo cacimba. Desta forma, o estudo reveste-se de importância social, pois contribui para o desenvolvimento do conhecimento dos fatores que condicionam a qualidade química da água do aqüífero freático, seja devido a fatores naturais, seja devido às conseqüências de um evento de poluição. Neste particular, destaca-se a importância do nitrato como poluente, cujas fontes de contaminação são representadas por fossas sépticas e negras e por aplicação de fertilizantes na região estudada. 
Este trabalho tem a intenção de promover o desenvolvimento do conhecimento do tema através dos seguintes objetivos específicos:

- caracterizar a hidráulica da infiltração da água na zona não saturada até o Aqüífero Adamantina, isto é, caracterizar o armazenamento, os sentidos e as velocidades de fluxo de água nesta zona no espaço e no tempo;

- caracterizar a evolução hidrogeoquímica da água da zona não saturada até o aqüífero freático, através da determinação dos mecanismos de interação entre a água e os minerais do solo; e

- simular o comportamento de contaminantes de interesse na zona não saturada, especialmente o nitrato, disposto na zona não saturada através de infiltração por fossas e através de aplicação de fertilizantes.

A área onde se desenvolveu a pesquisa localiza-se no município de Urânia, na região noroeste do Estado de São Paulo, próximo do município de Jales e a $600 \mathrm{~km}$ da capital (Figura 1). Esta região foi escolhida para a execução de estudos hidrogeoquímicos devido às concentrações anômalas de cromo na água subterrânea e que motivaram a execução de um projeto de pesquisa financiado pela FAPESP, da qual o presente estudo faz parte.

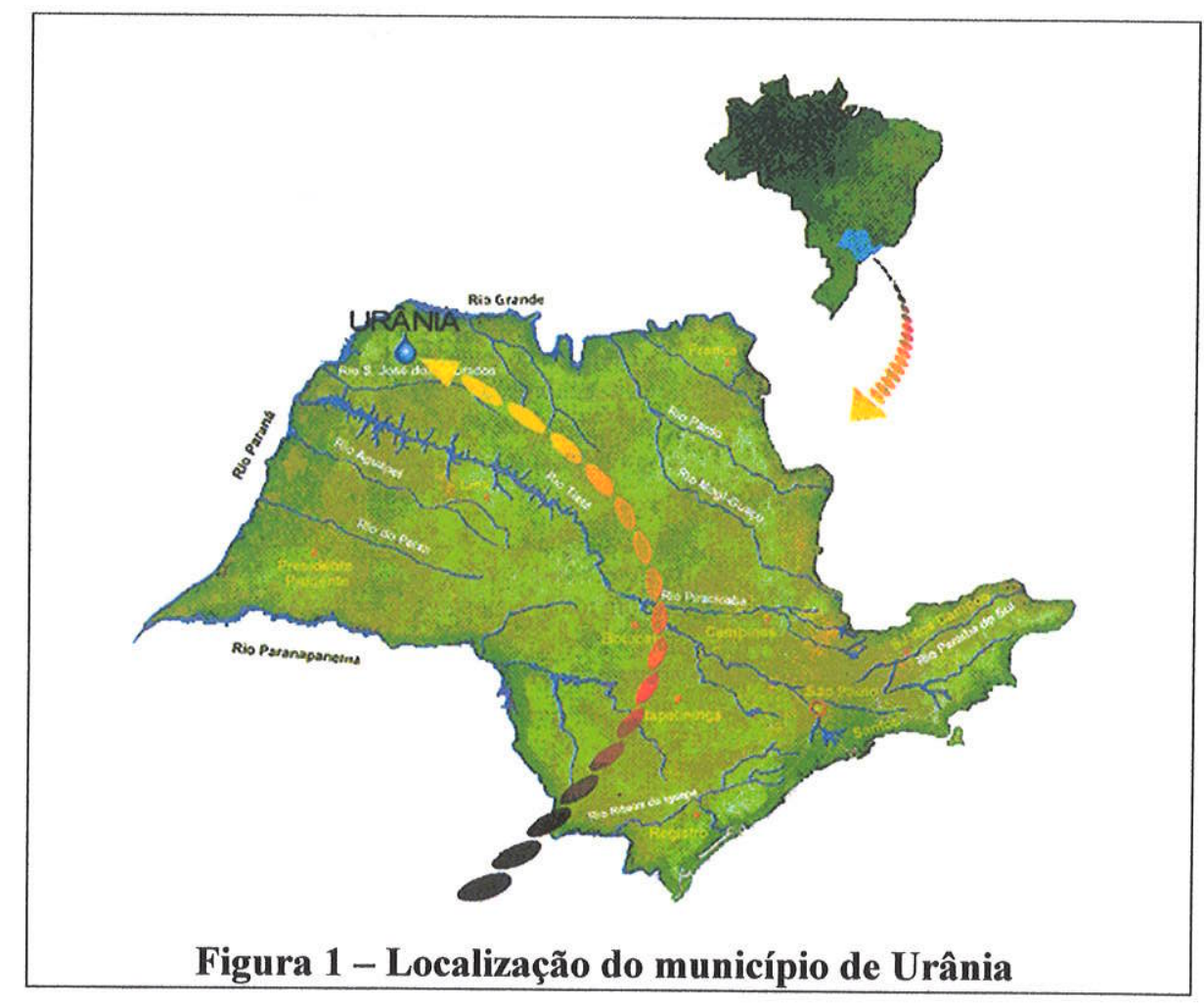


Para a execução deste trabalho, foi construída uma estação de monitoramento da zona não saturada, de onde foram obtidos dados periódicos de potenciais hidráulicos, coletadas amostras de água para análises químicas e coletadas amostras de solo para análises químicas e mineralógicas e para a obtenção de algumas propriedades hidráulicas que contribuem para a caracterização do fluxo e da reservação da água na zona não saturada.

A técnica utilizada para o monitoramento da zona não saturada é, inclusive, inédita no Brasil, consistindo na instalação dos equipamentos de monitoramento (tensiômetros e lisímetros de sucção) ao longo da parede de um poço escavado.

Algumas técnicas modernas também foram utilizadas nesta pesquisa de forma a aprimorar o entendimento dos processos hidráulicos, hidroquímicos e de transporte de contaminantes, através do tratamento dos dados com modelos matemáticos de hidroquímica e de fluxo e transporte de contaminantes na zona não saturada. 


\section{Revisão Bibliográfica}

\subsection{Aspectos Teóricos}

\subsubsection{Movimento e Reservação da Água na Zona Não Saturada}

Há farto material que aborda o tema de movimento e reservação da água na zona não saturada. Para efeito de discussão deste tema neste item, foram consideradas as publicações de Reichardt (1996), Freeze \& Cherry (1979) e Hillel (1980).

A zona não saturada corresponde à porção superficial do material geológico situada entre a superfície do solo e o topo do aqüffero freático, e que serve como via para a água a caminho do aquífero freático após os eventos de infiltração através da chuva. Caracteriza-se por ser um meio cujos poros estão ocupados pelas fases líquida e gasosa em diferentes proporções no espaço e no tempo, e onde as forças da gravidade, capilares e adsortivas do meio poroso desempenham papel importante na circulação da água, juntamente com as atividades climáticas e biológicas.

O movimento da água na zona não saturada dá-se somente em resposta a diferenças de potencial hidráulico ( $\mathrm{h}$ - expresso em metros de coluna d'água) entre dois pontos. O potencial hidráulico, por sua vez, corresponde à somatória do potencial de elevação (z), que representa a elevação (em metros) do ponto de monitoramento em relação a um datum (por exemplo, o nível do mar ou a superfície do solo), e do potencial matricial ( $\Psi$ - em metros) de acordo com a equação 1 .

$$
\mathbf{h}=\mathrm{z}+\psi \quad \text { Equação } 1
$$

O potencial matricial $(\Psi)$, segundo Reichardt (1996), corresponde ao resultado do efeito combinado das forças de capilaridade e de adsorção da água e da matriz sólida, mas que não são facilmente separadas. $O$ potencial matricial representa, portanto, a resultante das forças de sucção que retém a água na matriz do solo. Em materiais geológicos arenosos, a adsorção é pouco importante e os fenômenos capilares predominam na determinação do potencial matricial, ao passo que o contrário se dá nos materiais com texturas mais finas. Esta força resultante apresenta algumas denominações diferentes na literatura, tal como tensão capilar, potencial capilar, ou ainda carga de pressão (pressure head) e potencial de pressão (pressure potential) na literatura internacional (Freeze \& Cherry, 1979 e Hillel, 1980). Este trabalho considera o termo "potencial matricial" como o mais adequado por englobar a resultante das forças de retenção. 
Os dados de potencial matricial são normalmente obtidos em campo na forma de pressões menores que a atmosférica ( $\mathrm{em} \mathrm{mm} \mathrm{Hg}$ ), e convencionalmente medidas com valores negativos, através de tensiômetros. A transformação da expressão deste dado para a forma de metros de coluna d'água se dá através da seguinte relação (Freeze \& Cherry, 1979):

$$
\psi=\mathrm{p} / \mathrm{\rho} \cdot \mathrm{g} \quad \text { Equação } 2
$$

onde:

$\psi$ é o potencial matricial, em metros de coluna d'água,

p é o potencial matricial, em N/m² (Pascal); ( $1 \mathrm{~mm} \mathrm{Hg}=133$ Pascal),

$\rho$ é a densidade de massa, igual a $1000 \mathrm{~kg} / \mathrm{m}^{3}$

$\mathrm{g}$ é a aceleração da gravidade, $\mathrm{em} \mathrm{m} / \mathrm{s}^{2}$

A quantidade de água presente em um determinado ponto da zona não saturada (ou umidade, $\theta$ ) corresponde a uma parcela da porosidade total e é função do potencial matricial. A dependência destes dois fatores indica que quanto maior o valor de potencial matricial (ou quanto menor as forças de retenção), maior a quantidade de umidade no solo. Esta relação é não linear, histerética e normalmente é obtida através de ensaios de laboratório (curvas de retenção). A equação da curva que melhor representa a relação entre potencial matricial e umidade para determinado solo, obtida em ensaios de laboratório, foi desenvolvida por van Genuchten (1980):

$$
\theta=\theta_{r}+\frac{\left(\theta_{s}-\theta_{r}\right)}{\left[1+(\alpha . \Psi)^{n}\right]^{m}} \quad \text { Equação } 3
$$

onde:

$\theta=$ umidade volumétrica para determinado potencial matricial (vol. água/vol. sólido);

$\theta_{\mathrm{r}}=$ umidade volumétrica de retenção (volume água retida/volume de sólido);

$\theta_{\mathrm{s}}=$ umidade volumétrica de saturação (volume total de água/volume de sólido, numericamente igual à porosidade total);

$\Psi=$ potencial matricial $\left(\mathrm{em} \mathrm{cm}\right.$ de $\mathrm{H}_{2} \mathrm{O}$ );

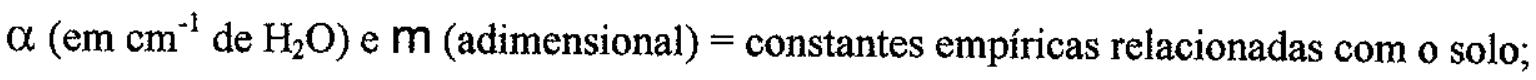
$n=1 /(1-m)$. 
De posse dos dados de potencial matricial obtidos em campo em diferentes tempos e com base na equação obtida a partir dos ensaios em laboratório relacionando potencial matricial com umidade, é possivel determinar, portanto, as variações da umidade em função do tempo para as diferentes profundidades da zona não saturada investigadas no campo.

A condutividade hidráulica na zona não saturada, componente essencial para a caracterização da intensidade de fluxo de água, também varia em função do potencial matricial e da umidade do solo. Uma das formas de se relacionar a condutividade hidráulica com a umidade foi também desenvolvida por van Genuchten (1980), através da obtenção da condutividade hidráulica saturada da amostra de solo em laboratório e combinando a equação 3 com o modelo de Mualem (1976 in van Genuchten, 1980), obtendo:

$$
K_{(\theta)}=K \cdot \omega^{L}\left[1-\left(1-\omega^{1 / m}\right)^{m}\right]^{k} \quad \text { Equação } 4
$$

onde: $\mathrm{K}_{(\theta)}=$ condutividade hidráulica em função da umidade $(\mathrm{L} / \mathrm{T})$

$\mathrm{K}=$ condutividade hidráulica saturada $(\mathrm{L} / \mathrm{T})$

$\omega=$ saturação efetiva $=\frac{\left(\theta-\theta_{\mathrm{r}}\right)}{\left(\theta_{\mathrm{s}}-\theta_{\mathrm{r}}\right)}$

$L=$ parâmetro empírico estimado em 0,5 (adimensional)

A determinação das relações entre os parâmetros potencial matricial, umidade e condutividade hidráulica possibilita, por sua vez, efetuar a caracterização dos fluxos transientes de água subterrânea em meios não saturados. A equação 5 , denominada equação de Richards, caracteriza o fluxo de água neste meio em uma dimensão (direção $z$ - profundidade) e está escrita em função da variação do potencial matricial (Freeze \& Cherry, 1979):

$$
\frac{\partial}{\partial \mathrm{z}}\left[\mathrm{K}(\Psi)\left(\frac{\partial \Psi}{\partial \mathrm{z}}+1\right)\right]=\mathrm{C}(\Psi) \frac{\partial \Psi}{\partial \mathrm{t}} \quad \text { Equação } 5
$$

onde: $\mathbf{C}_{(\Psi)}$ representa a propriedade de armazenamento não saturado $=\mathrm{d} \theta / \mathrm{d} \psi$.

Esta equação é normalmente utilizada no processamento matemático de modelos numéricos em uma dimensão para simular a ocorrência de fluxos de água na zona não saturada. 


\subsubsection{Hidrogeoquímica da Zona Não Saturada}

Uma ampla gama de processos geoquímicos ocorre de forma intensa na zona não saturada. Isto se deve pois o processo de formação do solo se dá com as reações químicas dos minerais da rocha original quando expostas às aç̃es do intemperismo químico. Estas reações ocorrem pois o ambiente que formou os minerais da rocha original é termodinamicamente diferente daquele próximo da superficie. Neste novo ambiente, além da pressão e temperatura mais baixas, a rocha encontra-se exposta a uma maior quantidade de água e compostos químicos provenientes das ações do clima, vegetação e atividade biológica, o que leva a transformação dos minerais originais para formas mais estáveis termodinamicamente neste novo ambiente.

De uma forma geral, os seguintes fatores controlam a composição química da água subterrânea, em particular a da zona não saturada (Appelo \& Postma, 1993):

\section{a) Evaporação e evapotranspiração:}

A quantidade de sólidos dissolvidos na água da chuva é substancialmente menor que a da água em trânsito pela zona não saturada. Um dos processos que leva ao aumento de concentração de íons é a evaporação e evapotranspiração da água na zona não saturada. Este aumento é proporcional à quantidade de água evaporada e o íon cloreto, que é bastante conservativo, pode ser utilizado para estimar a intensidade destes fenômenos, a menos que haja contaminação de origem antrópica por este elemento.

b) Ação da biomassa viva:

A captura e estocagem de componentes químicos pela biomassa (raizes de vegetação, microorganismos, etc.) na zona não saturada pode influenciar profundamente as suas concentrações na água. De acordo com Likens et al. (1977 in Appelo \& Postma, 1993), os fluxos de praticamente todos os elementos que entram no solo por precipitação ou que saem do aquífero como fluxo de base representam apenas uma pequena parcela do fluxo de elementos presentes na biomassa. Neste estudo, os elementos mais intensamente reciclados pela biomassa, com relação ao fluxo de base do aquúfero, são, pela ordem, o fósforo ( 900 vezes), potássio (34 vezes), nitrogênio ( 20 vezes), e o sódio e cálcio (aproximadamente 4,5 vezes). 


\section{c) Degradação de matéria orgânica:}

A degradação da matéria orgânica é o processo inverso da captura e estocagem de elementos pela biomassa, correspondendo a uma reação de óxido-redução que utiliza oxigênio dissolvido na água, ou outro receptor de elétron, para produzir gás carbônico (reação 1). $\mathrm{O}$ gás carbônico produzido corresponde, por sua vez, a uma importante fonte de acidez na zona não saturada (reações 2 e 3 ):

$$
\begin{array}{ll}
\mathrm{CH}_{2} \mathrm{O}+\mathrm{O}_{2} \rightarrow \mathrm{CO}_{2}+\mathrm{H}_{2} \mathrm{O} & \text { Reação 1 } \\
\mathrm{CO}_{2}+\mathrm{H}_{2} \mathrm{O} \leftrightarrow \mathrm{H}_{2} \mathrm{CO}_{3} & \text { Reação 2 } \\
\mathrm{H}_{2} \mathrm{CO}_{3} \leftrightarrow \mathrm{H}^{+}+\mathrm{HCO}_{3}^{-} & \text {Reação 3 }
\end{array}
$$

$\mathrm{O}$ composto $\mathrm{CH}_{2} \mathrm{O}$ da reação 1 corresponde a uma simplificação de um composto orgânico, que na realidade é bastante complexo e corresponde a uma mistura de várias substâncias. A matéria orgânica apresenta alguns constituintes menores como fósforo, potássio, nitrogênio e enxofre que são liberados durante a degradação. $O$ gás carbônico, além do processo da reação 1 , também pode ser produzido a partir da respiração das raízes, o que faz com que a sua pressão parcial na fase gasosa da zona não saturada seja muitas vezes maior que a da atmosfera.

\section{d) Reações de dissolução e precipitação de minerais:}

A elevada oferta de acidez da água gerada pelas reações 2 e 3 atua na dissolução de minerais primários do perfil de alteração do solo. Este processo de dissolução causa o consumo de acidez e a liberação de elementos para a água; porém, a oxidação da matéria orgânica e a respiração das raízes constituem uma fonte de reposição de gás carbônico. $\mathrm{O} \mathrm{CO}_{2}$ volta a reagir com a água, produzindo mais acidez. Assim, quando o novo evento de recarga passa pela zona não saturada, os processos biogeoquímicos providenciam um suprimento contínuo de acidez que promove as reações entre os minerais e a água. A zona não saturada, normalmente rica em matéria orgânica, funciona como uma bomba geradora de acidez que reage com os materiais geológicos originais, transformando-os em espécies mais estáveis termodinamicamente neste ambiente (Freeze \& Cherry, 1979).

Alguns minerais, como os carbonatos e evaporitos, dissolvem rapidamente e mudam significativamente a composição da água ainda no solo, enquanto outros, como os silicatos, dissolvem lentamente e mudam a composição da água de forma que mais dificilmente se faz notar (Appelo \& Postma, 1993). 
As reações de dissolução de minerais primários podem ser congruentes (isto é, a reação pode ser reversível, como no caso dos minerais carbonáticos) ou incongruentes (ou seja, a reação é irreversível, como no caso dos minerais silicáticos primários). As reações congruentes, geram, tipicamente, produtos dissolvidos na fase líquida, enquanto que as reações incongruentes podem gerar, além dos produtos dissolvidos, uma fase sólida secundária (argilominerais).

O intemperismo de minerais aluminossilicáticos normalmente produz a formação de argilas, cujos tipos dependem da composição da rocha original e do estágio do intemperismo. Normalmente, quanto mais avançado o estágio de intemperismo, mais lixiviado em cátions e de sílica se torna o argilomineral, até que restam somente as formas de hidróxido de alumínio. Em regiões de clima árido, o processo de evaporação pode levar à precipitação uma série de minerais no solo, que incluem a calcita, o gipso e outros sais menos solúveis.

A Tabela 1 apresenta uma relação de algumas reações congruentes e incongruentes mais comuns e importantes que podem ocorrer em uma zona não saturada arenosa sob clima tropical, dentre as quais aquelas de aluminossilicatos que geram caulinita como argilomineral secundário (Freeze \& Cherry, 1979 e Appelo \& Postma, 1993):

\section{Tabela 1 - Algumas reações de dissolução/precipitação de minerais que podem ocorrer na zona não saturada de aqüíferos sedimentares arenosos em clima tropical}

\begin{tabular}{|c|c|}
\hline $\begin{array}{l}2 \mathrm{NaAlSi}_{3} \mathrm{O8}+2 \mathrm{H}^{+}+9 \mathrm{H}_{2} \mathrm{O} \rightarrow \mathrm{Al}_{2} \mathrm{Si}_{2} \mathrm{O}_{5}(\mathrm{OH})_{4}+2 \mathrm{Na}^{+}+4 \mathrm{H}_{4} \mathrm{SiO}_{4} \\
\text { Caubita }\end{array}$ & Reação 4 \\
\hline $\begin{array}{l}\text { CaAlSi } \mathrm{O}_{8}+2 \mathrm{H}^{+}+\mathrm{H}_{2} \mathrm{O} \rightarrow \mathrm{Al}_{2} \mathrm{Si}_{2} \mathrm{O}_{5}(\mathrm{OH})_{4}+\mathrm{Ca}^{+2} \\
\text { Anortita }\end{array}$ & Reação 5 \\
\hline $\begin{array}{l}2 \mathrm{KAISi}_{3} \mathrm{O}_{8}+2 \mathrm{H}^{+}+9 \mathrm{H}_{2} \mathrm{O} \rightarrow \mathrm{Al}_{2} \mathrm{Si}_{2} \mathrm{O}_{5}(\mathrm{OH})_{4}+2 \mathrm{~K}^{+}+4 \mathrm{H}_{4} \mathrm{SiO}_{4} \\
\text { K-feldspato }\end{array}$ & Reação 6 \\
\hline $\begin{array}{l}2 \mathrm{~K}\left[\mathrm{Mg}_{2} \mathrm{Fe}_{3}\right]\left[\mathrm{AlSi}_{3}\right\} \mathrm{O}_{10}(\mathrm{OH})_{2}+10 \mathrm{H}^{+}+5 \mathrm{O}_{2}+7 \mathrm{H}_{2} \mathrm{O} \rightarrow \mathrm{Al}_{2} \mathrm{Si}_{2} \mathrm{O}_{5}(\mathrm{OH})_{4}+2 \mathrm{~K}^{+}+4 \mathrm{Mg}^{+2}+2 \mathrm{Fe}(\mathrm{OH})_{3}+4 \mathrm{H}_{4} \mathrm{SiO}_{4} \\
\text { Biotita }\end{array}$ & Reação 7 \\
\hline $\begin{array}{l}\mathrm{CaCO}_{3}+\mathrm{H}^{+}=\mathrm{Ca}^{2+}+\mathrm{HCO}_{3} \\
\text { Calcita }\end{array}$ & Reação 8 \\
\hline $\begin{array}{l}\mathrm{CaMg}\left(\mathrm{CO}_{3}\right)_{2}+2 \mathrm{H}^{\mathrm{r}}=\mathrm{Ca}^{2+}+\mathrm{Mg}^{2+}+2 \mathrm{HCO}_{3}{ }^{-} \\
\text {Dolomita }\end{array}$ & Reação 9 \\
\hline $\begin{array}{l}\mathrm{CaSO}_{4} .2 \mathrm{H}_{2} \mathrm{O}=\mathrm{Ca}^{+2}+\mathrm{SO}_{4}{ }^{-2}+2 \mathrm{H} 2 \mathrm{O} \\
\text { Gipso }\end{array}$ & Reação 10 \\
\hline $\begin{array}{l}\mathrm{CaF}_{2}=\mathrm{Ca}^{+2}+2 \mathrm{~F} \\
\text { Fluorita }\end{array}$ & Reação 11 \\
\hline
\end{tabular}




\section{e) Reações de adsorção e troca iônica:}

As reações de adsorção e troca iônica são reconhecidas como os fenômenos químicos mais importantes que ocorrem no solo, principalmente pela sua relevância nos processos de nutrição vegetal (Wutke \& Camargo, 1972), e nos processos de retenção de contaminantes orgânicos e de metais pesados (McBride, 1994; Appelo \& Postma, 1993).

Adsorção corresponde a um fenômeno de aderência de íons ou moléculas presentes numa solução à uma fase sólida que apresenta elevada superficie específica. Os materiais do solo que possuem esta característica (argilas, matéria orgânica e óxidos e hidróxidos) normalmente apresentam-se negativamente carregados eletricamente, atraindo cátions para a sua superfície, a fím de que ocorra a estabilização elétrica. Há situações inversas, porém, em que a fase sólida apresenta-se positivamente carregada, atraindo ânions para a sua superficie. As variáveis que definem se haverá ocorrência de adsorção de cátions ou ânions são o tipo de material adsorvente e o pH da solução percolante. Se o pH da solução percolante for mais elevado que o $\mathrm{pH}$ do material adsorvente no qual a carga elétrica da sua superfície seja zero (definido como $\mathrm{pH}_{\mathrm{zp}}$, ou pH de "zero point of charge"), haverá condições para a adsorção de cátions, e vice-versa.

A troca iônica corresponde ao processo reversivel em que íons adsorvidos numa fase sólida são substituídos em quantidade equivalente por outros que se encontram em solução. Como os materiais do solo exibem com maior freqüência os fenômenos de adsorção e troca catiônica, um conceito importante é o da capacidade de troca de cátions (CTC), que corresponde à medida quantitativa da capacidade de retenção de cátions por diferentes materiais, normalmente expresso em equivalentes de cargas positivas por massa de material adsorvente. Os valores de CTC variam de material para material, em função das suas diferentes superfícies específicas. A Tabela 2 apresenta valores de CTC e de $\mathrm{pH}_{\mathrm{zpo}}$ de alguns materiais mais comuns (Appelo \& Postma, 1993 e Deutsch, 1997):

\begin{tabular}{|l|c|c|}
\hline \multicolumn{2}{|c|}{ Tabela 2-Medidas de capacidades de troca de cátions e de $\mathbf{p H}_{\mathrm{zpc}}$ de alguns } \\
materiais comuns
\end{tabular}


A reação de troca catiônica ocorre numa situação de não equilíbrio químico, quando a solução disponibiliza cátions que substituem aqueles que ocupavam o espaço sobre a superfície de adsorção da fase sólida. Os principais cátions que participam das reações de troca catiônica são o cálcio, magnésio, potássio, sódio, hidrogênio e alumínio, sendo que a soma da concentração destes íons em situação de adsorção representa uma boa aproximação da medida de capacidade de troca de cátions (CTC) (Hounslow, 1994; Wutke \& Camargo, 1972).

Além da quantidade de íons disponibilizados na solução, os fatores que promovem a ocorrência de uma reação de troca catiônica são a valência e os raios iônicos hidratados dos cátions envolvidos. Normalmente, os materiais do solo retém com maior intensidade os íons de maior valência e de menor raio iônico hidratado. A afinidade pela adsorção decresce na seguinte ordem (sem considerar os metais pesados, que apresentam-se em pequenas quantidades no material do solo): $\mathrm{Al}^{+3}>\mathrm{Ca}^{+2}>\mathrm{Mg}^{+2}>\mathrm{K}^{+}>\mathrm{Na}^{+}$. O hidrogênio tem comportamento especial, assemelhando-se ao de um cátion divalente fracamente hidratado, sendo mais fortemente retido pela caulinita que o cálcio, ocorrendo o inverso com a montmorilonita (Wutke \& Camargo, 1972). Isto acontece provavelmente devido aos diferentes tipos de ligações químicas que o hidrogênio realiza com os diversos materiais trocadores (ligações eletrostáticas e covalentes).

No ambiente do solo, o hidrogênio é a principal espécie que desencadeia as reações de troca iônica, promovendo o efeito de acidez do solo, que é um processo que se desenvolve à medida que os cátions básicos adsorvidos (cálcio, magnésio, potássio e sódio) são deslocados para a solução do solo pelos íons $\mathrm{H}^{+}$. As principais fontes de acidez (ou de hidrogênio) do solo, dentre outras menos comuns para o contexto da área de estudo, são a degradação de matéria orgânica (reações 1 a 3), a conseqüência da respiração de organismos vivos com a produção de gás carbônico seguida da ocorrência das reações 2 e 3 , a ocorrência de chuva ácida, e a utilização de fertilizantes a base de amônio (principalmente o nitrato de amônio), que sofre oxidação de acordo com a reação 12 (McBride, 1994):

$$
\mathrm{NH}_{4}^{+}+2 \mathrm{O}_{2} \rightarrow \mathrm{NO}_{3}{ }^{+}+2 \mathrm{H}^{+}+\mathrm{H}_{2} \mathrm{O} \quad \text { Reação } 12
$$

\section{f) Ações antropogênicas:}

As atividades humanas podem mudar completamente a qualidade da água, ocasionando a sua contaminação. Estas mudanças podem ocorrer como efeito das atividades de urbanização (sistemas de saneamento in situ, lixões, vazamentos em aterros sanitários, vazamento de tanques de combustíveis, etc.), industrial (derrames acidentais de produtos químicos, disposição inadequada de resíduos industriais, existência de lagoas de infiltração, ocorrência de chuva 
ácida, etc.), agrícola (aplicação de fertilizantes, adubos orgânicos e defensivos agrícolas, irrigação, atividades pecuárias, etc.), e de mineração (lixiviação de bota-foras, etc.). Todos estes processos devem ser considerados, portanto, durante a investigação da hidrogeoquímica da água subterrânea.

A Tabela 3 a seguir apresenta um resumo dos processos que são importantes como fonte de íons maiores para a água e os processos que limitam as suas concentrações (Hounslow, 1995):

Tabela 3 - Resumo dos principais processos que produzem e que controlam as concentrações dos íons na água.

\begin{tabular}{|c|c|c|}
\hline lon & $\begin{array}{l}\text { Processos que produzem íons } \\
\text { para a água }\end{array}$ & Processos que removem os ions da água \\
\hline $\mathrm{Na}^{+}$ & Dissolução albita, troca iônica & Troca de iônica \\
\hline $\mathrm{K}^{+}$ & Dissolução de microclínio e micas e troca iônica & $\begin{array}{l}\text { Formação de ilita (adsorção irreversível), troca iônica e } \\
\text { ação de biomassa viva }\end{array}$ \\
\hline $\mathrm{Mg}^{++}$ & $\begin{array}{l}\text { Dissolução de dolomita e silicatos } \\
\text { ferromagnesianos }\end{array}$ & $\begin{array}{l}\text { Precipitação de dolomita, formação de argilominerais e } \\
\text { troca iônica }\end{array}$ \\
\hline $\mathrm{Ca}^{++}$ & $\begin{array}{l}\text { Dissolução de calcita, dolomita, gipso, anortita e } \\
\text { piroxênios e troca iônica }\end{array}$ & Precipitação da calcita e gipso e troca iônica \\
\hline $\mathrm{Cl}^{-}$ & $\begin{array}{l}\text { Concentração por evapotranspiração da água da } \\
\text { chuva, infiltração de águas servidas }\end{array}$ & Nenhum \\
\hline $\mathrm{HCO}_{3}^{*}$ & $\begin{array}{l}\text { Pressão parcial } \mathrm{CO}_{2} \text { e intemperismo de minerais } \\
\text { aluminossilicáticos e carbonáticos }\end{array}$ & Solubilidade de minerais carbonáticos \\
\hline $\mathrm{SO}_{4}^{-}$ & Oxidação de pirita e dissolução de gipso & Redução do sulfato e precipitação de gipso \\
\hline $\mathrm{NO}_{3}^{-}$ & $\begin{array}{l}\text { Fertilizantes, águas servidas e degradação de } \\
\text { matéria orgânica }\end{array}$ & Ação de biomassa viva e denitrificação \\
\hline $\mathrm{Si}$ & Dissolução minerais silicáticos & Formação de calcedônia e sílica amorfa \\
\hline
\end{tabular}

\subsubsection{Modelos Hidrogeoquímicos}

Os modelos matemáticos hidrogeoquímicos compreendem uma série de programas de computador que auxiliam no entendimento dos processos que fazem parte do modelo geoquímico conceitual de um sistema, que pode ser entendido como uma tentativa de explicação das características químicas deste sistema em termos das interações entre as fases aquosa, mineral e gasosa (Deutsch, 1997). Estes modelos também realizam previsões de respostas do sistema a partir de mudanças nas condições químicas do meio.

Basicamente, existem três tipos de modelos hidrogeoquímicos: os modelos de especiação, os modelos de previsão e os modelos inversos (ou de balanço de massa). 
- Modelos de Especiação

Os modelos de especiação calculam, a partir do resultado da composição química de uma amostra de água, a distribuição e as atividades das espécies dissolvidas entre íons livres e os seus diferentes complexos, assim como o índice de saturação de diferentes minerais, levando-se em conta a força iônica da solução. Para a execução dos cálculos das concentrações (atividades) das várias espécies químicas e dos índices de saturação dos minerais, os programas baseiam-se no princípio geral da lei de ação de massas e utilizam-se de extensos bancos de dados de termodinâmica e de constantes de equilíbrio das principais reações químicas.

$\mathrm{O}$ cálculo do índice de saturação por esses modelos é útil no desenvolvimento de modelos geoquímicos conceituais. Este parâmetro mede o desequilíbrio existente entre a solução e os minerais da rocha através da relação entre o produto das atividades dos íons formadores de um mineral (IAP, ou, em inglês, ion activity product), obtido com os resultados das análises químicas da água e com a constante de equilibrio químico do mineral $(\mathrm{K})$, de acordo com a seguinte equação:

$$
\text { IS }=\log \frac{\mathrm{IAP}}{\mathrm{K}} \quad \text { Equação } 6
$$

Valores positivos do índice de saturação indicam que a solução está supersaturada com relação a determinado mineral, o que o leva à precipitação. Valores negativos sinalizam que o mineral encontra-se em processo de dissolução e valores próximos de zero indicam que a solução está em equilíbrio químico com o mineral.

\section{- Modelos de Previsão}

O princípio de funcionamento de um modelo de previsão consiste em apresentar ao programa a composição de uma água de montante e fazer a previsão da composição de uma água de jusante em um mesmo sistema de fluxo, após a primeira ter entrado em contato com uma ou várias fases minerais e/ou gasosas ou sofrido alguma alteração nas condições ambientais (por exemplo, temperatura, $\mathrm{pH}$ ou Eh). Como resultado, o programa fornece a especiação e os índices de saturação da água de jusante, bem como as quantidades de massa transferidas de uma fase para outra. Vários tipos de reações químicas entre as fases podem ser modeladas por estes programas, tais como dissolução/precipitação, óxido-redução, troca iônica, adsorção e complexação de superficies sólidas. 
- Modelos Inversos ou de Balanço de Massa

Nestes modelos, fornece-se ao programa as composições químicas de duas amostras de água coletadas a montante e a jusante de um mesmo sistema de fluxo, enumera-se os tipos de fases sólidas existentes entre os dois pontos e um índice de incerteza dos resultados das análises químicas, devido a erros analíticos e de amostragem. A saída do programa corresponde a uma série de sugestões de reações químicas que justificam as mudanças de composição qquímica da água entre os dois pontos. Estes programas utilizam-se apenas da estequiometria das reações na resolução do problema, não utilizando constantes de equilíbrio químico ou dados termodinâmicos nos seus cálculos matemáticos.

Dentre os programas de modelagem hidroquímica disponíveis, destacam-se o MinteqA2 (Allison et al., 1991), desenvolvido pelo USEPA, e o Phreeqc (Parkhurst, 1995), desenvolvido pelo USGS. O primeiro executa modelos de especiação e de previsão e conta com um extenso banco de dados de termodinâmica de reações, especialmente de metais potencialmente poluentes. $O$ programa Phreeqc executa os mesmos modelos do MinteqA2 e também a modelagem inversa, além de apresentar outros recursos como modelagem de mistura de águas e transporte advectivo.

A habilidade de um modelo geoquímico em simular de forma precisa os sistemas naturais é limitada por uma série de fatores, tais como acuracidade dos dados de campo e laboratório, a extensão e precisão da base de dados termodinâmicos, mas principalmente com relação à velocidade das reações químicas.

A utilização do princípio do equilíbrio químico para reações geoquímicas é válida principalmente para aquelas que são relativamente rápidas (da ordem de dias), o que é comum para as principais reações de especiação, de dissolução/precipitação congruentes (sais de carbonato, cloreto, sulfato, fosfato) e reações de troca iônica/adsorção. As reações de dissolução incongruentes, como as que ocorrem em aluminossilicatos, e algumas reações redox, possuem velocidades de processamento muito lentas, o que desfavorece a utilização do princípio do equilíbrio químico em estudos de hidrogeoquímica, principalmente para águas de fluxos rápidos, tal como o trânsito da água na zona não saturada. No caso destas últimas reações, a utilização dos modelos geoquímicos torna-se limitada e uma abordagem da cinética das reações ganha importância, mas que não será considerada neste trabalho. 
Analisando os efeitos da cinética das reações geoquímicas dos aluminossilicatos, a abordagem através da utilização de diagramas de estabilidade (cujos limites de campos foram construídos a partir de equações de equilíbrio químico entre fases), representa apenas uma primeira aproximação sobre a dinâmica destas reações, devendo os resultados serem interpretados com circunspeç̧ão.

Os processos de adsorção e troca iônica podem ser explicados pelo princípio da lei da ação de massas. No caso de elementos traços (metais pesados), o processo de adsorção é normalmente descrito através de isotermas de adsorção, que são obtidas através de ensaios de laboratório e cujos resultados alimentam os modelos matemáticos hidrogeoquímicos e de fluxo e transporte de contaminantes. Já a troca iônica pode ser descrita como uma reação com constante de equilíbrio, normalmente designada como coeficiente de equilíbrio (Appelo \& Postma, 1993). Infelizmente os valores dos coeficientes de equilíbrio não são constantes, pois o cátion a ser trocado não se comporta idealmente, sendo necessária a aplicação de coeficientes de atividade para superfícies de troca, semelhantes àqueles que são aplicados para íons na água, mas que ainda não são conhecidos para sólidos. Tais dificuldades restringem as tentativas de se executar modelagens envolvendo troca iônica dos principais cátions em modelos hidrogeoquímicos.

\subsection{Sintese de Trabalhos Publicados}

A hidráulica e hidroquímica da zona não saturada sempre foram objeto de estudos da área das ciências do solo e muito do desenvolvimento do conhecimento das relações entre as frações sólida, líquida, gasosa e biológica do solo aconteceu para a aplicação na agronomia. A maior parte das equações que governam fluxo e reservação de água na zona não saturada (relações entre umidade, potenciais e condutividade hidráulica) foram, por exemplo, desenvolvidas por profissionais que atuam na área de ciências do solo.

A partir da década de 80 , a zona não saturada começou a despertar maior interesse por parte dos hidrogeólogos e profissionais que atuam na área de meio ambiente, devido aos problemas engendrados pela poluição do solo e da água subterrânea. Embora em menor quantidade que os trabalhos na área de ciências do solo, vários trabalhos abordando a hidráulica e a hidroquímica da poluição da zona não saturada, devido a vários tipos de contaminantes orgânicos e inorgânicos, começaram a ser publicados em revistas voltadas para a comunidade hidrogeológica. 
Alguns exemplos do estágio atual de conhecimento sobre as técnicas de monitoramento e amostragem da zona não saturada, sobre a hidráulica e hidrogeoquímica natural e da poluição da zona não saturada e sobre a utilização do modelo de fluxo e transporte VS2DT são apresentados a seguir.

\subsubsection{Monitoramento da Zona Não Saturada}

Zilberbrand \& Gvirtzman (1996) realizaram um trabalho de avaliação do método de investigação da zona não saturada através da instalação de tensiômetros e lisímetros de sucção nas paredes de poços escavados na Ucrânia, vários deles instalados na mesma profundidade, em contexto de clima árido e de sedimentos de loess argiloso. Os autores avaliaram os efeitos da variabilidade lateral da tensão capilar e da qualidade da água, as influências entre os tensiômetros e os lisímetros de suç̧ão, a representatividade dos dados obtidos e o monitoramento de fluxo e transporte a longo prazo.

Como resultado, os autores verificaram que o potencial matricial apresentou forte variação lateral a $1 \mathrm{~m}$ de profundidade, devido aos sucessivos processos de infiltração e evaporação e à existência de canais de raízes e de macroporos no solo, que causam diferentes taxas de percolação da água. Abaixo dos $3 \mathrm{~m}$, os tensiômetros marcaram as mesmas medidas de potencial matricial, indicando uma maior homogeneidade do solo. Quanto à variabilidade lateral das concentrações iônicas, os autores verificaram variações que chegaram a $105 \%$ da superficie até 3,5 m, diminuindo nos horizontes mais profundos para até 3,3\%. Quanto à influência entre os tensiômetros e os lisímetros, os autores não verificaram variações de potencial matricial nos tensiômetros distantes em 0,1 m de um lisímetro em suç̧ão. No entanto, observou-se, para estas distâncias, variações de concentração de $\mathrm{HCO}_{3}{ }^{\circ}$ de 25 a $75 \%$, que foram associadas às variações nas concentrações de $\mathrm{CO}_{2}$ induzidas pela instalação do tensiômetro e à aplicação de vácuo. Neste caso, os autores recomendam que os tensiômetros e lisímetros sejam instalados numa distância mínima de $0,5 \mathrm{~m}$. Quanto à representatividade, os autores verificaram que os dados provenientes de um único poço podem ser representativos, caso não haja grandes variações climáticas, estratigráficas e de atividades antropogênicas entre dois locais. No trabalho, também comparou-se dados de potencial matricial e de concentrações de cloreto entre dois poços situados em contexto semelhante e não se verificou diferenças pronunciadas. 
Ainda com relação ao raio de influência de lisímetros de sucção, Hart \& Lowery (1997) demonstraram que o raio de amostragem não ultrapassou $3 \mathrm{~cm}$ em solos não saturados arenosos, sob condições de potenciais matriciais diferentes e sucção de amostragem em lisímetros de porcelana da ordem de $-375 \mathrm{~mm} \mathrm{Hg}\left(-5 \mathrm{~m} \mathrm{H}_{2} \mathrm{O}\right)$.

Suarez (1987) avaliou experimentalmente os erros de pH decorrente da desgaseificação da água durante a amostragem através de lisímetros de sucção, o que promove a perda do gás carbônico, uma subseqủente elevação do pH e uma eventual precipitação de carbonatos, fosfatos e óxidos no interior do lisímetro. O principal fator que controla o erro do $\mathrm{pH}$ são, na ordem, a proporção entre os volumes da amostra e o do recipiente que armazena a amostra no interior do lisímetro, a composição química inicial do gás no interior do lisímetro e a intensidade de sucção aplicada no lisímetro durante a amostragem. Para lisímetros contendo ar no seu interior e com sucção em $30 \mathrm{mmHg}\left(0,4 \mathrm{~m} \mathrm{H}_{2} \mathrm{O}\right)$ menor que o potencial matricial do solo, o autor observou variações que alcançam uma unidade de $\mathrm{pH}$, principalmente quando o volume da amostra de água situa-se ao redor de $10 \%$ do volume total do lisímetro. Este erro é praticamente desprezível quando o recipiente do lisímetro é completamente preenchido pela amostra.

\subsubsection{Hidráulica e Hidrogeoquímica da Zona Não Saturada}

Dutton (1990) combinou dados de hidráulica (medição de umidade através de sonda de nêutrons), petrografia (microscopia óptica, microscopia eletrônica, difração de raio X em argilas e ensaios de capacidade de troca de cátions) e hidroquímica (análises químicas em amostras de água da zona não saturada) para ilustrar os mecanismos que controlam a evolução da composição química da água em depósitos arenosos recentes contendo linhita, no contexto subtropical úmido da região leste do estado do Texas, EUA. O autor conclui que a dissolução de feldspatos com a precipitação de caulinita e esmectita e a troca iônica são os processos que controlam a mudança da composição da água de uma zona não saturada de 4 metros de espessura, de bicarbonatada cálcica para bicarbonatada sódica. A textura dos grãos de feldspato e a variação sazonal das concentrações iônicas na água parecem estar de acordo com o modelo cinético de reação intempérica de superfície (surface-reaction). O movimento de infiltração da água como recarga ocorre de outubro a março e as concentrações iônicas foram gradualmente decrescendo de dezembro a janeiro com o movimento de infiltração da frente de molhamento. 
Zilberbrand (1995), estudando a hỉdrogeoquímica da zona não saturada nas estações de monitoramento da Ucrânia descritas acima (Zilberbrand \& Gvirtzman, 1996), observou a ocorrência de precipitação de minerais carbonáticos e gipso na zona de raízes. A zona não saturada na estação 2 em Krestovka apresenta espessuras de $24 \mathrm{~m}$ em contexto de clima árido e a frente de molhamento, gerada por evento de irrigação, leva cerca de 50 meses para atingir o aqüífero freático (Zilberbrand \& Gvirtzman, 1996). A concentração de sólidos dissolvidos é elevada, variando de 521 a $16500 \mathrm{mg} / \mathrm{L}$ ao longo do perfil da zona não saturada. Entre 0,5 e 2,5 m, a composição da água muda de $\mathrm{HCO}_{3}-\mathrm{SO}_{4}-\mathrm{Ca}$ para $\mathrm{SO}_{4}-\mathrm{Na}$, sendo esta última a composição da água do aqüífero freático. A zona de raízes funciona como uma barreira geoquímica que retém o cálcio que predomina nas águas da chuva e de irrigação, ocasionando a precipitação da calcita e do gipso. Esta precipitação é acompanhada pela remoção do $\mathrm{HCO}_{3}$ e $\mathrm{SO}_{4}$ da solução e pela elevação da concentração de sólidos dissolvidos como resultado da evapotranspiração.

Zilberbrand (1999) verificou que as constantes de equilíbrio químico das principais reações geoquímicas são diferentes para solos e sedimentos muito secos com relação àquelas constantes utilizadas para soluções que se encontram sob pressão atmosférica. $O$ autor conclui, dentre outras observações, que quanto mais secos são os sedimentos, menores são as constantes de equilíbrio para reações de dissolução/precipitação, o que torna mais fácil a precipitação. Entretanto, só haverá uma modificação expressiva das constantes para solos e sedimentos que exibem potenciais matriciais menores que $-1,5 \mathrm{MPa}$ (ou $-15 \mathrm{~atm}$, ou $-150 \mathrm{~m} \mathrm{H}_{2} \mathrm{O}$, ou ainda $11300 \mathrm{mmHg}$ ), valores estes que são inferiores ao coeficiente de murchamento e que são possíveis em ambientes de clima desértico. No contexto climático desta pesquisa, em que os valores de potencial matricial raramente foram menores que $-650 \mathrm{mmHg}$ (ou $9 \mathrm{~m} \mathrm{H} \mathrm{H}_{2} \mathrm{O}$ ), as constantes de equilíbrio calculadas para soluções sob pressão atmosférica podem ser utilizadas sem restrições.

Edmunds et al. (1992 a) extraiu amostras de água de uma zona não saturada de $35 \mathrm{~m}$ de espessura, formada por dunas arenosas quaternárias sob clima semi-árido no norte do Senegal. Os autores observaram um perfil de eventos de recarga que cobriu 70 anos e verificaram que o pH da solução do solo encontra-se abaixo de 4 e com baixas concentrações de cátions de base adsorvidos nos primeiros $10 \mathrm{~m}$. Abaixo desta profundidade, há elevação gradual do $\mathrm{pH}$, da razão entre $\mathrm{Na} / \mathrm{Cl}$ e das concentrações dos demais solutos, em resposta às reações de troca iônica e de dissolução de minerais silicáticos. 
Os efeitos da infiltração de chuva ácida em solos arenosos com pouca capacidade de neutralização (ou tamponização) foram estudados na Dinamarca por Hansen \& Postma (1995), na Finlândia por Soveri (1989), e na Inglaterra por Moss \& Edmunds (1989) e Edmunds et al. (1992 b). Hansen \& Postma (1995) observaram que o aporte de hidrogênio da chuva ácida (pH entre 4 e 5) promove a dissolução de minerais secundários até $5 \mathrm{~m}$ de profundidade, tal como argilas e hidróxidos de alumínio, liberando alumínio dissolvido para a água. Soveri (1989) observou que o conteúdo de íons alcalinos na água do solo é devido à troca iônica por hidrogênio nos minerais do solo e que a água subterrânea na Finlândia é particularmente sensível a este tipo de poluição pois, no geral, é baixa a capacidade de atenuação da acidez. Moss \& Edmunds (1989) e Edmunds et al. (1992 b) notaram uma elevação no pH da água ao longo da zona não saturada de 4 para 5,5 devido à troca iônica do hidrogênio pelos cátions de base (Na, $\mathrm{K}, \mathrm{Ca}, \mathrm{Mg}$ ) e pelo intemperismo de minerais aluminossilicáticos. Os autores também observaram elevadas concentrações de $\mathrm{Al}$ e de outros metais ( $\mathrm{Fe}, \mathrm{Mn}, \mathrm{Cu}, \mathrm{Ni}, \mathrm{Co}, \mathrm{Zn}, \mathrm{Be}$ ) na água intersticial da zona não saturada.

Os efeitos da poluição sobre a hidrogeoquímica da zona não saturada, ocasionada por mineração de carvão (linhita), foram estudados por Houghton et al. (1987). De acordo com os experimentos de laboratório e modelagem química, os principais processos que controlam a hidrogeoquímica da zona não saturada nas áreas não mineradas são: dissolução de gases gerados pela oxidação de compostos orgânicos, oxidação de minerais a base de sulfeto de ferro (pirita), dissolução de minerais carbonáticos, precipitação e dissolução de gipso, troca de cátions em argilas e troca de cátions e adsorção na linhita. Todos esses processos são acelerados com as atividades de mineração.

A origem e comportamento do gás carbônico na zona não saturada também são objeto de pesquisas de Wood \& Petraitis (1984) e Keller (1991). Os primeiros, em pesquisa na região oeste do estado do Texas (EUA), observaram que a pressão de $\mathrm{CO}_{2}$ era mais elevada em maiores profundidades da zona não saturada que na zona de solo, o que aparentemente contradiz que o processo de geração de $\mathrm{CO}_{2}$ se dá somente na zona de solo para depois se espalhar por difusão até o aqüífero freático. A hipótese mais provável, segundo os autores, seria que o carbono orgânico particulado e dissolvido teria sido transportado para a base da zona não saturada, onde teria sido oxidado por bactérias que se utilizam de oxigênio proveniente da superfície. $O$ mesmo fenômeno foi observado por Keller (1991) em Saskatoon (Canadá), que concluiu que a produção do $\mathrm{CO}_{2}$ na base da zona não saturada e no aquáfero raso é devida às comunidades microbiológicas que utilizam o carbono orgânico do solo e sedimento como substrato. Este 
processo se dá em profundidades abaixo da zona do solo e em um sistema relativamente fechado e desconectado dos efeitos das variações climáticas que limitam a pressão de $\mathrm{CO}_{2}$ na zona do solo.

A hidrogeoquímica da zona não saturada em solos originados em terrenos carbonáticos foi estudada por Thrailkill \& Robl (1981) na região da Caverna Mammoth (Kentucky, EUA). Os autores identificaram dois tipos de fluxo de água na zona não saturada: os de fluxo maior em poros grandes onde a água está sempre não saturada em relação à calcita e que é responsável pela dissolução do terreno calcário que forma a caverna, e os de fluxo menor que podem estar ou não saturados em relação à calcita, muitos dos quais são responsáveis pela formação de espeleotemas na caverna.

No Brasil, dentre os trabalhos que enfocam hidráulica e hidrogeoquímica da zona não saturada, destacam-se aqueles liderados por Szikszay (1986, 1987, 1989 e 1990), que construiu uma estação de monitoramento na cidade universitária da USP, onde foram monitorados tensiômetros e coletadas e analisadas amostras de solo e água das zonas saturada e não saturada.

Em Szikszay et al. (1986) são descritos os critérios de locação e os detalhes construtivos da estação de monitoramento. Foram instalados 4 poços para a investigação da zona saturada, e 13 tensiômetros e 23 lisímetros de sucção, espaçados a cada $0,5 \mathrm{~m}$ de profundidade e atingindo o máximo de até $10,5 \mathrm{~m}$. As porções mais profundas da zona não saturada foram investigadas com a instalação dos equipamentos no interior de uma vala escavada de $3 \mathrm{~m}$ de profundidade média, e cuja superfície foi cimentada e coberta. O contexto geológico é o dos sedimentos da Bacia de São Paulo, sendo que o material perfurado consiste de uma alternância de camadas arenosas e argilosas de espessuras decimétricas.

Quanto ao movimento da água da zona não saturada, Szikszay et al. (1987) verificaram que a influência pluviométrica na variação do nível hidrostático do aquífero freático foi observada após uma faixa de tempo de 50 a 170 dias, que pode ser considerada como o período de tempo de trânsito da água na zona não saturada. Estes estudos indicaram, inclusive, que a linha de evaporação situa-se numa profundidade que varia de 0,5 a $1,5 \mathrm{~m}$, e que as condições de recarga natural dos aqüíferos ocorrem principalmente no período do verão ao início do outono, época de maior pluviometria. Os dados de condutividade hidráulica saturada medidos variaram de $3,7 \mathrm{E}-3$ a $8,4 \mathrm{E}-6 \mathrm{~cm} / \mathrm{s}$, conferindo elevada heterogeneidade vertical para o material da zona não saturada. 
Os resultados sobre a hidrogeoquímica da zona não saturada são descritas em Szikszay \& Toledo-Groke (1989) e Szikszay et al. (1990). Observou-se que a água do solo, da superfície até a profundidade de $1,5 \mathrm{~m}$, apresenta concentrações mais elevadas de sólidos dissolvidos, ocorrendo um decréscimo nos valores até a zona saturada por processos de diluição. As concentrações mais elevadas de sais na água do solo mais superficial está ligada aos eventos contínuos de evaporação e infiltração na porção do solo definida pela linha de evaporação.

Quanto à composição iônica, observou-se que a água passa de predominantemente cálcica até 4,0 m para sódica e potássica até o aquífero freático, onde volta a predominar o cálcio novamente. Este fenômeno está ligado aos mecanismos de troca iônica do cálcio pelo sódio e pela caulinitização de muscovitas e feldspatos na zona não saturada, que liberam o potássio que posteriormente será adsorvido em profundidades maiores. Quanto aos ânions, o bicarbonato, originado a partir da oxidação da matéria orgânica e de reações bioquímicas, predomina a partir da linha de evaporação até o aquúfero freático. Observou-se que não ocorreram variações pronunciadas na composição química das amostras de água coletadas ao longo dos anos, em função da sazonalidade das chuvas.

Alexandre (1995) investigou o comportamento geoquímico de metais pesados originários de pesticidas agrícolas nas zonas saturada e não saturada do manto de intemperismo de terrenos cristalinos pré-cambrianos sob clima úmido no município de Louveira (SP). A autora instalou 5 tensiômetros de 0,1 até $2 \mathrm{~m}$ de profundidade, 13 lisímetros de sucção de 0,5 a $4,5 \mathrm{~m}$ de profundidade e 2 poços de monitoramento. A condutividade hidráulica saturada medida varia de $3,7 \mathrm{E}-4$ a $1,5 \mathrm{E}-5 \mathrm{~cm} / \mathrm{s}$ e a linha de evaporação situa-se entre 0,5 e $1,0 \mathrm{~m}$ de profundidade. $\mathrm{O}$ sentido de fluxo de água da zona não saturada se dá para o aqüífero freático, ocorrendo, porém, fluxos ascendentes acima da linha de evaporação nos meses mais secos. Os níveis d'água do aqüífero tiveram resposta poucos dias após os eventos de chuva, devido à pequena profundidade do nível d'água. Quanto à hidroquímica, a autora verificou que a água passa de cálcicamagnesiana até $4 \mathrm{~m}$ para magnesiana-cálcica até o aquuifero freático e que a água é fortemente nitratada após os $3 \mathrm{~m}$ de profundidade devido à ação de fertilizantes. Apesar de terem sido detectadas ocorrências dos metais pesados adsorvidos em minerais ferruginosos e em baixas concentrações na água, o que evidencia retenção pelo material sólido, os solos estudados não apresentam características que favorecem a retenção de grandes quantidades dos metais pesados estudados, devido às baixas concentrações de matéria orgânica, predominância de caulinita entre os minerais de argila e devido às condições de permeabilidade e gradientes hidráulicos. 
Surita (1999) avaliou a contaminação da água da zona não saturada de sedimentos da então denominada Formação Adamantina em Monte Aprazivel (a aproximadamente $120 \mathrm{~km}$ de Urânia) devido à disposição de efluentes de curtimento de couro. A estação de monitoramento instalada em superficie conta com 1 poço de monitoramento, 6 tensiômetros e 13 lisímetros de sucção, instalados a cada 0,5 até $7,5 \mathrm{~m}$. As leituras de potencial matricial indicaram a ocorrência de potenciais de infiltração em todo o perfil ao longo do ano.

Neste trabalho, a caracterização da hidroquímica da zona não saturada antes da impactação do solo com efluentes foi parcialmente caracterizada. Observou-se que, da superficie até a região da franja capilar, o $\mathrm{pH}$ e a condutividade elétrica apresentaram queda nos valores. A água é magnesiana-cálcica após os $3 \mathrm{~m}$ de profundidade até o aqüífero freático e o nitrato apresenta-se também com elevadas concentrações na zona não saturada (até $85 \mathrm{mg} / \mathrm{L}$ ), decrescendo em profundidade. Como resultado principal, o estudo mostra que o solo e a água foram intensamente impactados pela infiltração dos efluentes.

Um monitoramento da qualidade da água das zonas saturada e não saturada do Aqüífero Botucatu em uma área de fertirrigação com vinhaça foi realizado por Gloeden et al. (1991) no município de Serrana (SP). Após a instalação de 54 tensiômetros entre as profundidades de 0,4 a 2,2 m, observou-se a existência de baixa intensidade de fluxos de água da zona não saturada que podem ser ascendentes ou descendentes durante os períodos de baixa pluviosidade, e de intensidades de fluxo de água mais elevadas no sentido descendente durante os períodos de elevada pluviosidade. Constatou-se também que os sedimentos arenosos apresentam baixa capacidade de armazenamento de água na zona não saturada e elevada capacidade de transporte dos constituintes da vinhaça. As análises químicas da água do aqüífero freático indicaram que as concentrações de cloreto, carbono orgânico, amônio e nitrogênio orgânico aumentaram e diminuíram drasticamente e retornaram às suas concentrações originais em apenas dois meses após a disposição da vinhaça em superfície.

\subsubsection{Modelos Matemáticos de Fluxo e Transporte da Zona Não Saturada}

Trabalhos científicos, que enfocam a utilização do modelo de fluxo e transporte da zona não saturada VS2DT (Lappala et al., 1987), são raros na literatura. Verificou-se a sua utilização em duas situações: uma para modelar hidráulica de aqüífero e outra para verificar transporte de pesticidas na zona não saturada. 
Halford (1997) utilizou o VS2DT para avaliar os efeitos da zona não saturada em testes de condutividade hidráulica executados em aqüífero freático raso. Através da comparação dos resultados do VS2DT com os resultados de modelagem do aqüífero com o programa MODFLOW, o autor concluiu que o primeiro modelo fornece uma gama mais completa de ferramentas para analisar os testes de aqüiferos não confinados e estima melhor os efeitos da variação da condutividade hidráulica, tal como o atraso na chegada da frente de molhamento no aqüúfero.

Chakka \& Munster (1997) utilizaram o VS2DT acoplado a um modelo de fluxo em aquấfero freático para simular transporte preferencial do agroquímico atrazina através de macroporos de solos argilosos até a zona de descarga do aqüífero freático, representado por um rio e por um poço. Os resultados indicaram que o bombeamento provocou o transporte da atrazina até a base do aqüifero arenoso $(19 \mathrm{~m})$, mas que o composto não chegou a ser transportado para o rio. As simulações realizadas tiveram acordo com os resultados observados e medidos no campo.

\subsection{Características Regionais do Meio Fisico}

\subsubsection{Aspectos Fisioclimáticos}

Segundo DAEE (1976), na região de Urânia dominam os efeitos da massa equatorial continental, da continental tropical e das massas polares, o que caracteriza o clima como tropical úmido, com duas estaçôes bem definidas: uma com temperaturas médias mensais superiores a $20^{\circ} \mathrm{C}$ no verão (dezembro a março) e outra com temperaturas inferiores a $19^{\circ} \mathrm{C}$ no inverno (abril a setembro). O período de chuvas ocorre no verão e o período seco no inverno, sendo que a distribuição das chuvas sofre grandes variações. Durante o período de 1959 a 1999, o posto pluviométrico B7-006 do DAEE em Urânia indicou que os meses de dezembro, janeiro e fevereiro apresentaram as maiores alturas médias de chuvas $(196,234$ e $179 \mathrm{~mm}$, respectivamente), enquanto que os meses de julho, agosto e setembro registraram as menores médias $(30,16$ e $17 \mathrm{~mm})$. A pluviometria média anual foi de $1271 \mathrm{~mm}$ no município de Urânia neste período.

Do ponto de vista hidrográfico, o município de Urânia situa-se sobre os divisores hidrográficos das unidades 18 (São José dos Dourados, a sul) e 15 (Turvo/Grande, a norte). É na cidade de Urânia que ocorrem algumas nascentes que fazem parte do Córrego da Porteira, tributário do Ribeirão da Ponte Pensa, que tem sentido oeste e deságua no Rio Paraná (unidade 18); e as nascentes do Ribeirão Comprido, que tem sentido norte e deságua no Córrego 
Cascavel, que é tributário do Rio Grande (unidade 15) (IGC-DAEE, 1996).

Não há dados hidrometeorológicos diretos das bacias mencionadas acima. Porém, o posto 8B-002 no Rio São José dos Dourados (DAEE, 1976) apresenta dados que podem ser extrapolados para a região de Urânia, por situar-se num mesmo contexto geológico, geomorfológico e climático, além de monitorar o Ribeirão do Coqueiro, cujas nascentes estão no município de Jales, junto à divisa de Urânia. Segundo os dados de balanço hídrico deste posto, a chuva na região foi de 1430,0 $\mathrm{mm}$ em 1974, sendo que deste total, 83,6\% participou dos processos de evapotranspiração, 7,4\% corresponde ao escoamento superficial e apenas $9,0 \%$ corresponde à recarga subterrânea.

O município de Urânia situa-se na unidade morfoescultural denominada Planalto Centro Ocidental do Planalto Ocidental Paulista (Ross \& Moroz, 1997), que apresenta colinas amplas e baixas com topos convexos e aplanados ou tabulares, entalhamento médio dos vales inferiores a $20 \mathrm{~m}$, interflúvios com dimensões médias entre 1750 e $3750 \mathrm{~m}$, densidade de drenagem baixa, altimetrias variando de 400 a $700 \mathrm{~m}$ e declividades médias das vertentes entre 2 e $10 \%$.

Os solos da região são classificados como argilossolos vermelho-amarelos (ou podzólicos vermelho-amarelos) (EMBRAPA/IAC, 1999). São superficialmente arenosos com nítida diferenciação textural entre os horizontes $\mathrm{A}$ e $\mathrm{B}$, apresentando sub-horizonte $\mathrm{A} 2$ e transição abrupta a clara entre os horizontes.

\subsubsection{Geologia}

$\mathrm{Na}$ área de estudo afloram os sedimentos da Formação Adamantina do Grupo Bauru (Cretáceo Superior), que recobrem os basaltos da Formação Serra Geral (Juro-Cretáceo).

A Formação Adamantina é constituída por bancos de arenitos finos de coloração rósea a creme e cimentação carbonática localizada. Podem ocorrer de forma alternada com lamitos, siltitos e arenitos lamíticos de cores avermelhadas, sendo que o conjunto foi depositado em ambiente continental fluvial (Soares et al., 1980). A mineralogia dos sedimentos é composta principalmente por quartzo e secundariamente feldspatos, sendo reconhecidos por Brandt Neto et al. (1985) os argilo-minerais caulinita, montmorilonita e palygorskita.

Coimbra (1976) indica como área fonte os sedimentos fanerozóicos preexistentes a noroeste e sudeste, áreas de rochas básicas do Grupo São Bento, metamórficas dos Grupos Araxá e Canastra e alcalinas do Triângulo Mineiro a nordeste.

O contato inferior da Formação Adamantina normalmente se dá com a Formação Santo Anastácio de forma transicional e interdigitada. Na região de Urânia, porém, o contato inferior 
desta formação se dá direta e discordantemente com os basaltos da Formação Serra Geral (IPT, 1981). O contato superior da Formação Adamantina é transicional com a Formação Marília e em discordância erosiva com os depósitos de coberturas de idade cenozóica (Fúlfaro \& Bjornberg, 1993).

As maiores espessuras da Formação Adamantina ocorrem geralmente nas porções ocidentais dos espigões entre os grandes rios (Figura 1). Atinge $160 \mathrm{~m}$ entre os rios São José dos Dourados e do Peixe, $190 \mathrm{~m}$ entre os rios Santo Anastácio e Paranapanema, e 100 a $150 \mathrm{~m}$ entre os rios do Peixe e Turvo, adelgaçando-se destas regiões em direção a leste e nordeste (Soares et al., 1980).

Almodovar (1995) identificou como sendo de $208 \mathrm{~m}$ a maior espessura do pacote de sedimentos da Formação Adamantina na cidade de Guzolândia. Em Urânia, onde afloram arenitos argilo-siltosos avermelhados, os sedimentos da Formação Adamantina foram encontrados até $160 \mathrm{~m}$. Em Fernandópolis foram identificados, em amostras de poços tubulares profundos, sedimentos das Formações Botucatu e Pirambóia do Grupo São Bento, sob os basaltos. Neste município as espessuras encontradas para os sedimentos da Formação Adamantina, basaltos e os sedimentos das formações Botucatu e Pirambóia foram, respectivamente, de 130,1207, 143 e $165 \mathrm{~m}$. Na cidade de Jales, vizinha à Urânia, um poço profundo apresentou $85 \mathrm{~m}$ de sedimentos da Formação Adamantina, $901 \mathrm{~m}$ de basaltos e $219 \mathrm{~m}$ de arenitos da Formação Botucatu.

A estratigrafia da porção nordeste da Bacia Bauru foi recentemente revista por Fernandes (1998). Nesta nova concepção estratigráfica duas unidades geológicas cronocorrelatas são identificadas como formadoras desta bacia: grupos Caiuá e Bauru. Estes dois sistemas deposicionais teriam se formado sob condições geológicas semelhantes com clima semi-árido nas bordas passando a desértico no interior da bacia. O Grupo Caiuá é subdividido nas formações Rio Paraná, Goio-Erê e Santo Anastácio, que ocorre no extremo oeste do estado de São Paulo. Já o Grupo Bauru, predominante no estado de São Paulo, aflora nos domínios orientais da bacia e é subdividido nas formações Vale do Rio do Peixe, Araçatuba, São José do Rio Preto, Presidente Prudente e Marília e analcimitos Taiúva.

Neste contexto, afloram na cidade de Urânia os sedimentos da Formação Vale do Rio do Peixe. Esta unidade estratigráfica é constituída por arenitos muito finos a finos de cores marrom claro, rosado a alaranjado, seleção moderada a boa, com intercalações de siltitos de cores creme e marrom. A geometria dos arenitos é predominantemente tabular submétrica de aspecto maciço com zonas de estratificação/laminação plano-paralela grosseira e estratos também tabulares com 
estratificação cruzada tabular e acanalada de pequeno a médio porte. $O$ autor sugere que a deposição da Formação Vale do Rio do Peixe se deu por ação principalmente eólica em extensas áreas planas (lençóis de areia com campos de dunas baixas) e subordinadamente por torrentes esporádicas (loesse e wadis). Finalmente, Fernandes (1998) propõe que o contato inferior da Formação Vale do Rio do Peixe é gradual com a Formação Santo Anastácio ou, conforme ocorre na área de estudo, discordante e diretamente sobre os basaltos da Formação Serra Geral, e que o contato superior é interdigitado e transgressivo com a Formação Araçatuba.

O topo das colinas do denominado Planalto Ocidental podem apresentar, entretanto, as denominadas Coberturas Cenozóicas, que são compostas por sedimentos arenosos, aluviais e coluviais e que foram erroneamente interpretadas como solos, apresentando espessuras variáveis e contato basal por superfícies de erosão bem marcadas (Landim et al., 1974).

\subsubsection{Hidrogeologia e Hidrogeoquímica}

O município de Urânia encontra-se no contexto hidrogeológico do Sistema Aqüífero Bauru, que relaciona-se com as rochas do Grupo Bauru e ocupa uma área de cerca de $40 \%$ do território do Estado de São Paulo. O Sistema Aqüífero Bauru é regionalmente do tipo livre, localmente semi-confinado, com espessura saturada média de $100 \mathrm{~m}$ e podendo chegar até $250 \mathrm{~m}$, tendo as rochas basálticas da Formação Serra Geral como o seu divisor inferior (DAEE, 1976 e 1988).

A recarga natural do Sistema Aqüífero Bauru é dada diretamente pelas chuvas. A natureza essencialmente livre do aqüífero faz surgir superfícies potenciométricas com formas que acompanham a geometria da superfície do terreno, com linhas de fluxo de água subterrânea convergindo para as calhas dos rios, e com os divisores das bacias hidrogeológicas coincidindo com os divisores das bacias hidrográficas.

O Sistema Aqǘfero Bauru é normalmente subdividido em unidades hidrogeológicas que são correlacionadas com as respectivas formações geológicas que compõe o Grupo Bauru. Desta forma, atribui-se o nome de Aqǘfero Adamantina à unidade aqüífera composta pelos sedimentos da Formação Adamantina de Soares et al. (1980) (Hirata et al., 1997). Ao longo deste trabalho, a denominação Aqüífero Adamantina será considerada por ser um termo consagrado no meio hidrogeológico. A nova subdivisão estratigráfica desenvolvida por Fernandes (1998), que faz tornar inexistente a Formação Adamantina, poderá implicar em mudanças na denominação desta unidade aqüífera no futuro. Iritani et al. (2000) já puderam constatar de forma preliminar, inclusive, uma marcante correlação entre a nova subdivisão 
estratigráfica proposta por Fernandes (1998) e os parâmetros hidrodinâmicos obtidos de poços tubulares profundos locados nos Grupos Bauru e Caiuá. Novos estudos deverão ser realizados para se verificar correlações entre produtividade dos poços e as unidades do Grupo Bauru.

O Aqüífero Adamantina possui extensão regional e tem comportamento livre a semiconfinado. A recarga ocorre naturalmente pela infiltração da chuva $e$ as superfícies potenciométricas são fortemente influenciadas pela geomorfologia da área, onde os divisores de água subterrâneas coincidem com os divisores das bacias hidrográficas. As linhas de fluxo convergem para os rios, tendo desta forma um caráter efluente. É provável, embora não tenha sido comprovado, que exista um sistema de circulação regional de maior profundidade, com tempos de trânsito maiores e que poderia transpor várias bacias hidrográficas (Hirata et al., 1997).

Quanto à produtividade, Rocha et al. (1982), observou que valores de capacidade específica entre 0,5 a $1,0 \mathrm{~m}^{3} / \mathrm{h} / \mathrm{m}$ são os mais freqüentes nos domínios da Formação Adamantina. A transmissividade apresenta distribuição similar à variação da capacidade específica, com valores entre $3,0 \mathrm{E}-4$ e $6,0 \mathrm{E}-4 \mathrm{~m}^{2} / \mathrm{s}$ e os valores de condutividade hidráulica variam de $1,0 \mathrm{E}-6$ a $1,0 \mathrm{E}-3 \mathrm{~m} / \mathrm{s}$.

Do ponto de vista hidrogeológico local, os poços tubulares de Urânia, Aspásia e Santa Salete mostram espessura saturada média de $100 \mathrm{~m}$, capacidade específica de $0,24 \mathrm{~m}^{3} / \mathrm{h} / \mathrm{m}$ e transmissividade de $6,31 \mathrm{~m}^{2} /$ dia (Hirata \& Rodolfi, 1993). Os perfis litológicos dos poços perfurados na cidade de Urânia mostram profundidades que variam de 70 a $270 \mathrm{~m}$, nível estático variando de 4,5 a $50 \mathrm{~m}$ e vazão entre 2,2 e $18,8 \mathrm{~m}^{3} / \mathrm{h}$ (Almodovar, 1995).

Hirata (2000) realizou a modelagem matemática do fluxo de água subterrânea em duas dimensões do Aqüífero Adamantina na cidade de Urânia e arredores. As figuras 2 e 3 apresentam os resultados dos mapas potenciométricos da área, com e sem os poços profundos da cidade em funcionamento. Nota-se que a mancha urbana do município situa-se sobre um divisor de bacias hidrogeológicas e que o bombeamento conjunto dos poços profundos da SABESP gera um único cone de rebaixamento sob a cidade.

Quanto à qualidade da água do Sistema Aqüífero Bauru, um dos primeiros estudos sobre a hidrogeoquímica foi realizado por Taltasse (1968). O autor distinguiu duas fácies hidrogeoquímicas para os arenitos cretáceos do Bauru: a das águas bicarbonatadas cálcicas e a das águas bicarbonatadas magnesianas. 


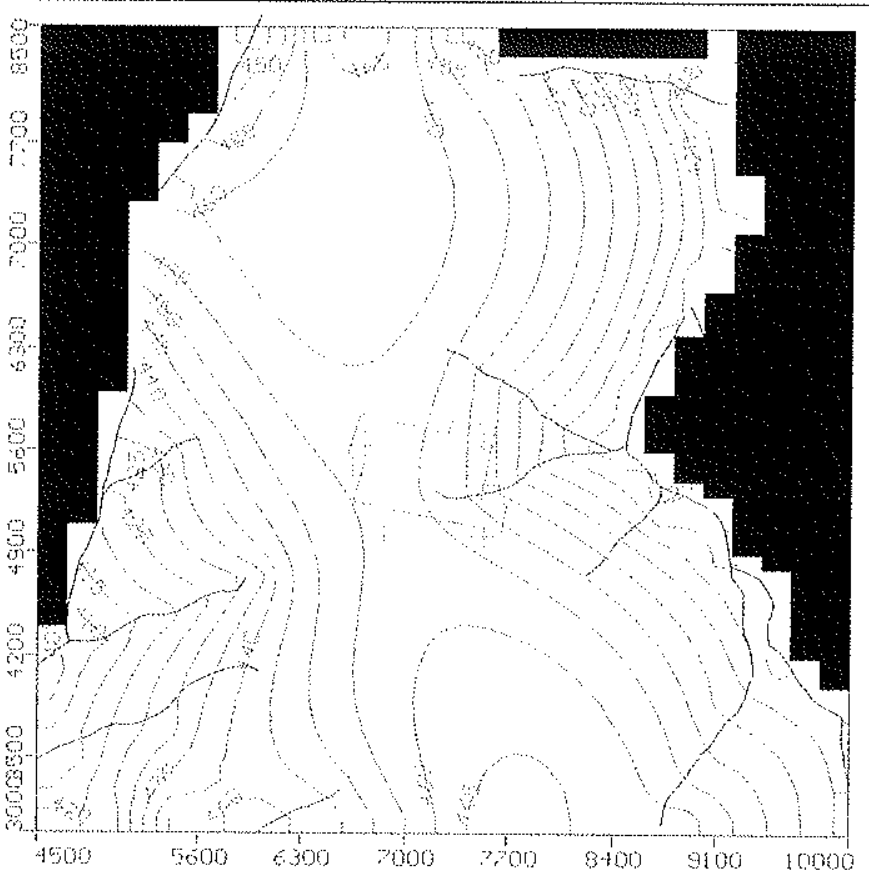

Figura 2 - Potenciometria da cidade de Urânia e arredores (Hirata, 2000)

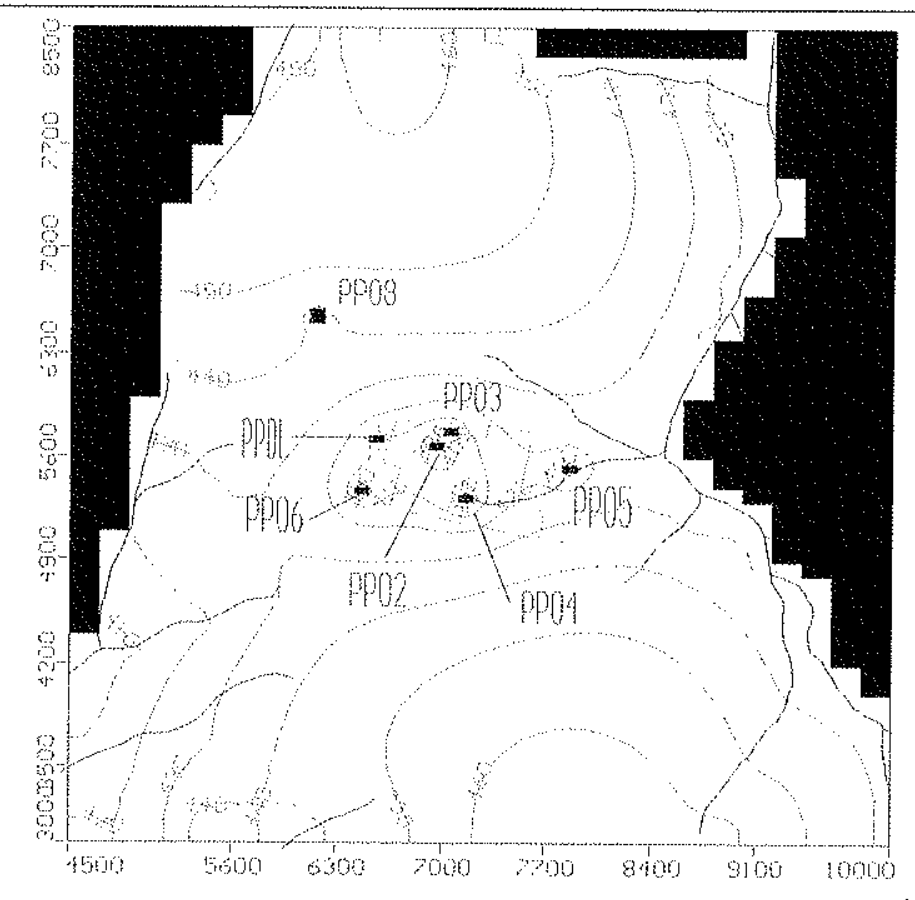

Figura 3 - Potenciometria da cidade de Urânia e arredores com a operação dos poços profundos da SABESP (Hirata, 2000) 
DAEE (1976), estudando a região de Bauru, São José do Rio Preto, Araçatuba, Presidente Prudente e Marília, identificou dois grupos hidrogeoquímicos principais: $\mathrm{rCa}>\mathrm{rMg}>\mathrm{rNa}$ e $\mathrm{rHCO}_{3}>>\mathrm{rCl}$, para as águas pertencentes ao Bauru Superior e $\mathrm{rNa}>\mathrm{rCa}>\mathrm{rMg}$ e $\mathrm{rHCO}_{3}>>\mathrm{rCl}$, refletindo um enriquecimento em sódio, provenientes de um aqüífero mais profundo. As águas do primeiro grupo são classificadas como bicarbonatadas cálcicas, secundariamente magnesianas ou sódicas e as do segundo grupo, bicarbonatadas sódicas, secundariamente cálcicas.

No estudo da bacia do rio São José dos Dourados, realizado por Mezzalira et al. (1979), foram analisados $\delta^{18} \mathrm{O}, \delta^{3} \mathrm{H} \mathrm{D}, \mathrm{P}, \mathrm{Cl}, \mathrm{Mg}, \mathrm{NH}_{4} \mathrm{e} \mathrm{NO}_{3}$. A conclusão destes autores foi de que as águas não apresentam fortes sinais de evaporação durante a recarga, o que indica um sistema de rápida infiltração e de alta condutividade hidráulica.

Rocha et al. (1982) sugerem um zoneamento hidrogeoquímico do Sistema Aqüifero Bauru. Dois domínios são indicados: águas bicarbonatadas cálcicas e águas bicarbonatadas cálciomagnesianas. Nos espigões e planaltos, correspondentes aos arenitos da parte superior da Formação Adamantina e Formação Marilia, as águas apresentam concentrações salinas mais elevadas, fortemente bicarbonatadas cálcicas. A partir dos espigões, nos vales, as concentrações salinas diminuem, às vezes na mesma formação, e as águas são do tipo bicarbonatadas cálcicamagnesianas. Nesta progressão, a ocorrência de águas bicarbonatadas sódicas no extremo sudoeste sugere uma evolução hidrogeoquímica no sentido $\mathrm{Ca} \rightarrow \mathrm{Mg} \rightarrow \mathrm{Na}$, de montante para jusante dos principais rios interiores que percolam o Grupo Bauru.

Segundo Campos (1987 e 1993), as águas do Sistema Aqüífero Bauru apresentam dois tipos químicos dominantes: águas bicarbonatadas cálcio-magnesianas e águas bicarbonatadas cálcicas. Os estudos estatísticos mostram que os íons $\mathrm{HCO}_{3}^{-}, \mathrm{Ca}^{2+}{\mathrm{e} \mathrm{Mg}^{2+}}^{2}$ são os principais responsáveis no processo de enriquecimento salino das águas. A composição mineralógica dos sedimentos das distintas formações do Grupo Bauru (com exceção da Formação Caiuá) parece contribuir significativamente para a predominância destes íons maiores. $O$ carbonato de cálcio (calcrete) e os argilo-minerais, constituintes do cimento das litofácies, devem ser as principais fontes de enriquecimento iônico do meio aqüífero. 
Hirata (2000) estudou a hidrogeoquímica das águas subterrâneas dos poços cacimba e tubulares profundos da cidade de Urânia. Observou que há uma evolução química da água de fluxos mais rasos para os mais profundos de nitratada cálcica (poços cacimba - $\mathrm{pH}$ médio de 5,3) para bicarbonatada cálcica (poços tubulares de particulares, com média de $80 \mathrm{~m}$ de profundidade - pH médio de 6,4) e depois para bicarbonatada sódica (poços profundos da SABESP, com média de $140 \mathrm{~m}$ de profundidade $-\mathrm{pH}$ médio de 7,3). O nitrato dos poços cacimba é considerado um poluente com origem ligada à ocorrência de carga orgânica em fossas e/ou à aplicação de fertilizantes. Com a profundidade, ocorre a dispersão do nitrato e o ânion dominante passa a ser o bicarbonato. Dentre os cátions, o cálcio predomina em superfície e diminui gradativamente em profundidade, enquanto o sódio vai se enriquecendo, também de forma gradativa. Os prováveis mecanismos hidrogeoquímicos que ocorrem em maiores profundidades e que explicam o comportamento dos cátions maiores são a dissolução de minerais com sódio e/ou a troca iônica do sódio pelo cálcio e magnésio na fase sólida.

Almodovar (1995) constatou a ocorrência de concentrações anômalas e acima dos limites de potabilidade de cromo na água subterrânea do Sistema Aqüífero Bauru em vários municípios do oeste paulista. Almodovar (2000), continuando esta investigação, realizou um estudo de maior detalhe em Urânia a fim identificar as causas da origem do cromo na água subterrânea naquele município. Como resultado, identificou que a origem do cromo é natural e não está ligada a nenhum evento de poluição de origem antrópica, que os sedimentos apresentam elevadas concentrações do elemento em relação a outros contextos geológicos e que as águas de circulação mais profunda e de maior tempo de trânsito no aqüffero são aquelas que apresentam as maiores concentrações de cromo. A utilização de modelos de equilíbrio químico pela autora resultaram, inclusive, na existência de ambiente hidroquímico favorável à dissolução de minerais com cromo. 


\section{Material e Método}

\subsection{Instalação da Estação de Monitoramento}

\subsubsection{Critério de Locação da Estação}

Para possibilitar a caracterização da hidráulica da infiltração da água na zona não saturada e da sua evolução hidrogeoquímica até o aquuífero freático, uma estação de monitoramento foi construída junto ao poço PP-06 da SABESP (Figura 4). A estação de monitoramento consiste de um poço escavado onde tensiômetros e lisímetros de sucção foram instalados ao longo da sua parede. Este método de monitoramento de potenciais matriciais e de coleta de amostras de água através de equipamentos instalados na parede do poço escavado justifica-se pois previa-se que o nível d'água estaria abaixo dos $7 \mathrm{~m}$ de profundidade, o que implicaria em dificuldades nas amostragens de água através dos lisímetros em profundidades maiores que esta, caso estes estivessem instalados da forma tradicional, junto à superfície.

O principal critério para a locação da estação era de que esta deveria situar-se sobre a zona de contribuição de um poço profundo da SABESP com histórico de ocorrência de elevados índices de cromo na sua água. Desta forma, o local de execução do poço escavado deu-se ao lado do poço PP-06 e no interior da área cercada ao redor deste poço. Este local foi o escolhido por ser de propriedade da SABESP, o que facilitaria o monitoramento dos equipamentos instalados por longos períodos e por atender a questões de logística e segurança.

\subsubsection{Perfuração, Revestimento e Acesso ao Poço}

A fim de ilustrar alguns aspectos da forma de construção da estação de monitoramento, vide relatório fotográfico apresentado no Anexo 1. Os principais aspectos construtivos da estação de monitoramento descritos a seguir, foram publicados inicialmente em Bertolo \& Hirata (2000).

$\mathrm{O}$ poço da estação de monitoramento foi escavado no diâmetro médio de $1,75 \mathrm{~m} \mathrm{e}$ alcançou a profundidade de $11,0 \mathrm{~m}$, sendo que o nível d'água foi atingido a $9,78 \mathrm{~m}$. O diâmetro do poço foi determinado com o propósito de ser possível realizar os trabalhos posteriores de instalação e monitoramento dos equipamentos. O critério utilizado para a interrupção da escavação foi o de se atingir um substrato que pudesse sustentar o peso dos tubos de revestimento, o que ocorreu a $11 \mathrm{~m}$, quando a escavação atingiu um estrato de arenito duro. A Figura 5 apresenta os detalhes construtivos do poço. 


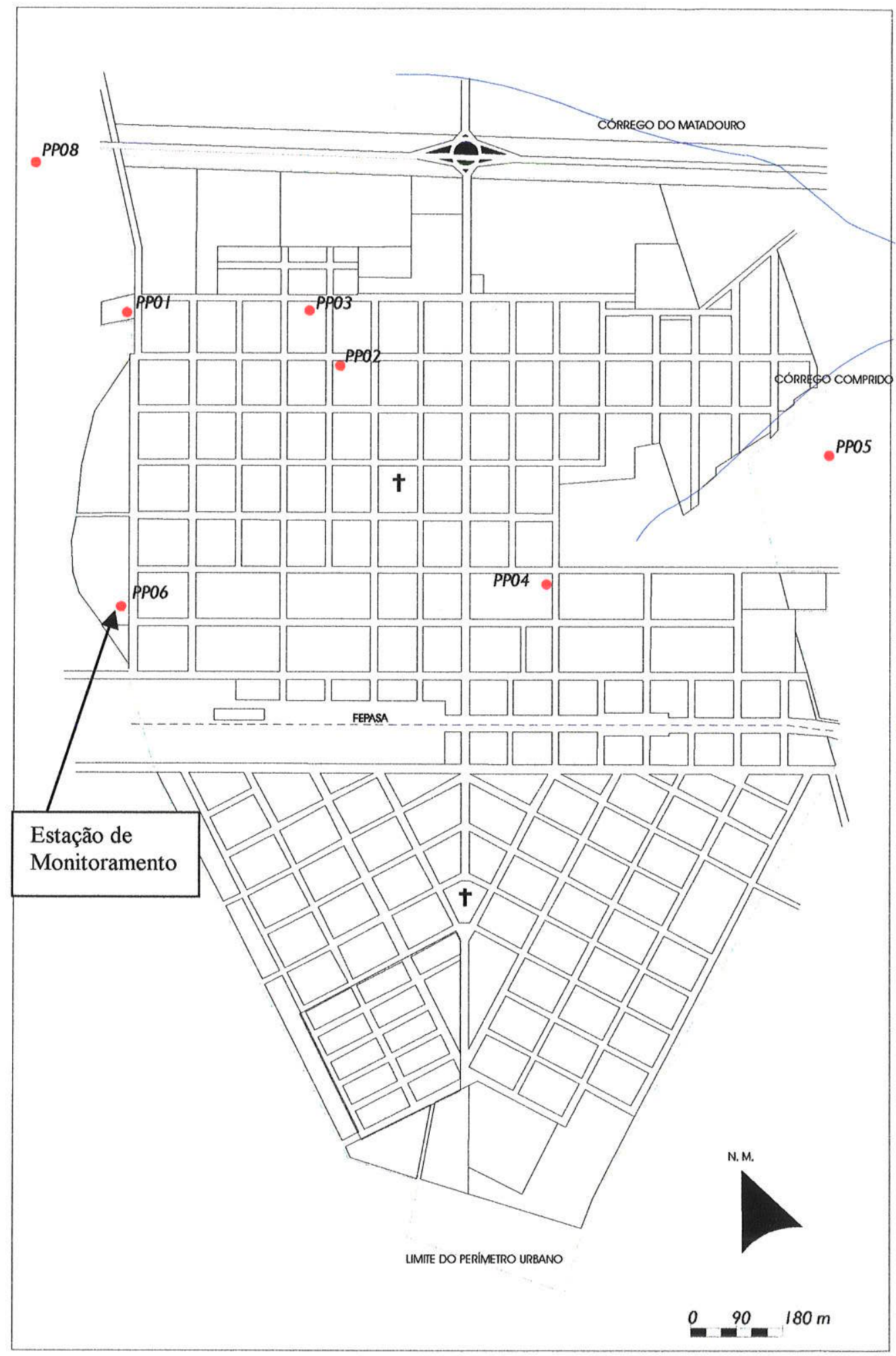

- Localização dos poços tubulares profundos da SABESP.

Figura 4 - Localização da estação de monitoramento na área urbana de Urânia 


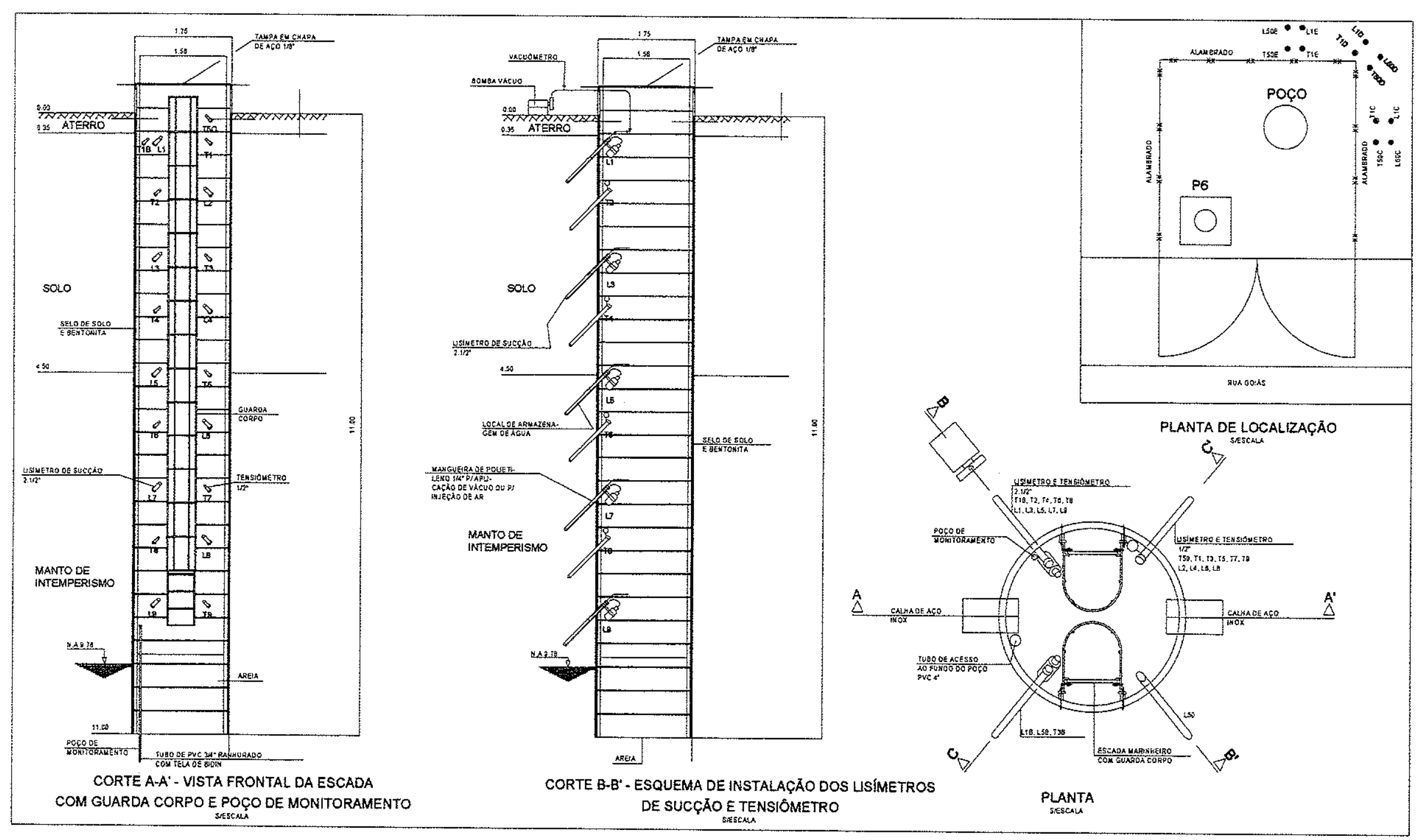

Figura 5 - Planta construtiva da estação de monitoramento da zona não saturada 
O revestimento do poço foi feito com a utilização de 28 anéis de concreto armado de $1,62 \mathrm{~m}$ de diâmetro externo, $6 \mathrm{~cm}$ de espessura e $40 \mathrm{~cm}$ de altura, representando um peso estimado em $300 \mathrm{~kg}$ cada unidade. O último anel colocado representa a elevação de $50 \mathrm{~cm}$ do poço em relação à superficie do solo para a colocação da tampa (Figura 5 - cortes A-A' e B-B'). O método de fabricação destes anéis consistiu na colocação de uma estrutura de ferro em forma de malha circular dentro do molde e o preenchimento do espaço com concreto, que foi vibrado antes de sua secagem, de forma a evitar a ocorrência de bolhas de ar no interior da estrutura do anel. Este procedimento promove um adensamento do cimento, acarretando uma maior resistência e prolongamento da vida útil do anel, evitando a ocorrência prematura de rachaduras e a oxidação da estrutura de ferro.

O espaço anelar entre a parede da perfuração e o anel de revestimento no trecho acima do nível d'água foi preenchido com uma mistura de bentonita e o próprio solo perfurado. Este procedimento favorece a impermeabilização da parede do poço revestido através da hidratação e expansão do volume da bentonita, evitando que a água da zona não saturada possa entrar dentro do poço através do espaço existente entre um anel e outro, o que promoveria interferências nas leituras dos tensiômetros e perdas da água de amostragem dos lisímetros de sucção. Abaixo do nível d'água, o preenchimento do espaço anelar se deu com o próprio material da perfuração. $\mathrm{O}$ último 0,5 $\mathrm{m}$ de espaço anelar foi preenchido com uma mistura de solo, bentonita e cimento, garantindo uma boa vedação e resistência deste espaço anelar junto à boca do poço.

O acesso ao interior do poço se dá através de duas escadas de ferro com guarda corpo de $9,5 \mathrm{~m}$ de comprimento cada, situadas uma oposta à outra. A construção da escada seguiu uma adaptação das normas SABESP de construção de escadas tipo marinheiro. As escadas são fixadas nos anéis do revestimento do poço através de ganchos rosqueados a pinos fixados nos anéis, situados a cada $1,20 \mathrm{~m}$, garantindo rigidez e segurança à estrutura (Figura 5, corte A-A').

O fundo do poço, após a instalação do poço de monitoramento, foi preenchido com $2 \mathrm{~m}^{3}$ de areia grossa limpa, desde os $11,0 \mathrm{~m}$ até $9,6 \mathrm{~m}$ (Figura 5, corte $\mathrm{A}-\mathrm{A}^{\prime}$ ). Desta forma, em janeiro/99, o fundo do poço apresentava-se seco, com o nível d'água situando-se $0,18 \mathrm{~m}$ abaixo do nivel aterrado.

A boca do poço é fechada por uma tampa em chapa de ferro redonda de $1 / 8$ " de espessura e 1,68 m de diâmetro. Esta tampa possui duas alças e é fixada por dois cadeados fixados na parede do último anel do revestimento, garantindo a segurança (Figura 5). 


\subsubsection{Instalação dos Equipamentos de Monitoramento}

No interior do poço escavado e revestido foi realizada a instalação de equipamentos para a coleta de amostras (lisímetros de sucção) e para o monitoramento do comportamento hidráulico da água de infiltração da zona não saturada (tensiômetros). A água do aqüífero freático também pode ser monitorada e amostrada, através de um poço de monitoramento instalado no fundo do poço escavado.

Os detalhes construtivos dos equipamentos instalados encontram-se na Figura 5. Apresenta-se a seguir uma descrição técnica dos equipamentos instalados, bem como dos seus procedimentos de pré-instalação e de instalação.

\section{a-Poço de Monitoramento}

O poço de monitoramento do aqüífero freático é constituído por um tubo de PVC branco de $3 / 4$ " com ponteira, $2,5 \mathrm{~m}$ de comprimento e $0,5 \mathrm{~m}$ de seção filtrante envolta por uma manta de bidim. Após os trabalhos de escavação, foi realizado um furo de sondagem de $0,5 \mathrm{~m}$ de profundidade sobre uma das surgências do poço, dentro do qual foi colocada a seção filtrante do poço de monitoramento, que atingiu a profundidade total de $11,5 \mathrm{~m}$ (Figura 5 , Corte A-A $\mathrm{A}^{3}$ ). Todo o espaço existente no poço escavado até o nível d'água foi, então, preenchido com areia grossa. A boca do poço de monitoramento encontra-se a $70 \mathrm{~cm}$ do fundo do poço.

\section{$b-$ Tensiômetros}

O tensiômetro consiste de uma cápsula de cerâmica conectada a um vacuômetro através de um tubo de PVC com água. A cápsula de cerâmica, enterrada no solo até a profundidade desejada, transmite a tensão da água do solo para o vacuômetro. O monitoramento do tensiômetro objetiva a obtenção do potencial matricial do solo, que, somado ao potencial de elevação, fornece o dado de potencial hidráulico de determinado ponto (Equação 1).

O tensiômetro utilizado compreende uma cápsula de cerâmica porosa de $1 / 2$ " por $6 \mathrm{~cm}$ de comprimento conectada a um tubo de PVC de $1 / 2$ " por $1 \mathrm{~m}$ de comprimento com tampa rosqueável (Figura 5). Um vacuômetro analógico foi instalado na extremidade do tubo, sendo possível a obtenção de leituras variando de 0 a $-760 \mathrm{mmHg}\left(-10,3 \mathrm{~m} \mathrm{H}_{2} \mathrm{O}\right)$ e precisão de 20 $\mathrm{mmHg}\left(0,27 \mathrm{~m} \mathrm{H}_{2} \mathrm{O}\right)$. 
$O$ procedimento de pré-instalação consistiu no preenchimento total do tubo do tensiômetro com água destilada previamente fervida e, portanto, isenta de gases dissolvidos. A presença de gases dissolvidos na água promove o surgimento de bolhas de ar no interior no tensiômetro, que supostamente provocam imprecisões na leitura das medidas de potenciais matriciais (ASTM, 1996).

Doze tensiômetros foram instalados no poço, formando uma inclinação de $45^{\circ}$ com a parede do revestimento do poço, sendo que as cápsulas porosas situam-se no interior do material escavado, distando cerca de $60 \mathrm{~cm}$ da parede do revestimento do poço. Os tensiômetros foram instalados nas posições C', B e C do poço em duas campanhas de campo (Figura 5). Na posição $\mathrm{C}^{\prime}$, foram instalados os tensiômetros T50, T1, T3, T5, T7 e T9 nas profundidades de 0,5, 1, 3, 5, 7 e 9 m (janeiro/99); na posição B foram instalados os tensiômetros T1B, T2, T4, T6 e T8 nas profundidades de 1, 2, 4, 6 e $8 \mathrm{~m}$ (maio/99); e na posição $\mathrm{C}$ foi instalado o tensiômetro T3B na profundidade de $3 \mathrm{~m}$ (maio/99).

O método de instalação dos tensiômetros consistiu na quebra da parede do anel do revestimento e a perfuração do solo com um trado manual de $1 / 2$ " de forma helicoidal, especialmente fabricado para a instalação deste tipo de equipamento. Após a perfuração até a profundidade desejada, foi executada uma mistura do material perfurado com água, formando uma calda bem mole, que foi introduzida no interior do furo. Após este procedimento, o tensiômetro foi cuidadosamente empurrado para dentro do furo até a profundidade final. Este procedimento visa assegurar que a cápsula porosa esteja toda em contato com o solo, a fim de garantir a existência de conexão hidráulica entre a cápsula e o material do solo. Após a colocação do tensiômetro, foi realizado o preenchimento do furo do anel do revestimento com uma pasta de bentonita pura e feito o acabamento final com cimento.

Uma terceira campanha de campo foi realizada em agosto/99 para instalação de outros 6 tensiômetros em superfície e na área externa do poço, conforme localização na planta de localização da Figura 5, sendo três instalados a $0,5 \mathrm{~m}$ e outros três a $1 \mathrm{~m}$ de profundidade (tensiômetros T50C, T50D, T50E, T1C, T1D e T1E). A instalação destes tensiômetros objetivou investigar a variação lateral da tensão capilar do solo provocada pela presença de vegetação $\mathrm{e}$ heterogeneidades da estrutura do solo, bem como a possível influência do material de aterro existente ao redor do poço. 


\section{c-Lisimetros de Sucção com Cápsula Porosa de Cerâmica}

Lisímetro de sução é utilizado para a amostragem de água da zona não saturada e consiste de uma cápsula porosa de cerâmica conectada ao corpo de um tubo. As amostras de água são obtidas através da aplicação de vácuo no interior do amostrador, que induz a entrada da água da zona não saturada através da cápsula porosa, sendo armazenada no interior do corpo do tubo. Posteriormente, a água armazenada é coletada em garrafas de amostragem através da despressurização do sistema e da aplicação de ar sob pressão no interior do tubo.

O lisímetro utilizado compreende uma cápsula de cerâmica porosa de $2 \frac{1 / 2 "}{2}$ por $6 \mathrm{~cm}$ de comprimento conectada a um tubo de PVC de $2 \frac{1}{2}$ " por $1 \mathrm{~m}$ de comprimento com tampa.

Todos os lisímetros instalados passaram por dois tipos de procedimentos de préinstalação realizados em laboratório, de acordo com a norma ASTM (1996). O primeiro procedimento consistiu na descontaminação das cápsulas porosas e o segundo correspondeu aos testes de vazamentos nos equipamentos.

A descontaminação das cápsulas porosas é um procedimento importante pois os seus poros podem ter sido contaminados com poeira durante a sua fabricação. O método de descontaminação consistiu em fazer passar uma solução de ácido clorídrico $1 \mathrm{~N}$ através da seção porosa por 24 horas, seguida de enxágüe com água destilada, até que a condutividade elétrica da água que saía das cápsulas apresentasse valor semelhante ao da condutividade elétrica da água destilada utilizada. A norma ASTM (1996) recomenda a utilização de ácido clorídrico $8 \mathrm{~N}$, porém a cola das conexões do lisímetro é corroída quando se utiliza o ácido nesta concentração.

Outro procedimento foi o teste de vácuo, realizado para evitar vazamentos de ar durante o processo de amostragem da água. $O$ teste consistiu na ligação de uma bomba a vácuo na mangueira de ar do lisímetro e na ligação de um vacuômetro na mangueira de amostragem. Aplicou-se uma sucção de $-650 \mathrm{mmHg}$ no sistema e monitorou-se esta sucção aplicada em função do tempo. Verificou-se ser freqüente a ocorrência de vazamentos, principalmente na cola da junção entre a cápsula e o corpo do tubo dos lisímetros. Corrigido os problemas que se apresentaram na cola das junções, verificou-se que todas as cápsulas porosas apresentaram valores de suç̧ão de entrada de ar (ou, em inglês, "air entry value") inferiores a-650 mmHg. 
Doze lisimetros de sucção foram instalados no poço, cada qual formando uma inclinação de $45^{\circ}$ com relação à parede do revestimento do poço, sendo que as cápsulas porosas situam-se no interior do material escavado e distando cerca de $60 \mathrm{~cm}$ da parede do revestimento do poço. Zilberbrand \& Gvirtzman (1996) observaram que quando as cápsulas porosas dos lisímetros de sucção e dos tensiômetros são instalados numa distância horizontal de mais de $0,5 \mathrm{~m}$ da parede do revestimento, não ocorrem interferências significativas da parede do poço sobre os resultados das análises químicas e as leituras de tensão capilar.

Os lisímetros de sucção foram instalados nas posições B, C', B' e C do poço em duas campanhas de campo (Figura 5). Na posição B, foram instalados os lisímetros L1, L3, L5, L7 e L9 nas profundidades de 1, 3, 5, 7 e $9 \mathrm{~m}$ (janeiro/99); na posição $\mathrm{C}^{\prime}$ foram instalados os lisímetros L2, L4, L6 e L8 nas profundidades de 2, 4, 6 e $8 \mathrm{~m}$ (maio/99); na posição B' foi instalado o lisímetro $L 50$ na profundidade de $0,5 \mathrm{~m}$ (maio/99); e na posição $\mathrm{C}$ foram instalados os lisímetros L1B e L5B nas profundidades de 1 e $5 \mathrm{~m}$. Optou-se pela colocação dos lisímetros de forma intercalada nas posições $\mathrm{B}$ e C' (e não exatamente um sob o outro numa única fila), pois na época da instalação não havia informações sobre a possibilidade de ocorrência de interferências entre os cones de sucção, o que diminuiria o volume de água de amostragem já naturalmente escasso de cada lisímetro. Mais tarde, verificou-se em Hart \& Lowery (1997) que os raios de influência são pequenos e que este cuidado não precisaria ser tomado.

O método de instalação dos lisímetros é semelhante ao descrito para a instalação dos tensiômetros, utilizando-se, porém, de um trado manual de $2 \frac{1}{2}$ " para a perfuração. Ao contrário do sugerido em ASTM (1996), porém, a perfuração não foi realizada num diâmetro maior que o do lisímetro para que pudesse ser possível a utilização de pó de sílica, que é utilizada para melhorar o contato hidráulico entre a parede da perfuração e a cápsula porosa. Isto implicaria na realização de uma perfuração muito larga na parede do revestimento.

Em agosto/99, seis novos lisímetros de sucção foram instalados em superfície e na área externa do poço, conforme localização na Figura 5 , sendo três instalados a $0,5 \mathrm{~m}$ e outros três a 1 $m$ de profundidade (lisímetros L50C, L50D, L50E, L1C, L1D e L1E). A instalação destes lisímetros objetivou complementar a investigar a variação lateral da qualidade da água do solo, bem como a influência do material de aterro existente ao redor do poço sobre a qualidade da água do solo nestas profundidades. 


\subsection{Coleta e Análises de Amostras de Solo}

Durante a escavação do poço, 13 amostras de solo foram coletadas para a realização de análises granulométricas, químicas e mineralógicas. Outras 6 amostras de solo foram também coletadas nos furos dos lisímetros externos ao poço para a execução de análises granulométricas e químicas. A Tabela 4 apresenta o tipo de análise, número de amostras, o método da análise realizada e o laboratório utilizado para as análises:

\begin{tabular}{|c|c|c|c|}
\hline \multicolumn{4}{|c|}{ Tabela 4 - Análises realizadas em amostras deformadas de solo } \\
\hline Análise & $\begin{array}{l}\text { Número de } \\
\text { Amostras }\end{array}$ & Método & Laboratório \\
\hline Granulometria ${ }^{(1)}$ & 19 & $\begin{array}{l}\text { Espectroscopia por } \\
\text { correlaçäo de fótons } \\
\text { (ISO, 1996) }\end{array}$ & $\begin{array}{c}\text { Escola Politécnica } \\
\text { LCT-Eng Minas - USP }\end{array}$ \\
\hline Granulometria & 4 & $\begin{array}{l}\text { Peneiramento e } \\
\text { pipetagem } \\
\text { (Suguio, 1973) }\end{array}$ & DGSA/IGc/USP \\
\hline Análise Mineralógica & 13 & Microscopia Óptica & $\mathrm{DMG} / / \mathrm{Gc} / \mathrm{USP}$ \\
\hline Análise Mineralógica ${ }^{(2)}$ & 23 & $\begin{array}{l}\text { Difraçäo } \\
\text { de raio } X\end{array}$ & $\begin{array}{l}\text { Lab. Difração Raio X } \\
\text { DMG/IGc/USP }\end{array}$ \\
\hline Análise Química ${ }^{(1)}$ & 30 & $\begin{array}{c}\text { ICP-AES Plasma } \\
\text { (Janasi et al., 1996) }\end{array}$ & $\begin{array}{l}\text { Lab. Química e ICP-AES - } \\
\text { DMG/IGC/USP }\end{array}$ \\
\hline Análise Química & 3 & $\begin{array}{l}\text { Microscopia Eletrônica } \\
\text { de Varredura }\end{array}$ & $\begin{array}{c}\text { DGSA/GC/USP e } \\
\text { Esc. Politécnica Enga Minas - USP }\end{array}$ \\
\hline $\begin{array}{l}\text { Capacidade de Troca de } \\
\text { Cátions, pH do solo e teor } \\
\text { de matéria orgânica }\end{array}$ & 15 & $\begin{array}{c}\text { Vários } \\
\text { (Raij \& Quaggio, 1983) }\end{array}$ & $\begin{array}{l}\text { Lab. Centro Ciências Agrárias - } \\
\text { UFSCar - Araras - SP }\end{array}$ \\
\hline
\end{tabular}

(1) Parte dos resultados publicados inicialmente em Almodovar (2000)

(2) Seleção, tratamento de amostras, execução de ensaios e publicação inicial dos resultados em Almodovar (2000).

Análises químicas por ICP-AES e mineralógicas por difração de raio $\mathrm{X}$ foram executadas em todas as amostras de solo total e em três amostras da fração fina, três amostras dos minerais leves e três amostras dos minerais pesados. $O$ tratamento das amostras de solo para a obtenção da fração fina, dos minerais leves e dos minerais pesados foi realizado por Almodovar (2000), através de peneiramento via úmido. O peneiramento separou a amostra de solo em fração fina em uma peneira de 635 mesh $(20 \mu \mathrm{m})$. A fração retida na peneira (grossa) foi utilizada para separar, por densidade, os minerais leves dos pesados, através do uso de bromofórmio $(\mathrm{d}=2,89 \mathrm{~kg} / \mathrm{L})$. 


\subsubsection{Análises Granulométricas}

O método de análise de espectroscopia de correlação de fótons consiste em iluminar a amostra de solo/sedimento dispersa em água com um feixe de raios laser monocromático. A luz é dispersada pelas partículas num ângulo (freqüentemente $90^{\circ}$ ) que é registrado por um detetor, cuja saída alimenta um correlator ligado a uma central de processamento de dados. $\mathrm{O}$ decaimento da função de correlação da intensidade do espalhamento é interpretado pelo método cumulativo em termos do tamanho médio das partículas e do índice de polidispersividade (ISO, 1996). Os resultados apresentados no relatório foram interpretados considerando as seguintes faixas granulométricas: argila $(<2 \mu \mathrm{m})$, silte $(2$ a $65,61 \mu \mathrm{m})$, areia fina $(65,61$ a $258,95 \mu \mathrm{m})$, areia média $(258,95$ a $477,01 \mu \mathrm{m})$ e areia grossa $(>477,01 \mu \mathrm{m})$.

Novos ensaios de granulometria foram realizados utilizando-se do método de peneiramento e pipetagem a fim de se confirmar os resultados obtidos com o método de espectroscopia de correlação de fótons. Esta confirmação justifica-se pois, de forma inesperada, a fração argila não foi detectada por este método.

$\mathrm{O}$ método de peneiramento e pipetagem consiste em se realizar o peneiramento das faixas granulométricas maior que silte grosso $(0,02 \mathrm{~mm}$ de diâmetro) e a pipetagem das frações granulométricas menores (argila e silte fino) após tempo padrão de sedimentação segundo a Lei de Stokes, utilizando-se da pipeta de Robinson. Os resultados apresentados no relatório consideram as seguintes faixas granulométricas: argila $(<2 \mu \mathrm{m})$, silte fino $(2$ a $20 \mu \mathrm{m})$, silte grosso $(20 \mathrm{a} 50 \mu \mathrm{m})$, areia fina $(50 \mathrm{a} 200 \mu \mathrm{m})$ e areia média + grossa $(>200 \mu \mathrm{m})$.

\subsubsection{Análises Mineralógicas}

Foram confeccionadas 13 lâminas petrográficas do material deformado do solo coletado nas profundidades de 0,2 a $11,5 \mathrm{~m}$. A confecção das lâminas petrográficas foi precedida pela impregnação das amostras de solo com uma resina formada por uma mistura de araldite, endurecedor e acetona comercial. As análises mineralógicas foram realizadas em microscópios de luz transmitida para a seleção de minerais que foram analisados semi-quantitativamente no microscópio eletrônico de varredura (MEV). 
Análises mineralógicas por difração de raios $\mathrm{X}(\mathrm{DRX})$ foram inicialmente executadas por Almodovar (2000) e os resultados obtidos são reinterpretados neste trabalho. Foram analisadas 14 amostras de solo total, 2 amostras da fração fina, 3 amostras da fração leve (densidade menor que $2,89 \mathrm{~kg} / \mathrm{L}$ ) e 3 amostras da fração pesada (densidade maior que 2,89 $\mathrm{kg} / \mathrm{L})$.

O princípio de funcionamento do equipamento relaciona-se com a emissão de feixes de raios $X$ através de um tubo até o difratômetro, onde se encontra a amostra analisada. Os raios $\mathrm{X}$ são difratados de forma diferente em função de cada espécie mineral; os raios difratados passam por um detetor, sendo posteriormente amplificados e depois lidos.

O difratômetro utilizado (Siemens-Bruker, modelo D5000) contém tubos de raios X de cobre e apresentava condições de operação de $40 \mathrm{kV}$ e $40 \mu \mathrm{A}$ e varredura $2 \theta$ variando de $3^{\circ}$ a $65^{\circ}$, com $0,05^{\circ}$ num tempo de 2 segundos. As amostras foram satisfatoriamente acondicionadas de acordo com Buhrke (1998). A identificação dos minerais foi realizada através do programa DIFFRAC-plus e pela comparação com o Powder Diffraction File-PDF do ICDD (1995).

\subsubsection{Análises Químicas}

\section{a-Análise Química por ICP/AES-Plasma}

Análises químicas por ICP/AES-Plasma foram executadas em 26 amostras de solo total (18 amostras de solo do poço, 7 amostras externas ao poço e 1 amostra do material de mistura de solo do poço com bentonita), 4 amostras da fração fina, 3 amostras da fração leve e 3 amostras da fração pesada.

O método analítico foi desenvolvido por Janasi et al. (1996). As amostras foram previamente moídas até uma granulação menor que 200 mesh em uma panela de carbeto de tungstênio. Em seguida, foram determinados, em parcelas das amostras, os parâmetros umidade (por diferença de peso entre a amostra total e a amostra seca em estufa a $100^{\circ} \mathrm{C}$ ) e perda de massa de elementos voláteis a fogo (também por diferença de peso entre a amostra total e amostra submetida a $1000^{\circ} \mathrm{C}$ de temperatura). As amostras foram, então, submetidas à fusão alcalina (em cadinhos de grafite contendo fundente de metaborato e tetraborato de lítio em forno de $1000^{\circ} \mathrm{C}$ de temperatura) e transformadas em soluções aquosas após ataques com os ácidos nítrico e fluorídrico. Estas soluções foram posteriormente analisadas para os principais elementos maiores e menores no ICP/AES, que corresponde a um espectrômetro seqüencial de emissão atômica com plasma induzido acoplado. 
Foram executados três tipos de controle de qualidade das análises, através de duplicatas, branco de laboratório e soluções padrão, sendo os resultados apresentados no Anexo 6. Análises duplicatas foram realizadas nas amostras de solo total do poço coletadas em 2,6 e $9 \mathrm{~m}$, na amostra 6F (fração fina) e na amostra de solo total L1D. A maioria dos parâmetros apresentaram excelentes resultados reprodutivos e abaixo dos $10 \%$ (que é considerado como o limite de aceitação do resultado da análise), com exceção do $\mathrm{Na}_{2} \mathrm{O}(6 \mathrm{~m}), \mathrm{P}_{2} \mathrm{O}_{5}(\mathrm{~L} 1 \mathrm{D}$ e $6 \mathrm{~F})$ e $\mathrm{Ni}(2 \mathrm{~m})$. Alguns resultados foram ligeiramente inferiores a $10 \%$ como o $\mathrm{CaO}(6 \mathrm{~m}), \mathrm{Na}_{2} \mathrm{O}(9 \mathrm{~m}), \mathrm{K}_{2} \mathrm{O}$ (L1D), dentre outros. Nesses casos, porém, o resultado encontra-se próximo do limite de deteç̧ão das análises. As análises de branco de laboratório forneceram excelentes resultados, quase sempre inferiores ao limite de deteç̧ão do método de análise, o que atesta a não ocorrência de contaminação no laboratório. As duas análises de soluções padrão (Nist 2709 e Nist 2711) indicaram excelente reprodutibilidade dos resultados obtidos e certificados para todos os compostos, exceto o ZrO. Observa-se, entretanto, que a diferença absoluta entre os resultados das análises obtidas e certificadas para os parâmetros $\mathrm{CaO}, \mathrm{Na}_{2} \mathrm{O}$ e $\mathrm{K}_{2} \mathrm{O}$ são mais elevadas que os resultados desses parâmetros obtidos na maior parte das amostras analisadas, o que faz ser importante interpretar esses resultados com reservas, principalmente porque os elementos $\mathrm{Ca}$, $\mathrm{Na}$ e $\mathrm{K}$ ocorrem de forma muito pouco concentrada nas amostras de solo e próximos do limite de deteç̧ão das análises.

A amostra de mistura de solo do poço com bentonita, utilizada como material de preenchimento do espaço anelar entre o furo e o revestimento do poço, foi analisada no ICPAES/Plasma, para verificar se os minerais constituintes da bentonita poderiam interferir nas análises químicas da água da zona não saturada. Os resultados obtidos na análise (Anexo 6) não diferem significativamente dos resultados das demais amostras analisadas, de onde se conclui que o material de preenchimento não deve interferir na qualidade da água da zona não saturada.

\section{b-Microscópio Eletrônico de Varredura (MEV)}

$\mathrm{OMEV}$ foi utilizado com o objetivo de caracterizar quimicamente os minerais primários e secundários observados na etapa de microscopia ótica, notadamente com relação à localização dos elementos $\mathrm{Na}, \mathrm{K}$, Ca e Mg no solo.

O MEV é composto por detetor de elétrons secundários (morfologia dos grãos), detetor de elétrons retroespalhados (contraste dos grãos), catodoluminescência e espectrômetro de energia dispersiva EDS (Energy Dispersive System). O princípio de funcionamento consiste em 
se fazer atingir um feixe de elétrons através de um mineral, cujos átomos ionizam-se e ejetam elétrons de suas camadas internas. Para recuperar a estabilidade, os elétrons de outras camadas substituem as vacâncias geradas, emitindo determinadas quantias de energia, cuja medida permite identificar os elementos presentes no material analisado.

Os microscópios utilizados foram os do DGSA/IGc/USP e do LCT/Poli-Minas/USP. Antes do início das seções no $\mathrm{MEV}$, as lâminas petrográficas sofreram tratamento através de recobrimento com um filme de carbono. No microscópio do DGSA/IGc/USP foram realizadas, na lâmina de solo de $10,0 \mathrm{~m}$, análises semi-quantitativas em cinco pontos e a utilização da técnica "line scan" em uma ocasião, que corresponde a uma varredura de alguns elementos ao longo de uma linha. As condições analíticas do EDS em todas as análises foram de $20 \mathrm{kV}$ de voltagem de trabalho, $25 \mathrm{~mm}$ de distância de trabalho, calibração das energias em cobalto e tempo de exposição ao feixe de 100 segundos. A avaliação dos resultados do EDS é dada pelos valores de correlação interna, que devem situar-se próximos de 1. De uma forma geral, esses valores foram próximos de 0,7 para o oxigênio, cloreto e ferro nos pontos $1.1,6.1$ e 6.3 , e variando entre 0,85 e 1 para todos os demais elementos em todas as lâminas.

No microscópio do LCT/Poli-Minas/USP, foram analisadas as lâminas de amostras de solo de 3,0,5,0 e 7,0 m. A técnica de investigação utilizada foi o "dot map", que consiste na varredura de determinados elementos selecionados (no caso, o $\mathrm{Na}, \mathrm{K}, \mathrm{Ca}, \mathrm{Mg}$ e $\mathrm{Al}$ ) ao longo de uma área. Uma análise semi-quantitativa foi realizada na lâmina de $7,0 \mathrm{~m}$ sobre um argilomineral de área de $20 \times 20 \mu \mathrm{m}$. As condições analíticas de operação do EDS foram as mesmas do microscópio do DGSA/IGc/USP.

\section{c-Capacidade de Troca de Cátions, pH do solo e Teor de Matéria Orgânica}

Foram executadas análises químicas em 15 amostras de solo total, a fim de se determinar o parâmetro capacidade de troca de cátions (CTC), os principais cátions formadores do CTC $\left(\mathrm{Na}, \mathrm{K}, \mathrm{Ca}, \mathrm{Mg}, \mathrm{H}, \mathrm{e} \mathrm{Al}\right.$ ), o pH do solo em solução de $\mathrm{CaCl}_{2}$, e os teores de matéria orgânica do solo. $O$ conjunto dessas análises é normalmente referido pelos técnicos em ciências do solo, como "análises químicas do solo para fins de fertilidade". O método de análise utilizado neste trabalho corresponde ao descrito em Raij \& Quaggio (1983), com adaptações, que foram verbalmente descritas pelo técnico responsável pelas análises no Laboratório de Análise Química de Solo e Planta da UFSCar (Araras - SP). 
Inicialmente as amostras são secas, desagregadas e homogeneizadas. $\mathrm{O}$ pH do solo é medido misturando-se $10 \mathrm{~cm}^{3}$ de solo em $25 \mathrm{ml}$ de solução $0,01 \mathrm{M} \mathrm{de} \mathrm{CaCl}_{2}$, que é utilizado pois o $\mathrm{pH}$ resultante é mais próximo daquele existente no ambiente radicular das plantas. $\mathrm{O}$ teor de matéria orgânica é obtido através da oxidação completa da matéria orgânica contida em determinado volume de amostra de solo com mistura de dicromato e ácido sulfúrico, seguida de titulação da solução resultante com uma solução $0,4 \mathrm{~N}$ de sulfato ferroso amoniacal, após adição de $\mathrm{H}_{3} \mathrm{PO}_{4}$.

O parâmetro capacidade de troca de cátions (CTC) representa a somatória das concentrações dos principais cátions trocáveis e que estão adsorvidos no solo ( $\mathrm{Na}, \mathrm{K}, \mathrm{Ca}, \mathrm{Mg}, \mathrm{Al}$ e H). Outros cátions encontram-se adsorvidos, porém em menores concentrações que estes principais, cuja somatória representa uma boa aproximação do CTC total.

A determinação do Al trocável é feita através de uma solução do solo analisado com $\mathrm{KCl}$ $1 \mathrm{~N}$. Após determinado tempo, o extrato sobrenadante é titulado com uma solução $0,025 \mathrm{~N}$ de $\mathrm{NaOH}$, cujo volume é utilizado para o cálculo da concentração (em meq $/ \mathrm{kg}$ ) de Al trocável. $\mathrm{O}$ $\mathrm{H}^{+}$trocável é determinado através da solução tampão SMP, que consiste de uma mistura de sais neutros com vários tampões. A análise é realizada adicionando-se a solução SMP à suspensão onde foi determinado o $\mathrm{pH}$ em $\mathrm{CaCl}_{2}$. Após um tempo de agitação e repouso, é realizada a leitura do $\mathrm{pH}$ da nova suspensão tampão, denominado $\mathrm{pH}_{\mathrm{smp}}$. $\mathrm{A}$ concentração de $\left(\mathrm{H}^{+}+\mathrm{Al}\right)$ é obtida a partir da leitura de uma curva de regressão, dado o $\mathrm{pH}_{\text {smp. }}$ A determinação do $\mathrm{H}^{+}$ trocável é feita pela subtração do Al calculado pelo método anterior da soma $\left(\mathrm{H}^{+}+\mathrm{Al}\right)$.

O processo de extração do cálcio e magnésio se dá através de uma solução do solo com $\mathrm{KCl} 1 \mathrm{~N}$. Após determinado tempo de contato para a ocorrência da troca iônica do cálcio e magnésio pelo potássio, a solução sobrenadante é separada e analisada por espectrofotometria de absorção atômica. A determinação do sódio é feita através de uma solução do solo com ácido clorídrico $0,1 \mathrm{~N}$. Após a ocorrência da troca iônica do sódio pelo hidrogênio, a solução é separada e analisada por espectrofotometria de chama. A extração de potássio da amostra se dá com uma resina trocadora de cátions. O solo é misturado com a resina saturada em sódio, que permanece em agitação por 16 horas, até que todos os cátions do solo se transfiram para a resina. A resina é separada da argila e do solo por lavagem com água deionizada e, então, atacada com uma solução de $50 \mathrm{~mL}$ de $\mathrm{NH}_{4} \mathrm{Cl}(0,8 \mathrm{~N})$ e $\mathrm{HCl}(0,2 \mathrm{~N})$. O extrato resultante é analisado para potássio por espectrofotometria de chama. 
Os resultados de controle de qualidade das análises não estão disponíveis, apesar de existirem. O Laboratório de Análise Química de Solo e Planta da UFSCar (Araras - SP) é membro do programa de Laboratórios de Análises de Solos do Estado de São Paulo, que é coordenado pelo Instituto Agronômico de Campinas (IAC). O IAC fornece amostras padrão para os laboratórios membros para serem analisadas mensalmente, sem que os laboratórios saibam a composição química. O IAC recebe os resultados e, caso estes sejam reprodutíveis, fornece um selo de qualidade que é colado em todos os laudos emitidos pelo laboratório, certificando que as análises são exatas e precisas.

\subsection{Coleta e Ensaios em Laboratório de Amostras Indeformadas de Solo}

Foram também coletadas durante a escavação do poço, 7 amostras indeformadas de solo de dimensões de $15 \times 15 \times 15 \mathrm{~cm}$, nas profundidades de $0,5,1,3,5,7,9$ e $9,5 \mathrm{~m}$. Para evitar a quebra das amostras durante o seu manuseio, todas as amostras foram parafinadas. Nestas amostras, foram determinados os parâmetros condutividade hidráulica saturada (vertical e horizontal), densidade aparente e as curvas de retenção. A partir dos dados de densidade aparente do solo seco e da estimativa da densidade dos minerais do solo (igual a $2,65 \mathrm{~g} / \mathrm{cm}^{3}$ ), foi possível determinar o parâmetro porosidade total. Todos esses ensaios são importantes para a caracterização da hidráulica de infiltração da água no solo, bem como para a modelagem matemática de fluxo.

O ensaio de condutividade hidráulica saturada foi realizado em 25 amostras de solo, sendo 16 na direção do eixo Z, 3 na direção do eixo X e 6 na direção do eixo Y. Dependendo da disponibilidade de amostras, os ensaios na direção do eixo $Z$ foram realizados em duplicata ou triplicata, para se ter um melhor controle estatístico de erros. Como subproduto deste ensaio, foi também determinado o parâmetro densidade aparente do solo seco.

Estes ensaios foram realizados no Laboratório de Física dos Solos e Irrigação/AGAMA/DIGEO do Instituto de Pesquisas Tecnológicas (IPT). O método utilizado corresponde ao procedimento DIGEO-LFSI-PE-006, baseado no método citado em Klute (1996) e descrito em Freeze \& Cherry (1979), e consiste em se fazer passar água sob uma carga hidráulica constante $(\Delta \mathrm{H})$ através da amostra de solo indeformado e medindomse a vazão correspondente $(\mathrm{V} / \mathrm{t})$. Dado também o comprimento $(\mathrm{L})$ e a área da seção transversal da amostra (A), o cálculo do parâmetro condutividade hidráulica é obtido através da simples aplicação da expressão que representa a Lei de Darcy. 
As curvas de retenção foram obtidas em 15 amostras indeformadas de solo, representando 6 profundidades distintas $(1,3,5,7,9$ e 9,5 $\mathrm{m})$. Os ensaios também foram realizados em duplicata ou triplicata e o parâmetro densidade aparente do solo seco também foi obtido como subproduto. As curvas de retenção relacionam a quantidade de água que a amostra de solo pode reter por um dado valor de potencial matricial.

O método utilizado para a obtenção das curvas de retenção corresponde ao descrito em Klute (1996) e Hillel (1980), e consiste em se fazer leituras do conteúdo de umidade em função da tensão aplicada após a saturação completa da amostra. As curvas obtidas são de secagem e não foram considerados os efeitos de histerese. Estes ensaios foram realizados no laboratório do Departamento de Ciência do Solo da ESALQ-USP, através do método dos funis (para as tensões de 0,02 e 0,05 atm) e através da câmara de pressão de Richards (para tensões de 0,1,1 e 15 atm).

\subsection{Monitoramento do Comportamento Hidráulico das Zonas Saturada e Nâo Saturada}

O comportamento da água da zona não saturada na estação de monitoramento foi monitorado através da realização das leituras de potencial matricial dos tensiômetros com freqüência mínima de duas vezes por semana, a partir da data de instalação destes equipamentos. Esta frequêencia tornou-se diária após a ocorrência de alguns eventos de recarga. As leituras foram sempre executadas na mesma hora do dia, a fim de se evitar os efeitos da variação da temperatura ambiente, que interfere no potencial matricial do solo. A zona saturada também foi monitorada na mesma frequência de medições dos tensiômetros, através de leituras de nível d'água no poço de monitoramento.

\subsection{Coleta e Análises Químicas de Amostras de Água}

\subsubsection{Procedimentos de Amostragem}

Cinco campanhas de amostragem de água dos lisímetros de sucção e do poço de monitoramento foram realizadas (abril e agosto/99 e janeiro, abril e setembro/2000). O Anexo 7 apresenta a relação das amostras coletadas por evento de amostragem e alguns dados que representam as condições de amostragem (potencial matricial do solo na data da coleta, tempo de sucção dos lisímetros durante a coleta, volume de amostra coletada e fator de diluição da amostra realizada em campo). 
Na primeira campanha, apenas os lisímetros ímpares de dentro do poço estavam instalados e mesmo assim apenas nos lisímetros L3, L7 e L9 foi possível realizar amostragem para análises. Os lisímetros L1 e L5 apresentaram, respectivamente, pequeno volume de água disponível e problemas de instalação. Em agosto/99, todos os lisímetros instalados dentro do poço foram amostrados, enquanto se instalava os lisímetros externos. A campanha de janeiro/2000 teve a realização da coleta de amostras dos lisímetros externos (L50C a L1D), mas vários lisímetros (L50E, L1E - externos ao poço e L2 a L7 - no poço) não tiveram água amostrada devido à seca. Em abril/2000, todos os lisímetros foram amostrados, exceto o lisímetro L8, que encontrava-se quebrado. Na campanha de setembro/2000, os lisímetros L1 a L9 do poço foram amostrados, enquanto que os lisímetros externos e o lisímetro L50 (do poço) não apresentaram água disponível devido à ação da seca. Amostras de água do poço de monitoramento foram coletadas em todas as campanhas, exceto em abril/99. Foram também coletadas três amostras de água de chuva, sendo duas em janeiro/2000 e outra em setembro/2000.

O método de coleta de água nos lisímetros consistiu na aplicação de uma sucção de -650 $\mathrm{mmHg}$ em cada lisímetro, através de uma bomba a vácuo de bancada operada por energia elétrica. A sucção aplicada nos lisímetros era monitorada através de vacuômetros e a eventual perda de sucção era reposta com uma bomba a vácuo manual. O tempo em que cada lisímetro era submetido à sucção até o momento da amostragem era função da disponibilidade de água do solo, que era avaliada a partir das leituras de potencial matricial dos tensiômetros. O tempo de sucção individual dos lisímetros variou de 20 a 113 horas, com média de 50,6 horas (e desvio padrão de 23 horas).

Durante os procedimentos de amostragem dos lisímetros L/3 (campanhas de abril e setembro/2000) e L.7 (todas as campanhas), observou-se uma perda de sucção mais intensa após poucas horas da aplicação individual. No caso das campanhas de abril e setembro/2000, as amostragens desses lisímetros se deram através da ligação destes num único sistema de mangueiras, onde foram aplicados eventos de sucção através da bomba a vácuo elétrica, que permanentemente era ligada quando se notava queda da sucção para valores superiores a -400 mmHg. Uma eventual diferença na composição química da água amostrada pelos dois métodos utilizados foi medida com a coleta, em abril/2000, de amostras de água destes dois lisímetros, tanto pelo método de sucção individual como pelo método de ligação dos lisímetros em série. Os resultados são apresentados no item a seguir. 
Após o período de sucção, a coleta das amostras de água dos lisímetros era complementada com a utilização de uma bomba pneumática que promovia a extração da água de dentro do lisímetro para os vidros das amostras através a pressurização com ar da câmara armazenadora de água do lisímetro. Os vidros das amostras foram limpos com água e sabão, descontaminados com $\mathrm{HCl}$ concentrado (1:1) e enxaguados com água deionizada por várias vezes antes de cada evento de amostragem.

Seguindo a orientação da norma ASTM (1996), foi descartada a primeira amostra de água coletada em todos os lisímetros, pois estas ainda poderiam sofrer a influência da água deionizada que embebia o lisímetro antes de sua instalação no solo.

\subsubsection{Análises Realizadas e Controle de Qualidade dos Resultados}

Das amostras coletadas, foram obtidos em campo os parâmetros temperatura, $\mathrm{pH}, \mathrm{Eh}$, condutividade elétrica, alcalinidade total e, dependendo da disponibilidade de volume de amostra, os parâmetros nitrato, nitrito, amônio, ferro II'e cromo hexavalente, através de kits de campo. Os seguintes equipamentos foram utilizados em campo: medidor de $\mathrm{pH}$ e de Eh 330/SET-1-WTW; condutivímetro WTW modelo LF330/SET; kit RqFlex de análises de nitrato, nitrito, amônio e ferro por análise reflectométrica. O medidor de Eh utilizado possui eletrodo de cloreto de mercúrio e não de hidrogênio. Neste caso, às medidas de Eh acrescentou-se $250 \mathrm{mV}$ para correção.

Apenas a alcalinidade total foi executada em campo e o resultado todo atribuído à concentração do íon $\mathrm{HCO}_{3}{ }^{-}$, já que os baixos valores de $\mathrm{pH}$ obtidos em campo isentaram da necessidade de se analisar a alcalinidade parcial. A análise da alcalinidade total foi feita por titulação, utilizando-se de $10,25,50$ ou $100 \mathrm{~mL}$ da amostra (dependendo da disponibilidade), indicador misto, ácido sulfúrico $0,01 \mathrm{~N}$ (padronizado previamente no laboratório com $\mathrm{Na}_{2} \mathrm{CO}_{3}$ ) e bureta com escala de $0,01 \mathrm{~mL}$ de precisão.

Ainda em campo, as amostras foram filtradas em filtros de acetato celulose de $0,45 \mu \mathrm{m}$ e preservadas para análises em laboratório, onde foram obtidos os cátions e ânions maiores, metais pesados, alumínio, sílica e carbono orgânico dissolvido. Os laboratórios utilizados foram os do CEPAS e Alfa. A Tabela 5 resume os parâmetros analisados em cada laboratório e o método de análise utilizado. 
Tabela 5 - Parâmetros químicos analisados em amostras de água, preservação, laboratório e método de análise

\begin{tabular}{|c|c|c|c|}
\hline Parâmetros & Preservação & Laboratório & Método de Análise e equipamento \\
\hline $\mathrm{Na}, \mathrm{K}$ & $\mathrm{H}_{2} \mathrm{SO}_{4}$ & CEPAS/IGC/USP & $\begin{array}{l}\text { Espectrofotometria de Chama } \\
\text { (modelo B262 - Micronal) }\end{array}$ \\
\hline $\begin{array}{l}\mathrm{Ca}, \mathrm{Mg}, \mathrm{Ba}, \mathrm{Sr}, \mathrm{Al}, \mathrm{Fe}, \mathrm{Mn} \\
\mathrm{Ag}, \mathrm{Cr}, \mathrm{Cu}, \mathrm{Ni}, \mathrm{Pb}, \mathrm{Zn}\end{array}$ & $\mathrm{HNO}_{3}$ & CEPAS/IGc/USP & $\begin{array}{l}\text { Espectrofotometria de absorção atômica } \\
\text { (espectrómetro CG AA7000 BC) }\end{array}$ \\
\hline $\begin{array}{l}\mathrm{SO}_{4}, \mathrm{Cl}, \mathrm{Br}, \mathrm{F} \\
\mathrm{PO}_{4}, \mathrm{NO}_{3}, \mathrm{NO}_{3}\end{array}$ & congelamento & CEPAS/IGc/USP & $\begin{array}{l}\text { Cromatografia líquida (cromatografo } \\
\text { de ânions DIONEX 2010i) }\end{array}$ \\
\hline $\mathrm{SiO}_{2}$ & $\begin{array}{l}\text { Nenhum/ } \\
\text { resfriamento }\end{array}$ & ALFA & $\begin{array}{l}\text { Colorimetria: Standard Methods, } \\
20^{\mathrm{a}} \text { ed., Método } 4500-\mathrm{SiO}_{2}-\mathrm{C}\end{array}$ \\
\hline COD & $\begin{array}{l}\text { Nenhum/ } \\
\text { resfriamento }\end{array}$ & ALFA & $\begin{array}{l}\text { Digestão com tiosulfato e quantificação } \\
\text { de } \mathrm{CO}_{2} \text { por colorimetria. Standard } \\
\text { Methods } 20^{\text {a }} \text { ed., método } 5310-\mathrm{C}\end{array}$ \\
\hline
\end{tabular}

O volume de amostra mínimo necessário para a análise nos laboratórios para cada ponto somou $160 \mathrm{~mL}$, sendo $50 \mathrm{~mL}$ apenas para a análise de sílica. Por ser muito escasso o volume de água obtido de alguns lisímetros de sucção, houve a necessidade, em determinadas ocasiões, de não se analisar algum parâmetro químico, ou a amostra toda, ou ainda de se recorrer à diluição da amostra até que fosse atingido o volume mínimo para a execução das análises.

Quanto às amostras diluídas analisadas, as diluições foram realizadas em água deionizada de acordo com os fatores apresentados nas tabelas do Anexo 7. Os resultados apresentados destas amostras já se encontram corrigidos em função do fator de diluição utilizado. Nas amostras diluídas, o limite de deteç̧ão do parâmetro analisado foi considerado como sendo $n$ vezes maior que o limite de deteç̧ão do método de análise, sendo $n$ o fator de diluição. Em nenhuma das análises realizadas o novo limite de deteç̧ão calculado foi maior que o resultado do parâmetro. Os parâmetros de campo, entretanto, foram sempre obtidos a partir das amostras originais, sem serem diluídas.

Os resultados das análises químicas foram submetidos a dois tipos de controle de qualidade: a realização de cálculos de balanço iônico, a fím de se quantificar possíveis erros na execução das análises, e a execução de análises em amostras duplicatas, objetivando quantificar a reprodutibilidade dos resultados.

No caso do balanço iônico, considerando os cátions e ânions expressos na forma de meq/L, a seguinte relação foi utilizada para o cálculo do desvio:

$$
\mathrm{E}=\frac{\sum \text { cátions }-\sum \text { ânions }}{\sum \text { cátions }+\sum \text { ânions }} \times 100 \quad \text { Equação } 7
$$


Os resultados de balanço iônico das amostras de água dos lisímetros e do poço de monitoramento, apresentados no Anexo 7, indicam que as análises químicas apresentaram erro relativo variando entre $-12,6 \%$ (L7 - abr/99) e $+13,85 \%$ (PM2 - set/00), com média de 3,93\% e desvio padrão de $4,07 \%$, sendo que praticamente todas as análises apresentaram desvios menores que $10 \%$, o que pode ser considerado favorável para a execução de estudos hidrogeoquímicos.

Considerando o módulo do desvio de $10 \%$ como limite de aceitação das análises, foram descartados, dentre todas as análises, apenas os resultados da amostra duplicata PM2 (set/00). Houve uma tolerância um pouco maior com os dados das análises L3 (abr/99), L7 (abr/99 e set/2000) e PM (jan/2000, abr/2000 e set/2000), que apresentaram desvios ligeiramente superiores a $10 \%$ e mesmo assim foram considerados nos estudos hidroquímicos.

As três amostras de água da chuva, por serem muito diluídas, apresentaram erro relativo variando de $-19 \%$ a $+10 \%$. Estes elevados desvios estão relacionados à dificuldade em se estabelecer as concentrações de alcalinidade (Chuva 1 - jan/2000) e cálcio (setembro/2000). Relativizando-se estes fatores, os resultados dos demais parâmetros químicos foram considerados nos estudos hidroquímicos.

Os resultados das análises químicas dos lisímetros L1, L1B e L2 da campanha de setembro/2000 devem ser considerados com reservas. Estes três pontos, nesta ocasião, tiveram um volume de amostra muito reduzido, o que impediu a realização do parâmetro alcalinidade total em campo. Este parâmetro foi calculado fazendo-se o raciocínio inverso, ou seja, considerou-se o desvio relativo da análise igual a zero e calculou-se a quantidade de bicarbonato suficiente para manter a solução eletricamente neutra. Obviamente, para estas análises, não há controle de qualidade dos resultados, apesar de os resultados apresentarem-se coerentes com aqueles produzidos nas campanhas de amostragem anteriores. Mesmo sem esse controle de qualidade, estes resultados foram considerados nos estudos hidroquímicos realizados.

Os resultados da reprodutibilidade das análises em amostras duplicatas são apresentados na Tabela 6 . Observa-se que a maior parte dos resultados encontram-se abaixo ou ao redor de $10 \%$, conferindo reprodutibilidade às análises. Observam-se, entretanto, valores freqüentemente acima de $20 \%$ para os parâmetros fosfato, brometo, bário e alumínio, principalmente devido às baixas concentrações detectadas para estes parâmetros em todos os eventos de amostragem. Neste caso, as interpretações hidroquímicas que consideram esses elementos devem ser consideradas com prudência. 
Tabela 6 - Reprodutibilidade das análises de amostras de água duplicata do lisímetro L9 e do poço de monitoramento PM.

\begin{tabular}{|c|c|c|c|c|c|c|c|}
\hline & $\begin{array}{c}\text { L9 - } \\
\text { Abr/99 }\end{array}$ & $\begin{array}{c}\text { L9 - } \\
\text { Ago/99 }\end{array}$ & $\begin{array}{l}\text { L9 - } \\
\operatorname{Jan} / 00\end{array}$ & $\begin{array}{c}\mathrm{L} 9- \\
\mathrm{Abr} / 00\end{array}$ & $\begin{array}{l}\text { L5- } \\
\text { Set/00 }\end{array}$ & $\begin{array}{c}\mathrm{L} 8- \\
\text { Set/00 }\end{array}$ & $\begin{array}{l}\mathrm{PM}- \\
\text { Set } / 00\end{array}$ \\
\hline Bicarbonato & $=$ & 29,2 & 11,1 & 7,8 & - & 0,7 & 2,2 \\
\hline Sulfato & 12,5 & 9,1 & 3,7 & 4,8 & 33,3 & 0,0 & 0,6 \\
\hline Cloreto & 4,4 & 0,6 & 1,5 & 8,3 & 6,5 & 9,3 & 7,0 \\
\hline Nitrato & 0,9 & 0,2 & 0,2 & 0,2 & 0,0 & 1,4 & 0,1 \\
\hline Nitrito & nd & nd & nd & nd & 100,0 & nd & nd \\
\hline Fluoreto & 14,3 & 12,0 & 9,1 & 33,3 & 1,8 & 33,3 & 0,0 \\
\hline Fosfato total & 20,0 & 14,3 & 42,9 & 30,4 & 20,0 & 27,3 & 85,7 \\
\hline Brometo & 9,1 & 42,9 & nd & 55,5 & 100,0 & nd & nd \\
\hline Sódio & 0,0 & 0,0 & 0,0 & 0,0 & 0,0 & 0,0 & 2,4 \\
\hline Potássio & 3,7 & 3,2 & 0,0 & 0,0 & 0,0 & 0,0 & 0,0 \\
\hline Cálcio & 1,3 & 1,3 & 25,9 & 3,4 & 12,0 & 0,7 & 0,6 \\
\hline Magnésio & 0,8 & 0,0 & 26,5 & 0,0 & 10,0 & 0,6 & 0,0 \\
\hline Estrôncio & 0,0 & 0,0 & 9,1 & 0,0 & 0,0 & 0,0 & 1,0 \\
\hline Bário & 0,0 & 15,2 & 44,4 & 20,0 & 100,0 & 0,0 & 25,0 \\
\hline Ferro total & 100,0 & nd & nd & nd & nd & nd & nd \\
\hline Manganês & 0,0 & nd & nd & nd & nd & 0,0 & nd \\
\hline Alumínio & 23,1 & nd & 29,4 & nd & 100,0 & nd & 100,0 \\
\hline Cromo total & nd & 33,3 & nd & nd & nd & 100,0 & nd \\
\hline Chumbo & nd & nd & nd & nd & nd & nd & nd \\
\hline Cobre & nd & nd & nd & nd & nd & nd & nd \\
\hline Zinco & 14,3 & nd & 0 & 0 & nd & 0,0 & nd \\
\hline Cádmio & nd & nd & nd & nd & nd & nd & nd \\
\hline Níquel & 100 & nd & nd & nd & nd & nd & nd \\
\hline Prata & nd & nd & nd & nd & nd & nd & nd \\
\hline Sílica & 3,3 & 3,4 & 0,0 & 1,5 & - & - & 1,1 \\
\hline $\mathrm{COD}$ & nd & 9,8 & 0,0 & 16,5 & $=$ & - & 1,5 \\
\hline
\end{tabular}

Reprodutibilidade da análise é dada pela medida do desvio dos resultados e expressa em porcentagem: (diferença)/(soma) x 100. Resultado expresso em módulo.

nd representa parâmetro não detectado acima do limite de deteç̧ão nos dois eventos de análises.

O controle de qualidade das análises a partir da análise de uma solução padrão ocorreu apenas com os parâmetros sílica e carbono orgânico dissolvido (COD), analisados pelo laboratório Alfa. Os desvios máximos observados em todas as campanhas de amostragem foram de 7,3\% para sílica e de 7,5\% para o COD. Esses valores são inferiores a $10 \%$ e, portanto, satisfatórios para a execução de interpretações. 
Quanto ao método de amostragem, algumas situações de campo foram comparadas (Tabela 7). O par de amostras L3 e ADL3, coletadas em agosto/99, refere-se à prova da necessidade de se descartar a primeira amostra de água a cada evento de amostragem. As amostras L8 e L8SF, também coletadas em agosto/99, dizem respeito à necessidade de filtragem das amostras de água a $0,45 \mu \mathrm{m}$ para a execução em laboratório de análises de metais, já que a água sofre uma filtragem prévia ao atravessar a cápsula de porcelana do lisímetro. Os pares $\mathrm{L} 3 \mathrm{a} / \mathrm{L} 3 \mathrm{~b}$ e L7a/L $7 \mathrm{~b}$, coletados em abril/2000, referem-se ao controle de qualidade das amostragens realizadas pelos métodos de sucção individual e de ligação dos lisímetros em série.

Tabela 7 - Reprodutibilidade das análises da água para avaliação de diferentes procedimentos de amostragem

\begin{tabular}{|c|c|c|c|c|}
\hline Parâmetro & $\begin{array}{c}\text { L3/ADL3 } \\
\text { AGO/99 }\end{array}$ & $\begin{array}{l}\text { L8/L8SF } \\
\text { AGO/99 }\end{array}$ & $\begin{array}{l}\mathrm{L3a} / \mathrm{L} 3 \mathrm{~b} \\
\mathrm{ABR} / 00\end{array}$ & $\begin{array}{l}\mathrm{L} \text { /a/L } 7 \mathrm{~b} \\
\mathrm{ABR} / 00\end{array}$ \\
\hline $\mathrm{pH}$ & 3,6 & 0,0 & 0,1 & 1,9 \\
\hline Cond. Elétr. & 2,4 & 0,0 & 0,3 & 10,3 \\
\hline $\mathrm{HCO} 3-$ & 3,0 & 0,00 & 11,1 & 16,3 \\
\hline Sulfato & $\mathbf{3 3 , 3}$ & 33,3 & 58,8 & 47,3 \\
\hline Cloreto & 2,5 & 3,1 & 47,8 & 24,1 \\
\hline Nitrato & 12,8 & 0,8 & 9,9 & 4,4 \\
\hline Nitrito & nd & nd & nd & 100,0 \\
\hline Fluoreto & 25,5 & 10,0 & 34,5 & 40,0 \\
\hline Fosfato total & 37,1 & 0,0 & 100,0 & 60,0 \\
\hline Brometo & 100,0 & nd & 100,0 & 53,8 \\
\hline Sódio & 12,2 & 0,0 & 23,0 & 36,3 \\
\hline Potássio & 0,0 & 0,0 & 15,3 & 23,0 \\
\hline Cálcio & 2,8 & 1,0 & 0,8 & 6,2 \\
\hline Magnésio & 2,6 & 0,0 & 2,9 & 2,1 \\
\hline Estrôncio & 14,2 & 0,0 & 9,0 & 20,0 \\
\hline Bário & 23,0 & 0,0 & 28,5 & 45,4 \\
\hline Ferro total & nd & nd & nd & nd \\
\hline Manganês & nd & nd & nd & nd \\
\hline Alumínio & nd & nd & nd & nd \\
\hline Cromo total & nd & 100,0 & nd & nd \\
\hline Chumbo & nd & nd & nd & nd \\
\hline Cobre & nd & nd & nd & nd \\
\hline Zinco & nd & nd & 100,0 & 14,2 \\
\hline Cádmio & nd & nd & nd & nd \\
\hline Níquel & nd & nd & nd & nd \\
\hline Prata & nd & nd & nd & nd \\
\hline Silica & 0,0 & - & 3,2 & 11,1 \\
\hline $\mathrm{COD}$ & - & - & $=$ & - \\
\hline
\end{tabular}

Vide texto para explicações mais detalhadas do significado das comparações.

Reprodutibilidade da análise é dada pela medida do desvio dos resultados e expressa em porcentagem: (diferença)/(soma) $\times 100$. 
Os desvios das análises do lisímetro L3 foram elevados apenas para os parâmetros que se apresentam em concentrações mais baixas, como o $\mathrm{SO}_{4}^{-2}, \mathrm{~F}^{*}, \mathrm{PO}_{4}^{-3}, \mathrm{Br}^{-}$e $\mathrm{Ba}^{+2}$, mas não o bastante para justificar a necessidade de se descartar a primeira água de amostragem toda vez que se procede um novo trabalho de amostragem no campo. A reprodutibilidade das análises do lisímetro L8 também indica a ocorrência de desvios pequenos (exceto o $\mathrm{SO}_{4}^{-2}$, que apresenta baixa concentração), demonstrando que não houve a presença de interferentes na amostra não filtrada que pudessem alterar significativamente o resultado das análises. Já a comparação dos dois métodos de amostragem (sucção individual e de ligação dos lisímetros em série) mostra variações mais expressivas num maior número de parâmetros, porém todos eles apresentam baixas concentrações na água. Não ocorreram erros significativos nos principais parâmetros que definem a característica química da água, tal como o $\mathrm{pH}$ e os íons dominantes nas duas amostras $\left(\mathrm{HCO}_{3}{ }^{-}, \mathrm{NO}_{3}{ }^{-}, \mathrm{Ca}^{+2} \mathrm{e} \mathrm{Mg}^{+2}\right)$. Tal resultado indica que os dois métodos de amostragem utilizados não alteraram significativamente a composição química da água amostrada.

\subsection{Tratamento de Dados}

\subsubsection{Caracterização Hidráulica da Zona Não Saturada}

Para a caracterização da hidráulica da zona não saturada foi realizada, inicialmente, uma caracterização do meio poroso, com a descrição visual do material de perfuração e o tratamento dos resultados dos ensaios de granulometria, de condutividade hidráulica saturada, de retenção e de porosidades.

Os dados de condutividade hidráulica saturada obtidos em amostras indeformadas foram tratados e apresentados em gráficos. A partir dos dados de ensaios de granulometria, a condutividade hidráulica também foi calculada para fins de comparação.

Os resultados obtidos com os ensaios de retenção foram tratados no programa Curvaret (van Lier \& Dourado Neto, 1992) para a obtenção das curvas de retenção e para o cálculo dos parâmetros porosidade total e de retenção e os índices $\alpha, m$ e $n$ das equações de van Genuchten.

Já os dados de potencial matricial monitorados em campo tiveram a unidade transformada de $\mathrm{mmHg}$ para metros de coluna d'água (valor este numericamente negativo), sendo então somados ao potencial de elevação, obtendo-se o potencial hidráulico do ponto em relação ao datum aproximado do nível do mar (Equação 1). Estes dados já transformados são tratados em planilhas para a execução de gráficos de variação de potencial hidráulico no tempo e no espaço. 
Posteriormente, o programa VS2DT foi utilizado para melhorar o modelo conceitual de fluxo de água na zona não saturada, bem como para avaliar as condições de reservação no tempo e no espaço. Procurou-se calibrar o modelo a partir dos dados de potenciais matriciais medidos no campo, utilizando-se dos parâmetros obtidos com tratamento dos dados de ensaios de retenção (porosidade total e de retenção e os índices $\alpha, m$ e $n$ das equações de van Genuchten) e admitindo-se a condutividade hidráulica saturada como variável de calibração.

Com a calibração do modelo, foram obtidos gráficos contendo informações sobre variações de umidade, velocidade de fluxos de água e balanços de fluxos de entrada e saída do modelo. As variações de umidade e de condutividade hidráulica não saturada $\left(\mathrm{K}_{\theta}\right)$ tiveram uma avaliação complementar através da aplicação direta das equações 3 e 4 aos dados de potenciais matriciais medidos e aos valores de condutividade hidráulica saturada $\left(\mathrm{K}_{\mathrm{s}}\right), \alpha^{\prime}, \beta^{\prime}$ e porosidades total e de retenção utilizados no modelo.

O modelo de fluxo e transporte da zona não saturada VS2DT (Variably Saturated 2-D Flow and Transport Model - Lappala et al., 1987), foi desenvolvido originalmente pelo U.S. Geological Survey (USGS) para ambiente DOS. Este modelo corresponde a um dos programas do pacote denominado UnSat Suite, desenvolvido pela Waterloo Hydrogeologic Inc. (1999), que trabalha em ambiente Windows.

O VS2DT do pacote UnSat Suite utiliza o método das diferenças finitas centradas no bloco da célula para resolver a equação de Richards (de fluxo de água subterrânea em meio não saturado - Equação 5), e simular o fluxo e transporte de contaminantes na zona não saturada em uma dimensão. Por ser um modelo numérico, admite heterogeneidades e anisotropias do meio físico.

A alimentação do modelo se constitui em:

(1) criar um perfil de zona não saturada, onde todos os parâmetros físicos são definidos (profundidade, tipos de material geológico, espessuras das camadas, condutividade hidráulica saturada, porosidades total e de retenção, parâmetros de van Genuchten);

(2) definir as propriedades de transporte do contaminante (dispersão, decaimento, retardação e difusão);

(3) definir as condições iniciais de distribuição de umidade e de contaminantes ao longo do perfil; 
(4) definir a malha e as condições de contorno superior e inferior do perfil para fluxo e transporte; $\mathrm{e}$

(5) definir os tempos parciais e máximo de simulação;

Após o processamento dos dados, o programa apresenta os resultados em várias formas, dentre as quais destacam-se:

(1) gráficos de potenciais, de conteúdo de umidade, de velocidade de fluxos, ou de concentrações de contaminantes em função da profundidade, para diferentes tempos de observação especificados;

(2) gráficos de potenciais, de conteúdo de umidade, de velocidade de fluxos, ou de concentrações de contaminantes em função do tempo, para profundidades especificadas;

(3) gráficos e tabelas de balanço de fluxo e de massa de contaminantes (entradas e saídas);

\subsubsection{Caracterização Hidrogeoquímica da Zona Não Saturada e Modelagem Matemática}

Os resultados das análises químicas e mineralógicas do solo e os resultados das análises químicas da água foram tratados de forma a ser possível definir quais são os mecanismos geoquímicos que justificam a composição química da água da zona não saturada no tempo e no espaço.

Inicialmente, os resultados das análises químicas e mineralógicas do solo foram organizados em planilhas eletrônicas onde foram realizados vários diagramas de correlação $e$ gráficos, a fim de se caracterizar a fase sólida e estabelecer correlações entre as composições químicas e mineralógicas desta fase.

Os dados obtidos com as cinco campanhas de coleta e análise de água foram também organizados em planilhas, onde foram executados diagramas de correlação, diagramas de classificação hidroquímica, e vários gráficos que caracterizam o comportamento das espécies químicas da água no tempo e no espaço.

Após a caracterização individual das fases sólida e líquida, algumas técnicas foram utilizadas para estabelecer o modelo conceitual de hidrogeoquímica da zona não saturada, a fim de identificar os processos geoquímicos que definem a relação água/rocha. As técnicas utilizadas 
foram: (1) execução da especiação das análises químicas e do cálculo de índices de saturação de minerais através do modelo hidroquímico MinteqA2 (Allison et al., 1991), cujos resultados foram expressos na forma de gráficos em função do tempo e do espaço; (2) utilização de diagramas de estabilidade de aluminossilicatos, a fim de se determinar quais são os minerais aluminossilicáticos mais estáveis em cada profundidade de amostragem; (3) execução de correlações entre as análises de capacidade de troca de cátions com as análises químicas da água; (4) e execução de modelagem hidroquímica inversa, através do modelo hidroquímico Phreeqc (Parkhurst, 1995).

Com a execução destas tarefas, sempre levando-se em consideração as características de fluxo e reservação da água na zona não saturada, coletou-se uma série de elementos para fazer juízo dos processos hidrogeoquímicos que ocorrem na zona não saturada.

\subsubsection{Modelagem de Transporte de Contaminantes}

Duas situações de transporte de contaminantes foram simuladas utilizando-se do modelo de fluxo melhor calibrado: infiltração de efluentes domésticos através de fossas e o nitrogênio de fertilizantes.

Na primeira simulação, procurou-se detectar com o modelo qual seria o fluxo mínimo de entrada de efluentes a fim de que o tempo de residência dos contaminantes fosse maior que 50 dias na zona não saturada, contando que esse período seja suficiente para a degradação de microorganismos patógenos contidos no efluente. Somando-se o valor deste fluxo ao da recarga por chuva, também calculado pelo modelo através de dados reais medidos nos tensiômetros, e admitindo-se um valor médio de concentração de nitrato no efluente, estimou-se qual seria a área mínima que comportasse um certo número de fossas, a fím de que a água subterrânea não seja impactada com concentrações de nitrado acima do limite de potabilidade.

No caso da simulação de transporte de nitrogênio de fertilizantes, procurou-se definir as concentrações de chegada do nitrato no aqüífero freático mediante alguns cenários de infiltração de carga efetiva do contaminante a partir da recarga por chuva, considerando que esta infiltração não é constante no tempo devido aos efeitos da diluição.

Nos dois cenários modelados, foram consideradas apenas a adveç̧ão e a dispersão como parâmetros de transporte, devido à natureza conservativa do nitrato. 


\section{Hidráulica da Zona Não Saturada}

\subsection{Caracterização do Meío Poroso}

\subsubsection{Descrição Visual do Material de Perfuração}

A descrição visual do material perfurado no poço da estação de monitoramento dá conta de larga predominância de areias finas quartzosas mais ou menos argilosas ao longo do perfil (Tabela 8). Foi possível, também, observar as diferentes estratificações dos horizontes pedológicos.

\begin{tabular}{|c|c|c|}
\hline \multicolumn{2}{|c|}{ Tabela 8- Descrição visual do material de perfuração do poço da estação de } \\
monitoramento
\end{tabular}

\subsubsection{Ensaios de Granulometria}

No Anexo 2 são apresentados os resultados, em porcentagem, das faixas de granulometria dos sedimentos coletados no poço escavado da estação de monitoramento e também das amostras de solo dos lisímetros de sucção instalados fora da área do poço, através do método de espectroscopia de correlação de fótons. A Figura 6 apresenta os resultados desses ensaios de granulometria das amostras do poço em função da profundidade. 
Observa-se, de forma geral, a predominância de areias finas argilo-siltosas em praticamente todo o perfil. O material de aterro (até $0,35 \mathrm{~m}$ ) apresenta faixa de granulometria diferente do material de solo subjacente, com uma maior quantidade de finos que o material do solo. A granulometria do material do solo, por sua vez, apresenta ligeira modificação desde 0,5 $\mathrm{m}$ até $8 \mathrm{~m}$, havendo uma queda na porcentagem dos termos arenosos e um aumento na quantidade da fração argilo-siltosa. A partir dos $9 \mathrm{~m}$, a porcentagem da fração fina diminui e há um aumento da porcentagem da fração arenosa, que apresenta distribuição heterogênea entre as frações fina, média e grossa.

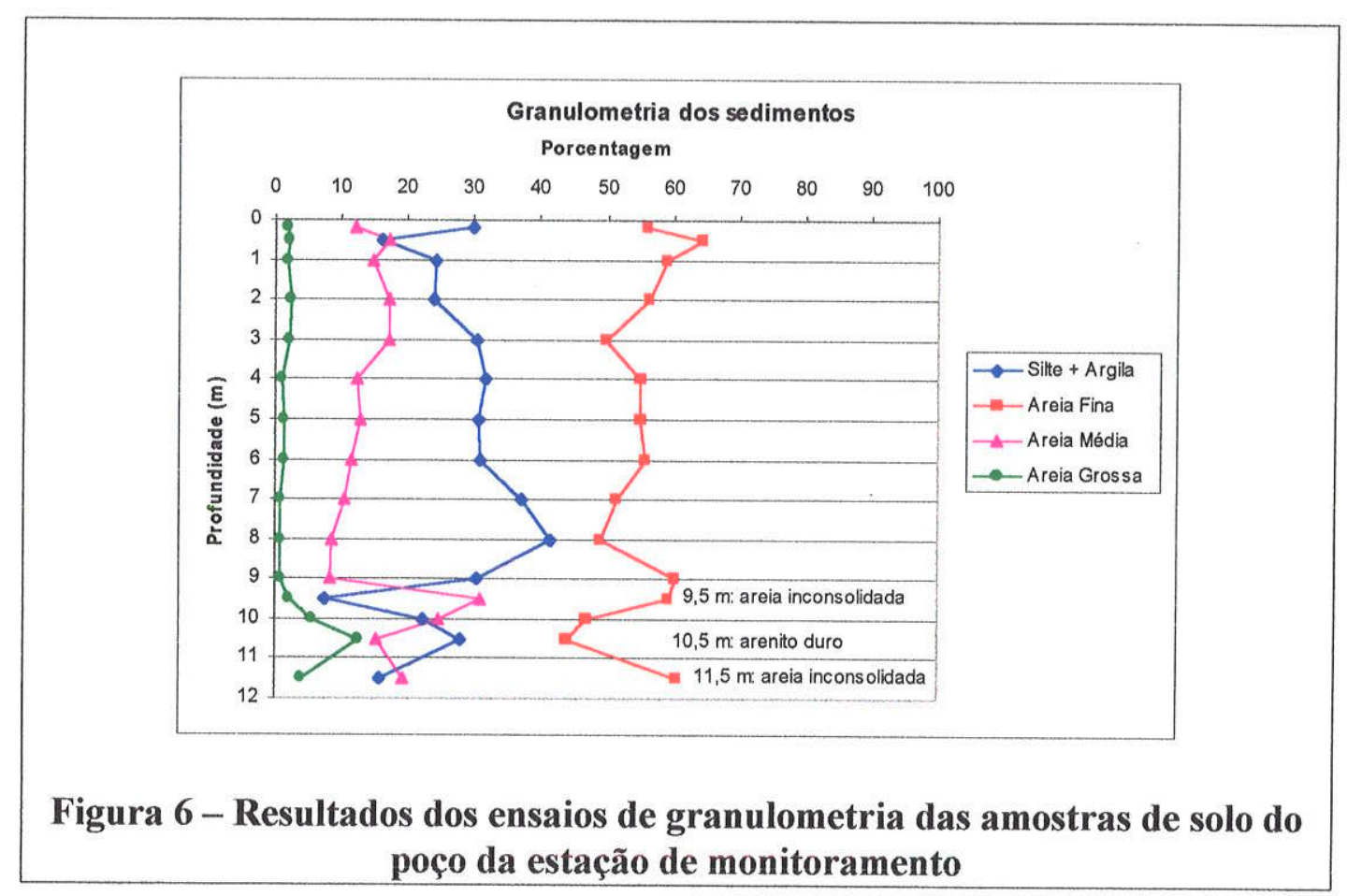

Os ensaios de granulometria das amostras coletadas nas profundidades de 0,5 e 1,0 $\mathrm{m}$ dos lisímetros externos apresentaram resultados semelhantes àquelas amostras do poço coletadas nestas profundidades (Anexo 2). Predomina largamente a fração arenosa fina (média de 62\%) sobre a siltosa $(21 \%)$ na profundidade de $0,5 \mathrm{~m}$, havendo uma ligeira queda na fração arenosa fina $(58 \%)$ em relação à argilo-siltosa $(27 \%)$ a $1 \mathrm{~m}$.

Novos ensaios de granulometria, realizados pelo método tradicional, confirmaram os resultados obtidos com o método de espectroscopia de correlação de fótons. Esta confirmação foi realizada pois, de forma inesperada, a fração argila não foi detectada por este método. A Tabela 9 apresenta os resultados obtidos para quatro amostras e uma comparação com os resultados obtidos para as mesmas amostras no primeiro ensaio. 


\begin{tabular}{|c|c|c|c|c|c|c|c|c|}
\hline \multirow[t]{2}{*}{$\begin{array}{c}\text { Profund. } \\
(\mathrm{m})\end{array}$} & \multicolumn{2}{|c|}{ Argila } & \multicolumn{2}{|c|}{$\begin{array}{c}\text { Silte fino }+ \text { silte } \\
\text { grosso }\end{array}$} & \multicolumn{2}{|c|}{ Areia fina } & \multicolumn{2}{|c|}{$\begin{array}{c}\text { Areia Média }+ \text { Areia } \\
\text { Grossa }\end{array}$} \\
\hline & E1 & E2 & E1 & E2 & $\mathrm{E} 1$ & $\mathrm{E} 2$ & E1 & E2 \\
\hline 0,2 & 0 & 21,62 & 30,03 & 9,61 & 56,06 & 56,08 & 13,91 & 12,69 \\
\hline 0,5 & 0 & 14,29 & 16,18 & 7,12 & 64,53 & 56,21 & 19,29 & 22,38 \\
\hline 3,0 & 0 & 24,37 & 30,56 & 7,23 & 49,87 & 52,44 & 19,57 & 15,96 \\
\hline 8,0 & 0 & 29,13 & 41,42 & 9,86 & 49,19 & 51,28 & 9,39 & 9,73 \\
\hline
\end{tabular}

E1: ensaio de granulometria 1 - método por espectroscopia de correlação de fótons;

E2: ensaio de granulometria 2 - método tradicional (peneiramento e pipetagem)

Os novos resultados indicaram a ocorrência da fração argila em quantidades consideráveis, uma menor quantidade da fração silte e quantidades semelhantes de areia nos dois métodos. Com exceção da amostra de $0,5 \mathrm{~m}$, observa-se que a quantidade de silte obtida pelo primeiro método é semelhante à soma das quantidades das frações silte e argila pelo segundo método. Esses resultados indicam que o método por espectroscopia de correlação de fótons apresentou alguma limitação na detecção da fração argila. Neste trabalho, as quantidades de silte medidas pelo método de espectroscopia de correlação de fótons são considerados como sendo a soma das frações silte e argila, com predomínio desta última.

\subsubsection{Ensaios de Condutividade Hidráulica Saturada}

Os resultados dos ensaios de condutividade hidráulica saturada realizados em amostras indeformadas de solo encontram-se no Anexo 2. A Tabela 10 apresenta os resultados médios, sendo que as condutividades hidráulicas no eixo $Z$ (vertical) foram calculadas a partir da média geométrica de dois ou três ensaios individuais realizados nesta direção. Nesta tabela também são apresentados os resultados de condutividade hidráulica calculados a partir da curva granulométrica (Freeze \& Cherry, 1979), em que:

$$
\mathbf{K}_{\mathrm{gr}}=\mathbf{A} * \mathbf{d}_{10}{ }^{2} \quad \text { Equação } 8
$$

onde:

$\mathbf{K}_{\mathrm{gr}}$ é dado em $\mathrm{cm} / \mathrm{s}$,

A é um coeficiente relacionado ao grau de arredondamento dos grãos, normalmente igual a 1 ; e

$\mathbf{d}_{10}$ é o diâmetro, em mm, representativo dos $10 \%$ mais finos. 
Trata-se, este método, de uma aproximação válida originalmente para sedimentos arenosos homogêneos, porém fornece uma estimativa válida para vários solos que variam de areia fina a muito grossa. As figuras 7 e 8 representam graficamente os resultados de condutividade hidráulica obtidos pelos dois métodos em função da profundidade de coleta das amostras.

\begin{tabular}{|c|c|c|c|c|c|c|c|c|}
\hline Tabela & $\begin{array}{c}0-\text { Result } \\
\text { por cur }\end{array}$ & $\begin{array}{l}\text { ados de co } \\
\text { va de gran }\end{array}$ & $\begin{array}{l}\text { ndutividade } \\
\text { lulometria }\end{array}$ & hidx & ulice & mostr & deform: & solo e \\
\hline Prof. (m) & $K_{x}(\mathrm{~cm} / \mathrm{s})$ & $\mathrm{K}_{\mathrm{y}}(\mathrm{cm} / \mathrm{s})$ & $K_{z}(\mathrm{~cm} / \mathrm{s})^{(1)}$ & $K_{z} / K_{x}$ & $K_{2} / K_{y}$ & $\begin{array}{r}\text { En } \\
\text { Granulo }\end{array}$ & io & $\mathrm{K}_{\mathrm{z}} / \mathrm{K}_{\mathrm{gr}}^{(3)}$ \\
\hline & & & & & & d10 (mm) & $\mathrm{K}_{\mathrm{gr}}(\mathrm{cm} / \mathrm{s})$ & \\
\hline 0,2 & - & $7,76 \mathrm{E}-04$ & $2,42 E-03$ & - & 3,1 & 0,0249 & $6,20 \mathrm{E}-04$ & 3,90 \\
\hline 0,5 & - & - & - & - & - & 0,04728 & $2,24 \mathrm{E}-03$ & - \\
\hline 1 & - & - & $3,76 E-03$ & - & - & 0,03109 & $9,67 \mathrm{E}-04$ & 3,90 \\
\hline 2 & - & - & - & - & - & 0,02891 & $8,36 \mathrm{E}-04$ & - \\
\hline 3 & $9,98 \mathrm{E}-04$ & $1,45 \mathrm{E}-03$ & $2,77 \mathrm{E}-03$ & 2,8 & 1,9 & 0,01573 & $2,47 \mathrm{E}-04$ & 11,20 \\
\hline 4 & - & - & - & - & - & 0,0231 & $5,34 \mathrm{E}-04$ & - \\
\hline 5 & $6,73 \mathrm{E}-04$ & $1,33 E-03$ & $1,29 \mathrm{E}-03$ & 1,9 & 1,0 & 0,02362 & $5,58 \mathrm{E}-04$ & 2,32 \\
\hline 6 & - & - & - & - & 1 & 0,02391 & $5,72 \mathrm{E}-04$ & 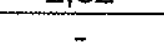 \\
\hline 7 & $1,36 \mathrm{E}-03$ & $1,22 \mathrm{E}-03$ & $9,71 \mathrm{E}-04$ & 0,7 & 0,8 & 0,0211 & $4,45 \mathrm{E}-04$ & 2,18 \\
\hline 8 & - & - & - & - & 1 & 0,01597 & $2,55 \mathrm{E}-04$ & - \\
\hline 9 & - & $3,36 \mathrm{E}-04$ & $1,26 \mathrm{E}-04$ & - & 0,4 & 0,02064 & $4,26 \mathrm{E}-04$ & 0,30 \\
\hline 9,5 & - & $2,87 \mathrm{E}-03$ & $2,55 \mathrm{E}-03$ & - & 0,9 & 0,09748 & $9,50 \mathrm{E}-03$ & 0,27 \\
\hline 10 & - & - & - & - & - & 0,03042 & $9,25 \mathrm{E}-04$ & - \\
\hline 10,5 & - & - & - & - & - & 0,02307 & $5,32 \mathrm{E}-04$ & - \\
\hline 11,5 & - & - & - & - & - & 0,0424 & $1,80 \mathrm{E}-03$ & - \\
\hline $\mathrm{L} 50 \mathrm{C}$ & - & - & - & - & - & 0,03855 & $1,49 \mathrm{E}-03$ & - \\
\hline L50D & - & - & - & - & - & 0,03778 & $1,43 \mathrm{E}-03$ & - \\
\hline L50E & - & - & - & - & - & 0,02165 & $4,69 \mathrm{E}-04$ & - \\
\hline L1C & - & - & - & - & - & 0,02968 & $8,81 \mathrm{E}-04$ & - \\
\hline L.1D & - & - & - & 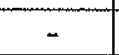 & - & 0,02688 & $7,23 \mathrm{E}-04$ & - \\
\hline L1E & - & - & - & - & - & 0,0321 & $1,03 \mathrm{E}-03$ & - \\
\hline
\end{tabular}

(1) Condutividade hidráulica no eixo $\mathrm{Z}$ (vertical) calculada a partir da média geométrica de dois ou três ensaios. Resultados parciais de $\mathrm{K}_{\mathrm{z}}$ no Anexo 2. (2) Condutividade hidráulica calculada a partir da curva d10\% do ensaio granulométrico pela equação $\mathrm{K}=1 * \mathrm{~d}_{10}{ }^{2}$, com K em cm/s e $\mathrm{d}_{10}{ }^{2} \mathrm{em} \mathrm{mm} \mathrm{(Freeze} \mathrm{\&} \mathrm{Cherry,} \mathrm{1979).} \mathrm{(3)} \mathrm{Grau} \mathrm{de}$ variação das condutividades hidráulicas obtidas em amostras não deformadas $\left(\mathrm{K}_{2}\right)$ e pela curva granulométrica. 


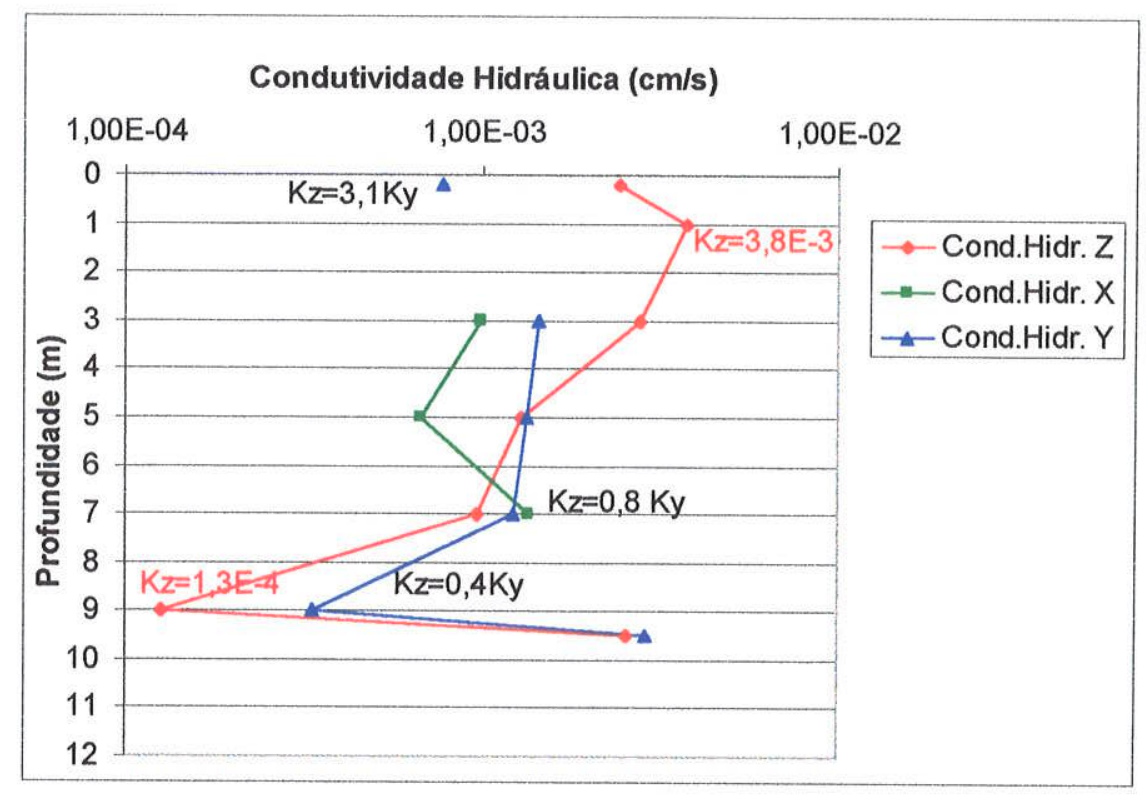

Figura 7 - Condutividades hidráulicas nas direções $\mathrm{Z}, \mathrm{X}$ e Y de amostras indeformadas de solo em função da profundidade.

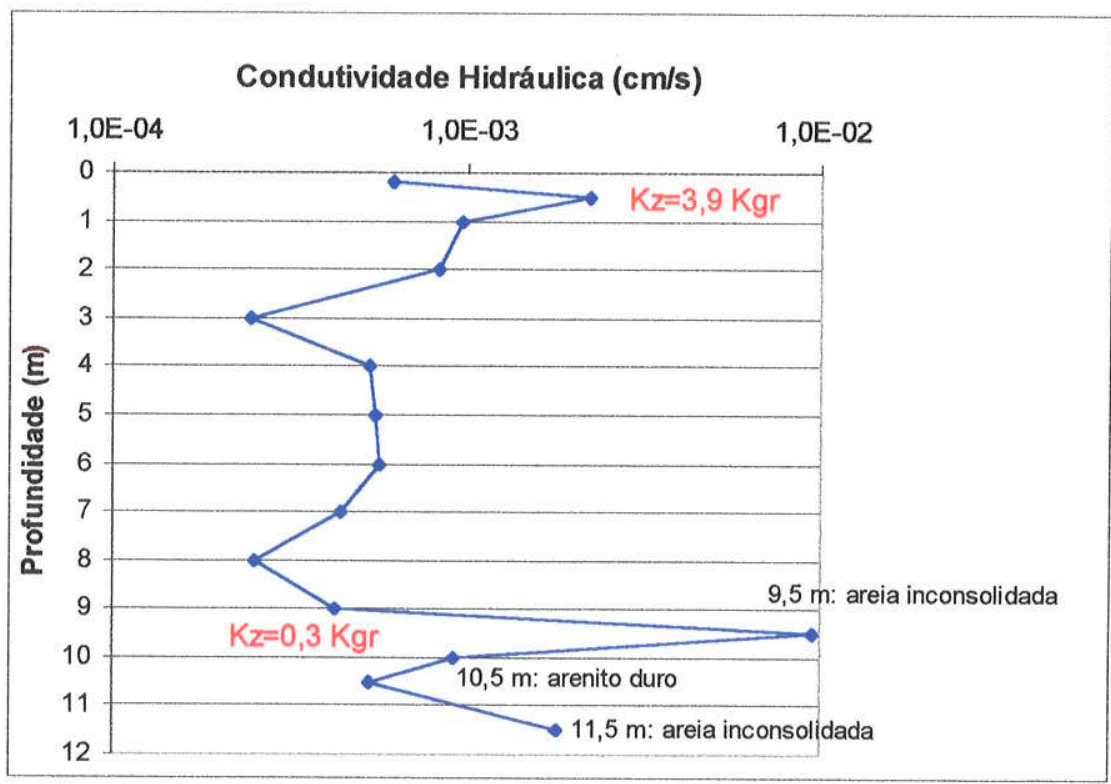

Figura 8 - Condutividade hidráulica calculada a partir dos ensaios granulométricos em função da profundidade. 
Observa-se, da Tabela 10 e da Figura 7, que a condutividade hidráulica saturada na direção $Z$ (vertical) da amostra do aterro $(0,2 \mathrm{~m})$ é ligeiramente menor que a da amostra de solo na profundidade de $1 \mathrm{~m}$. Desta profundidade até $9 \mathrm{~m}$, a condutividade hidráulica diminui cerca de 20 vezes. A partir de então, há um aumento abrupto na profundidade de $9,5 \mathrm{~m}$.

A diferença nos valores de condutividade hidráulica saturada em função da direção do ensaio indica que a direção $Z$ (vertical) tem maior permeabilidade desde a superfície até $5 \mathrm{~m}$, quando os valores nas três direções tendem a se equiparar. A partir de $5 \mathrm{~m}$, a condutividade hidráulica no sentido vertical é menor que nas demais direções. Aos $9,5 \mathrm{~m}$, a condutividade hidráulica é semelhante nos dois sentidos medidos pois trata-se de uma areia fina inconsolidada.

Os maiores valores de condutividade hidráulica no sentido vertical nos primeiros $5 \mathrm{~m}$ do solo devem-se aos macroporos verticais gerados a partir das ação do intemperismo químico e da ação biológica (raizes e animais), que destrói a estrutura original da rocha e cuja quantidade tende a diminuir com a profundidade. A partir dos $5 \mathrm{~m}$, o solo vai paulatinamente obtendo a estrutura original da rocha sedimentar, que apresenta permeabilidade no sentido vertical menor que nos demais sentidos horizontais, devido à preferência de deposição dos minerais durante a sedimentação.

O gráfico da Figura 8 indica que a curva de variação de condutividade hidráulica calculada a partir das curvas granulométricas em função da profundidade apresenta padrão semelhante ao da curva da Figura 7. Observa-se que a condutividade hidráulica da amostra do aterro $(0,2 \mathrm{~m})$ é ligeiramente menor que a da amostra de solo na profundidade de $0,5 \mathrm{~m}$ e que, exceto o resultado de $3 \mathrm{~m}$, a partir de 0,5 até $8 \mathrm{~m}$, a condutividade hidráulica diminui cerca de 9 vezes, aumentando também abruptamente na profundidade de 9,5 m, na camada de areia fina. A partir desta profundidade, a condutividade hidráulica cai até $10,5 \mathrm{~m}$ (arenito duro silicificado) e aumenta novamente aos 11,5 m na camada de areia fina a média. Observa-se, assim, que os resultados de condutividade hidráulica guardam uma boa correlação com os diferentes materiais perfurados e descritos na Tabela 8. 
Apesar da semelhança na forma das curvas nos dois gráficos, os valores de condutividade hidráulica medidos pelos dois métodos são diferentes. A Tabela 10 apresenta, ainda, uma relação do grau de variação dos resultados de condutividade hidráulica vertical de amostras indeformadas de solo com a condutividade hidráulica obtida pela curva granulométrica. Observa-se que, com exceção da amostra de $3 \mathrm{~m}$ que apresenta elevada diferença de valores nos diferentes métodos, há uma tendência para a ocorrência de valores mais elevados da relação $\mathrm{Kz} / \mathrm{K}_{\mathrm{gr}}$ junto da superficie, diminuindo no sentido de maior profundidade. Interpreta-se que esta tendência está relacionada ao fato de que o $\mathrm{K}_{\mathrm{gr}}$ não apresenta a interferência da estrutura do solo (macroporos), que atua como variável no $\mathrm{Kz}$ medido na amostra de solo indeformado.

\subsubsection{Curvas de Retenção}

Uma vez obtidos os dados de laboratório de potencial matricial por umidade, foi possível calcular os parâmetros porosidade total, porosidade de retenção, $\alpha, m$ e $n$, através do programa Curvaret (van Lier \& Dourado Neto, 1992) (Tabela 11, figuras 9 a 13 e Anexo 2).

Tabela 11 - Resultados calculados dos parâmetros da equação de van Genuchten a partir das curvas de retenção de água

\begin{tabular}{|c|c|c|c|c|c|c|c|}
\hline Amostra & $\alpha$ & $\alpha^{3}(=-1 / \alpha)$ & $m$ & $n(=\beta)$ & $\theta_{r}$ & $\theta_{s}$ & Correlação \\
\hline $1 \mathrm{~A}$ & 0,0836 & $-11,9617$ & 0,3314 & 1,495663 & 0,14 & 0,46 & 0,982 \\
\hline $1 \mathrm{~B}$ & 0,0505 & $-19,802$ & 0,3447 & 1,526019 & 0,15 & 0,423 & 0,989 \\
\hline $1 \mathrm{C}$ & 0,0939 & $-10,6496$ & 0,3612 & 1,565435 & 0,143 & 0,513 & 0,980 \\
\hline 3A & 0,038 & $-26,3158$ & 0,3171 & 1,464343 & 0,128 & 0,445 & 0,965 \\
\hline 3B & 0,0414 & $-24,1546$ & 0,2976 & 1,42369 & 0,146 & 0,45 & 0,979 \\
\hline 3C & 0,0372 & $-26,8817$ & 0,3838 & 1,62285 & 0,128 & 0,453 & 0,986 \\
\hline $5 \mathrm{~A}$ & 0,0306 & $-32,6797$ & 0,3308 & 1,494322 & 0,142 & 0,45 & 0,988 \\
\hline 5B & 0,0234 & $-42,735$ & 0,4121 & 1,70097 & 0,143 & 0,46 & 0,988 \\
\hline CC & 0,0375 & $-26,6667$ & 0,3251 & 1,481701 & 0,142 & 0,44 & 0,986 \\
\hline $7 \mathrm{~A}$ & 0,0415 & $-24,0964$ & 0,3085 & 1,446132 & 0,163 & 0,449 & 0,978 \\
\hline $7 \mathrm{~B}$ & 0,0258 & $-38,7597$ & 0,3781 & 1,607976 & 0,157 & 0,46 & 0,986 \\
\hline $7 \mathrm{C}$ & 0,0228 & $-43,8596$ & 0,6093 & 2,559509 & 0,252 & 0,43 & 0,997 \\
\hline 9A & 0,0276 & $-36,2319$ & 0,2823 & 1,39334 & 0,269 & 0,45 & 0,979 \\
\hline 9B & 0,0337 & $-29,6736$ & 0,2681 & 1,366307 & 0,229 & 0,442 & 0,982 \\
\hline 9,5 & 0,0282 & $-35,461$ & 0,5121 & 2,0496 & 0,096 & 0,408 & 0,985 \\
\hline
\end{tabular}

$\theta_{\mathrm{r}}=$ umidade volumétrica de retenção; $\theta_{\mathrm{s}} \approx$ umidade volumétrica de saturação;

$\alpha\left(\mathrm{em} \mathrm{cm}^{-1}\right.$ de $\left.\mathrm{H}_{2} \mathrm{O}\right)$ e $\mathrm{m}$ (adimensional) $=$ constantes empíricas relacionadas com o solo; e $\mathrm{n}=1-1 / \mathrm{m}$ 
Os valores de umidade volumétrica de saturação correspondem, na maior parte dos casos, aos valores de porosidade total, apresentadas no item a seguir. Em alguns casos, os valores da porosidade total, além de todos os valores da porosidade de retenção, foram estimados com base no comportamento das curvas das Figuras 9 a 13. A maioria das curvas apresentaram coeficiente de correlação entre a curva calculada e os dados do ensaio superiores a $98 \%$. Os valores de $(-1 / \alpha)$ e $\beta$ foram calculados, pois são esses os parâmetros que alimentam o modelo de fluxo da zona não saturada.
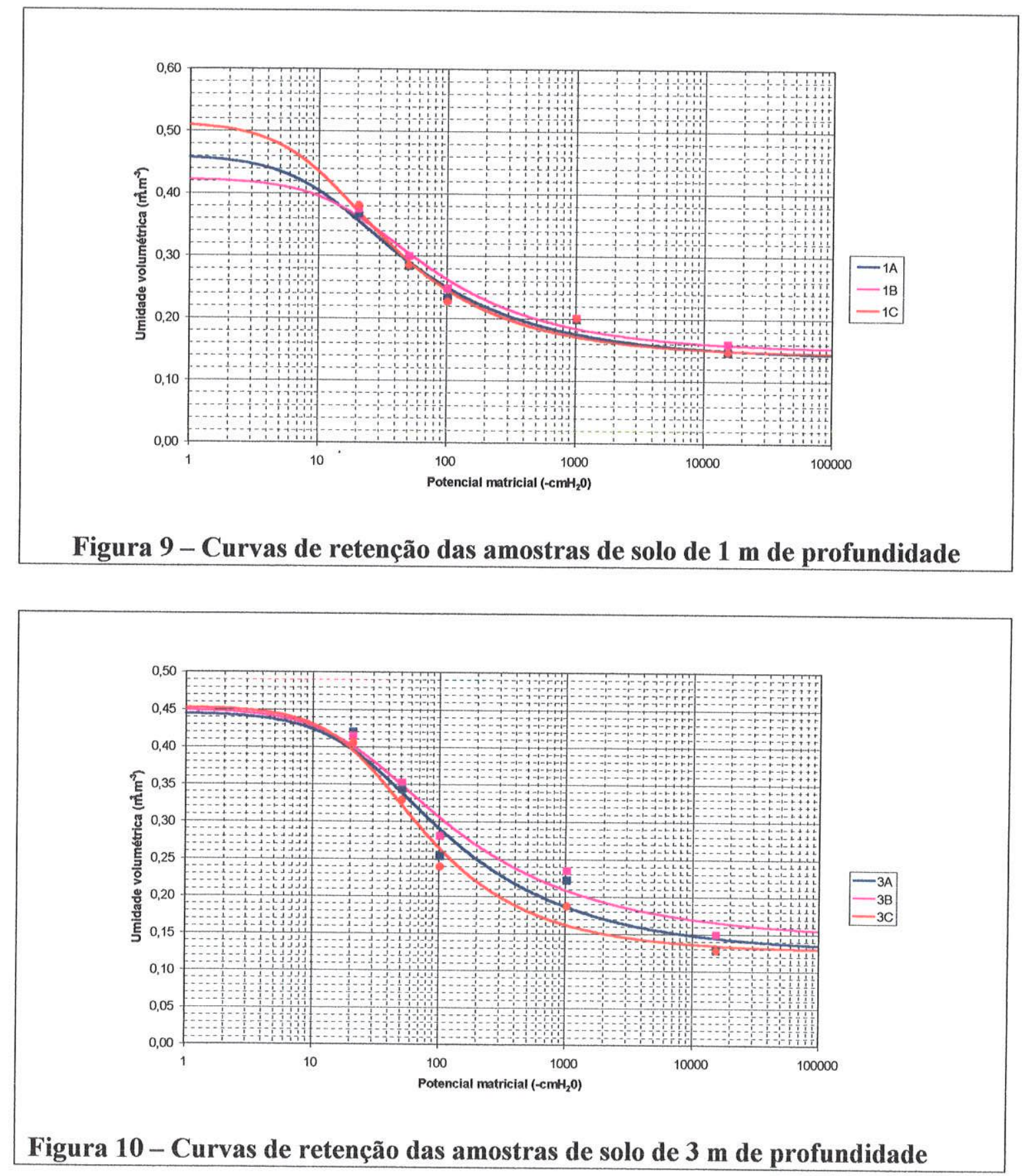


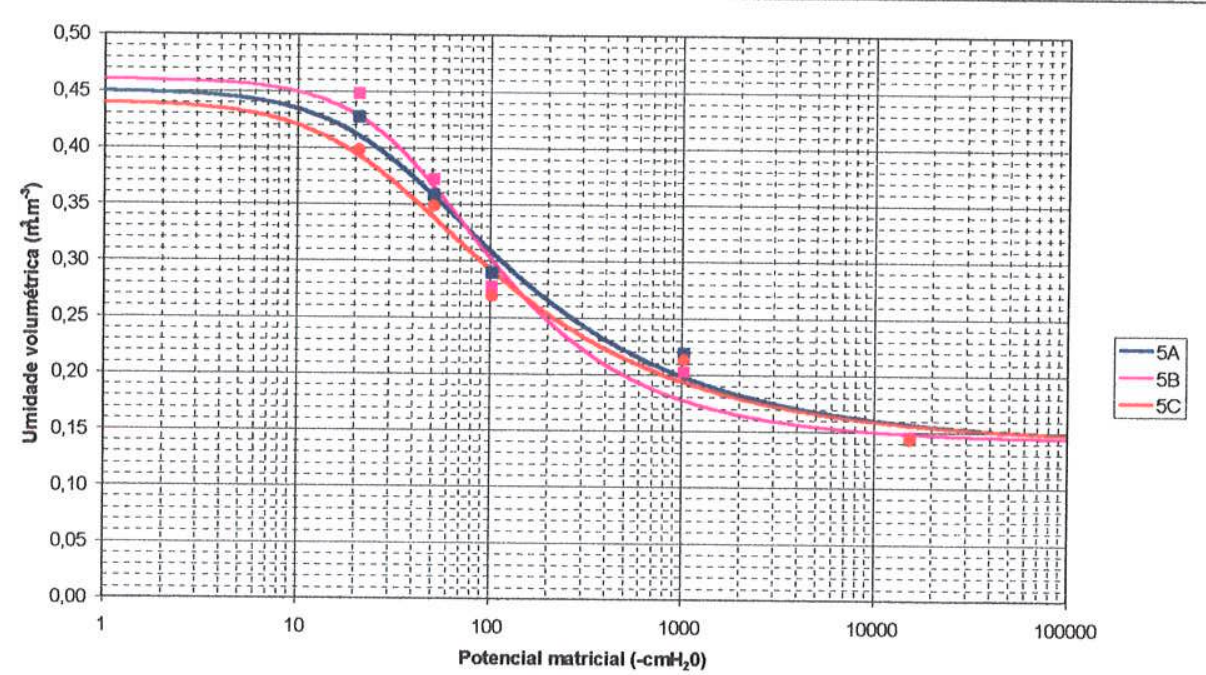

Figura 11 - Curvas de retenção das amostras de solo de 5 m de profundidade

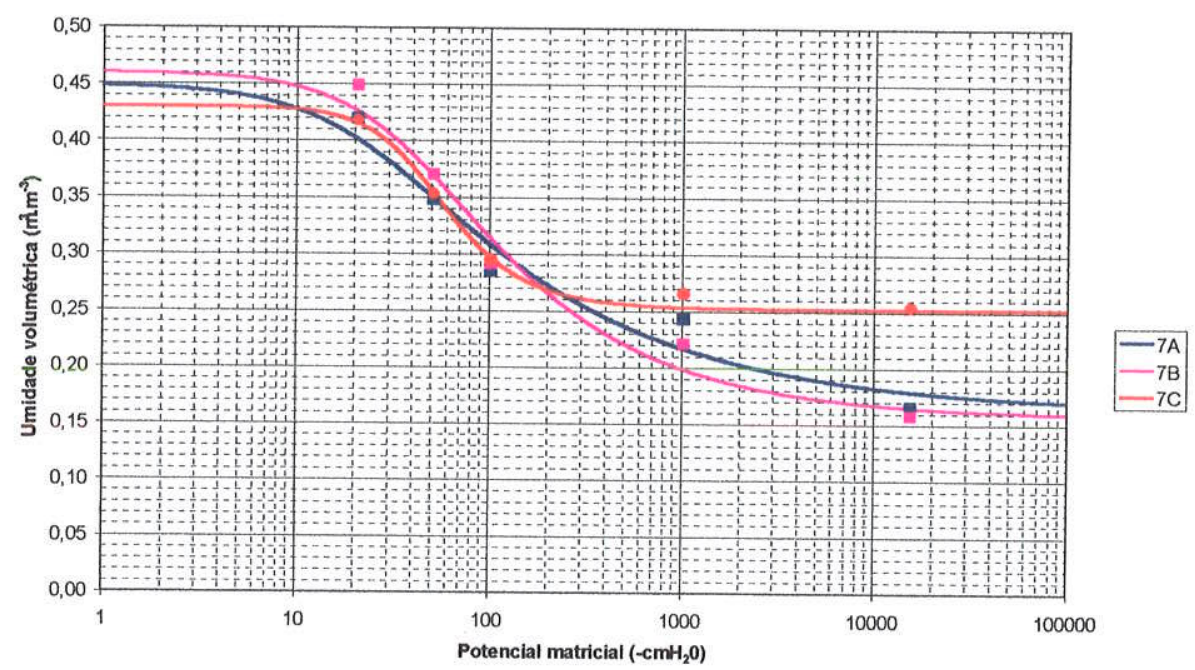

Figura 12 - Curvas de retenção das amostras de solo de $7 \mathrm{~m}$ de profundidade

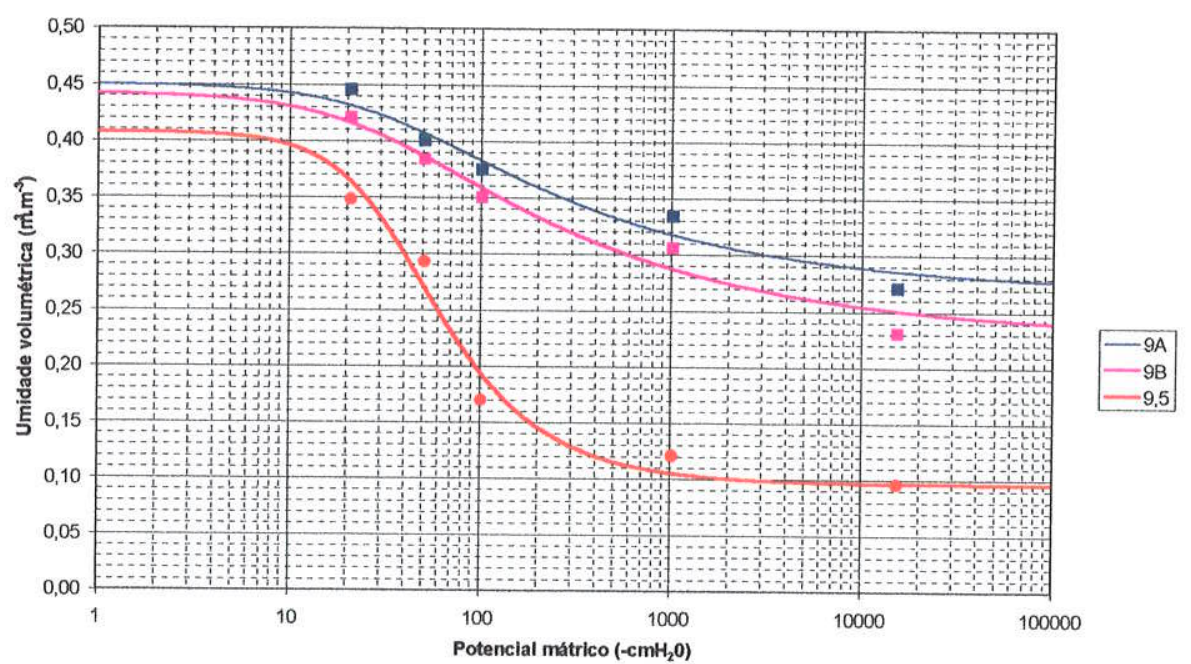

Figura 13 - Curvas de retenção das amostras de solo de 9 e $9,5 \mathrm{~m}$ de profundidade 


\subsubsection{Porosidades Total e Efetiva}

A porosidade total das amostras de solo foi calculada a partir dos dados de densidade aparente das amostras indeformadas de solo utilizados para a execução dos ensaios de retenção e cujos resultados encontram-se no Anexo 3. Assumindo que a densidade dos sólidos é igual a $2,65 \mathrm{~g} / \mathrm{cm}^{3}$, utiliza-se a seguinte relação para a obtenção da porosidade total:

$$
\mathrm{n}=1-\rho_{\mathrm{b}} / \rho_{\mathrm{s}} \quad \text { Equação } 9
$$

onde:

n é a porosidade total (vol./vol.),

$\rho_{b}$ é a densidade aparente da amostra $\left(\mathrm{em} \mathrm{g} / \mathrm{cm}^{3}\right)$, e

$\rho_{s}$ é a densidade dos sólidos $\left(\mathrm{em} \mathrm{g} / \mathrm{cm}^{3}\right)$.

A porosidade efetiva foi calculada subtraindo-se a porosidade de retenção da porosidade total. O termo porosidade de retenção, por sua vez, é aqui considerado sinônimo de "capacidade de campo', que é obtida da curva de retenção e corresponde ao valor de umidade relativo à tensão matricial de 0,1 atm. (ou $103 \mathrm{~cm}$ de $\mathrm{H}_{2} \mathrm{O}$ ) (Buckman \& Brady, 1968). A Tabela 12 apresenta os resultados das porosidades total, de retenção e efetiva calculados a partir dos dados do Anexo 2.

\section{Tabela 12 - Porosidades total, de retenção (capacidade de campo) e efetiva das amostras indeformadas de solo}

\begin{tabular}{|c|c|c|c|}
\hline Amostra & Porosidade Total & Porosidade de Retenção & Porosidade Efetiva \\
\hline 1A & 46,04 & 23,24 & 22,80 \\
\hline $1 \mathrm{~B}$ & 42,26 & 24,74 & 17,52 \\
\hline $1 \mathrm{C}$ & 51,32 & 22,72 & 28,60 \\
\hline $3 \mathrm{~A}$ & 44,53 & 25,31 & 19,22 \\
\hline $3 \mathrm{~B}$ & 38,49 & 28,02 & 10,47 \\
\hline $3 \mathrm{C}$ & 45,28 & 23,91 & 21,37 \\
\hline $5 \mathrm{~A}$ & 40,00 & 28,89 & 11,11 \\
\hline $5 \mathrm{~B}$ & 43,77 & 27,70 & 16,07 \\
\hline $5 \mathrm{C}$ & 40,00 & 26,87 & 13,13 \\
\hline $7 \mathrm{~A}$ & 44,91 & 28,47 & 16,44 \\
\hline $7 \mathrm{~B}$ & 44,53 & 29,11 & 15,42 \\
\hline $7 \mathrm{C}$ & 43,02 & 29,51 & 13,51 \\
\hline $9 \mathrm{~A}$ & 41,13 & 37,44 & 3,69 \\
\hline $9 \mathrm{~B}$ & 44,15 & 35,03 & 9,12 \\
\hline 9,5 & 40,75 & 16,96 & 23,79 \\
\hline
\end{tabular}




\subsection{Potenciais Hidráulicos na Zona Não Saturada}

Este item apresenta os principais dados levantados para a caracterização dos sentidos dos fluxos da água na zona não saturada, bem como uma descrição geral dos processos que interferem nos potenciais hidráulicos no tempo e no espaço. O Anexo 3 apresenta os dados brutos de monitoramento de potencial matricial dos tensiômetros, com as unidades em $\mathrm{mmHg}$ e os mesmos dados transformados em metros de coluna d'água.

\subsubsection{Variações de Potenciais Hidráulicos com a Profundidade}

São apresentadas na Figura 14, as curvas de potenciais hidráulicos totais resultantes do monitoramento dos tensiômetros instalados dentro do poço da estação de monitoramento ao longo dos anos de 1999, 2000 e os primeiros meses de 2001. O gráfico foi construído transformando-se as unidades dos dados de potencial matricial dos tensiômetros de $\mathrm{mmHg}$ para metros de coluna d'água através da Equação 2 e somando-se o resultado à posição do tensiômetro em relação à cota de $465 \mathrm{~m}$, que corresponde à cota da superfície em relação ao datum aproximado do nível do mar, através da Equação 1. O movimento da água se dá dos pontos de maior para os de menor potencial hidráulico para cada data específica (verticalmente para baixo ou para cima), sendo que as variações temporais dos potenciais hidráulicos estão ligadas aos eventos sazonais de seca e recarga.

No decorrer do tempo, nota-se que o perfil da zona não saturada apresenta um período de secagem ao longo de toda a sua espessura estendendo-se desde março/99 até principalmente o início de janeiro/2000, quando inicia-se um período de recarga que se prolonga até o final de março/2000. O evento de recarga do início de janeiro/2000 gerou uma frente de molhamento na zona não saturada que se deslocou verticalmente para baixo e atingiu o aqǘfero freático após um período de três meses, por volta do início de abril/2000. Nesta ocasião, o aquúfero freático teve rápida elevação de níveis, após um longo período de drenagem. 


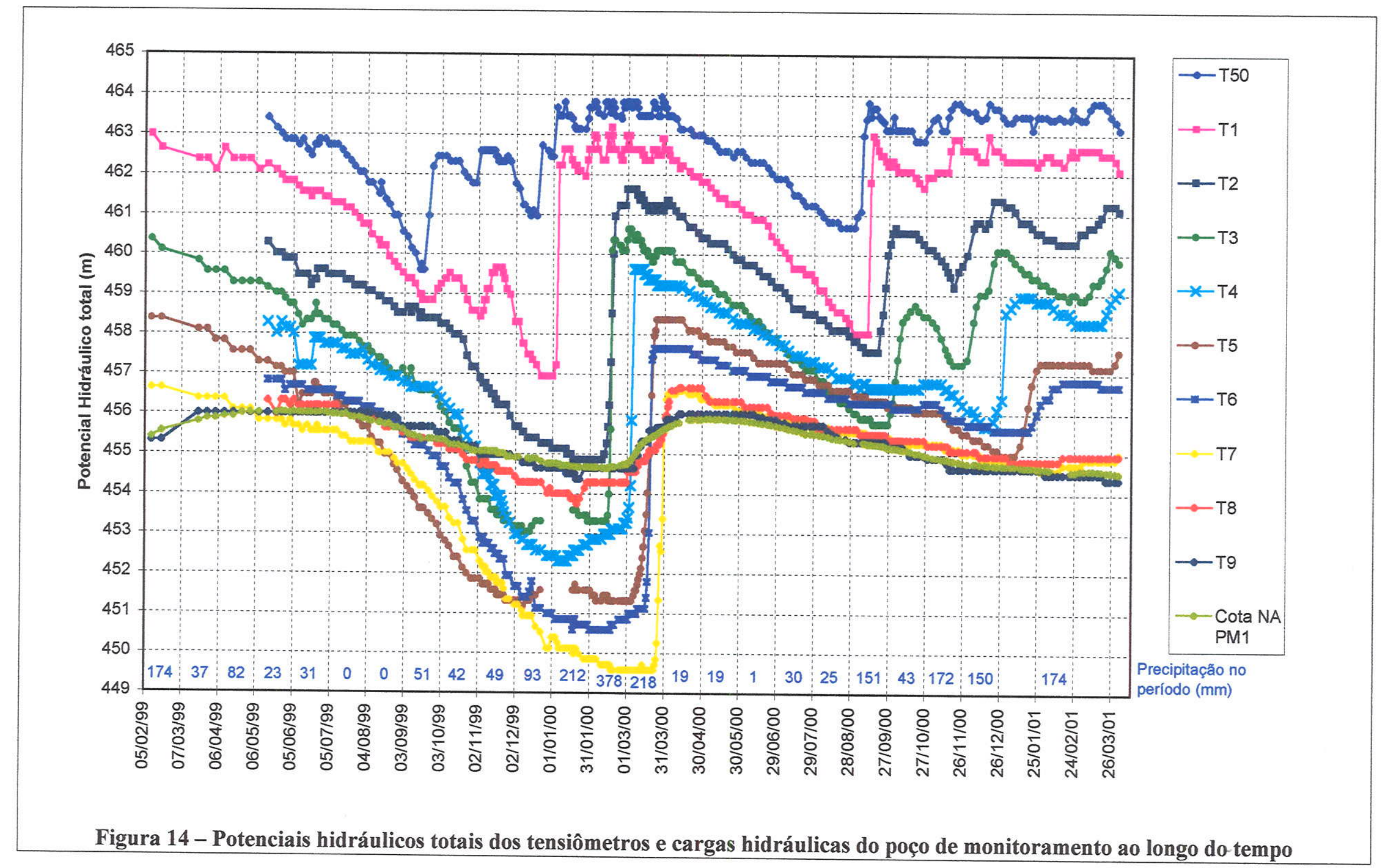


O início de um novo ciclo de estiagem se dá no princípio de abril/2000, quando se nota um novo processo de aprofundamento do nível do aqüífero freático e uma lenta queda dos potenciais hidráulicos em todos os tensiômetros. A estiagem se estendeu até setembro/2000, quando deu-se o início da recarga e a geração de algumas pequenas frentes de molhamento que sofreram dissipação completa até $5 \mathrm{~m}$ de profundidade. O início do processo mais intenso de recarga ocorreu, porém, a partir de dezembro/2000. A frente de molhamento deste evento de recarga ainda não havia chegado no aqüífero freático até o final de março/2001, encontrando-se estacionada entre as profundidades de 7 e 8 metros.

Nota-se, portanto, um comportamento diferente nos tempos de trânsito das frentes de molhamento dos eventos de recarga de 1999/2000 e 2000/2001, que está relacionado com a intensidade e distribuição dos eventos de precipitação que geram recarga. A precipitação acumulada em cada período de 30 dias encontra-se anotada no gráfico da Figura 14 e verifica-se que os eventos do período 1999/2000 foram mais intensos e concentrados no tempo em relação àqueles do período 2000/2001.

De uma forma geral, observa-se que o molhamento do perfil do solo se dá sob a forma de um pulso, seguido de um longo e paulatino processo de secagem até o novo evento de recarga. Os efeitos da seca são bastante intensos no auge destes períodos, verificando-se valores de potenciais matriciais que chegam a $-680 \mathrm{mmHg}$ (ou $-9,23 \mathrm{~m}$ de coluna d'água - T50C julho/2000) (Anexo 3). Em algumas ocasiões, inclusive, os potenciais matriciais do solo eram inferiores ao valor de air entry value dos tensiômetros, o que promovia a entrada de ar dentro dos aparelhos e a subseqüente perda das leituras, como se pode notar pela ausência de dados de alguns aparelhos em algumas situações (Anexo 3).

Observa-se, ainda na Figura 14, um padrão diferente das curvas de potenciais hidráulicos dos tensiômetros entre os períodos de março a outubro dos anos de 1999 e 2000, que correspondem aos dois períodos de secagem do perfil do solo. Constata-se que o evento de recarga em setembro/2000 se mostra como uma frente de molhamento que chega aos tensiômetros T3 e T4, respectivamente, no início de outubro e de novembro, enquanto que o evento de recarga de setembro/1999 formou uma frente de molhamento que se dissipou após $1 \mathrm{~m}$ de profundidade. De setembro/99 a março/2000, os potenciais hidráulicos de vários tensiômetros (destacando-se o T5, T6 e T7), apresentavam-se mais baixos que a carga hidráulica do aqǘfero freático, denotando a ocorrência de potenciais de fluxos ascendentes da água do aqüifero freático para a zona não saturada. O mesmo padrão não ocorreu, entretanto no mesmo período 
do ano seguinte. Estas características de comportamento dos potenciais hidráulicos acima descritas estão relacionados com a ocorrência da ação de evapotranspiração causada pelas raízes de uma árvore ao longo do ano de 1999, e que foi sacrificada em janeiro/2000. Ao longo do ano 2000, quando não há a ocorrência de evapotranspiração gerada pela árvore, nota-se que há predominância de potenciais de fluxos descendentes da água de infiltração desde a superficie até o aqüífero freático.

Subtraindo-se a ação de evapotranspiração ocasionada pela árvore ao longo do ano de 1999, é possível identificar a ocorrência de três zonas hidráulicas na zona não saturada através da leitura do comportamento dos potenciais hidráulicos dos tensiômetros. A primeira, engloba os tensiômetros situados entre 0,5 e (eventualmente) $2 \mathrm{~m}$, e caracteriza-se por sofrer mais intensamente os efeitos das variações climáticas e do uso e ocupação do solo. Nesta espessura, os potenciais hidráulicos respondem rápida e intensamente a cada pequeno evento de recarga ou secagem, como se observará mais claramente no próximo item, onde são apresentados e discutidos os dados dos tensiômetros externos ao poço da estação de monitoramento.

A segunda zona situa-se entre as profundidades de 2 e $7 \mathrm{~m}$, e distingue-se das demais por apresentar características de transição entre a primeira e terceira zonas. Nesta faixa, as pequenas frentes de molhamento sofrem dissipação e os tensiômetros registram apenas mudanças de potenciais matriciais que se relacionam com eventos mais longos de recarga ou de secagem. As dissipações das pequenas frentes de molhamento ocorrem devido aos efeitos da evaporação que ocorrem na primeira zona, e possivelmente devido à ação de alguma evapotranspiração provocada por raízes de árvores mais distantes.

A terceira zona relaciona-se com as profundidades de $7 \mathrm{~m}$ até o nível d'água (que apresentou profundidades mínima e máxima de $8,96 \mathrm{~m}$ em 26/05/99 e 10,47 m em 31/03/2001) e caracteriza-se por apresentar valores de potenciais hidráulicos muito próximos e acompanhando as variações dos valores de carga hidráulica do aqüífero freático, característica esta que se apresenta de forma bastante nítida principalmente após abril/2000, quando não há mais a influência da intensa evapotranspiração provocada pela árvore (Figura 14). Os valores semelhantes de potenciais hidráulicos totais dos tensiômetros T7, T8 e T9 sinalizam que o fluxo vertical descendente da água neste intervalo de profundidade é virtualmente desprezível.

Uma interpretação importante que se faz dos dados de descrição da geologia e da condutividade hidráulica dos materiais é de que não deve haver uma conexão hidráulica direta entre a base da zona não saturada e o aquúf́ero freático na estação de monitoramento, devido à 
ocorrência da camada de arenito duro e de baixa condutividade hidráulica entre 10,5 e 11,2 m (Tabela 8). Esta característica abre espaço para a possibilidade da ocorrência de fluxos laterais de água na base da zona não saturada a partir de $7 \mathrm{~m}$ de profundidade, que poderia ser comprovada através da instalação de outros equipamentos de monitoramento lateralmente nestas profundidades.

\subsubsection{Variações Laterais de Potenciais Hidráulicos}

Notou-se, no decorrer das pesquisas, a ocorrência de variações laterais dos potenciais hidráulicos nos tensiômetros instalados nas mesmas profundidades. Estas variações foram atribuídas à camada de aterro situada ao redor do poço e também à ação da evapotranspiração gerada por raízes de vegetação.

As Figuras 15 e 16 apresentam os potenciais hidráulicos dos tensiômetros externos e internos ao poço instalados nas profundidades de 0,5 e $1 \mathrm{~m}$. Observa-se que os potenciais dos tensiômetros T50, T1 e T1B, instalados dentro do poço, são sempre mais elevados que os demais tensiômetros análogos instalados fora do poço, principalmente durante o período de estiagem. Neste período, os tensiômetros de dentro do poço indicam que o solo seca menos e mais lentamente, ocorrendo o inverso no período de recarga, quando ocorre molhamento maior e mais rápido que o solo monitorado pelos tensiômetros de fora do poço (T50C, T1C, T50D, T1D, T50E e T1E) (Anexo 3).

Esta característica está relacionada com os efeitos da camada de $0,35 \mathrm{~m}$ de aterro menos permeável sobre os tensiômetros instalados na parede do poço. Ocorre que o material do aterro possui maior quantidade de argila que o solo arenoso natural de fora do poço, caracterizando-o por reter com maior facilidade a umidade durante o período da estiagem, e de ser mais molhante que o solo natural superficial durante o período de recarga.

Acredita-se que a influência do material do aterro sobre os potenciais matriciais da zona não saturada no poço da estação de monitoramento não deva exceder as profundidades de 2 ou 3 m. Uma evidência direta pode ser observada no destaque da Figura 17, que mostra os potenciais totais dos tensiômetros externos T50D e T1D em relação ao tensiômetro T2 interno ao poço. No período do início de dezembro/2000 até meados de fevereiro de 2001 ocorre um evento de secagem do perfil detectado pelos tensiômetros externos, mas que não foram detectados pelos tensiômetros T50 e T1 do poço no mesmo período (Figura 14). Caso ocorresse influência do 
material do aterro na profundidade de $2 \mathrm{~m}$, os potenciais nesta profundidade deveriam variar na mesma proporção da variação dos potenciais dos tensiômetros T50 e T1. Esta observação será retomada no próximo item, em que se utilizou o modelo VS2DT para aprimorar o entendimento do modelo de circulação da água na zona não saturada.

Ainda na Figura 17, foi possível identificar a ocorrência de uma linha de evaporação situada ao redor de $1 \mathrm{~m}$ de profundidade no período de maio a final de agosto/2000, quando os potenciais hidráulicos do tensiômetro T50D eram menores que os do tensiômetro T1D. Este mesmo padrão ocorreu com os demais tensiômetros instalados nestas profundidades, exceto nos tensiômetros de dentro do poço (Figura 14), pois a camada de aterro menos permeável impediu a ocorrência da linha de evaporação na mesma profundidade dos demais.

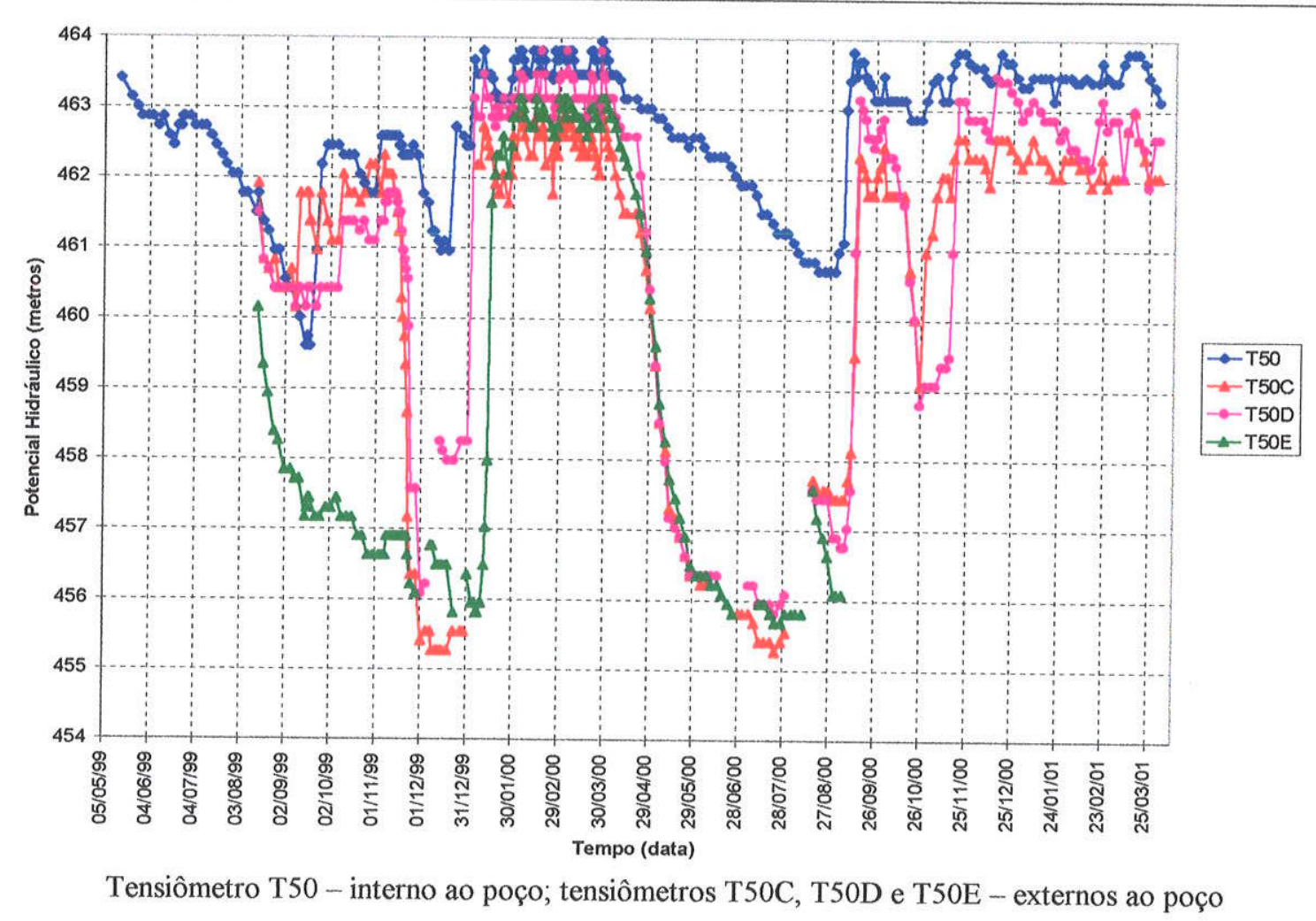

Figura 15 - Potenciais hidráulicos totais dos tensiômetros de $0,5 \mathrm{~m}$ ao longo do tempo 


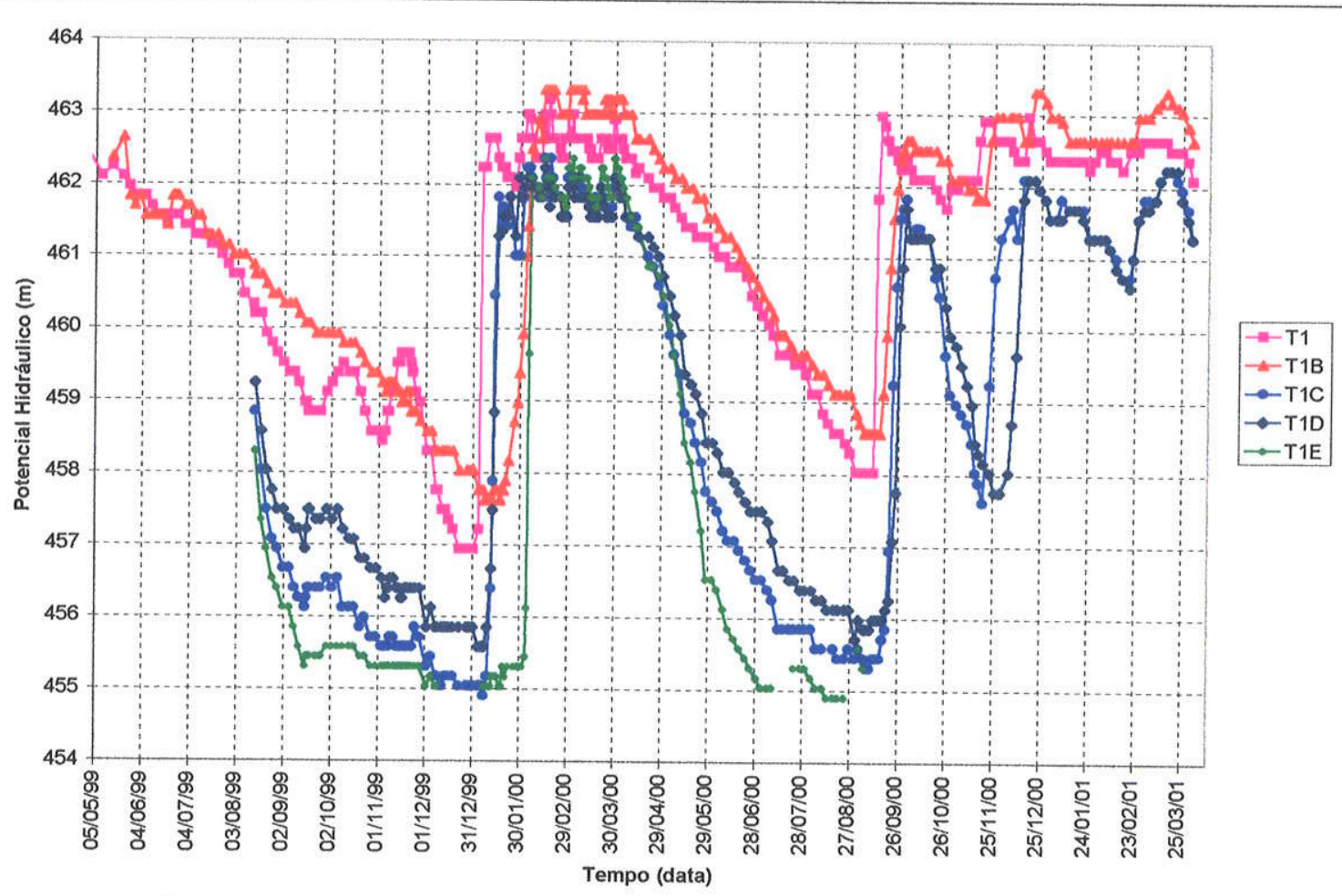

Tensiômetros T1 e T1B - internos ao poço; tensiômetros T1C, T1D e T1E - externos ao poço

Figura 16-Potenciais hidráulicos totais dos tensiômetros de $1,0 \mathrm{~m}$ ao longo do tempo

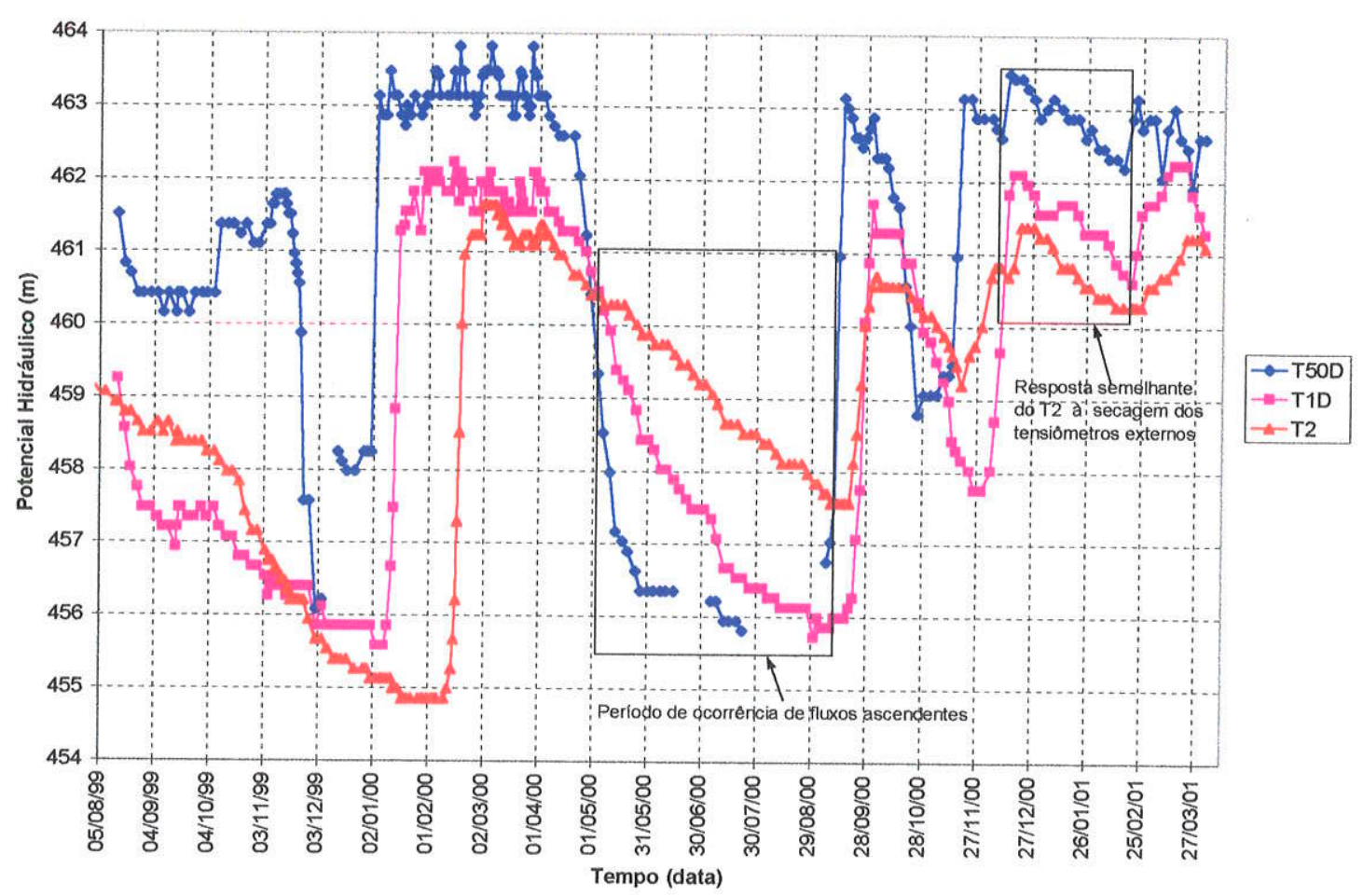

Tensiômetro T50D e T1D - externos ao poço; tensiômetro T2 - interno ao poço

Figura 17 - Potenciais hidráulicos dos tensiômetros de T50D, T1D e T2 ao longo do tempo 
Considerando, porém, que a influência do aterro possa não se estender para além da profundidade de $2 \mathrm{~m}$, o período de maio a final de agosto/2000 da Figura 17 ainda indica a existência de potenciais de fluxos ascendentes de água provenientes da profundidade de $2 \mathrm{~m}$, o que pode definir a ocorrência da linha de evaporação ao redor desta profundidade no período indicado.

Variações laterais no comportamento dos potenciais hidráulicos também foram identificadas devido à ação de evapotranspiração. Na Figura 18, é possível verificar a variação dos potenciais hidráulicos em função da profundidade em três situações de tempo, sendo que a ocorrência da variação lateral é observada na curva de outubro/99. Nota-se que os potenciais hidráulicos dos tensiômetros T1, T3, T5 e T7 apresentam valores relativamente mais baixos que os dos tensiômetros T2, T4 e T6, formando um ziguezague no gráfico. Estes dois grupos de tensiômetros situam-se, respectivamente, nas posições C' e B do poço (Figura 5), e os valores de potenciais hidráulicos medidos nos tensiômetros indicam que um lado do poço (posição C') permaneceu mais seco que o outro (posição B) no período. Esta ocorrência deve-se à ação das raízes profundas da árvore sacrificada em janeiro/2000, com maior densidade de ocorrência na posição C' do poço.

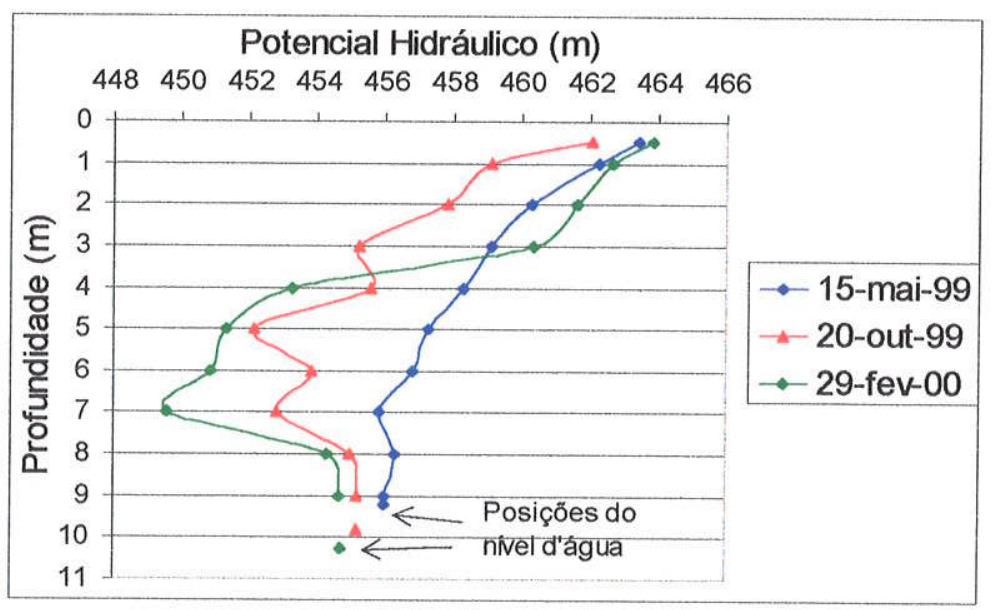

Figura 18 - Variação do potencial hidráulico em função da profundidade em três situações de tempo 
A ação destas raízes motivou a ocorrência de velocidades diferentes da frente de molhamento principal gerada durante o evento de recarga de 1999/2000. O lado B do poço que contém os tensiômetros pares (T2, T4 e T6) detectaram a passagem da frente de molhamento de forma mais rápida que os tensiômetros ímpares (T3, T5 e T7) instalados no lado C', mais seco. No Anexo 3, verifica-se que os tensiômetros T2, T4 e T6 registraram o início do evento de molhamento nos dias 11/02, 17/02 e 02/03/2000, respectivamente. Os tensiômetros T3, T5 e T7 registraram este evento nos dias 14/02, 06/03 e 23/03/2000. Verifica-se, destes dados, que a frente de molhamento alcançou a profundidade de $6 \mathrm{~m}$ na posição $\mathrm{B}$ antes da profundidade de 5 m na posição C'. O fato de um lado estar mais seco reflete num menor valor de condutividade hidráulica não saturada, ocasionando uma menor velocidade da frente de molhamento.

A ação da transpiração da vegetação também foi evidenciada com o monitoramento do par de tensiômetros T50E e T1E (Figuras 15 e 16 e Anexo 3). Estes tensiômetros sempre registravam valores mais baixos de potencial matricial que os demais tensiômetros análogos até a data do sacrifício da árvore. Após o sacrifício, estes tensiômetros tiveram rápida elevação de potenciais e passaram a apresentar comportamento similar aos demais.

Algumas outras variações laterais nas medidas de potenciais matriciais puderam ser notadas. Verificou-se, em meados de fevereiro/2000, que o aqüífero freático apresentou elevação de nível d'água antes da chegada da frente de molhamento, que ainda se encontrava na profundidade de $5 \mathrm{~m}$ (Figura 14 e Anexo 3). Isto significa que o aqüifero sofreu a chegada prévia de frentes de molhamento de áreas vizinhas à do poço da estação. Este comportamento deve-se, em tese, à ação combinada da camada de aterro do poço, da transpiração da vegetação e a possível existência de porosidade secundária (fraturas verticais) na zona não saturada da área vizinha, que geraria zonas de fluxo preferencial da água de infiltração.

O comportamento da curva do tensiômetro T3 entre junho e o final de setembro/2000 (Figura 14) apresenta comportamento anômalo. Os potenciais hidráulicos medidos neste tensiômetro são menores que aqueles do tensiômetro T4 no período e também menores que os potenciais medidos nos tensiômetros $\mathrm{T} 5 \mathrm{e} \mathrm{T} 6 \mathrm{em}$ algumas ocasiões. $\mathrm{O}$ tensiômetro T3B (Anexo 3) apresenta valores de potenciais hidráulicos semelhantes ao do tensiômetro T3 neste período. Este comportamento sugere a ocorrência de fluxos ascendentes entre as profundidades de 3 e 4 $\mathrm{m}$ neste período de secagem do perfil, que talvez possa estar relacionada com o efeito de evapotranspiração de raízes de outras árvores mais distantes. 


\subsection{Utilização do Modelo VS2DT na Avaliação de Fluxo e Reservação de Água na Zona Não Saturada}

\subsubsection{Concepção do Modelo}

O modelo matemático de fluxo e transporte VS2DT foi utilizado de forma a se aprimorar o entendimento das condições de fluxo e reservação da água na zona não saturada. Utilizando-se dos dados de monitoramento de potenciais matriciais dos tensiômetros, três situações foram modeladas para avaliar os efeitos da ocorrência da camada de aterro na dinâmica hidráulica da zona não saturada e também para ilustrar as diferenças que foram observadas quando se utilizam dados de molhamento e de secagem no perfil no modelo.

Os dados de entrada dos três modelos, denominados Urânia A, Urânia B e Urânia C, são apresentados no Anexo 4, que correspondem a relatórios criados pelo programa UnSat Suite. A diferença dos três modelos quanto à entrada de dados está na atribuição de diferentes valores de potenciais matriciais na condição de contorno superior (dados dos tensiômetros T50D e T1D, externos ao poço, no modelo Urânia $\mathrm{A}$ e dados de tensiômetros $\mathrm{T} 50$ e $\mathrm{T} 1$, internos ao poço, no modelo Urânia B) ou então diferentes períodos de modelagem (molhamento no modelo Urânia A e secagem no Urânia $C$ ).

Todos os três modelos tem em comum a estrutura do perfil (profundidade e espessuras das camadas), os valores de alguns parâmetros do solo (armazenamento específico, porosidades total e de retenção, e os parâmetros $\alpha^{\prime}$ e $\beta^{\prime}$ de van Genuchten), a ausência de ação de evapotranspiração, e os critérios utilizados para a definição da malha, convergência e resolução do modelo (solver settings e stress period defaults - Anexo 4), que são aqueles apresentados como default do programa.

Os fluxos da zona não saturada foram simulados entre as profundidades de 0,5 e 7,0 m, sendo que os tipos de condição de contorno utilizados foram os potenciais matriciais (unidades em L) medidos nos tensiômetros nestas profundidades, que foram convertidos em fluxo (L/T) pelo programa. A vantagem no uso dos potenciais matriciais como condição de contorno é que o modelo já leva embutido os efeitos da evaporação sobre todo o perfil da zona não saturada. $O$ modelo iniciou-se em $0,5 \mathrm{~m}$ por não se dispor de dados de infiltração a partir de balanço hídrico, e findou-se em $7,0 \mathrm{~m}$, pois os potenciais hidráulicos nas profundidades maiores da zona não saturada indicaram ser praticamente nulos os fluxos verticais de água (Figura 14). Os perfis modelados possuem 7 camadas, cada qual com $1 \mathrm{~m}$ de espessura, a não ser a última, com $0,5 \mathrm{~m}$. 
O modelo Urânia A simula a situação de molhamento do perfil utilizando-se os dados de potenciais matriciais do tensiômetro T50D, externo ao poço da estação, como condição de contorno superior, medidos no período de 02/02/2000 (após o sacrifício da árvore) até 14/06/2000 (quando a frente de molhamento alcança a profundidade de $7 \mathrm{~m}$ ), perfazendo um período de modelagem de 133 dias. $O$ modelo Urânia $B$ também simula a situação de molhamento do perfil e difere do modelo Urânia A apenas na condição de contorno superior, onde foram utilizados os dados de potenciais matriciais do tensiômetro T50, que sofre a influência do aterro do poço da estação. O período de simulação e os tempos de observação são idênticos nos dois modelos. As condições iniciais de cada profundidade do perfil dos dois modelos são de potenciais matriciais medidos nos tensiômetros no dia 02/02/2000. Para a profundidade de $1 \mathrm{~m}$, os valores de potenciais matriciais iniciais utilizados foram os dos tensiômetros T1D (no modelo Urânia A) e T1 (no modelo Urânia B).

O modelo Urânia $\mathrm{C}$ simula a secagem do perfil da zona não saturada, considerando os dados de potenciais matriciais do tensiômetro T50D como condição de contorno superior, medidos no período de 01/04/2000 (perfíl úmido no início da estação seca) a 18/10/2000 (perfil seco no início das primeiras chuvas), totalizando um período de modelagem de 200 dias de estiagem. Por ser um modelo com tempo de simulação diferente dos demais, os tempos de observação também são diferentes. As condições iniciais de cada profundidade do perfil são de potenciais matriciais medidos nos tensiômetros no dia 01/04/2000.

\subsubsection{Calibração}

A calibração dos três modelos se deu com a busca de resultados de potenciais matriciais calculados pelo modelo que fossem semelhantes àqueles medidos pelos tensiômetros, através da variação dos principais parâmetros do solo (condutividade hidráulica, porosidades e parâmetros da equação de van Genuchten).

Uma análise de sensibilidade prévia do modelo foi realizada através da variação para mais e para menos de um ou dois desvios padrões dos valores médios de condutividade hidráulica, $\alpha^{\prime}$, $\beta^{\prime}$ e porosidades total e de retenção obtidos dos ensaios de laboratório (tabelas 10 e 11). $O$ coeficiente de armazenamento específico também foi analisado, utilizando-se de valores arbitrários que variaram quatro ordens de grandeza. Esta análise revelou que o parâmetro que proporciona as maiores variações de resposta do modelo é a condutividade hidráulica, seguido dos parâmetros $\alpha^{\prime}$ e $\beta^{\prime}$. Variações dos valores das porosidades e principalmente do 
armazenamento específico produzem modificações apenas secundárias nos resultados de potenciais matriciais calculados. Valores mais elevados de condutividade hidráulica, $\alpha^{\prime}$ e $\beta^{\prime}$ produzem modelos que drenam mais facilmente. Por ser o parâmetro mais sensível, considerouse a condutividade hidráulica como a principal variável de calibração.

Os valores dos parâmetros $\alpha^{\prime}, \beta^{\prime}$ e porosidades total e de retenção utilizados nos três modelos são semelhantes àqueles obtidos nos ensaios de laboratório, com um desvio padrão para mais ou para menos em relação ao valor médio. A exceção é o valor $\alpha^{\prime}$ da profundidade de $1 \mathrm{~m}$, que foi reduzido para $-48 \mathrm{~cm}$ em razão de não haver proporcionalidade em relação aos valores das demais profundidades (Tabela 11). Provavelmente os valores elevados obtidos nas três curvas de retenção são decorrentes da deformação da amostra no momento da coleta do solo com o anel amostrador.

O Anexo 4 apresenta, ao final de cada relatório de dados de entrada dos três modelos, uma tabela contendo os resultados parciais de potenciais matriciais calculados, que foram comparados com os dados de potenciais matriciais medidos para fins de calibração dos modelos. O critério de calibração adotado foi através do cálculo da porcentagem de resíduo normalizado $\left(\mathrm{RMS}_{\text {norm }}\right.$ - \%) para cada data de observação e profundidade, definido como:

$$
\text { RMS }_{\text {norm }}=\frac{\sqrt{\sum_{i=1}^{n}\left(\Psi \text { obs }-\Psi_{\text {calc })_{i}^{2}}\right.}}{n} \times \frac{100}{\left(\Psi_{\text {obs }} \max -\Psi_{o b s_{\text {min }}}\right)} \quad \text { Equação } 10
$$

onde: $\quad \mathrm{RMS}_{\text {norm }}=$ resíduo normalizado (em \%);

Yobs = potencial matricial observado $(\mathrm{em} \mathrm{m})$;

$\Psi$ calc $=$ potencial matricial calculado pelo modelo $(\mathrm{em} \mathrm{m})$;

$\Psi_{\text {obs }}$ max $=$ máximo valor de potencial matricial observado (em $\mathrm{m}$ );

$\Psi_{o b s_{\min }}=$ mínimo valor de potencial matricial observado $(\mathrm{em} \mathrm{m})$.

Os valores de $\mathrm{RMS}_{\text {norm }}$ medem, portanto, o desvio relativo entre os valores medidos e calculados pelo modelo. Este critério é normalmente utilizado para efeito de calibração de modelos de fluxo de água subterrânea em três dimensões, tipo MODFLOW. O modelo VS2DT não possui acoplado uma rotina de cálculos de $\mathrm{RMS}_{\text {norm. }}$. Neste trabalho, os valores de $\mathrm{RMS}_{\text {norm }}$ foram calculados em planilhas eletrônicas. Valores de $\mathrm{RMS}_{\text {norm }}$ inferiores a $10 \%$ são convencionalmente aceitos para se considerar um modelo calibrado. A Tabela 13 apresenta os resultados de resíduos normalizados em função da profundidade e do tempo em dias, representando as melhores simulações conseguidas em cada modelo. 
Dentre os modelos concebidos, o único que pode ser considerado calibrado é o modelo Urânia A (molhamento usando os tensiômetros T50D e T1D externos ao poço), que apresentou resultados de $\mathrm{RMS}_{\text {norm }}$ freqüentemente inferiores a 10\%, mesmo considerando-se os resultados em função da profundidade ou do dia de observação. As razões para não se ter conseguido resultados semelhantes com os modelos Urânia B (molhamento com tensiômetros internos) e Urânia C (secagem) estão relacionadas, respectivamente, com o efeito do aterro e com o efeito da secagem do perfil, e cujos detalhes são discutidas no item a seguir.

\begin{tabular}{|c|c|c|c|c|c|}
\hline \multicolumn{6}{|c|}{ Tabela 13 - Resultados de resíduos normalizados dos três modelos } \\
\hline \multicolumn{2}{|c|}{ URÂNIA A } & \multicolumn{2}{|c|}{ URÂNIA B } & \multicolumn{2}{|c|}{ URÂNIA C } \\
\hline $\begin{array}{l}\text { Profundidade } \\
\text { (cm) }\end{array}$ & $\begin{array}{c}\text { RMS } \\
\text { normalizado (\%) }\end{array}$ & $\begin{array}{l}\text { Profundidade } \\
(\mathrm{cm})\end{array}$ & $\begin{array}{c}\text { RMS } \\
\text { normalizado (\%) }\end{array}$ & $\begin{array}{c}\text { Profundidade } \\
(\mathrm{cm})\end{array}$ & $\begin{array}{c}\text { RMS } \\
\text { normalizado (\%) }\end{array}$ \\
\hline 100 & 12,07 & 100 & 16,68 & 100 & 3,77 \\
\hline 200 & 3,72 & 200 & 7,60 & 200 & 11,52 \\
\hline 300 & 5,09 & 300 & 8,18 & 300 & 5,71 \\
\hline 400 & 3,68 & 400 & 6,26 & 400 & 15,45 \\
\hline 500 & 6,78 & 500 & 14,78 & 500 & 15,64 \\
\hline 600 & 2,74 & 600 & 3,60 & 600 & 17,38 \\
\hline Geral & 5,68 & Geral & 9,52 & Geral & 11,58 \\
\hline Dia & $\begin{array}{c}\text { RMS } \\
\text { normalizado (\%) }\end{array}$ & Dia & $\begin{array}{c}\text { RMS } \\
\text { normalizado (\%) }\end{array}$ & Dia & $\begin{array}{c}\text { RMS } \\
\text { normalizado (\%) }\end{array}$ \\
\hline 3 & 1,81 & 3 & 1,11 & 12 & 11,54 \\
\hline 21 & 3,19 & 21 & 3,53 & 28 & 5,34 \\
\hline 43 & 6,26 & 43 & 12,72 & 56 & 6,69 \\
\hline 52 & 3,93 & 52 & 5,20 & 112 & 4,53 \\
\hline 94 & 10,88 & 94 & 40,17 & 156 & 4,06 \\
\hline 133 & 9,90 & 133 & 32,05 & 200 & 26,53 \\
\hline Geral & 6,00 & Geral & 15,80 & Geral & 9,78 \\
\hline
\end{tabular}

\subsubsection{Resultados Obtidos}

A Tabela 14 apresenta os valores de condutividade hidráulica saturada utilizados nos três modelos. As figuras 19 a 21 apresentam gráficos de potenciais matriciais em função da profundidade construídos a partir dos resultados dos modelos e a partir de dados medidos e que se encontram sumarizados no Anexo 4. 


\begin{tabular}{|c|c|c|c|c|}
\hline \multicolumn{5}{|c|}{$\begin{array}{c}\text { Tabela } 14 \text { - Comparação de valores de condutividade hidráulica saturada } \\
\text { medidas em laboratório e utilizadas nos modelos }\end{array}$} \\
\hline $\begin{array}{l}\text { Profundidade } \\
(\mathrm{m})\end{array}$ & $\begin{array}{c}\text { Kat laboratório } \\
(\mathrm{cm} / \mathrm{s})\end{array}$ & $\begin{array}{c}\mathrm{K}_{\text {sat Modelo }} \\
\text { Urânia A }(\mathrm{cm} / \mathrm{s})\end{array}$ & $\begin{array}{c}\mathrm{K}_{\text {sat Modelo }} \\
\text { Urănia B }(\mathrm{cm} / \mathrm{s})\end{array}$ & $\begin{array}{c}\text { K } \text { sat Modelo } \\
\text { Urânia } \mathrm{C}(\mathrm{cm} / \mathrm{s})\end{array}$ \\
\hline 1 & 0,00376 & 0,003348 & 0,001289 & 0,03134 \\
\hline 2 & & 0,002653 & 0,0009286 & 0,02483 \\
\hline 3 & 0,00277 & 0,001876 & 0,0006565 & 0,01756 \\
\hline 4 & & 0,001319 & 0,0004616 & 0,01234 \\
\hline 5 & 0,00129 & 0,000960 & 0,0004052 & 0,008986 \\
\hline 6 & & 0,0007348 & 0,0004356 & 0,006877 \\
\hline 7 & 0,000971 & 0,0006316 & 0,0003744 & 0,005911 \\
\hline
\end{tabular}

O modelo Urânia A, que utiliza os dados do tensiômetro T50D (externo ao poço) como condição de contorno superior, apresenta uma frente de molhamento que situa-se inicialmente entre 1 e $2 \mathrm{~m}$ de profundidade e que se desloca até $7 \mathrm{~m}$ próximo do dia 52 de modelagem. Em seguida, inicia-se um período de secagem do perfil que se estende até o dia 133. As curvas dos gráficos calculado e real são bastante semelhantes (Figura 19) e o modelo, no geral, apresenta bons resultados de resíduo normalizado. O erro só é maior a $1 \mathrm{~m}(12,07 \%$ - Tabela 13) pois esta profundidade sofre mais com os efeitos do período de secagem dos dias 94 e 133, que também apresentam resíduos mais elevados (10,88 e 9,9\%). As condutividades hidráulicas utilizadas neste modelo são semelhantes àquelas medidas em laboratório (Tabela 14) e apresentam queda gradativa nos valores na medida em que se aprofunda na zona não saturada.

O modelo Urânia B utiliza os dados do tensiômetro T50 (interno ao poço) como condição de contorno superior, representando um potencial matricial e condições de umidade mais elevados que o modelo anterior, devido à proteção exercida pela camada de aterro menos permeável. Para se conseguir resultados semelhantes de comportamento da frente de molhamento em relação ao modelo anterior (Figura 20), foi necessário reduzir os valores de condutividade hidráulica para todo o perfil (Tabela 14) para manter a velocidade da frente de molhamento. Esta medida, porém, fez agravar os erros devidos ao período de secagem $(40,17 \%$ no dia 94 e 32,05\% no dia 133), pois o perfil com condutividade hidráulica menor faz reter a umidade com maior intensidade. Os valores de condutividade hidráulica utilizados são, em média, 3 vezes menores que aqueles medidos em laboratório, e não apresentam uma diminuição harmônica nos valores com a profundidade, encontrando-se valores menores a $5 \mathrm{~m}$ em relação às profundidades vizinhas. 


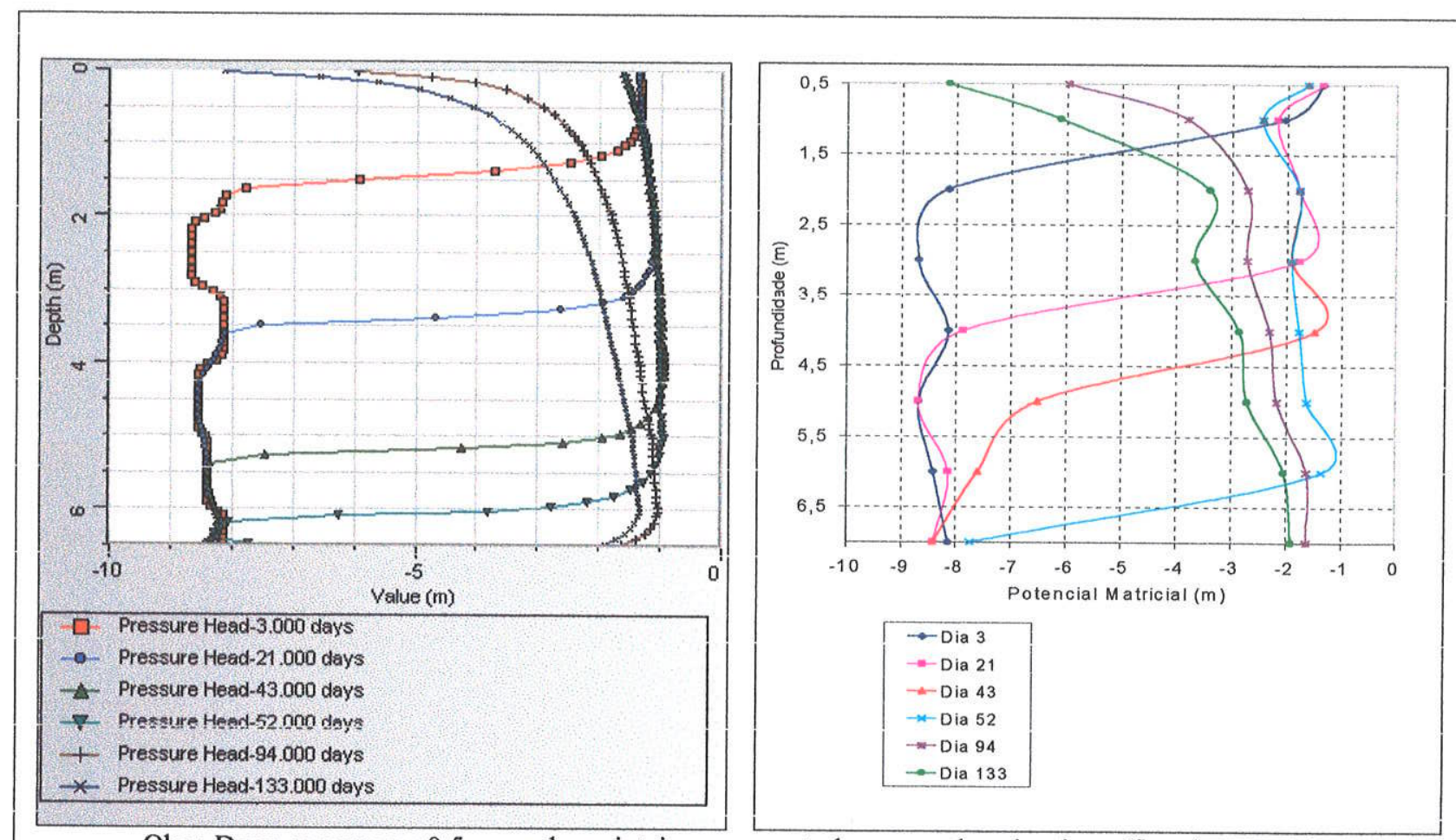

Obs.: Deve-se acrescer 0,5 aos valores inteiros apresentados nas ordenadas do gráfico da esquerda.

Figura 19 - Potenciais matriciais calculados e reais - modelo Urânia A

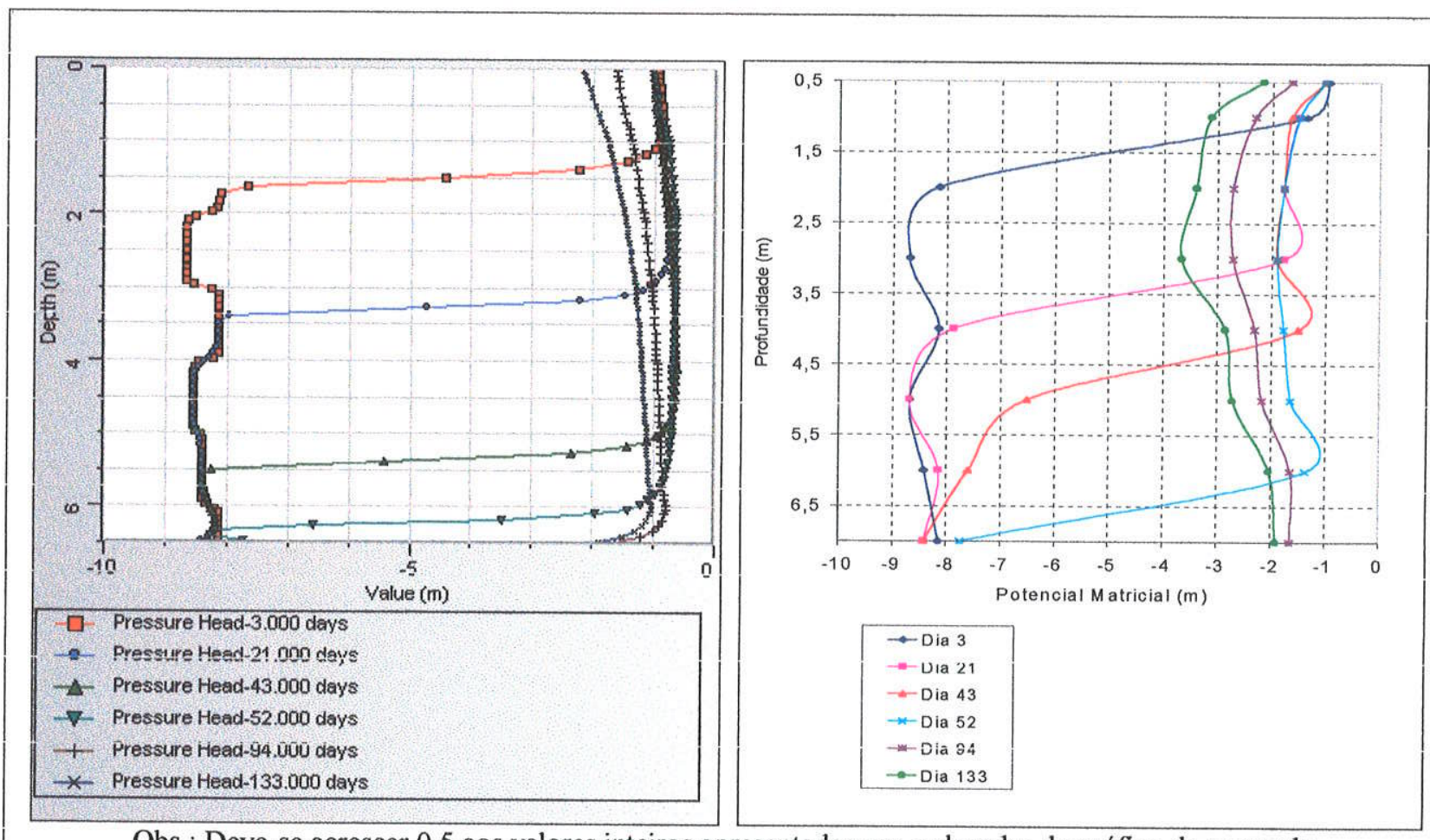

Obs.: Deve-se acrescer 0,5 aos valores inteiros apresentados nas ordenadas do gráfico da esquerda.

Figura 20 - Potenciais matriciais calculados e reais - modelo Urânia B 
As distorções observadas no modelo Urânia $\mathrm{B}$ em relação ao primeiro modelo (erros mais elevados no período de secagem e valores de condutividade hidráulica não harmônicos e 3 vezes menores que os medidos em laboratório), faz acreditar que o modelo Urânia A se aproxima mais da realidade. Esta observação encontra acordo com a hipótese de que a influência do material do aterro sobre os potenciais matriciais da zona não saturada no poço da estação de monitoramento não deva exceder as profundidades de 2 ou $3 \mathrm{~m}$, conforme discutido no item 4.2.2.

$O$ fato de o modelo Urânia A ter apresentado dificuldades em drenar o perfil durante o período de estiagem motivou a execução do modelo Urânia $\mathrm{C}$, que utiliza dados do tensiômetro T50D (externo ao poço) como condição de contorno superior, e modela um período completo de estiagem a partir de uma situação de molhamento total do perfil até a situação de pico de estiagem no dia 156, finalizando no dia 200 com uma nova frente chegando na profundidade de 3 m. A Figura 21 apresenta uma comparação dos potenciais matriciais calculados e reais, de onde se observa que o padrão das curvas são pouco semelhantes na melhor situação de calibração. Para se conseguir valores calculados de potenciais matriciais na mesma ordem dos observados no período próximo do pico de secagem, valores elevados de condutividade hidráulica tiveram de ser utilizados, para facilitar a drenagem do perfil. Os elevados valores de condutividade hidráulica empregados (vide Anexo 4) promoveram uma rápida drenagem do perfil do dia 12 e uma rápida passagem por todo o perfil da frente de molhamento do dia 200 que deveria situar-se a $2 \mathrm{~m}$, o que fez gerar erros elevados nesses dias que se distribuíram ao longo de todas as profundidades (Tabela 13). Os valores de condutividade hidráulica utilizados no modelo são muito elevados, em média uma ordem de grandeza maior que os valores utilizados no modelo Urânia A e medidos no laboratório (Tabela 14), o que comprova a inadequação do modelo Urânia $\mathrm{C}$ em representar a situação real.

A hipótese que talvez melhor explique as diferenças entre os resultados dos modelos de molhamento e secagem é a da existência de ação de evapotranspiração por raízes de árvores mais distantes e cujos efeitos seriam mais pronunciados durante o período da estiagem, muito embora a maior parte da ação da evapotranspiração tenha sido eliminada com o sacrificio da árvore no início de 2000. Esta hipótese é corroborada pela observação da ocorrência de dissipação das pequenas frentes de molhamento a partir da profundidade de $3 \mathrm{~m}$, tal como apontado no item 4.2.1, bem como a existência de potenciais de fluxos ascendentes de água de $4 \mathrm{~m}$ para $3 \mathrm{~m}$ durante o período de estiagem de junho a setembro de 2000 (Figura 14). 


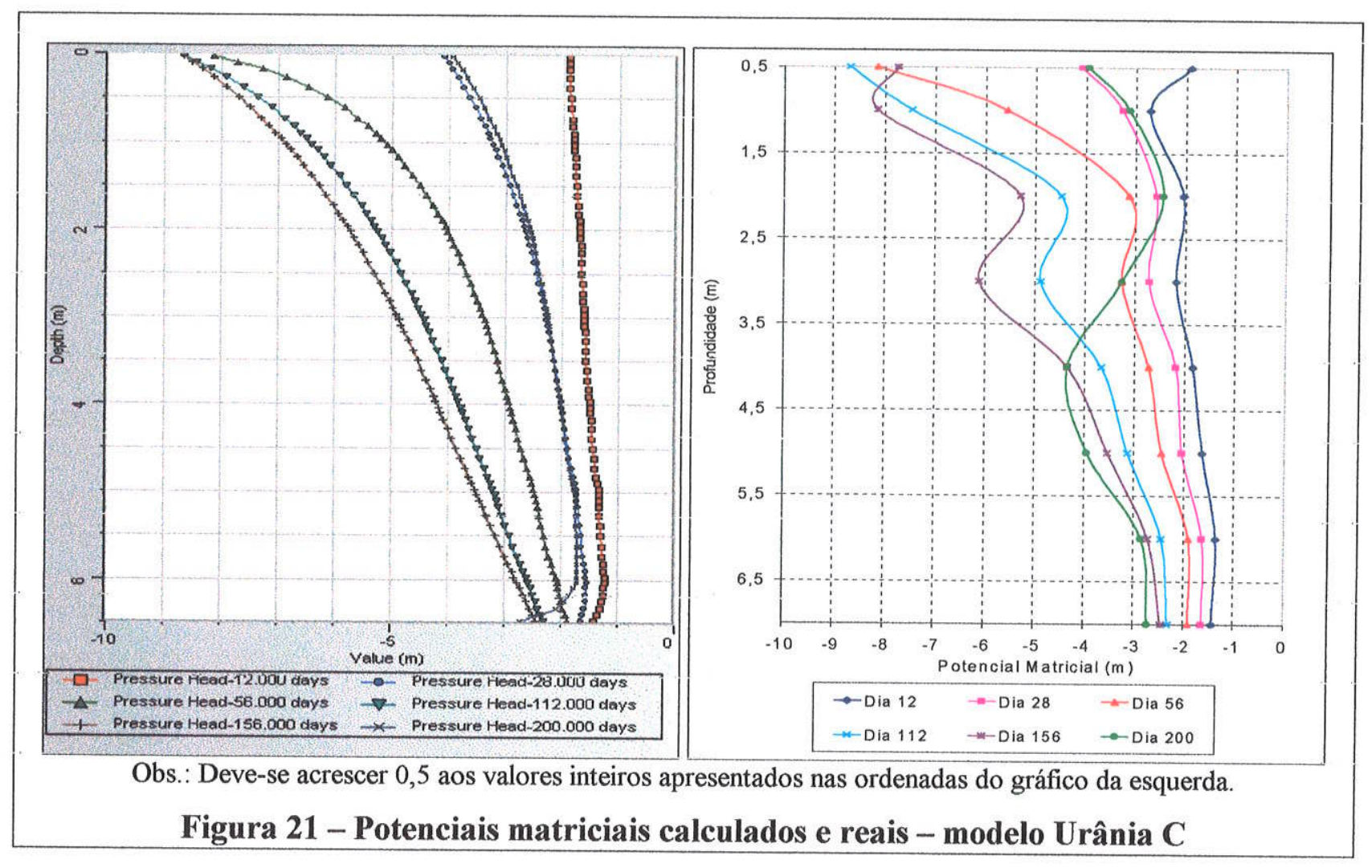

A hipótese de se atribuir aos efeitos da histerese o comportamento do molhamento e secagem do modelo não é adequado, pois as curvas de retenção obtidas em laboratório são de secagem. Desta forma, o modelo de secagem deveria apresentar resultados semelhantes àqueles utilizados no modelo de molhamento.

Outra hipótese avaliada, mas que aparentemente não explica este comportamento, é a possibilidade da equação de van Genuchten não ser adequada para avaliar a condutividade hidráulica não saturada $\left(\mathrm{K}_{\theta}\right)$ em solos contendo baixas quantidades de umidade, tal como investigado por Khaleel et al. (1995). Estes autores verificaram, para sedimentos exclusivamente arenosos e muito secos $(\theta<10 \%)$, que o método de avaliação de $K_{\theta}$ através da equação de van Genuchten chega a ser subestimada em até duas ordens de grandeza em relação a outros dois métodos diretos de obtenção deste parâmetro. Esta possibilidade promoveria uma secagem mais rápida do perfil durante os eventos de estiagem, e um molhamento mais lento durante os eventos de recarga. Os autores indicam, porém, que a relação de van Genuchten é apropriada para solos de textura mais fina contendo maior quantidade de umidade, que é o caso desta pesquisa, e que as suas observações são válidas para solos exclusivamente arenosos em contexto de clima árido, onde pequenas variações de umidade já fazem o $\mathrm{K}_{\theta}$ variar em muitas ordens de grandeza. 


\subsubsection{Variações de Umidade e de Velocidade de Fluxos na Zona Não Saturada}

Tomando-se o modelo Urânia A como o que mais se aproxima da situação real, o programa VS2DT calculou os valores de umidade (em conteúdo de umidade - vol/vol - e em porcentagem de saturação), as velocidades dos fluxos de água (em $\mathrm{cm} / \mathrm{dia})$, e o balanço de entradas e saídas dos fluxos de água no sistema $\left(\mathrm{em}^{3} / \mathrm{dia}\right)$, para cada período de tempo. As figuras 22 e 23 apresentam esses resultados para os dias de observação selecionados.

Nota-se, na Figura 22, o avanço da frente de molhamento entre os dias 3 e 52 promovendo uma elevação do conteúdo de umidade ao longo do perfil do solo, seguida de sua diminuição nos dias 94 e 133. As curvas de umidade apresentam correlação com os potenciais hidráulicos da Figura 19, embora os gráficos da Figura 22 mostrem alterações bruscas no conteúdo de umidade de uma camada para outra, devido aos diferentes valores de porosidade total atribuídos. Há que se lembrar que o período de secagem do modelo Urânia A é um pouco subdimensionado (Tabela 13), sendo os resultados apresentados neste gráfico são um pouco mais úmidos que a realidade.
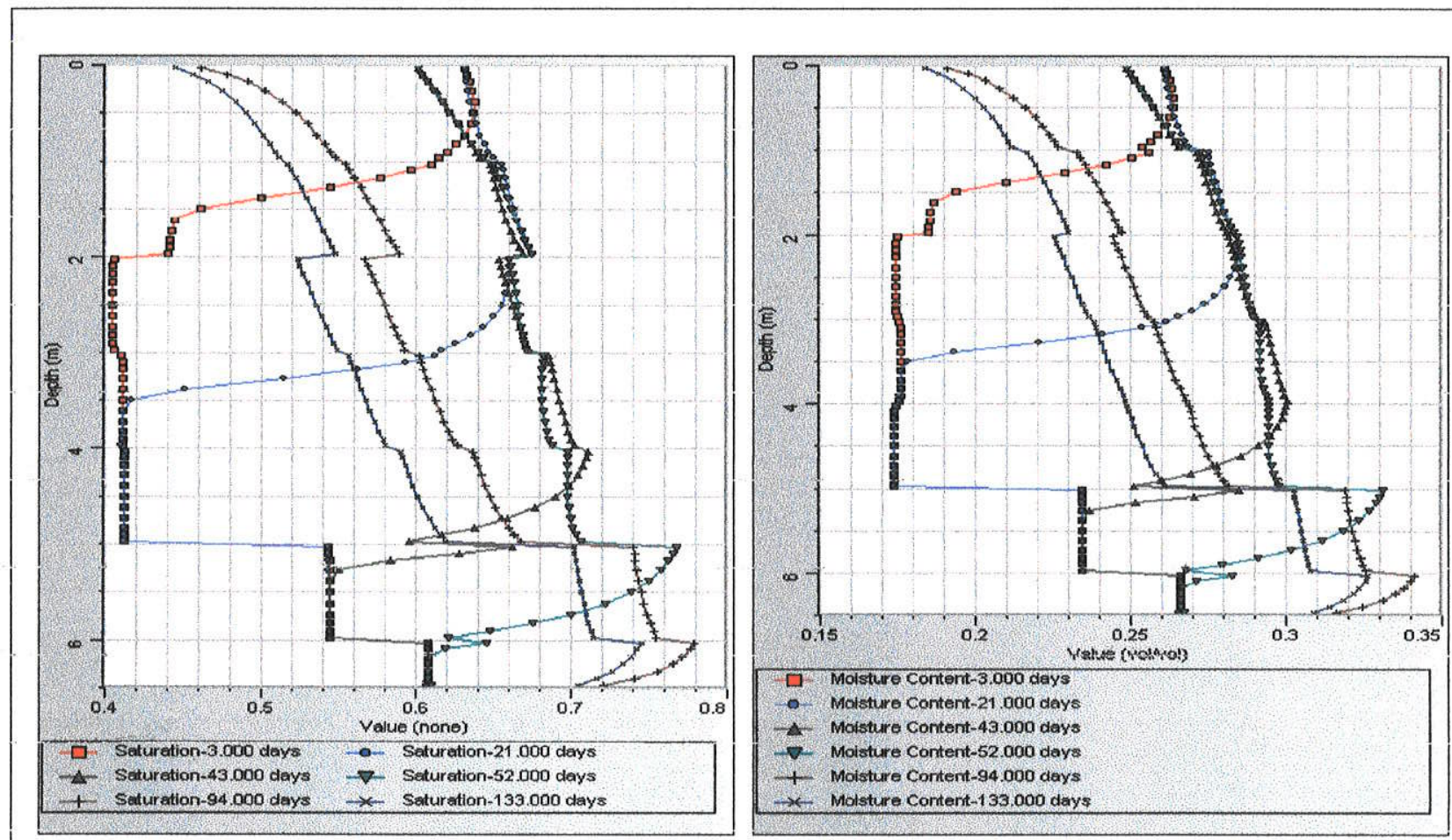

Obs.: Deve-se acrescer 0,5 aos valores inteiros apresentados nas ordenadas dos gráficos.

Figura 22 - Variações de umidade do modelo Urânia A, expressas em \% de saturação e em conteúdo de umidade (vol/vol). 
A Figura 23 apresenta as velocidades dos fluxos de água em cada profundidade nas situações de tempo selecionadas. Inicialmente, nota-se que a velocidade da água na zona não saturada é zero antes da chegada da frente de molhamento. A velocidade máxima ocorre na frente de molhamento, em valores da ordem de $4 \mathrm{~cm} / \mathrm{dia}$, diminuindo novamente em seguida com a passagem da frente e com o início do processo de secagem. Nota-se, na curva do dia 94, a ocorrência de velocidades negativas do início do modelo $(0,5 \mathrm{~m})$ até a profundidade um pouco superior a $1 \mathrm{~m}$, denotando a ocorrência de fluxo ascendente da água entre essas profundidades.
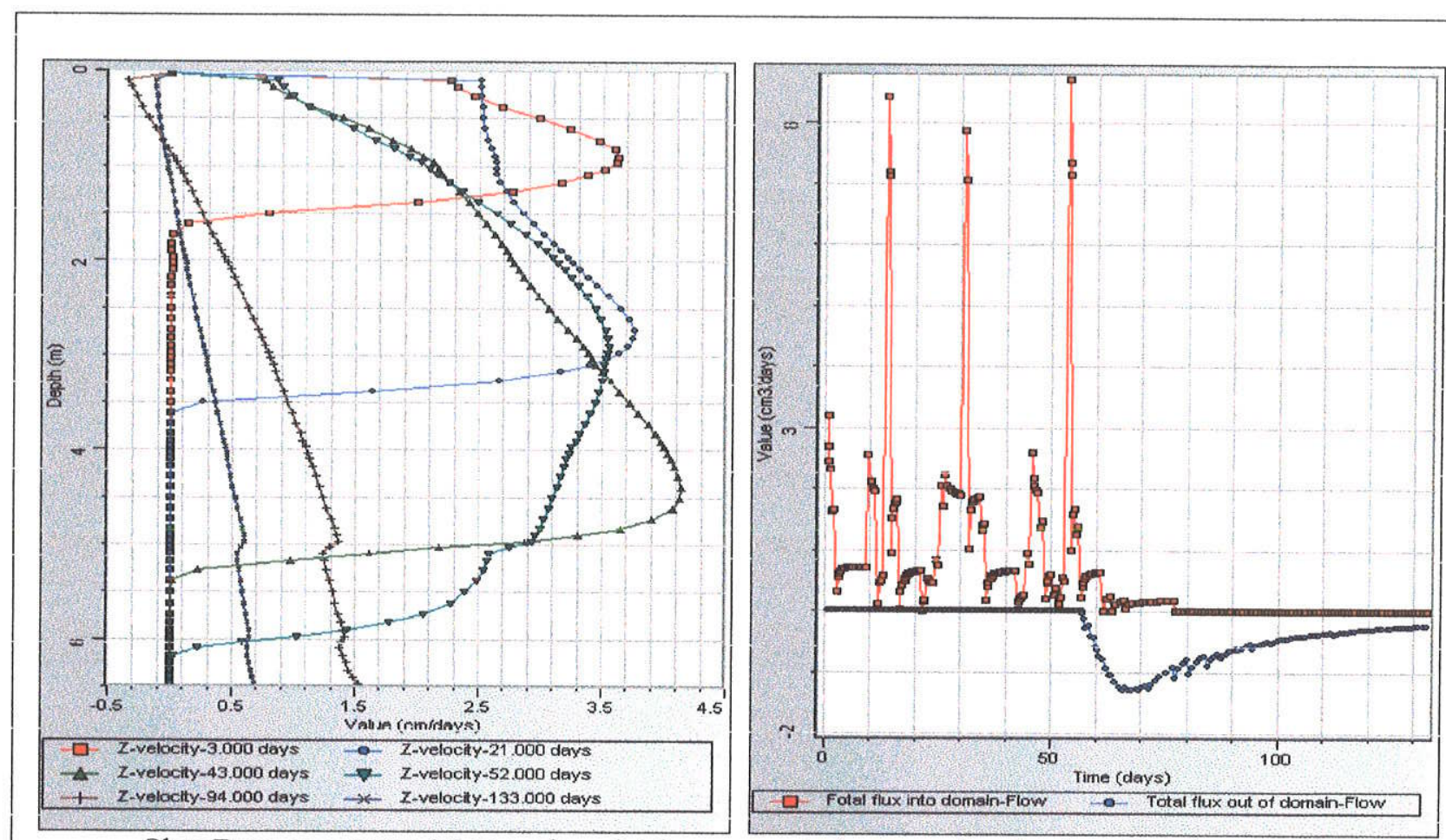

Obs.: Deve-se acrescer 0,5 aos valores inteiros apresentados nas ordenadas do gráfico da esquerda.

Figura 23 - Velocidades de fluxo de água e balanço de fluxos de entrada e saída do modelo Urânia A.

O segundo gráfico da Figura 23 apresenta os valores de entrada e saída de fluxos de água na zona não saturada, expressos em $\mathrm{cm}^{3} / \mathrm{dia}$, calculados a partir da transformação dos valores de potenciais matriciais. Nota-se que a água entra no sistema desde o início do período simulado até próximo do dia 60 , sob a forma de pulsos. A saída da água do sistema inicia-se entre os dias 50 e 60, atinge um valor máximo entre os dias 60 e 70 e vai diminuindo gradativamente até o fim do período de modelagem. 
As variações de umidade e de condutividade hidráulica não saturada $\left(\mathrm{K}_{\theta}\right)$ tiveram uma avaliação complementar através da aplicação direta das equações 3 e 4 aos dados de potenciais matriciais medidos e aos valores de condutividade hidráulica saturada $\left(\mathrm{K}_{\mathrm{s}}\right), \alpha^{\prime}, \beta^{\prime}$ e porosidades total e de retenção utilizados no modelo Urânia $A$ (exceto as profundidades de 8 e $9 \mathrm{~m}$, que tiveram os dados de laboratório utilizados para os cálculos). Os resultados de umidade (expressa sob a forma de saturação) e de $\mathrm{K}_{\theta}$ são apresentados no Anexo 5. Ao contrário do modelo, esses valores são calculados a partir de potenciais matriciais medidos no campo, e não calculados pelo modelo, o que produz resultados mais próximos da realidade, principalmente na situação de estiagem.

Os gráficos da Figura 24 apresentam a variação temporal das curvas de umidade de saturação, construídas a partir dos valores apresentados no Anexo 5, para cada profundidade. De uma forma geral, observa-se que (1) o padrão das curvas de umidade de saturação é, como esperado, semelhante ao das curvas de potenciais hidráulicos totais (Figura 14), refletindo as variações sazonais da recarga; (2) a umidade de saturação beirou o valor mínimo de $40 \%$ nas profundidades de 3 a $5 \mathrm{~m}$ durante o pico de estiagem de 1999/2000 devido à ação da árvore sacrificada, o que não deixa de ser curioso, pois $40 \%$ de umidade ainda representa uma quantidade de água considerável para a forte intensidade da estiagem; (3) as variações bruscas e intensas de umidade estão presentes nas profundidades mais rasas em curto espaço de tempo; (4) um padrão semelhante de saturação se manifesta entre as profundidades de 3 a $5 \mathrm{~m}$; e (5) uma nítida elevação da saturação com a profundidade ocorre principalmente após a profundidade de $6 \mathrm{~m}$.

A variação temporal da condutividade hidráulica não saturada para cada profundidade é apresentada nos gráficos da Figura 25, cujas curvas foram construídas a partir dos valores apresentados no Anexo 5. Das curvas apresentadas, além do padrão semelhante ao das curvas de potenciais hidráulicos e de umidade de saturação, nota-se que os valores de condutividade hidráulica não saturada chegam a variar 5 ordens de grandeza, sendo que os mais baixos foram observados nas profundidades de 5 a $7 \mathrm{~m}$ durante o pico de estiagem de 1999/2000, também devido à ação da árvore sacrificada. Esses valores, da ordem de 2,5 a $5,0 \mathrm{E}-9 \mathrm{~cm} / \mathrm{s}$, são muito pequenos, refletindo na virtual ausência de circulação da água nestas profundidades. 


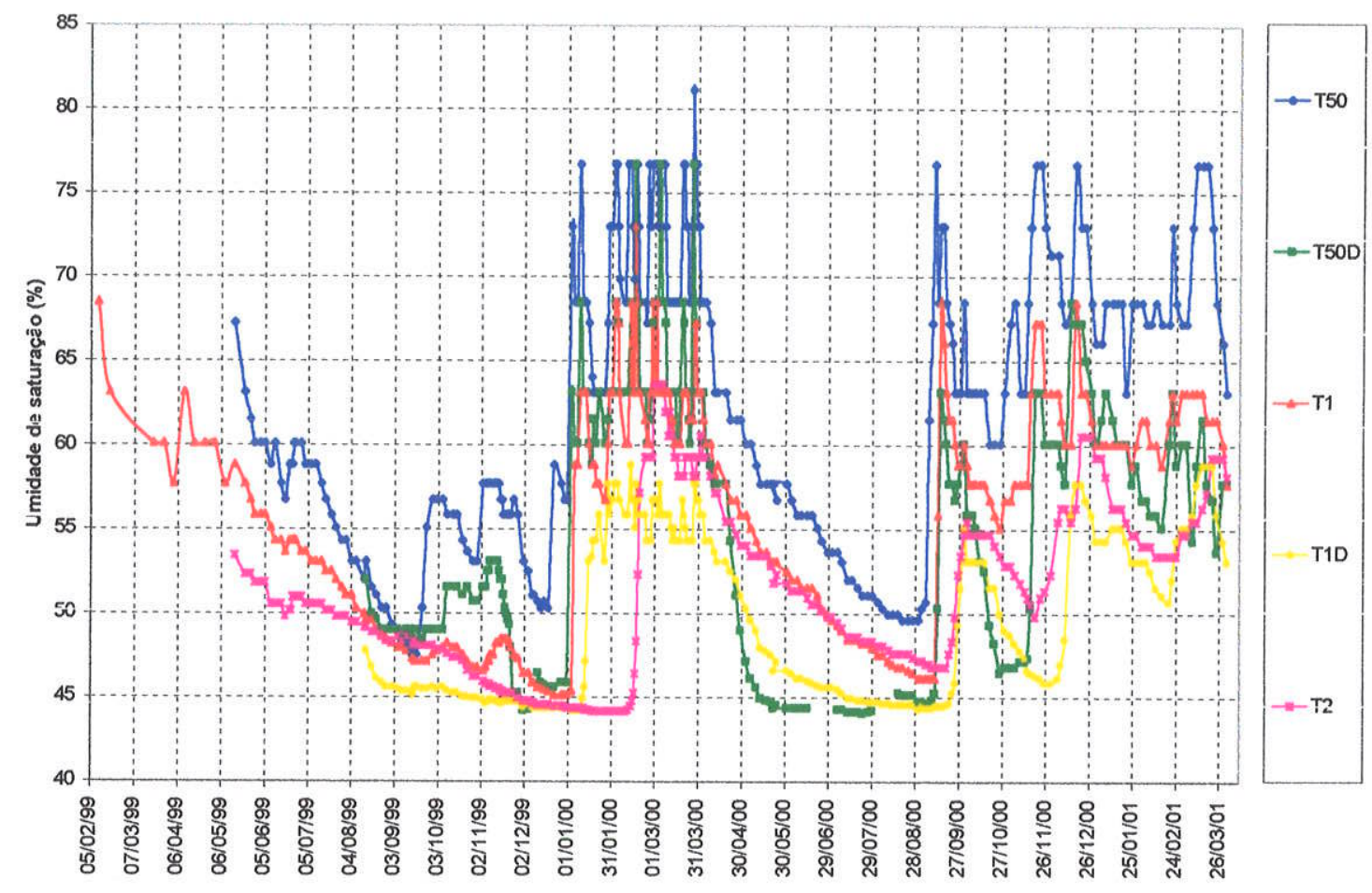

Tensiômetros T50, T1 E T2 - internos ao poço; tensiômetros T50D e T1D - externos ao poço

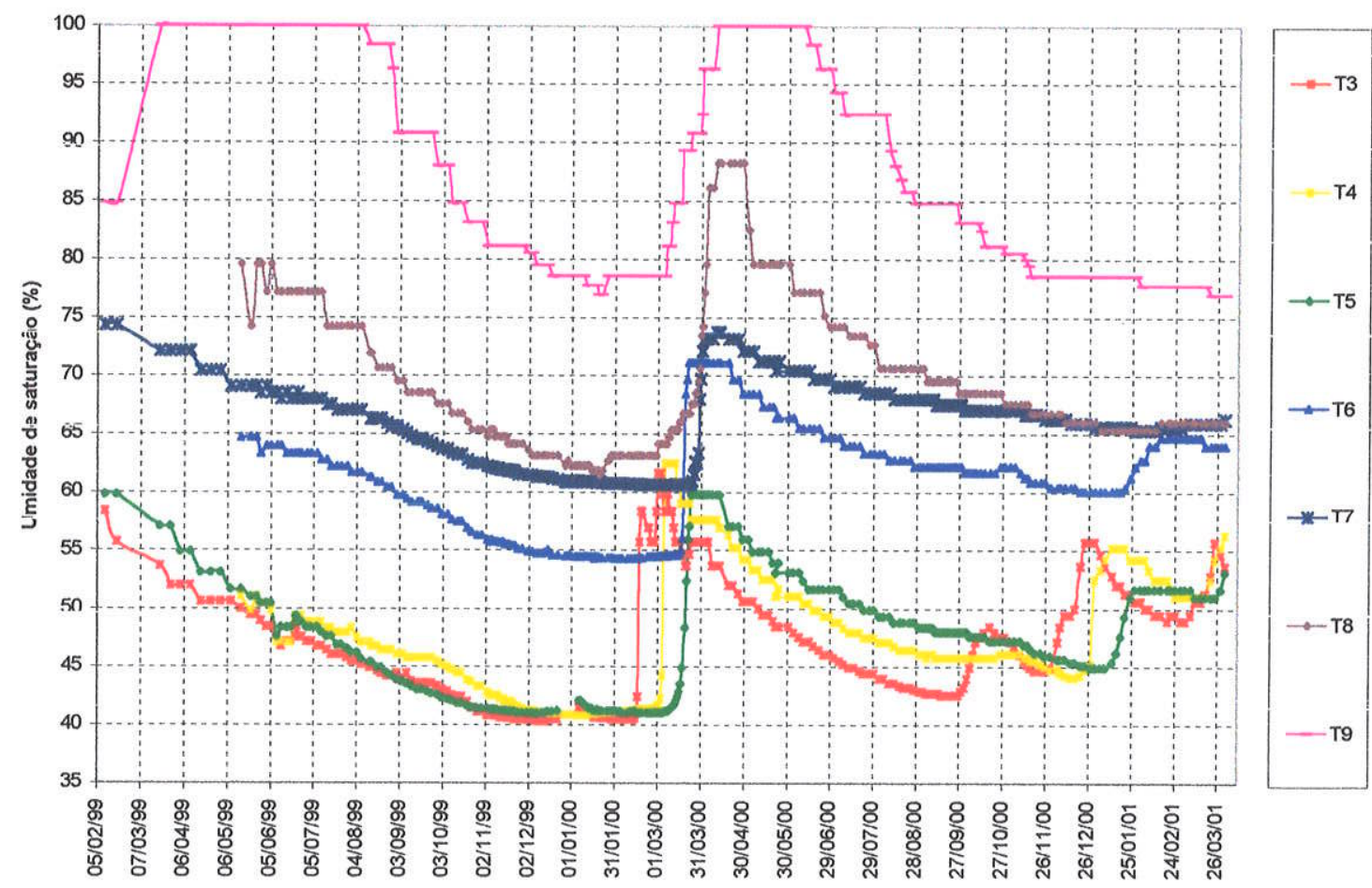

Figura 24 - Variação temporal da umidade de saturação. 


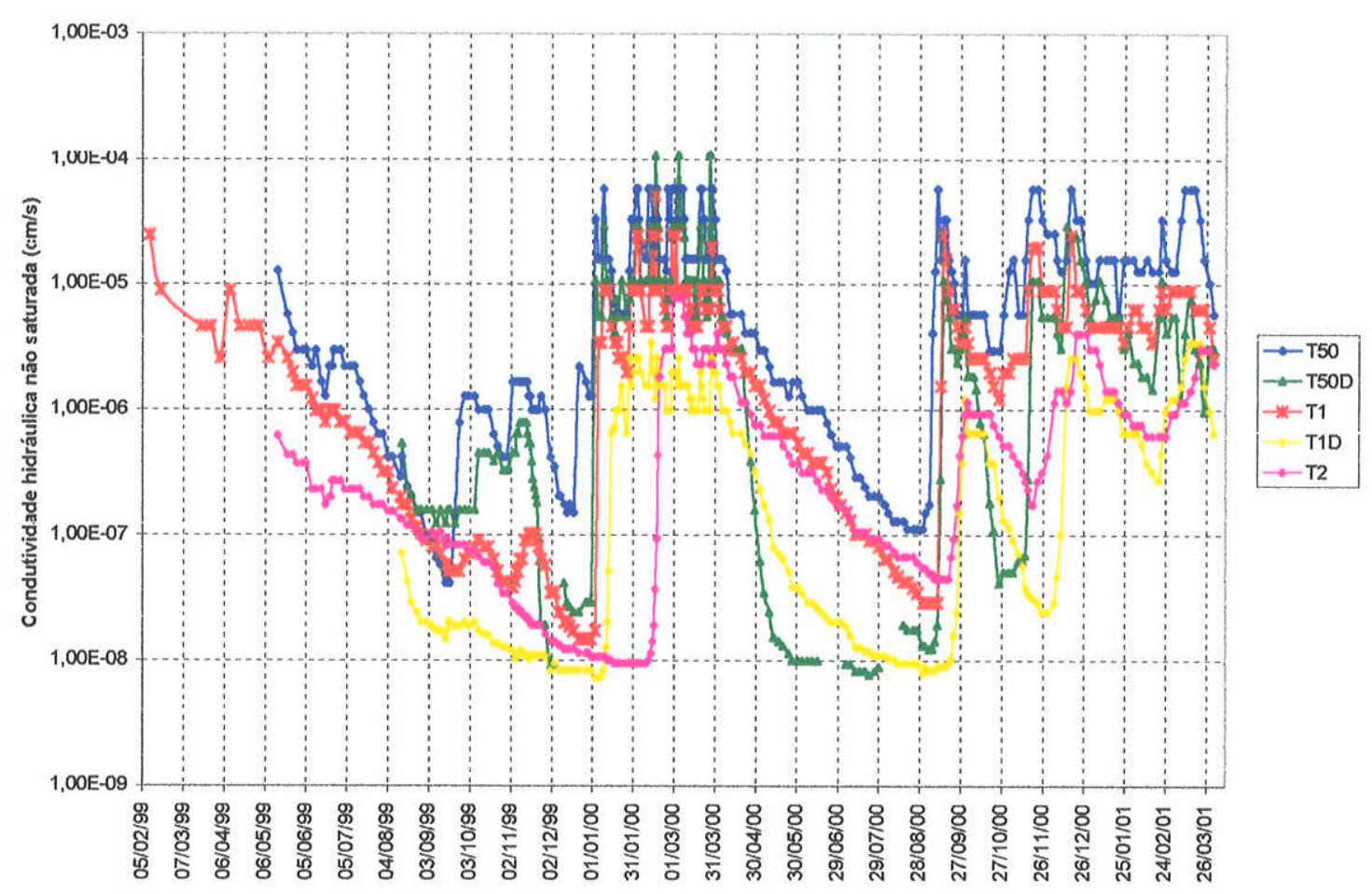

Tensiômetros T50, T1 E T2 - internos ao poço; tensiômetros T50D e T1D - externos ao poço

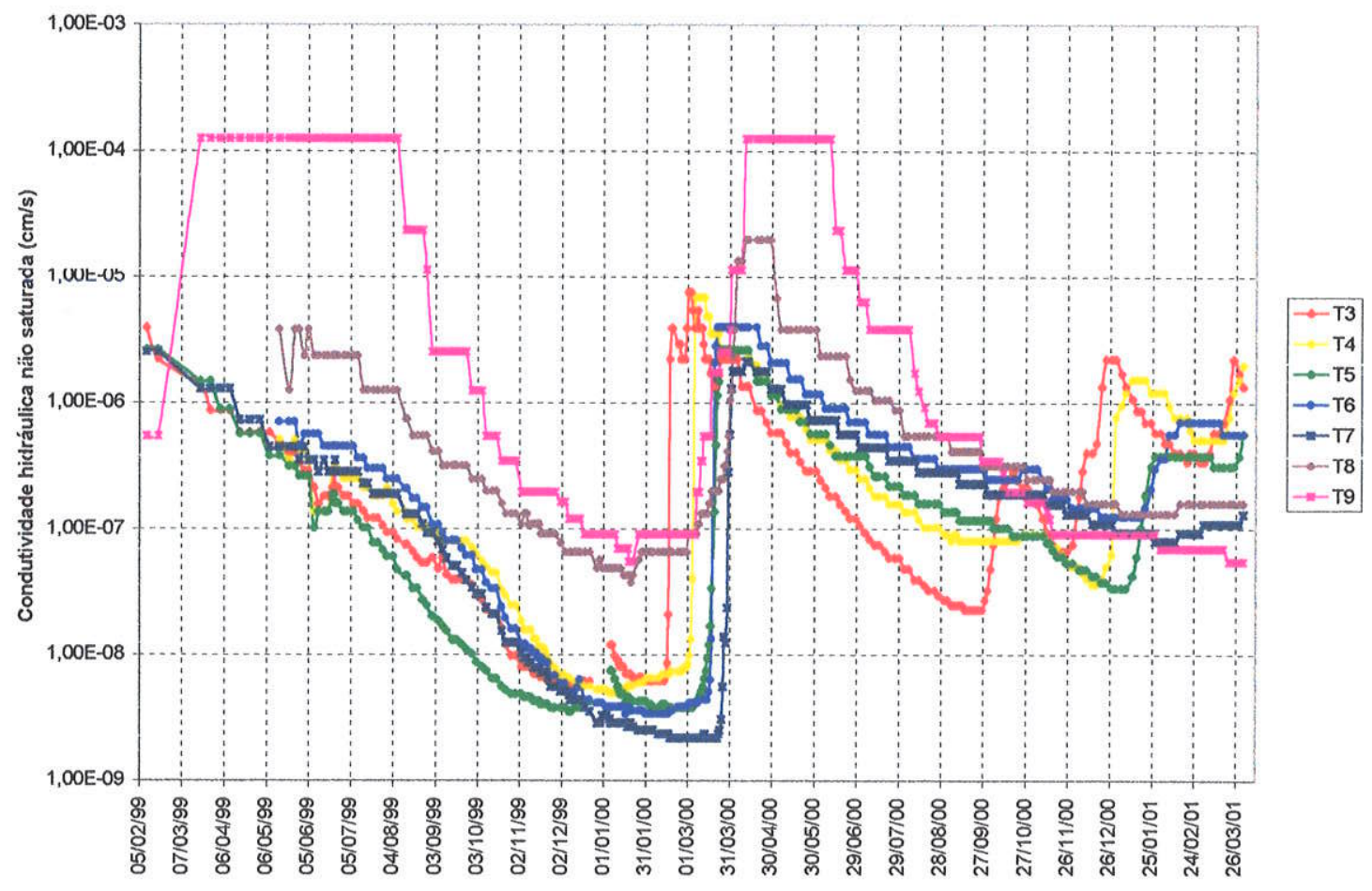

Figura 25 - Variação temporal da condutividade hidráulica não saturada 


\section{Hidrogeoquímica da Zona Não Saturada}

\subsection{Mineralogia e Composição Química da Fase Sólida da Zona Năo Saturada}

\subsubsection{Microscopia Ótica}

Das 13 lâminas petrográficas confeccionadas, aquelas que correspondem às profundidades de 0,2, 3, 5, 6 e $7 \mathrm{~m}$ apresentam-se muito alteradas, dificultando a identificação de qualquer outro mineral que não sejam opacos, rutilo, zircão e quartzo, sendo que o último apresenta-se muito fragmentado e fraturado. Os demais minerais são produto de alteração (minerais argilosos), não sendo possível determinar as suas características em microscópio óptico.

Nas demais lâminas (das amostras mais profundas, de 8 a 11,5 m), foram identificados de forma esparsa, além dos minerais acima, o microclínio. Na lâmina da amostra de $0,2 \mathrm{~m}$ (aterro), foi observado um fragmento de rocha contendo plagioclásio, piroxênio e anfibólio, o que foi interpretado como sendo um diabásio.

\subsubsection{Análises Mineralógicas por Difração de Raio X (DRX)}

Os resultados das análises por difração de raio X são apresentados na Tabela 15 e o Anexo 6 apresenta alguns difratogramas como exemplo. Todas amostras de solo total indicam a ocorrência de quartzo, além de caulinita nas amostras de 1,2, 3 e $8 \mathrm{~m}$, feldspato (a 9,5, 10,5 e $11,5)$, e um mineral do grupo da montmorilonita, na amostra de $11,5 \mathrm{~m}$.

De uma forma geral, as curvas dos difratogramas das amostras de solo total apresentam as características de picos bastante pronunciados no quartzo (contagens elevadas no pico de $3,34 \AA$ ) sobre background de contagem baixa. A elevada quantidade de quartzo mascara a eventual presença de outros minerais que ocorrem em pequenas quantidades. Neste caso, os resultados apresentados nos difratogramas de solo total são apenas indicativos, havendo a necessidade de se proceder a separação de frações granulométricas e dar mais ênfase àquelas menos quartzosas. 
Os demais minerais foram identificados através de picos bastante sutis nos difratogramas, com valores próximos da curva de background e melhor visualizados através da ampliação do difratograma na tela do computador. Além do quartzo, foram identificados, em algumas ocasiões, a caulinita, apresentando picos em 3,53 $\AA$; o feldspato (provavelmente microclínio), com picos em $3,24 \AA$; e um mineral do grupo da montmorilonita (saponita?), com picos em 15,57 e $4,48 \AA$.

\begin{tabular}{|c|c|c|c|}
\hline \multicolumn{4}{|c|}{ Tabela 15 - Resultados de análises mineralógicas por difração de raio X } \\
do solo do poco - fracôes fina, flutuado e afundado
\end{tabular}

Os difratogramas das amostras de fração fina (PC1F e PC6F) apresentam menor quantidade de quartzo, fazendo com que os picos dos demais minerais sejam melhor destacados sobre os valores de contagem background. Nas análises realizadas nesta fração foram identificados, além do quartzo e da caulinita, a goetita. $O$ programa interpretou a existência de picos de goetita na amostra PC1F, porém estes não são claramente visíveis. Os picos de hematita interpretados pelo programa na amostra PC6F devem ser considerados como de goetita $(2,51 \mathrm{e}$ $2,72 \AA$ ), já que ambos apresentam respostas muito parecidas. 
As análises da fração leve (PC1,0FL, PC6,0FL e PC9,5FL) indicaram a presença de quartzo na sua totalidade. O padrão das curvas são semelhantes àqueles das amostras de solo total, com os picos de quartzo predominando sobre um background de contagem baixa.

As análises de difração de raio $X$ da fração pesada (PC1,0A, PC6,0A e PC9,5A) indicaram a ocorrência de uma série de minerais pesados, tais como ilmenita, rutilo, magnetita, zircão, hematita, goetita, magnesita.

\subsubsection{Análises Químicas por ICP/AES-Plasma}

Os resultados das análises químicas das amostras de solo por ICP/AES (frações total, fina, leve e pesada) são apresentados no Anexo 6. A Figura 26 apresenta os resultados das análises das amostras totais em função da profundidade.

Esta figura indica que a sílica predomina largamente ao longo do perfil, com média de $83 \%$ em massa, seguida dos óxidos de alumínio (média $6,7 \%$ ), ferro $(3,9 \%)$, potássio $(0,6 \%)$, magnésio $(0,5 \%)$, cálcio $(0,1 \%)$ e sódio $(0,03 \%)$. As concentrações dos cátions de base $(\mathrm{K}, \mathrm{Mg}$, $\mathrm{Ca}$ e $\mathrm{Na}$ ) são, inclusive, muito baixas e, em algumas situações, próximas do limite de detecção da análise.

Os resultados indicam haver uma boa correlação com a descrição do material de perfuração (Tabela 8). O material de aterro $(0,2 \mathrm{~m})$ apresenta composição ligeiramente diferenciada em relação à primeira amostra de solo $(0,5 \mathrm{~m})$, que é mais quartzosa e com menos óxidos de ferro, alumínio, cálcio, magnésio, potássio e sódio. A $1 \mathrm{~m}$ de profundidade, o solo volta a apresentar maiores quantidades de todos os elementos e redução de sílica. Esta tendência é também verificada nas amostras de solo coletadas a 0,5 e $1,0 \mathrm{~m}$ externas ao poço quando da instalação dos lisímetros externos (Anexo 6). As diferenças na composição química das amostras de 0,5 e $1 \mathrm{~m}$ indicam a ocorrência de perdas do alumínio, ferro e dos cátions de base através da lixiviação dos colóides do horizonte A do solo. 

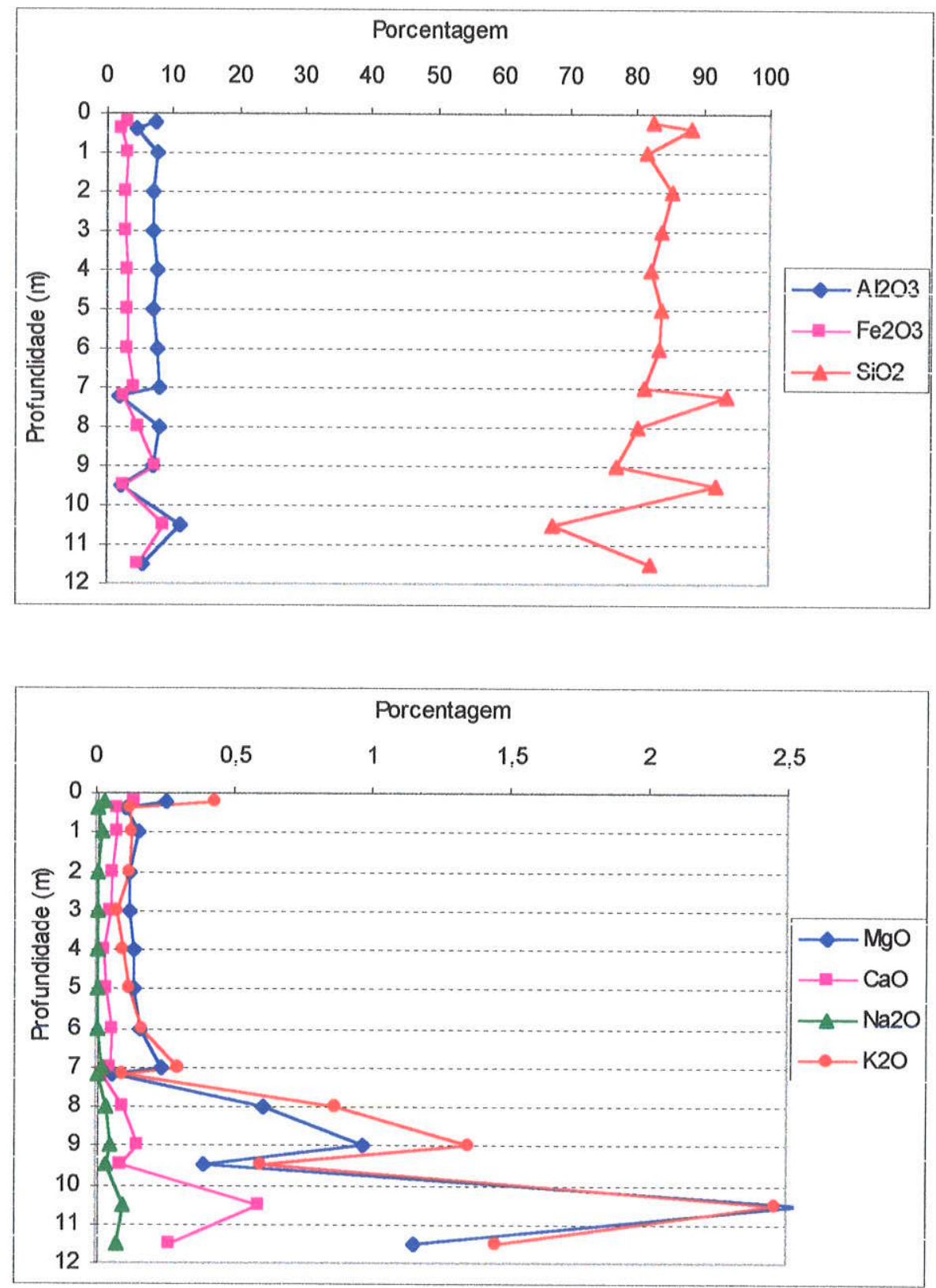

Figura 26 - Variação da composição química das amostras de solo total com a profundidade 
Houve boa correlação entre os resultados das análises químicas das amostras de 7,2, 9,5 e 11,5 m com a descrição do perfil geológico. Essas três amostras encontram-se em níveis mais arenosos, o que refletiu em mais elevadas porcentagens de sílica e menores de óxidos de ferro, alumínio, cálcio, magnésio, potássio e sódio nas análises químicas. A amostra de $10,5 \mathrm{~m}$, já no contexto do aqüífero freático, é a que apresenta as maiores quantidades relativas de todos os elementos, com exceção da sílica, o que indica que esta amostra pode ser quimicamente mais parecida com a rocha sedimentar original.

Quando não se leva em consideração os resultados das análises de 7,2, 9,5 e 11,5 m, observa-se, a partir de $1 \mathrm{~m}$ até $10,5 \mathrm{~m}$, a ocorrência de uma contínua queda nas concentrações de sílica (principalmente a 9 e 10,5 m), um aumento de óxido de ferro a partir dos $6 \mathrm{~m}$, uma queda nas concentrações do magnésio, cálcio e potássio até aproximadamente $3 \mathrm{~m}$, seguido de elevação na concentração destes elementos e do sódio a partir dos $6 \mathrm{~m}$. O óxido de alumínio não exibe um padrão característico de mudança de concentração ao longo do perfil do solo. $O$ padrão exibido por estas espécies químicas tem relação com o perfil de alteração do solo, sendo que ocorre uma maior probabilidade de se encontrar minerais primários em profundidades maiores que $7 \mathrm{~m}$.

A Tabela 16 apresenta a composição química média das frações total, fina, afundada e flutuada das amostras de solo das profundidades de 1,6 e $9,5 \mathrm{~m}$.

\begin{tabular}{|c|c|c|c|c|c|c|c|}
\hline & $\mathrm{SiO}_{2} \%$ & $\mathrm{Al}_{2} \mathrm{O}_{3} \%$ & $\mathrm{Fe}_{2} \mathrm{O}_{3} \%$ & $\mathrm{MgO} \%$ & $\mathrm{CaO} \%$ & $\mathrm{Na}_{2} \mathrm{O} \%$ & $\mathrm{~K}_{2} \mathrm{O} \%$ \\
\hline Fração total & 85,57 & 5,89 & 2,91 & 0,23 & 0,08 & 0,02 & 0,30 \\
\hline Fracaão fina & 50,19 & 22,67 & 9,07 & 1,03 & 0,26 & 0,03 & 0,63 \\
\hline Fração afundada & 12,48 & 4,05 & 36,76 & 1,14 & 0,11 & 0,09 & 0,16 \\
\hline Fração flutuada & 97,26 & 1,15 & 0,86 & 0,09 & 0,02 & 0,02 & 0,16 \\
\hline
\end{tabular}

Observa-se que na fração fina a sílica predomina, mas cai para $50 \%$ em relação à fração total, e há expressivo aumento de óxidos de alumínio $(22,7 \%)$ e de ferro $(9 \%)$. Os óxidos de magnésio, potássio, cálcio e sódio ainda encontram-se em concentrações relativamente baixas, mas expressivamente mais elevadas que na fração total, especialmente para o magnésio, cálcio e potássio. A maior abundância relativa de todos os elementos na fração fina, excetuando-se a sílica, deve-se às argilas, aos hidróxidos de ferro e aos cátions adsorvidos. 
A fração do solo composta por minerais mais leves e de granulometria maior que 635 mesh apresenta larga predominância de sílica (97,3\%), seguida de alumínio $(1,2 \%)$ e ferro $(0,9 \%)$. Praticamente toda a massa corresponde à mineralogia do quartzo. A fração afundada é composta por minerais pesados e de granulometria maior que 635 mesh. Os elementos predominantes são o titânio (39\% - Anexo 6) e ferro (36,8\%), seguido da sílica $(12,5 \%)$, alumínio (4,1\%) e magnésio (1,1\%). Nesta fração, o bário, cromo, níquel, estrôncio, vanádio e zircão encontram-se sob as mais elevadas concentrações (Anexo 6).

Verifica-se, da Tabela 16, que a sílica predomina principalmente na fração leve, o alumínio na fina, o ferro na pesada, o potássio na fina, o magnésio nas frações fina e pesada e o cálcio na fina. O sódio encontra-se em quantidades muito pequenas em todas as frações.

A Tabela 17 apresenta uma matriz de correlação entre os resultados das análises químicas com os resultados das análises granulométricas das amostras de solo total coletadas na zona não saturada do poço da estação. Nesta matriz não foram consideradas as amostras de dentro do aqüífero freático, dos lisímetros de fora do poço e as amostras das frações fina, afundada e flutuada.

Tabela 17 - Matriz de correlação das análises químicas do solo total por ICP/AES e ensaios de granulometria

\begin{tabular}{|c|c|c|c|c|c|c|c|c|c|c|c|c|c|c|c|c|c|}
\hline & $\begin{array}{l}\text { O๊ } \\
\text { in }\end{array}$ & $\begin{array}{l}M \\
\text { Ò } \\
\frac{1}{<}\end{array}$ & 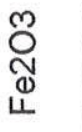 & $\begin{array}{l}\text { OO } \\
\sum\end{array}$ & ర్ల & $\begin{array}{l}\text { ্ָ } \\
\text { Z }\end{array}$ & 오 & $\begin{array}{l}\stackrel{0}{\complement} \\
\sum\end{array}$ & 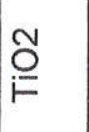 & ஜ & ঊ & iz & के & $\begin{array}{l}\overline{\bar{D}} \\
+ \\
0 \\
\bar{\alpha}\end{array}$ & 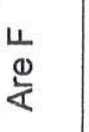 & 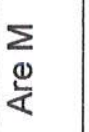 & $\begin{array}{l}\text { 可 } \\
\text { Q } \\
\text { 远 }\end{array}$ \\
\hline $\mathrm{SiO} 2$ & 1,00 & $-0,69$ & $-0,87$ & $-0,79$ & $-0,46$ & $-0,80$ & $-0,77$ & $-0,62$ & $-0,86$ & $-0,76$ & $-0,50$ & \begin{tabular}{|l|}
0,38 \\
\end{tabular} & $-0,75$ & $|-0,65|$ & 0,28 & 0,81 & 0,68 \\
\hline $\mathrm{Al} 2 \mathrm{O} 3$ & & 1,00 & 0,28 & 0,16 & $-0,06$ & 0,26 & 0,16 & $-0,06$ & 0,62 & 0,15 & 0,50 & $-0,76$ & 0,13 & 0,77 & $-0,67$ & $-0,56$ & $-0,49$ \\
\hline $\mathrm{Fe} 2 \mathrm{O} 3$ & & & 1,00 & 0,97 & 0,61 & 0,88 & 0,95 & 0,82 & 0,83 & 0,94 & 0,45 & $-0,10$ & 0,93 & 0,46 & $-0,04$ & $-0,76$ & $-0,63$ \\
\hline $\mathrm{MgO}$ & & & & 1,00 & 0,72 & 0,93 & 0,99 & 0,85 & 0,77 & 0,98 & 0,32 & 0,04 & 0,98 & 0,40 & 0,02 & $-0,74$ & $-0,58$ \\
\hline $\mathrm{CaO}$ & & & & & 1,00 & 0,85 & 0,78 & 0,81 & 0,36 & 0,82 & $-0,06$ & 0,44 & 0,83 & 0,00 & 0,32 & $-0,42$ & $-0,11$ \\
\hline $\mathrm{Na} 2 \mathrm{O}$ & & & & & & 1,00 & 0,96 & 0,86 & 0,70 & 0,97 & 0,29 & 0,10 & 0,97 & 0,42 & $-0,02$ & $-0,74$ & $-0,52$ \\
\hline K2O & & & & & & & 1,00 & 0,86 & 0,76 & 1,00 & 0,31 & 0,09 & 1,00 & 0,41 & 0,02 & $-0,75$ & $-0,57$ \\
\hline $\mathrm{MnO}$ & & & & & & & & 1,00 & 0,49 & 0,88 & 0,27 & 0,40 & 0,88 & 0,04 & 0,38 & $-0,53$ & $-0,39$ \\
\hline $\mathrm{TiO} 2$ & & & & & & & & & 1,00 & 0,74 & 0,69 & $-0,45$ & 0,73 & 0,79 & $-0,37$ & $-0,93$ & $-0,82$ \\
\hline $\mathrm{Ba}$ & & & & & & & & & & 1,00 & 0,30 & 0,13 & 1,00 & 0,38 & 0,06 & $-0,74$ & $-0,54$ \\
\hline $\mathrm{Cr}$ & & & & & & & & & & & $i, \overline{0}$ & $-0,36$ & 0,29 & 0,64 & $-0,38$ & $-0,65$ & $-0,72$ \\
\hline $\mathrm{Ni}$ & & & & & & & & & & & & 1,00 & 0,14 & $-0,69$ & 0,77 & 0,28 & 0,28 \\
\hline $\mathrm{Sr}$ & & & & & & & & & & & & & 1,00 & 0,36 & 0,07 & $-0,74$ & $-0,54$ \\
\hline
\end{tabular}

Obs 1: população de 11 amostras, de 0,2 a $9 \mathrm{~m}$, do poço da estação de monitoramento. Obs 2: correlações com intervalo de significância de $95 \%$. Obs 3: Arg+Sil = fração argila mais silte; Are F = fração areia fina; Are $M=$ fração areia média; Are $\mathrm{Gr}=$ fração areia grossa. Obs 4: números em vermelho: ocorrência de correlações negativas; números em azul: ocorrência de correlações positivas. 
Nesta matriz de correlação, destacam-se as seguintes observações: (1) as correlações negativas entre as concentrações de sílica com o alumínio, ferro, cátions de base e fração argila + silte, indicando que os estratos mais quartzosos são mais pobres nos outros elementos; (2) a boa correlação entre o alumínio e a fração fina, indicando a existência de argilominerais; (3) a ausência de correlação nítida entre o alumínio com os cátions de base, de onde se conclui que os argilominerais talvez não sejam os minerais que participam exclusivamente dos processos de adsorção; (4) as correlações positivas entre o óxido de ferro com os cátions de base, indicando que os óxidos e hidróxidos de ferro podem desempenhar papel determinante na adsorção dos cátions de base; (5) as fortes correlações entre os cátions de base, manganês, bário, estrôncio e titânio; (6) a ausência de correlação entre a fração argila + silte com o óxido de ferro e os cátions de base, o que parece ser contraditório, já que as análises da fração fina indicaram quantidades expressivas de óxidos de ferro e dos principais cátions de base (Tabela 16).

\subsubsection{Análises de Capacidade de Troca de Cátions, pH e Matéria Orgânica}

Os resultados das análises de capacidade de troca de cátions (CTC) e dos principais cátions formadores da CTC são apresentados no Anexo 6 e na Figura 27. Observa-se que a CTC total aumenta com a profundidade, principalmente após $6 \mathrm{~m}$. Todos os cátions formadores da CTC, com exceção do $\mathrm{H}^{+}$, apresentam maiores concentrações adsorvidas com a profundidade. Em termos quantitativos, até $7 \mathrm{~m}$ de profundidade, o cálcio é o principal cátion adsorvido, seguido do hidrogênio, magnésio, sódio, potássio e alumínio. Na base da zona não saturada, a $9 \mathrm{~m}$ de profundidade, esta relação é modificada para $\mathrm{Ca}^{+2}>\mathrm{Mg}^{+2}>\mathrm{H}^{+}>\mathrm{Al}^{+3}>\mathrm{Na}^{+}>\mathrm{K}^{+}$.

Desconsiderando-se os resultados de CTC das profundidades de 0,2 (aterro) e de $10,5 \mathrm{~m}$, que apresentaram concentrações anômalas de sódio e cálcio, respectivamente, possivelmente devido a algum problema analítico, observa-se que os valores de CTC variam ao redor de 4,0 meq $/ 100 \mathrm{~g}$ nas profundidades de 1 a $7 \mathrm{~m}$ até $22 \mathrm{meq} / 100 \mathrm{~g}$ a $11 \mathrm{~m}$. Levando-se em conta que a totalidade da CTC seja atribuída à fração fina do solo, e que esta seja aproximadamente $20 \%$ da massa total do solo, calcula-se que a ordem da CTC na fração fina varie de 20 a 110 meq/100 $\mathrm{g}$. Comparando-se estes valores com aqueles da Tabela 2 , conclui-se que a caulinita não deve ser o material adsorvente exclusivo da zona não saturada, pois a sua faixa de valores é teoricamente menor. Neste caso, considerando-se que as análises de CTC possuam um mínimo de exatidão, deduz-se que os minerais de ferro devem também desempenhar papel importante na adsorção de cátions. 


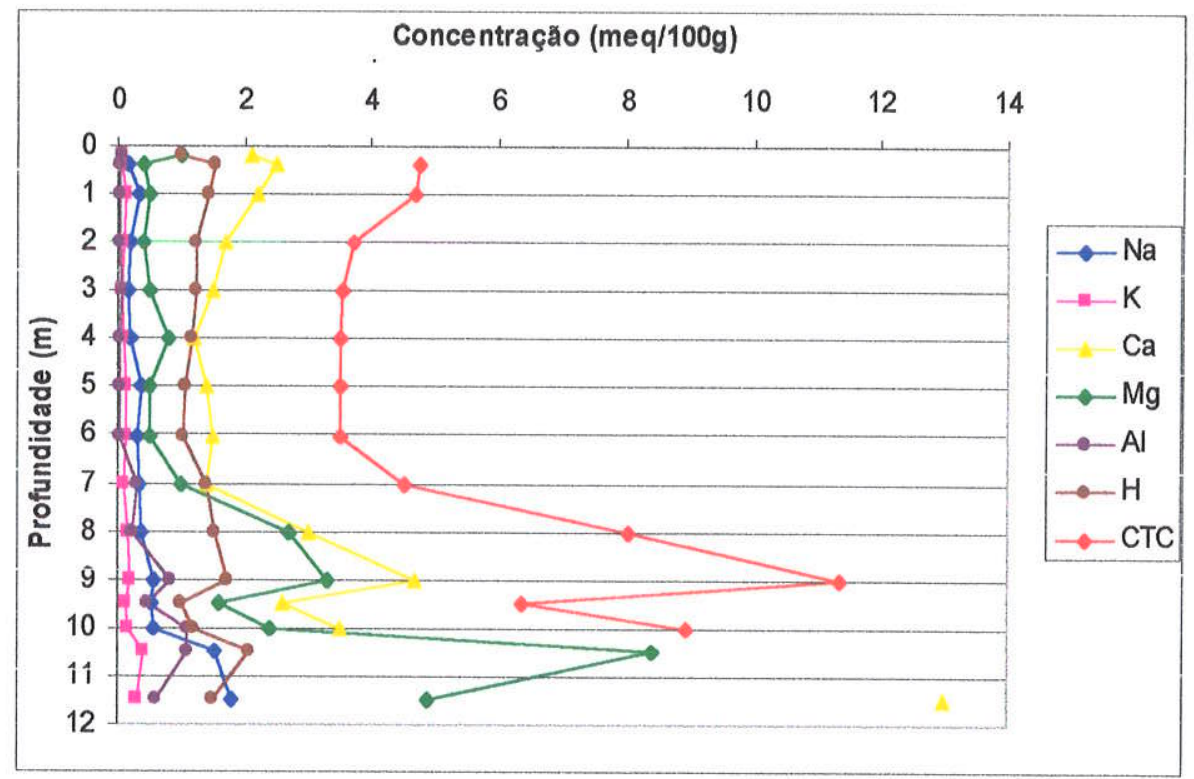

Figura 27 - Resultados das análises de capacidade de troca de cátions

A Figura 28 apresenta os resultados de concentração de matéria orgânica e pH do solo. A matéria orgânica apresenta pequenas concentrações no material do aterro e concentrações elevadas a 0,5 e $1 \mathrm{~m}$ ( 1 e $0,8 \%$ da massa das amostras, respectivamente), diminuindo intensamente até $3 \mathrm{~m}$ e então até $11,5 \mathrm{~m}$. As maiores concentrações a 0,5 e $1 \mathrm{~m}$ são concordantes com a descrição visual do material de perfuração, que apresenta coloração mais escura nestas profundidades. Nota-se que a CTC é ligeiramente maior nestas profundidades, provavelmente devido às maiores concentrações de matéria orgânica nesta faixa. $\mathrm{O} \mathrm{pH}$ do solo, medido em solução de cloreto de cálcio, é normalmente baixo (média $=5,0$ ), porém observa-se uma intensa queda nos valores a partir de $7 \mathrm{~m}$ de profundidade.

A Figura 29 apresenta uma normalização das concentrações dos cátions adsorvidos em relação à CTC. Observa-se que a relação $\mathrm{Ca} / \mathrm{CTC}$ diminui até $7 \mathrm{~m}$, sendo que o contrário vai ocorrendo com a relação $\mathrm{Mg} / \mathrm{CTC}$. A relação $\mathrm{H} / \mathrm{CTC}$ permanece relativamente estável até $7 \mathrm{~m}$ quando cai a partir de então, enquanto que há novo aumento da relação $\mathrm{Ca} / \mathrm{CTC}$ nesta faixa de profundidade. As relações $\mathrm{Na} / \mathrm{CTC}$ e K/CTC são relativamente baixas e constantes ao longo do perfil. O comportamento das curvas do gráfico sugere a ocorrência de um fenômeno de troca catiônica envolvendo o cálcio e o magnésio até $7 \mathrm{~m}$ e a ocorrência de um ambiente hidroquímico diferente a partir de então, com a brusca diminuição das quantidades relativas de hidrogênio e a elevação da quantidade de cálcio. 


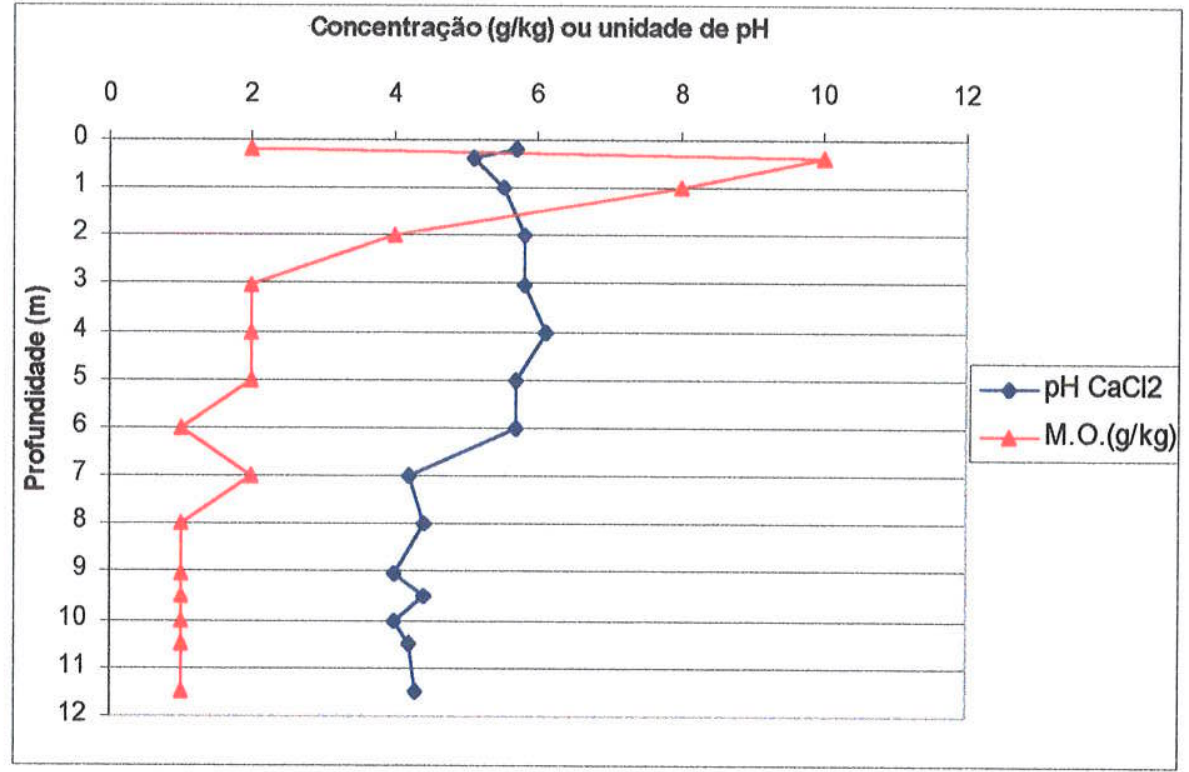

Figura 28 - Resultados das análises de pH e matéria orgânica do solo

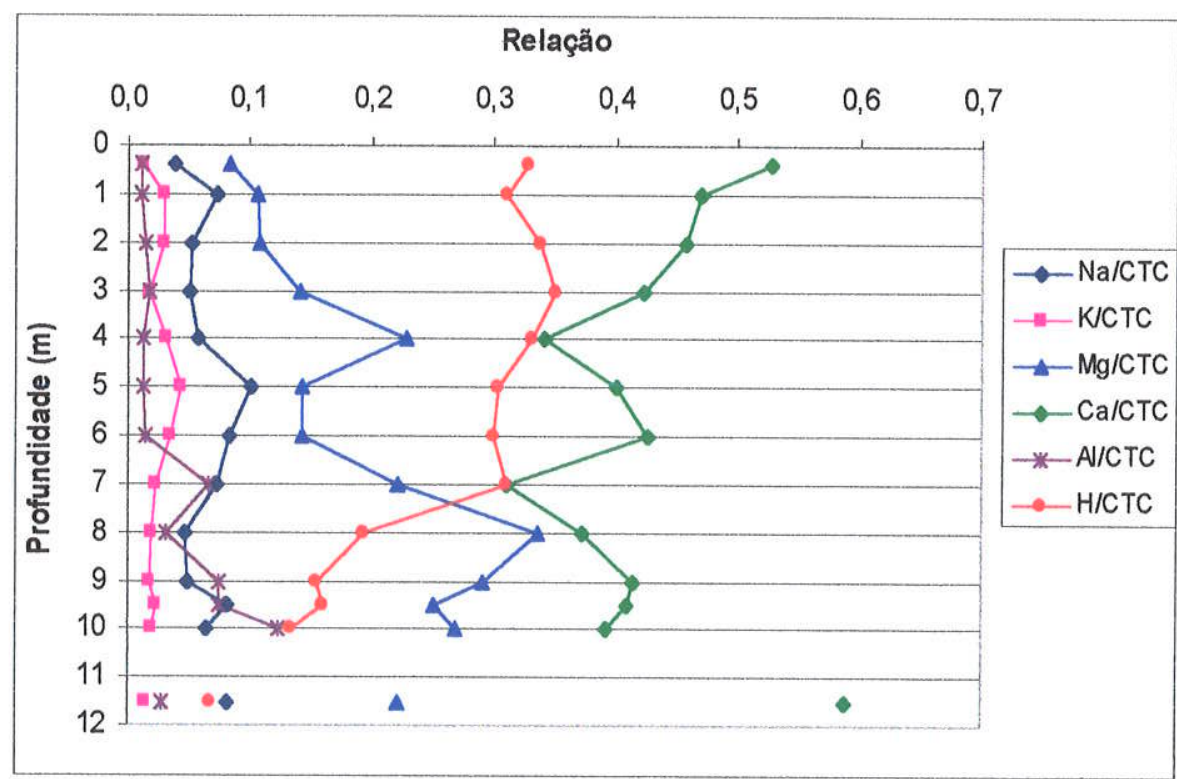

Figura 29 - Relações entre cátions adsorvidos e capacidade de troca de cátions

A Tabela 18 apresenta uma matriz de correlação entre os resultados das análises de CTC com as análises de solo total por ICP/AES. Da mesma forma que a matriz de correlação da Tabela 17, foram consideradas apenas as análises das amostras de solo total coletadas na zona não saturada do poço da estação até a profundidade de $9 \mathrm{~m}$. 


\begin{tabular}{|c|c|c|c|c|c|c|c|c|c|}
\hline & Mat.Org. & $\mathrm{pH}_{\mathrm{CaCl} 2}$ & $\mathrm{NaCTC}$ & K CTC & $\mathrm{Ca}$ CTC & $\mathrm{Mg} \mathrm{CTC}$ & Al CTC & HCTC & CTC \\
\hline $\mathrm{SiO} 2$ & 0,58 & 0,56 & $-0,84$ & $-0,73$ & $-0,55$ & $-0,79$ & $-0,76$ & $-0,37$ & $-0,71$ \\
\hline $\mathrm{Al} 2 \mathrm{O} 3$ & $-0,65$ & $-0,07$ & 0,38 & 0,38 & $-0,18$ & 0,22 & 0,11 & $-0,24$ & 0,02 \\
\hline $\mathrm{Fe} 2 \mathrm{O} 3$ & $-0,49$ & $-0,76$ & 0,88 & 0,75 & 0,81 & 0,94 & 0,96 & 0,61 & 0,92 \\
\hline $\mathrm{MgO}$ & $-0,40$ & $-0,77$ & 0,85 & 0,71 & 0,90 & 0,98 & 0,93 & 0,67 & 0,98 \\
\hline $\mathrm{CaO}$ & $-0,05$ & $-0,49$ & 0,73 & 0,25 & 0,83 & 0,68 & 0,62 & 0,44 & 0,73 \\
\hline $\mathrm{Na} 2 \mathrm{O}$ & $-0,33$ & $-0,74$ & 0,86 & 0,58 & 0,86 & 0,94 & 0,82 & 0,60 & 0,91 \\
\hline $\mathrm{K} 2 \mathrm{O}$ & $-0,40$ & $-0,77$ & 0,84 & 0,65 & 0,90 & 0,98 & 0,91 & 0,64 & 0,97 \\
\hline Mat.Org. & 1,00 & 0,12 & $-0,37$ & $-0,32$ & 0,00 & $-0,44$ & $-0,34$ & 0,29 & $-0,20$ \\
\hline $\mathrm{pH}_{\mathrm{CaCl} 2}$ & & 1,00 & $-0,71$ & $-0,48$ & $-0,70$ & $-0,76$ & $-0,81$ & $-0,80$ & $-0,80$ \\
\hline $\mathrm{Na} \mathrm{CTC}$ & & & 1,00 & 0,90 & 0,73 & 0,80 & 0,82 & 0,52 & 0,82 \\
\hline K CTC & & & & 1,00 & 0,57 & 0,67 & 0,63 & 0,44 & 0,68 \\
\hline $\mathrm{Ca}$ CTC & & & & & 1,00 & 0,85 & 0,84 & 0,79 & 0,96 \\
\hline $\mathrm{Mg}$ CTC & & & & & & 1,00 & 0,87 & 0,65 & 0,95 \\
\hline Al CTC & & & & & & & 1,00 & 0,69 & 0,91 \\
\hline HCTC & & & & & & & & 1,00 & 0,80 \\
\hline CTC & & & & & & & & & 1,00 \\
\hline
\end{tabular}

Obs 1: população de 11 amostras, de 0,2 a $9 \mathrm{~m}$, do poço da estação de monitoramento

Obs 2: correlações com intervalo de significância de $95 \%$.

Obs 3: números em vermelho: correlações negativas; números em azul: correlações positivas.

Nesta matriz de correlação, destacam-se as seguintes observações: (1) a ocorrência de correlações positivas entre a maioria dos cátions trocáveis e o parâmetro CTC; (2) as correlações negativas entre os cátions trocáveis com o $\mathrm{pH}_{\mathrm{CaCl} 2}$ da solução do solo, indicando que quanto mais ácida a solução do solo, maior a quantidade de elementos adsorvidos, notadamente a partir de $7 \mathrm{~m}$ de profundidade, o que parece ser contraditório, já que a maior disponibilidade de cátions $\mathrm{H}^{+}$faria diminuir a adsorção dos outros cátions; (3) a ausência de correlação significativa entre ocorrência de matéria orgânica e a quantidade de elementos adsorvidos; (4) a correlação negativa entre ocorrência de sílica e a CTC, bem como da maioria dos cátions trocáveis, indicando que os estratos mais quartzosos possuem menor capacidade de adsorção de elementos; (5) a ausência de correlação entre a ocorrência de óxido de alumínio com a CTC e elementos adsorvidos, indicando, novamente, que os argilominerais possam ter participação secundária nos processos de adsorção; (6) as elevadas correlações positivas entre o óxido de ferro com a CTC e os cátions trocáveis, indicando ser provável que estes materiais participem ativamente dos processos de adsorção; e (7) as elevadas correlações positivas entre os óxidos de magnésio, cálcio, sódio e potássio com a maior parte dos cátions trocáveis. 
Para melhor avaliar esta última observação, comparou-se as quantidades dos cátions de base trocáveis com os mesmos cátions analisados por ICP/AES, após a devida uniformizaçã das unidades de expressão. Os resultados, expressos em porcentagem de cátions trocáveis sobre cátions totais, são apresentados na Tabela 19.

\begin{tabular}{|c|c|c|c|c|}
\hline \multicolumn{5}{|c|}{$\begin{array}{c}\text { Tabela } 19 \text { - Relação entre cátions adsorvidos sobre cátions } \\
\text { totais no solo da zona não saturada (em \%) }\end{array}$} \\
\hline Prof. & $\mathrm{Mg}$ & $\mathrm{Ca}$ & $\mathrm{Na}$ & $\mathrm{K}$ \\
\hline 0,2 & 8,06 & 42,06 & 295,98 & 0,66 \\
\hline 0,4 & 7,33 & 87,63 & 56,05 & 2,36 \\
\hline 1 & 6,72 & 77,11 & 53,42 & 5,07 \\
\hline 2 & 6,72 & 79,45 & 60,63 & 4,32 \\
\hline 3 & 8,40 & 84,12 & 56,05 & 3,53 \\
\hline 4 & 11,52 & 112,16 & 62,92 & 5,18 \\
\hline 5 & 7,20 & 98,14 & 109,14 & $5 ; 89$ \\
\hline 6 & 6,30 & 70,10 & 90,54 & 3,32 \\
\hline 7 & 8,40 & $78 ; 51$ & 51,07 & 1,57 \\
\hline 8 & 8,92 & 84,12 & 29,61 & 0,87 \\
\hline 9 & 6,86 & 87,86 & 34,28 & 0,70 \\
\hline
\end{tabular}

Da Tabela 19, verifica-se que o cálcio encontra-se em elevadas proporções na fração adsorvida, muitas vezes próximas de $100 \%$, o que faz crer que este elemento encontra-se no solo quase que exclusivamente na forma adsorvida, a não ser na camada de $0,2 \mathrm{~m}$ (aterro). $\mathrm{O}$ sódio encontra-se quase sempre em porcentagens mais elevadas que $50 \%$, mas as concentrações medidas são muito baixas e próximas ao limite de deteç̧ão do método analítico do ICP/AES, o que faz com que imprecisões importantes possam estar embutidas nestes resultados. A maior probabilidade é a de que este elemento esteja todo adsorvido. $O$ magnésio (5 a 12\%) e principalmente o potássio (1 a $6 \%$ ) apresentam-se adsorvidos em baixas proporções, fazendo crer que eles estejam, em sua maior parte, fazendo parte da estrutura cristalina de algum mineral. Pode também contribuir para a pequena proporção de potássio adsorvido, a possibilidade do elemento estar irreversivelmente adsorvido em minerais de argila (Appelo \& Postma, 1993), o que pode ser a razão de sua baixa detecção nas análises de CTC.

A Tabela 20 apresenta uma matriz de correlação entre as análises de capacidade de troca de cátions (CTC) e os ensaios de granulometria, também considerando apenas as análises das amostras de solo total coletadas na zona não saturada do poço da estação até $9 \mathrm{~m}$. 


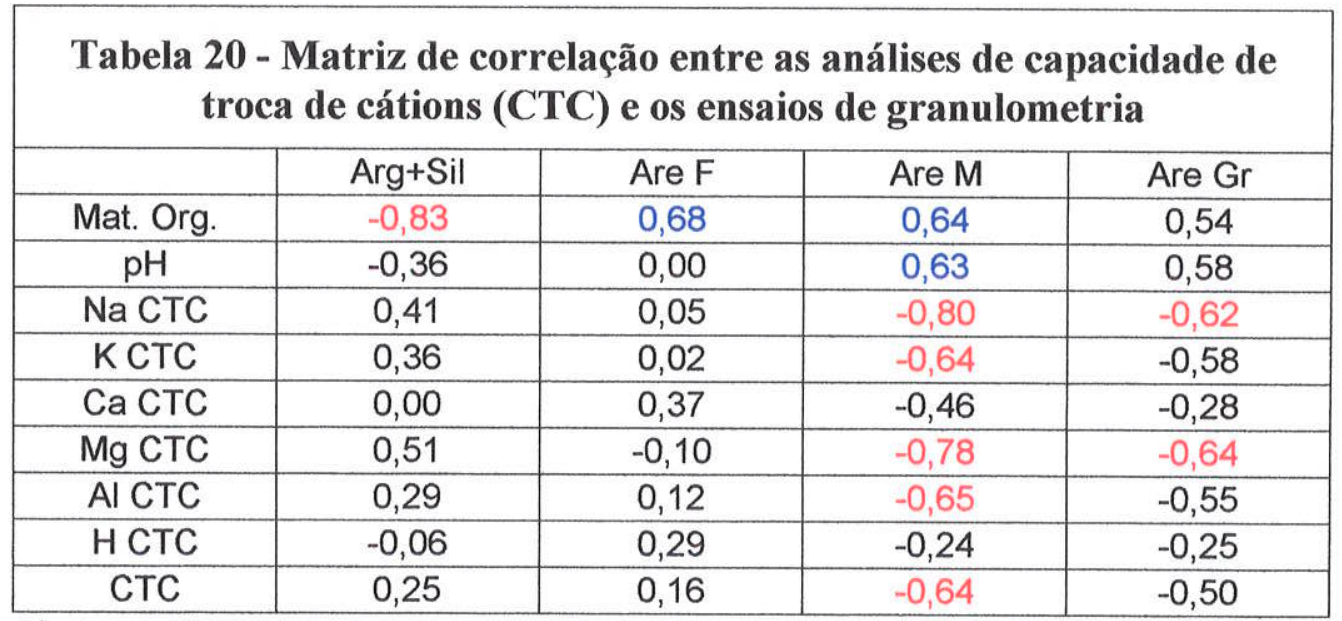

Obs 1: população de 11 amostras, de 0,2 a $9 \mathrm{~m}$, do poço da estação de monitoramento. Obs 2 : correlações com intervalo de significância de $95 \%$. Obs 3: Arg+Sil = fração argila mais silte;

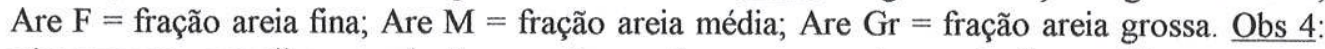
números em vermelho: correlações negativas; números em azul: correlações positivas.

Da Tabela 20 observa-se que não existe correlação entre ocorrência de fração fina e elementos adsorvidos, o que parece contraditório, já que os materiais adsorventes (caulinita, hidróxidos de ferro, etc.) fazem parte principalmente desta fração granulométrica (Tabela 16). Nota-se, porém, a correlação negativa entre a fração areia média com os elementos adsorvidos.

\subsubsection{Análises em Microscópio Eletrônico de Varredura (MEV)}

O Anexo 6 apresenta uma tabela com os resultados das análises semiquantitativas realizadas em alguns minerais no microscópio eletrônico de varredura (MEV), bem como as imagens disponíveis de alguns desses minerais.

Os pontos 1.1 e 6.1 da lâmina de $10 \mathrm{~m}$ foram interpretados como sendo feldspatos potássicos através de microscopia ótica e depois confirmados nas análises no $\mathrm{MEV}$, em que as relações entre potássio, alumínio e silício são praticamente idênticas às da fórmula química do mineral. O ponto 6.3 é um mineral que possui uma maior quantidade de magnésio, ferro e titânio, e cuja soma é pouco maior que três vezes a quantidade de potássio. O silício é três vezes maior que o alumínio. Essas características sugerem que o mineral corresponde a uma biotita, apesar desta não ter sido observada por nenhum outro método de análise.

A técnica de "line scan" foi utilizada em uma seção formada por um grão de quartzo envolto por argilomineral na lâmina de $10 \mathrm{~m}$, conforme indicado pela figura no Anexo 6 . Infelizmente não há imagem disponível dos minerais. Os elementos potássio, cálcio e ferro foram varridos nesta seção e os demais cátions de base não foram rastreados por não terem sido detectados. Como resultado, obteve-se três curvas, cujos picos indicam uma maior concentração 
do elemento analisado. Pelas curvas do potássio e do ferro é possível delimitar a localização do argilomineral e do quartzo, sendo que as maiores concentrações nestes elementos encontram-se no argilomineral. $O$ cálcio não apresenta picos de concentração, parecendo distribuir-se de maneira uniforme e em pequenas concentraçðes.

Foram realizadas análises semiquantitativas em dois pontos ao longo da seção que apresentam maiores concentrações de potássio e ferro no argilomineral (pontos 6.3 e 6.4). Os resultados indicam uma relação silício/alumínio de $3 / 2$ e $2 / 1$, respectivamente. Interpreta-se que o argilomineral corresponde à uma massa disforme composta por caulinita e quartzo microcristalino, que faz elevar a quantidade de silício na relação com o alumínio.

O Anexo 6 apresenta, ainda, as imagens obtidas com as análises do MEV pela técnica de "dot map", que rastreou os elementos $\mathrm{Na}, \mathrm{K}, \mathrm{Ca}, \mathrm{Mg}$ e $\mathrm{Al}$ em áreas das lâminas de 3, 5 e 7m. Na lâmina de $7 \mathrm{~m}$, foram obtidas imagens em duas áreas, sendo a área $7 \mathrm{~m}-\mathrm{B}$ uma ampliação da primeira área. Três imagens são disponíveis por área rastreada, sendo a primeira imagem a original em preto e branco, a segunda com os pontos de localização do alumínio, potássio, magnésio, cálcio e sódio, e a terceira com os esses elementos menos o alumínio. As imagens originais dos "dot maps" foram tratadas no programa Corel Draw, executando-se uma ampliação dos pontos para facilitar a sua visualização.

Nas imagens em preto e branco, os minerais em cinza claro são o quartzo, envoltos por uma massa mais escura, que são os argilominerais. Os minerais brancos são opacos ricos em metais. Nas imagens "dot maps" com alumínio, nota-se que as áreas mais brancas correlacionam-se com a presença do quartzo e que as áreas azuis (alumínio) relacionam-se com a ocorrência de argilominerais. Subtraindo-se o alumínio, observa-se a ausência de correlação entre a ocorrência de cálcio, sódio, potássio e magnésio com os minerais das lâminas de 3 e $5 \mathrm{~m}$. Somente nas áreas A e B da lâmina de $7 \mathrm{~m}$ observou-se uma maior concentração de potássio (amarelo) num feldspato potássico e de magnésio em um mineral opaco.

De uma forma geral, avalia-se que os resultados obtidos com o MEV foram relativamente limitados, tendo sido identificados apenas os elementos que fazem parte da estrutura dos minerais, tais como o alumínio nos argilominerais, o potássio no feldspato e o magnésio em mineral opaco. Observa-se que o método não detectou, por exemplo, elementos que encontramse adsorvidos. Entretanto, deve-se relativizar esta observação, pois os elementos analisados são leves e se encontram em pequenas concentrações nas amostras, o que torna mais difícil as suas deteç̧ões no espectrômetro do MEV. 


\subsubsection{Correlações entre Mineralogia e Composição Química do Solo}

Em síntese, as seguintes correlações podem ser feitas entre a mineralogia observada e as análises químicas realizadas:

1 - A sílica deve corresponder quase que exclusivamente ao mineral quartzo na faixa granulométrica maior que 635 mesh. Na fração fina, a sílica deve fazer parte principalmente da estrutura de argilominerais, mas pode, teoricamente, fazer parte de um mineral secundário microcristalino (por exemplo, sílica amorfa ou calcedônia).

2 - O alumínio encontra-se principalmente na fração fina, fazendo parte da estrutura de argilominerais. A relação molar entre sílica e alumínio na fração fina das amostras das profundidades de 1 e $6 \mathrm{~m}$ é de 1,3/1, indicando a predominância de argilominerais $1: 1$, que é característica da caulinita. A maior quantidade relativa da sílica sobre alumínio nesta fração indica a possibilidade de existência de alguma quantidade de sílica microcristalina. Embora em quantidade pequena, o alumínio pode também fazer parte de um argilomineral do grupo da montmorilonita, que foi detectado em maiores profundidades.

3-O ferro encontra-se predominantemente na forma de hematita, ilmenita e magnetita na fração mais densa e na forma de goetita na fração fina. Em ambientes de perfil de alteração de solo, o ferro pode encontrar-se na fração fina sob a forma de materiais precipitados com estrutura cristalina pobremente desenvolvida, tal como a ferridrita (Hem, 1985). Talvez esta observação explique a relativa pequena deteç̧ão de minerais contendo ferro nas análises de difração de raio $\mathrm{X}$ da fração fina, já que análises de composição química revelaram que é elevada a quantidade de ferro nesta fração.

4 - O magnésio deve encontrar-se em maiores quantidades fazendo parte da estrutura cristalina de minerais opacos, que são correlacionados com os minerais metálicos mais densos da fração afundada (detectado no $\mathrm{MEV}$ ). Ainda nesta fração, o magnésio também pode se encontrar em minerais como a magnesita (detectada pelo DRX) e biotita (detectada pelo MEV). $\mathrm{Na}$ fração fina, o magnésio deve encontrar-se adsorvido nos minerais ferruginosos e na caulinita.

5 - O potássio foi verificado adsorvido em quantidades relativamente pequenas, apesar das análises químicas indicarem haver maiores concentrações do elemento na fração fina, o que pode indicar a ocorrência de alguma adsorção irreversível. O potássio também é verificado como sendo associado ao mineral feldspato potássico, detectado em microscopia ótica e MEV. 
6 - O cálcio encontra-se fortemente associado à fração fina e a união das análises químicas e de capacidade de troca de cátions indicam que o elemento encontra-se praticamente todo adsorvido nos minerais da fração fina.

7 - O sódio foi detectado em baixas concentrações e próximo do limite de deteç̧ão nas análises químicas, o que dificulta executar correlações. Acredita-se, entretanto, que o sódio existente no perfil encontra-se praticamente todo adsorvido.

Convém lembrar que, além do sódio, as análises de cálcio e potássio estão sujeitas a erros maiores por apresentarem concentrações menores que a diferença absoluta entre os resultados das análises obtidas e certificadas (ver item 3.2.3), o que pode levar a erros de interpretação.

Investigações mais aprofundadas devem ser realizadas com relação aos mecanismos que definem a adsorção. As correlações estatísticas realizadas e os valores de CTC obtidos em relação aos tabelados pela literatura, fazem crer que os minerais ferruginosos participam mais ativamente dos processos de adsorção que a caulinita, que é o principal argilomineral.

Entretanto, verifica-se na literatura que os valores de $\mathrm{pH}_{\mathrm{zpc}}$ de alguns minerais ferruginosos são relativamente elevados (por exemplo, entre 7 e 8 para a goetita - Tabela 2) em relação ao pH da água, que varia aproximadamente entre 5 e 7, como será observado nos itens posteriores. Esta característica faz crer que haja condições químicas mais propícias para a ocorrência de adsorção de ânions no perfil do solo, e não de cátions.

Esta aparente contradição deve ser relativizada pelas seguintes considerações: (1) é possível que haja no perfil do solo minerais ferruginosos de baixo grau de organização cristalina e que não apresente características de $\mathrm{pH}_{\mathrm{zpc}}$ como aqueles publicados para minerais específicos, como a goetita. A princípio, inclusive, quanto maior o grau de desorganização cristalina, maior a superficie específica e, portanto, maior a capacidade de troca iônica; (2) é comum ocorrer adsorção de cátions em ambientes de $\mathrm{pH}$ inferiores ao $\mathrm{pH}_{\mathrm{zpc}}$ de minerais (Deutsch, 1997), pois a afinidade química de um sólido por um soluto pode ser forte o suficiente para permitir a adsorção, mesmo ocorrendo repulsão eletrostática do soluto pela superfície; (3) as principais observações teóricas são baseadas em experimentos de laboratório e com grande parte das variáveis controladas, ao contrário das condições de campo, que corresponde a um sistema aberto e sujeito a influências das quais não há controle, tal como a ocorrência de microambientes e ação de vegetação e microorganismos. 
Os mecanismos de adsorção são complexos e aparentemente pouco se sabe sobre o comportamento dos minerais ferruginosos como superficies adsorventes. Os livros textos, inclusive, explicam os fenômenos de adsorção mais em função dos diferentes argilominerais e da matéria orgânica do que em função dos minerais ferruginosos. Este assunto deve merecer atenção para futuras pesquisas, pois em contexto de clima tropical úmido, em que o principal argilomineral é a caulinita, os minerais ferruginosos devem desempenhar a função mais importante nos mecanismos de adsorção. A adsorção, por sua vez, representa o mecanismo de retardação de contaminantes mais importante em casos de poluição de solo e água subterrânea.

Nesta pesquisa, avalia-se que investigações mais aprofundadas devem ser realizadas principalmente para a melhor caracterização das propriedades químicas e mineralógicas das frações fina e pesada, ou seja, aquelas que não contenham quantidades elevadas de quartzo. Observou-se, por exemplo, que o quartzo teve elevada influência nos resultados das análises de difração de raios $\mathrm{X}$, levando à possível não detecção de fases mineralógicas que se encontram em baixas concentrações, mas que talvez sejam importantes no controle da composição química da água. Com relação aos fenômenos de adsorção, as investigações futuras devem realizar a separação dos minerais ferruginosos dos minerais argilosos e proceder análises químicas, difração de raios $\mathrm{X}$ e capacidade de troca de cátions em ambas as fases. Estas tarefas são, porém, trabalhosas, requerem elevada quantidade de amostra disponível para tratamento e devem ser realizadas no maior número possível de profundidades.

\subsection{Evolução da Composição Química da Água}

\subsubsection{Resultados das Análises}

O Anexo 7 apresenta os resultados das análises químicas de água efetuadas e o Anexo 8 os resultados estatísticos básicos destas análises. A tabela do Anexo 7 também apresenta dados de volumes de água obtidos nas amostragens, potenciais matriciais do dia da amostragem e tempo em dias após a passagem da última frente de molhamento.

Obteve-se, em geral, pequenos volumes de água nas campanhas de amostragem, principalmente nos lisímetros instalados dentro do poço até $7 \mathrm{~m}$ (média de $120 \mathrm{~mL}$ ). Os volumes são bem maiores (>1500 mL) nos lisímetros L8 e L9, localizados próximo do nível d'água. Como era de se esperar, notou-se uma forte correlação entre volumes de amostra obtidos com o potencial matricial, com forte queda nos volumes disponíveis durante os períodos de estiagem. 
Além do efeito da estação seca, observou-se que as raízes também interferiram na disponibilidade de volume de amostras. Tomando-se a campanha de agosto/99 como exemplo, observa-se que o volume médio das amostras dos lisímetros ímpares instalados na posição B (L1, L3, L5 e L7 - Figura 5) é quase quatro vezes maior (157 $\mathrm{mL})$ que o volume médio das amostras dos lisímetros pares instalados na posição C' (L2, L4 e L6 - $40 \mathrm{~mL}$ ), onde havia maior densidade de raízes da árvore sacrificada.

Observa-se, na tabela do Anexo 7, que as temperaturas das amostras de água são, em geral, elevadas. Para os pontos situados dentro do poço da estação, as temperaturas apresentam-se mais elevadas nos meses mais quentes (média de $27,1^{\circ} \mathrm{C}$ nas campanhas dos meses de janeiro e abril) que nos meses mais frios (média de $24,4^{\circ} \mathrm{C}$ nas campanhas de agosto). Nos lisímetros externos, a média de temperatura é ainda maior nos meses mais quentes $\left(29,1^{\circ} \mathrm{C}\right)$. As temperaturas das amostras não refletem a temperatura da zona não saturada, pois as leituras eram tomadas após a água entrar dentro do vidro amostrador, que sofria rápida elevação da temperatura devido ao pouco volume de amostra e à elevada temperatura do ar.

Quanto ao Eh medido em campo, foram observados valores médios em torno de $480 \mathrm{mV}$, refletindo condições oxidantes para o meio em todo o período monitorado. Excetuando-se os valores das profundidades de 6 e $7 \mathrm{~m}$ da campanha de abril/2000, que apresentaram-se anormalmente mais baixos $(333 \mathrm{mV})$ e os valores elevados da água da chuva $(673 \mathrm{mV})$, nota-se a predominância de valores entre 400 e $600 \mathrm{mV}$, mas sem apresentar tendências no tempo e no espaço que façam caracterizar algum ambiente hidroquímico diferenciado.

Os comportamentos dos parâmetros $\mathrm{pH}$ e condutividade elétrica no tempo e no espaço serão principalmente analisados nos próximos itens. Observaram-se, porém (Anexos 7 e 8), valores médios de $\mathrm{pH}$ em torno de 6,5 e valores de média menos desvio padrão e de média mais desvio padrão de 5,9 e 7,1, valores estes que são comuns para zonas não saturadas com capacidade de neutralização. Variações expressivas de $\mathrm{pH}$ num mesmo ponto ao longo das campanhas de amostragem foram notadas nos lisímetros $L 50$ (desvio padrão $=0,57$ unidade de $\mathrm{pH}), \mathrm{L} 1 \mathrm{~B}(\mathrm{dp}=0,53)$ e $\mathrm{L} 8(\mathrm{dp}=0,50)$. A condutividade elétrica média é de $150 \mu \mathrm{S} / \mathrm{cm}$, refletindo, de uma forma geral, pequenas concentrações de sais dissolvidos na água, e valores mínimos e máximos relativos ao desvio padrão de 54 e $264 \mu \mathrm{S} / \mathrm{cm}$. 
As variações das concentrações dos principais parâmetros químicos detectados nas amostras são observadas nas figuras 30-A a 30-R, que apresentam gráficos contendo os valores médios mais ou menos o desvio padrão dos parâmetros analisados nas cinco campanhas de amostragem realizadas.

Observa-se que, excetuando-se as amostras de água dos lisímetros L5 e LSB, todos os demais pontos de amostragem apresentam ao menos um parâmetro que exibe forte variação de concentrações entre diferentes eventos de amostragem. O parâmetro que mostra as mais fortes variações de concentração é o nitrato, principalmente nos lisímetros mais próximos da superfície, chegando a variar até duas ordens de grandeza (lisímetro L50D - Figura 30B). Pelos gráficos, inclusive, nota-se que é freqüente a ocorrência concentrações elevadas de nitrato e que superam o limite de potabilidade (45 mg/L de $\mathrm{NO}_{3}$ - Portaria 36 do Ministério da Saúde), o que indica a ocorrência de contaminação de origem antrópica, provavelmente relacionada com a utilização de fertilizantes, que é deduzida a partir da avaliação do uso do solo (essencialmente agrícola) no local da estação de monitoramento.

Outros parâmetros que também sofrem variações expressivas em alguns pontos são o cálcio (nos lisímetros rasos, com forte correlação com o nitrato), o bicarbonato (L1B, L3, L4, L6, PM), o gás carbônico (L50, L1, L1B, L2, L4, L6, L9 e PM), a sílica (L8, L9 e PM) e, apenas localmente, o sulfato (L50C e L1B) e cloreto (L1D). Para os demais parâmetros detectados (sódio, potássio, magnésio, fluoreto e o cloreto e sulfato na maior parte dos pontos - vide Anexo 8), os gráficos indicam pequenas concentrações, porém, guardadas as devidas proporções, são também observadas variações de concentrações expressivas destes parâmetros. Em algumas ocasiões, inclusive, observa-se a ocorrência de valores negativos de média menos desvio padrão (nitrato - L50C, L50D, L1C e L1D, sulfato - L50C, cloreto - L1D, L2 e L7, cálcio - L50D, $\mathrm{CO}_{2}-\mathrm{L} 1 \mathrm{~B}, \mathrm{~L} 2, \mathrm{~L} 6$ e L9).

Estas observações indicam que os valores médios não são representativos, e a sua utilização torna inconsistente o estudo hidroquímico, principalmente porque o número de eventos de amostragem é pequeno para as variações obtidas. Observa-se na tabela do Anexo 8, inclusive, que é rara a ocorrência de mais que 3 dados por parâmetro em cada ponto de amostragem. Desta forma, as interpretações que se seguem levam em consideração os dados de cada evento de amostragem separadamente. 


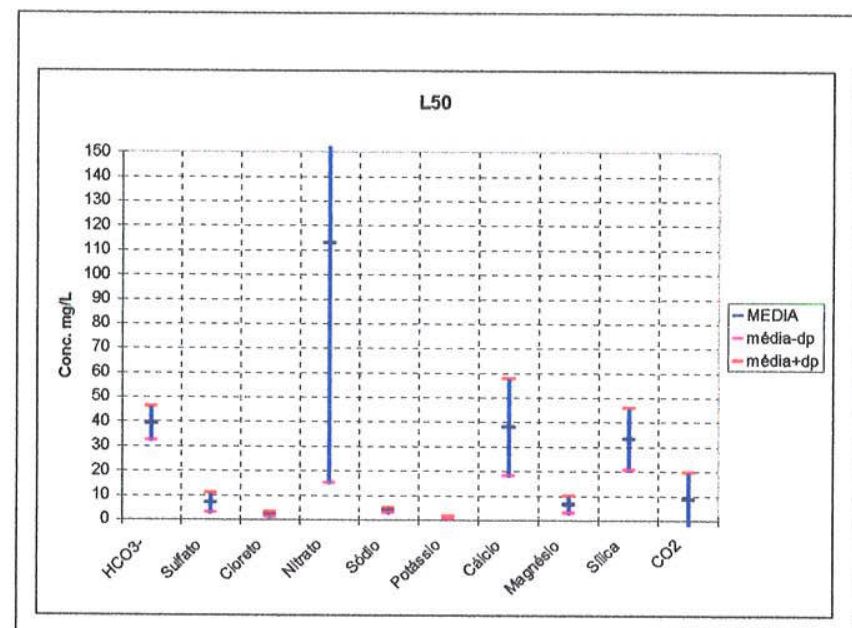

A

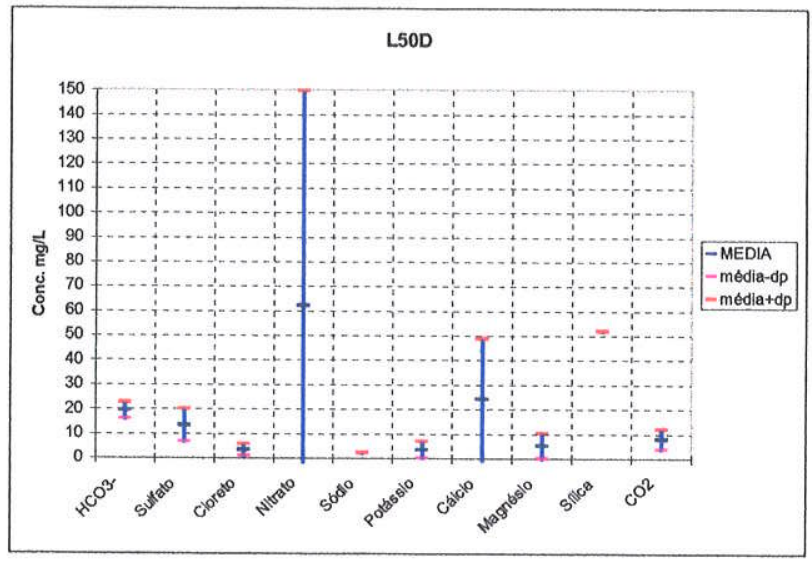

C

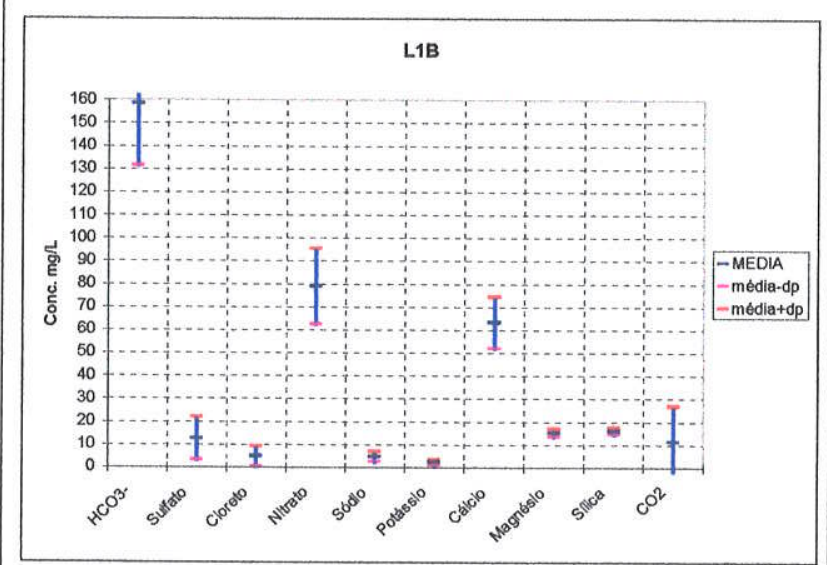

E

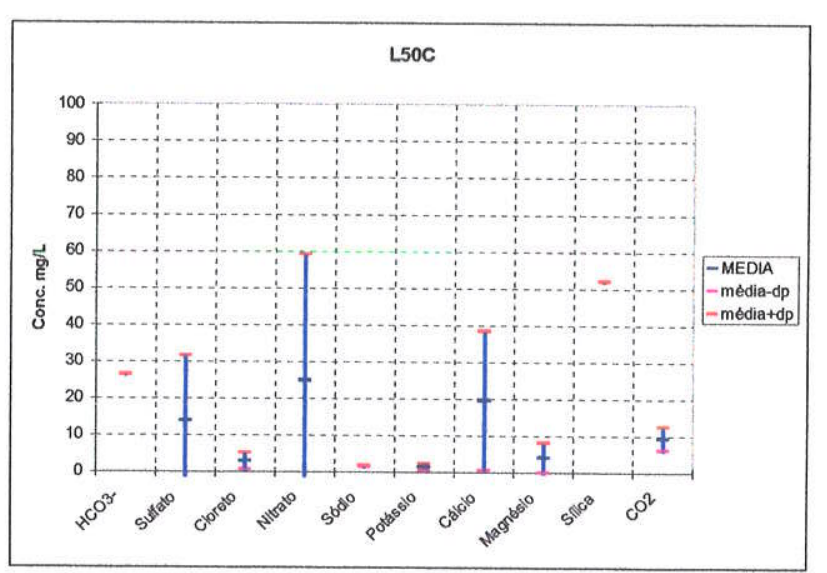

B

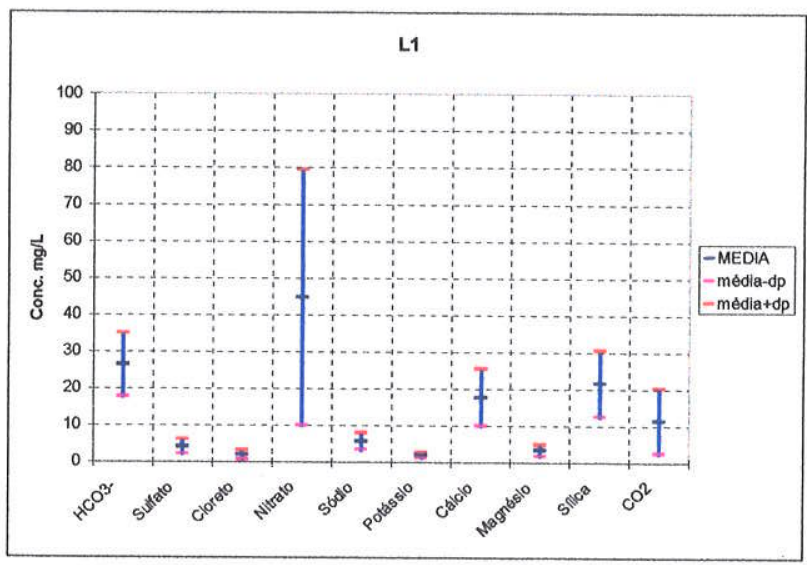

D

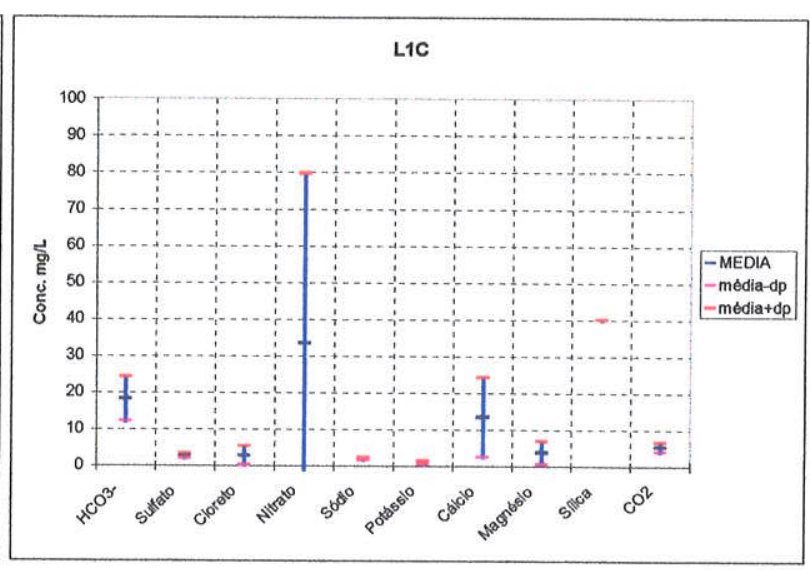

F

Figura 30 - Faixa de concentrações dos parâmetros químicos em relação ao desvio padrão em torno da média 


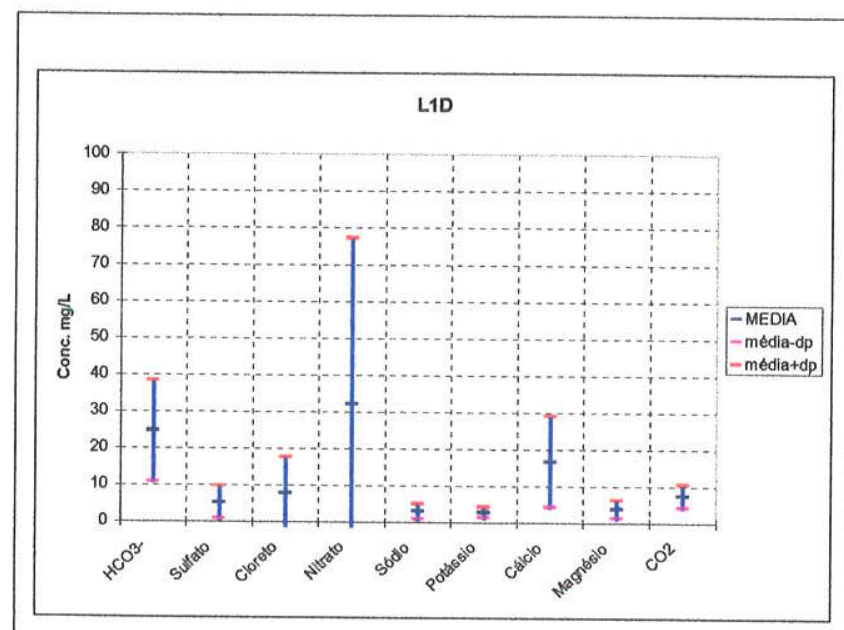

G

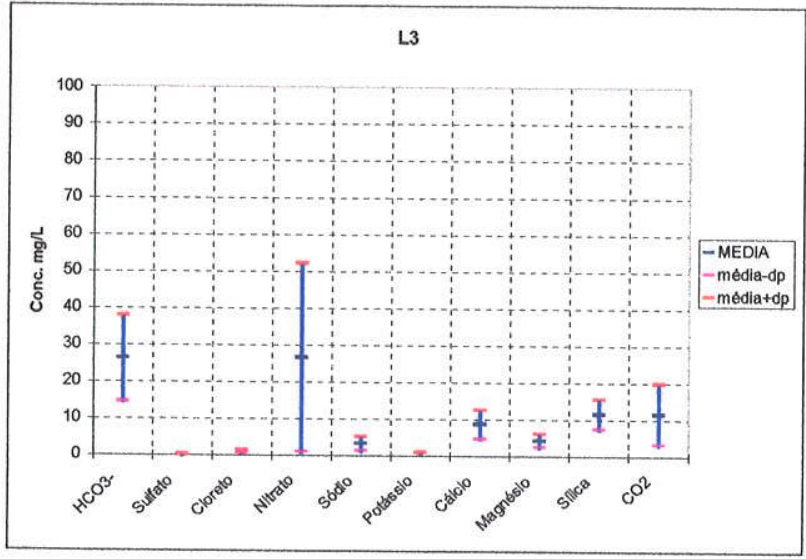

I

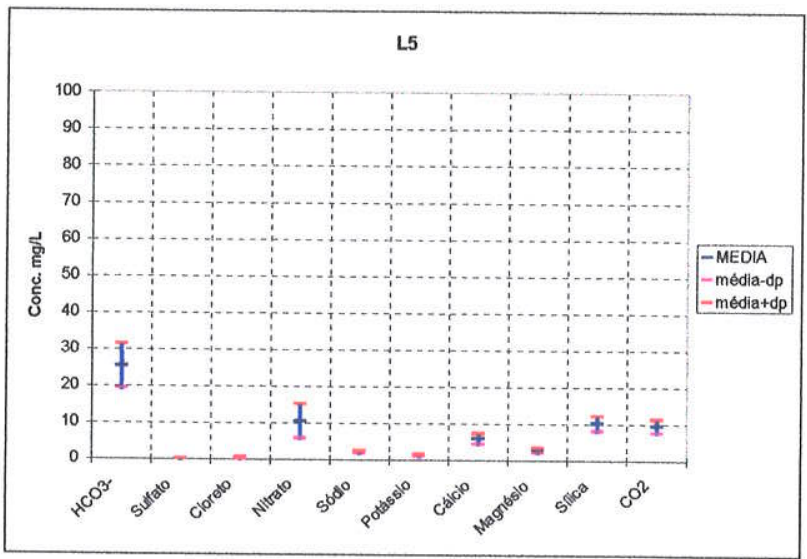

K

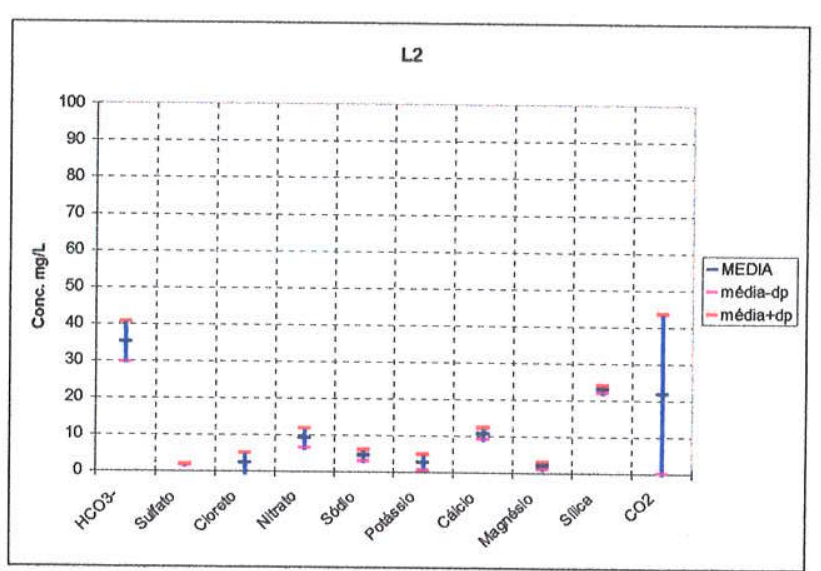

$\mathrm{H}$

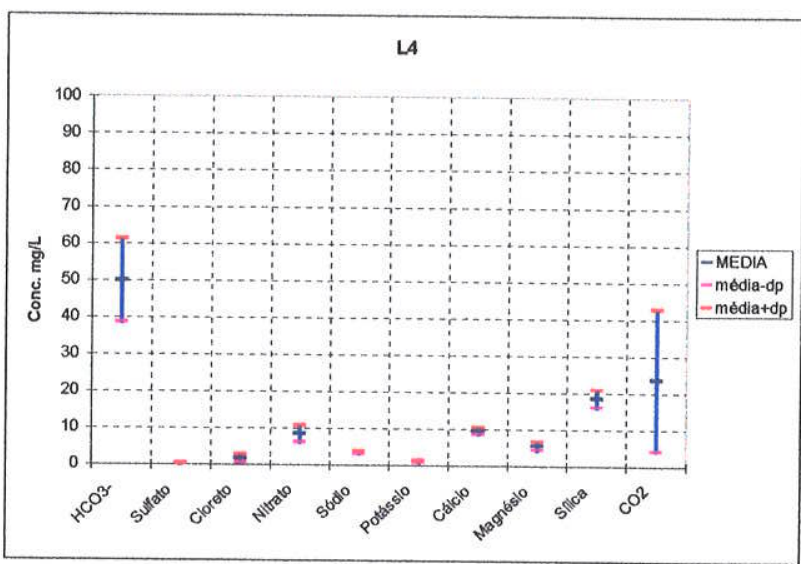

$\mathrm{J}$

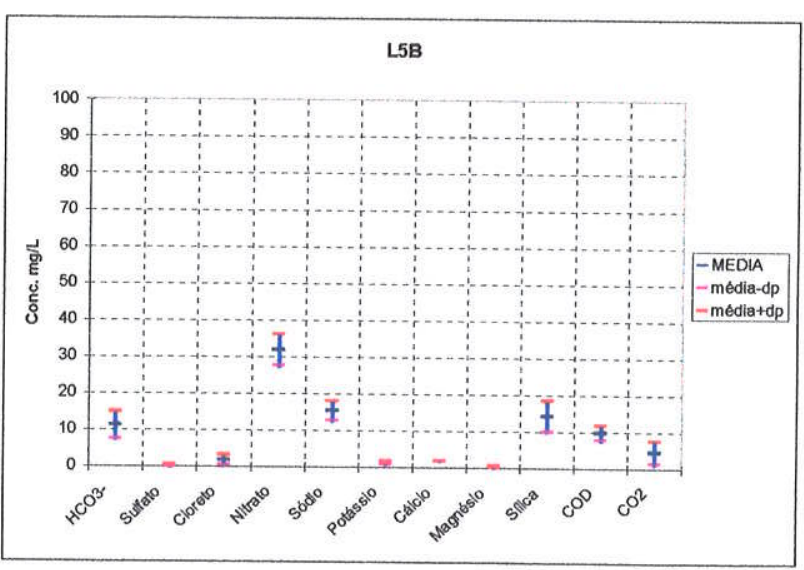

$\mathrm{L}$

Figura 30 - continuação - Faixa de concentrações dos parâmetros químicos em relação ao desvio padrão em torno da média 


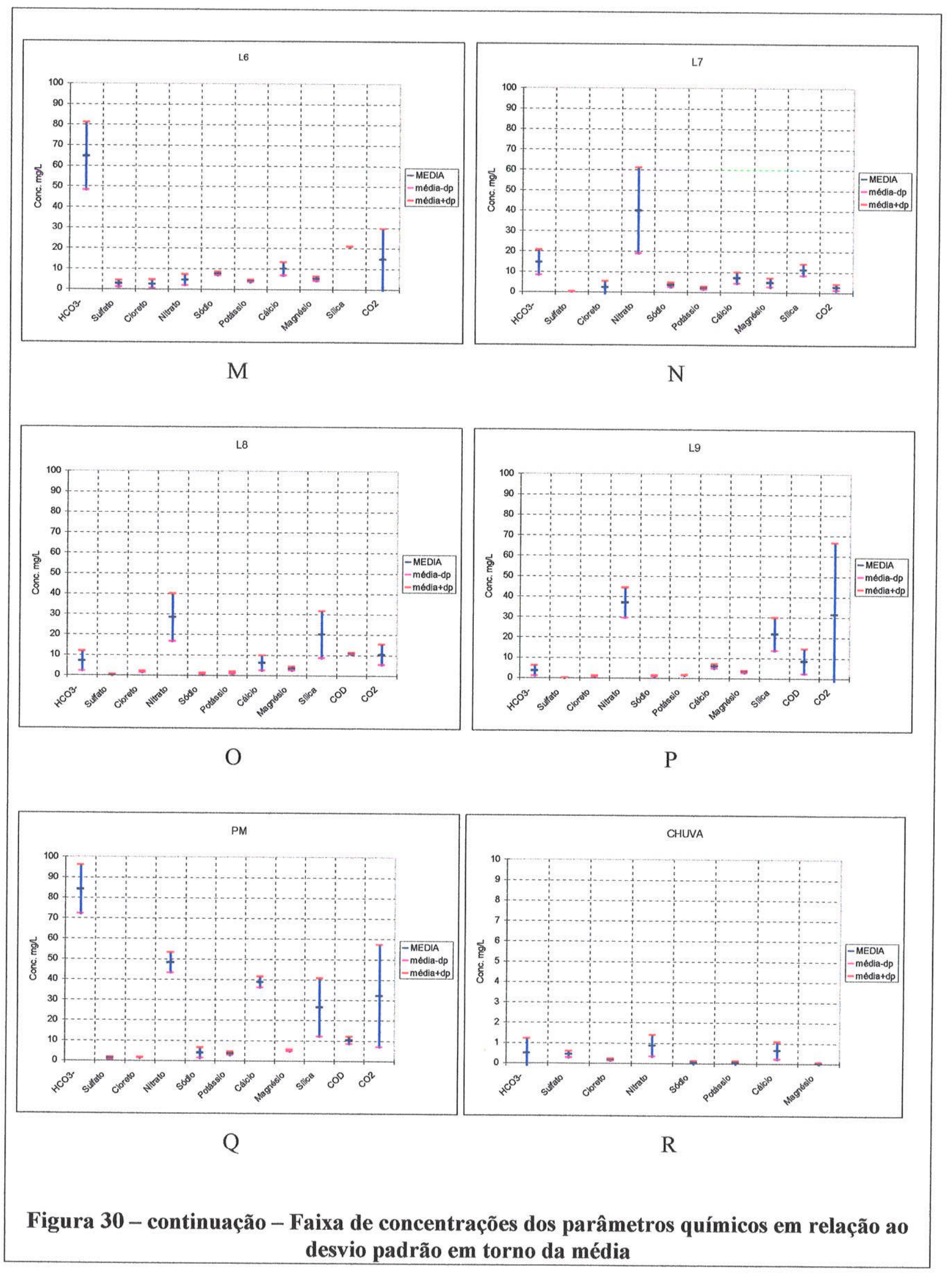


Ainda com relação aos resultados das análises apresentadas no Anexo 7, observa-se que os metais pesados chumbo, cádmio, níquel e prata não foram detectados em nenhuma das análises realizadas. Além destes elementos, o nitrito, brometo, ferro total, manganês, alumínio e cromo total foram raramente detectados nas análises e na maior parte das vezes muito próximos ou até mesmo abaixo dos limites de deteç̧ão. O cobre, zinco, bário e fosfato total foram mais freqülentemente detectados, porém com valores próximos dos limites de detecção ou apresentando desvios elevados nas análises de reprodutibilidade (Tabela 6), principalmente por apresentarem-se em pequenas concentrações. Assim sendo, todos estes elementos citados não são examinados nas considerações hidrogeoquímicas que se seguem.

\subsubsection{Classificação Hidroquímica}

A Figura 31 apresenta a localização das amostras de água analisadas em diagramas de Piper para os cinco eventos de amostragem. De uma forma geral, nota-se que a maior parte dos pontos localizam-se no canto esquerdo do losango, caracterizando as águas como bicarbonatadas cálcio-magnesianas.

Nota-se no triângulo dos ânions, que a maior parte dos pontos situam-se no extremo esquerdo, denotando águas predominantemente bicarbonatadas. Há exceções em todos os gráficos, porém. A água do lisímetro L9 é sempre mais cloretada, assim como dos lisímetros L8 em agosto/99 e L7 em abril/99, pontos estes que correspondem às porções mais profundas da zona não saturada. No diagrama de janeiro/2000, nota-se uma maior dispersão dos pontos no triângulo dos ânions, indicando que os lisímetros mais rasos (internos e externos ao poço e que predominam nesta campanha de amostragem), apresentaram maior quantidade relativa de sulfato e cloreto nesta ocasião. Um ligeiro distanciamento da aresta do $\mathrm{HCO}_{3}$ é também notado para alguns lisímetros mais rasos nos meses de agosto/99 (L50 e L1), abril/2000 (L50D) e agosto/2000 (L1, L1B e L2). Como regra, verifica-se que as águas dos pontos L3 a L6 e do poço de monitoramento são sempre mais fortemente bicarbonatadas em todas as campanhas.

Quanto aos cátions, verifica-se, no geral, dois grupos de pontos principais: um mais cálcico e outro cálcico-magnesiano. No primeiro grupo encontra-se a água dos lisímetros rasos (L50s, L1s e L2) e do poço de monitoramento; o grupo cálcico-magnesiano, corresponde à água dos lisímetros L3 a L9. A água do lisímetro L5B é diferente dos demais grupos, sendo sempre intensamente sódica. A exceção a esses grupos é a água dos lisímetros L1 e L2 da campanha de agosto/2000, que é cálcica-sódica. 


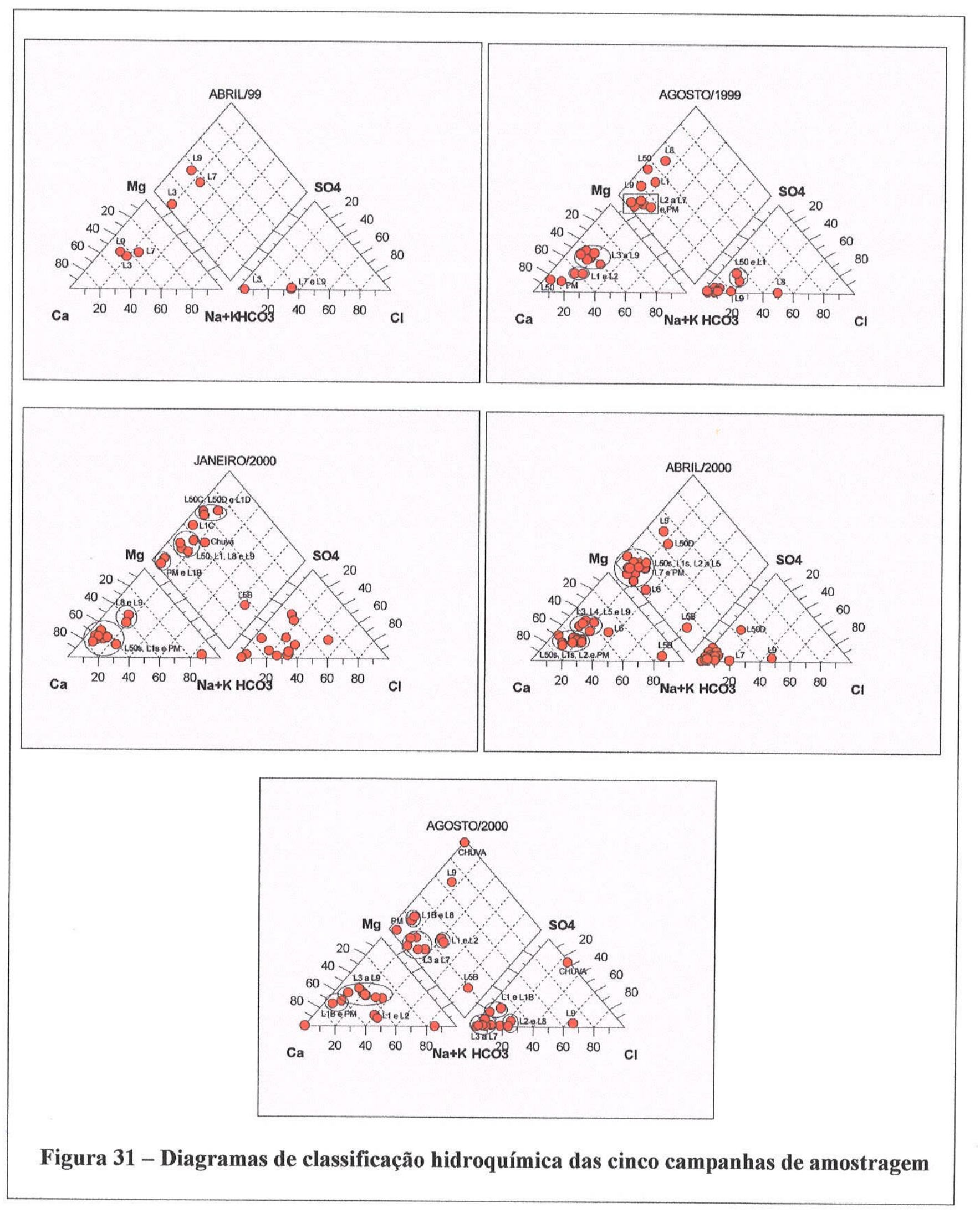


Pelos diagramas, identifica-se a ocorrência de três horizontes na zona não saturada com águas de diferentes composições químicas e que guardam relação similar com as três zonas hidráulicas identificadas na zona não saturada e descritas no item 4.2.1. O primeiro horizonte compreende as amostras de 0,5, 1 e $2 \mathrm{~m}$ (independentemente do lisímetro, se externo ou interno ao poço), que são bicarbonatadas cálcicas e eventualmente apresentam concentrações mais elevadas de sulfato e cloreto; o segundo horizonte engloba as águas das profundidades de 3 a 6 m (ou $7 \mathrm{~m}$ ), que são exclusivamente bicarbonatadas cálcicas-magnesianas; e o terceiro horizonte compreende as águas das profundidades de 8 e $9 \mathrm{~m}$, que são bicarbonatadas-cloretadas cálcicasmagnesianas, sendo que a profundidade de $7 \mathrm{~m}$ também pode exibir esta característica. A água do aqǘf́ero freático possui característica diferenciada do horizonte anterior, sendo exclusivamente bicarbonatada cálcica. A água do lisímetro L5B corresponde a uma anomalia local, que será discutida no item 5.2.4.

\subsubsection{Variações da Composição Química com a Profundidade}

A Figura 32 apresenta gráficos contendo as variações de concentrações dos parâmetros químicos (em meq/L) em função da profundidade nos cinco eventos de amostragem realizados. Para auxiliar a interpretação dos gráficos, a Tabela 21 apresenta uma matriz de correlação dos parâmetros químicos analisados na água dos lisímetros L50 a L9. Nesta matriz foram considerados os dados das campanhas de agosto/99, abril e agosto/2000 por serem mais completos e ocorrerem na maior parte dos pontos amostrados.

No conjunto destes gráficos da Figura 32, identifica-se, mais uma vez, a ocorrência de três horizontes na zona não saturada com características distintas: a primeira, entre a superfície e as profundidades de 1 ou $2 \mathrm{~m}$; a segunda, entre a base da primeira zona e a profundidade de $7 \mathrm{~m}$; e a terceira, entre $7 \mathrm{~m}$ e o aqüífero freático, que também apresenta características distintas da água da zona não saturada.

\section{a- Horizonte de $0 a 2 m$}

No primeiro horizonte, a água caracteriza-se por apresentar maiores concentrações dos íons nitrato, cálcio e secundariamente magnésio, o que também reflete em valores mais elevados de condutividade elétrica em relação aos outros horizontes. A sílica e outros íons menores, como o sulfato e estrôncio, também apresentam-se em concentrações mais elevadas nesta zona. Outra característica deste horizonte é que ocorre uma maior variação temporal dos parâmetros químicos citados de uma campanha de amostragem para outra. 

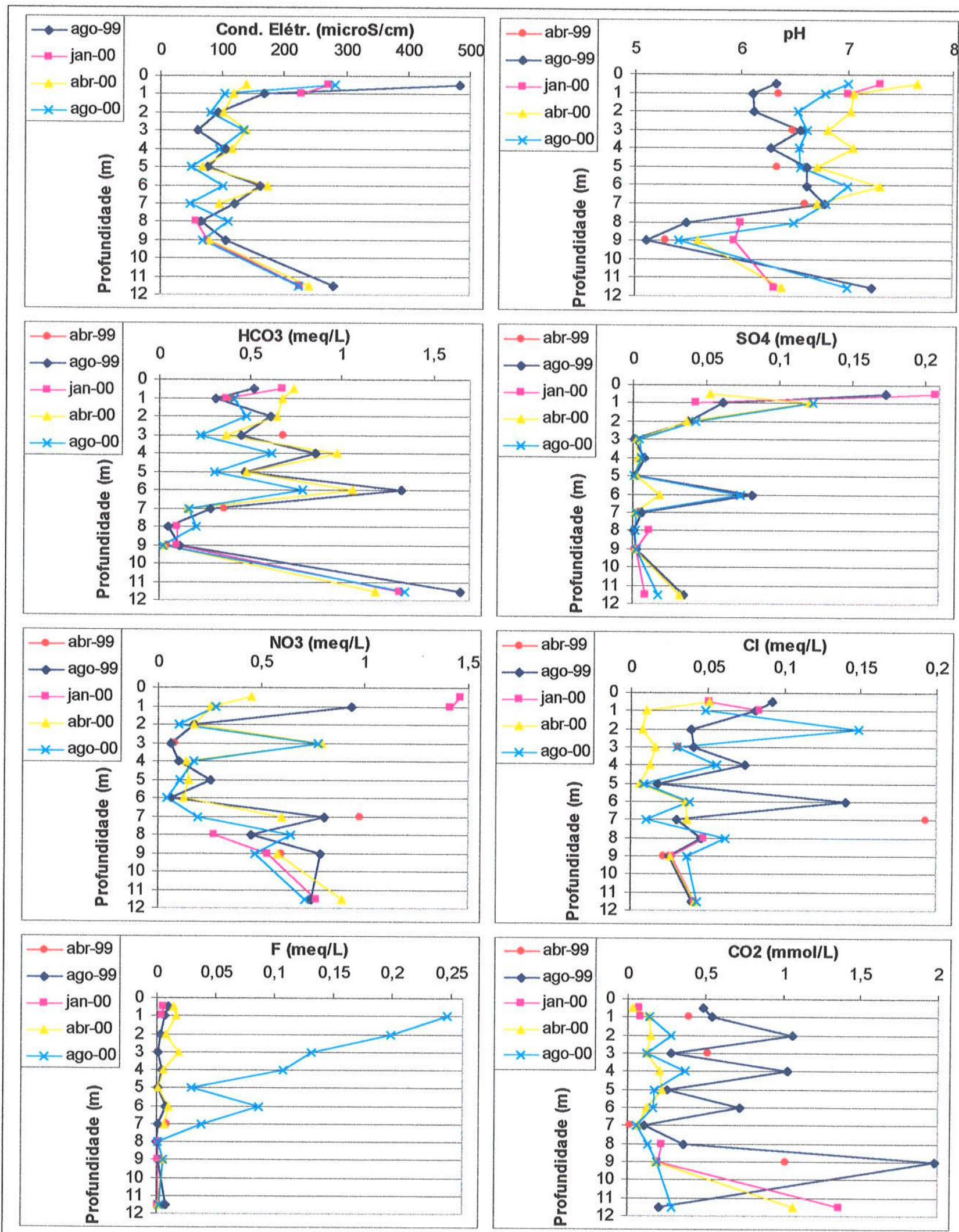

Figura 32 - Variações da composição química da água com a profundidade nas cinco campanhas de amostragem 


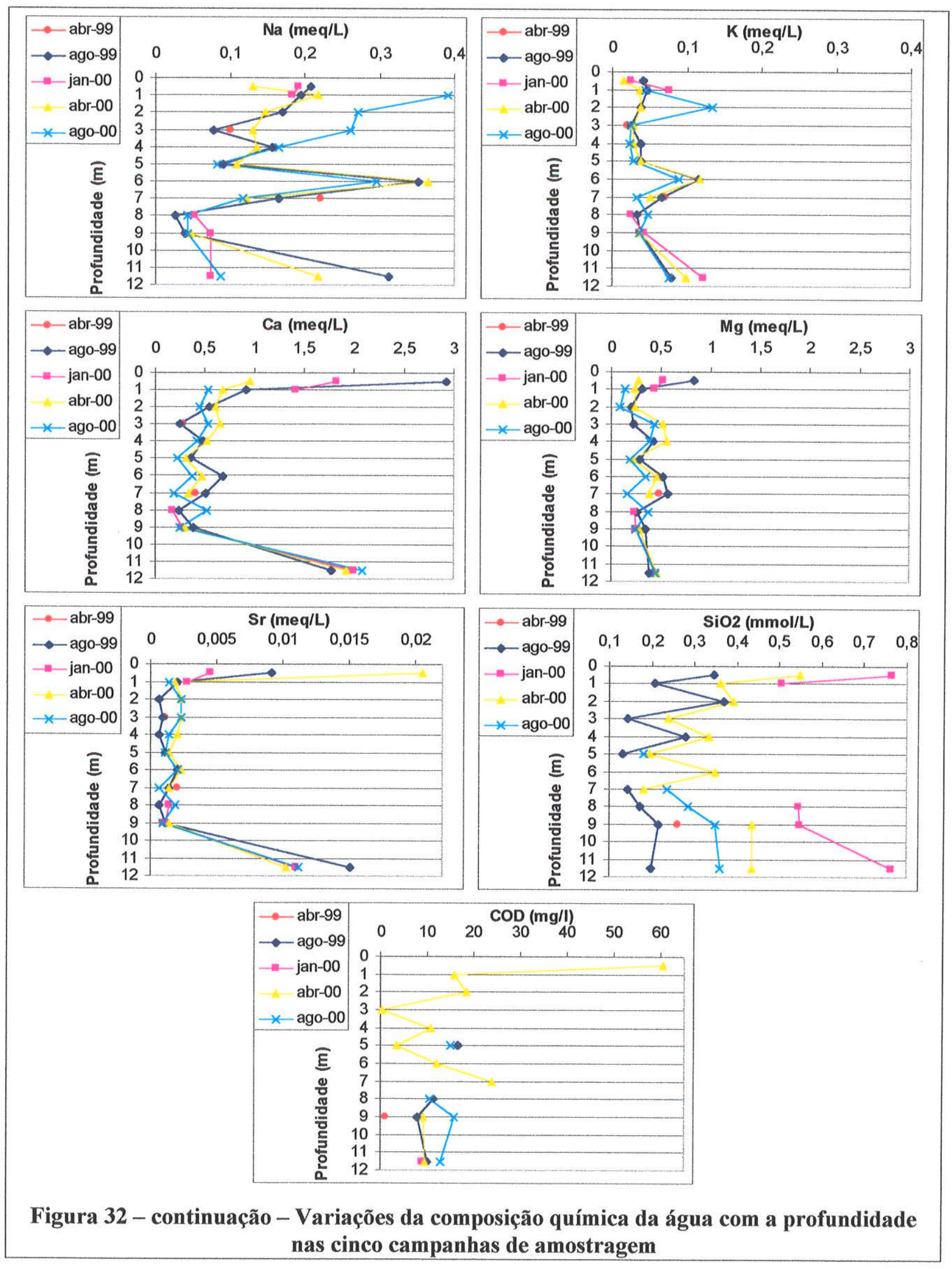




\begin{tabular}{|c|c|c|c|c|c|c|c|c|c|c|c|c|c|c|c|c|}
\hline \multicolumn{17}{|c|}{$\begin{array}{c}\text { Tabela } 21 \text { - Matriz de correlação dos parâmetros químicos analisados na água dos } \\
\text { lisímetros L50 a L9 }\end{array}$} \\
\hline & 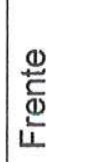 & I & 它 & O̊ & 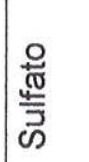 & $\frac{.2}{0}$ & 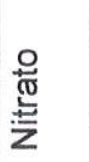 & $\mid \begin{array}{l}\frac{0}{0} \\
\frac{0}{2} \\
\frac{\partial}{4}\end{array}$ & $\frac{\text { 을 }}{8}$ & 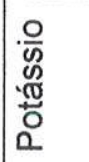 & 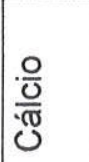 & 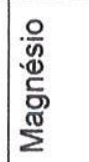 & 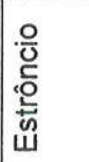 & 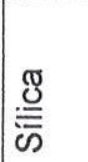 & Oి & O̊ \\
\hline Pot. Matr. & 0,31 & 0,24 & 0,00 & 0,17 & 0,18 & 0,30 & $-0,10$ & 0,62 & 0,47 & 0,09 & 0,04 & $-0,14$ & $-0,14$ & $-0,40$ & 0,08 & $-0,09$ \\
\hline Frente $^{(1)}$ & 1,00 & $-0,58$ & $-0,16$ & $-0,23$ & $-0,12$ & 0,29 & $-0,03$ & 0,03 & $-0,11$ & 0,06 & $-0,17$ & $-0,08$ & $-0,35$ & $-0,49$ & $-0,29$ & 0,48 \\
\hline $\mathrm{pH}$ & & 1,00 & 0,08 & 0,58 & 0,22 & $-0,10$ & $-0,21$ & 0,16 & 0,48 & 0,16 & 0,09 & 0,08 & 0,40 & 0,23 & 0,49 & $-0,59$ \\
\hline Cond. El. & & & 1,00 & 0,24 & 0,68 & 0,36 & 0,88 & $-0,09$ & 0,32 & 0,10 & 0,97 & 0,75 & 0,43 & 0,25 & 0,33 & 0,09 \\
\hline $\mathrm{HCO}_{3}$ & & & & 1,00 & 0,35 & 0,31 & $-0,23$ & $-0,02$ & 0,61 & 0,42 & 0,19 & 0,29 & 0,21 & 0,38 & 0,23 & 0,05 \\
\hline Sulfato & & & & & \begin{tabular}{|l|}
1,00 \\
\end{tabular} & 0,39 & 0,48 & 0,29 & 0,60 & 0,21 & 0,72 & 0,21 & 0,35 & 0,39 & 0,35 & 0,00 \\
\hline Cloreto & & & & & & 1,00 & 0,19 & 0,30 & 0,42 & 0,61 & \begin{tabular}{|l|}
0,35 \\
\end{tabular} & 0,16 & 0,16 & 0,11 & 0,35 & 0,21 \\
\hline Nitrato & & & & & & & 1,00 & $-0,13$ & \begin{tabular}{|l|}
$-0,04$ \\
\end{tabular} & $-0,15$ & 0,88 & 0,65 & \begin{tabular}{|l|}
0,34 \\
\end{tabular} & 0,08 & 0,11 & 0,09 \\
\hline Fluoreto & & & & & & & & 1,00 & 0,58 & 0,26 & $-0,07$ & $\mid-0,32$ & $-0,05$ & 0,11 & 0,34 & $\mid-0,19$ \\
\hline Sódio & & & & & & & & & 1,00 & 0,62 & 0,23 & 0,14 & 0,05 & 0,24 & 0,11 & $-0,12$ \\
\hline Potássio & & & & & & & & & & 1,00 & $-0,02$ & 0,06 & $-0,15$ & $-0,07$ & $-0,30$ & 0,01 \\
\hline Cálcio & & & & & & & & & & & 1,00 & 0,63 & 0,52 & 0,30 & 0,69 & 0,07 \\
\hline Magnésio & & & & & & & & & & & & 1,00 & 0,18 & 0,02 & $-0,08$ & 0,09 \\
\hline Estrôncio & & & & & & & & & & & & & 1,00 & 0,60 & 0,92 & $-0,15$ \\
\hline Sílica & & & & & & & & & & & & & & 1,00 & 0,54 & $-0,09$ \\
\hline COD & & & & & & & & & & & & & & & 1,00 & $\mid-0,28$ \\
\hline
\end{tabular}

Obs: matriz de correlação considerando dados de 28 amostras dos lisímetros L50 a L9 de dentro do poço e das campanhas de agosto/99, abril/2000 e agosto/2000. Correlações com intervalo de significância de $95 \%$. Números em vermelho e azul: ocorrência de correlações negativas e positivas, respectivamente.

(1) Frente: número de dias decorridos após a passagem da última frente de molhamento.

As maiores concentrações relativas dos íons e as maiores variações temporais nas concentrações, sugerem a ocorrência de mecanismos de evaporação e infiltração sucessivos nesta zona mais rasa, delimitada e definida pela linha de evaporação. Esta suposição é compatível com as características hidráulicas descritas nos itens 5.2.1 e 5.2.2.

\section{$\underline{b-H o r i z o n t e ~ d e ~} 2 a 7 m$}

$\mathrm{O}$ segundo horizonte, de 2 a $7 \mathrm{~m}$, apresenta água com menores quantidades de íons dissolvidos em relação à primeira zona, notadamente devido à redução das concentrações de cálcio e nitrato. O bicarbonato passa a ser o principal ânion e apresenta uma tendência de elevação de concentrações até $6 \mathrm{~m}$. O nitrato apresenta variações intensas de concentrações até $7 \mathrm{~m}$, mas com tendência de queda até $6 \mathrm{~m}$. O cloreto e o sulfato, assim como o sódio e potássio apresentam-se em pequenas concentrações, porém ocorrem valores anômalos em algumas profundidades em determinados eventos de amostragem. Dentre estes íons em menores concentrações, destaca-se uma anomalia a $6 \mathrm{~m}$, onde há maiores concentrações relativas de potássio, sódio e sulfato e outra a $2 \mathrm{~m}$, onde há maiores concentrações de potássio e cloreto na campanha de setembro/2000. Estas anomalias colaboram para a ocorrência de correlações positivas entre estes elementos, de acordo com a Tabela 21. 
O cálcio é o cátion dominante nesta zona, porém nota-se uma variação de concentrações relativamente pequena entre os eventos de amostragem, mas uma ligeira tendência de elevação nas concentrações entre as profundidades de 3 e $7 \mathrm{~m}$ na campanha de agosto/99 e o inverso (ligeira tendência de queda) nas campanhas de abril e agosto/2000. O magnésio não apresenta queda nas concentrações tão intensa quanto o cálcio da primeira para a segunda zona, mas exibe concentrações semelhantes ao daquele na segunda zona. $O$ magnésio também exibe tendências semelhantes ao do cálcio em termos de variação de concentrações entre as profundidades de 3 e $7 \mathrm{~m}$, o que confere uma correlação positiva entre essas espécies na Tabela 21. A sílica apresenta tendência de queda nas concentrações nesta faixa de profundidade, de acordo com os eventos de amostragem de agosto/99 e abril/2000.

Uma característica marcante desta segunda zona, para a maior parte dos parâmetros, é que as concentrações das espécies químicas são geralmente maiores nos lisímetros pares $(2,4$ e 6$)$ que nos ímpares ( 3,5 e 7), formando um efeito ziguezague nestes gráficos (a exceção é a anomalia de concentrações de nitrato, cálcio e magnésio no lisímetro L3 em abril e agosto/2000). Este efeito está ligado à ação da evapotranspiração ocasionada pela árvore sacrificada, com maior densidade de ocorrência de raízes na posição C' do poço da estação de monitoramento (Figura 5), onde estão localizados os lisímetros de número par.

Esta característica tem concordância com o comportamento hidráulico descrito no item 4.2.2, em que se observa, através da Figura 18, que a posição C' do poço apresentava menor quantidade de umidade em relação à posição B durante a estação seca de 1999, devido à ação de raízes, o que sugere que a sucção por elas produzidas tenha ocasionado uma maior concentrações das espécies químicas.

$\mathrm{O}$ comportamento do $\mathrm{pH}$, bicarbonato e gás carbônico (cujas concentrações foram calculadas a partir do uso de modelos químicos de especiação), apresenta intensa relação com a ação da respiração das raízes, tal como descrito nas reações 2 e 3. No evento de amostragem de agosto/99, nota-se valores menores de $\mathrm{pH}$ e maiores de bicarbonato e de $\mathrm{CO}_{2}$ nos lisímetros $\mathrm{L} 2$, L4 e L6, indicando a ocorrência de maior ação da respiração das raizes no lado C' do poço da estação (Figura 5). O nitrato, nesta ocasião, apresentava concentrações menores nos lisímetros L4 e L6 em relação aos lisímetros L5 e L7, sugerindo que as raízes estariam também consumindo o nitrato como nutriente. 
Os eventos de amostragem de abril e agosto/2000 indicaram, porém, uma mudança nas condições químicas da zona não saturada, principalmente devido ao pH, que sofreu elevação em todos os lisímetros em relação à campanha de agosto/2000, provavelmente devido à interrupção da produção de gás carbônico pelas raízes da árvore sacrificada em janeiro/2000, cuja concentração também caiu em toda a zona não saturada depois deste evento (Figura 32). Curioso verificar que a curva de $\mathrm{pH}$ da campanha de abril/2000 tem desenho oposto ao da curva da campanha de agosto/2000, ou seja, observa-se valores mais elevados de $\mathrm{pH}$ na campanha de abril/2000 nos mesmos lisímetros em que foram observados os menores valores na campanha de agosto/1999. Nota-se pela Tabela 21, inclusive, a ocorrência de correlação negativa entre o pH e o número de dias decorridos da passagem da última frente de molhamento, ou seja, o $\mathrm{pH}$ tende a se tornar mais ácido com o maior tempo de residência da água na zona não saturada.

Mudanças significativas na concentração das demais espécies químicas não se fizeram sentir após o evento do sacrificio da árvore, tanto que ainda se observa o efeito ziguezague nos gráficos dos parâmetros bicarbonato, cálcio, magnésio e sílica nos eventos de amostragem de abril e agosto/2000. Uma melhor avaliação das possíveis mudanças do comportamento destes parâmetros químicos somente poderão ser realizadas com a execução de novas campanhas de coleta e análises de água para verificar a evolução de sua composição química com a ausência dos efeitos mais intensos da evapotranspiração, bem como os eventuais efeitos da degradação da matéria orgânica das raízes, que tendem a produzir gás carbônico (reação 1), e liberar para a água vários cátions e ânions que encontravam-se estocados na matéria viva.

\section{c-Horizonte de $7 m$ ao aqüifero freático}

Neste terceiro horizonte, que hidraulicamente caracteriza-se por ser mais úmido e menos permeável que os horizontes sobrepostos e por apresentar fluxos verticais reduzidos (item 4.2.1), também se caracteriza por apresentar um ambiente hidroquímico diferenciado dos demais.

O principal parâmetro que caracteriza o ambiente hidroquímico desta zona é o $\mathrm{pH}$, que sofre uma brusca queda a partir de $7 \mathrm{~m}$ e situando-se pouco acima de 5,0 na profundidade de $9 \mathrm{~m}$ na maior parte dos eventos de amostragem. $O$ bicarbonato também apresenta a mesma tendência de queda, assim como o sódio e o potássio, embora em menor escala (Figura 33). Nesta zona o nitrato volta a sofrer elevação nas concentrações, sendo o principal ânion. $O$ cálcio e o magnésio também são os principais cátions, encontrando-se em concentrações semelhantes, ainda que se note uma ligeira queda em suas concentrações em relação às profundidades mais rasas. 
Esta zona caracteriza-se por apresentar as menores variações de composição química da água da zona não saturada entre os diferentes eventos de amostragem, denotando o reduzido efeito das variações climáticas e da vegetação sobre a composição química da água no local. Nota-se, porém, um valor mais elevado de $\mathrm{pH}$ no evento de amostragem de janeiro/2000, período este em que o aqüífero freático encontrava-se mais raso, indicando a possível ocorrência de uma mistura da água desta zona com a do aqüífero.

Não há uma explicação aparente que esclareça a origem deste ambiente até o momento. Procurou-se inicialmente associar a ocorrência da maior acidez com alguma fonte de matéria orgânica em decomposição, tal como observado por Wood \& Petraitis (1984) e Keller (1991) (item 2.2.2), porém as análises disponíveis de carbono orgânico dissolvido (COD) não parecem indicar a existência de uma fonte razoável de matéria orgânica nesta profundidade. Ao contrário, observa-se concentrações mais elevadas de COD nas profundidades de 0,5, 1,0 e 2,0 m (Figura 33), em concordância com as análises de matéria orgânica da fração sólida (item 5.1.4). Mesmo as concentrações de $\mathrm{CO}_{2}$ nesta profundidade são irregulares e baixas nas campanhas de janeiro, abril e agosto/2000.

Aparentemente, a acidez mais elevada da água nesta zona tem alguma relação com os fenômenos da adsorção, já que se observa na Figura 29 uma queda abrupta da relação hidrogênio adsorvido/capacidade de troca cationica (H/CTC), embora haja elevação do valor absoluto de hidrogênio adsorvido nas profundidades de 8 e $9 \mathrm{~m}$ em relação às profundidades mais rasas (Figura 27). Esta observação é oposta ao que foi obtida por Edmunds et al. (1992a e 1992b), Hansen \& Postma (1995), Soveri (1989) e Moss \& Edmunds (1989) (item 2.2.2), pois em situação de algum equilíbrio químico, espera-se uma elevação do $\mathrm{pH}$ da solução em contato com uma maior quantidade de cátions de base adsorvidos, como é o caso desta faixa de profundidade, que apresenta uma brusca elevação da CTC em relação às profundidades menores.

De qualquer forma, esta zona hidroquímica não apresenta informações mais detalhadas sobre as suas características hidráulicas, por ser provável a ocorrência de fluxos horizontais dos quais não se possui informações sobre a natureza dos processos químicos que ocorrem nos arredores. A acidez mais elevada indica, porém, que este é um ambiente mais agressivo para a dissolução de minerais primários, que ocorrem em maior quantidade nesta zona. 


\section{d-o aqüifero freático}

O aqüífero freático na estação de monitoramento não possui conexão hidráulica direta com a zona não saturada $\mathrm{e}$, devido aos fluxos laterais, possui composição química bastante distinta. $\mathrm{A}$ água do aqüífero freático possui pH mais elevado e quantidades mais elevadas de íons, indicado pela forte elevação da condutividade elétrica (Figura 33). O bicarbonato é o principal ânion, porém nota-se elevadas quantidades de nitrato. O cálcio volta a apresentar elevação nas concentrações, não sendo acompanhado pelo magnésio na mesma proporção. Dentre os íons secundários, nota-se ligeira elevação nas concentrações de sulfato, sódio, potássio e estrôncio.

Temporalmente, a água do aqüífero freático exibiu uma certa constância na sua composição química. Observaram-se, porém, valores de $\mathrm{pH}$ mais elevados durante os períodos mais secos, representados pelas amostragens de agosto/99 e agosto/2000.

Ainda na Figura 33, nota-se o comportamento diferenciado das concentrações de fluoreto da campanha de agosto/00 em relação aos demais. No geral, as concentrações desta espécie foram pequenas em todas as campanhas, mas nota-se uma tendência de diminuição em função da profundidade. As elevadas concentrações obtidas na campanha de agosto/00, da ordem de 4,7 $\mathrm{mg} / \mathrm{L}$ no lisímetro L1, tem correlação com o potencial matricial do solo, tal como se observa na Tabela 21. Nota-se, também, que o sódio apresenta correlação com as concentrações de fluoreto.

\subsubsection{Variações Laterais da Composição Química}

A ocorrência e intensidade das variações laterais da composição química da água é avaliada através dos resultados das análises químicas da água dos lisímetros instalados nas profundidades de $0,5,1,0$ e 5,0 m, apresentados nos gráficos da Figura 30 e nos anexos 7 e 8 . A princípio, considera-se que as maiores concentrações da maior parte das espécies químicas na água dos lisímetros pares (posição $\mathrm{C}^{\prime}$ ) em relação à dos lisímetros ímpares (posição B), conforme descritas no item anterior, já correspondem a variações laterais da composição química da água da zona não saturada, ocasionada por efeitos de evapotranspiração por raízes profundas.

No geral, as análises químicas dos lisímetros de 0,5 e 1,0 m indicaram que, exceto o lisímetro L1B, as amostras apresentam classificações hidroquímicas semelhantes (são nitratadas cálcicas em janeiro/2000 e bicarbonatadas cálcicas em abril/2000) e concentrações das espécies químicas na mesma ordem de grandeza e aproximadamente na mesma proporção em todos os 
lisímetros para uma mesma campanha de coleta (salvo algumas exceções, tal como as maiores concentrações de sulfato no L50C e cloreto no L1D). Estas características indicam que a influência do material do aterro sobre a composição química da água dos lisímetros de dentro do poço é pequena, embora as concentrações de nitrato dos lisímetros de fora do poço sofram variações mais bruscas que nos lisimetros L50 e L1.

O que se observa nestes lisímetros mais rasos é uma variação razoável nas concentrações dos componentes químicos mais em função do tempo do que do espaço, provocados pelas fortes variações de concentrações do nitrato e cálcio nas campanhas de coleta de janeiro e abril/2000. O nitrato no lisímetro L50D, por exemplo, diminui as suas concentrações de 124 para $0,39 \mathrm{mg} / \mathrm{L}$ de janeiro para abril $/ 2000$, ocorrendo variações semelhantes nos demais lisímetros externos.

Estas variações nas concentrações estão relacionadas com a lavagem da zona não saturada promovida pela passagem de sucessivas frentes de molhamento nestas profundidades. Em janeiro/2000 foram coletadas amostras de água da primeira frente de molhamento produzida na zona não saturada após meses de estiagem. Em abril/2000, o perfil já se encontrava bastante lavado pelos vários eventos de recarga que ocorreram ao longo da estação úmida do início de 2000 , que promoveram o transporte e a diluição das espécies químicas.

A água do lisímetro L1B é normalmente diferente da água dos demais lisímetros da mesma profundidade. A água do lisímetro L1 é nitratada cálcica e a água do lisímetro L1B é bicarbonatada-nitratada cálcica (Figura 30), além de possuir valores de $\mathrm{pH}$ e condutividade elétrica mais elevados que o L1. As concentrações mais elevadas de $\mathrm{HCO}_{3}^{-}$e de $\mathrm{Ca}^{++}$no lisímetro L1B tem provavelmente origem no material de preenchimento do espaço anelar entre a perfuração e o anel de revestimento, que nesta profundidade contém cimento adicionado na mistura solo/bentonita. O carbonato de cálcio do cimento deve estar consumindo acidez, sofrendo dissolução e enriquecendo a água com bicarbonato e cálcio neste ponto.

O lisímetro LSB também apresenta composição química bastante diferente do lisímetro L5. Neste lisímetro, a água é cálcica-magnesiana, enquanto que a água do lisímetro L5B é sódica, além de possuir maior concentração de nitrato. Estas características, somadas ao fato de ter sido possível realizar a amostragem da água do lisímetro L5B em janeiro/2000, quando todos os lisímetros de 2 a $7 \mathrm{~m}$ encontravam-se secos, indicam a possibilidade da origem da água do lisímetro L5B se dar através de macroporos ou por alguma zona de fluxo preferencial ao longo da parede da estação de monitoramento, não refletindo exatamente a composição química da água da zona não saturada nesta profundidade. 


\subsection{Modelo Hidrogeoquímico Conceitual}

No estabelecimento do modelo hidrogeoquímico conceitual, procura-se identificar, através dos dados disponiveis, a ocorrência e intensidade dos processos que teoricamente ocorrem na zona não saturada, tal como as ações da evaporação e evapotranspiração, a degradação da matéria orgânica, as reações de dissolução e precipitação de minerais, as reações de adsorção e troca iônica e as ações antropogênicas.

Através da interpretação dos gráficos apresentados nos itens anteriores, foi possível identificar a ocorrência de alguns destes processos, tal como a evaporação, evapotranspiração, degradação de matéria orgânica e ações antropogênicas. Já para a identificação dos processos de interação água rocha, tal como reações de dissolução/precipitação e troca iônica, é necessário lançar mão de algumas técnicas de tratamento de dados no qual o uso de modelos matemáticos é bastante útil, tal como o cálculo de índices de saturação e a modelagem inversa. A utilização dos modelos hidroquímicos e de outras técnicas de interpretação são descritas nos próximos itens e, em seguida, é realizada uma síntese dos principais processos que ocorrem na zona não saturada e que compõem o modelo hidrogeoquímico conceitual.

\subsubsection{Cálculo de Índices de Saturação através de Modelo de Especiação}

São apresentados no Anexo 9 os resultados de índices de saturação, calculados pelo MinteqA2, de uma série de minerais que controlam a composição química da água, e que são considerados reativos, entrando mais rapidamente em equilíbrio químico com o meio.

$O$ índice de saturação é um parâmetro que auxilia na verificação da ocorrência potencial de reações de dissolução e precipitação, sendo calculado a partir das análises químicas da água (equação 6). Assim sendo, não é possível obter este parâmetro para minerais cujas espécies químicas não tenham sido detectadas nas análises, tal como o alumínio e o ferro, que tendem a ser muito pouco móveis e a se fixar na fase sólida. Desta forma, não são disponiveis os valores de índice de saturação para os aluminossilicatos, argilominerais e para as principais espécies minerais que contém ferro. Os minerais considerados são aqueles mais facilmente reativos e que participam de reações congruentes, de acordo com a relação de minerais apresentados por Deutsch (1997).

A Figura 33 apresenta gráficos de índice de saturação dos minerais calcita, dolomita e magnesita (carbonatos de cálcio e/ou magnésio), gipso e anidrita (sulfatos de cálcio), fluorita 
(fluoreto de cálcio), e sílica amorfa e calcedônia (formas criptocristalinas e secundárias de sílica), em função da profundidade (lisímetros instalados dentro do poço), e para os vários eventos de amostragem.

Dentre os minerais carbonáticos, nota-se a existência de condições para a ocorrência de dissolução destes minerais em todos os eventos de amostragem, e que há uma tendência da solução ser mais intensamente reativa para esses minerais nas profundidades de 8 e $9 \mathrm{~m}$. A calcita, inclusive, por apresentar-se subsaturada em todas as amostragens e por ser um mineral bastante reativo e de rápida cinética, deve não fazer parte da massa mineral da zona não saturada, mesmo em quantidades abaixo dos limites das análises realizadas.

A fluorita também apresenta condições de ocorrência de dissolução na maior parte dos eventos de amostragem, porém nota-se a ocorrência de equilíbrio químico da solução com a fase sólida na profundidade de $1 \mathrm{~m}$ em agosto/2000, o que indica a ocorrência de condições favoráveis para a precipitação do mineral nesta ocasião. $O$ gipso e a anidrita apresentam-se sempre com valores de índice de saturação negativos, não havendo condições para as suas formações, principalmente devido às baixas concentrações de sulfato observadas.

Dentre as formas secundárias de sílica, é comum ocorrer condições para a formação de calcedônia nas profundidades mais rasas (todos os eventos), na base da zona não saturada e no aqüífero freático (eventos de amostragem de janeiro, abril e agosto/2000). A disponibilização de sílica para a solução é devida à dissolução do quartzo, que, embora seja muito estável e pouco reativo, encontra-se em quantidades muito elevadas no solo, participando com mais de $80 \%$ da massa mineral.

Dentre os lisímetros de 0,5 e 1,0 m (Anexo 9), observa-se que há condições para a precipitação de calcita e dolomita no lisímetro L1B nos eventos de janeiro e abril/00, porém, como mencionado anteriormente, as condições hidroquímicas do local sugerem que o cimento do material de preenchimento do espaço anelar do poço esteja interferindo nos resultados das análises. O gipso e a anidrita sempre encontram condições de dissolução em todos os pontos, assim como a magnesita. A fluorita encontra-se supersaturada no lisímetro L1B em agosto/2000, sugerindo a ocorrência de precipitação. A sílica amorfa encontra-se em equilíbrio químico nos lisímetros L50C e L50D em janeiro/2000, indicando maior probabilidade de sua precipitação durante os períodos mais secos, e a calcedônia apresenta-se supersaturada ou em equilíbrio químico em todos os lisímetros rasos nos eventos de janeiro, abril e agosto/2000. 


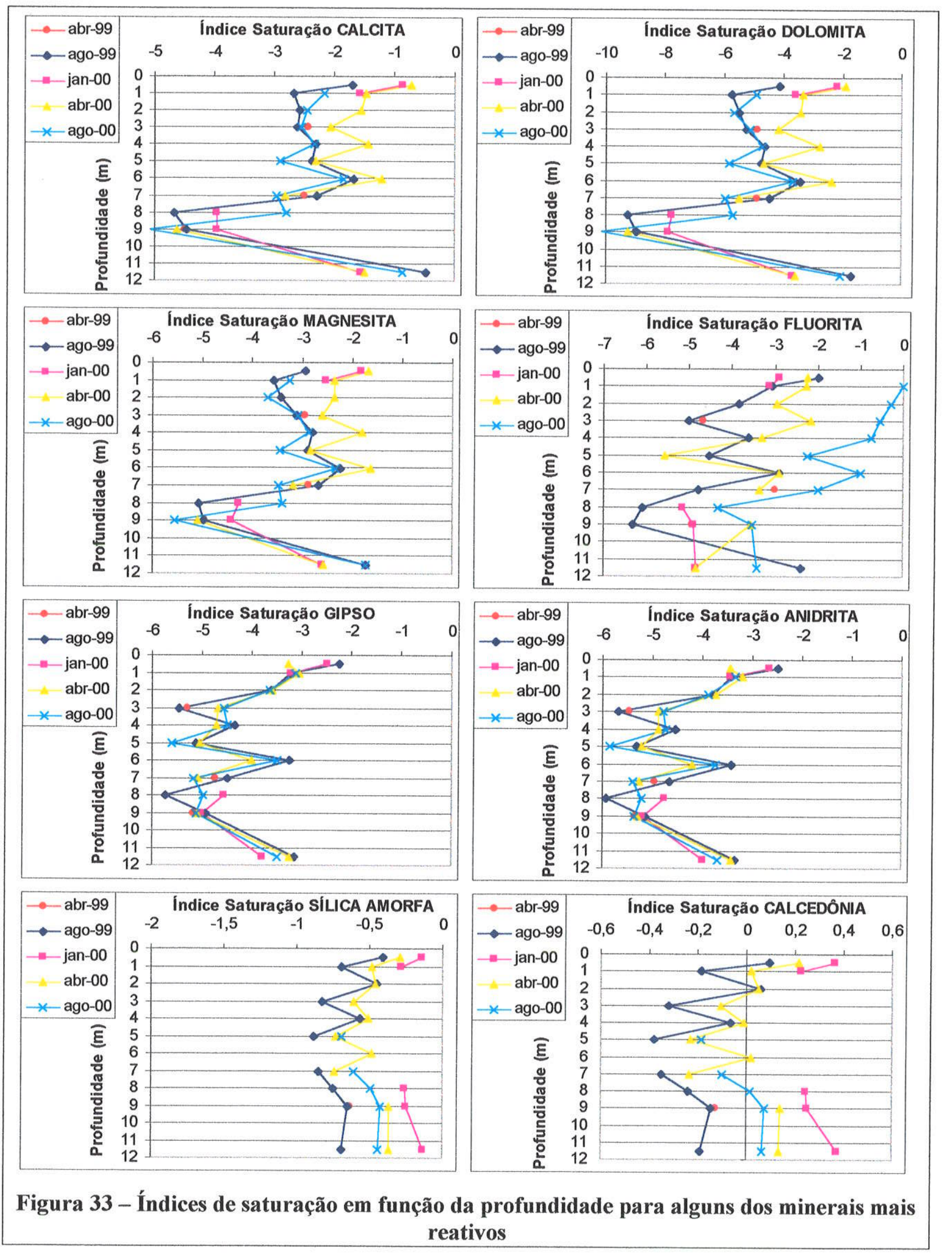




\subsubsection{Diagramas de Estabilidade de Aluminossilicatos}

A estabilidade dos minerais aluminossilicáticos é normalmente determinada através de diagramas contendo campos de predomínio de minerais, separados por linhas que expressam a situação de equilíbrio químico entre os diferentes minerais. Estas linhas são plotadas considerando o $\mathrm{pH}$ e as atividades da sílica e do cálcio, sódio ou potássio da solução, e considerando que o alumínio é completamente preservado na fase sólida, não havendo lixiviação para a água. Tais diagramas foram desenvolvidos para se estudar os fenômenos de dissolução e precipitação de minerais aluminossilicáticos, pois é comum a não detecção do alumínio nas análises químicas de água, o que impede a realização de cálculos de índices de saturação destes minerais, que representam uma grande parcela da massa mineral do manto de intemperismo e das rochas em geral.

Os gráficos da Figura 34 representam os diagramas de estabilidade dos sistemas $\mathrm{Na}_{2} \mathrm{O}$ $\mathrm{Al}_{2} \mathrm{O}_{3}-\mathrm{SiO}_{2}, \mathrm{CaO}-\mathrm{Al}_{2} \mathrm{O}_{3}-\mathrm{SiO}_{2}$ e $\mathrm{K}_{2} \mathrm{O}-\mathrm{Al}_{2} \mathrm{O}_{3}-\mathrm{SiO}_{2}$, supondo os feldspatos albita, anortita e microclínio como os minerais primários, e a montmorilonita cálcica ou sódica, a caulinita e a gibsita como produtos de alteração. Os gráficos representam os eventos de amostragem de agosto/99 e janeiro, abril e agosto/2000, para as amostras que contém análises disponíveis de todas as espécies químicas envolvidas.

De uma forma geral, a maioria das análises químicas de água indicam que a caulinita é o mineral aluminossilicático mais estável para os três sistemas, como era de se esperar em ambiente de manto de intemperismo sob clima tropical úmido. Observa-se para o conjunto de diagramas da campanha de janeiro/2000, entretanto, uma migração dos pontos mais para a direita dos gráficos, no sentido do campo de estabilidade da montmorilonita, nos sistemas que contém sódio e cálcio. Da mesma maneira, a campanha de abril/2000 apresenta os pontos com tendência a migrarem para a parte alta do gráfico, reflexo do maior $\mathrm{pH}$ das soluções nesta campanha em todos os pontos. Nota-se, também de forma geral, que os pontos que representam os lisímetros mais rasos $(0,5$ e $1,0 \mathrm{~m})$ encontram-se mais próximos das linhas que definem o equilíbrio entre os campos da caulinita com a montmorilonita (sódio e cálcio) ou microclínio (potássio), e os pontos dos lisímetros das profundidades de 8 e $9 \mathrm{~m}$ situando-se em posições mais definidas no campo da caulinita para os três sistemas, definindo uma maior reatividade da solução no local. 


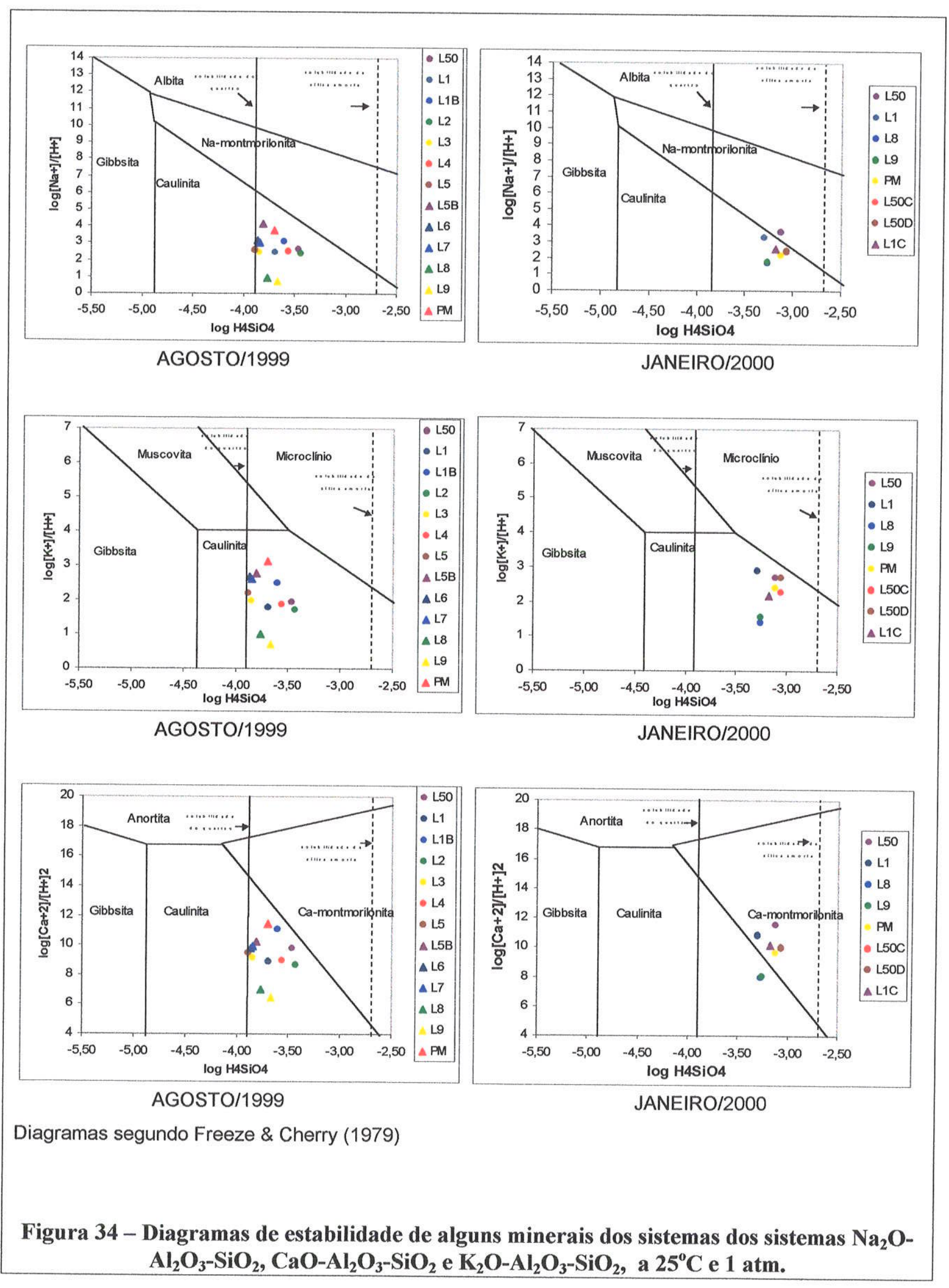

BERTOLO, R.A. - Tese de Doutoramento - 2001 


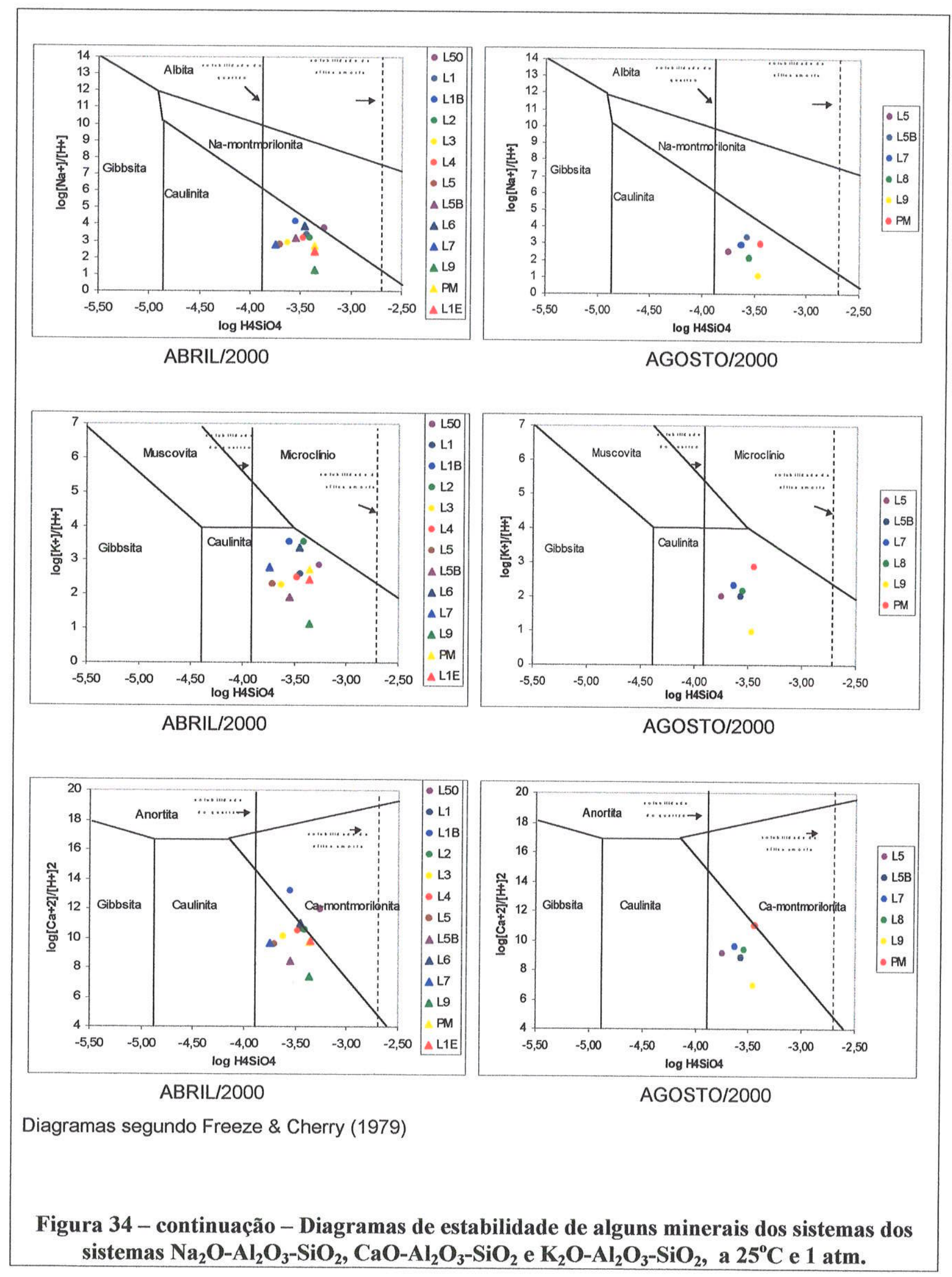

BERTOLO, R.A. - Tese de Doutoramento - 2001 
Destes gráficos, os mais representativos são aqueles do sistema $\mathrm{K}_{2} \mathrm{O}-\mathrm{Al}_{2} \mathrm{O}_{3}-\mathrm{SiO}_{2}$ pois o microclínio foi claramente identificado na fase sólida. Para este sistema, a caulinita é sempre o mineral mais estável, independente do evento de amostragem.

\subsubsection{Relações entre Capacidade de Troca de Cátions e Composição Química da Água}

Considerando-se que os fenômenos de reações de adsorção se processam de forma relativamente rápida no ambiente do solo, um exercício teórico interessante a ser realizado é imaginar qual seria a composição química da água caso toda a quantidade de espécies adsorvidas se desligassem da matriz sólida e se dirigissem para a água. Tal exercício fornece uma medida da importância deste fenômeno no controle da composição química da água, bem como das ordens de grandeza envolvidas quando se investiga as fases sólida e líquida de um aqüífero ou zona não saturada.

A Tabela 22 apresenta os resultados de CTC expressos na forma de $\mathrm{mg} / \mathrm{L}$ ou em unidades de $\mathrm{pH}$, caso todos os cátions adsorvidos fossem para a água. Para a execução do cálculo, considerou-se (1) o peso específico dos minerais em $2,65 \mathrm{~g} / \mathrm{cm}^{3}$ para transformar a unidade de $\mathrm{meq} / \mathrm{g}$ para meq $/ \mathrm{cm}^{3}$ de grãos de sedimento; (2) os valores médios de porosidade total da Tabela 12 na transformação das unidades de $\mathrm{meq} / \mathrm{cm}^{3}$ de grãos de sedimento para meq/ $\mathrm{cm}^{3}$ de volume aparente do sedimento; (3) os valores médios calculados de umidade absoluta, que variam de 0,19 (L3) a 0,38 (L9). Em síntese, para a transformação de unidades da CTC de meq/100g para meq/L, utilizou-se da seguinte relação:

$$
\mathrm{CTC}_{(\text {meq/L) }}=\left[\frac{\mathrm{CTC}_{(\mathrm{meq} / 100 \mathrm{~g})}}{100}\right] \times 2,65 \times 1000 \times \frac{(1-n)}{\theta} \quad \text { Equação 11 }
$$

onde $\mathbf{n}$ é a porosidade total; $\mathrm{e}$

$\theta$ é a umidade absoluta média.

A Tabela 22 ilustra que as quantidades de cátions adsorvidos são consideravelmente maiores que as quantidades observadas em solução, mesmo que as concentrações na fase sólida pareçam ser pequenas. Em média, os cátions de base encontram-se sob concentrações 200 vezes menores em solução, podendo chegar até próximo de 700 vezes, tal como se observa com o cálcio na profundidade de $8 \mathrm{~m}$. Se todo o hidrogênio sofresse desadsorção, o pH da solução resultante estaria em torno de 1, o que representa uma concentração de hidrogênio na água em torno de 100.000 vezes maior que aquele que se observa. 


\begin{tabular}{|c|c|c|c|c|c|}
\hline \multicolumn{6}{|c|}{$\begin{array}{c}\text { Tabela } 22 \text { - Composição química teórica da água na hipótese de } \\
\text { ocorrência de desadsorção dos cátions de base adsorvidos }\end{array}$} \\
\hline & $\mathrm{Na}(\mathrm{mg} / \mathrm{L})$ & $\mathrm{K}(\mathrm{mg} / \mathrm{L})$ & $\mathrm{Ca}(\mathrm{mg} / \mathrm{L})$ & $\mathrm{Mg}(\mathrm{mg} / \mathrm{L})$ & $\mathrm{pH}$ \\
\hline $\mathrm{L} 50$ & 205,07 & 115,65 & 2464,79 & 239,58 & 1,12 \\
\hline $\mathrm{L} 1$ & 521,22 & 359,79 & 2892,02 & 399,30 & 1,02 \\
\hline $\mathrm{L} 2$ & 325,73 & 311,32 & 2461,04 & 351,78 & 1,04 \\
\hline $\mathrm{L} 3$ & 305,21 & 172,12 & 2201,05 & 445,71 & 1,04 \\
\hline $\mathrm{L} 4$ & 327,57 & 301,68 & 1683,43 & 681,79 & 1,09 \\
\hline $\mathrm{L} 5$ & 546,57 & 395,76 & 1889,39 & 409,93 & 1,15 \\
\hline $\mathrm{L} 6$ & 444,20 & 310,15 & 1983,05 & 401,57 & 1,16 \\
\hline $\mathrm{L} 7$ & 507,92 & 262,00 & 1876,24 & 814,15 & 1,03 \\
\hline $\mathrm{L} 8$ & 436,84 & 310,91 & 2981,85 & 1630,32 & 1,11 \\
\hline $\mathrm{L} 9$ & 513,10 & 315,44 & 3791,74 & 1617,34 & 1,15 \\
\hline
\end{tabular}

Há, portanto, um potencial muito grande de controle da composição química da água pelos fenômenos de adsorção e troca catiônica, sendo que pequenos distúrbios no equilíbrio do sistema, que provoquem uma pequena adsorção ou desadsorção, podem causar uma considerável mudança na composição química da solução. Desta tabela conclui-se, inclusive, que a ocorrência de fases mineralógicas em concentrações muitas vezes abaixo do limite de deteç̧ão dos métodos de análise utilizados, pode justificar a composição química da água.

Apesar de todo o potencial que a fase sólida possui em influenciar a composição química da solução do solo, não se observa, com os dados disponíveis, uma relação lógica entre a composição da água e a CTC, a não ser pelo fato de que a ordem de abundância dos cátions de base $(\mathrm{Ca}>\mathrm{Mg}>\mathrm{Na}>\mathrm{K})$ é observada tanto para a composição da água como para a CTC. Esta afirmação está ilustrada na Tabela 23, que apresenta os coeficientes de correlação entre os cátions adsorvidos e em solução para os eventos de amostragem de agosto/99 e abril e agosto/2000. Nota-se que não há correlações entre os cátions de base adsorvidos e em solução, como seria de se esperar teoricamente, e que somente há uma correlação negativa entre o pH da solução com o hidrogênio adsorvido nos três eventos de amostragem. Tratam-se de correlações falsas, pois elas se relacionam às profundidades de 8 e $9 \mathrm{~m}$, onde ocorre menor pH da solução e maior quantidade de hidrogênio adsorvido, tal como descrito no item 5.2.3. 
Tabela 23 - Coeficientes de correlação entre cátions adsorvidos e em solução

\begin{tabular}{|l|c|c|c|c|c|c|c|c|c|c|c|c|c|c|c|}
\hline & \multicolumn{9}{|c|}{ Agosto/99 } & \multicolumn{9}{c|}{ Abril/00 } & \multicolumn{5}{c|}{ Agosto/00 } \\
\hline & $\mathrm{pH}$ & $\mathrm{Na}$ & $\mathrm{K}$ & $\mathrm{Ca}$ & $\mathrm{Mg}$ & $\mathrm{pH}$ & $\mathrm{Na}$ & $\mathrm{K}$ & $\mathrm{Ca}$ & $\mathrm{Mg}$ & $\mathrm{pH}$ & $\mathrm{Na}$ & $\mathrm{K}$ & $\mathrm{Ca}$ & $\mathrm{Mg}$ \\
\hline $\mathrm{H}_{\mathrm{CTC}}$ & $-0,79$ & & & & & $-0,76$ & & & & & $-0,71$ & & & & \\
\hline $\mathrm{Na}_{\mathrm{CTC}}$ & & $-0,41$ & & & & & $-0,24$ & & & & & $-0,63$ & & & \\
\hline $\mathrm{K}_{\mathrm{CTC}}$ & & & 0,03 & & & & & 0,22 & & & & & $-0,13$ & & \\
\hline $\mathrm{Ca}_{\mathrm{CTC}}$ & & & & $-0,05$ & & & & & $-0,24$ & & & & & $-0,17$ & \\
\hline $\mathrm{Mg}_{\mathrm{CTC}}$ & & & & & $-0,21$ & & & & & $-0,09$ & & & & & 0,20 \\
\hline
\end{tabular}

\subsubsection{Modelagem Inversa}

Na modelagem inversa, assume-se que uma solução reage com minerais e gases para produzir a composição química observada de uma segunda solução, coletada a jusante da primeira. O modelo inverso calcula, portanto, as quantidades de gases e minerais precipitados ou dissolvidos a partir das diferenças de concentrações das espécies entre as duas soluções, dada as análises químicas das soluções e os tipos de fases sólidas existentes. Deste modo, o modelo inverso apresenta-se como uma ferramenta útil na determinação de reações químicas de dissolução/precipitação e troca iônica, colaborando no estabelecimento de modelos conceituais de hidrogeoquímica.

O Anexo 9 apresenta um exemplo de relatório de modelagem inversa executada pelo modelo Phreeqc (Parkhurst, 1995). O relatório completo compõe-se de três partes, sendo que a primeira apresenta os dados de entrada, que consiste da composição química das duas soluções, das fases mineralógicas (às quais é possível instruir ao programa considerar a ocorrência de dissolução ou precipitação), e da instrução "uncertainty" para a execução da modelagem inversa mediante uma porcentagem de erro. Este erro está associado às análises químicas e aos procedimentos de amostragem e quanto maior o seu valor, maior o número de modelos possíveis. Em seguida, utilizam-se as instruções "balances", "range" e "tolerance". A primeira instrução é semelhante à instrução "uncertainty" e associa um erro diferenciado (e maior) à espécie definida (no caso o nitrato), para ser possível o cálculo das equações de balanço molar para elementos que não estão contidos em nenhumas das fases mineralógicas consideradas. A instrução "range" indica ao programa o intervalo de valores de transferência molar de cada fase, de acordo com a incerteza definida, e a instrução "tolerance" relaciona-se com o processamento do programa, sendo utilizados os valores default. 
A segunda parte do relatório compreende a apresentação dos resultados dos cálculos de especiação das soluções e dos índices de saturação dos principais minerais, que não são apresentados no Anexo 9 devido à sua extensão. $\mathrm{Na}$ terceira parte do relatório se apresenta os resultados da modelagem inversa e, também devido à sua extensão, apenas a primeira das possibilidades de modelos inversos é apresentada de forma completa no Anexo 9.

Os resultados do modelo inverso começam com a listagem de três colunas contendo os resultados das análises expressos em $\mathrm{mol} / \mathrm{kg}$. A primeira coluna contém os dados analíticos originais, a segunda contém os ajustes dos valores da primeira coluna a partir das incertezas apresentadas e a terceira coluna corresponde à soma das duas primeiras, representando os resultados analíticos ajustados. Em seguida são apresentados os resultados de transferência molar entre as fases, sendo que a primeira coluna contém os resultados da modelagem inversa que são consistentes com as características das soluções ajustadas. No exemplo apresentado no Anexo 9, a solução L.3 ajustada mais a transferência molar entre as fases mineralógicas é exatamente igual à composição da solução L5 ajustada. Valores positivos e negativos de transferência molar indicam, respectivamente, dissolução e precịpitação de minerais.

Duas modelagens inversas que levam em conta os processos de dissolução/precipitação e troca iônica/adsorção foram executadas, considerando-se as análises dos pontos L3 e L5 da campanha de agosto/99 e as análises dos pontos L5 e L7 da campanha de agosto/2000. Apesar das pequenas diferenças na composição química entre as soluções nestes pontos, estas foram as duas situações em que não se verificaram interferências marcantes de outros processos na composição química da água, tal como a evaporação (que ocorre entre a superfície e o L2), os efeitos de raizes (mais intensos no lado do poço onde se situa os pontos $\mathrm{L} 4$ e $\mathrm{L} 6$ ), influência de fluxos laterais (L8 e L9) e de poluição ou outras anomalias (por exemplo, o ponto L3 nas campanhas de abril e agosto/2000).

As simulações ocorrem de forma isolada pois não se observa, como descrito anteriormente, uma evolução lógica da composição química da água ao longo de toda a zona não saturada e que seja comum a todas as campanhas de amostragem. Assim sendo, os resultados das simulações se aplicam somente aos trechos simulados e para a data da simulação, sendo somente indicativos da possibilidade de ocorrência das reações ao longo das outras profundidades da zona não saturada. 
Os dados de entrada da simulação dos pontos L3 e L5 em agosto/99 encontra-se no Anexo 9. A simulação foi concebida admitindo se incertezas de $9 \%$ em cada análise, que foi o menor erro admitido pelo programa sem que houvesse problemas de processamento. Esta incerteza é, porém, compatível com os erros analíticos obtidos nestes pontos (Anexo 7). Entre os pontos L3 e L5 nesta ocasião, observou-se elevação das concentrações de cálcio, magnésio, sódio e potássio, uma ligeira elevação do $\mathrm{pH}$, uma pequena variações da alcalinidade e da sílica. $\mathrm{Na}$ determinação das fases, de acordo com os resultados das análises químicas e mineralógicas executadas, admitiu-se a existência de microclínio, caulinita, quartzo, de minerais com sítios de troca para cálcio, magnésio, sódio, potássio e hidrogênio, e de gás carbônico. Impôs-se ao modelo que o microclínio somente poderia dissolver e a caulinita somente precipitar. $\mathrm{O}$ hidrogênio adsorvido foi fixado como somente precipitando pois, do contrário, o modelo apresentava erros no seu processamento.

Apresentado ao modelo as incertezas, as composições químicas das soluções $\mathrm{e}$ as características das fases minerais, obteve-se como resposta a possibilidade de ocorrência de oito modelos, cujos resultados resumidos encontram-se na Tabela 24.

\begin{tabular}{|c|c|c|c|c|c|c|c|c|c|}
\hline & 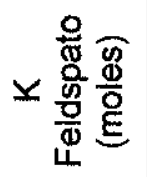 & 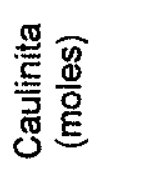 & 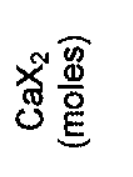 & 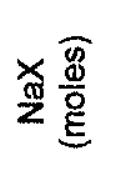 & $\underset{\underline{\underline{g}}}{\frac{\widehat{g}}{\mathrm{~g}}}$ & 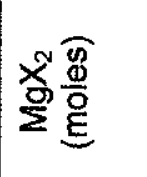 & 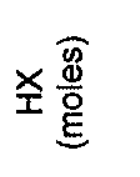 & 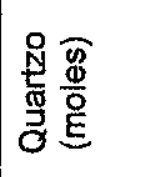 & 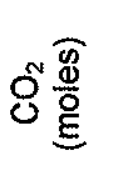 \\
\hline Modelo 1 & $8.4 e-5$ & $-4.2 \theta-5$ & $2.7 e-5$ & $5.2 e-6$ & $-7.1 \mathrm{e}-5$ & $5.8 e-6$ & & $-1.8 \theta-4$ & $9.8 e-5$ \\
\hline Modelo 2 & $7.9 e-5$ & $-3.9 e-5$ & $2.7 e-5$ & & $-6.6 e-5$ & $5.8 e-6$ & & $-1.6 e-4$ & $9.0 e-5$ \\
\hline Modelo 3 & & & $2.7 e-5$ & $5.2 e-6$ & $1.2 \mathrm{e}-5$ & $5.8 e-6$ & $-8.4 e-5$ & & $9.8 \mathrm{e}-5$ \\
\hline Modelo 4 & & & $2.7 \theta-5$ & & $1.2 \mathrm{e}-5$ & $5.8 \theta-6$ & $-7.9 e-5$ & & $9.0 e-5$ \\
\hline Modelo 5 & $1.2 e-5$ & $-6.3 e-6$ & $2.7 e-5$ & $5.2 e-6$ & & $5.8 e-6$ & $-7.1 \mathrm{e}-5$ & $-3.7 e-5$ & $9.8 e-5$ \\
\hline Modelo 6 & $1.2 e-5$ & $-6.3 e-6$ & $2.7 e-5$ & & & $5.8 e-6$ & $-6.6 e-5$ & $-3.7 e-5$ & $9.0 e-5$ \\
\hline Modelo 7 & & & $2.7 e-5$ & $5.2 e-6$ & $1.2 \mathrm{e}-5$ & $5.8 e-6$ & $-8.4 e-5$ & $-1.1 \mathrm{e}-5$ & $9.8 e-5$ \\
\hline Modelo 8 & & & $2.7 e-5$ & & $1.2 \mathrm{e}-5$ & $5.8 \mathrm{e}-6$ & $-7.9 e-5$ & $-1.1 e-5$ & $9.0 \mathrm{e}-5$ \\
\hline
\end{tabular}

Dentre os modelos possíveis, reconhece-se dois conjuntos distintos: o grupo dos modelos $1,2,5$ e 6 e o grupo dos modelos $3,4,7$ e 8 . Dentro do mesmo conjunto, o que se nota são pequenas variações nos resultados devido às concentrações de sódio, $\mathrm{pH}$, alcalinidade e sílica, que variaram muito pouco entre os dois pontos e se situam dentro da faixa de incerteza atribuída. 
O modelo 1 admite a dissolução do microclínio com formação de caulinita (na proporção molar de 2 para 1 - reação 6), a adsorção de parte do potássio produzido, a desadsorção de cálcio, sódio e magnésio (possivelmente devido à troca iônica com o potássio), a precipitação do quartzo (ou, mais corretamente, de formas criptocristalinas de sílica) e a dissolução de gás carbônico, para justificar $o$ aumento da alcalinidade. $O$ modelo 5 apresenta resultados semelhantes, a não ser pelo acréscimo de hidrogênio adsorvido e a menor quantidade de microclínio dissolvido, o que já justificaria as concentrações de potássio na água no ponto L5 sem haver a necessidade de adsorção de seu excesso. Neste modelo 5, a dissolução de apenas 3 mg de microclínio (1,2E-5 mol) já justificaria a variação de concentração de potássio na água.

O segundo grupo de modelos, em que se destaca o modelo 7 , consegue justificar as variações das concentrações de cátions da água somente com reações de adsorção. Verifica-se a liberação dos cátions de base para a solução, a adsorção do hidrogênio e a precipitação do quartzo.

O Anexo 9 também apresenta os dados de entrada da simulação dos pontos L5 e L7 em agosto/2000. As incertezas associadas ao modelo é de $8 \%$ para a solução L5 e de $10 \%$ para a solução L7, valores estes semelhantes aos erros analíticos obtidos nestes pontos (Anexo 7). Entre os pontos L5 e L7 nesta ocasião, observou-se diminuição das concentrações de cálcio, variação inexpressiva na concentração do magnésio, elevação das concentrações de sódio, potássio, e sílica, elevação do $\mathrm{pH}$ e diminuição da alcalinidade. Na determinação das fases, admitiu-se as mesmas da simulação anterior, ou seja, o microclínio, caulinita, quartzo, de minerais com sítios de troca para cálcio, magnésio, sódio, potássio e hidrogênio, e de gás carbônico. Impôs-se ao modelo que o microclínio somente poderia dissolver e a caulinita somente precipitar.

Após a entrada dos dados e o processamento do programa, obteve-se como resposta a possibilidade de ocorrência de 12 tipos de modelos, apresentados de forma resumida na Tabela 25. Dois conjuntos de modelos podem ser distinguidos: o conjunto dos modelos que envolvem a dissolução do microclínio com formação de caulinita (modelos $1,2,3,4,7$ e 9) e o conjunto dos modelos que envolvem somente adsorção dos cátions de base (modelos $5,6,8,10,11 \mathrm{e} 12$ ).

No primeiro conjunto, os três primeiros modelos $(1,2$ e3) são improváveis, pois o aumento da quantidade de sílica na água do L7 é justificada somente pela ocorrência de dissolução do microclínio, não sobrando sílica para precipitação. Os modelos 4,7 e 9 são semelhantes, diferindo apenas nas possibilidades da não existência de variaçð̃es de concentrações do cálcio e 
magnésio entre os pontos, devido às incertezas atribuídas. Nestes modelos, o potássio da solução é proveniente da dissolução do microclínio, formando caulinita. O cálcio e o magnésio são adsorvidos, o sódio e o hidrogênio adsorvidos são liberados, o quartzo sofre dissolução e o gás carbônico é formado e vai para a atmosfera, fazendo elevar o $\mathrm{pH}$ e diminuir a massa de carbono inorgânico na água.

Tabela 25 - Resultados da modelagem inversa entre os pontos L5 e L7 (agosto/2000)

\begin{tabular}{|c|c|c|c|c|c|c|c|c|c|}
\hline & 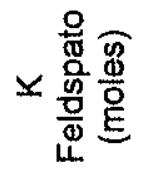 & 递忽 & 恿总 & 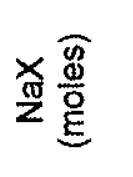 & 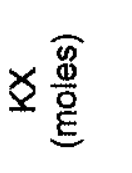 & $\begin{array}{l}x^{N} \bar{m} \\
x^{0} \\
\sum^{\circ}\end{array}$ & 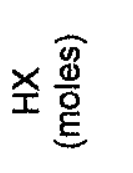 & 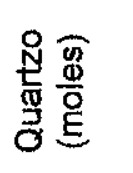 & 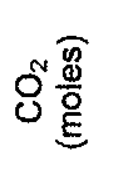 \\
\hline Modelo 1 & $4.4 e-5$ & $-2.2 e-5$ & $-2.7 e-5$ & $3.4 e-5$ & $-3.9 e-5$ & $-1.0 \mathrm{e}-5$ & $7.8 e-5$ & & $-7.1 e-5$ \\
\hline Modelo 2 & $4.4 e-5$ & $-2.2 \theta-5$ & & $1.6 e-5$ & $-3.9 e-5$ & $-2.5 e-5$ & $7.3 e-5$ & & $-6.2 e-5$ \\
\hline Modelo 3 & $4.4 e-5$ & $-2.2 e-5$ & $-3.5 e-5$ & $3.1 \mathrm{e}-5$ & $-3.9 e-5$ & & $7.8 e-5$ & & $-7.1 e-5$ \\
\hline Modelo 4 & $5.1 \mathrm{e}-6$ & $-2.5 e-6$ & $-2.7 e-5$ & $3.4 \theta-5$ & & $-1.0 e-5$ & $3.9 e-5$ & $7.8 \mathrm{e}-5$ & $-7.1 e-5$ \\
\hline Modelo 5 & & & & $1.6 \mathrm{e}-5$ & & $-2.5 e-5$ & $3.4 \mathrm{e}-5$ & $8.8 e-5$ & $-7.1 e-5$ \\
\hline Modelo 6 & & & $-2.7 e-5$ & $3.4 e-5$ & $5.10-6$ & $-1.0 e-5$ & $3.4 e-5$ & $8.8 e-5$ & $-7.1 e-5$ \\
\hline Modelo 7 & $5.1 e-6$ & $-2.5 e-6$ & $-3.5 e-5$ & $3.1 e-5$ & & & $3.9 e-5$ & $7.8 e-5$ & $-7.1 e-5$ \\
\hline Modelo 8 & & & $-3.4 e-5$ & $3.4 e-5$ & & & $3.4 e-5$ & $8.8 e-5$ & $-7.1 e-5$ \\
\hline Modelo 9 & $5.1 e-6$ & $-2.5 e-6$ & & $1.6 \mathrm{e}-5$ & & $-2.5 e-5$ & $3.4 e-5$ & $7.8 e-5$ & $-6.2 e-5$ \\
\hline Modelo 10 & & & $-3.5 e-5$ & $3.1 e-5$ & $5.1 \theta-6$ & & $3.4 e-5$ & $8.8 e-5$ & $-7.1 e-5$ \\
\hline Modelo 11 & & & $-2.4 e-5$ & $3.4 \theta-5$ & & $-1.0 e-5$ & $3.4 e-5$ & $8.8 e-5$ & $-7.1 e-5$ \\
\hline Modelo 12 & & & & $1.6 e-5$ & $5.1 e-6$ & $-2.5 e-5$ & $2.9 e-5$ & $8.8 e-5$ & $-6.2 e-5$ \\
\hline
\end{tabular}

O segundo conjunto dos modelos $(5,6,8,10,11$ e 12) explica as variações das concentrações dos cátions de base na solução apenas por fenômenos de adsorção. O modelo 6 é o mais completo e os demais admitem a possibilidade da não existência de variações de concentrações do cálcio, potássio ou magnésio entre os pontos, devido às incertezas atribuídas. Entretanto, estes modelos indicam adsorção do cálcio e magnésio, desadsorção do sódio, potássio e hidrogênio, dissolução do quartzo, e formação de gás carbônico.

De uma forma geral, conclui-se, pelos resultados dos modelos L3/L5 e L5/L7, que não há como estabelecer um modelo conceitual único para a zona não saturada ao longo do tempo na faixa de profundidade considerada. Isto se deve às pequenas variações na composição química da água entre os pontos considerados, que podem ser explicadas por processos de dissolução de aluminossilicatos e/ou por adsorção/desadsorção de cátions de base, e até mesmo pelos próprios erros associados aos resultados das análises químicas. 


\subsubsection{Síntese do Modelo Hidrogeoquímico Conceitual}

O modelo hidrogeoquímico conceitual da zona não saturada investigada é sintetizado de acordo com os seguintes processos que controlam a composição química da água:

\section{I-Ações Antropogênicas}

A principal ação antropogênica verificada é a ocorrência de elevadas concentrações de nitrato na água, provavelmente originada pela aplicação de fertilizantes no solo. $O$ nitrato apresenta correlações positivas com as concentrações de cálcio e magnésio, indicando ser um agente que favorece a desadsorção destes cátions.

\section{2-Evaporação}

O processo de evaporação ocorre até a profundidade aproximada de $2 \mathrm{~m}$ e foi verificado através da existência de potenciais hidráulicos ascendentes com o monitoramento dos tensiômetros, através da observação de concentrações mais elevadas de vários parâmetros químicos nesta faixa de profundidade (nitrato, cálcio, magnésio, sílica, sulfato, estrôncio), e pela constatação de uma maior variação temporal nas concentrações destes parâmetros químicos entre os eventos de amostragem, o que sinaliza a ocorrência de eventos sucessivos de concentração das espécies durante a estação seca, seguida de diluição e carreação destes elementos ao longo da estação mais úmida. Este processo é verificado comparando-se as composições químicas das amostras de água dos lisímetros rasos nos eventos de janeiro (primeira frente de molhamento, mais concentrada em íons, especialmente nitrato e cálcio, após longo período de estiagem) e abril/2000 (soluções mais diluídas no final da estação úmida, com pouco nitrato, produzidas após sucessivos eventos de infiltração da zona não saturada).

\section{3 -. Evapotranspiração, respiração vegetal e degradação de matéria orgânica}

Observou-se que a ação da vegetação viva produz sensíveis variações na composição química da água até a profundidade $7 \mathrm{~m}$, através dos processos de evapotranspiração e respiração vegetal, que produziram efeitos variados no comportamento de várias espécies químicas durante o período monitorado, principalmente devido ao sacrifício da árvore vizinha à estação em janeiro/2000. Abaixo de $7 \mathrm{~m}$, na porção basal e mais úmida da zona não saturada, não se nota efeitos da ação de vegetação viva. 
Antes do sacrifício da árvore (campanha de agosto/99), notou-se a ação da evapotranspiração com a observação de concentrações mais elevadas de bicarbonato, cálcio, magnésio, sílica e secundariamente de sulfato, cloreto, sódio e potássio nos lisímetros de número par (L2, L4 e L6), situados na posição C' do poço da estação de monitoramento, que possui maior densidade de raízes (Figura 32). Os tensiômetros situados neste lado do poço indicavam potenciais matriciais mais baixos neste lado do poço, comprovando a ação das raízes.

Ainda na campanha de agosto/99, observou-se uma maior pressão parcial de $\mathrm{CO}_{2}, \mathrm{pH}$ mais ácido e maiores concentrações de bicarbonato no lado do poço que contém maior densidade de raízes (Figura 32), indicando a ocorrência das reaçôes 2 e 3 (dissolução do gás carbônico, com produção de ácido carbônico, seguida da dissociação do hidrogênio e do bicarbonato) devido aos efeitos da respiração das raízes da árvore. A ação da vegetação também é notada através das concentrações mais baixas de nitrato nos lisímetros LA e L6 em relação aos lisímetros L5 e L7, sugerindo que as raízes estariam também consumindo o nitrato como nutriente.

Após o sacrifício da árvore (campanhas de abril e agosto/2000), notou-se uma sensível diminuição da pressão parcial de $\mathrm{CO}_{2}$ e uma elevação do pH da água da zona não saturada, indicando a interrupção do processo de respiração da árvore, embora não se tenha notado uma uniformização das concentrações de bicarbonato, cálcio, magnésio, sílica, que ainda continuavam mais elevadas no lado do poço que contém os lisímetros pares (Figura 32).

A degradação da matéria orgânica com produção de $\mathrm{CO}_{2}$ (reação 1) é um processo que não se percebe de forma tão direta quanto a respiração das raízes. Observa-se apenas a correlação entre as concentrações mais elevadas de matéria orgânica do solo nas profundidades entre $0,5 \mathrm{e}$ $2 \mathrm{~m}$ (Figura 28) e a ocorrência de concentrações mais elevadas de carbono orgânico dissolvido na água nessas profundidades (Figura 32), o que é um indício da ocorrência da reação.

\section{4 - Dissolução/precipitação de minerais}

As análises mineralógicas detectaram uma quantidade reduzida de espécies minerais que podem sofrer reações de dissolução. De acordo com as análises e ainda que em quantidades muito reduzidas, somente abaixo da profundidade de $7 \mathrm{~m}$ é que se tem uma maior probabilidade de se encontrar minerais primários no perfil da zona não saturada, tal como o microclínio, biotita e magnesita. Nesta faixa de profundidade, inclusive, é que se encontra condições mais propícias para a ocorrência de dissolução de minerais, já que a solução presente é mais reativa, por possuir pH mais baixo. 
O quartzo forma mais de $80 \%$ da massa mineral da zona não saturada. Apesar de ser muito pouco reativo, o quartzo também sofre alguma dissolução, produzindo uma quantidade de sílica solúvel suficiente para ser possível a precipitação de formas criptocristalinas de sílica, como a calcedônia e, eventualmente, a sílica amorfa, tal como se observa nos gráficos de índice de saturação de minerais (Figura 33).

A caulinita é o argilomineral mais estável e que ocorre em maior quantidade no perfil. Esta característica somada à reduzida quantidade de minerais primários, especialmente acima de $7 \mathrm{~m}$, indica que a zona não saturada no local encontra-se num estágio avançado de intemperismo, pois a maior parte dos aluminossilicatos do sedimento original já se transformou em caulinita. A formação de caulinita ainda é possível, embora em pequenas quantidades, devido às quantidades de microclínio e de montmorilonita detectados.

Através dos cálculos de índice de saturação, verificou-se a impossibilidade de ocorrência de precipitação dos minerais mais reativos, como os carbonatos (calcita, dolomita) e os sulfatos (gipso) em todos os eventos de amostragem. Durante as estações mais secas, notou-se condições para a formação de fluorita.

\section{5 - Adsorção/troca iônica}

Os fenômenos de adsorção e troca iônica aparentemente desempenham um papel importante no controle da composição química da água na zona não saturada. As análises de capacidade de troca catiônica indicaram que a quantidade de cátions de base adsorvidos compõe um importante estoque de elementos que interagem com a água. As principais superfícies adsorventes são os óxidos e hidróxidos de ferro, a caulinita e, mais restritamente devido à pequena quantidade, a montmorilonita. A CTC eleva-se bastante após a profundidade de $7 \mathrm{~m}$ em decorrência das maiores quantidades dos minerais adsorventes.

Os cátions adsorvidos, por ordem de abundância, são o cálcio, magnésio, sódio e potássio, sendo que a quantidade existente de cálcio e sódio na zona não saturada pode ser totalmente devida à adsorção. A seqüência de abundância de cátions de base adsorvidos é igual à ordem de abundância de cátions de base na água em todas as campanhas de amostragem, sugerindo a ocorrência de algum grau de equilíbrio químico.

Subtraindo-se os efeitos da evapotranspiração, nota-se, também, que não existe uma evolução nítida na composição química da água entre as profundidades de 3 e $7 \mathrm{~m}$. Observa-se apenas uma tendência, na campanha de agosto/99, de aumento do $\mathrm{pH}$ e das concentrações de 
cálcio e magnésio entre estas profundidades, sugerindo a ocorrência de troca iônica do cálcio e magnésio pelo hidrogênio. Nota-se também que as concentrações mais elevadas de nitrato na solução promovem um aumento das concentrações de cálcio e magnésio na água, sugerindo que este ânion promova alguma desadsorção destes cátions.

As modelagens inversas indicaram que não há como estabelecer um modelo conceitual único para as faixas de profundidade modeladas ( 3 a $5 \mathrm{~m}$ e 5 a $7 \mathrm{~m}$ ). Isto ocorre devido às pequenas variações na composição química da água entre os pontos considerados, que podem ser explicadas por processos de dissolução de aluminossilicatos e/ou por adsorção/desadsorção de cátions de base, e até mesmo pelos próprios erros associados aos resultados das análises químicas (o que indicaria a ausência de alguma reação química entre os pontos).

Uma observação importante na execução do modelo hidrogeoquímico conceitual é que as concentrações dos cátions de base na fase sólida são pequenas e próximas do limite de deteç̧ão. Ainda assim, as quantidades existentes são suficientes para justificar as composições químicas da água em pelo menos duas ordens de grandeza. Neste caso, é possível que pequenos distúrbios no equilíbrio químico possam produzir mudanças significativas na composição química da água, assim como podem existir fases mineralógicas bastante reativas e não detectáveis também participando do controle da composição química da água.

Não há, até o momento, uma razão que esclareça as características hidrogeoquímicas da base da zona não saturada, abaixo de $7 \mathrm{~m}$ até o aquüífero freático. Aparentemente, a acidez mais elevada da água nesta zona não tem relação com a existência de alguma fonte de matéria orgânica em decomposição, mas sim com os fenômenos de adsorção. De qualquer forma, esta zona hidroquímica não apresenta informações mais detalhadas sobre as suas características hidráulicas, sendo provável a ocorrência de fluxos horizontais dos quais não se possui informações sobre a natureza dos seus processos hidroquímicos.

Com o intuito de se aprofundar o entendimento da hidrogeoquímica da zona não saturada no local, necessita-se, no futuro, estender e adensar os eventos de coleta de água, instalar novos lisímetros de suç̧ão (no mínimo de metro em metro e um embaixo do outro), e amostrar a água na medida em que a frente de molhamento chega nos lisímetros. Na fração sólida, é importante investigar com maior profundidade os mecanismos que definem a adsorção de cátions e ânions, tal como discutido no item 5.1.6. 


\section{Simulações de Transporte de Nitrato na Zona Não Saturada}

Um dos principais problemas que afetam a qualidade da água subterrânea do aqǘfero freático em Urânia é a ocorrência de nitrato em concentrações acima do limite de potabilidade (Hirata, 2000). A carga contaminante é atribuída aos dejetos humanos depositados em fossas e/ou através da aplicação de adubos orgânicos e fertilizantes agrícolas nitrogenados. Sabe-se, inclusive, que os problemas observados em Urânia estão se repetindo em muitas cidades do Estado de São Paulo, que apresentam as mesmas características hidrogeológicas e os mesmos históricos de ocupação do meio físico.

Tendo em vista esse problema, duas situações de contaminação do aqǘfero freático por nitrato foram simuladas com o uso do modelo VS2DT, envolvendo fossas e aplicação de fertilizantes como fontes de contaminação. Em ambas as situações, as simulações de transporte utilizam-se das propriedades hidráulicas obtidas com o modelo Urânia A (item 4.3 e Anexo 4), que é considerado como aquele que apresenta as condições de fluxo mais próximas da realidade para o perfil de zona não saturada modelado.

\subsection{Transporte de Contaminantes através de Fossas}

O nitrato é um íon conservativo em condições oxidantes, não sofrendo degradação ou retenção no solo. Espera-se, desta forma, que a concentração de nitrato no aquífero freático seja a mesma do efluente após determinado tempo de infiltração, independentemente da espessura da zona não saturada, pois este é aplicado nas caixas de infiltração das fossas como carga constante.

Além do nitrato, os microorganismos patogênicos fecais são importantes contaminantes a serem considerados em fossas, sendo que estes, em geral, não possuem tempo de sobrevivência maior que 50 dias em aquíferos. Desta forma, utilizou-se o modelo VS2DT para determinar qual é o menor valor de taxa de infiltração constante que pode ser aplicada na superficie a fím de que o tempo de trânsito da água na zona não saturada de $7 \mathrm{~m}$ de espessura do modelo Urânia A seja superior a 50 dias, tempo suficiente para haver a degradação dos patógenos produzidos antes das suas chegadas no aquífero freático.

A Figura 35 apresenta os resultados da simulação de transporte de uma pluma de nitrato ao longo da zona não saturada, cuja carga hidráulica constante foi definida em $2,2 \mathrm{~cm} /$ dia para o tempo de trânsito de 50 dias da água. Observa-se na figura, inclusive, que as concentrações que chegam no aqüifero freático são as mesmas da carga contaminante já no dia 200 da simulação. 
Para efeito de interpretação, considera-se que o tempo de trânsito dos microorganismos patogênicos seja o mesmo da pluma de nitrato. Ainda nesta simulação, não foram considerados os efeitos de adsorção, troca iônica, decaimento e difusão molecular, mas apenas a dispersão, cujo coeficiente de dispersividade adotado foi de $0,3 \mathrm{~m}$ (Anexo 10).

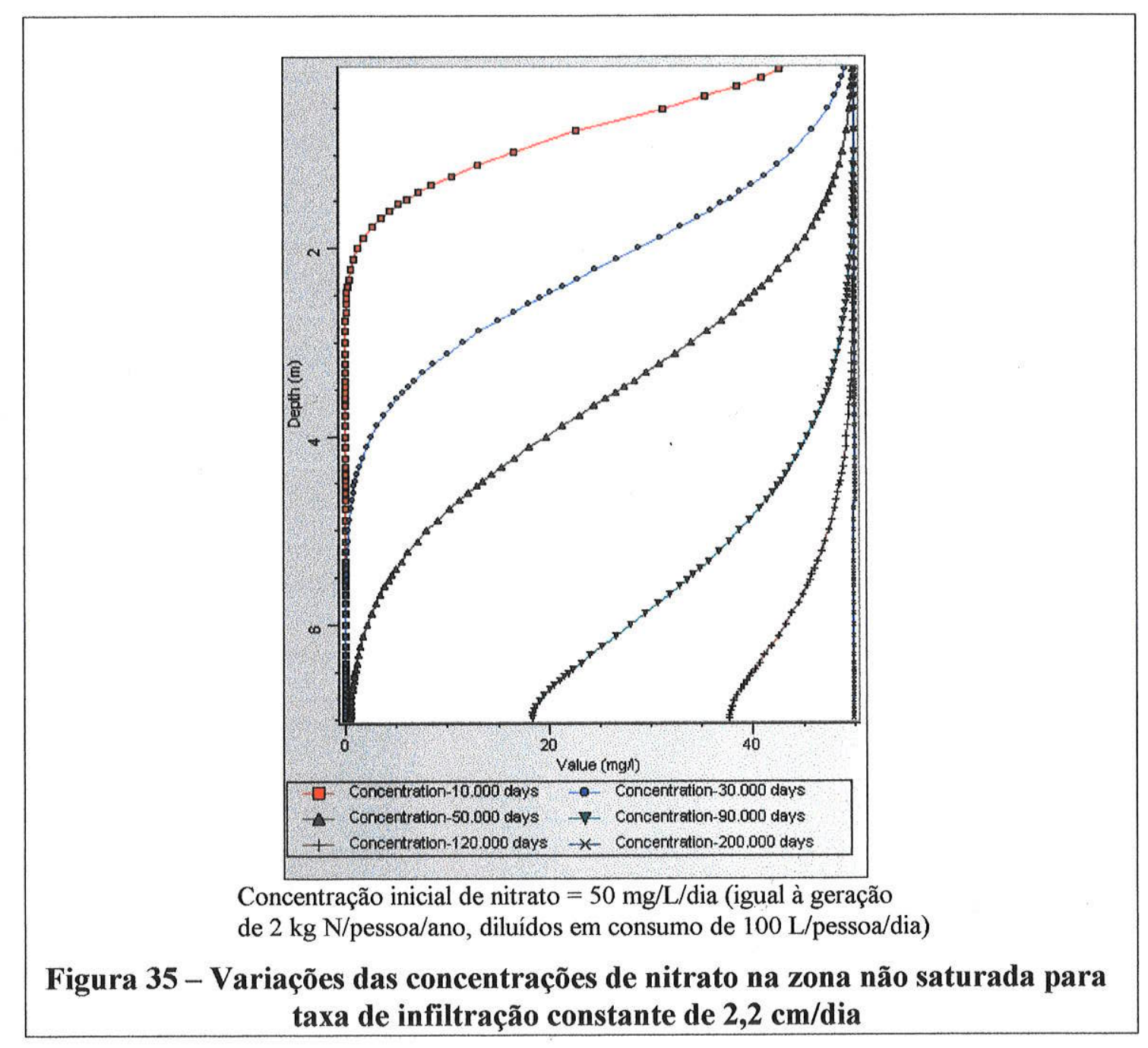

A determinação da taxa de infiltração pode definir, por sua vez, a área mínima de projeto para a infiltração dos efluentes através de fossas, com a simples constatação de que a taxa de infiltração é uma função da vazão de efluente produzida através de uma área. Considerando a vazão de efluentes produzida por pessoa igual a $100 \mathrm{~L} / \mathrm{dia}$, obtém-se a área de $4,5 \mathrm{~m}^{2}$ para a taxa de infiltração de $2,2 \mathrm{~cm} /$ dia. De acordo com as condições de simulação e considerando que cada fossa atenda uma família de 4 pessoas, a área de infiltração da fossa deveria atingir $18 \mathrm{~m}^{2}$, o que pode ser considerado um valor elevado quando se compara com as condições reais. 
Com relação ao nitrato, é possível calcular qual seria a densidade populacional máxima (ou o número de fossas por hectare) necessária para que as concentrações de nitrogênio (na forma de nitrato) no aqüffero sejam de no máximo $10 \mathrm{mg} / \mathrm{L}$ (limite de potabilidade, Portaria 36/GM de 19.01.90 do Decreto 79367 de 09.03.77 do Ministério da Saúde), levando-se em consideração as taxas de infiltração devido ao efluente e à recarga por chuvas, segundo a seguinte relação (Foster \& Hirata, 1988):

$$
C=\frac{1000 \cdot a \cdot A \cdot f}{0,36 \cdot A \cdot U+10 \cdot 1}
$$

\section{Equação 12}

Onde $\quad C=$ concentração de nitrogênio nitrato na água subterrânea $(\mathrm{mg} / \mathrm{L})$;

$a=$ taxa de produção de nitrogênio por pessoa por ano ( $\mathrm{kg} /$ pessoa/ano);

$A=$ número de habitantes por hectare;

$f=$ índice que varia de 0,2 a 0,6 referente à perda de nitrogênio antes de sua disponibilização para infiltração;

$\mathrm{U}=$ taxa de infiltração devido ao efluente (L/habitante/dia); e

$\mathrm{I}=$ taxa de infiltração devido à recarga por chuva ( $\mathrm{mm} / \mathrm{ano})$.

O valor de a adotado é de $4 \mathrm{~kg} /$ pessoa/ano (Foster \& Hirata, 1988), sendo porém possível encontrar outras estimativas na literatura, tal como uma faixa de valores que varia entre 0,7 e 2,6 $\mathrm{kg} /$ pessoa/ano (Tchobanoglous \& Burton, 1991). O índice de perda de nitrogênio (f) é adotado em 0,2 (ou seja, com $80 \%$ de remoção do nitrogênio original), pois considera-se que o sistema séptico seja eficiente e que possua características construtivas completas, com tanque de sedimentação, tanque de biodigestão e área de infiltração, e também com um plano de manutenção, o que faria aumentar o índice de remoção de nitrogênio ainda na forma orgânica.

A taxa de infiltração devido ao efluente foi adotada em $100 \mathrm{~L} /$ pessoa/dia. A taxa de infiltração devido à recarga por chuva foi estimada com base em uma nova simulação com o VS2DT, que determinou o volume de água acumulado que atravessou as profundidades de 4 a 6 $\mathrm{m}$ ao longo do ano de 2000. O valor da taxa de infiltração, calculado em $213,2 \mathrm{~mm} / \mathrm{ano}$, corresponde a aproximadamente $15 \%$ do total das chuvas no período, e é considerado como o valor que efetivamente participou da recarga do aqüífero freático neste ano, descontando-se os efeitos da transpiração e da evaporação. 
Aplicando-se os valores adotados das variáveis apresentadas à Equação12, obtém-se como resultado que a densidade populacional não deve ultrapassar 48 pessoas/hectare para que o aqüífero freático não seja impactado com concentrações de nitrogênio acima de $10 \mathrm{mg} / \mathrm{L}$. Da mesma forma, considerando que cada residência possua uma fossa que atenda 4 pessoas, os cálculos indicam que deveria haver uma densidade máxima de 12 casas num quarteirão de 100 por $100 \mathrm{~m}$. Este valor é muito pequeno em relação às condições reais de uso e ocupação do solo urbano que se verifica em Urânia e em praticamente todas as áreas urbanas que se encontram em situação hidrogeológica semelhante.

Considerando-se (1) a densidade populacional máxima de 48 pessoas/hectare para que o impacto do nitrogênio na qualidade da água do aqüífero freático seja tolerável; (2) que uma fossa deve apresentar uma área de infiltração de $4,5 \mathrm{~m}^{2} /$ pessoa para que o trânsito de patógenos seja maior que 50 dias para uma zona não saturada de $7 \mathrm{~m}$; e (3) que estes valores são incompatíveis com o atual sistema de ocupação do solo urbano, conclui-se que é preferível que haja investimentos nos serviços de coleta e tratamento de esgotos urbanos, tal como já acontece com o município de Urânia na maior parte de sua área, para que haja controle desta importante fonte difusa de contaminação da porção freática do Aqüífero Adamantina, que é freqüentemente explorado pela população através de poços cacimba e poços tubulares rasos.

\subsection{Transporte de Nitrato através de Fertilizantes}

Diferentemente do nitrato em fossas, a infiltração do nitrato contido em fertilizantes na zona não saturada não ocorre como carga constante, mas a partir da infiltração gerada por eventos de recarga através de chuvas e/ou por irrigação. Considerando que as chuvas ocorrem de forma concentrada em determinado período do ano, que a fertilização do solo ocorreu antes do período chuvoso (o que promove uma maior taxa de perdas) e que as chuvas contribuem para a diluição do nitrato, utilizou-se do modelo VS2DT para prever qual seria a concentração máxima de nitrogênio que chega no aqüífero freático após os eventos de recarga natural.

A determinação da carga efetiva de nitrogênio infiltrado é uma tarefa complexa, pois infiltra-se para o aqüífero apenas uma parcela de nitrogênio do fertilizante aplicado no solo e que não foi aproveitado pelas plantas. Esta parcela, por sua vez, é função de uma série de fatores, tais como a permeabilidade e espessura do solo, excesso de chuva, eficiência da irrigação, continuidade do cultivo, freqüência de aragem e o controle da aplicação do fertilizante (Foster \& Hirata, 1988). 
Dado a complexidade da tarefa de se estimar a carga efetiva infiltrada a partir de um valor de nitrogênio aplicado no solo, utilizou-se do modelo para simular dois cenários de contaminação de nitrato por fertilizantes, considerando-se livremente alguns valores de cargas efetivas (200 e $1000 \mathrm{mg} / \mathrm{L}$ de nitrato como nitrato). O primeiro valor corresponde, inclusive, à concentração máxima medida no lisímetro L50 na campanha de agosto/99.

O Anexo 10 apresenta os dados de entrada das duas simulações de contaminação. Assim como na simulação anterior, considerou-se apenas os efeitos de dispersão sobre o contaminante nos dois modelos, com coeficiente de dispersividade igual a $0,3 \mathrm{~m}$. O período de simulação é de 730 dias ( 2 anos), tomando-se como condições de contorno superior e inferior os dados medidos de potenciais matriciais do ano 2000 (de $1^{\circ}$ de janeiro a 31 de dezembro), repetidos por duas vezes. Não se considerou os dados de potenciais matriciais do ano de 2001 por não haver dados posteriores a 31 de março, que seriam necessários para observar a chegada da pluma de contaminação no contorno inferior. As condições iniciais do perfil referem-se aos potenciais matriciais medidos no dia 31/12/1999.

Considerou-se que as concentrações de entrada de nitrato decaem exponencialmente a partir das situações iniciais até zero no final do período de recarga, que ocorre após 98 dias do início da simulação (detalhes no Anexo 10). Esta situação é semelhante à que foi observada quanto às concentrações de nitrato na água dos lisímetros rasos nas campanhas de janeiro/2000 (início do período de recarga) e abril/2000 (fim do período de recarga), quando a água sofreu redução da ordem de 100 para alguns décimos de $\mathrm{mg} / \mathrm{L}$ de uma campanha para a outra. As simulações ocorrem com concentrações iniciais de nitrato no perfil igual a zero.

A Figura 36 apresenta os resultados das duas simulações. No primeiro gráfico, em que as concentrações iniciais são de $200 \mathrm{mg} / \mathrm{L}$, nota-se que a maior concentração de nitrato que chega no aqüífero é de $45 \mathrm{mg} / \mathrm{L}$ após 492 dias do início da simulação, que é semelhante à que se encontra no aqüifero freático na área da estação de monitoramento. No segundo gráfico, os resultados são semelhantes, pois é também no dia 492 que se observa a maior concentração de chegada da contaminação no aqüífero, da ordem de $240 \mathrm{mg} / \mathrm{L}$ para uma concentração inicial de nitrato de $1000 \mathrm{mg} / \mathrm{L}$.

Plotando-se num mesmo gráfico as concentrações iniciais em função das concentrações de chegada de nitrato no aqüífero freático do dia 492 (Figura 37), observa-se que os pontos são unidos por uma reta com origem na coordenada $(0,0)$. A partir deste gráfico é possível estimar a concentração de chegada de nitrato no aqüífero a partir de qualquer concentração inicial de nitrato, de acordo com as condições de simulação adotadas. 


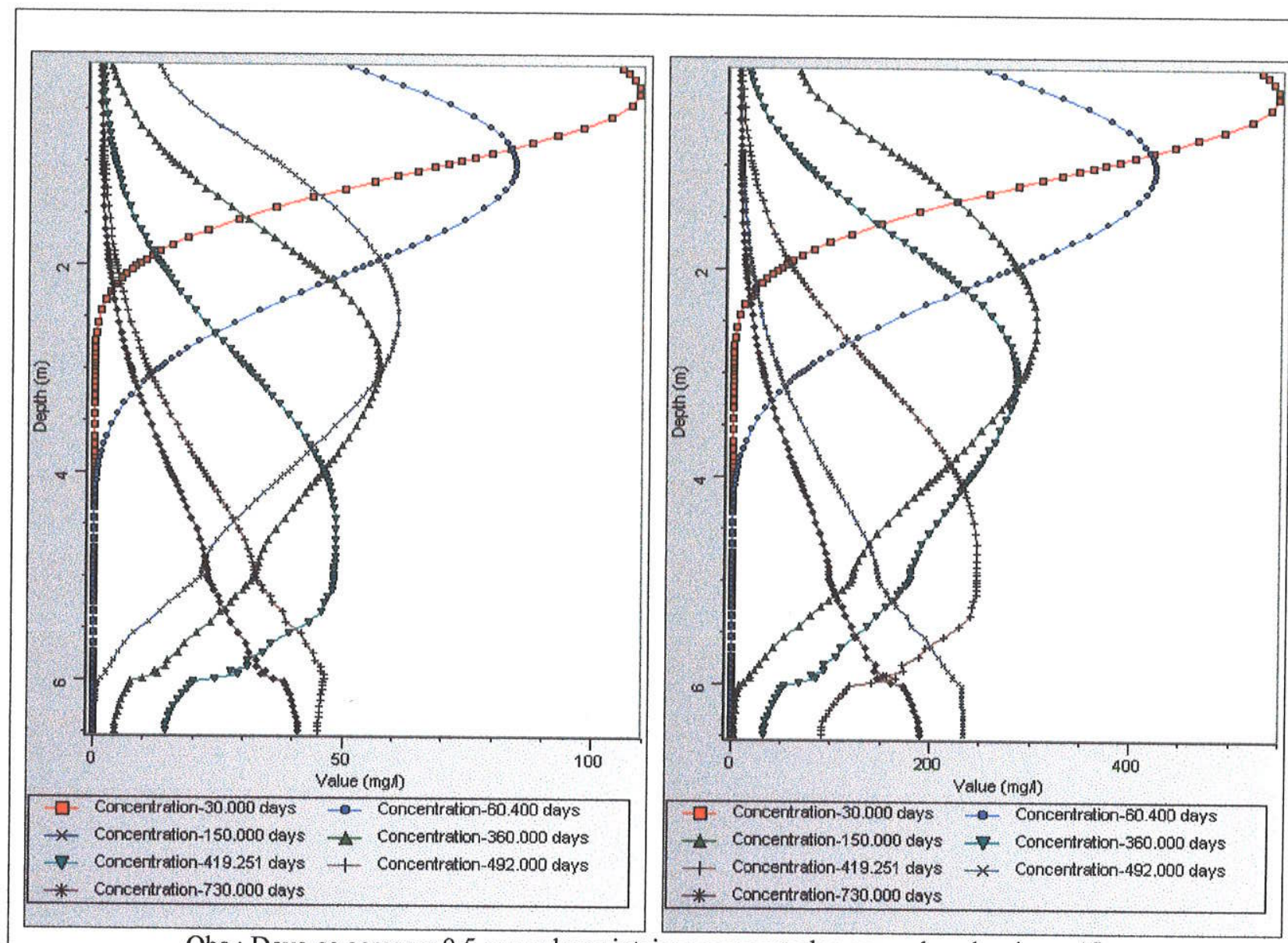

Obs.: Deve-se acrescer 0,5 aos valores inteiros apresentados nas ordenadas dos gráficos

Figura 36 - Variações das concentrações de nitrato com a profundidade para duas situações de contaminação inicial ( 200 e $1000 \mathrm{mg} / \mathrm{L}$ )

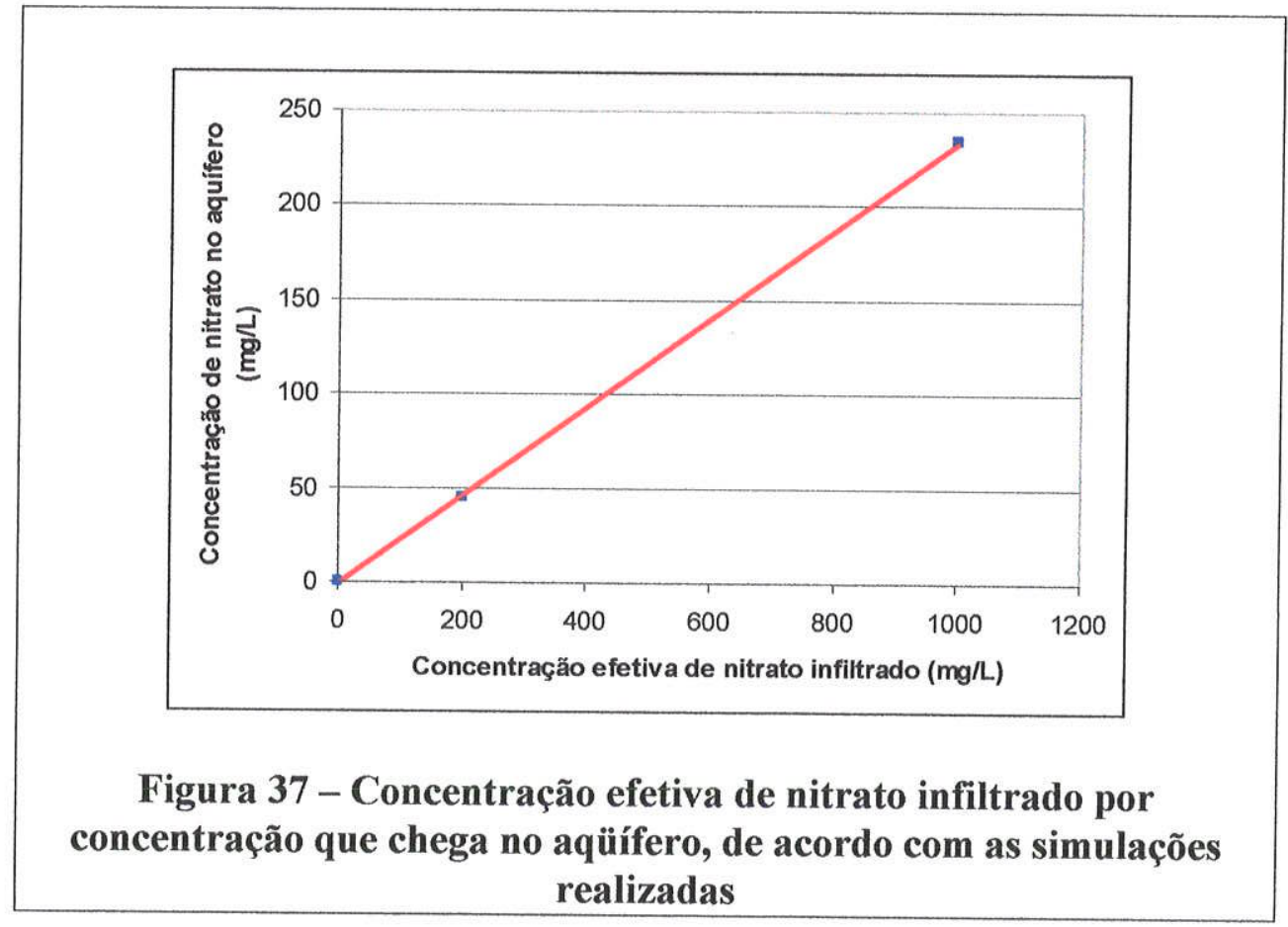


A Figura 38 apresenta os resultados de uma simulação semelhante à da primeira simulação (em que as concentrações iniciais de nitrato são de $200 \mathrm{mg} / \mathrm{L}$ ), mas com período de cinco anos e repetindo-se as concentrações de entrada a cada início de ano. Tomou-se sempre o regime de infiltração do ano 2000 como referência e as mesmas demais condições de simulação. Observase que do segundo até o quinto ano as concentrações de chegada de nitrato no aqüífero são de aproximadamente $42-45 \mathrm{mg} / \mathrm{L}$, indicando que após o segundo ano as concentrações de chegada parecem atingir um regime estacionário.

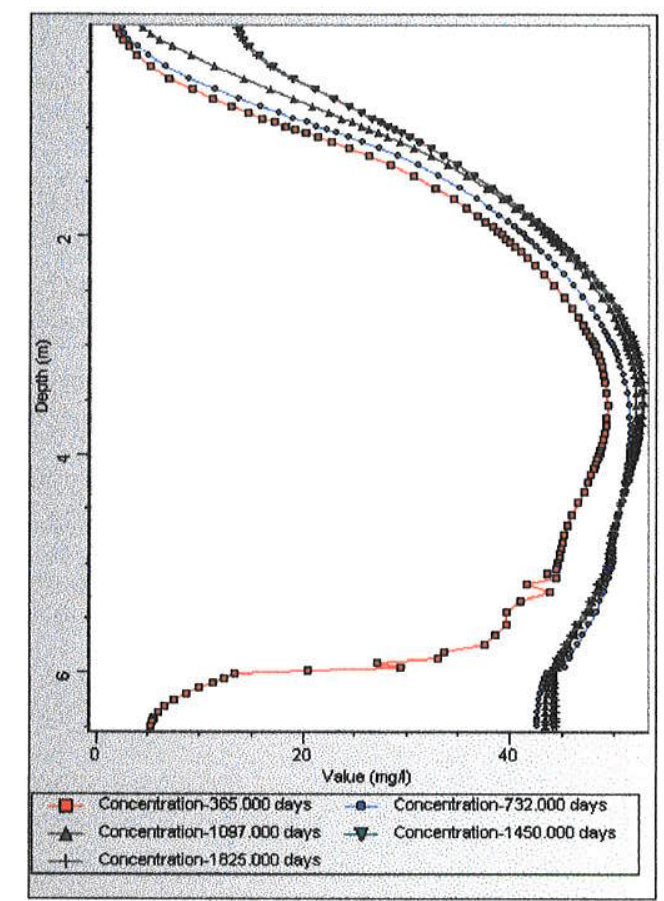

Obs.: Deve-se acrescer 0,5 aos valores inteiros apresentados na ordenada do gráfico

Figura 38 - Variações das concentrações de nitrato para concentração inicial de $200 \mathrm{mg} / \mathrm{L}$ em cinco anos de simulação

As concentrações de nitrato ao redor de $45 \mathrm{mg} / \mathrm{L}$ representam o limite de potabilidade da água e, para uma taxa de infiltração da ordem de 200 mm/ano, corresponde a uma quantidade de fertilizante perdida por lixiviação da ordem de $20 \mathrm{~kg} / \mathrm{ha} /$ ano (segundo estimativa em Foster \& Hirata, 1988). Esta perda é compatível com as taxas anuais de aplicação de fertilizantes para cultivo de cana de açúcar (1000 t/ha/ano de fertilizante NPK) e laranja (220 t/ha/ano) no Estado de São Paulo, e de soja (476 t/ha/ano) e milho (439 t/ha/ano) no Estado do Paraná (Hirata \& Jahnel, 1997), e fornecem uma medida do elevado grau de importância dos fertilizantes como fonte de contaminação da água subterrânea, mesmo considerando uma quantidade de $20 \%$ de nitrogênio em sua formulação. 


\section{Conclusões}

Tendo em vista o descrito neste trabalho e considerando os objetivos propostos, as seguintes conclusões são apresentadas:

\section{1 - Quanto à hidráulica de infiltração da água na zona não saturada}

As medidas de condutividade hidráulica vertical diminuíram, nas profundidades de 1 a $9 \mathrm{~m}$, de 3,76E 03 para $9,71 \mathrm{E}-04 \mathrm{~cm} / \mathrm{s}$. A condutividade hidráulica no sentido horizontal é menor que a do sentido vertical até a profundidade de $5 \mathrm{~m}$, devido à ação de raízes e de animais, que geram macroporos no sentido vertical, de fluxos preferenciais. A partir desta profundidade, a condutividade hidráulica no sentido vertical torna-se menor que no sentido horizontal, pois o solo vai obtendo a estrutura da rocha sedimentar original.

Durante o período de dois anos de monitoramento dos potenciais hidráulicos, a espessura da zona não saturada variou de 9 a $10,5 \mathrm{~m}$, reflexo das variações sazonais da recarga do aqüífero. Neste período, ocorreram dois eventos de recarga intercalados por períodos de estiagem. $\mathrm{O}$ primeiro evento de recarga deu-se de janeiro a março/2000 e gerou uma frente de molhamento que chegou ao aqüífero freático no início de abril/2000, conferindo um tempo de trânsito de 3 meses da água na zona não saturada. O segundo evento de recarga ocorreu de setembro/2000 a março/2001, mas teve um regime de chuvas irregular, gerando pequenas frentes de molhamento que sofreram dissipação.

Notou-se a ocorrência de forte influência da evapotranspiração causada pelas raízes de uma árvore vizinha da estação de monitoramento sobre os potenciais hidráulicos durante ano de 1999, causando, inclusive, potenciais de fluxos ascendentes da água do aqüífero freático para a zona não saturada. Esta árvore foi sacrificada no início do ano 2000, e a partir de então, notou-se uma mudança no regime hidráulico da zona não saturada, predominando potenciais de fluxos descendentes desde a superfície até o aqüífero freático.

Os tensiômetros instalados externamente ao poço da estação indicaram variações laterais de potenciais hidráulicos devido a uma camada de aterro menos permeável situado ao redor do poço. Esta camada impediu a determinação da linha de evaporação através da leitura de potenciais hidráulicos dos tensiômetros de dentro do poço da estação. Com base nos tensiômetros externos e com o auxílio da modelagem de fluxo, a linha de evaporação foi definida situando-se entre 1 e $2 \mathrm{~m}$ de profundidade nos meses mais secos.

Subtraindo-se os efeitos da evapotranspiração e da camada de aterro, identificou-se a ocorrência de três zonas hidráulicas na zona não saturada. A primeira zona situa-se entre a 
superfície e a linha de evaporação $(2 \mathrm{~m})$, e caracteriza-se por sofrer os efeitos das variações climáticas, sendo que os potenciais hidráulicos respondem rápida e intensamente a cada pequeno evento de recarga ou secagem. Na segunda zona, situada entre 2 e $7 \mathrm{~m}$, as pequenas frentes de molhamento sofrem dissipação e os tensiômetros registram apenas mudanças de potenciais matriciais que se relacionam com eventos mais longos de recarga ou de secagem. A terceira zona situa-se entre $7 \mathrm{~m}$ e o nível d'água e apresenta valores de potenciais hidráulicos muito próximos e acompanhando as variações da carga hidráulica do aqüifero freático, indicando que o fluxo vertical descendente neste intervalo de profundidade é desprezível e que a circulação da água tem uma componente horizontal. A ocorrência de uma camada de arenito duro entre 10,5 e $11,2 \mathrm{~m}$ indica que pode não haver uma conexão hidráulica direta entre a base da zona não saturada e o aquuífero freático na estação de monitoramento.

A modelagem de fluxo da água utilizando o modelo VS2DT auxiliou no entendimento do modelo de circulação da água na zona não saturada, notadamente com relação aos efeitos da camada de aterro e da ação da evapotranspiração sobre o comportamento dos potenciais matriciais medidos no campo. O modelo numérico também mostrou-se útil na determinação das variações de umidade e de condutividade hidráulica da zona não saturada.

\section{2-Quanto à evolução hidrogeoquímica da água da zona não saturada}

As análises mineralógicas realizadas indicaram a larga predominância de quartzo na zona não saturada, seguida do argilomineral caulinita. Foram também identificadas ocorrências de goetita, microclínio e de uma espécie de montmorilonita, dentre outros minerais pesados.

As análises químicas do solo por ICP/AES indicam que a sílica predomina no perfil (média de $83 \%$ em massa), seguida dos óxidos de alumínio (média $6,7 \%$ ), ferro $(3,9 \%$ ), potássio $(0,6 \%)$, magnésio $(0,5 \%)$, cálcio $(0,1 \%)$ e sódio $(0,03 \%)$. As concentrações dos cátions de base são, inclusive, muito baixas e próximas do limite de deteç̧ão da análise em algumas situações.

As análises de capacidade de troca de cátions indicaram valores de 4 a $22 \mathrm{meq} / 100 \mathrm{~g}$, sendo que há uma elevação dos valores a partir de $6 \mathrm{~m}$. A ordem de adsorção dos cátions de base é $\mathrm{Ca}>\mathrm{Mg} \gg \mathrm{Na}>\mathrm{K}$.O hidrogênio também é adsorvido em grandes proporções, porém diminui em relação aos outros cátions a partir de $7 \mathrm{~m}$. As correlações da CTC com as análises químicas de ICP/AES fazem crer que as principais superficies adsorventes do perfil do solo sejam os minerais de ferro e secundariamente a caulinita.

Os resultados das análises químicas e mineralógicas realizadas pelas diferentes técnicas e nas diferentes frações granulométricas indicaram, no geral, que a sílica deve corresponder quase que exclusivamente ao mineral quartzo; o alumínio encontra-se principalmente na fração fina, BERTOLO, R.A. - Tese de Doutoramento - 2001 
fazendo parte da estrutura da caulinita; o ferro encontra-se predominantemente na forma de hematita, ilmenita e magnetita na fração pesada e na forma de goetita na fração fina; o magnésio deve encontrar-se em maiores quantidades fazendo parte da estrutura de minerais opacos e adsorvido nos minerais ferruginosos e na caulinita na fração fina; o potássio deve encontrar-se adsorvido na fração fina e no mineral microclínio; e o cálcio encontra-se totalmente adsorvido na fração fina.

A água da zona não saturada é de baixa mineralização, com condutividade elétrica média de $150 \mu \mathrm{S} / \mathrm{cm}$ e valores médios de $\mathrm{pH}$ em torno de 6,5. Há uma estratificação da composição química da água em três zonas que coincidem com as zonas hidráulicas descritas. Na primeira zona, da superfície até $2 \mathrm{~m}$, as águas são mais mineralizadas, bicarbonatadas cálcicas, apresentaram fortes variações temporais na composição química e elevadas concentrações de nitrato durante os períodos de estiagem. A segunda zona, de 2 a $7 \mathrm{~m}$, apresenta águas bicarbonatadas cálcicas-magnesianas e com menores quantidades de íons dissolvidos em relação à primeira zona, especialmente o cálcio e nitrato. A terceira zona, de $7 \mathrm{~m}$ à superfície do aqüífero freático, apresenta águas bicarbonatadas-cloretadas cálcicas-magnesianas, com pH mais baixo (em torno de 5,5) e com maiores concentrações de nitrato. A água do aquuífero freático é bicarbonatada cálcica, possui pH mais elevado e concentrações elevadas de nitrato.

Os seguintes processos hidrogeoquímicos foram identificados ocorrendo na zona não saturada: (1) ações antropogênicas, com a ocorrência de elevadas concentrações de nitrato na água; (2) evaporação, até a profundidade aproximada de $2 \mathrm{~m}$, com a observação de concentrações mais elevadas de várias espécies químicas $\left(\mathrm{NO}_{3}^{-}, \mathrm{Ca}^{+2}, \mathrm{Mg}^{+2}\right.$ e $\left.\mathrm{SiO}_{2}\right)$ e de uma maior variação temporal nas concentraç̃̃es destes parâmetros entre os eventos de amostragem; (3) respiração vegetal e degradação de matéria orgânica, até a profundidade $7 \mathrm{~m}$, que produziram efeitos variados no comportamento de várias espécies químicas (dentre elas o de $\mathrm{CO}_{2}, \mathrm{pH}$, $\mathrm{HCO}_{3}^{-}, \mathrm{Ca}^{+2}, \mathrm{Mg}^{+2}$ e $\mathrm{SiO}_{2}$ ), principalmente como resultado do sacrifício da árvore vizinha à estação em janeiro/2000; (4) reações de dissolução de quartzo e aluminossilicatos e precipitação de caulinita e formas criptocristalinas de sílica, além de condições para a dissolução de minerais reativos, como os carbonatos; (5) reações de adsorção/troca iônica, pois as análises de capacidade de troca catiônica indicaram que a quantidade de cátions de base adsorvidos compõe um importante estoque de elementos que interagem com a água, que a quantidade existente de cálcio e sódio na zona não saturada é totalmente devida à adsorção, e que os cátions adsorvidos possuem a mesma ordem de abundância dos cátions dissolvidos na água $(\mathrm{Ca}>\mathrm{Mg}>\mathrm{Na}>\mathrm{K})$. 
As modelagens inversas indicaram que as pequenas variações na composição química da água entre os pontos considerados podem ser explicadas por processos de dissolução de aluminossilicatos e/ou por adsorção/desadsorção de cátions de base, e até mesmo pelos próprios erros associados aos resultados das análises químicas, o que indicaria a ausência de alguma reação química entre os pontos. Outra observação relevante é que a composição química da água também pode ser controlada pela existência de fases minerais que não foram detectadas nas análises realizadas na fase sólida.

\section{3 - Quanto às simulações de transporte de nitrato na zona não saturada}

As simulações de infiltração de efluentes em fossas resultaram que estas devem possuir uma área de infiltração de $4,5 \mathrm{~m}^{2} /$ pessoa para que o trânsito de patógenos seja maior que 50 dias em uma zona não saturada de $7 \mathrm{~m}$, e que a densidade populacional deve ser de, no máximo, 48 pessoas/hectare para que o impacto do nitrogênio na qualidade da água do aqüífero freático seja menor que o limite de potabilidade $(10 \mathrm{mg} / \mathrm{L}$ de nitrogênio). Estes valores são incompatíveis com o atual sistema de ocupação do solo urbano, o que sinaliza que o aqüífero apresenta elevada vulnerabilidade à poluição por esta fonte de contaminação.

As simulações de infiltração de nitrato originado por fertilizantes indicaram, de acordo com as condições adotadas, que é possivel que a água do aqüífero tenha a sua potabilidade comprometida após aproximadamente 500 dias da aplicação de uma concentração inicial de 200 $\mathrm{mg} / \mathrm{L}$ de nitrato, sob regime de infiltração através de recarga natural por chuvas. As concentrações observadas de nitrato no aqüífero da estação de monitoramento, próximas de 45 $\mathrm{mg} / \mathrm{L}$ de nitrato, correspondem a uma perda de fertilizante da ordem de $20 \mathrm{~kg} / \mathrm{ha} / \mathrm{ano}$, que é compatível com as taxas anuais de aplicação de fertilizantes para vários tipos de cultivo. Da mesma forma que as fossas, esses resultados indicam que o aqüifero também apresenta-se vulnerável à poluição devido à aplicação de fertilizantes. 


\section{Referências Bibliográficas}

ALEXANDRE, G. A. L. - 1995 - Contribuição ao estudo do comportamento geoquímico do As, $\mathrm{Cu}, \mathrm{Pb}$ e $\mathrm{Zn}$, originários de pesticidas agrícolas, nas zonas não saturada e saturada em área urbana e agrícola do município de Louveira (SP). Tese de doutoramento. Instituto de Geociências - USP.

ALLISON, J. D.; BROWN, D.S.; NOVO-GRADAK, K. J. - 1991 - MINTEQA2/PRODEFA2 - A geochemical assessment model for environmental systems. Version 3.0 - User's Manual. EPA Office of Research and Development. EPA/600/3-91/021. 100 p.

ALMODOVAR, M. L. N. - 1995 - Estudo da anomalia de cromo nas águas subterrâneas da região noroeste do Estado de São Paulo. São Paulo, 101 p. (Dissertação de Mestrado) - Instituto de Geociências - Universidade de São Paulo.

ALMODOVAR, M. L. N. - 2000 - A origem natural da poluição por cromo no Aqüífero Adamantina, município de Urânia (SP). São Paulo, 199 p. (Tese de Doutoramento) - Instituto de Geociências - Universidade de São Paulo.

APPELO, C. A. \& POSTMA, D. - 1993 - Geochemistry, Groundwater and Pollution. A. A. Baukema, Brookfield, Vt. 536p.

ASTM COMMITTEE D-18 ON SOIL AND ROCK - 1996 - ASTM standards on ground water and vadose zone investigations: drilling, sampling, well installation and abandonment procedures. Designation D 4696-92: Standard Guide for Pore-Liquid Sampling from the Vadose Zone. ASTM Publication Code Number 03-418196-38. p. 68-98.

BERTOLO, R. A. \& HIRATA, R. C. A. - 2000 - Monitoramento da zona não saturada: um estudo da hidráulica e hidroquímica na estação experimental de Urânia, São Paulo, Brasil. In: Congresso Mundial Integrado de Águas Subterrâneas, 1, Fortaleza, 2000. Anais.

BRANDT NETO, M.; PETRI, S.; COIMBRA, A. M. - 1985 - Argilominerais do Grupo Bauru: considerações genéticas. In: Simpósio Regional de Geologia, 5., São Paulo. Atas. São Paulo, SBG - Núcleo São Paulo. V.1, p. 61-74. 
BUCKMAN, H. O.; BRADY, N. C. - 1968 - Natureza e Propriedades dos Solos. Compêndio universitário sobre Edafologia. Livraria Freitas Bastos S.A.

BUHRKE, V. E.; JENKINS, R.; SMITH, D. K. - 1998 - Preparation of specimens for X-RayFluorescence and X-Ray Diffraction Analysis. New York, John Wiley \& Sons. 332 p.

CAMPOS, H. C. N. S. (1987). Contribuição do estudo hidrogeoquímico do Grupo Bauru no Estado de São Paulo. São Paulo, 158 p. (Dissertação de Mestrado - Instituto de Geociências/USP).

CAMPOS, H. C. N. S. (1993). Caracterização e cartografia das províncias hidrogeoquímicas do Estado de São Paulo. São Paulo, 177 p. (Tese de Doutoramento - Instituto de Geociências/USP).

CHAKKA, K. B.; MUNSTER, C. L. - 1997 - Modeling macropore transport of agricultural chemicals on a river floodplain: atrazine transport simulation. TRANS.-ASAE, vol, $40, \mathrm{n} .5, \mathrm{p}$ 1363-1372.

COIMBRA, A. M. - 1976 - Arenitos da Formação Bauru: estudo de áreas fonte. São Paulo, 2v. Dissertação de Mestrado. Instituto de Geociências, Universidade de São Paulo.

DAEE - DEPARTAMENTO DE ÁGUAS E ENERGIA ELÉTRICA - 1976 - Estudo de Águas Subterrâneas. Região Administrativa 7, 8 e 9, Bauru, São José do Rio Preto e Araçatuba. 4v. São Paulo.

DAEE - DEPARTAMENTO DE ÁGUAS E ENERGIA ELÉTRICA - 1988. Águas subterrâneas: reservas estratégicas. Águas e Energia. DAEE 5(13):13-23.

DEUTSCH, W. J. - 1997 - Groundwater Geochemistry - Fundamentals and Applications to Contamination. Lewis Publishers, 221 p.

DUTTON, A. R. - 1990 - Vadose-zone recharge and weathering in an Eocene sand deposit, East Texas, USA. - Journal of Hydrology, 114: 93-108.

EDMUNDS, W. M; FAYE, S.; GAYE, C. B. - 1992 a - Solute profiles in unsaturated quaternary sands from Senegal: environmental information and water-rock interaction. Proceedings of the $7^{\text {th }}$ Int. Symp. On Water Rock Interaction. WRI-7. Utah. USA. p 719-722. 
EDMUNDS, W. M.; KINNIGURGH, D. G.; MOSS, P. D. - 1992 b - Trace metals in interstitial waters from sandstones: acidic inputs to shallow groundwaters. Environmental Pollution ENPOEK, v. 77, n. 2/3, p 129-141.

EMBRAPA (EMPRESA BRASILEIRA DE PESQUISA AGROPECUÁRIA) \& IAC (INSTITUTO AGRONÔMICO DE CAMPINAS) - 1999 - Mapa Pedológico do Estado de São Paulo - escala 1:500.000. Folha 1-noroeste.

FERNANDES, L. A. - 1998 - Estratigrafia e evolução geológica da parte oriental da Bacia Bauru (Ks, Brasil). São Paulo, 216 p. (Tese de Doutoramento) - Instituto de Geociências, Universidade de São Paulo.

FOSTER, S. \& HIRATA, R. C. A. - 1988. Determinacion del Riesgo de Contaminación de Aguas Subterráneas: una Metodología Basada en Datos Existentes. Centro Panamericano de Ingenieria Sanitaria y Ciencias del Ambiente (CEPIS), 81p. $1^{\text {a }}$ edición.

FREEZE, R. A.; CHERRY, J. A. (1979). Groundwater. Englewood Cliffs, Prentice-Hall. 604 p.

FÚlFARO, V. J.; BJORNBERG, A. J. S. - 1993 - Geologia. In: Cintra, J.C.; Albiero, J. H. (ed.). Solos do Interior de São Paulo. São Paulo, ABMS, p. 1-42.

GLOEDEN, E.; CUNHA, R. C. A.; FRACCAROLI, R.; CLEARY, R. W. - 1991 - The behavior of vinasse constituents in the unsaturated and saturated zones in the Botucatu Aquifer recharge area. Water Science \& Technology, 24:225-235.

HALFORD, K. J. - 1997 - Effects of unsaturated zone on aquifer test analysis in a shallowaquifer system. Groundwater, vol. 35, n 3, p 512-522

HANSEN, B. K. \& POSTMA, D. - 1995 - Acidification, buffering, and salt effects in the unsaturated zone of a sandy aquifer, Klosterhede, Denmark. - Water Resources Research, vol. 31, n 11: 2795-2809.

HART, G. L. \& LOWERY, B. - 1997 - Axial-radial influence of porous cup soil solution samplers in a sandy soil. Soil Sci. Soc. Am. J. 61:1765-1773. 
HEM, J. D. - 1985 - Study and Interpretation of the Chemical Characteristics of Natural Water. $3^{\text {rd }}$ edition. USGS Supply Paper 2254.

HILLEL, D. - 1980 - Fundamentals of Soil Physics. Academic Press, Inc. New York, USA. $413 p$.

HIRATA, R. C. A.; BASTOS, C.; ROCHA, G. 1997. Mapeamento da vulnerabilidade à poluição dos aqüíferos do Estado de São Paulo. Secretaria do Meio Ambiente do Estado de São Paulo. São Paulo, 2v.

HIRATA, R. C. A.; RODOLFI, G. - 1993 - Presença de cromo nas águas subterrâneas em Urânia. São Paulo, Secretaria do Meio Ambiente/ Instituto Geológico. 24 p. (Relatório Técnico).

HIRATA, R. C. A. \& JAHNEL, M. - 1997 - Agricultural contaminant risk on groundwater quality in Brazil: a first approach. CIHEAM Journal Options Méditerranéennes.

HIRATA, R. C. A. - 2000 - Os mecanismos controladores da partição do cromo no sistema rocha-solo-água no Aqüífero Bauru, noroeste de São Paulo. Relatório Final de Projeto FAPESP, processo $97 / 13879-6$.

HOUGHTON, R. L.; THORSTENSON, D. C., FISHER, D. W., GROENEWOLD, G. H. - 1987 - Hydrogeochemistry of the upper part of the Fort Union Group in the Gascoyne lignite stripmining area, North Dakota. USGS Professional Paper 1034. 104p. Apenas resumo disponível.

HOUNSLOW, A. W. - 1995 - Water Quality Data. Analysis and Interpretation. Lewis Publishers. 397 p.

ICDD (INTERNATIONAL CENTRE FOR DIFFRACTION DATA) - 1995 - Powder diffraction file: PDF-2 Database Sets 1-45. Pennsylvania, ICDD. (CD-ROM).

IGC (INSTITUTO GEOGRÁFICO E CARTOGRÁFICO) \& DAEE (DEPARTAMENTO DE ÁGUAS E ENERGIA ELÉTRICA) - 1996 - Unidades Hidrográficas de Gerenciamento de Recursos Hídricos do Estado de São Paulo - Escala 1.1.000.000. Plano Estadual de Recursos Hídricos/Plano Cartográfico do Estado de São Paulo. 
IPT - INSTITUTO DE PESQUISAS TECNOLÓGICAS - 1981 - Mapa Geológico do Estado de São Paulo. São Paulo, IPT. V. 1. Escala 1:500.000.

IRITANI, M. A., ODA, G. H., KAKAZU, M. C., CAMPOS, J. E., FERREIRA, L. M. R., SILVEIRA E. C. e AZEVEDO, A. A. B. - 2000 - Zoneamento das características hidrodinâmicas (transmissividade e capacidade específica) do Sistema Aqüifero Bauru no Estado de São Paulo, Brasil. In: Congr. Mundial Integrado de Águas Subterrâneas, 1. Fortaleza 2000. ABAS. Resumos expandidos, $14 \mathrm{p}$.

ISO (INTERNATIONAL ORGANIZATION FOR STANDARDIZATION) - 1996 - Particle size analysis - Photon correlation spectroscopy. International Standard ISO 13321. $1^{\text {st }}$ edition 199607-01.

JANASI, V. A;; ANDRADE, S.; ULBRICH, H. H. G. J. - 1996 - A correção do drift instrumental em ICP-AES com espectrômetro seqüencial e a análise de elementos maiores, menores e traços em rochas. Boletim IG-USP, Série Científica, v. 26, p. 45-58.

KHALEEL, R.; RELYEA, J. F.; CONCA, J. L. - 1995 - Evaluation of van Genuchten-Mualem relationships to estimate unsaturated hydraulic conductivity at low water contents. Water Resources Research, v. 31, n. 11, p. 2659-2668.

KELLER, C. K. - 1991 - Hydrogeochemistry of a clayey till 2. Sources of $\mathrm{CO}_{2}$. - Water Resources Research, v. 27, n. 10, p. 2555-2564.

KLUTE, A. - 1986 - Methods of soil analysis: Part 1-physical and mineralogical methods. 2nd ed. Agron. Monogr. 9. ASA and SSSA, Madison, WI.

LANDIM, P. M. B.; SOARES, P. C.; FÚLFARO, V. J. - 1974 - Cenozoic deposits in southcentral Brazil and the engineering geology. In International Congress of IAEG, 2, São Paulo. Proceedings: IAEG, v. 1, t. III, p. III-II.1-7.

LAPPALA, E. G., HEALY, R. W.; WEEKS, E. P. - 1987 - Documentation of computer program VS2D to solve the equations of fluid flow in variably saturated porous media. U.S. Geological Survey WRIR 83-4009. 184 p. 
LIKENS, G. E., BORMANN, F. H.; PIERCE, R. S.; EATON, J. S.; JOHNSON, N. M. - 1977 Biogeochemistry of a Forested Ecosystem. Springer Verlag, Berlin, 146 p.

McBRIDE, M. B. - 1994 - Environmental Chemistry of Soils. Oxford University Press. 406 p.

MEZZALIRA, S.; SALATI, E; MATSUI, E.; BOTELHO, P. F.; VIEIRA, P. C. - 1979 Contribuição geoquímica ao estudo das águas da Formação Bauru na bacia do rio São José dos Dourados, SP. An. Acad. Bras. Ciências. 51 (4): 677-694.

MOSS, P. D. \& EDMUNDS, W. M. - 1989 - Interstitial water-rock interaction in the unsaturated zone of a Permo-Triassic sandstone aquifer. In D. L. Miles (ed.), Water-Rock Interaction. Proc. $6^{\text {th }}$ Water Rock Interaction Symp., Malvern, UK. Balkema, Rotterdam, p. 495499.

MUALEM, Y. - 1976 - A new model for predicting the hydraulic conductivity of unsaturated porous media. Water Resources Research, Washington, v, 12, n. 3, p. 513-522.

PARKHURST, D. L. - 1995 - User's guide to PHREEQC, a computer model for speciation, reaction path, advective transport and inverse geochemical calculations. U.S. Geological Survey.

RAIJ, B. van \& QUAGGIO, J. A . -1983 - Métodos de análise de solo para fins de fertilidade. Boletim Técnico 81. Instituto Agronômico de Campinas. Campinas - SP.

REICHARDT, K. - 1996 - Dinâmica da Matéria e da Energia em Ecossistemas. Departamento de Física e Meteorologia - ESALQ-USP. $2^{\text {a }}$ edição. 513 p.

ROCHA, G.; BERTACHINI, A.; CAMPOS, H; CAIXETA, J. 1982. Tentativa de zoneamento das características hidráulicas e hidrogeoquímicas do Aqüúfero Bauru. In: ENCONTRO DE GEOLOGIA E HIDROGEOLOGIA. Publicação Especial ABAS/SBG, São Paulo. 1v. p. 37-46.

ROSS, J. L. C.; MOROZ, I. C. - 1997 - Mapa Geomorfológico do Estado de São Paulo - escala 1:500.000. Convênio FFLCH USP (Faculdade de Filosofia, Letras e Ciências Humanas) e IPT (Laboratório de Cartografia Geotécnica - DIGEO). 
SOARES, P. C.; LANDIM, P. M. B.; FÚlFARO, V. J.; SOBREIRO NETO, A. F. - 1980 Ensaios de caracterização estratigráfica do Cretáceo no Estado de São Paulo: Grupo Bauru. Revista Brasileira de Geociências, v.10, n.3, p. 177-185.

SOVERY, J. - 1989 - Acid percolation and disintegration, transformation and mobilization of some substances in Finnish Quaternary Deposits. Proceedings of a Symposium on Groundwater Contamination, Baltimore - Maryland. IAHS Publication n. 185, p 163-170.

SUAREZ, D. L. - 1987 - Predictions of pH errors in soil-water extractors due to degassing. Soil Sci. Soc. Am. J., v. 51. p. 64-67

SUGUIO, K. - 1973 - Determinação das propriedades das rochas sedimentares em laboratório. In: Introdução à Sedimentologia. São Paulo, Edgard Blucher Ltda. P. 26-175

SURITA, C. A. - 1999 - Avaliação de contaminação de águas intersticiais e solo, devido a disposição de efluentes de curtimento em superfície - um estudo de campo. Tese de doutoramento. Instituto de Geociências - USP.

SZIKSZAY, M; CONSONI, A. J.; GUIGUER, N.; HASSUDA, S.; KIMMELMANN, A. A.; PARISOT, E; SGAMBATO, F.; YOSHINAGA, S. - 1986 - Instalação de uma estação experimental para estudo da dinâmica e da evolução da composição química da água na zona não saturada. Rev. Águas Subterrâneas, v. 10, p.5-20.

SZIKSZAY, M.; CONSONI, A. J.; YOKOTA, H. K.; ARAÚJO, J. R.; DUARTE, U.; KANEHISHA, M. S. - 1987 - Estudo preliminar da hidrodinâmica na zona não saturada da estação experimental (Cidade Universitária, São Paulo). Rev. Águas Subterrâneas, v.11, p.33-62.

SZIKSZAY, M.; KIMMELMAN, A. A.; HYPOLITO, R.; FIGUEIRA, R. M.; SAMESHIMA, R. H. - 1990 - Evolution of the chemical composition of water passing through the unsaturated zone to ground water at an experimental site at the University of São Paulo, Brazil. Journal of Hydrology, 118, p.175-190.

SZIKSZAY, M.; TOLEDO-GROKE, M. C. - 1989 - Correlation of the chemical composition of water from the unsaturated zone with the mineralogy of a profile on the São Paulo Basin, Brazil. Proceedings of the $6^{\text {th }}$ International Symposium on Water-Rock Interaction, Malvern, UK. 
TALTASSE, P. - 1968 - Os fácies hidroquímicos no Estado de São Paulo. In: $22^{\circ}$ Congr. Bras. Geol., Belo Horizonte. Anais... 1: 263-266.

TCHOBANOGLOUS, G.; BURTON, F. L. - 1991 - Wastewater Engineering: Treatment, Disposal and Reuse. McGraw-Hill, 1334 p.

THRAILKILL, J.; ROBL, T. L. - 1980 - Carbonate geochemistry of vadose water recharging limestone aquifers. Journal of Hydrology, 54:195-208.

VAN GENUCHTEN, M. Th. - 1980 - A closed-form equation for predicting the hydraulic conductivity of unsaturated soils. Soil Science Society of America Journal 44: 892-989.

VAN LIER, Q. J.; DOURADO NETO, D. - 1992 - Programa Curvaret para ajuste da curva de retenção - versão 2.16. Depto. Física e Meteorologia - ESALQ/USP.

WATERLOO HYDROGEOLOGIC, INC. - 1999 - WHI Unsat Suite. 1D unsaturated zone groundwater flow and contaminant transport modeling using VLEACH, PESTAN, VS2DT and HELP. Version 2.1.0.3.

WOOD, W. W. \& PERTRAITIS, M. J. - 1984 - Origin and distribution of carbon dioxide in the unsaturated zone of the Southern High Plains of Texas. Water Resources Research, v. 20, n.9, p.1193-1208.

WUTKE, A. C. P.; CAMARGO O. A. - Adsorção e Troca Iônica. In: MONIZ, A. C. (org.) Elementos de Pedologia. Editora Universidade de São Paulo, p 111-147.

ZILBERBRAND, M. - 1995 - The effect of carbonates and gypsum precipitation in the root zone on the chemical composition of groundwater. Journal of Hydrology v. 171 p. 5-22

ZILBERBRAND, M.; \& GVIRTZMAN, H. - 1996 - Monitoring of water flow and solute transport through the unsaturated zone using a large-diameter borehole. Ground Water, Vol. 34 n. 1 - January-February 1996.

ZILBERBRAND, M. - 1999 - On equilibrium constants for aqueous geochemical reactions in water unsaturated soils and sediments. Aquatic Geochemistry v. 5. p. 195-206. 


\section{Anexos}

\subsection{ANEXO 1 - RELATÓRIO FOTOGRÁFICO}

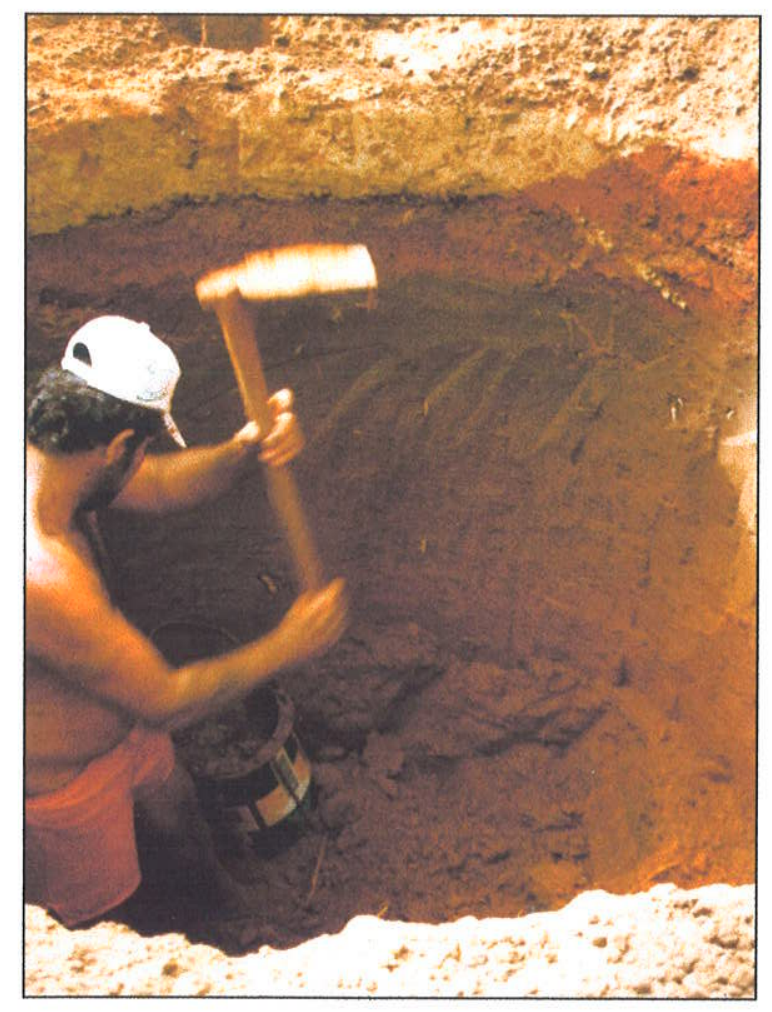

Fotografia 1 - Serviços de escavação do poço da estação de monitoramento. Notar a espessura da camada de aterro sobre material do solo (coloração vermelha), a coloração mais escura dos níveis mais ricos em matéria orgânica (horizonte $A$ ), e a ocorrência de raízes. 


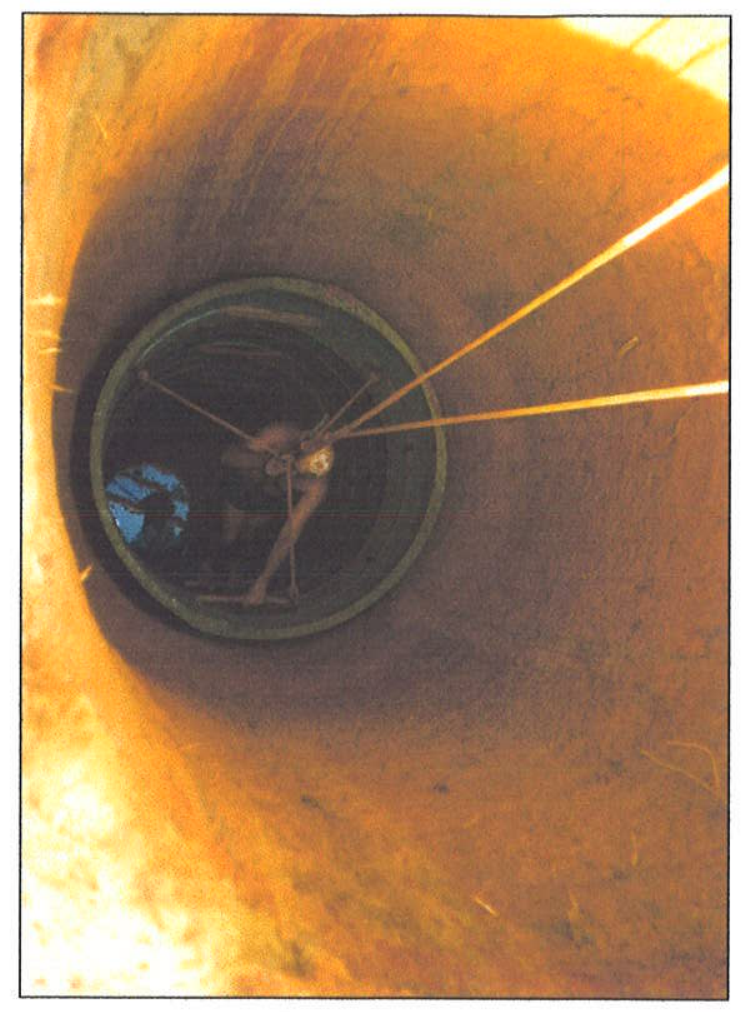

Fotografia 2 - Serviços de instalação de revestimento do poço da estação de monitoramento.

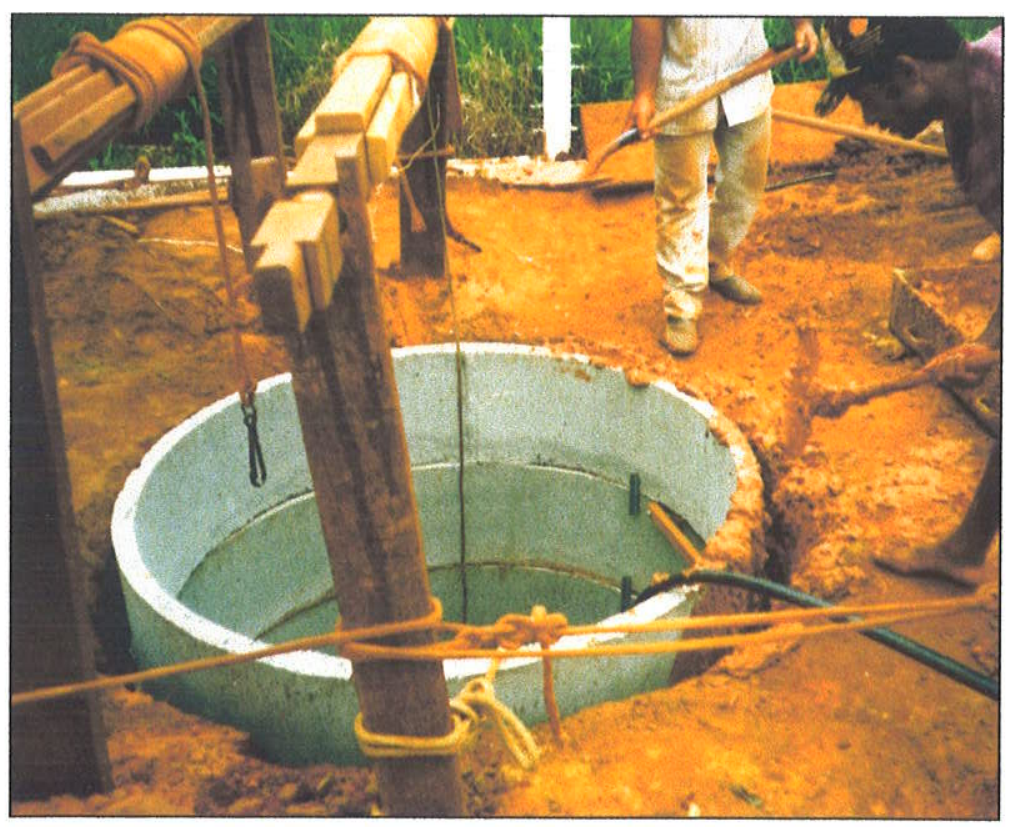

Fotografia 3 - Serviços de colocação de mistura de bentonita com solo de escavação, visando a impermeabilização da parede do poço. 


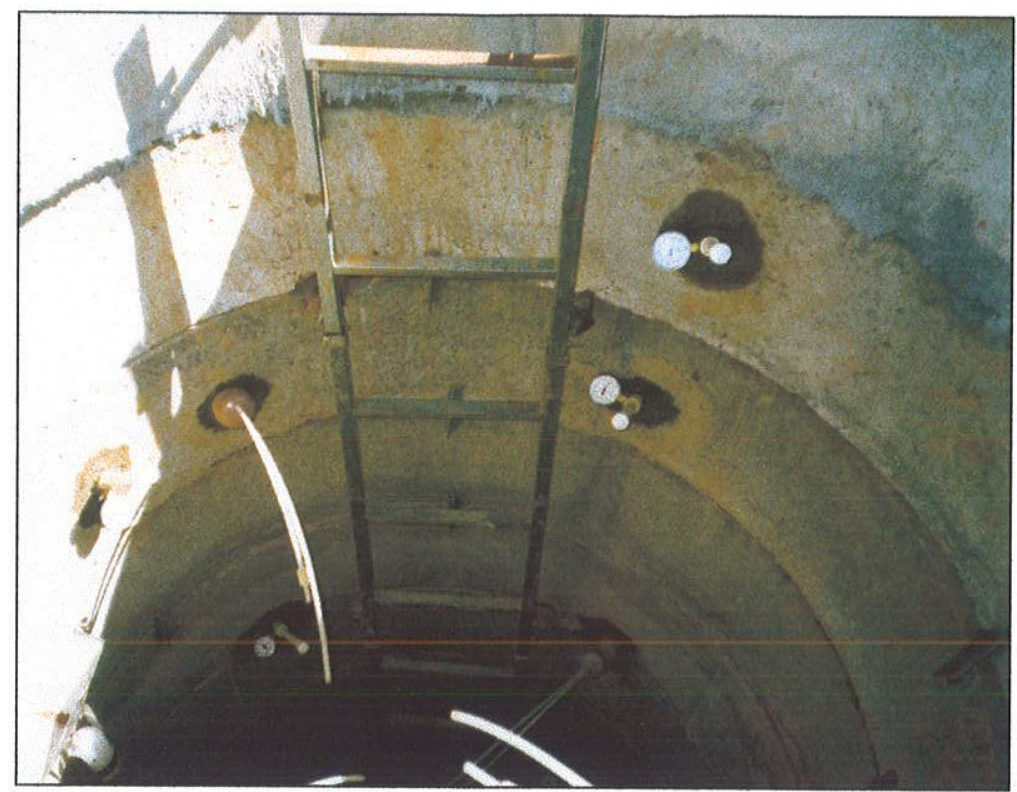

Fotografia 4 - Detalhe da instalação da escada de acesso ao poço e dos equipamentos de monitoramento: tensiômetros com vacuômetros analógicos e lisímetros de sucção instalados em ângulo de $45^{\circ}$ em relação à parede do poço.

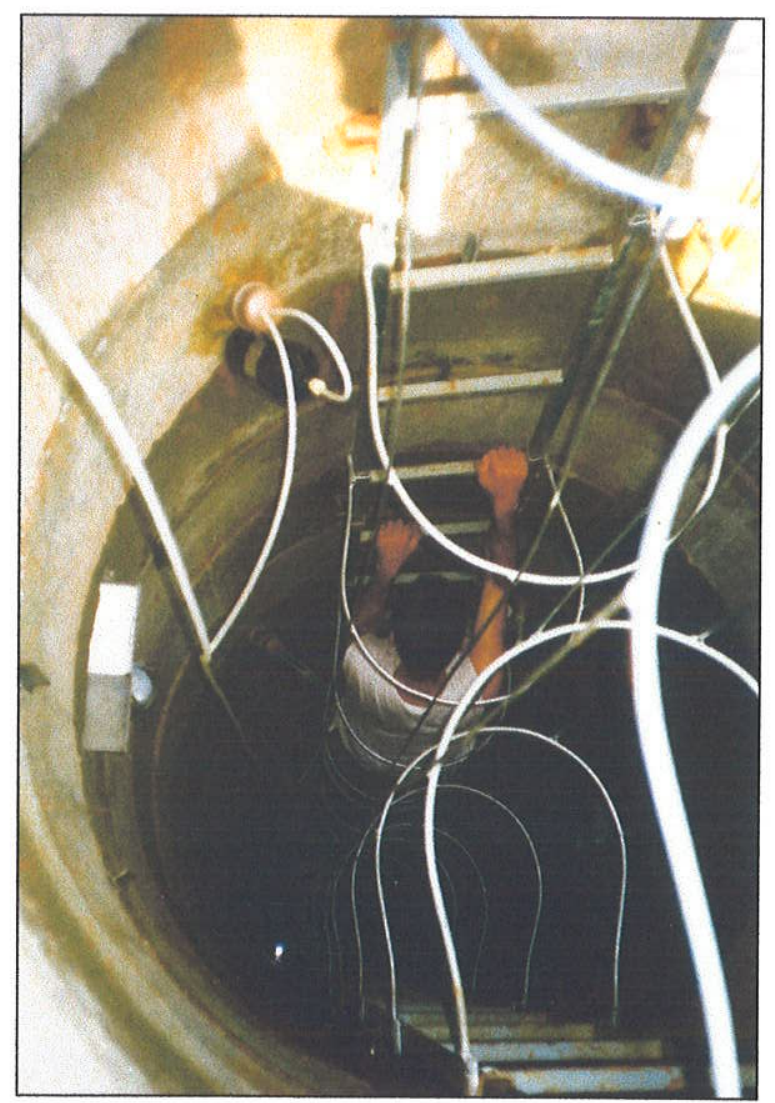

Fotografia 5 - Escada com guarda corpo instalado e lisímetros de sucção equipados com garrafa amostradora e ligados em série durante processo de amostragem. 


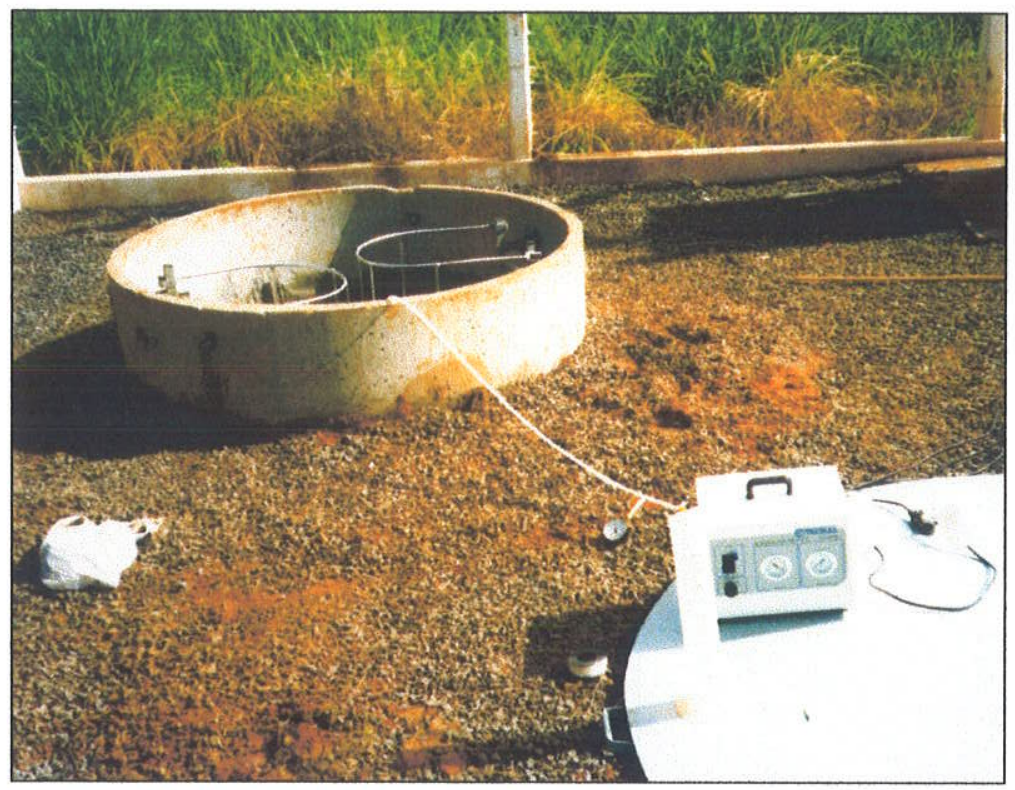

Fotografia 6 - Configuração do poço da estação de monitoramento durante processo de amostragem com uma bomba a vácuo.

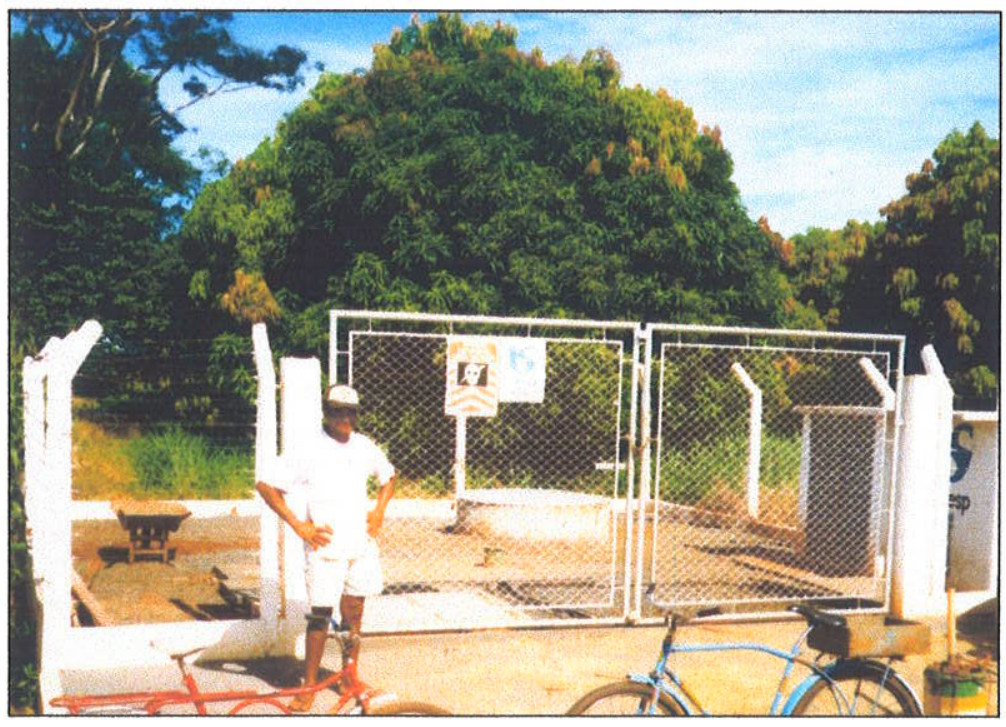

Fotografia 7 - Estação de monitoramento da zona não saturada de Urânia. Notar, em segundo plano, a localização da árvore (mangueira) que foi sacrificada em janeiro/2000. 


\subsection{ANEXO 2-RESULTADOS DE ENSAIOS REALIZADOS NO SOLO}

\begin{tabular}{|c|c|c|c|c|c|c|}
\hline \multicolumn{7}{|c|}{$\begin{array}{c}\text { Resultado dos ensaios granulométricos - método de espectroscopia de } \\
\text { correlação de fótons }\end{array}$} \\
\hline $\begin{array}{l}\text { Profund. } \\
(\mathrm{m})\end{array}$ & $\begin{array}{c}\text { Argila } \\
(<2 \mu \mathrm{m})\end{array}$ & $\begin{array}{l}\text { Silte }(2 \mathrm{a} \\
65,61 \mu \mathrm{m})\end{array}$ & $\begin{array}{c}\text { Areia Fina } \\
(65,61 \mathrm{a} \\
258,95 \mu \mathrm{m})\end{array}$ & $\begin{array}{c}\text { Areia Média } \\
(258,95 \mathrm{a} \\
477,01 \mu \mathrm{m})\end{array}$ & $\begin{array}{c}\text { Areia } \\
\text { Grossa }(> \\
477,01 \mu \mathrm{m})\end{array}$ & $\begin{array}{l}\text { TOTAL } \\
(\%)\end{array}$ \\
\hline 0,2 & 0 & 30,03 & 56,06 & 12,09 & 1,82 & 100 \\
\hline 0,5 & 0 & 16,18 & 64,53 & 17,23 & 2,06 & 100 \\
\hline 1 & 0 & 24,19 & 59,1 & 14,79 & 1,92 & 100 \\
\hline 2 & 0 & 23,94 & 56,31 & 17,34 & 2,41 & 100 \\
\hline 3 & 0 & 30,56 & 49,87 & 17,29 & 2,28 & 100 \\
\hline 4 & 0 & 31,8 & 54,89 & 12,34 & 0,97 & 100 \\
\hline 5 & 0 & 30,67 & 54,92 & 12,93 & 1,48 & 100 \\
\hline 6 & 0 & 31,06 & 55,92 & 11,65 & 1,37 & 100 \\
\hline 7 & 0 & 37,17 & 51,45 & 10,49 & 0,89 & 100 \\
\hline 8 & 0 & 41,42 & 49,19 & 8,52 & 0,87 & 100 \\
\hline 9 & 0 & 30,52 & 60,28 & 8,29 & 0,91 & 100 \\
\hline 9,5 & 0 & 7,47 & 59,33 & 30,91 & 2,29 & 100 \\
\hline 10 & 0 & 22,44 & 47,02 & 24,76 & 5,78 & 100 \\
\hline 10,5 & 0 & 28,08 & 43,92 & 15,32 & 12,68 & 100 \\
\hline 11,5 & 0 & 15,93 & 60,59 & 19,36 & 4,12 & 100 \\
\hline$L 50 C-0,5$ & 0 & 21,11 & 61,97 & 15,19 & 1,73 & 100 \\
\hline$L 50 D-0,5$ & 0 & 21,97 & 62,74 & 13,84 & 1,45 & 100 \\
\hline L5OE - 0,5 & 0 & 25,91 & 54,52 & 17,7 & 1,87 & 100 \\
\hline$L 1 C-1,0$ & 0 & 27,21 & 58,26 & 12,86 & 1,67 & 100 \\
\hline$L 1 D-1,0$ & 0 & 27,44 & 57,41 & 13,58 & 1,57 & 100 \\
\hline$L 1 E-1,0$ & 0 & 24,54 & 58,44 & 14,82 & 2,2 & 100 \\
\hline
\end{tabular}




\begin{tabular}{|c|c|c|c|c|}
\hline \multicolumn{5}{|c|}{ Resultados dos Ensaios de Condutividade Hidráulica - } \\
Amostras Indeformadas de Solo \\
\hline Amostra & Peso Seco (g) & Dens. Solo $\left(\mathrm{g} / \mathrm{cm}^{3}\right)$ & Cond. Hidr. $(\mathrm{mm} / \mathrm{H})$ & Cond. Hidr. (cm/s) \\
\hline $0,2 \mathrm{Za}$ & 117,53 & 1,34 & 116,72 & $3,24 \mathrm{E}-03$ \\
\hline $0,2 \mathrm{Zb}$ & 119,18 & 1,36 & 64,57 & $1,79 \mathrm{E}-03$ \\
\hline $0,2 \mathrm{Zc}$ & 120,26 & 1,37 & 80,08 & $2,22 \mathrm{E}-03$ \\
\hline $0,2 \mathrm{Y}$ & 129,25 & 1,48 & 27,95 & $7,76 \mathrm{E}-04$ \\
\hline $1 \mathrm{Za}$ & 122,85 & 1,4 & 135,19 & $3,76 \mathrm{E}-03$ \\
\hline $1 \mathrm{Zb}$ & & & & $3,56 \mathrm{E}-03$ \\
\hline $1 \mathrm{Zc}$ & & & & $4,00 \mathrm{E}-03$ \\
\hline $3 \mathrm{Za}$ & 123,14 & 1,41 & 92,86 & $2,58 \mathrm{E}-03$ \\
\hline $3 \mathrm{Zb}$ & 117,05 & 1,34 & 106,69 & $2,96 \mathrm{E}-03$ \\
\hline $3 \mathrm{Zc}$ & 110,96 & 1,27 & 173,17 & $4,81 \mathrm{E}-03$ \\
\hline $3 \mathrm{X}$ & 132,05 & 1,51 & 35,94 & $9,98 \mathrm{E}-04$ \\
\hline $3 \mathrm{Y}$ & 126,31 & 1,44 & 52,11 & $1,45 \mathrm{E}-03$ \\
\hline $5 \mathrm{Za}$ & 137,55 & 1,57 & 44,26 & $1,23 \mathrm{E}-03$ \\
\hline $5 \mathrm{Zb}$ & 139,58 & 1,6 & 44,06 & $1,22 \mathrm{E}-03$ \\
\hline $5 \mathrm{Zc}$ & 128,07 & 1,46 & 51,37 & $1,43 \mathrm{E}-03$ \\
\hline $5 \mathrm{X}$ & 139,79 & 1,6 & 24,21 & $6,73 \mathrm{E}-04$ \\
\hline $5 \mathrm{Y}$ & 133,89 & 1,53 & 47,92 & $1,33 \mathrm{E}-03$ \\
\hline $7 \mathrm{Za}$ & 127,84 & 1,46 & 195,66 & $5,44 \mathrm{E}-03$ \\
\hline $7 \mathrm{Zb}$ & 140,7 & 1,61 & 45,44 & $1,26 \mathrm{E}-03$ \\
\hline $7 \mathrm{Zc}$ & 141,08 & 1,61 & 24,47 & $6,80 \mathrm{E}-04$ \\
\hline $7 \mathrm{X}$ & 140,83 & 1,61 & 48,95 & $1,36 \mathrm{E}-03$ \\
\hline $7 \mathrm{Y}$ & 135,74 & 1,55 & 43,92 & $1,22 \mathrm{E}-03$ \\
\hline $9 \mathrm{Za}$ & 139,16 & 1,59 & 3,09 & $8,58 \mathrm{E}-05$ \\
\hline $9 \mathrm{Zb}$ & 135,84 & 1,55 & 5,99 & $1,66 \mathrm{E}-04$ \\
\hline $9 \mathrm{Y}$ & 132,81 & 1,52 & 12,11 & $3,36 \mathrm{E}-04$ \\
\hline $9,5 \mathrm{Za}$ & 152,73 & 1,75 & 91,84 & $2,55 \mathrm{E}-03$ \\
\hline $9,5 \mathrm{Y}$ & 145,67 & 1,67 & 103,45 & $2,87 \mathrm{E}-03$ \\
\hline
\end{tabular}

Ensaios realizados no Laboratório de Física dos Solos e Irrigação/AGAMA/DIGEO - IPT.

\begin{tabular}{|c|c|c|c|c|c|c|}
\hline \multicolumn{6}{|c|}{ Resultados dos Ensaios de Densidade Aparente e de Curvas de Retenção } \\
\hline Amostra & $\mathbf{0 , 0 2}$ atm. & $\mathbf{0 , 0 5}$ atm. & $\mathbf{0 , 1}$ atm. & 1 atm. & 15 atm. & Dens. Apar. (g/cm $\mathbf{c m}^{3}$ \\
\hline $1 \mathrm{~A}-1 \mathrm{~m}$ & 36,75 & 28,34 & 23,24 & 19,88 & 14,56 & 46,04 \\
\hline $1 \mathrm{~B}-1 \mathrm{~m}$ & 37,44 & 29,93 & 24,74 & 20,06 & 15,93 & 42,26 \\
\hline $1 \mathrm{C}-1 \mathrm{~m}$ & 38,08 & 28,46 & 22,72 & 19,97 & 14,71 & 51,32 \\
\hline $3 \mathrm{~A}-3 \mathrm{~m}$ & 41,94 & 34,30 & 25,31 & 22,16 & 12,80 & 44,53 \\
\hline $3 \mathrm{~B}-3 \mathrm{~m}$ & 41,45 & 35,18 & 28,02 & 23,43 & 14,90 & 38,49 \\
\hline $3 \mathrm{C}-3 \mathrm{~m}$ & 40,48 & 32,87 & 23,91 & 18,67 & 12,82 & 45,28 \\
\hline $5 \mathrm{~A}-5 \mathrm{~m}$ & 42,66 & 35,81 & 28,89 & 21,84 & 14,35 & 40,00 \\
\hline $5 \mathrm{~B}-5 \mathrm{~m}$ & 44,74 & 37,22 & 27,70 & 20,15 & 14,50 & 43,77 \\
\hline $5 \mathrm{C}-5 \mathrm{~m}$ & 39,81 & 34,88 & 26,87 & 21,31 & 14,33 & 40,00 \\
\hline $7 \mathrm{~A}-7 \mathrm{~m}$ & 41,93 & 34,82 & 28,47 & 24,25 & 16,53 & 44,91 \\
\hline $7 \mathrm{~B}-7 \mathrm{~m}$ & 44,88 & 37,03 & 29,11 & 22,09 & 15,82 & 44,53 \\
\hline $7 \mathrm{C}-7 \mathrm{~m}$ & 41,80 & 35,32 & 29,51 & 26,57 & 25,37 & 43,02 \\
\hline $9 \mathrm{~A}-9 \mathrm{~m}$ & 44,51 & 40,06 & 37,44 & 33,38 & 27,02 & 41,13 \\
\hline $9 \mathrm{~B}-9 \mathrm{~m}$ & 42,03 & 38,39 & 35,03 & 30,57 & 23,06 & 44,15 \\
\hline $9,5-9,5 \mathrm{~m}$ & 34,82 & 29,28 & 16,96 & 12,09 & 9,58 & 40,75 \\
\hline
\end{tabular}

Ensaios realizados nos laboratórios do Departamento de Ciência do Solo da ESALQ-USP. 


\subsection{ANEXO 3 - DADOS DE MONITORAMENTO DE POTENCIAL MATRICIAL DOS TENSIOOMETROS}

\begin{tabular}{|c|c|c|c|c|c|c|c|c|c|c|c|c|c|c|c|c|c|c|}
\hline \multicolumn{19}{|c|}{ UNIDADES EM $\mathrm{mmHg}$} \\
\hline data & T50 & $T 1$ & T1B & $T 2$ & T3 & $T 3 B$ & T4 & T5 & T6 & 77 & T8 & T9 & T50C & $T 500$ & T5OE & T1C & T1D & T1E \\
\hline $10 / 02 / 99$ & & -75 & & & -120 & & & -120 & & -100 & & -50 & & & & & & \\
\hline $18 / 02 / 99$ & & -100 & & & -140 & & & -120 & & -100 & & -50 & & & & & & \\
\hline 20/03/99 & & -120 & & & -160 & & & -140 & & -120 & & 0 & & & & & & \\
\hline $27 / 03 / 99$ & & -120 & & & -180 & & & -140 & & -120 & & 0 & & & & & & \\
\hline $03 / 04 / 99$ & & -140 & & & -180 & & & -160 & & -120 & & 0 & & & & & & \\
\hline $10 / 04 / 99$ & & -100 & & & -180 & & & -160 & & -120 & & 0 & & & & & & \\
\hline $17 / 04 / 99$ & & -120 & & & -200 & & & -180 & & -140 & & 0 & & & & & & \\
\hline $24 / 04 / 99$ & & -120 & & & -200 & & & -180 & & -140 & & 0 & & & & & & \\
\hline $01 / 05 / 98$ & & -120 & & & -200 & & & -180 & & -140 & & 0 & & & & & & \\
\hline 08/05/99 & & -140 & & & -200 & & & -200 & & -160 & & 0 & & & & & & \\
\hline $15 / 05 / 99$ & -80 & -130 & -120 & -200 & -210 & -190 & -200 & -200 & -160 & -160 & -50 & 0 & & & & & & \\
\hline $22 / 05 / 99$ & -100 & -140 & -100 & -220 & -220 & -200 & -220 & -210 & -160 & -160 & -75 & 0 & & & & & & \\
\hline $26 / 05 / 99$ & -110 & -150 & -160 & -220 & -220 & -210 & -200 & -210 & -160 & -160 & -50 & 0 & & & & & & \\
\hline $29 / 05 / 99$ & -120 & -160 & -170 & -230 & -230 & -210 & -210 & -220 & -180 & -170 & -50 & 0 & & & & & & \\
\hline $02 / 06 / 99$ & -120 & -160 & -160 & -230 & -240 & -200 & -210 & -220 & -170 & -160 & -60 & 0 & & & & & & \\
\hline $05 / 06 / 99$ & -120 & -160 & -180 & \begin{tabular}{|}
-230 \\
\end{tabular} & -240 & -220 & -220 & -220 & -170 & -170 & -50 & 0 & & & & & & \\
\hline $09 / 06 / 99$ & -130 & -170 & \begin{tabular}{|l|}
-180 \\
\end{tabular} & -260 & -260 & -280 & -280 & -280 & -170 & -170 & .60 & 0 & & & & & & \\
\hline $12 / 06 / 99$ & -120 & -180 & -180 & -260 & -280 & -280 & -280 & -260 & -170 & -180 & -60 & 0 & & & & & & \\
\hline $16 / 06 / 99$ & -140 & -180 & -180 & -260 & -270 & -280 & -280 & -260 & -180 & -170 & -60 & 0 & & & & & & \\
\hline $19 / 06 / 99$ & -150 & -190 & -190 & -280 & -270 & -280 & -280 & -260 & -180 & -180 & -60 & 0 & & & & & & \\
\hline $22 / 06 / 99$ & -130 & -180 & -160 & -270 & -260 & -220 & -230 & -240 & -180 & -180 & .60 & 0 & & & & & & \\
\hline $23 / 06 / 99$ & -130 & -180 & -160 & -270 & -240 & -220 & .230 & -240 & -180 & -180 & -60 & 0 & & & & & & \\
\hline $24 / 06 / 99$ & -130 & -180 & -160 & -250 & -260 & -220 & -230 & -250 & -180 & -170 & -60 & 0 & & & & & & \\
\hline $25 / 06 / 99$ & -120 & -180 & -160 & -250 & -260 & -220 & -230 & -250 & -180 & -180 & -60 & 0 & & & & & & \\
\hline $26 / 06 / 99$ & -120 & -180 & -160 & -250 & -260 & -220 & -230 & -250 & -180 & -180 & -60 & 0 & & & & & & \\
\hline $30 / 06 / 99$ & -120 & -190 & -170 & -250 & -270 & -230 & -240 & -260 & -180 & -180 & -60 & 0 & & & & & & \\
\hline $03 / 07 / 99$ & -130 & -190 & -170 & -260 & -270 & -230 & -240 & -260 & -180 & -180 & -60 & 0 & & & & & & \\
\hline $07 / 07 / 99$ & -130 & -200 & -180 & -260 & -280 & -230 & -240 & -260 & -180 & \begin{tabular}{|l|}
-180 \\
\end{tabular} & -60 & 0 & & & & & & \\
\hline $10 / 07 / 99$ & -130 & -200 & -180 & -260 & -280 & -240 & -240 & -270 & -190 & -180 & -60 & 0 & & & & & & \\
\hline $14 / 07 / 99$ & -140 & -200 & -200 & -260 & -290 & -240 & -250 & -280 & \begin{tabular}{|l|}
-190 \\
\end{tabular} & -190 & -75 & 0 & & & & & & \\
\hline $17 / 07 / 99$ & -150 & -210 & -200 & -270 & -300 & -240 & -250 & -280 & -200 & -190 & -75 & 0 & & & & & & \\
\hline $21 / 07 / 99$ & -160 & -210 & -200 & -270 & -300 & -240 & -260 & -300 & -200 & -200 & -75 & 0 & & & & & & \\
\hline $24 / 07 / 99$ & -170 & -220 & -210 & -280 & -300 & -240 & -260 & -300 & -200 & -200 & -75 & 0 & & & & & & \\
\hline $28 / 07 / 99$ & -180 & -230 & -210 & -280 & -310 & -240 & -260 & -310 & -200 & -200 & -75 & 0 & & & & & & \\
\hline $31 / 07 / 99$ & -180 & -240 & -220 & -280 & -320 & -240 & -250 & -320 & -210 & -200 & -75 & 0 & & & & & & \\
\hline $04 / 08 / 89$ & -200 & -240 & -220 & -290 & -320 & -250 & -270 & \begin{tabular}{|l|} 
\\
\end{tabular} & -210 & -200 & -75 & 0 & & & & & & \\
\hline $07 / 08 / 99$ & -200 & -260 & -220 & -290 & -330 & -250 & -280 & -340 & -210 & -200 & -75 & 0 & & & & & & \\
\hline $13 / 08 / 99$ & -220 & -270 & -230 & -300 & -340 & -260 & -280 & $\mathbf{- 3 5 0}$ & -220 & -220 & -90 & -5 & & & & & & \\
\hline $14 / 08 / 99$ & -200 & -280 & -240 & -300 & -340 & -260 & -290 & -350 & -220 & -220 & -90 & -5 & -190 & -220 & -320 & -380 & -350 & -420 \\
\hline $18 / 08 / 99$ & -230 & -280 & -240 & -310 & -350 & -260 & -290 & \begin{tabular}{|l|}
-370 \\
\end{tabular} & \begin{tabular}{|l|}
-230 \\
\end{tabular} & -220 & -100 & -5 & -270 & \begin{tabular}{|l|}
-270 \\
\end{tabular} & -380 & -440 & -400 & -490 \\
\hline $21 / 08 / 99$ & -240 & -300 & -250 & -310 & -360 & -260 & -300 & -370 & -230 & -220 & -100 & -5 & -280 & -280 & -410 & -480 & -440 & -520 \\
\hline $25 / 08 / 99$ & -260 & -310 & -260 & -320 & -370 & -270 & -300 & \begin{tabular}{|l|}
-390 \\
\end{tabular} & -240 & -230 & -100 & -5 & -270 & -300 & -450 & -510 & -460 & -550 \\
\hline $28 / 08 / 99$ & -260 & -320 & -260 & -330 & -370 & -280 & -300 & -400 & -240 & -240 & -100 & -10 & -300 & -300 & -460 & -520 & .480 & -560 \\
\hline $01 / 09 / 99$ & -290 & -330 & -270 & -330 & -360 & -280 & -310 & -420 & -260 & -240 & -110 & -25 & -300 & -300 & -490 & -540 & -480 & -580 \\
\hline $05 / 09 / 99$ & -300 & -340 & -270 & -320 & -380 & -280 & -310 & -430 & -260 & -250 & -110 & -25 & -280 & -300 & -490 & -540 & -490 & -580 \\
\hline $08 / 09 / 99$ & \begin{tabular}{|l|}
-320 \\
\end{tabular} & -340 & -270 & -330 & -360 & \begin{tabular}{|l|}
280 \\
\end{tabular} & -320 & -440 & -270 & -260 & -120 & -25 & -320 & -320 & -500 & -560 & -500 & .600 \\
\hline $11 / 09 / 99$ & -330 & -350 & -280 & 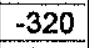 & -390 & -280 & -320 & -450 & -280 & -270 & -120 & -25 & -200 & -300 & -500 & -570 & -500 & -620 \\
\hline $15 / 09 / 99$ & -360 & -370 & -290 & -340 & -400 & -280 & -320 & -470 & -280 & -280 & -120 & -25 & -200 & \begin{tabular}{|l|}
320 \\
\end{tabular} & -540 & -580 & -520 & -640 \\
\hline $16 / 09 / 99$ & -350 & -370 & -290 & -330 & -400 & -280 & -320 & -470 & -280 & -280 & -120 & -25 & -200 & -300 & \begin{tabular}{|l|}
-530 \\
\end{tabular} & -570 & .500 & -630 \\
\hline $17 / 09 / 99$ & -360 & -380 & -290 & -340 & -400 & -280 & -320 & \begin{tabular}{|l|}
-470 \\
\end{tabular} & -280 & -280 & -120 & -25 & -230 & -300 & -520 & -560 & -480 & -630 \\
\hline $18 / 09 / 89$ & -360 & -380 & -290 & -340 & -400 & -280 & -320 & -470 & -280 & -280 & \begin{tabular}{|l|}
-120 \\
\end{tabular} & -25 & -230 & -300 & -520 & -560 & -480 & -630 \\
\hline $22 / 09 / 99$ & -260 & -380 & -300 & -340 & -400 & -280 & -320 & -480 & -290 & -290 & -120 & -25 & -260 & -320 & -540 & -560 & -490 & -630 \\
\hline $25 / 09 / 99$ & -170 & .380 & -300 & -340 & -400 & -280 & -320 & \begin{tabular}{|l|}
-490 \\
\end{tabular} & -300 & -300 & -120 & -25 & -200 & $\begin{array}{l}-300 \\
\end{array}$ & -540 & -560 & -490 & -630 \\
\hline $29 / 09 / 99$ & -150 & -360 & -300 & -340 & -410 & .290 & -330 & -500 & -300 & -310 & -130 & .35 & -230 & -300 & \begin{tabular}{|l|}
-530 \\
\end{tabular} & -550 & \begin{tabular}{|l|} 
\\
\end{tabular} & -620 \\
\hline $02 / 10 / 99$ & -150 & -350 & -300 & -350 & -430 & -300 & -340 & -520 & -320 & -320 & \begin{tabular}{|l|}
-130 \\
\end{tabular} & -35 & -250 & -300 & -530 & .560 & -490 & -620 \\
\hline $06 / 10 / 99$ & -150 & -340 & -300 & -350 & -440 & -300 & -350 & -530 & -320 & -320 & -130 & -35 & \begin{tabular}{|l|}
-250 \\
\end{tabular} & -300 & \begin{tabular}{|l|}
-520 \\
\end{tabular} & -550 & .480 & -620 \\
\hline $09 / 10 / 99$ & -160 & .330 & -310 & -360 & -460 & -300 & -360 & -540 & -340 & -340 & \begin{tabular}{|l|}
-140 \\
\end{tabular} & -50 & -180 & -230 & -540 & -580 & -500 & -620 \\
\hline $13 / 10 / 99$ & -160 & -340 & -310 & -370 & -470 & -310 & -370 & -560 & -350 & -350 & -140 & -50 & -200 & -230 & -540 & -580 & -510 & -620 \\
\hline $16 / 10 / 99$ & -160 & -340 & -310 & -370 & -470 & -310 & -370 & -560 & -350 & -350 & -140 & -50 & -200 & \begin{tabular}{|r|}
-230 \\
\end{tabular} & -540 & -580 & -510 & -620 \\
\hline
\end{tabular}




\begin{tabular}{|c|c|c|c|c|c|c|c|c|c|c|c|c|c|c|c|c|c|c|}
\hline \multicolumn{4}{|c|}{$\mathrm{SS} \mathrm{EM} \mathrm{mmHg}$} & & \multirow[b]{2}{*}{$T$} & & \multirow[b]{2}{*}{ T4 } & \multirow[b]{2}{*}{ T5 } & \multirow[b]{2}{*}{ T6 } & \multirow[b]{2}{*}{77} & & & & & & & & \\
\hline & & & & & & & & & & & & & $\mathrm{OC}$ & $\mathrm{DD}$ & $\mathrm{OF}$ & T1C & D & $T 10$ \\
\hline 10 & 18 & & & 80 & -500 & -320 & -400 & -580 & -380 & -380 & -150 & -60 & 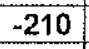 & -240 & 50 & 100 & & \\
\hline & & & & & & & & 590 & & & & & & & & 90 & 30 & 630 \\
\hline & & & & & 70 & & 30 & -600 & & & & 0 & & -250 & & & & \\
\hline & & & & & & & & 600 & & & & -6 & & 250 & 580 & 610 & 540 & $.64 \mathrm{C}$ \\
\hline & & & & 50 & 00 & 40 & -460 & -600 & & 100 & & -7 & 30 & -230 & & 30 & 50 & \\
\hline & & & 60 & & -600 & 350 & 480 & -610 & 7 & 30 & -16 & -7 & 160 & -230 & 580 & 620 & -570 & -640 \\
\hline & 0 & & 50 & & -600 & & & -610 & . & & & -76 & & & 880 & 320 & 60 & \\
\hline & 90 & & 50 & -460 & -600 & 350 & -480 & 610 & 460 & 30 & -16 & -7 & 180 & -210 & 580 & -620 & -560 & 64 \\
\hline & & & & & -600 & & & & & & & .7 & 80 & 200 & 60 & 10 & 50 & \\
\hline & 40 & & -350 & -470 & -600 & 350 & -48 & -610 & -460 & -440 & 17 & -7 & -180 & -200 & -560 & -610 & -550 & 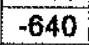 \\
\hline & & & & & & -360 & & & & & & & & -200 & -560 & -620 & & \\
\hline & 4 & & -360 & 480 & -620 & -360 & 00 & -62 & -47 & 10 & 47 & -7 & -200 & -200 & -560 & -620 & -560 & $=$ \\
\hline & & & & & & 60 & & 0 & & & & & & 0 & -560 & & & \\
\hline & 5 & & -370 & 90 & 20 & 600 & 22 & -62 & & 7 & -170 & -7 & -240 & -220 & -560 & -620 & -570 & $\pi$ \\
\hline & & & & & & 60 & & & & & & & & -220 & 00 & & & \\
\hline & 6 & & 370 & 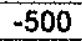 & -63 & 370 & -520 & -630 & 00 & $A B 0$ & & .7 & .310 & .240 & -560 & -620 & 560 & \\
\hline & 6 & & 80 & & & 30 & & -63 & 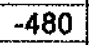 & & & -1 & 500 & -260 & 560 & 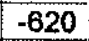 & & \\
\hline & 6 & & 380 & 00 & -630 & 70 & $x$ & -63 & 10 & 100 & & -7 & 350 & -270 & -50 & 630 & -560 & \\
\hline & & & 36 & & & 10 & 15 & 63 & -49 & -40 & & $-\pi$ & 000 & -280 & 000 & 320 & 60 & \\
\hline & 6 & & -38 & -500 & 30 & 80 & 4 & .630 & & 40 & & -7 & -430 & 200 & 500 & 600 & 560 & \\
\hline & & 10 & 38 & & & 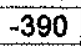 & -550 & -630 & -490 & $4 \pi$ & -10 & -7 & -540 & -340 & -580 & 620 & 00 & \\
\hline & 5 & & -38 & -50 & 30 & 400 & -560 & -640 & -520 & 10 & & -7 & $a 0$ & 510 & 040 & 000 & -560 & \\
\hline & & & -39 & $0<0$ & & 00 & 7 & $64 \mathrm{C}$ & -520 & -490 & 10 & -7 & -600 & -510 & 2 & 610 & & \\
\hline & 0 & & $-4 c$ & 540 & 856 & 30 & 600 & -640 & -540 & 500 & & .8 & 670 & 600 & & & -600 & \\
\hline & 1 & & -40 & -54 & & & 9 & 640 & -540 & & & -8 & -660 & -610 & & 30 & 80 & \\
\hline & 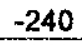 & & 12 & & & & no & -650 & reg & & & -00 & An & & 70 & 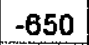 & 00 & -66 \\
\hline & -24 & & & & & & o & -65 & -56 & -52 & -2 & -90 & $-0 c$ & & 570 & -65 & 0 & \\
\hline & & & -42 & & & & & & & & & -90 & 80 & 20 & -590 & & & \\
\hline & 6 & & & & & & & 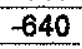 & 55 & -5 & & $-\pi$ & & -460 & -590 & -6 & 60 & \\
\hline & & & & & & & & & .53 & & & & & 170 & 506 & & & \\
\hline & & & & & & & & 0 & -58 & -5 & $-<0$ & -100 & & -48 & 990 & -65 & 30 & \\
\hline & & & & & & & & -62 & & & & & & & & & & \\
\hline & 4 & & 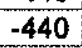 & & & & & & 59 & 2 & -22 & -10 & - & -46 & & -66 & -60 & \\
\hline & & & & & & & & & & & & & & & & & & \\
\hline & 5 & & & & & & & & 59 & -5 & -2 & -10 & & -460 & 000 & & 30 & \\
\hline & & & & & & & & & & -5 & & & & & & & & \\
\hline & & & & & & & & & & & -22 & 10 & & -12 & -63 & & & \\
\hline & & & & & & & & & & & -22 & & 70 & & 40 & & & \\
\hline & & & & & & & & & & & -22 & -10 & $=$ & -12 & -64 & & & \\
\hline & & & & & & & & & & & -2 & & & & & & & \\
\hline & & & & & & & & & & & & & & & & & & \\
\hline & & & & & & & & & & & -22 & & & & & & & \\
\hline & & & & & & & & & & & & & & & & & & \\
\hline & & & & & & & & & & & -2 & & & & 10 & & & \\
\hline & & & & & & & & & & & & & & & & & & \\
\hline & & & & & & & & & & & -2 & & & & & & & \\
\hline & & & & & & & & & & & & & & & & & & \\
\hline & & & & & & & & & & & & & & & & & & \\
\hline & & & & & & & & & & & & & & & & & & \\
\hline & & & & & & & & & & & & & & & & & & \\
\hline & & & & & & & & & & & & & & & & & & \\
\hline & & & & & & & & & & & & & & & & & & \\
\hline & & & & & & & & & & & & & & & & & & \\
\hline & & & & & & & & & & & & & & & & & & \\
\hline & & & & & & & & & & & & & & & 00 & & & \\
\hline & & & & & & & & & & & & & & & & & & \\
\hline & & & & & & & & & -62 & & 2 & & & -100 & -120 & & & 10 \\
\hline & -1 & & & & & & & & & & & & & & & & & \\
\hline & & & & & & & & & & & 20 & & & 100 & 130 & 160 & 160 & \\
\hline
\end{tabular}




\begin{tabular}{|c|c|c|c|c|c|c|c|c|c|c|c|c|c|c|c|c|c|c|}
\hline \multicolumn{19}{|c|}{ UNIDADES EM mmHg } \\
\hline & $T 50$ & 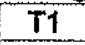 & $\mathrm{T1B}$ & $\mathrm{T2}$ & $T 3$ & T3B & T4 & T5 & T6 & $\pi 7$ & T8 & T9 & $750 \mathrm{C}$ & T50D & T50E & T1C & T1D & TTE \\
\hline $13 / 02 / 00$ & -50 & -75 & -50 & 570 & -640 & -580 & -590 & -630 & -620 & -610 & -200 & -100 & -120 & -75 & -100 & -120 & -130 & -120 \\
\hline $02 / 00$ & -60 & -100 & -50 & -540 & -630 & -580 & -590 & -630 & -620 & .610 & -200 & -100 & -140 & -100 & -120 & -140 & -150 & -140 \\
\hline $15 / 02 / 00$ & -70 & -10 & -50 & -500 & -590 & -570 & -590 & -640 & -620 & -610 & .200 & -100 & -140 & -100 & -120 & -140 & -150 & -140 \\
\hline $16 /$ & -50 & -60 & -50 & -420 & -470 & -570 & -590 & -640 & -620 & -610 & -200 & -100 & -140 & -50 & \begin{tabular}{|l|}
120 \\
\end{tabular} & -160 & -170 & -140 \\
\hline $17 / 02 / 00$ & -50 & -75 & -50 & -330 & -140 & -560 & -580 & -640 & -610 & -620 & -200 & -100 & -130 & -75 & -110 & -120 & \begin{tabular}{|l|}
-140 \\
\end{tabular} & -140 \\
\hline $18 /$ & -60 & -100 & -50 & -220 & -120 & -530 & -580 & -640 & -610 & -620 & -200 & -100 & -140 & -75 & -120 & -140 & -150 & -140 \\
\hline & .75 & -1 & -50 & -150 & -120 & -500 & -580 & -640 & -610 & -620 & .200 & -100 & -170 & -100 & -120 & -160 & -160 & -150 \\
\hline $23 / 02 / 00$ & -75 & -110 & -75 & -130 & -130 & -160 & -580 & -640 & -600 & -620 & -200 & -100 & -160 & -100 & -130 & -160 & -160 & -160 \\
\hline & -80 & & -75 & -130 & -130 & -150 & -580 & -640 & -600 & -620 & -200 & -100 & -200 & -120 & -140 & -180 & -180 & -160 \\
\hline $25 / 02 / 00$ & -50 & -120 & -75 & -130 & -140 & -150 & -580 & -640 & -600 & -620 & -200 & -100 & -150 & -110 & -140 & -180 & -180 & -160 \\
\hline & -60 & & -75 & -130 & -140 & -150 & -580 & -640 & -600 & -620 & -200 & -100 & -160 & -110 & -130 & -180 & -180 & -170 \\
\hline $27 / 02 / 00$ & -60 & -100 & .75 & -130 & -140 & -140 & -570 & -640 & -600 & -620 & -200 & -100 & -160 & -100 & \begin{tabular}{|l|} 
\\
\end{tabular} & -180 & -180 & -170 \\
\hline & -50 & -75 & -75 & -130 & -140 & -140 & -570 & -640 & -600 & -620 & -200 & -100 & -130 & .80 & -100 & -140 & -150 & -130 \\
\hline & .50 & -100 & -50 & -100 & -120 & -140 & -570 & -640 & -600 & -620 & -200 & -100 & -130 & -75 & -110 & -140 & -150 & -130 \\
\hline & -50 & -100 & -50 & -100 & -100 & -140 & -560 & -640 & -600 & -620 & -180 & -100 & -140 & -75 & -110 & -140 & -150 & -140 \\
\hline & -50 & -75 & -50 & -100 & -100 & -140 & -540 & -640 & -590 & -620 & -180 & -100 & -120 & -75 & -100 & -140 & -150 & -120 \\
\hline & -60 & -100 & -50 & -100 & -100 & -130 & -500 & -640 & -590 & -620 & -180 & -100 & -140 & -75 & -120 & -150 & -160 & -140 \\
\hline & -50 & -10 & -50 & -100 & -110 & -130 & -380 & -640 & -590 & -620 & -180 & -100 & -120 & -50 & -100 & -140 & -140 & -140 \\
\hline & -50 & -10 & -50 & -100 & -120 & -120 & -100 & -630 & -590 & -620 & -180 & -100 & -130 & -75 & -110 & -140 & .160 & -130 \\
\hline & -50 & -1 & -50 & -100 & -120 & -120 & -100 & -620 & -590 & -620 & -180 & -75 & -130 & -75 & -110 & -140 & -160 & -130 \\
\hline & -60 & -10 & -60 & -110 & -110 & -120 & -100 & -620 & -590 & -620 & -170 & -75 & -140 & -80 & -120 & -150 & -160 & -140 \\
\hline & -75 & -10 & -50 & -110 & -120 & -120 & -100 & -610 & -580 & -620 & -170 & -75 & -150 & -100 & -120 & -160 & -160 & -140 \\
\hline & -75 & -10 & -75 & -120 & -120 & -120 & -100 & -600 & -580 & -620 & -160 & -60 & -140 & -100 & -120 & -160 & -160 & -140 \\
\hline & .75 & -1 & .75 & -110 & -120 & -120 & -100 & -590 & -580 & -620 & -160 & -6 & -140 & -100 & -120 & -160 & -160 & -140 \\
\hline 12 & -75 & 4 & -75 & -120 & -130 & -130 & -100 & -580 & \begin{tabular}{|l}
-580 \\
\end{tabular} & -62 & -160 & -50 & -140 & -100 & -120 & -170 & -170 & -150 \\
\hline & -75 & & -75 & -120 & -140 & -130 & -100 & -560 & -580 & -610 & -160 & -50 & -160 & -100 & -130 & -170 & -180 & -160 \\
\hline 14 & -75 & -1 & -75 & -130 & -140 & -130 & -110 & -540 & -580 & -620 & -160 & -5 & -150 & -100 & -130 & \begin{tabular}{|l|}
-170 \\
\end{tabular} & -170 & -160 \\
\hline & .75 & & -75 & -130 & -140 & -130 & -110 & -510 & -580 & -620 & -160 & $\pi$ & -160 & -100 & -130 & -170 & -180 & 160 \\
\hline 16 & -75 & -1 & -75 & -130 & -140 & -140 & \begin{tabular}{|l|}
-110 \\
\end{tabular} & -480 & -560 & -62 & -150 & -5 & -160 & -120 & -130 & -160 & -180 & -170 \\
\hline & -75 & -1 & -75 & -140 & -150 & -140 & -120 & -440 & -530 & -62 & -150 & -5 & -160 & .120 & -140 & -180 & -180 & -170 \\
\hline $18 / 0$ & .75 & -1 & -75 & -140 & -150 & -140 & -120 & -370 & -440 & -62 & -140 & -3 & -160 & -100 & -130 & -180 & -180 & -160 \\
\hline & -50 & -10 & .75 & -140 & -160 & -140 & -120 & -260 & -120 & -62 & -140 & -3 & -140 & -75 & -110 & -150 & -150 & -13 \\
\hline & -50 & -100 & -75 & -140 & -160 & -140 & \begin{tabular}{|l|}
-120 \\
\end{tabular} & -190 & -110 & -62 & -140 & -3 & -150 & -80 & -110 & -160 & -160 & -130 \\
\hline & -60 & -1 & -60 & -130 & -150 & -150 & \begin{tabular}{|l|}
-120 \\
\end{tabular} & -150 & -100 & -62 & 140 & -3 & -160 & -100 & -120 & -170 & -170 & -14 \\
\hline & -60 & -100 & -60 & -130 & -150 & -150 & -120 & -140 & -100 & -61 & -140 & -3 & -160 & -100 & -120 & -170 & -180 & -14 \\
\hline & -75 & -11 & -75 & -130 & -140 & -150 & -130 & -120 & -100 & -60 & -130 & -2 & -170 & -110 & -130 & -180 & -180 & \\
\hline & -75 & & -60 & -130 & -140 & -140 & -130 & -120 & -100 & -57 & -130 & -2 & -180 & -120 & -130 & -180 & -180 & -16 \\
\hline & -75 & -11 & -60 & -130 & -140 & -150 & -130 & -120 & -100 & -49 & -130 & -2 & \begin{tabular}{|l|}
-180 \\
\end{tabular} & -110 & -130 & -180 & .180 & \\
\hline & -40 & -1 & -75 & -140 & -140 & -150 & -130 & -120 & -100 & -39 & -120 & -2 & -110 & -50 & .100 & -170 & -180 & -160 \\
\hline & -50 & -80 & -75 & -140 & -140 & -150 & -130 & -120 & -10 & -40 & -120 & -2 & -120 & -75 & -100 & 0 & -140 & \\
\hline & -50 & -80 & -60 & -140 & -140 & -150 & -130 & -120 & -100 & -34 & -110 & -2 & -130 & 10 & -100 & -150 & -140 & -12 \\
\hline & -60 & -10 & -60 & -130 & -140 & 150 & -130 & -120 & -1 & -1 & -100 & -2 & -140 & -100 & & & 50 & \\
\hline & -60 & & -60 & -130 & -140 & -150 & -130 & -120 & -10 & -15 & -80 & -2 & -150 & -100 & -110 & -150 & -150 & -1 \\
\hline & -75 & -1 & -60 & -120 & -140 & -150 & -130 & -120 & -10 & -12 & -7 & -1 & -160 & -100 & & & -160 & \\
\hline & -75 & & -60 & 20 & -140 & -140 & -130 & -120 & -100 & -11 & -6 & -1 & -160 & -100 & -120 & -160 & -160 & 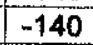 \\
\hline & -75 & -110 & -75 & 30 & 40 & 140 & -130 & -120 & -10 & 11 & -5 & -1 & & -100 & 0 & & -160 & \\
\hline & -75 & -1 & .75 & 30 & -140 & -140 & -130 & -120 & -100 & -11 & -30 & -1 & -180 & -120 & -130 & 180 & -180 & -16 \\
\hline 00 & -80 & 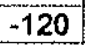 & -75 & .140 & 60 & $\Delta 0$ & 130 & -120 & 40 & & -3 & -1 & -2 & -130 & 50 & 90 & 30 & 80 \\
\hline & -100 & 135 & -100 & 50 & -160 & -155 & -130 & -120 & -100 & -10 & -26 & 0 & -220 & -140 & -160 & -18 & ก & 1 \\
\hline 20 & 100 & 30 & 00 & 50 & 60 & 60 & -135 & -120 & -1 & & -2 & & -220 & -140 & -170 & 00 & 200 & 90 \\
\hline & 100 & -140 & -100 & 70 & -180 & -170 & -140 & -140 & -100 & -11 & -2 & & -220 & -140 & -200 & -220 & 200 & \\
\hline & 10 & & -110 & 70 & 80 & 70 & -150 & -14 & -1 & -11 & -2 & & -240 & -180 & -220 & 30 & -210 & -230 \\
\hline & -110 & -150 & -120 & -180 & -190 & -180 & -150 & -140 & -110 & -11 & -26 & 1 & -280 & -240 & -260 & 250 & -220 & \\
\hline & & & 130 & 90 & 00 & -190 & -160 & -150 & -120 & -1 & -25 & & -320 & -300 & 310 & 270 & -240 & -260 \\
\hline & 120 & -160 & -130 & -190 & -200 & -200 & -160 & -150 & -120 & -12 & -40 & 8 & -380 & 380 & -360 & -300 & -260 & \\
\hline & 20 & & 40 & 200 & 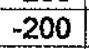 & -200 & -17 & 16 & -12 & -12 & -50 & & -440 & -440 & -420 & -320 & -280 & -320 \\
\hline & 30 & 80 & 140 & -200 & -210 & -200 & -170 & -160 & -12 & -13 & -5 & 1 & -470 & -480 & $A \Delta 0$ & 340 & 00 & 60 \\
\hline & 140 & -190 & 150 & $=0$ & -220 & -200 & -180 & -160 & -130 & 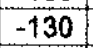 & -50 & & -530 & 540 & -500 & -380 & -340 & -410 \\
\hline $105 / 00$ & -140 & 90 & 150 & 200 & -220 & -200 & 80 & 160 & -130 & 30 & -50 & & -540 & 550 & 520 & 390 & -350 & -43 \\
\hline
\end{tabular}




\begin{tabular}{|c|c|c|c|c|c|c|c|c|c|c|c|c|c|c|c|c|c|c|}
\hline \multicolumn{19}{|c|}{ JNIDADES EM mmHg } \\
\hline data & 50 & $\mathrm{T1}$ & T1B & $\mathrm{T} 2$ & $T 3$ & T3B & T4 & T5 & T6 & $\mathrm{T} 7$ & T8 & T9 & T50C & T500 & T50E & T1C & T1D & 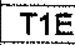 \\
\hline $20 / 05 / 00$ & -140 & -200 & -160 & -210 & -230 & -210 & -180 & -170 & 130 & -130 & -50 & 0 & -560 & -560 & -540 & -410 & -360 & -460 \\
\hline $24 / 05 / 00$ & 50 & 00 & & 220 & 240 & -220 & -190 & & & & 50 & & -580 & -580 & -560 & -430 & -380 & -500 \\
\hline & 140 & 200 & 80 & 230 & -240 & -220 & -200 & -180 & 140 & 140 & -50 & $c$ & -600 & -600 & -590 & -460 & -410 & -550 \\
\hline $1 / 05 / 00$ & 140 & -210 & -180 & -230 & -240 & -220 & -200 & -180 & 140 & 140 & -50 & & -600 & -600 & -600 & -470 & -410 & -550 \\
\hline & 150 & -220 & -190 & -240 & -250 & -230 & -200 & -180 & 140 & -140 & -60 & 0 & -610 & -600 & -600 & -480 & -420 & \\
\hline $5 / 00$ & 160 & -220 & -200 & -240 & -260 & -240 & -200 & -180 & 150 & 140 & -60 & & -810 & -600 & -600 & -500 & 140 & 580 \\
\hline & 160 & -230 & -200 & -240 & -270 & -240 & -210 & -190 & -150 & -140 & -60 & 0 & -610 & -600 & -610 & -510 & 440 & 0 \\
\hline 100 & 160 & -230 & -210 & -250 & -270 & -250 & -210 & -200 & -150 & -140 & -60 & -5 & -610 & -600 & -610 & -510 & 450 & -610 \\
\hline & 160 & -230 & -220 & -260 & -280 & -260 & -220 & -200 & -150 & .150 & .60 & -5 & -620 & & -620 & -520 & -460 & 67 \\
\hline & 170 & -240 & -230 & -260 & -290 & -270 & -220 & -200 & -150 & -150 & -60 & -10 & -630 & & -630 & -530 & 470 & 630 \\
\hline & 90 & 60 & -240 & -270 & -300 & -280 & -230 & -200 & -160 & 150 & -70 & -10 & -640 & & -640 & -540 & -480 & 640 \\
\hline $3 / 00$ & 190 & -270 & -250 & -280 & -300 & -280 & -230 & -200 & -160 & -150 & -75 & -10 & -640 & & & -550 & 480 & 650 \\
\hline & 90 & -280 & -260 & -280 & -310 & -290 & -240 & -200 & -160 & -160 & -75 & -15 & .640 & & & -550 & -480 & -660 \\
\hline & 90 & -290 & -270 & -290 & -320 & -290 & -240 & -200 & -160 & -160 & -75 & -15 & -640 & -610 & & -560 & 490 & -660 \\
\hline & 100 & 300 & -280 & -300 & -330 & -300 & -250 & -210 & 170 & 160 & -75 & -20 & -650 & -610 & & 70 & 510 & 660 \\
\hline & 20 & -320 & -300 & 320 & -340 & -320 & -260 & -220 & -170 & -160 & -80 & -20 & -670 & -630 & 330 & 300 & 540 & \\
\hline & 20 & 320 & -300 & 320 & -340 & -320 & -260 & -220 & 170 & 60 & -80 & -20 & -670 & -630 & -630 & 00 & 540 & \\
\hline & 30 & -320 & -310 & -320 & -350 & -330 & -260 & -220 & -170 & -160 & -80 & -20 & -670 & -630 & -640 & 600 & 550 & \\
\hline & 440 & -330 & -320 & -330 & -360 & -340 & -270 & -230 & 180 & 170 & -80 & -20 & -680 & -640 & -650 & -600 & 50 & \\
\hline & 80 & -330 & -320 & -330 & -360 & -340 & -270 & -230 & -180 & -170 & -85 & -20 & -670 & -630 & -650 & -600 & -560 & -640 \\
\hline & 40 & 340 & -320 & -330 & -360 & -340 & -270 & -230 & -180 & 170 & .85 & -20 & -660 & -620 & -640 & -600 & 60 & 640 \\
\hline & 50 & -360 & -330 & -340 & -380 & -370 & -280 & -240 & -180 & -170 & -100 & 20 & & & -640 & -600 & 560 & 650 \\
\hline & 60 & 360 & -340 & -340 & -380 & -370 & -280 & -240 & -180 & 170 & 100 & -20 & & & -640 & -620 & 570 & 660 \\
\hline & 70 & 880 & -340 & -350 & -400 & -380 & -280 & -240 & -190 & -170 & 100 & & & & .640 & -620 & 570 & 660 \\
\hline & 70 & 190 & .350 & -360 & -400 & -390 & -290 & -250 & 190 & 80 & 100 & -35 & & & & & 80 & 670 \\
\hline & 70 & 100 & 360 & -360 & -410 & -400 & -300 & -250 & 190 & 80 & 100 & -40 & 500 & -510 & 10 & 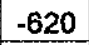 & 80 & 370 \\
\hline & 80 & 00 & -360 & -360 & -420 & -400 & -300 & -250 & -190 & 180 & 100 & 45 & 510 & -520 & 540 & -630 & 80 & 670 \\
\hline & 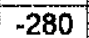 & & -360 & -360 & -420 & & -300 & -250 & -190 & 180 & 100 & & -510 & -5 & $=0$ & & & 670 \\
\hline & 80 & -42 & -360 & -370 & -430 & -410 & -300 & -250 & -200 & 80 & 100 & -50 & 510 & -52 & 80 & 20 & 80 & \\
\hline & 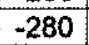 & & -380 & -380 & -440 & & 310 & 130 & -200 & 80 & 10 & & & -5 & 20 & & & \\
\hline & 60 & 440 & -390 & -380 & -440 & -430 & -310 & -260 & 200 & 80 & 10 & -50 & -520 & -560 & 20 & -620 & 90 & 620 \\
\hline & & & -400 & -390 & & & & & 200 & & & & & -5 & & & & \\
\hline & 10 & -44 & -400 & -390 & -450 & -4 & -310 & -26 & -200 & 180 & 11 & $-5 c$ & 520 & -5 & & -640 & 600 & \\
\hline & -80 & & -400 & -400 & 10 & & & -2 & & & & & & -5 & & & & \\
\hline & -5 & -4 & -400 & -400 & -45 & -4 & -32 & -270 & 200 & 90 & 11 & & 470 & -5 & & & & \\
\hline & -75 & & -400 & -400 & i & & -320 & -270 & & & & & & -2 & & & & \\
\hline & -60 & & -400 & -400 & -4 & 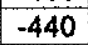 & 20 & -270 & 200 & & 11 & & 60 & -1 & & & 590 & \\
\hline & .6 & & -360 & -400 & -46 & -44 & -32 & -27 & & & & & 0 & & & & & \\
\hline & -75 & & -300 & -400 & -46 & & -320 & 37 & & & & & 180 & -1 & & & & \\
\hline & -8 & & -2 & -360 & -46 & -44 & -32 & -270 & & 90 & 17 & & 200 & -1 & & -520 & 80 & \\
\hline & $=$ & & & -330 & -46 & & & -27 & & & & & 000 & & & & & \\
\hline & 00 & & -1 & -280 & -46 & -4 & -32 & -27 & & & 17 & & 200 & & & 50 & 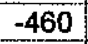 & \\
\hline & & & & 30 & & & & & & & & & & & & & & \\
\hline & -100 & & -1 & -200 & -440 & & -32 & -28 & 00 & & & & 0 & & & 0 & 0 & \\
\hline & $\pi$ & & & & & & & & & & & & & & & & & \\
\hline & -100 & -1 & -100 & -170 & -380 & & -320 & -280 & 10 & 00 & 120 & -60 & -200 & & & -200 & 00 & \\
\hline & & & & & & & & & & & & & & & & & & \\
\hline & -1 & -14 & -7 & -18 & -300 & -380 & -320 & -280 & & 00 & & -60 & -200 & -1 & & 90 & 00 & \\
\hline & -10 & -1 & 1 & -18 & & & & 78 & & & & -6 & -200 & -1 & & & & \\
\hline & -1 & & & -18 & -260 & & -320 & -280 & & -200 & & -65 & -200 & & & -200 & 00 & \\
\hline & 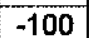 & -1 & 5 & -18 & -25 & -35 & -32 & -280 & $?$ & & & & -200 & -2 & & -200 & 00 & \\
\hline & 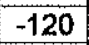 & & & -12 & -240 & -3 & 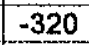 & -290 & & & & & -280 & & & -240 & 30 & \\
\hline & 12 & -16 & -12 & -19 & -25 & -3 & -32 & -290 & & & & -75 & -330 & -3 & & 260 & 30 & \\
\hline & -12 & & & -2 & & & & & & & & & 40 & & & 200 & & \\
\hline & 100 & {$[-15$} & -14 & -21 & -260 & -33 & -3 & -290 & -2 & -200 & & -8 & -260 & -400 & & 60 & 00 & \\
\hline & -80 & & & 2 & -270 & -3 & & & -2 & & & & -240 & & & & & \\
\hline & -75 & -14 & -1 & -220 & -280 & .33 & -31 & -290 & -200 & -200 & -1 & -8 & -200 & -40 & & -380 & 00 & \\
\hline & -10 & -12 & -1 & -2 & -3 & -3 & -3 & -2 & -2 & -2 & & & 1 & & & & & \\
\hline $1 / 11 / 00$ & -100 & -140 & -150 & -240 & -320 & -340 & -32 & -300 & -220 & -210 & -13 & -85 & -180 & -380 & & -410 & -370 & \\
\hline
\end{tabular}




\begin{tabular}{|c|c|c|c|c|c|c|c|c|c|c|c|c|c|c|c|c|c|c|}
\hline \multicolumn{19}{|c|}{ UNIDADES EM mmHg } \\
\hline data & T50 & $\mathrm{T} 1$ & T1B & T2 & T3 & $\mathrm{T} 3 \mathrm{~B}$ & T4 & T5 & T6 & 77 & T8 & T9 & T50C & T50D & T50E & T1C & T1D & T1E \\
\hline $13 / 11 / 00$ & -75 & -140 & -160 & -250 & -330 & -340 & -320 & -300 & -220 & -210 & -130 & -90 & -200 & -370 & & -440 & -410 & \\
\hline $15 / 11 / 00$ & -60 & -100 & -160 & -260 & -340 & -350 & -330 & -310 & -230 & -210 & -140 & -100 & -160 & -260 & & -450 & -420 & \\
\hline $18 / 11 / 00$ & -50 & -80 & -160 & -280 & -350 & -350 & -330 & -320 & -230 & -210 & -140 & -100 & -140 & -100 & & -470 & -430 & \\
\hline $22 / 11 / 00$ & -50 & -80 & -100 & -250 & -350 & -350 & -340 & -320 & -230 & -210 & -140 & -100 & -140 & -100 & & -350 & -440 & \\
\hline $25 / 11 / 00$ & -60 & -100 & -75 & -240 & -350 & -360 & -350 & -330 & -230 & -220 & -140 & -100 & -160 & -120 & & -240 & -460 & \\
\hline $29 / 11 / 00$ & -65 & -100 & -75 & -220 & -340 & -360 & -360 & -330 & -240 & -220 & -140 & -100 & -160 & -120 & & -200 & .460 & \\
\hline $04 / 12 / 00$ & -65 & -100 & -75 & -170 & -270 & -360 & -360 & -340 & -240 & -220 & -140 & -100 & -160 & -120 & & -180 & -440 & \\
\hline $06 / 12 / 00$ & -75 & -110 & -75 & -160 & -240 & -350 & -370 & -340 & -240 & -220 & -140 & -100 & -170 & -130 & & -170 & -390 & \\
\hline $09 / 12 / 00$ & -80 & -120 & -75 & -160 & -220 & -340 & -380 & -340 & -240 & -220 & -150 & -100 & -190 & -140 & & -200 & -320 & \\
\hline $13 / 12 / 00$ & -75 & -120 & -100 & -170 & -220 & -320 & -390 & -350 & -240 & -230 & -150 & -100 & -140 & -75 & & -140 & -160 & \\
\hline $16 / 12 / 00$ & -50 & -75 & -100 & -160 & -210 & -300 & -390 & -350 & -240 & -230 & -150 & -100 & -140 & -80 & & -140 & -140 & \\
\hline $20 / 12 / 00$ & .60 & -100 & -50 & -120 & -160 & -260 & -380 & -360 & -250 & -230 & -150 & -100 & -140 & .80 & & -140 & -140 & \\
\hline $23 / 12 / 00$ & .60 & -100 & -50 & -120 & -140 & -220 & -360 & -360 & -250 & -230 & -150 & -100 & -150 & -90 & & -150 & -150 & \\
\hline $27 / 12 / 00$ & -75 & -110 & -60 & -120 & -140 & -190 & -340 & -370 & -250 & -230 & -150 & -100 & -160 & -100 & & -160 & -160 & \\
\hline $30 / 12 / 00$ & .85 & -120 & -75 & -130 & -140 & -160 & -180 & -370 & -250 & -240 & -150 & -100 & -170 & -120 & & -180 & -180 & \\
\hline $03 / 01 / 01$ & -85 & -120 & -75 & -130 & -150 & -160 & -170 & -370 & -250 & -240 & -160 & -100 & -160 & -110 & & -180 & .180 & \\
\hline $06 / 01 / 01$ & -75 & -120 & -80 & -140 & -160 & -160 & -160 & -370 & -250 & -240 & -160 & -100 & -140 & -100 & & -160 & -180 & \\
\hline $11 / 01 / 01$ & -75 & -120 & -100 & -160 & -170 & -160 & -150 & -350 & -250 & -240 & -160 & -100 & -160 & -110 & & -170 & -170 & \\
\hline $14 / 01 / 01$ & -75 & -120 & -100 & -160 & -180 & -160 & -150 & -320 & -250 & -240 & -160 & -100 & -160 & -120 & & -170 & -170 & \\
\hline $17 / 01 / 01$ & -75 & -120 & -100 & -160 & -180 & -160 & -150 & -280 & -250 & -240 & -160 & -100 & -170 & -120 & & -170 & -170 & \\
\hline $20 / 01 / 01$ & -100 & -120 & -100 & -170 & -190 & -170 & -150 & -240 & -240 & -240 & -160 & -100 & -180 & -120 & & -170 & -180 & \\
\hline $24 / 01 / 01$ & -75 & -130 & -100 & -180 & -190 & -180 & -160 & -210 & -220 & -240 & -160 & -100 & -180 & -140 & & -200 & -200 & \\
\hline $27 / 01 / 01$ & .75 & -120 & -100 & -180 & -200 & -180 & -160 & -200 & -200 & -250 & -160 & -100 & -160 & -130 & & -200 & -200 & \\
\hline $31 / 01 / 01$ & -75 & -110 & -100 & -190 & -200 & -180 & -160 & -200 & -190 & -250 & -160 & -110 & -160 & -150 & & .200 & -200 & \\
\hline $03 / 02 / 01$ & -80 & -110 & -100 & -190 & -210 & -190 & -160 & -200 & -190 & -250 & -160 & -110 & -160 & -150 & & -200 & -200 & \\
\hline $06 / 02 / 01$ & -80 & -120 & -100 & -190 & -210 & -190 & -170 & -200 & -170 & -250 & -160 & -110 & -170 & -160 & & -210 & -210 & \\
\hline $10 / 02 / 01$ & -75 & -120 & -100 & -200 & -220 & -200 & -180 & -200 & -170 & -250 & -160 & -110 & -170 & -160 & & -220 & -230 & \\
\hline $14 / 02 / 01$ & -80 & -130 & -100 & -200 & -220 & -200 & -180 & -200 & -160 & -240 & -150 & -110 & -190 & -170 & & -240 & -240 & \\
\hline $19 / 02 / 01$ & -80 & -110 & -100 & -200 & -230 & -200 & -180 & -200 & -160 & -240 & -150 & -110 & -180 & -120 & & -240 & -250 & \\
\hline $21 / 02 / 01$ & -60 & -100 & -100 & -200 & -220 & -200 & -190 & -200 & -160 & -240 & -150 & -110 & -160 & -100 & & -220 & -220 & \\
\hline $24 / 02 / 01$ & .75 & -110 & -75 & -200 & -220 & -200 & -200 & -200 & -160 & -240 & -150 & -110 & -190 & -130 & & -180 & -180 & \\
\hline $28 / 02 / 01$ & -80 & -100 & -75 & -180 & -230 & -210 & -200 & -200 & -160 & -240 & -150 & -110 & -180 & -120 & & -160 & -170 & \\
\hline $03 / 03 / 01$ & -80 & -100 & -75 & -180 & -230 & -210 & -200 & -200 & -160 & -230 & -150 & -110 & -180 & -120 & & -160 & -170 & \\
\hline $07 / 03 / 01$ & -60 & -100 & -65 & -170 & -220 & -210 & -200 & -200 & -160 & -230 & -150 & -110 & -180 & -180 & & -160 & -160 & \\
\hline $10 / 03 / 01$ & -50 & -100 & -60 & -170 & -200 & -200 & -200 & -210 & -160 & -230 & -150 & -110 & -130 & -130 & & -140 & -140 & \\
\hline $14 / 03 / 01$ & -50 & -100 & -50 & -160 & -200 & -200 & -200 & -210 & -160 & -230 & -150 & -110 & -110 & -110 & & -130 & -130 & \\
\hline $17 / 03 / 01$ & -50 & -110 & -60 & -150 & -190 & -190 & -200 & -210 & -170 & -230 & -150 & -110 & -140 & -140 & & -130 & -130 & \\
\hline $21 / 03 / 01$ & -60 & -110 & -65 & -130 & -170 & -180 & -180 & -210 & -170 & -230 & -150 & -120 & -160 & -150 & & -140 & -130 & \\
\hline $24 / 03 / 01$ & -75 & -110 & -70 & -130 & -140 & -170 & -160 & -210 & -170 & -230 & -150 & -120 & -180 & -190 & & -150 & -160 & \\
\hline $28 / 03 / 01$ & -85 & -120 & -85 & -130 & -150 & -160 & -150 & -200 & -170 & -230 & -150 & -120 & -180 & -140 & & -170 & -180 & \\
\hline $31 / 03 / 01$ & -100 & -140 & -100 & -140 & -160 & -160 & -140 & -180 & -170 & -220 & -150 & -120 & -180 & -140 & & -200 & -200 & \\
\hline
\end{tabular}




\begin{tabular}{|c|c|c|c|c|c|c|c|c|c|c|c|c|c|c|c|c|c|}
\hline UNID & EM m & & & & & & & & & & & & & & & & \\
\hline data & $T 50$ & $T 1$ & T1B & $\mathrm{T2}$ & T3 & $T 3 B$ & T4 & T5 & 16 & $\pi$ & TB & $\mathrm{Tg}$ & $\mathrm{T} 50 \mathrm{C}$ & TSOD & TSOE & T1C & T10 \\
\hline $10 / 02 / 99$ & & $-1,02$ & & & $-1,63$ & & & $-1,63$ & & $-1,36$ & & $-0,68$ & & & & & \\
\hline $18 / 02 / 99$ & & $-1,36$ & & & $-1,90$ & & & $-1,63$ & & $-1,36$ & & $-0,63$ & & & & & \\
\hline $20 / 03 / 99$ & & $-1,63$ & & & $-2,17$ & & & $-1,90$ & & $-1,63$ & & 0,00 & & & & & \\
\hline $27 / 03 / 99$ & & $-1,63$ & & & $-2,44$ & & & $-1,90$ & & $-1,63$ & & 0,00 & & & & & \\
\hline $03 / 04 / 99$ & & $-1,90$ & & & $-2,44$ & & & $-2,17$ & & $-1,63$ & & 0,00 & & & & & \\
\hline $10 / 04 / 99$ & & $-1,36$ & & & $-2,44$ & & & $-2,17$ & & $-1,63$ & & 0,00 & & & & & \\
\hline $17 / 04199$ & & $-1,63$ & & & $-2,71$ & & & $-2,44$ & & $-1,90$ & & 0,00 & & & & & \\
\hline $24 / 04 / 99$ & & $-1,63$ & & & $-2,71$ & & & $-2,44$ & & $-1,90$ & & 0,00 & & & & & \\
\hline $01 / 05 / 99$ & & $-1,63$ & & & $-2,71$ & & & $-2,44$ & & $-1,90$ & & 0,00 & & & & & \\
\hline $08 / 05 / 99$ & & $-1,90$ & & & $-2,71$ & & & $-2,71$ & & $-2,17$ & & 0,00 & & & & & \\
\hline $15 / 05 / 99$ & -109 & $-1,76$ & $-1,63$ & $-2,71$ & $-2,85$ & $-2,58$ & $-2,71$ & $-2,71$ & $-2,17$ & $-2,17$ & $-0,68$ & 0,00 & & & & & \\
\hline 22105190 & $-1,36$ & $-1,90$ & $-1,36$ & $-2,99$ & $-2,99$ & $-2,71$ & $-2,99$ & $-2,85$ & $-2,17$ & $-2,17$ & $-1,02$ & 0,00 & & & & & \\
\hline $26 / 05 / 99$ & $-1,49$ & $-2,04$ & $-2,17$ & $-2,99$ & $-2,99$ & $-2,85$ & $-2,71$ & $-2,85$ & $.2,17$ & $-2,17$ & $-0,68$ & 0,00 & & & & & \\
\hline $29 / 05 / 99$ & $-1,63$ & $-2,17$ & $-2,31$ & 3,12 & $-3,12$ & $-2,85$ & $-2,85$ & $-2,99$ & $-2,44$ & $-2,31$ & $-0,68$ & 0,00 & & & & & \\
\hline $02 / 06 / 99$ & $-1,63$ & $-2,17$ & $-2,17$ & $-3,12$ & $-3,26$ & $-2,71$ & $-2,85$ & $-2,99$ & $-2,31$ & $-2,17$ & $-0,81$ & 0,00 & & & & & \\
\hline $05 / 06 / 99$ & $-1,63$ & -217 & $-2,44$ & -312 & $-3,26$ & $-2,99$ & $-2,99$ & $-2,99$ & $-2,31$ & $-2,31$ & $-0,68$ & 0,00 & & & & & \\
\hline $09 / 06 / 99$ & $-1,76$ & $-2,31$ & $-2,44$ & $-3,53$ & $-3,53$ & $-3,80$ & $-3,80$ & $-3,80$ & $-2,31$ & $-2,31$ & $-0,81$ & 0,00 & & & & & \\
\hline $19 / 06 / 99$ & $-2,04$ & $-2,58$ & $-2,58$ & $-3,80$ & $-3,66$ & $-3,80$ & $-3,80$ & $-3,53$ & $-2,44$ & $-2,44$ & $-0,81$ & 0,00 & & & & & \\
\hline $22 / 06 / 99$ & $-1,76$ & $-2,44$ & $-2,17$ & 3,66 & $-3,53$ & $-2,99$ & $-3,12$ & 3,26 & $-2,44$ & $-2,44$ & $-0,81$ & 0,00 & & & & & \\
\hline $23 / 06 / 99$ & $-1,76$ & $-2,44$ & $-2,17$ & 3,66 & $-3,26$ & $-2,99$ & $-3,12$ & $-3,26$ & $-2,44$ & $-2,44$ & $-0,81$ & 0,00 & & & & & \\
\hline $24106 / 99$ & $-1,76$ & $-2,44$ & $-2,17$ & $-3,39$ & $-3,53$ & $-2,99$ & $-3,12$ & $-3,39$ & $-2,44$ & $-2,31$ & $-0,81$ & 0,00 & & & & & \\
\hline $25 / 06 / 99$ & $-1,63$ & $-2,44$ & $-2,17$ & $-3,39$ & $-3,53$ & $-2,99$ & $-3,12$ & $-3,39$ & $-2,44$ & $-2,44$ & $-0,81$ & 0,00 & & & & & \\
\hline $26 / 06 / 99$ & $-1,63$ & $-2,44$ & $-2,17$ & 3,39 & $-3,53$ & $-2,99$ & $-3,12$ & $-3,39$ & $-2,44$ & $-2,44$ & $-0,81$ & 0,00 & & & & & \\
\hline $30 / 06 / 99$ & $-1,63$ & $-2,58$ & $-2,31$ & $-3,39$ & $-3,66$ & $-3,12$ & 3,26 & $-3,53$ & $-2,44$ & $-2,44$ & $-0,81$ & 0,00 & & & & & \\
\hline $03 / 07 / 99$ & $-1,76$ & $-2,58$ & $-2,31$ & 3,53 & $-3,66$ & 3,12 & $-3,26$ & $-3,53$ & $-2,44$ & $-2,44$ & $-0,81$ & 0,00 & & & & & \\
\hline 07107199 & $-1,76$ & $-2,71$ & $-2,44$ & $-3,53$ & $-3,80$ & $-3,12$ & $-3,26$ & $-3,53$ & $-2,44$ & $-2,44$ & $-0,81$ & 0,00 & & & & & \\
\hline $10 / 07 / 99$ & $-1,76$ & $-2,71$ & $-2,44$ & $-3,53$ & $-3,80$ & $-3,26$ & $-3,26$ & $-3,66$ & $-2,58$ & $-2,44$ & $-0,81$ & 0,00 & & & & & \\
\hline $14107 / 99$ & $-1,90$ & $-2,71$ & $-2,71$ & $-3,53$ & $-3,94$ & $-3,26$ & $-3,39$ & $-3,80$ & $-2,58$ & $-2,58$ & $-1,02$ & 0,00 & & & & & \\
\hline $17 / 07 / 99$ & $-2,04$ & $-2,85$ & $-2,71$ & $-3,66$ & $-4,07$ & $-3,26$ & $-3,39$ & $-3,80$ & $-2,71$ & $-2,58$ & $-1,02$ & $0, \infty$ & & & & & \\
\hline $21 / 07 / 99$ & $-2,17$ & $-2,85$ & $-2,71$ & $-3,66$ & $-4,07$ & $-3,26$ & $-3,53$ & $-4,07$ & $-2,71$ & $-2,71$ & $-1,02$ & 0,00 & & & & & \\
\hline $2407 / 99$ & $-2,31$ & $-2,99$ & -285 & $-3,80$ & $-4,07$ & $-3,26$ & $-3,53$ & $-4,07$ & $-2,71$ & $-2,71$ & $-1,02$ & 0,00 & & & & & \\
\hline $28 / 07 / 99$ & $-2,44$ & $-3,12$ & $-2,85$ & $-3,80$ & $-4,21$ & $-3,26$ & $-3,53$ & $-4,21$ & $-2,71$ & $-2,71$ & $-1,02$ & 0,00 & & & & & \\
\hline $31 / 07 / 99$ & $-2,44$ & $-3,26$ & $-2,99$ & 3,60 & $-4,34$ & $-3,26$ & $-3,39$ & $-4,34$ & $-2,85$ & $-2,71$ & $-1,02$ & $0, \infty$ & & & & & \\
\hline $04 / 08 / 99$ & $-2,71$ & $-3,26$ & $-2,99$ & $-3,94$ & $-4,34$ & $-3,39$ & $-3,68$ & $-4,34$ & $-2,85$ & $-2,71$ & $-1,02$ & $0, \infty$ & & & & & \\
\hline $07 / 08 / 99$ & $-2,71$ & $-3,53$ & $-2,99$ & $-3,94$ & $-4,48$ & $-3,39$ & $-3,80$ & $-4,61$ & $-2,85$ & $-2,71$ & $-1,02$ & 0,00 & & & & & \\
\hline $21 / 08 / 99$ & 3,26 & $-4,07$ & $-3,39$ & $-4,21$ & $-4,89$ & $-3,53$ & $-4,07$ & $-5,02$ & $-3,12$ & $-2,99$ & $-1,36$ & $-0,07$ & $-3,80$ & $-3,80$ & 5.56 & $.6,51$ & $-5,97$ \\
\hline $25 / 08 / 99$ & $-3,53$ & $-4,21$ & 3,53 & $-4,34$ & 5,02 & $-3,66$ & $-4,07$ & $-5,29$ & 3.26 & $-3,12$ & $-1,36$ & $-0,07$ & 3,66 & $-4,07$ & $-6,11$ & $-6,92$ & $-6,24$ \\
\hline $28 / 08 / 99$ & $-3,53$ & $-4,34$ & $-3,53$ & $-4,48$ & $-5,02$ & $-3,80$ & $-4,07$ & $-5,43$ & 3,26 & $-3,26$ & $-1,36$ & $-0,14$ & $-4,07$ & 4,07 & $-6,24$ & $-7,06$ & $-6,51$ \\
\hline $01 / 09 / 99$ & $-3,94$ & $-4,48$ & $-3,66$ & $-4,48$ & $-4,89$ & $-3,60$ & $-4,21$ & $-5,70$ & $-3,53$ & $-3,26$ & $-1,49$ & $-0,34$ & $-4,07$ & $-4,07$ & $-6,65$ & $-7,33$ & $-6,51$ \\
\hline $05 / 09 / 99$ & $-4,07$ & $-4,61$ & $-3,66$ & $-4,34$ & $-5,16$ & $-3,80$ & $-4,21$ & $-5,84$ & $-3,53$ & $-3,39$ & $-1,49$ & $-0,34$ & $-3,80$ & $-4,07$ & $-6,65$ & $-7,33$ & $-6,65$ \\
\hline $08 / 09 / 99$ & $-4,34$ & $4,6 !$ & 3,66 & $-4,48$ & -489 & $-3,80$ & $-4,34$ & $-5,97$ & $-3,66$ & $-3,53$ & $-1,63$ & $-0,34$ & $-4,34$ & $-4,34$ & $-6,79$ & $-7,60$ & $.6,79$ \\
\hline $11 / 09 / 99$ & $-4,48$ & $-4,75$ & $-3,80$ & $-4,34$ & $-5,29$ & $-3,80$ & $-4,34$ & $-6,11$ & $-3,80$ & $-3,66$ & $-1,63$ & $-0,34$ & $-2,71$ & $-4,07$ & $-6,79$ & $-7,73$ & $-6,79$ \\
\hline $15 / 09 / 99$ & $-4,69$ & $-5,02$ & $-3,94$ & $-4,61$ & $-5,43$ & $-3,80$ & $-4,34$ & $-6,38$ & 3,80 & $-3,80$ & $-1,63$ & $-0,34$ & $-2,71$ & $-4,34$ & $-7,33$ & $-7,87$ & $-7,06$ \\
\hline $16 / 09 / 99$ & $-4,75$ & $-5,02$ & 3,94 & $-4,48$ & $-5,43$ & 3,80 & $-4,34$ & $-6,38$ & 3,60 & 3,60 & $-1,63$ & $-0,34$ & -271 & $-4,07$ & $-7,19$ & $-7,73$ & $-6,79$ \\
\hline $17 / 09 / 99$ & $-4,89$ & $-5,16$ & $-3,94$ & $-4,61$ & $-5,43$ & $-3,80$ & $-4,34$ & $-6,38$ & $-3,80$ & $-3,80$ & $-1,63$ & $-0,34$ & $-3,12$ & $-4,07$ & $-7,06$ & $-7,60$ & $-6,51$ \\
\hline $18 / 09 / 99$ & $-4,89$ & $-5,16$ & $-3,94$ & $-4,61$ & $-5,43$ & $-3,80$ & $-4,34$ & $-6,38$ & $-3,80$ & $-3,80$ & $-1,63$ & $-0,34$ & $-3,12$ & $-4,07$ & $-7,06$ & $-7,60$ & $-6,51$ \\
\hline $22109 / 99$ & $-3,53$ & $-5,16$ & $-4,07$ & $-4,61$ & $-5,43$ & 3,80 & $-4,34$ & $-6,51$ & $-3,94$ & $-3,94$ & $-1,63$ & $-0,34$ & $-3,53$ & $-4,34$ & $-7,33$ & $-7,60$ & $-6,65$ \\
\hline $25 / 09 / 99$ & $-2,31$ & $-5,16$ & $-4,07$ & $-4,61$ & $-5,43$ & $-3,80$ & $-4,34$ & $-6,65$ & 4,07 & 4,07 & $-1,63$ & $-0,34$ & $-2,71$ & $-4,07$ & $-7,33$ & $-7,60$ & $-6,65$ \\
\hline $29 / 09 / 99$ & $-2,04$ & $-4,89$ & $-4,07$ & $-4,61$ & $-5,56$ & $-3,94$ & $-4,48$ & -679 & $-4,07$ & $-4,21$ & $-1,76$ & $-0,47$ & $-3,12$ & $-4,07$ & $-7,19$ & $-7,46$ & $-6,51$ \\
\hline $02 / 10 / 99$ & $-2,04$ & $-4,75$ & $-4,07$ & $-4,75$ & $-5,84$ & $-4,07$ & $-4,61$ & $-7,06$ & $-4,34$ & $-4,34$ & $-1,76$ & $-0,47$ & 3,39 & $-4,07$ & $-7,19$ & $-7,60$ & $-6,65$ \\
\hline $06 / 10 / 99$ & $-2,04$ & $-4,61$ & $-4,07$ & $-4,75$ & $-5,97$ & $-4,07$ & $-4,75$ & $-7,19$ & $-4,34$ & $-4,34$ & $-1,76$ & $-0,47$ & $-3,39$ & $-4,07$ & $-7,06$ & $-7,46$ & $-6,51$ \\
\hline $09 / 10 / 99$ & $-2,17$ & $-4,48$ & $-4,21$ & $-4,89$ & $-6,24$ & $-4,07$ & $-4,89$ & $-7,33$ & $-4,61$ & $-4,61$ & $-1,90$ & $-0,68$ & $-2,44$ & $-3,12$ & $-7,33$ & $-7,87$ & $-6,79$ \\
\hline $13 / 10 / 99$ & $-2,17$ & $-4,61$ & $-4,21$ & $-5,02$ & $-6,38$ & $-4,21$ & $-5,02$ & $-7,60$ & $-4,75$ & $-4,75$ & $-1,90$ & $-0,68$ & $-2,71$ & $-3,12$ & $-7,33$ & $-7,87$ & $-6,92$ \\
\hline $16 / 10 / 99$ & $-2,+7$ & $-4,61$ & $-4,21$ & 5,02 & $-6,38$ & $-4,21$ & $-5,02$ & $-7,60$ & $-4,75$ & $-4,75$ & $-1,90$ & $-0,68$ & $-2,71$ & $-3,12$ & $-7,33$ & $-7,87$ & $-6,92$ \\
\hline $20 / 10 / 99$ & $-2,44$ & $-4,89$ & $-4,34$ & $-5,16$ & $-6,79$ & $-4,34$ & $-5,43$ & $-7,87$ & $-5,16$ & $-5,16$ & $-2,04$ & $-0,81$ & $-2,85$ & $-3,26$ & $-7,60$ & $-8,14$ & $-7,19$ \\
\hline $23 / 10 / 99$ & $-2,58$ & $-5,16$ & $-4,48$ & $-5,56$ & $-7,33$ & $-4,34$ & $-5,56$ & 8,01 & 5,43 & $-5,43$ & $-2,17$ & $-0,81$ & $-2,71$ & $-3,12$ & $-7,60$ & -8.01 & $-7,19$ \\
\hline $27 / 10 / 99$ & $-2,71$ & $-5,43$ & $-4,61$ & $-5,84$ & 4,73 & $-4,48$ & $-5,84$ & $-8,14$ & 5,70 & $-5,43$ & $-2,17$ & $-0,81$ & $-2,31$ & $-3,39$ & $-7,87$ & $-8,28$ & $-7,33$ \\
\hline $30 / 10 / 99$ & $-2,71$ & $-5,43$ & $-4,61$ & 5,84 & $-7,73$ & $-4,48$ & $-5,84$ & $-8,14$ & $-5,70$ & $-5,43$ & $-2,17$ & $-0,81$ & $-2,31$ & $-3,39$ & $-7,87$ & $-8,28$ & $-7,33$ \\
\hline $0 \$ 111 / 99$ & $-1,90$ & $-5,56$ & $-4,75$ & $-6,11$ & $-8,14$ & $-4,61$ & $-6,24$ & $-8,14$ & $-6,11$ & $-5,70$ & $-2,31$ & $-1,02$ & $-2,71$ & $-3,12$ & $-7,87$ & $-8,41$ & $-7,46$ \\
\hline $05 / 11 / 99$ & $-1,90$ & $-5,43$ & $-4,89$ & $-8,24$ & $-8,14$ & $-4,75$ & $-6,51$ & $-8,28$ & $-6,24$ & $-5,84$ & $-2,17$ & $-1,02$ & $-2,17$ & $-3,12$ & $-7,87$ & $-8,41$ & $-7,73$ \\
\hline $06 / 11 / 99$ & $-1,90$ & $-5,16$ & $-4,75$ & $-6,24$ & $-8,14$ & $-4,75$ & $-6,51$ & $-8,28$ & $-6,11$ & $-5,84$ & $-2,17$ & $-1,02$ & $-2,44$ & $-2,85$ & $-7,87$ & $-8,41$ & $-7,60$ \\
\hline $07 / 11 / 99$ & $-1,90$ & $-5,16$ & $-4,75$ & $-6,24$ & $-8,14$ & $-4,75$ & $-6,51$ & $-8,28$ & $-6,24$ & $-5,84$ & $-2,17$ & $-1,02$ & $-2,44$ & $-2,85$ & $-7,87$ & $-8,41$ & $-7,60$ \\
\hline $09 / 11 / 90$ & $-1,90$ & $-4,89$ & $-4,75$ & $-6,38$ & $-8,14$ & $-4,75$ & $-6,51$ & $-8,28$ & $-6,24$ & $-5,97$ & $-2,31$ & $-1,02$ & $-2,44$ & $-2,71$ & $-7,60$ & 8,28 & $-7,46$ \\
\hline $10 / 11 / 99$ & $-1,90$ & $-4,89$ & $-4,75$ & $-6,38$ & -8.14 & $-4,75$ & $-6,51$ & $-8,28$ & $-6,24$ & -5.97 & $-2,31$ & $-1,02$ & $-2,44$ & $-2,71$ & $-7,60$ & $+8,2 B$ & $-7,46$ \\
\hline $12 / 14 / 99$ & $-1,90$ & $-4,48$ & $-4,69$ & $-6,51$ & $-8,41$ & $-4,89$ & $-6,79$ & $-8,41$ & $-6,38$ & $-6,11$ & $-2,31$ & $-1,02$ & $-2,71$ & $-2,71$ & $.7,60$ & $-8,41$ & $-7,60$ \\
\hline $13 / 11 / 99$ & $-1,90$ & $-4,48$ & $-4,89$ & $-6,51$ & $-8,41$ & $-4,89$ & $-6,79$ & $-8,41$ & $-6,38$ & $-6,11$ & $-2,31$ & $-1,02$ & $-2,71$ & $-2,71$ & $-7,60$ & $-8,41$ & $-7,60$ \\
\hline $14 / 11 / 99$ & $-1,90$ & $-4,48$ & $-4,89$ & $-6,51$ & $-8,41$ & $-4,89$ & $-6,79$ & $-8,41$ & $-6,38$ & $-6,11$ & $-2,31$ & $-1,02$ & $-2,99$ & $-2,85$ & $-7,60$ & $-8,41$ & $-7,60$ \\
\hline $15 / 11 / 99$ & $-2,04$ & $-4,34$ & $-5,02$ & $-6,65$ & $-8,41$ & $-4,69$ & $-7,06$ & $-8,41$ & $-6,51$ & $-6,11$ & $-2,31$ & $-1,02$ & $-3,26$ & $-2,99$ & $-7,60$ & $-8,41$ & $-7,73$ \\
\hline $16 / 11 / 99$ & $-2,04$ & $-4,34$ & $-5,02$ & $-6,65$ & $-8,41$ & $-4,89$ & $-7,06$ & $-8,41$ & $-6,51$ & $-6,11$ & $-2,31$ & $-1,02$ & $-3,26$ & $-2,99$ & $-7,60$ & $-8,41$ & $-7,73$ \\
\hline $17 / 11 / 99$ & $-2,17$ & $-4,34$ & $-5,02$ & $-6,79$ & $-6,55$ & $-5,02$ & $-7,06$ & 8,55 & $-6,51$ & $-6,24$ & $-2,44$ & $-1,02$ & $-4,21$ & $-3,26$ & $-7,60$ & $-8,41$ & $-7,60$ \\
\hline $18 / 11 / 99$ & $-2,17$ & $-4,34$ & $-4,89$ & 6,79 & $-8,55$ & $-5,02$ & $.7,06$ & $-8,55$ & $-6,51$ & $-6,24$ & $-2,44$ & $-1,02$ & $-4,48$ & $-3,53$ & $-7,60$ & $-8,41$ & $-7,60$ \\
\hline $19 / 11 / 99$ & $-2,17$ & $-4,34$ & $-4,89$ & $-6,79$ & $-8,55$ & $-5,02$ & $-7,06$ & $-8,55$ & $-6,65$ & $-6,24$ & $-2,44$ & $-1,02$ & $-4,75$ & $-3,66$ & -760 & $-8,41$ & $-7,60$ \\
\hline
\end{tabular}




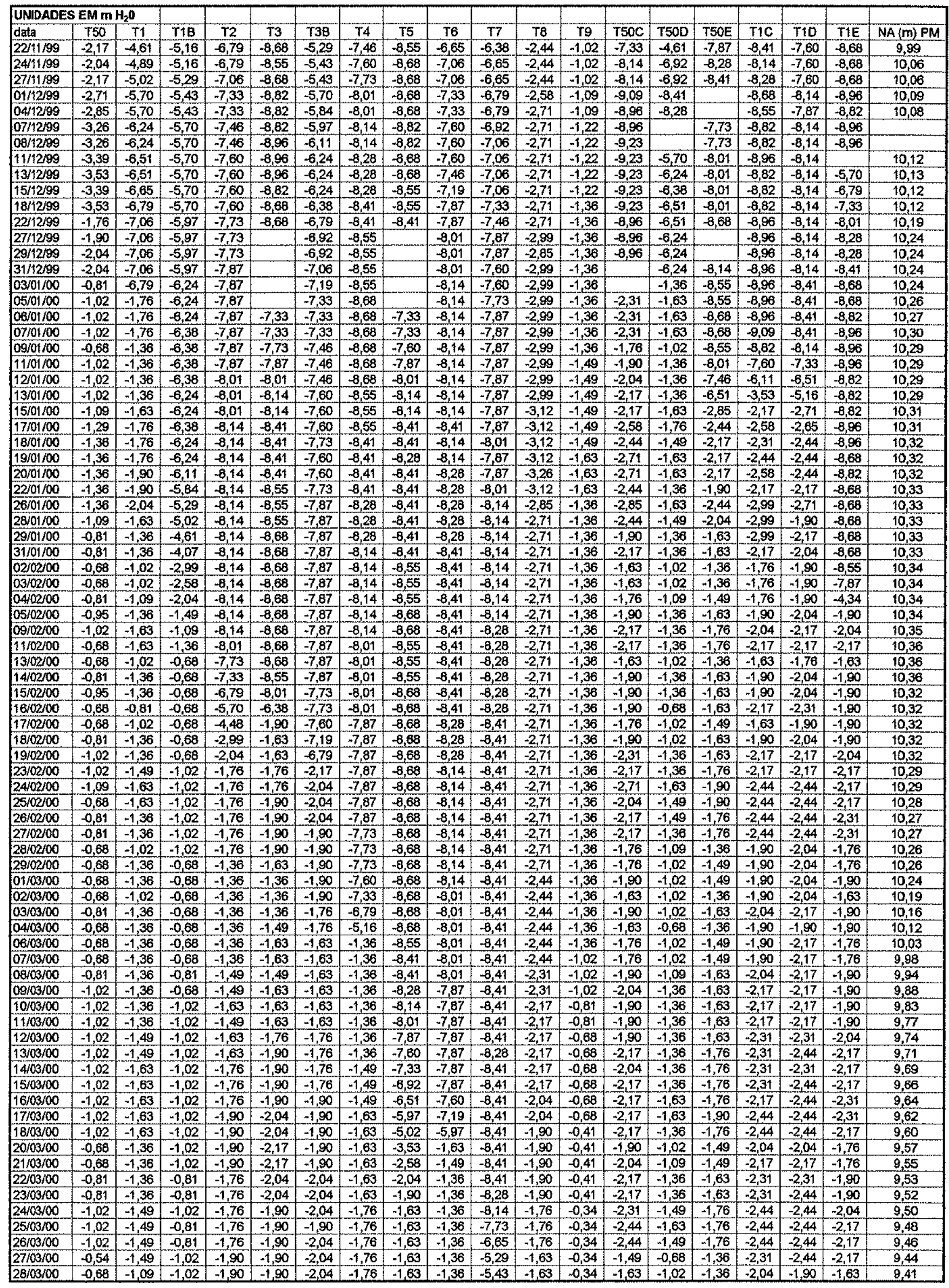




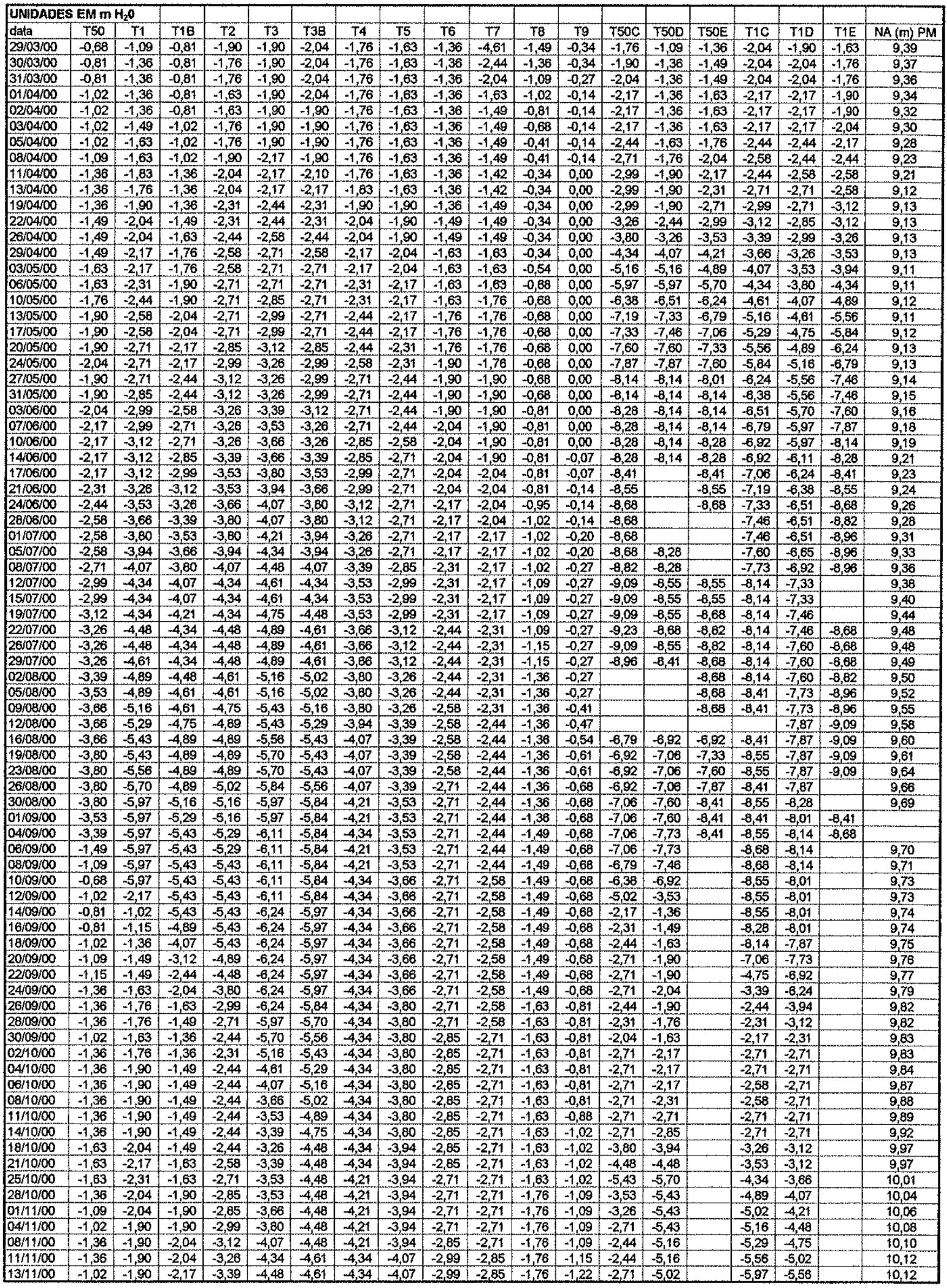




\begin{tabular}{|c|c|c|c|c|c|c|c|c|c|c|c|c|c|c|c|c|c|c|c|}
\hline \multicolumn{3}{|c|}{ UNIDADES EM im H ${ }_{2} \mathrm{O}$} & \multirow[b]{2}{*}{ T1B } & \multirow[b]{2}{*}{ T2 } & \multirow[b]{2}{*}{ T3 } & \multirow[b]{2}{*}{$\mathrm{T} 3 \mathrm{~B}$} & \multirow[b]{2}{*}{$T 4$} & \multirow[b]{2}{*}{ T5 } & \multirow[b]{2}{*}{ T6 } & \multirow[b]{2}{*}{7} & \multirow[b]{2}{*}{ T8 } & \multirow[b]{2}{*}{ T9 } & \multirow[b]{2}{*}{ T5OC } & \multirow[b]{2}{*}{ T50D } & \multirow[b]{2}{*}{ T50E } & \multirow[b]{2}{*}{ T1C } & \multirow[b]{2}{*}{ T10 } & \multirow[b]{2}{*}{ TIE } & \multirow[b]{2}{*}{ NA (m) PM } \\
\hline data & $T 50$ & T1 & & & & & & & & & & & & & & & & & \\
\hline $15 / 11 / 00$ & $-0,81$ & $-1,36$ & $-2,17$ & $-3,53$ & $-4,61$ & $-4,75$ & $-4,48$ & $-4,21$ & 3,12 & $-2,85$ & $-1,90$ & $-1,36$ & $-2,17$ & $-3,53$ & & $-6,11$ & $-5,70$ & & 10,14 \\
\hline $18 / 11 / 00$ & 0,68 & $-1,09$ & $-2,17$ & $-3,80$ & $-4,75$ & $-4,75$ & $-4,48$ & $-4,34$ & $-3,12$ & $-2,85$ & $-1,90$ & $-1,36$ & $-1,90$ & $-1,36$ & & $-6,38$ & $-5,84$ & & 10,15 \\
\hline $22 / 11 / 00$ & $-0,68$ & $-1,09$ & $-1,36$ & $-3,39$ & $-4,75$ & $-4,75$ & $-4,61$ & $-4,34$ & $-3,12$ & $-2,25$ & $-1,90$ & $-1,36$ & $-1,90$ & $-1,36$ & & $-4,75$ & $-5,97$ & & 10,17 \\
\hline $25 / 1+/ 00$ & $-0,81$ & $-1,36$ & $-1,02$ & $-3,26$ & $-4,75$ & $-4,89$ & $-4,75$ & $-4,48$ & $-3,12$ & $-2,99$ & $-1,90$ & $-1,36$ & $-2,17$ & $.1,63$ & & $-3,26$ & $-6,24$ & & 10,20 \\
\hline $29 / 11 / 00$ & $-0,88$ & $-1,36$ & $-1,02$ & $-2,99$ & $-4,61$ & $-4,89$ & $-4,89$ & $-4,48$ & $-3,26$ & $-2,99$ & $-1,90$ & $-1,30$ & $-2,17$ & $-1,63$ & & $-2,71$ & $-6,24$ & & 10,22 \\
\hline $04 / 12 / 00$ & $-0,88$ & $-1,36$ & $-1,02$ & $-2,31$ & $-3,66$ & $-4,89$ & $-4,89$ & $-4,61$ & $-3,26$ & $-2,99$ & -1.90 & $-1,36$ & $-2,17$ & $-1,63$ & & $-2,44$ & $-5,97$ & & 10,22 \\
\hline $06 / 12 / 00$ & $-1,02$ & $-1,49$ & $-1,02$ & $-2,17$ & $-3,26$ & $-4,75$ & $-5,02$ & $-4,61$ & $-3,26$ & $-2,99$ & $-1,90$ & $-1,36$ & $-2,31$ & $-7,76$ & & $-2,31$ & $-5,29$ & & 10,22 \\
\hline $09 / 12 / 00$ & $-1,09$ & $-1,63$ & $-1,02$ & $-2,17$ & $-2,99$ & 4,61 & $-5,16$ & $-4,61$ & 3,26 & $-2,99$ & $-2,04$ & $-1,36$ & $-2,58$ & $-1,90$ & & $-2,71$ & $-4,34$ & & 10,24 \\
\hline $13 / 12 / 00$ & $-1,02$ & $-1,63$ & $-1,36$ & $-2,31$ & $-2,99$ & $-4,34$ & $-5,29$ & $-4,75$ & $-3,26$ & $-3,12$ & $-2,04$ & $-1,36$ & $-1,90$ & $-1,02$ & & $-1,90$ & $-2,17$ & & 10,25 \\
\hline $16 / 12 / 00$ & $-0,68$ & $-1,02$ & $-1,36$ & $-2,17$ & $-2,85$ & $-4,07$ & $-5,29$ & $-4,75$ & $-3,26$ & $-3,12$ & $-2,04$ & $-1,36$ & $-1,90$ & $-1,09$ & & $-1,90$ & $-1,90$ & & 10,27 \\
\hline $20 / 12 / 00$ & $-0,81$ & $-1,36$ & $-0,68$ & $-1,63$ & $-2,17$ & $-3,53$ & $-5,16$ & $-4,89$ & $-3,39$ & $-3,12$ & $-2,04$ & $-1,36$ & $-1,90$ & $-1,09$ & & $-1,90$ & $-1,90$ & & 10,27 \\
\hline $23 / 1200$ & $-0,81$ & $-1,36$ & $-0,68$ & $-1,63$ & $-1,90$ & $-2,99$ & $-4,89$ & $-4,89$ & $-3,39$ & $-3,12$ & $-2,04$ & $-1,36$ & $-2,04$ & $-1,22$ & & $-2,04$ & $-2,04$ & & 10,28 \\
\hline $27 / 12100$ & $-1,02$ & $-1,49$ & $-0,81$ & $-1,63$ & $-1,90$ & $-2,58$ & $-4,61$ & $-5,02$ & $+3,39$ & 3,12 & $-2,04$ & $-1,36$ & $-2,17$ & $-1,36$ & & $-2,17$ & $-2,17$ & & 10,28 \\
\hline $30 / 1200$ & $-1,15$ & $-1,63$ & $-1,02$ & $-1,76$ & $-1,90$ & $-2,17$ & $-2,44$ & $-5,02$ & $-3,39$ & $-3,26$ & -204 & $-1,36$ & $-2,31$ & $-1,63$ & & $-2,44$ & -2.44 & & 10,29 \\
\hline $03 / 01 / 01$ & $-1,15$ & $-1,63$ & $-1,02$ & -1.76 & $-2,04$ & $-2,17$ & $-2,31$ & $-5,02$ & $-3,39$ & 3.26 & $-2,17$ & $-1,36$ & $-2,17$ & $-1,49$ & & $-2,44$ & $-2,44$ & & 10,29 \\
\hline $06 / 01 / 01$ & $-1,02$ & $-1,63$ & $-1,09$ & $-1,90$ & -2.17 & $-2,17$ & $-2,17$ & $-5,02$ & $-3,39$ & $-3,26$ & $-2,17$ & $-1,36$ & $-1,90$ & $-1,36$ & & $-2,17$ & -2.44 & & 10,29 \\
\hline $11 / 01 / 01$ & $-1,02$ & $-1,63$ & $-1,36$ & $-2,17$ & $-2,31$ & $-2,17$ & $-2,04$ & $-4,75$ & $-3,39$ & $-3,26$ & $-2,17$ & $-1,36$ & $-2,17$ & $-1,49$ & & $-2,31$ & $-2,31$ & & 10,31 \\
\hline $1401 / 01$ & $-1,02$ & $-1,63$ & $-1,36$ & $-2,17$ & $-2,44$ & $-2,17$ & $-2,04$ & $-4,34$ & $-3,39$ & $-3,26$ & $-2,17$ & $-1,36$ & $-2,17$ & $-1,63$ & & $-2,31$ & $-2,31$ & & 10,33 \\
\hline $20 / 01 / 01$ & $-1,36$ & $-1,63$ & $-1,36$ & $-2,34$ & $-2,58$ & $-2,31$ & $-2,04$ & $-3,26$ & 3,26 & $-3,26$ & $-2,17$ & $-1,36$ & $-2,44$ & $-1,63$ & & $-2,31$ & $-2,44$ & & 10,33 \\
\hline $24101 / 01$ & $-1,02$ & $-1,76$ & $-1,36$ & $-2,44$ & $-2,58$ & $-2,44$ & $-2,17$ & $-2,85$ & $-2,99$ & $-3,26$ & $-2,17$ & $-1,36$ & $-2,44$ & $-1,90$ & & $-2,71$ & $-2,71$ & & 10,35 \\
\hline $27 / 01 / 01$ & $-1,02$ & $-1,63$ & $-1,36$ & $-2,44$ & $-2,71$ & $-2,44$ & $-2,17$ & $-2,71$ & $-2,71$ & $-3,39$ & $-2,17$ & $-1,36$ & $-2,17$ & $-1,76$ & & $-2,71$ & $-2,71$ & & 10,35 \\
\hline $31 / 01 / 01$ & $-1,02$ & $-1,49$ & $-1,36$ & $-2,58$ & $-2,71$ & -244 & $-2,17$ & $-2,71$ & $-2,58$ & $-3,39$ & $-2,17$ & $-1,49$ & $-2,17$ & $-2,04$ & & $-2,71$ & -271 & & 10,38 \\
\hline $03 / 02 / 01$ & $-1,09$ & $-1,49$ & $-1,36$ & $-2,58$ & $-2,85$ & $-2,58$ & $-2,17$ & $-2,71$ & $-2,58$ & $-3,39$ & $-2,17$ & $-1,49$ & $-2,17$ & $-2,04$ & & $-2,71$ & $-2,71$ & & 10,37 \\
\hline $06 / 02101$ & $-1,09$ & $-1,63$ & $-1,36$ & $-2,58$ & $-2,85$ & $-2,58$ & $-2,31$ & $-2,71$ & $-2,31$ & 3,39 & $-2,17$ & $-1,49$ & $-2,31$ & $-2,17$ & & $-2,85$ & $-2,85$ & & \\
\hline $10 / 02 / 01$ & $-1,02$ & $-1,63$ & $-1,36$ & $-2,71$ & $-2,99$ & $-2,71$ & $-2,44$ & $-2,71$ & $-2,31$ & $-3,39$ & $-2,17$ & $-1,49$ & $-2,31$ & $-2,17$ & & $-2,99$ & $-3,12$ & & \\
\hline $14 / 02 / 01$ & $-1,09$ & $-1,76$ & $-1,36$ & $-2,71$ & $-2,99$ & $-2,71$ & $-2,44$ & $-2,71$ & $-2,17$ & $-3,26$ & $-2,04$ & $-1,49$ & $-2,58$ & $-2,31$ & & $-3,26$ & $-3,26$ & & \\
\hline $19 / 02 / 01$ & $-1,09$ & $-1,49$ & $-1,36$ & $-2,71$ & 3,12 & $-2,71$ & $-2,44$ & $-2,71$ & $-2,17$ & $-3,26$ & $-2,04$ & $-1,49$ & $-2,44$ & $-1,63$ & & $-3,26$ & $-3,39$ & & \\
\hline $21 / 02 / 01$ & $-0,81$ & $-1,36$ & $-1,36$ & $-2,71$ & $-2,99$ & $-2,71$ & $-2,58$ & $-2,71$ & $-2,17$ & $-3,26$ & $-2,04$ & $-1,49$ & $-2,17$ & $-1,36$ & & $-2,99$ & $-2,99$ & & 10,44 \\
\hline $24 / 02 / 01$ & $-1,02$ & $-1,49$ & $-1,02$ & $-2,71$ & $-2,99$ & $-2,71$ & $-2,71$ & $-2,71$ & $-2,17$ & $-3,26$ & $-2,04$ & $-1,49$ & $-2,58$ & $-1,76$ & & $-2,44$ & $-2,44$ & & 10,44 \\
\hline $28 / 02 / 01$ & $-1,09$ & $-1,36$ & $-1,02$ & $-2,44$ & $-3,12$ & $-2,85$ & $-2,71$ & $-2,71$ & $-2,17$ & $-3,26$ & $-2,04$ & $-1,49$ & $-2,44$ & $-1,63$ & & $-2,17$ & $-2,31$ & & 10,39 \\
\hline $03 / 03 / 01$ & $-1,09$ & $-1,36$ & $-1,02$ & $-2,44$ & -3.12 & $-2,85$ & $-2,71$ & $-2,71$ & $-2,17$ & $-3,12$ & $-2,04$ & $-1,49$ & $-2,44$ & $-1,63$ & & $-2,17$ & -231 & & 10,39 \\
\hline $07 / 03 / 01$ & $-0,81$ & $-1,36$ & $-0,88$ & $-2,31$ & $-2,99$ & $-2,85$ & $-2,71$ & $-2,71$ & $-2,17$ & $-3,12$ & $-2,04$ & $-1,49$ & $-2,44$ & $-2,44$ & & $-2,17$ & $-2,17$ & & 10,39 \\
\hline $10 / 03 / 01$ & $-0,68$ & $-1,36$ & $-0,81$ & $-2,31$ & $-2,71$ & $-2,71$ & $-2,71$ & $-2,85$ & $-2,17$ & $-3,12$ & $-2,04$ & $-1,49$ & $-1,76$ & $-1,76$ & & $-1,90$ & -190 & & 10,39 \\
\hline $14 / 03 / 01$ & $-0,68$ & $-1,36$ & $-0,66$ & $-2,17$ & $-2,71$ & $-2,71$ & $-2,71$ & $-2,85$ & $-2,17$ & 3,12 & $-2,04$ & $-1,49$ & $-1,49$ & $-1,49$ & & $-1,76$ & $-1,76$ & & 10,40 \\
\hline $17 / 03 / 01$ & $-0,68$ & $-1,49$ & $-0,81$ & $-2,04$ & $-2,58$ & $-2,58$ & $-2,71$ & $-2,85$ & $-2,31$ & $-3,12$ & $-2,04$ & $-1,49$ & $-1,90$ & $-1,90$ & & $-1,76$ & $-1,76$ & & 10,41 \\
\hline $21 / 03 / 01$ & $-0,81$ & $-1,49$ & $-0,88$ & $-1,76$ & $-2,31$ & $-2,44$ & -2.44 & $-2,85$ & $-2,31$ & $-3,12$ & $-2,04$ & $-1,63$ & $-2,17$ & $-2,04$ & & $-1,90$ & $-1,76$ & & 10,43 \\
\hline
\end{tabular}




\subsection{ANEXO 4-RELATÓRIO DE DADOS DE ENTRADA DO MODELO VS2DT}

\section{MODELO URÂNIA A}

Modelo simulando molhamento de 0,5 a $7 \mathrm{~m}$ de profundidade de $02 / 02 / 2000$ a 14/06/2000 (133 dias). Condição de contorno superior utilizando dados do tensiômetro T50D.

\section{Profile. URÂNIA A}

\section{Model Settings}

[VS2DT] Case Settings

\begin{tabular}{|l|c|c|}
\hline \multicolumn{1}{|c|}{ Parameter } & Value & Units \\
\hline Initial Conditions: Water & Nonuniform Pressure Head & $(-)$ \\
Initial Conditions: Chemical & Uniform Concentration & $(-)$ \\
Max. Simulation Time & 133 & $($ days) \\
Evapotranspiration & No evapotranspiration & $(-)$ \\
Transport Simulation & No transport simulation & $(-)$ \\
Soil Hydraulic Function & van Genuchten & $(-)$ \\
\hline
\end{tabular}

[VS2DT] Solver Settings

\begin{tabular}{|l|c|c|}
\hline \multicolumn{1}{|c|}{ Parameter } & Value & Units \\
\hline Flow Closure Criteria & 0.00100 & $(\mathrm{~m})$ \\
Relaxation & 0.900 & $(-)$ \\
Weighting Hydr. Cond. & 0.5 & $(-)$ \\
Min. Iterations & 2 & $(-)$ \\
Max. Iterations & 50 & $(-)$ \\
Space Differencing & Center-in-Space & $(-)$ \\
Time Differencing & Center-in-Time & $(-)$ \\
Maximum Number of Time Steps & 5000 & $(-)$ \\
Display Balance Every Time Step & no & $-(-)$ \\
\hline
\end{tabular}

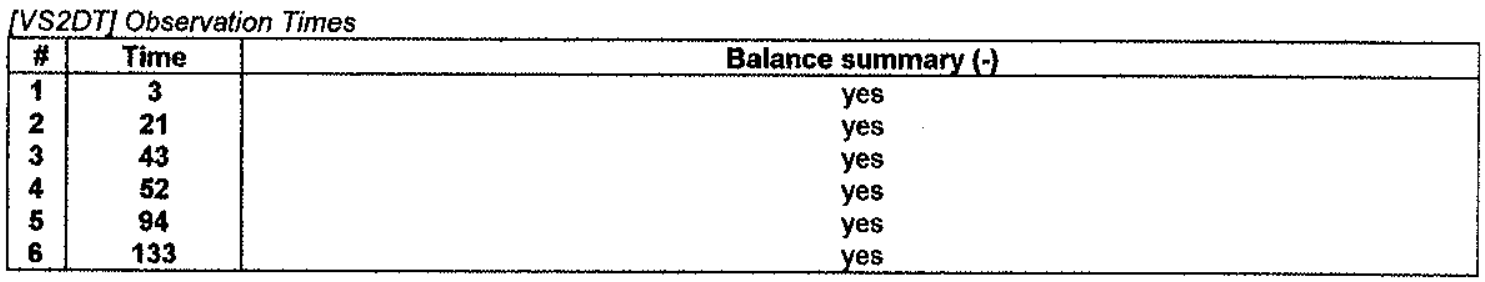

\begin{tabular}{|c|c|c|c|c|c|c|}
\hline$\#$ & Start Time & End Time & Type & $\begin{array}{l}\text { UPPER BOUNDARY } \\
(\mathrm{m})\end{array}$ & Allowed Ponding (m) & $\begin{array}{l}\text { LOWER BOUNDARY } \\
\text { (m) }\end{array}$ \\
\hline 1 & 0 & 1 & Pressure Head (m) & -1.02 & 0.01000 & -8.14 \\
\hline 2 & 1 & 2 & Pressure Head (m) & -1.09 & 0.01000 & -8.14 \\
\hline 3 & 2 & 3 & Pressure Head (m) & -1.36 & 0.01000 & -8.14 \\
\hline 4 & 3 & 7 & Pressure Head (m) & -1.36 & 0.01000 & -8.28 \\
\hline 5 & 7 & 9 & Pressure Head (m) & -1.36 & 0.01000 & -8.28 \\
\hline 6 & 9 & 11 & Pressure Head (m) & -1.02 & 0.01000 & -8.28 \\
\hline 7 & 11 & 12 & Pressure Head $(m)$ & -1.36 & 0.01000 & -8.28 \\
\hline 8 & 12 & 13 & Pressure Head $(m)$ & -1.36 & 0.01000 & -8.28 \\
\hline 9 & 13 & 14 & Pressure Head (m) & -0.68 & 0.01000 & -8.28 \\
\hline 10 & 14 & 15 & Pressure Head (m) & -1.02 & 0.01000 & -8.41 \\
\hline 11 & 15 & 16 & Pressure Head (m) & -1.02 & 0.01000 & -8.41 \\
\hline 12 & 16 & 17 & Pressure Head (m) & $-1,36$ & 0.01000 & -8.41 \\
\hline 13 & 17 & 21 & Pressure Head (m) & -1.36 & 0.01000 & -8.41 \\
\hline 14 & 21 & 22 & Pressure Head (m) & -1.63 & 0.01000 & -8.41 \\
\hline 15 & 22 & 23 & Pressure Head (m) & -1.49 & 0.01000 & -8.41 \\
\hline 16 & 23 & 24 & Pressure Head (m) & -1.49 & 0.01000 & -8.41 \\
\hline 17 & 24 & 26 & Pressure Head (m) & -1.36 & 0.01000 & -8.41 \\
\hline 18 & 25 & 26 & Pressure Head (m) & -1.09 & 0.01000 & -8.41 \\
\hline 19 & 26 & 27 & Pressure Head (m) & -1.02 & 0.01000 & -8.41 \\
\hline 20 & 27 & 28 & Pressure Head (m) & -1.02 & 0.01000 & -8.41 \\
\hline 21 & 28 & 29 & Pressure Head (m) & -1.02 & 0.01000 & -8.41 \\
\hline 22 & 29 & 30 & Pressure Head (m) & -1.02 & 0.01000 & -8.41 \\
\hline 23 & 30 & 31 & Pressure Head (m) & -0.68 & 0.01000 & -8.41 \\
\hline 24 & 31 & 33 & Pressure Head (m) & -1.02 & 0.01000 & -8.41 \\
\hline 25 & 33 & 34 & Pressure Head (m) & -1.02 & 0.01000 & 8.41 \\
\hline 26 & 34 & 35 & Pressure Head (m) & -1.09 & 0.01000 & -8.41 \\
\hline 27 & 35 & 36 & Pressure Head (m) & -1.36 & 0.01000 & -8.41 \\
\hline 28 & 36 & 37 & Pressure Head (m) & -1.36 & 0.01000 & -8.41 \\
\hline 29 & 37 & 38 & Pressure Head (m) & -1.36 & 0.01000 & -8.41 \\
\hline 30 & 38 & 39 & Pressure Head (m) & -1.36 & 0.01000 & -8.41 \\
\hline
\end{tabular}




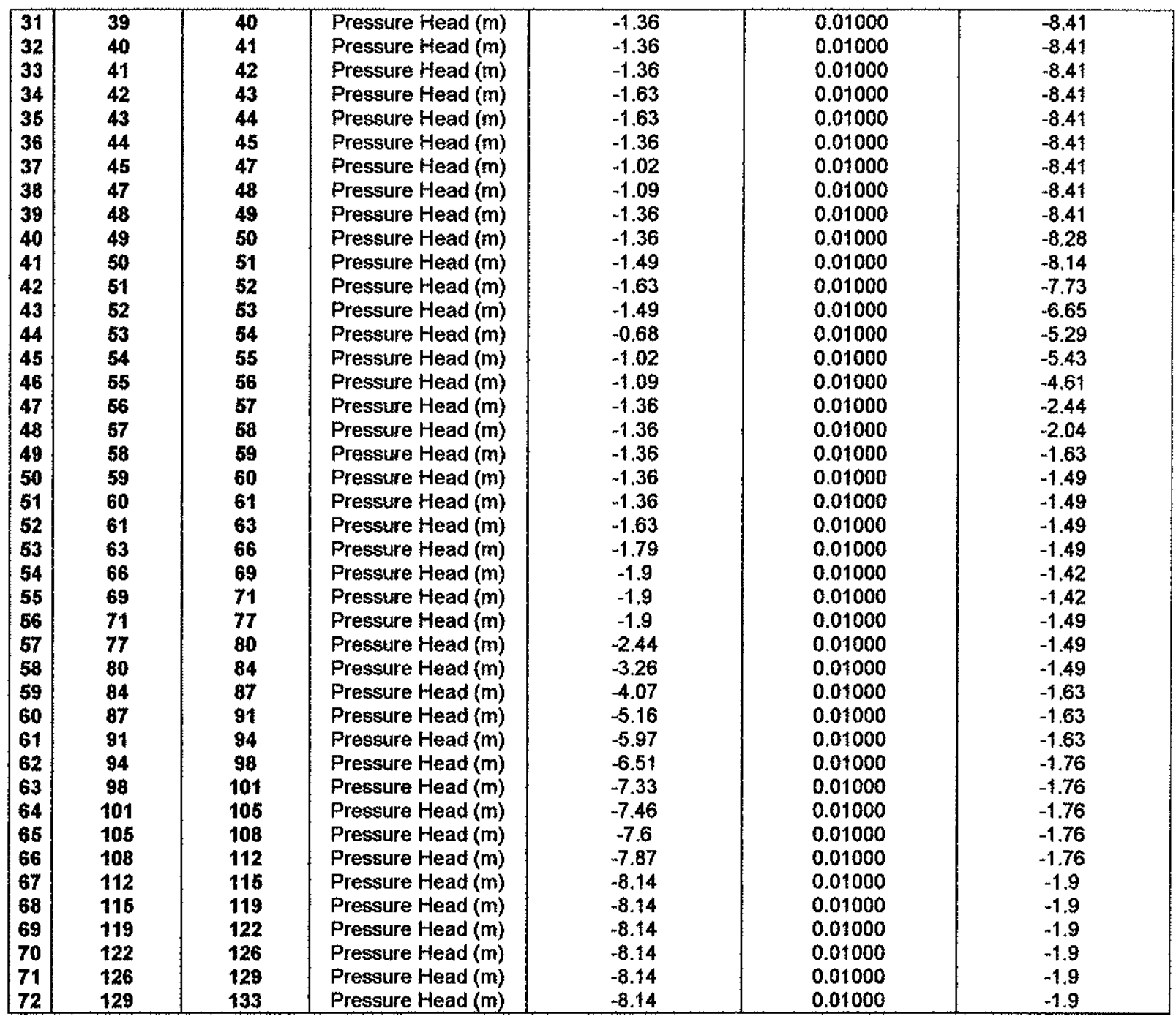

IVS2DT] Stress Period Defaults
\begin{tabular}{|l|c|c|}
\hline \multicolumn{1}{|c|}{ Parameter } & Value & Units \\
\hline Initial Time Step & 0.5 & (days) \\
Time Step Multiplier & 1.20 & $(-)$ \\
Maximum Time Step & 10.0000000 & (days) \\
Minimum Time Step & 0.0100000 & (days) \\
Reduction Factor & 0.40 & $(-)$ \\
Maximum Head Change & 1.00000 & $(\mathrm{~m})$ \\
Head Criterion & 0.00100 & (m) \\
\hline
\end{tabular}

Profile Structure
\begin{tabular}{|l|c|c|c|}
\hline Layer & Top $(\mathrm{m})$ & Bottom $(\mathrm{m})$ & Thickness $(\mathrm{m})$ \\
\hline [01] ARE 0,5-1,5 & -0.5000 & -1.5000 & 1.0000 \\
\hline [02] ARE 1,5-2,5 & -1.5000 & -2.5000 & 1.0000 \\
[03] ARESILT 2,5-3,5 & -2.5000 & -3.5000 & 1.0000 \\
[04] ARESILT 3,5-4,5 & -3.5000 & -4.5000 & 1.0000 \\
[05] ARESILT 4,5-5,5 & -4.5000 & -5.5000 & 1.0000 \\
[06] ARESILT 5,5-6,5 & -5.5000 & -6.5000 & 1.0000 \\
\hline [07] ARESILT 6,5-7,5 & -6.5000 & -7.0000 & 0.5000 \\
\hline
\end{tabular}


1.1. Layer. [01] ARE 0,5-1,5

IVSDT] Soil Parameters

\begin{tabular}{|l|c|c|}
\hline \multicolumn{1}{|c|}{ Parameter } & Value & Units \\
\hline Horizontal Sat.Hydr.Conductivity & 0.003348 & $(\mathrm{~cm} / \mathrm{sec})$ \\
Specific Storage & 0.00000010 & $(1 / \mathrm{cm})$ \\
Porosity & 0.4136 & $($ vol/vol) \\
Qr & 0.1579 & $($ volvol) \\
Alpha' (van Genuchten) & -48 & $(\mathrm{~cm})$ \\
Beta' (van Genuchten) & 1.81 & $(-)$ \\
\hline
\end{tabular}

[VS2DTIInitial Conditions

\begin{tabular}{|c|c|c|}
\hline \multicolumn{1}{|c|}{ Parameter } & Value & Units \\
\hline Pressure Head & -1.9 & (m) \\
\hline
\end{tabular}

1.2. Layer. [02] ARE 1,5-2,5

[VS2DT] Soil Parameters

\begin{tabular}{|l|c|c|}
\hline \multicolumn{1}{|c|}{ Parameter } & Value & Units \\
\hline Horizontal Sat.Hydr.Conductivity & 0.002653 & $(\mathrm{~cm} / \mathrm{sec})$ \\
Specific Storage & 0.00000010 & $(1 / \mathrm{cm})$ \\
Porosity & 0.4205 & $(\mathrm{vol} / \mathrm{vol})$ \\
Qr & 0.1544 & $(\mathrm{vol} / \mathrm{vol})$ \\
Alpha' (van Genuchten) & -47.0114 & $(\mathrm{~cm})$ \\
Beta' (van Genuchten) & 1.7481 & $(-)$ \\
\hline
\end{tabular}

VS2DTI Initial Conditions

\begin{tabular}{|c|c|c|}
\hline Parameter & Value & Units \\
\hline Pressure Head & -8.14 & $(\mathrm{~m})$ \\
\hline
\end{tabular}

1.3. Layer. [03] ARESILT 2,5-3,5

VS2DTI Soil Parameters

\begin{tabular}{|c|c|c|}
\hline Parameter & Value & Units \\
\hline $\begin{array}{l}\text { Horizontal Sat.Hydr.Conductivity } \\
\text { Specific Storage } \\
\text { Porosity } \\
\text { Qr } \\
\text { Alpha' (van Genuchten) } \\
\text { Beta' (van Genuchten) }\end{array}$ & $\begin{array}{c}0.001876 \\
0.0000001 \\
0.4313 \\
0.1445 \\
-49.4782 \\
1.7844 \\
\end{array}$ & $\begin{array}{c}(\mathrm{cm} / \mathrm{sec}) \\
(1 / \mathrm{cm}) \\
(\mathrm{vol} / \mathrm{vol}) \\
(\mathrm{vol} / \mathrm{vol}) \\
(\mathrm{cm}) \\
(-)\end{array}$ \\
\hline \multicolumn{3}{|l|}{ VS 2DTJ Initial Conditions } \\
\hline Parameter & Value & Units \\
\hline Pressure Head & -8.68 & (m) \\
\hline
\end{tabular}

1.4. Layer. [04] ARESILT 3,5-4,5

[VS2DT] Soil Parameters

\begin{tabular}{|l|c|c|}
\hline \multicolumn{1}{|c|}{ Parameter } & Value & Units \\
\hline Horizontal Sat.Hydr.Conductivity & 0.001319 & (cm/sec) \\
Specific Storage & 0.0000001 & $(1 / \mathrm{cm})$ \\
Porosity & 0.4278 & $($ vol/vol) \\
Qr & 0.1460 & (volvol) \\
Alpha' (van Genuchten) & -53.0786 & (cm) \\
Beta' (van Genuchten) & 1.8178 & $(-)$ \\
\hline
\end{tabular}

VS2DT] Initial Conditions

\begin{tabular}{|c|c|c|}
\hline Parameter & Value & Units \\
\hline Pressure Head & -8.14 & (m) \\
\hline
\end{tabular}

1.5. Layer. [05] ARESILT 4,5-5,5

[VS2DT] Soil Parameters

\begin{tabular}{|l|c|c|}
\hline \multicolumn{1}{|c|}{ Parameter } & Value & Units \\
\hline Horizontal Sat.Hydr.Conductivity & 0.00096 & $(\mathrm{~cm} / \mathrm{sec})$ \\
Specific Storage & 0.0000001 & $(1 / \mathrm{cm})$ \\
Porosity & 0.4225 & $($ vol/vol) \\
Qr & 0.1441 & (vol/vol) \\
Alpha' (van Genuchten) & -55.1309 & (cm) \\
Beta' (van Genuchten) & 1.8138 & $(-)$ \\
\hline
\end{tabular}

[VS2DT] Initial Conditions

\begin{tabular}{|c|c|c|}
\hline Parameter & Value & Units \\
\hline Pressure Head & -8.55 & $(\mathrm{~m})$ \\
\hline
\end{tabular}


1.6. Layer. [06] ARESILT 5,5-6,5

[VS2DT] Soil Parameters

\begin{tabular}{|l|c|c|}
\hline \multicolumn{1}{|c|}{ Parameter } & Value & Units \\
\hline Horizontal Sat.Hydr.Conductivity & 0.0007348 & $(\mathrm{~cm} / \mathrm{sec})$ \\
Specific Storage & 0.0000001 & $(1 / \mathrm{cm})$ \\
Porosity & 0.431 & $(\mathrm{vol} / \mathrm{vol})$ \\
Qr & 0.2106 & $(\mathrm{vol} / \mathrm{vol})$ \\
Alpha' (van Genuchten) & -53.5646 & $(\mathrm{~cm})$ \\
Beta' (van Genuchten) & 1.8123 & $(-)$ \\
\hline
\end{tabular}

[VS2DT] Initial Conditions

\begin{tabular}{|c|c|c|}
\hline \multicolumn{1}{|c|}{ Parameter } & Value & Units \\
\hline Pressure Head & -8.41 & (m) \\
\hline
\end{tabular}

1.7. Layer. [07] ARESILT 6,5-7,5

[VS2DT] Soil Parameters

\begin{tabular}{|l|c|c|}
\hline \multicolumn{1}{|c|}{ Parameter } & Value & Units \\
\hline Horizontal Sat.Hydr.Conductivity & 0.0006316 & $(\mathrm{~cm} / \mathrm{sec})$ \\
Specific Storage & 0.0000001 & $(1 / \mathrm{cm})$ \\
Porosity & 0.4376 & $(\mathrm{vol} / \mathrm{vol})$ \\
Qr & 0.2456 & $(\mathrm{vol} / \mathrm{vol})$ \\
Alpha' (van Genuchten) & -48.9694 & $(\mathrm{~cm})$ \\
Beta' (van Genuchten) & 1.7978 & $(-)$ \\
\hline
\end{tabular}

VS2DTJ Initial Conditions

\begin{tabular}{|c|c|c|}
\hline Parameter & Value & Units \\
\hline Pressure Head & -8.14 & $(\mathrm{~m})$ \\
\hline
\end{tabular}

\begin{tabular}{|c|c|c|c|}
\hline \multicolumn{4}{|c|}{ RESULTADOS PARCIAIS DO MODELO URÁNIA A } \\
\hline Dia & $\begin{array}{l}\text { Profundidade } \\
\text { (cm) }\end{array}$ & $\begin{array}{c}\text { Potencial Matricial } \\
\text { Calculado }(\mathrm{cm})\end{array}$ & $\begin{array}{c}\text { Potencial Matricial } \\
\text { Observado }(\mathrm{cm})\end{array}$ \\
\hline $\begin{array}{c}3 \\
21 \\
43 \\
52 \\
94 \\
133 \\
\end{array}$ & $\begin{array}{l}100 \\
100 \\
100 \\
100 \\
100 \\
100 \\
\end{array}$ & $\begin{array}{l}-132,00 \\
-132,00 \\
-143,00 \\
-144,00 \\
-293,00 \\
-408,00 \\
\end{array}$ & $\begin{array}{l}-204,00 \\
-217,00 \\
-244,00 \\
-244,00 \\
-407,00 \\
-611,00 \\
\end{array}$ \\
\hline $\begin{array}{c}3 \\
21 \\
43 \\
52 \\
94 \\
133 \\
\end{array}$ & $\begin{array}{l}222 \\
222 \\
222 \\
222 \\
222 \\
222 \\
\end{array}$ & $\begin{array}{l}-811,00 \\
-113,00 \\
-118,00 \\
-114,00 \\
-192,00 \\
-257,00\end{array}$ & $\begin{array}{l}-814,00 \\
-176,00 \\
-176,00 \\
-176,00 \\
-258,00 \\
-326,00\end{array}$ \\
\hline $\begin{array}{c}3 \\
21 \\
43 \\
52 \\
94 \\
133 \\
\end{array}$ & $\begin{array}{l}300 \\
300 \\
300 \\
300 \\
300 \\
300 \\
\end{array}$ & $\begin{array}{l}-868,00 \\
-111,00 \\
-108,00 \\
-106,00 \\
-166,00 \\
-218,00 \\
\end{array}$ & $\begin{array}{l}-868,00 \\
-176,00 \\
-190,00 \\
-190,00 \\
-258,00 \\
-353,00\end{array}$ \\
\hline $\begin{array}{c}3 \\
21 \\
43 \\
52 \\
94 \\
133 \\
\end{array}$ & $\begin{array}{l}400 \\
400 \\
400 \\
400 \\
400 \\
400\end{array}$ & $\begin{array}{l}-814,00 \\
-752,00 \\
-97,90 \\
-103,00 \\
-145,00 \\
-186,00 \\
\end{array}$ & $\begin{array}{l}-814,00 \\
-787,00 \\
-149,00 \\
-176,00 \\
-217,00 \\
-271,00 \\
\end{array}$ \\
\hline $\begin{array}{c}3 \\
21 \\
43 \\
52 \\
94 \\
133 \\
\end{array}$ & $\begin{array}{l}500 \\
500 \\
500 \\
500 \\
500 \\
500 \\
\end{array}$ & $\begin{array}{l}-855,00 \\
-855,00 \\
-103,00 \\
-99,80 \\
-126,00 \\
-160,00 \\
\end{array}$ & $\begin{array}{l}-855,00 \\
-868,00 \\
-353,00 \\
-163,00 \\
-204,00 \\
-258,00 \\
\end{array}$ \\
\hline $\begin{array}{c}3 \\
21 \\
43 \\
52 \\
94 \\
133 \\
\end{array}$ & $\begin{array}{l}600 \\
600 \\
600 \\
600 \\
600 \\
600 \\
\end{array}$ & $\begin{array}{l}-841,00 \\
-841,00 \\
-841,00 \\
-114,00 \\
-110,00 \\
-140,00 \\
\end{array}$ & $\begin{array}{l}-841,00 \\
-814,00 \\
-760,00 \\
-136,00 \\
-149,00 \\
-204,00 \\
\end{array}$ \\
\hline $\begin{array}{c}3 \\
21 \\
43 \\
52 \\
94 \\
133 \\
\end{array}$ & $\begin{array}{l}697 \\
697 \\
697 \\
697 \\
697 \\
697 \\
\end{array}$ & $\begin{array}{l}-814,00 \\
-841,00 \\
-841,00 \\
-773,00 \\
-163,00 \\
-190,00 \\
\end{array}$ & $\begin{array}{l}-814,00 \\
-841,00 \\
-841,00 \\
-773,00 \\
-163,00 \\
-190,00\end{array}$ \\
\hline
\end{tabular}


Modelo simulando molhamento de 0,5 a $7 \mathrm{~m}$ de profundidade de 02/02/2000 a 14/06/2000 (133 dias). Condição de contorno superior utilizando dados do tensiômetro T50.

1. Profile. URÂNIA B

\section{Model Settings}

[VS2DT] Case Settings

IGUAL AO MODELO URÂNIA A

[VS2DT] Solver Settings

IGUAL AO MODELO URÂNIA A

[VS2DT] Observation Times

\section{IGUAL AO MODELO URÂNIA A}

[VS2DT] Flow Upper Boundary

\begin{tabular}{|c|c|c|c|c|c|}
\hline$\#$ & Start Time & End Time & Type & Value & Allowed Ponding (m) \\
\hline 1 & 0 & 1 & Pressure Head $(\mathrm{m})$ & -0.68 & 0.01000 \\
\hline 2 & 1 & 2 & Pressure Head (m) & -0.81 & 0.01000 \\
\hline 3 & 2 & 3 & Pressure Head (m) & -0.95 & 0.01000 \\
\hline 4 & 3 & 7 & Pressure Head (m) & -1.02 & 0.01000 \\
\hline 5 & 7 & 9 & Pressure Head (m) & -0.68 & 0.01000 \\
\hline 6 & 9 & 11 & Pressure Head (m) & -0.68 & 0.01000 \\
\hline 7 & 11 & 12 & Pressure Head (m) & -0.81 & 0.01000 \\
\hline 8 & 12 & 13 & Pressure Head (m) & -0.95 & 0.01000 \\
\hline 9 & 13 & 14 & Pressure Head (m) & -0.68 & 0.01000 \\
\hline 10 & 14 & 15 & Pressure Head (m) & -0.68 & 0.01000 \\
\hline 11 & 15 & 16 & Pressure Head (m) & -0.81 & 0.01000 \\
\hline 12 & 16 & 17 & Pressure Head (m) & -1.02 & 0.01000 \\
\hline 13 & 17 & 21 & Pressure Head (m) & -1.02 & 0.01000 \\
\hline 14 & 21 & 22 & Pressure Head (m) & -1.09 & 0.01000 \\
\hline 15 & 22 & 23 & Pressure Head (m) & -0.68 & 0.01000 \\
\hline 16 & 23 & 24 & Pressure Head (m) & -0.81 & 0.01000 \\
\hline 17 & 24 & 25 & Pressure Head (m) & -0.81 & 0.01000 \\
\hline 18 & 25 & 26 & Pressure Head (m) & -0.68 & 0.01000 \\
\hline 19 & 26 & 27 & Pressure Head (m) & -0.68 & 0.01000 \\
\hline 20 & 27 & 28 & Pressure Head (m) & -0.68 & 0.01000 \\
\hline 21 & 28 & 29 & Pressure Head (m) & -0.68 & 0.01000 \\
\hline 22 & 29 & 30 & Pressure Head (m) & -0.81 & 0.01000 \\
\hline 23 & 30 & 31 & Pressure Head $(m)$ & -0.68 & 0.01000 \\
\hline 24 & 31 & 33 & Pressure Head (m) & -0.68 & 0.01000 \\
\hline 25 & 33 & 34 & Pressure Head (m) & -0.68 & 0.01000 \\
\hline 26 & 34 & 35 & Pressure Head (m) & -0.81 & 0.01000 \\
\hline 27 & 35 & 36 & Pressure Head (m) & -1.02 & 0.01000 \\
\hline 28 & 36 & 37 & Pressure Head (m) & -1.02 & 0.01000 \\
\hline 29 & 37 & 38 & Pressure Head (m) & -1.02 & 0.01000 \\
\hline 30 & 38 & 39 & Pressure Head (m) & -1.02 & 0.01000 \\
\hline 31 & 39 & 40 & Pressure Head (m) & -1.02 & 0.01000 \\
\hline 32 & 40 & 41 & Pressure Head (m) & -1.02 & 0.01000 \\
\hline 33 & 41 & 42 & Pressure Head (m) & -1.02 & 0.01000 \\
\hline 34 & 42 & 43 & Pressure Head (m) & -1.02 & 0.01000 \\
\hline 35 & 43 & 44 & Pressure Head (m) & -1.02 & 0.01000 \\
\hline 36 & 44 & 45 & Pressure Head (m) & -1.02 & 0.01000 \\
\hline 37 & 45 & 47 & Pressure Head (m) & -0.68 & 0.01000 \\
\hline 38 & 47 & 48 & Pressure Head (m) & -0.68 & 0.01000 \\
\hline 39 & 48 & 49 & Pressure Head (m) & -0.81 & 0.01000 \\
\hline 40 & 49 & 50 & Pressure Head (m) & -0.81 & 0.01000 \\
\hline 41 & 50 & 51 & Pressure Head (m) & -1.02 & 0.01000 \\
\hline 42 & 51 & 52 & Pressure Head (m) & -1.02 & 0.01000 \\
\hline 43 & 52 & 53 & Pressure Head (m) & -1.02 & 0.01000 \\
\hline 44 & 53 & 54 & Pressure Head (m) & -0.54 & 0.01000 \\
\hline 45 & 54 & 55 & Pressure Head (m) & -0.68 & 0.01000 \\
\hline 46 & 55 & 56 & Pressure Head (m) & -0.68 & 0.01000 \\
\hline 47 & 56 & 57 & Pressure Head (m) & -0.81 & 0.01000 \\
\hline 48 & 57 & 58 & Pressure Head (m) & -0.81 & 0.01000 \\
\hline 49 & 58 & 59 & Pressure Head (m) & -1.02 & 0.01000 \\
\hline 50 & 59 & 60 & Pressure Head (m) & -1.02 & 0.01000 \\
\hline 51 & 60 & 61 & Pressure Head (m) & -1.02 & 0.01000 \\
\hline 52 & 61 & 63 & Pressure Head (m) & -1.02 & 0.01000 \\
\hline 53 & 63 & 66 & Pressure Head (m) & -1.09 & 0.01000 \\
\hline 54 & 66 & 69 & Pressure Head (m) & -1.36 & 0.01000 \\
\hline 55 & 69 & 71 & Pressure Head (m) & -1.36 & 0.01000 \\
\hline 56 & 71 & 77 & Pressure Head (m) & -1.36 & 0.01000 \\
\hline
\end{tabular}

BERTOLO, R.A. - Tese de Doutoramento - 2001 


\begin{tabular}{|l|l|l|l|l|l|}
57 & 77 & 80 & Pressure Head (m) & -1.49 & 0.01000 \\
58 & 80 & 84 & Pressure Head (m) & -1.49 & 0.01000 \\
59 & 84 & 87 & Pressure Head (m) & -1.49 & 0.01000 \\
60 & 87 & 91 & Pressure Head (m) & -1.63 & 0.01000 \\
61 & 91 & 94 & Pressure Head (m) & -1.63 & 0.01000 \\
62 & 94 & 98 & Pressure Head (m) & -1.76 & 0.01000 \\
63 & 98 & 101 & Pressure Head (m) & -1.9 & 0.01000 \\
64 & 101 & 105 & Pressure Head (m) & -1.9 & 0.01000 \\
65 & 105 & 108 & Pressure Head (m) & -1.9 & 0.01000 \\
66 & 108 & 112 & Pressure Head (m) & -2.04 & 0.01000 \\
67 & 112 & 115 & Pressure Head (m) & -1.9 & 0.01000 \\
68 & 115 & 119 & Pressure Head (m) & -1.9 & 0.01000 \\
69 & 119 & 122 & Pressure Head (m) & -2.04 & 0.01000 \\
70 & 122 & 126 & Pressure Head (m) & -2.17 & 0.01000 \\
71 & 126 & 129 & Pressure Head (m) & -2.17 & 0.01000 \\
72 & 129 & 133 & Pressure Head (m) & -2.17 & 0.01000 \\
\hline
\end{tabular}

IVS2DT] Flow Lower Boundary

IGUAL AO MODELO URÂNIA A

IVS2DT] Stress Period Defaults

IGUAL AO MODELO URÂNIA A

\section{Profile Structure \\ IGUAL AO MODELO URÂNIA A}

\subsection{Layer. [01] ARE 0,5-1,5}

[VS2DT] Soil Parameters

\begin{tabular}{|c|c|c|}
\hline Parameter & Value & Units \\
\hline Horizontal Sat.Hydr.Conductivity & 0.001289 & (cm/sec) \\
\hline
\end{tabular}

VS2DTInitial Conditions

\begin{tabular}{|c|c|c|}
\hline Parameter & Value & Units \\
\hline Pressure Head & -1.02 & $(\mathrm{~m})$ \\
\hline
\end{tabular}

1.2. Layer. [02] ARE 1,5-2,5

[VS2DT] Soil Parameters

\begin{tabular}{|c|c|c|}
\hline Parameter & Value & Units \\
\hline Horizontal Sat.Hydr.Conductivity & 0.0009286 & (cm/sec) \\
\hline
\end{tabular}

[VS2DT] Initial Conditions

\begin{tabular}{|c|c|c|}
\hline Parameter & Value & Units \\
\hline Pressure Head & -8.14 & $(\mathrm{~m})$ \\
\hline
\end{tabular}

\subsection{Layer. [03] ARESILT 2,5-3,5}

[VS2DT] Soil Parameters

\begin{tabular}{|c|c|c|}
\hline Parameter & Value & Units \\
\hline Horizontai Sat.Hydr.Conductivity & 0.0006565 & (cm/sec) \\
\hline
\end{tabular}

IVS2DTI Initial Conditions

\begin{tabular}{|c|c|c|}
\hline Parameter & Value & Units \\
\hline Pressure Head & -8.68 & $(\mathrm{~m})$ \\
\hline
\end{tabular}

1.4. Layer. [04] ARESILT 3,5-4,5

IVS2DT] Soil Parameters

\begin{tabular}{|c|c|c|}
\hline Parameter & Value & Units \\
\hline Horizontal Sat.Hydr.Conductivity & 0.0004616 & $(\mathrm{~cm} / \mathrm{sec})$ \\
\hline
\end{tabular}

[VS2DT] Initial Conditions

\begin{tabular}{|c|c|c|}
\hline Parameter & Value & Units \\
\hline Pressure Head & -8.14 & $(\mathrm{~m})$ \\
\hline
\end{tabular}

1.5. Layer. [05] ARESILT 4,5-5,5

IVS2DTI Soll Parameters

\begin{tabular}{|c|c|c|}
\hline Parameter & Value & Units \\
\hline Horizontal Sat.Hydr.Conductivity & 0.0004052 & $(\mathrm{~cm} / \mathrm{sec})$ \\
\hline
\end{tabular}

[VS2DT] Initial Conditions

\begin{tabular}{|c|c|c|}
\hline Parameter & Value & Units \\
\hline Pressure Head & -8.55 & $(\mathrm{~m})$ \\
\hline
\end{tabular}


1.6. Layer. [06] ARESILT 5,5-6,5

(VS2DT] Soil Parameters

\begin{tabular}{|c|c|c|}
\hline Parameter & Value & Units \\
\hline Horizontal Sat. Hydr.Conductivity & 0.0004356 & $(\mathrm{~cm} / \mathrm{sec})$ \\
\hline \multicolumn{3}{|l|}{ [VS2DT] Initial Conditions } \\
\hline Parameter & Value & Units \\
\hline Pressure Head & -8.41 & (m) \\
\hline
\end{tabular}

1.7. Layer. [07] ARESILT 6,5-7,5

IVS2DT] Soil Parameters

\begin{tabular}{|c|c|c|}
\hline Parameter & Value & Units \\
\hline Horizontal Sat.Hydr.Conductivity & 0.0003744 & (cm/sec) \\
\hline
\end{tabular}

IVS2DTI Initial Conditions

\begin{tabular}{|c|c|c|}
\hline \multicolumn{1}{|c|}{ Parameter } & Value & Units \\
\hline Pressure Head & -8.14 & $(\mathrm{~m})$ \\
\hline
\end{tabular}

\begin{tabular}{|c|c|c|c|}
\hline \multicolumn{4}{|c|}{ RESULTADOS PARCIAIS DO MODELO URANIIA B } \\
\hline Dia & $\begin{array}{l}\text { Profundidade } \\
\text { (cm) }\end{array}$ & $\begin{array}{l}\text { Potencial Matricial } \\
\text { Calculado }(\mathrm{cm})\end{array}$ & $\begin{array}{l}\text { Potencial Matricial } \\
\text { Observado }(\mathrm{cm})\end{array}$ \\
\hline $\begin{array}{c}3 \\
21 \\
43 \\
52 \\
94 \\
133 \\
\end{array}$ & $\begin{array}{l}100 \\
100 \\
100 \\
100 \\
100 \\
100\end{array}$ & $\begin{array}{l}-89,00 \\
-98,60 \\
-99,40 \\
-93,00 \\
-153,00 \\
-198,00\end{array}$ & $\begin{array}{l}-136,00 \\
-149,00 \\
-163,00 \\
-149,00 \\
-231,00 \\
-312,00\end{array}$ \\
\hline \begin{tabular}{|c|}
3 \\
21 \\
43 \\
52 \\
94 \\
133 \\
\end{tabular} & $\begin{array}{l}222 \\
222 \\
222 \\
222 \\
222 \\
222 \\
\end{array}$ & $\begin{array}{l}-812,00 \\
-79,90 \\
-83,00 \\
-69,60 \\
-123,00 \\
-156,00 \\
\end{array}$ & $\begin{array}{l}-814,00 \\
-176,00 \\
-176,00 \\
-176,00 \\
-271,00 \\
-339,00\end{array}$ \\
\hline $\begin{array}{c}3 \\
21 \\
43 \\
52 \\
94 \\
133 \\
\end{array}$ & $\begin{array}{l}300 \\
300 \\
300 \\
300 \\
300 \\
300\end{array}$ & $\begin{array}{c}-868,00 \\
-77,20 \\
-74,50 \\
-64,90 \\
-111,00 \\
-140,00\end{array}$ & $\begin{array}{l}-868,00 \\
-176,00 \\
-190,00 \\
-190,00 \\
-271,00 \\
-366,00\end{array}$ \\
\hline $\begin{array}{c}3 \\
21 \\
43 \\
52 \\
94 \\
133 \\
\end{array}$ & $\begin{array}{l}400 \\
400 \\
400 \\
400 \\
400 \\
400 \\
\end{array}$ & $\begin{array}{c}-814,00 \\
-814,00 \\
-65,80 \\
-66,80 \\
-99,60 \\
-125,00\end{array}$ & $\begin{array}{l}-814,00 \\
-787,00 \\
-149,00 \\
-176,00 \\
-231,00 \\
-285,00\end{array}$ \\
\hline $\begin{array}{c}3 \\
21 \\
43 \\
52 \\
94 \\
133\end{array}$ & $\begin{array}{l}500 \\
500 \\
500 \\
500 \\
500 \\
500\end{array}$ & $\begin{array}{l}-855,00 \\
-855,00 \\
-65,60 \\
-70,60 \\
-92,50 \\
-117,00\end{array}$ & $\begin{array}{l}-868,00 \\
-868,00 \\
-651,00 \\
-163,00 \\
-217,00 \\
-271,00\end{array}$ \\
\hline $\begin{array}{c}3 \\
21 \\
43 \\
52 \\
94 \\
133 \\
\end{array}$ & $\begin{array}{l}600 \\
600 \\
600 \\
600 \\
600 \\
600 \\
\end{array}$ & $\begin{array}{l}-841,00 \\
-841,00 \\
-825,00 \\
-78,60 \\
-86,30 \\
-109,00\end{array}$ & $\begin{array}{l}-841,00 \\
-814,00 \\
-760,00 \\
-136,00 \\
-163,00 \\
-204,00\end{array}$ \\
\hline \begin{tabular}{c|}
3 \\
21 \\
43 \\
52 \\
94 \\
133 \\
\end{tabular} & $\begin{array}{l}697 \\
697 \\
697 \\
697 \\
697 \\
697 \\
\end{array}$ & $\begin{array}{l}-814,00 \\
-841,00 \\
-841,00 \\
-773,00 \\
-163,00 \\
-190,00 \\
\end{array}$ & $\begin{array}{l}-814,00 \\
-841,00 \\
-841,00 \\
-773,00 \\
-163,00 \\
-190,00 \\
\end{array}$ \\
\hline
\end{tabular}




\section{URÂNIA C}

Modelo simulando secagem de 0,5 a $7 \mathrm{~m}$ de profundidade de 01/04/2000 a 18/10/2000 (200 dias). Condição de contorno superior utilizando dados do tensiômetro T50D.

\section{Profile. URÂNIA C}

Model Settings

[VS2DT] Case Settings

\begin{tabular}{|l|c|c|}
\hline \multicolumn{1}{|c|}{ Parameter } & Value & Units \\
\hline Initial Conditions: Water & Nonuniform Pressure Head & $(-)$ \\
Initial Conditions: Chemical & Uniform Concentration & $(-)$ \\
Max. Simulation Time & 200 & $($ days $)$ \\
Evapotranspiration & No evapotranspiration & $(-)$ \\
Transport Simulation & No transport simulation & $(-)$ \\
Soil Hydraulic Function & van Genuchten & $(-)$ \\
\hline
\end{tabular}

[VS2DT] Solver Seltings

IGUAL AOS MODELOS URÂNIA A E B

[VS2DT] Observation Times

\begin{tabular}{|c|c|c|}
\hline$\#$ & Time & Balance summary $(-)$ \\
\hline 1 & 12 & yes \\
2 & 28 & yes \\
3 & 56 & yes \\
4 & 112 & yes \\
5 & 156 & yes \\
6 & 182 & yes \\
7 & 200 & yes \\
\hline
\end{tabular}

\begin{tabular}{|c|c|c|c|c|c|c|}
\hline \multicolumn{4}{|c|}{ [VS2DT] Flow Boundary } & \multicolumn{2}{|c|}{ Upper Boundary } & Lower Boundary \\
\hline$\#$ & Start Time & End Time & Type & Value (m) & Allowed Ponding (m) & Value (cm) \\
\hline 1 & 0 & 2 & Pressure Head & -1.36 & 0.01000 & -149.27 \\
\hline 2 & 2 & 7 & Pressure Head & -1.76 & 0.01000 & -149.27 \\
\hline 3 & 7 & 12 & Pressure Head & -1.9 & 0.01000 & -142.485 \\
\hline 4 & 12 & 18 & Pressure Head & -1.9 & 0.01000 & -149.27 \\
\hline 5 & 18 & 21 & Pressure Head & -2.44 & 0.01000 & -162.84 \\
\hline 6 & 21 & 28 & Pressure Head & -4.07 & 0.01000 & -162.84 \\
\hline 7 & 28 & 35 & Pressure Head & -5.97 & 0.01000 & -176.41 \\
\hline 8 & 35 & 42 & Pressure Head & -7.33 & 0.01000 & -176.41 \\
\hline 9 & 42 & 49 & Pressure Head & -7.6 & 0.01000 & -189.98 \\
\hline 10 & 49 & 66 & Pressure Head & -8.14 & 0.01000 & -189.98 \\
\hline 11 & 56 & 63 & Pressure Head & -8.14 & 0.01000 & -189.98 \\
\hline 12 & 63 & 70 & Pressure Head & -8.14 & 0.01000 & $-203,55$ \\
\hline 13 & 70 & 77 & Pressure Head & -8.28 & 0.01000 & -203.55 \\
\hline 14 & 77 & 84 & Pressure Head & -8.28 & 0.01000 & -217.12 \\
\hline 15 & 84 & 91 & Pressure Head & -8.28 & 0.01000 & -217.12 \\
\hline 16 & 91 & 98 & Pressure Head & -8.28 & 0.01000 & -217.12 \\
\hline 17 & 98 & 105 & Pressure Head & -8.55 & 0.01000 & -230.69 \\
\hline 18 & 105 & 112 & Pressure Head & -8.68 & 0.01000 & -230.69 \\
\hline 19 & 112 & 119 & Pressure Head & -8.68 & 0.01000 & -230.69 \\
\hline 20 & 119 & 126 & Pressure Head & -8.28 & 0.01000 & -244.26 \\
\hline 21 & 126 & 133 & Pressure Head & -8.28 & 0.01000 & -244.26 \\
\hline 22 & 133 & 140 & Pressure Head & -8.68 & 0.01000 & -244.26 \\
\hline 23 & 140 & 147 & Pressure Head & -8.68 & 0.01000 & -244.26 \\
\hline 24 & 147 & 153 & Pressure Head & -8.68 & 0.01000 & -244.26 \\
\hline 25 & 153 & 156 & Pressure Head & -8.68 & 0.01000 & -244.26 \\
\hline 26 & 156 & 160 & Pressure Head & -7.46 & 0.01000 & -257.83 \\
\hline 27 & 160 & 164 & Pressure Head & -3.53 & 0.01000 & -257.83 \\
\hline 28 & 164 & 168 & Pressure Head & -1.49 & 0.01000 & -257.83 \\
\hline 29 & 168 & 172 & Pressure Head & -1.9 & 0.01000 & -257.83 \\
\hline 30 & 172 & 176 & Pressure Head & -2.04 & 0.01000 & -257.83 \\
\hline 31 & 176 & 180 & Pressure Head & -1.76 & 0.01000 & -271.4 \\
\hline 32 & 180 & 182 & Pressure Head & -1.63 & 0.01000 & -271.4 \\
\hline 33 & 182 & 186 & Pressure Head & -2.17 & 0.01000 & -271.4 \\
\hline 34 & 186 & 190 & Pressure Head & -2.31 & 0.01000 & -271.4 \\
\hline 35 & 190 & 196 & Pressure Head & -2.85 & 0.01000 & -271.4 \\
\hline 36 & 196 & 200 & Pressure Head & -3.94 & 0.01000 & -271.4 \\
\hline
\end{tabular}


[VS2OT] Stress Period Defaults

IGUAL AOS MODELOS URÂNIA A E B

\section{Profile Structure}

IGUAL AOS MODELOS URÂNIA A E B

\subsection{Layer. [01] ARE 0,5-1,5}

[VS2DT] Soil Parameters

\begin{tabular}{|c|c|c|}
\hline Parameter & Value & Units \\
\hline Horizontal Sat.Hydr.Conductivity & 0.03134 & (cm/sec)
\end{tabular}

IV2DTI Initial Conditions

\begin{tabular}{|c|c|c|}
\hline \multicolumn{1}{|c|}{ Parameter } & Value & Units \\
\hline Pressure Head & -217.12 & $(\mathrm{~cm})$ \\
\hline
\end{tabular}

1.2. Layer. [02] ARE 1,5-2,5

[VS2DT] Soil Parameters

\begin{tabular}{|c|c|c|}
\hline Parameter & Value & Units \\
\hline Horizontal Sat.Hydr.Conductivity & 0.02483 & $(\mathrm{~cm} / \mathrm{sec})$ \\
\hline
\end{tabular}

[VS2DT] Initial Conditions

\begin{tabular}{|c|c|c|}
\hline Parameter & Value & Units \\
\hline Pressure Head & -162.84 & (cm) \\
\hline
\end{tabular}

1.3. Layer. [03] ARESILT 2,5-3,5

IVS2DT] Soil Parameters

\begin{tabular}{|c|c|c|}
\hline Parameter & Value & Units \\
\hline Horizontal Sat.Hydr.Conductivity & 0.01756 & (cm/sec) \\
\hline \\
[VS2DT] Initial Conditions \\
\hline Parameter & & \\
\hline Pressure Head Value & Units \\
\hline
\end{tabular}

1.4. Layer. [04] ARESILT 3,5-4,5

IVS2DT7 Soil Parameters

\begin{tabular}{|c|c|c|}
\hline Parameter & Value & Units \\
\hline Horizontal Sat.Hydr.Conductivity & 0.01234 & $(\mathrm{~cm} / \mathrm{sec})$ \\
\hline
\end{tabular}

[VS2DT] Initial Conditions

\begin{tabular}{|c|c|c|}
\hline \multicolumn{1}{|c|}{ Parameter } & Value & Units \\
\hline Pressure Head & -176.41 & (cm) \\
\hline
\end{tabular}

\subsection{Layer. [05] ARESILT 4,5-5,5}

[VS2DT] Soil Parameters

\begin{tabular}{|c|c|c|}
\hline Parameter & Value & Units \\
\hline Horizontal Sat.Hydr.Conductivity & 0.008986 & (cm/sec) \\
\hline
\end{tabular}

IVS2DT7 Initial Conditions

\begin{tabular}{|l|c|c|}
\hline \multicolumn{1}{|c|}{ Parameter } & Value & Units \\
\hline Pressure Head & -162.84 & (cm) \\
\hline
\end{tabular}

\subsection{Layer. [06] ARESILT 5,5-6,5}

[VS2DT] Soil Parameters

\begin{tabular}{|c|c|c|}
\hline Parameter & Value & Units \\
\hline Horizontal Sat.Hydr.Conductivity & 0.006877 & (cm/sec) \\
\hline
\end{tabular}

\begin{tabular}{|c|c|c|}
\hline Parameter & Value & Units \\
\hline Pressure Head & -135.7 & $(\mathrm{~cm})$ \\
\hline
\end{tabular}


1.7. Layer. [07] ARESILT 6,5-7,5

[VS2DT] Soil Parameters

\begin{tabular}{|c|c|c|}
\hline Parameter & Value & Units \\
\hline Horizontal Sat.Hydr.Conductivity & 0.005911 & $(\mathrm{~cm} / \mathrm{sec})$ \\
\hline
\end{tabular}

[VS2DT] Initial Conditions

\begin{tabular}{|l|c|c|}
\hline \multicolumn{1}{|c|}{ Parameter } & Value & Units \\
\hline Pressure Head & -162.84 & $(\mathrm{~cm})$ \\
\hline
\end{tabular}

\begin{tabular}{|c|c|c|c|}
\hline \multicolumn{4}{|c|}{ RESULTADOS PARCIAIS DO MODELLO URANIA C } \\
\hline Dia & $\begin{array}{l}\text { Profundidade } \\
\text { (cm) }\end{array}$ & $\begin{array}{l}\text { Potencial Matricial } \\
\text { Calculado (cm) }\end{array}$ & $\begin{array}{c}\text { Potencial Matricial } \\
\text { Observado }(\mathrm{cm})\end{array}$ \\
\hline $\begin{array}{c}12 \\
28 \\
56 \\
112 \\
156 \\
200 \\
\end{array}$ & $\begin{array}{l}100 \\
100 \\
100 \\
100 \\
100 \\
100\end{array}$ & $\begin{array}{l}-187,00 \\
-364,00 \\
-613,00 \\
-736,00 \\
-771,00 \\
-348,00 \\
\end{array}$ & $\begin{array}{l}-271,40 \\
-326,00 \\
-556,00 \\
-746,00 \\
-814,00 \\
-312,00 \\
\end{array}$ \\
\hline $\begin{array}{c}12 \\
28 \\
56 \\
112 \\
156 \\
200 \\
\end{array}$ & $\begin{array}{l}200 \\
200 \\
200 \\
200 \\
200 \\
200\end{array}$ & $\begin{array}{l}-176,00 \\
-293,00 \\
-451,00 \\
-580,00 \\
-631,00 \\
-282,00\end{array}$ & $\begin{array}{l}-204,00 \\
-257,83 \\
-312,11 \\
-447,81 \\
-529,23 \\
-244,26\end{array}$ \\
\hline $\begin{array}{c}12 \\
28 \\
56 \\
112 \\
156 \\
200 \\
\end{array}$ & $\begin{array}{l}300 \\
300 \\
300 \\
300 \\
300 \\
300 \\
\end{array}$ & $\begin{array}{l}-166,00 \\
-246,00 \\
-369,00 \\
-484,00 \\
-534,00 \\
-241,00 \\
\end{array}$ & $\begin{array}{l}-217,00 \\
-271,40 \\
-325,68 \\
-488,52 \\
-610,65 \\
-325,68\end{array}$ \\
\hline $\begin{array}{c}12 \\
28 \\
56 \\
112 \\
156 \\
200 \\
\end{array}$ & $\begin{array}{l}400 \\
400 \\
400 \\
400 \\
400 \\
400\end{array}$ & $\begin{array}{l}-157,00 \\
-214,00 \\
-315,00 \\
-416,00 \\
-460,00 \\
-214,00\end{array}$ & $\begin{array}{l}-183,00 \\
-217,12 \\
-271,40 \\
-366,39 \\
-434,24 \\
-434,24\end{array}$ \\
\hline $\begin{array}{c}12 \\
28 \\
56 \\
112 \\
156 \\
200 \\
\end{array}$ & $\begin{array}{l}500 \\
500 \\
500 \\
500 \\
500 \\
500 \\
\end{array}$ & $\begin{array}{l}-145,00 \\
-188,00 \\
-273,00 \\
-358,00 \\
-397,00 \\
-190,00\end{array}$ & $\begin{array}{l}-162,84 \\
-203,55 \\
-244,26 \\
-312,11 \\
-352,82 \\
-393,53 \\
\end{array}$ \\
\hline $\begin{array}{c}12 \\
28 \\
56 \\
112 \\
156 \\
200 \\
\end{array}$ & $\begin{array}{l}600 \\
600 \\
600 \\
600 \\
600 \\
600 \\
\end{array}$ & $\begin{array}{l}-129,00 \\
-163,00 \\
-235,00 \\
-306,00 \\
-338,00 \\
-167,00\end{array}$ & $\begin{array}{l}-135,70 \\
-162,84 \\
-189,98 \\
-244,26 \\
-271,40 \\
-284,97\end{array}$ \\
\hline $\begin{array}{c}12 \\
28 \\
56 \\
112 \\
156 \\
200 \\
\end{array}$ & $\begin{array}{l}700 \\
700 \\
700 \\
700 \\
700 \\
700 \\
\end{array}$ & $\begin{array}{l}-121,00 \\
-151,00 \\
-205,00 \\
-257,00 \\
-278,00 \\
-168,00\end{array}$ & $\begin{array}{l}-142,49 \\
-162,84 \\
-189,98 \\
-230,69 \\
-244,26 \\
-271,40\end{array}$ \\
\hline
\end{tabular}




\subsection{ANEXO 5-UMIDADE E CONDUTIVIDADE HIDRÁULICA NÃO SATURADA}

\begin{tabular}{|c|c|c|c|c|c|c|c|c|c|c|c|c|c|c|c|c|c|c|}
\hline \multicolumn{19}{|c|}{ UMIDADE DE SATURACAO (\%) } \\
\hline & T50 & TSOC & TSOD & TSOE & $\mathrm{T1}$ & T1B & T1C & $\mathrm{T1D}$ & T1E & $T 2$ & 13 & T $3 B$ & $T 4$ & T5 & 76 & $\pi$ & T8 & T9 \\
\hline alfa linha & $-48,0$ & $-48,0$ & $-48,0$ & $-48,0$ & $-48,0$ & $-48,0$ & $-48,0$ & $-48,0$ & $-48,0$ & $-47,0$ & $-49,5$ & $-49,5$ & $-53,1$ & $-55,1$ & $-53,6$ & $-49,0$ & & \\
\hline alfa & 0,021 & 0,021 & 0,021 & 0,021 & 0,021 & 0.021 & 0,021 & 0.021 & 0,021 & 0,021 & 0,020 & 0,020 & 0,019 & 0,018 & 0,019 & 0,020 & 0,030 & 0,034 \\
\hline $\mathrm{m}$ & 0,448 & 0,448 & 0,448 & 0,448 & 0,448 & 0,448 & 0.448 & 0,448 & 0,448 & 0,428 & 0,440 & 0,440 & 0.450 & 0,449 & 0,448 & 0,444 & 0,328 & 0,268 \\
\hline$n$ & 1,810 & 1,810 & 1,810 & 1,810 & 1,810 & 1,810 & 1,810 & 1,810 & 1,810 & 1,748 & 1,784 & 1.784 & 1.818 & 1,814 & 1,812 & 1,798 & 1,487 & 1,366 \\
\hline TETAr & 0,158 & 0,158 & 0,158 & 0,158 & 0,158 & 0,158 & 0,158 & 0,158 & 0.158 & 0,154 & 0,145 & 0,145 & 0,146 & 0,144 & 0,211 & 0,246 & 0,193 & 0,229 \\
\hline TETAS & 0,414 & 0,414 & 0.414 & 0,414 & 0,414 & 0,414 & 0,414 & 0,414 & 0,414 & 0,421 & 0.431 & 0,431 & 0,428 & 0,423 & 0,431 & 0,438 & 0,451 & 0,442 \\
\hline data & $T 50$ & $\mathrm{~T} 50 \mathrm{C}$ & T50D & $\mathrm{T} 50 \mathrm{E}$ & $T 1$ & T1B & T1C & T1D & $T+E$ & $T 2$ & $T 3$ & T3B & T4 & 75 & T6 & $T 7$ & 78 & T9 \\
\hline $10 / 02 / 99$ & & & & & 68,5 & & & & & & 58,4 & & & 59,8 & & 74,3 & & 84,8 \\
\hline $18 / 02 / 99$ & & & & & 63,2 & & & & & & 55,8 & & & 59,8 & & 74,3 & & 84.8 \\
\hline $20 / 03 / 99$ & & & & & 60,1 & & & & & & 53,7 & & & 57,1 & & 72,2 & & 100,0 \\
\hline $27 / 03 / 99$ & & & & & 60,1 & & & & & & 52,0 & & & 57,1 & & 72,2 & & 100,0 \\
\hline $03 / 04 / 99$ & & & & & 57,8 & & & & & & 52,0 & & & 54,9 & & 72,2 & & 100,0 \\
\hline $10 / 04 / 99$ & & & & & 63,2 & & & & & & 52,0 & & & 54,9 & & 72,2 & & 100,0 \\
\hline $17 / 04 / 99$ & & & & & 60,1 & & & & & & 50,6 & & & 53,2 & & 70,5 & & 100,0 \\
\hline $24 / 04 / 99$ & & & & & 60,1 & & & & & & 50,6 & & & 53,2 & & 70,5 & & 100,0 \\
\hline $01 / 05 / 99$ & & & & & 60,1 & & & & & & 50,6 & & & 53.2 & & 70,5 & & 100,0 \\
\hline $08105 / 99$ & & & & & 57,8 & & & & & & 50,6 & & & 51,7 & & 69,1 & & 100,0 \\
\hline $15 / 05 / 99$ & 67,3 & & & & 58,9 & 60.1 & & & & 53,4 & 50,0 & 51,3 & 51,1 & 51,7 & 64,7 & 69.1 & 79,6 & 100,0 \\
\hline $22 / 05 / 99$ & 63,2 & & & & 57,8 & 63,2 & & & & 52,3 & 49,5 & 50,6 & 49,9 & 51,0 & 64,7 & 69,1 & 74,3 & 100,0 \\
\hline $26 / 05 / 99$ & 61,5 & & & & 56,8 & 55,9 & & & & 52,3 & 49,5 & 50,0 & 51.1 & 51,0 & 64,7 & 69,1 & 79,6 & 100,0 \\
\hline $29 / 05 / 99$ & 60,1 & & & & 55,9 & 55,1 & & & & 51,8 & 48,9 & 50,0 & 50,5 & 50,4 & 63,4 & 68,5 & 79,6 & 100,0 \\
\hline $02 / 06 / 99$ & 60,1 & & & & 55,9 & 55,9 & & & & 51,8 & 48,4 & 50,6 & 50,5 & 50,4 & 64,0 & 69,1 & 77,2 & 100,0 \\
\hline $05 / 06 / 99$ & 60,1 & & & & 55,9 & 54,4 & & & & 51,8 & 48,4 & 49,5 & $49, \theta$ & 50,4 & 64,0 & 68,5 & 79,6 & 100,0 \\
\hline $09 / 06 / 99$ & 58.9 & & & & 55,1 & 54,4 & & & & 50,6 & 47,6 & $46, \mathrm{~B}$ & 47,1 & 47,6 & 64,0 & 68,5 & 77,2 & 100,0 \\
\hline $12 / 06 / 99$ & 60.1 & & & & 54,4 & 54,4 & & & & 50,6 & 46,8 & 46,8 & 47.1 & 48,4 & 64,0 & 68,0 & 77,2 & 100,0 \\
\hline $16 / 06 / 99$ & 57,8 & & & & 54,4 & 54,4 & & & & 50,6 & 47,2 & 46,8 & 47,1 & 48,4 & 63,4 & 68,5 & 77,2 & 100,0 \\
\hline $19 / 06 / 99$ & 56,8 & & & & 53,7 & 53,7 & & & & 49,8 & 47,2 & 46,8 & 47.1 & 48,4 & 63,4 & 68,0 & 77,2 & 100,0 \\
\hline $22 / 06 / 99$ & 58,9 & & & & 54,4 & 55,9 & & & & 50,2 & 47,6 & 49,5 & 49,3 & 49.4 & 63,4 & 68,0 & 77,2 & 100,0 \\
\hline $23 / 06 / 99$ & 58,9 & & & & 54,4 & 55.9 & & & & 50,2 & 48,4 & 49,5 & 49,3 & 49,4 & 63,4 & 68,0 & 77,2 & 100,0 \\
\hline 24106199 & 58,9 & & & & 54,4 & 55,9 & & & & 51,0 & 47,6 & 49,5 & 49,3 & 48,9 & 63,4 & 68,5 & 77,2 & 100,0 \\
\hline $25 / 06199$ & 60,1 & & & & 54,4 & 55,9 & & & & 51,0 & 47.6 & 49,5 & 49,3 & 48,9 & 63,4 & 68,0 & 77,2 & 100,0 \\
\hline $26106 / 99$ & 60,1 & & & & 54,4 & 55,9 & & & & 51,0 & 47,6 & 49.5 & 49,3 & 48,9 & 63,4 & 68,0 & 772 & 100,0 \\
\hline $30 / 06 / 99$ & 60,1 & & & & 537 & 55,1 & & & & 51,0 & 47,2 & 48,9 & 48,8 & 48,4 & 63.4 & 68,0 & 77,2 & 100,0 \\
\hline $03 / 07 / 99$ & 58,9 & & & & 53,7 & 55,1 & & & & 50,6 & 47,2 & 48,9 & 48,8 & 48,4 & 63,4 & 68,0 & 77,2 & 100,0 \\
\hline $07 / 07 / 99$ & 58,9 & & & & 53,1 & 54,4 & & & & 50,6 & 46,8 & 48,9 & 48,8 & 48,4 & 63,4 & 68,0 & 77,2 & 100,0 \\
\hline $10 / 07 / 99$ & 58,9 & & & & 53,1 & 54,4 & & & & 50,6 & 46.8 & 48,4 & 48,8 & 48,0 & 62,8 & 68,0 & 77,2 & 100,0 \\
\hline $14 / 07 / 99$ & 57,8 & & & & 53,1 & 53,1 & & & & 50,6 & 46,4 & 48,4 & 48,4 & 47,6 & 62,8 & 67,5 & 74,3 & 100,0 \\
\hline $17 / 07 / 99$ & 56,8 & & & & 52,5 & 53,1 & & & & 50,2 & 46,1 & 48,4 & 48,4 & 47,6 & 62,2 & 67,5 & 74,3 & 100,0 \\
\hline $21 / 07 / 99$ & 55,9 & & & & 52,5 & 53,1 & & & & 50,2 & 46,1 & 48,4 & 47,9 & 46,9 & 62,2 & 67.1 & 74,3 & 100,0 \\
\hline $24 / 07 / 99$ & 55,1 & & & & 52,0 & 52,5 & & & & 49.8 & 46,1 & 48,4 & 47,9 & 46,9 & 62,2 & 67.1 & 74,3 & 100,0 \\
\hline $28 / 07 / 99$ & 54,4 & & & & 51,5 & 52,5 & & & & 49,8 & 45,8 & 48,4 & 47,9 & 46,6 & 62,2 & 67,1 & 74,3 & 100,0 \\
\hline $31 / 07 / 99$ & 54,4 & & & & 51,1 & 52,0 & & & & 49,8 & 45,5 & 48,4 & 48,4 & 46,3 & 61,7 & 67,1 & 74,3 & 100,0 \\
\hline $04 / 08 / 99$ & 53,1 & & & & 51,1 & 52,0 & & & & 49,5 & 45,5 & 48,0 & 47,5 & 46,3 & 61,7 & 67,1 & 74,3 & 100,0 \\
\hline $07 / 08 / 99$ & 53,1 & & & & 50,3 & 52,0 & & & & 49,5 & 45,2 & 48,0 & 47,1 & 45,7 & 61,7 & 67,1 & 74,3 & 100,0 \\
\hline $13 / 08 / 99$ & 52,0 & & & & 50,0 & 51,5 & & & & 49,2 & 45,0 & 47,6 & 47,1 & 45,4 & 61,3 & 66,3 & 72,0 & 98,4 \\
\hline $14 / 08 / 99$ & 53,1 & 53,7 & 52,0 & 48,5 & 49,6 & 51,1 & 47,2 & 47.8 & 46,5 & 49,2 & 45.0 & 47,6 & 46.8 & 45,4 & 61,3 & 66,3 & 72,0 & 98,4 \\
\hline $18 / 08 / 99$ & 51,5 & 50,0 & 50,0 & 47,2 & 49,6 & 51,1 & 46,2 & 46,8 & 45,5 & 48,9 & 44,7 & 47,6 & 46,8 & 44,9 & 60,9 & 66,3 & 70,7 & 98,4 \\
\hline $21 / 08 / 99$ & 51,1 & 49,6 & 49,6 & 46,6 & 49,0 & 50,7 & 45,6 & 46,2 & 45,2 & 48,9 & 44,5 & 47,6 & 46,4 & 44,9 & 60,9 & 66,3 & 70,7 & 98,4 \\
\hline $25 / 08 / 99$ & 50,3 & 50,0 & 49,0 & 46,0 & 48,7 & 50,3 & 45,3 & 45,9 & 44,9 & 48,6 & 44,2 & 47,2 & 46,4 & 44,5 & 60.5 & 66,0 & 70,7 & 98,4 \\
\hline $28 / 08 / 99$ & 50,3 & 49,0 & 49,0 & 45,9 & 48,5 & 50,3 & 45,2 & 45,6 & 44,8 & 48,3 & 44,2 & 46,8 & 46,4 & 44,3 & 60,5 & 65.7 & 70,7 & 96,3 \\
\hline $01 / 09 / 99$ & 49,3 & 49,0 & 49,0 & 45,5 & 48,2 & 50,0 & 45,0 & 45,6 & 44,6 & 48,3 & 44,5 & 46,8 & 46,1 & 43,9 & 59,8 & 65,7 & 69,5 & 90,8 \\
\hline $05 / 09 / 99$ & 49,0 & 49,6 & 49,0 & 45,5 & 48,0 & 50,0 & 45,0 & 45,5 & 44,6 & 48,6 & 44,0 & 46,8 & 46,1 & 43,7 & 59,8 & 65,4 & 69,5 & 90,8 \\
\hline $08 / 09 / 99$ & 48,5 & 48,5 & 48,5 & 45,4 & 48,0 & 50,0 & 44,8 & 45,4 & 44,4 & 48,3 & 44,5 & 46,8 & 45,8 & 43,5 & 59,4 & 65,1 & 68,5 & 90,8 \\
\hline $11 / 09 / 99$ & 48,2 & 53,1 & 49,0 & 45,4 & 47,8 & 49,6 & 44,7 & 45,4 & 44,2 & 48,6 & 43,8 & 46,8 & 45,8 & 43,4 & 59,1 & 64,8 & 68,5 & 90,8 \\
\hline $15109 / 99$ & 47,6 & 53,1 & 48,5 & 45,0 & 47,4 & 49,3 & 44,6 & 45,2 & 44,1 & 48,1 & 43,6 & 46,8 & 45,8 & 43,0 & 59,1 & 64,6 & 68,5 & 90,8 \\
\hline $16 / 09 / 99$ & 47,8 & 53,1 & 49,0 & 45,1 & 47.4 & 49,3 & 44,7 & 45,4 & 44,2 & 48,3 & 43,6 & 46,8 & 45,8 & 43,0 & 59,1 & 64,6 & 68,5 & 90,8 \\
\hline $17 / 09 / 99$ & 47,6 & 51,5 & 49,0 & 45,2 & 47,2 & 49,3 & 44,8 & 45,6 & 44,2 & 48,1 & 43,6 & 46,8 & 45,8 & 43,0 & 59,1 & 64,6 & 68,5 & $\$ 0,8$ \\
\hline $18 / 09 / 99$ & 47,6 & 51,5 & 49,0 & 45,2 & 47,2 & 49,3 & 44,8 & 45,6 & 44,2 & 48,1 & 43,6 & 46,8 & 45,8 & 43,0 & 59,1 & 64,6 & 68,5 & 90,8 \\
\hline $22109 / 99$ & 50,3 & 50,3 & 48,5 & 45,0 & 47,2 & 49,0 & 44,8 & 45,5 & 44,2 & 48,1 & 43,6 & 46,8 & 45,8 & 42,9 & 58,9 & 64,4 & 68,5 & 90,8 \\
\hline $25 / 09 / 99$ & 55,1 & 53,1 & 49,0 & 45,0 & 47,2 & 49,0 & 44,8 & 45,5 & 44,2 & 48,1 & 43,6 & 46,8 & 45,8 & 42,8 & 58,6 & 64,1 & 68,5 & 90,8 \\
\hline $29 / 09 / 99$ & 56,8 & 51,5 & 49,0 & 45,1 & 47,6 & 49,0 & 44,9 & 45,6 & 44,2 & 48,1 & 43,4 & 46,4 & 45,5 & 42,6 & 58,6 & 63,9 & 67,6 & 88,0 \\
\hline $02 / 10 / 90$ & 56,8 & 50,7 & 49,0 & 45,1 & 47,8 & 49,0 & 44,8 & 45,5 & 44,2 & 47,9 & 43,1 & 46,1 & 45,3 & 42,3 & 58,1 & 63,8 & 67,6 & 88,0 \\
\hline $06 / 10 / 99$ & 56,8 & 50,7 & 49,0 & 45,2 & 48,0 & 49,0 & 44,9 & 45,6 & 44,2 & 47,9 & 429 & 46,1 & 45,0 & 42,2 & 58,1 & 63,8 & 67,6 & 88,0 \\
\hline $09 / 10 / 99$ & 55,9 & 54,4 & 51,5 & 45,0 & 482 & 48,7 & 44,6 & 45,4 & 44,2 & 47,6 & 42,6 & 46,1 & 44,8 & 42,1 & 57,7 & 63,4 & 66,8 & 84,8 \\
\hline $13 / 10 / 99$ & 55,9 & 53,1 & 51,5 & 45,0 & 48,0 & 48,7 & 44,6 & 45,3 & 44,2 & 47,4 & 42,4 & 45,8 & 44,5 & 41,9 & 57,5 & 63,2 & 66,8 & 84,8 \\
\hline $16 / 10 / 99$ & 55,9 & 53,1 & 51,5 & 45,0 & 48,0 & 48,7 & 44,6 & 45,3 & 44,2 & 47,4 & 42,4 & 45,8 & 44,5 & 41,9 & 57,5 & 63,2 & 66,8 & 84,8 \\
\hline $20 / 10 / 99$ & 54,4 & 52,5 & 51,1 & 44,8 & 47.6 & 48,5 & 44,4 & 45,1 & 44,2 & 47,2 & 42,0 & 45,5 & 43,9 & 41,7 & 56,9 & 62,8 & 66,1 & 83,2 \\
\hline $23 / 10 / 99$ & 53,7 & 53,1 & 51,5 & 44,8 & 47,2 & 48,2 & 44,5 & 45,1 & 44,2 & 46,6 & 41,5 & 45,5 & 43,7 & 41,5 & 56,6 & 62,5 & 65,4 & 83,2 \\
\hline $27 / 10 / 99$ & 53,1 & 55,1 & 50,7 & 44,6 & 46,8 & 48,0 & 44,3 & 45,0 & 44,1 & 46,3 & 41,2 & 45,2 & 43,3 & 41,4 & 56,3 & 62,5 & 65,4 & 83,2 \\
\hline $30 / 10 / 99$ & 53,1 & 55,1 & 50,7 & 44,6 & 46,8 & 48,0 & 44,3 & 45,0 & 44,1 & 46,3 & 41,2 & 45,2 & 43,3 & 41,4 & 56,3 & 62,5 & 65,4 & 83,2 \\
\hline $03 / 11 / 99$ & 57,8 & 53,1 & 51,5 & 44,6 & 46,6 & 47,8 & 44,2 & 44,9 & 44,1 & 46,0 & 40,9 & 45,0 & 42,9 & 41,4 & 55,9 & 62,3 & 64,8 & 81,1 \\
\hline $05 / 11 / 99$ & 57,8 & 55,9 & 515 & 44,6 & 46,8 & 47,6 & 44,2 & 44,7 & 44,1 & 45,8 & 40,9 & 44,7 & 42,6 & 41,4 & 55,8 & 62,2 & 65,4 & 81,1 \\
\hline $06 / 11 / 99$ & 57,8 & 54,4 & 52,5 & 44,6 & 47,2 & 47,8 & 44,2 & 448 & 44,1 & 45,8 & 40,9 & 44,7 & 42,6 & 41,4 & 55,9 & 62.2 & 65,4 & 81,1 \\
\hline
\end{tabular}




\begin{tabular}{|c|c|c|c|c|c|c|c|c|c|c|c|c|c|c|c|c|c|c|}
\hline \multicolumn{19}{|c|}{ UMIDADE DE SATURACAO (\%) } \\
\hline & T50 & T50C & T50D & T50E & T1 & T1B & T1C & T1D & $T 1 E$ & $\mathrm{~T} 2$ & T3 & T3B & $T 4$ & T5 & T6 & 17 & T8 & T9 \\
\hline $07 / 11 / 99$ & 57,8 & 54,4 & 52,5 & 44,6 & 47,2 & 47,8 & 44,2 & 44,8 & 44,1 & 45,8 & 40,9 & 44,7 & 42,6 & 41,4 & 55,8 & 62,2 & 65.4 & 81.1 \\
\hline $08 / 11 / 99$ & 57,8 & 54,4 & 53,1 & 44,8 & 47,6 & 47,8 & 44,3 & 44,9 & 44,1 & 45,7 & 40,9 & 44,7 & 42,8 & 41,4 & 55,8 & 62,1 & 64,8 & 81,1 \\
\hline $10 / 11 / 90$ & 57,8 & 54,4 & 53,1 & 44,8 & 47.6 & 47,8 & 44,3 & 44,9 & 44,1 & 45,7 & 40,9 & 44,7 & 42,6 & 41,4 & 55,8 & 62,1 & 64,8 & 81,1 \\
\hline $12 / 11 / 90$ & 57,8 & 53,1 & 53,1 & 44,8 & 48,2 & 47,6 & 44,2 & 44,8 & 44,1 & 45,5 & 40,7 & 44,5 & 42,3 & 41,3 & 55,7 & 62,0 & 64,8 & 81,1 \\
\hline $13 / 11 / 99$ & 57,8 & 53,1 & 53,1 & 44,8 & 48,2 & 47,6 & 44,2 & 44,8 & 44,1 & 45,5 & 40,7 & 44,5 & 42,3 & 41,3 & 55.7 & 62,0 & 64,8 & 81.1 \\
\hline $14 / 11 / 99$ & 57,8 & 52,0 & 52,5 & 44,8 & 48,2 & 47,6 & 44,2 & 44,8 & 44,1 & 45,5 & 40,7 & 44,5 & 42,3 & 41,3 & 55,7 & 62,0 & 64,8 & 81,1 \\
\hline $15 / 11 / 99$ & 56,8 & 51,1 & 52,0 & 44,8 & 48,5 & 47,4 & 44,2 & 44,7 & 44,1 & 45,4 & 40,7 & 44.5 & 42,0 & 41,3 & 55,6 & 62,0 & 64,8 & 81,1 \\
\hline $16 / 11 / 99$ & 56,8 & 51,1 & 52,0 & 44,8 & 48,5 & 47,4 & 44,2 & 44,7 & 44,1 & 45,4 & 40,7 & 44,5 & 42,0 & 41,3 & 55,6 & 62,0 & 64,8 & 81,1 \\
\hline $17 / 11 / 99$ & 55,9 & 48.7 & 51,1 & 44,8 & 48,5 & 47,4 & 44,2 & 44,8 & 44,1 & 45,3 & 40,6 & 44,2 & 42,0 & 41,2 & 55,6 & 61,9 & 64,2 & 81,1 \\
\hline $18 / 11 / 99$ & 55,9 & 48,2 & 50,3 & 44,8 & 48,5 & 47,6 & 44,2 & 44,8 & 44,1 & 45,3 & 40,6 & 44,2 & 42,0 & 41,2 & 55,6 & 61,9 & 64,2 & 81,1 \\
\hline $19 / 11 / 99$ & 55.9 & 47,8 & 50,0 & 44,8 & 48.5 & 47.6 & 44,2 & 44,8 & 44,1 & 45,3 & 40,6 & 44,2 & 42.0 & 41,2 & 55,4 & 61,9 & 64.2 & 81.1 \\
\hline $20 / 11 / 99$ & 55,9 & 47,2 & 49,6 & 44,8 & 48,5 & 47,6 & 44,2 & 44,8 & 44,1 & 45,3 & 40,6 & 44,2 & 41,9 & 41,2 & 55,4 & 61,9 & 64,2 & 81,1 \\
\hline $21 / 11 / 99$ & 55,9 & 46,3 & 49,3 & 44,8 & 48,2 & 47.2 & 44,2 & 44,8 & 44,1 & 45,3 & 40,6 & 44,0 & 41,8 & 41,2 & 55,4 & 61,9 & 64,2 & 81,1 \\
\hline $22 / 11 / 99$ & 55,9 & 45,0 & 48,0 & 44,6 & 48,0 & 47,2 & 44,2 & 44,8 & 44,1 & 45,3 & 40,5 & 43,8 & 41,7 & 41,2 & 55,4 & 61,8 & 64,2 & 81,1 \\
\hline $24 / 11 / 99$ & 56,8 & 44,4 & 45,3 & 44,3 & 47,6 & 47,2 & 44,4 & 44,8 & 44,1 & 45,3 & 40,6 & 43,6 & 41.6 & 41,1 & 55,1 & 61,6 & 64,2 & 81,1 \\
\hline $27 / 11 / 99$ & 55,9 & 44,4 & 45,3 & 44,2 & 47,4 & 47,0 & 44,3 & 44,8 & 44,1 & 45,0 & 40,5 & 43,6 & 41,5 & 41,1 & 55,1 & 61,6 & 64,2 & 81,1 \\
\hline $01 / 12 / 99$ & 53,1 & 43,9 & 44,2 & & 46,5 & 46,8 & 44,1 & 44,4 & 43.9 & 44,8 & 40,4 & 43,2 & 41,3 & 41,1 & 54,9 & 61,5 & 63,7 & 80,5 \\
\hline $04 / 12 / 99$ & 52,5 & 43,9 & 44,3 & & 46,5 & 46,6 & 44,2 & 44,6 & 44,0 & 44,8 & 40,4 & 43,1 & 41,3 & 41,1 & 54,9 & 61,5 & 63,2 & 80,5 \\
\hline $07 / 12 / 99$ & 51,1 & 43,9 & & 44,7 & 45,9 & 46,5 & 44,0 & 44,4 & 43,9 & 44,7 & 40,4 & 42,9 & 41,2 & 41,0 & 54,8 & 61,4 & 63,2 & 79,5 \\
\hline $0 \mathrm{~g} / 12 / 99$ & 51,1 & 438 & & 44,7 & 45,9 & 46,5 & 44,0 & 44,4 & 43,9 & 44,7 & 40,3 & 42,7 & 41,2 & 41,0 & 54,8 & 61,3 & 63,2 & 79.5 \\
\hline $11 / 12 / 99$ & 50,7 & 43,8 & 46,5 & 44,5 & 45,6 & 46.5 & 43,9 & 44,4 & & 44,6 & 40,3 & 42,6 & 41,1 & 41,1 & 54,8 & 61,3 & 63,2 & 79,5 \\
\hline $13 / 12 / 99$ & 50,3 & 43,8 & 45,9 & 44,5 & 45,6 & 46,5 & 44,0 & 44,4 & 46,5 & 44,6 & 40,3 & 42,6 & 41,1 & 41,1 & 54,9 & 61,3 & 63,2 & 79,5 \\
\hline $15 / 12 / 99$ & 50.7 & 43.8 & 45,8 & 44,5 & 45,5 & 46,5 & 44,0 & 44,4 & 45,4 & 44,6 & 40,4 & 42,6 & 41,1 & 41,2 & 55,0 & 61,3 & 63,2 & 79.5 \\
\hline $18 / 12 / 99$ & 50,3 & 43,8 & 45.6 & 44,5 & 45,4 & 46,5 & 44,0 & 44,4 & 45,0 & 44,6 & 40,5 & 42,4 & 41,0 & 41,2 & 54,6 & 61,2 & 63,2 & 78,6 \\
\hline $22 / 12 / 99$ & 58,9 & 43,9 & 45,6 & 44,1 & 45,2 & 46,2 & 43,9 & 44,4 & 44,5 & 44,5 & 40,5 & 42,0 & 41,0 & 41,3 & 54,6 & 61,1 & 63,2 & 78,6 \\
\hline $27 / 12 / 99$ & 57,8 & 43,9 & 45,9 & & 45,2 & 46,2 & 43,9 & 44,4 & 44,3 & 44,5 & & 41,9 & 40,9 & & 54,5 & 60,9 & 62,3 & 78,6 \\
\hline $29 / 12 / 99$ & 56,8 & 43,9 & 45,9 & & 45,2 & 46,2 & 43,9 & 44,4 & 44,3 & 44,5 & & 41,9 & 40,9 & & 54,5 & 60,9 & 62.7 & 78,6 \\
\hline $31 / 12 / 99$ & 56,8 & & 45,9 & 44,4 & 45,2 & 46,2 & 43,9 & 44,4 & 44,2 & 44,4 & & 41.7 & 40,9 & & 54,5 & 61,0 & 62,3 & 78,6 \\
\hline $03 / 01 / 00$ & 73,0 & & 63,2 & 44,2 & 45,4 & 45,9 & 43,9 & 44,2 & 44,1 & 44,4 & & 41,6 & 40,9 & & 54,5 & 61,0 & 62,3 & 78,6 \\
\hline $05 / 01 / 00$ & 68,5 & 55,1 & 60,1 & 44,2 & 58.9 & 45,9 & 43,9 & 44,2 & 44,1 & 44,4 & & 41,5 & 40,8 & & 54,5 & 61,0 & 62,3 & 78,6 \\
\hline $06 / 01 / 00$ & 68,5 & 55,1 & 60,1 & 44,1 & 58,8 & 45,9 & 43,9 & 44,2 & 44,0 & 44,4 & 41,5 & 41,5 & 40,8 & 42,1 & 54,5 & 60,9 & 62,3 & 78,6 \\
\hline $07 / 01 / 00$ & 68,5 & 55,1 & 60,1 & 44,1 & 58,9 & 45,8 & 43,9 & 44,2 & 43,9 & 44,4 & 41,5 & 41,5 & 40,8 & 42,1 & 54,5 & 60,9 & 62,3 & 78,6 \\
\hline $09 / 01 / 00$ & 76,7 & 58,9 & 68,5 & 44,2 & 63,2 & 45,8 & 44,0 & 44,4 & 43,9 & 44,4 & 41,2 & 41,4 & 40,8 & 41,9 & 54,5 & 60,9 & 62,3 & 78,6 \\
\hline $11 / 01 / 00$ & 68,5 & 578 & 63,2 & 44,5 & 63,2 & 45,8 & 44,8 & 45,0 & 43,9 & 44,4 & 41,1 & 41,4 & 40,8 & 41,7 & 54,5 & 60,9 & 62,3 & 77,7 \\
\hline $12 / 01 / 00$ & 68,5 & 56,8 & 63,2 & 44,9 & 63,2 & 45,8 & 46,0 & 45,6 & 44,0 & 44,3 & 41,0 & 41,4 & 40,8 & 41,5 & 54,5 & 60,9 & 62,3 & 77,7 \\
\hline $13 / 01 / 00$ & 68,5 & 55,9 & 63,2 & 45,6 & 63,2 & 45,9 & 50,3 & 47,2 & 44,0 & 44,3 & 40,9 & 41,3 & 40,9 & 41,4 & 54,5 & 60,9 & 62,3 & 77,7 \\
\hline $15 / 01 / 00$ & 67.3 & 55,9 & 60,1 & 52,5 & 60,1 & 45,9 & 55,9 & 53,1 & 44,0 & 44,3 & 40,8 & 41,3 & 40,9 & 41,4 & 54,5 & 60,9 & 61,9 & 77,7 \\
\hline $17 / 01 / 00$ & 64,1 & 53,7 & 58,9 & 54,4 & 58,9 & 45,8 & 53,7 & 53,4 & 43,9 & 44,2 & 40,7 & 41,3 & 40,9 & 41,3 & 54,3 & 60,9 & 61,9 & 77,7 \\
\hline $18 / 01 / 00$ & 63,2 & 54,4 & 61,5 & 55.9 & 58,9 & 45,9 & 55,1 & 54,4 & 43,9 & 44,2 & 40,7 & 41,2 & 41,0 & 41,3 & 54,5 & 60,8 & 61,9 & 77.7 \\
\hline $19 / 01 / 00$ & 63,2 & 53,1 & 60,1 & 55,9 & 58,9 & 45,9 & 54,4 & 54,4 & 44,1 & 44.2 & 40,7 & 41.3 & 41,0 & 41,4 & 54,5 & 60,9 & 61,9 & 77,0 \\
\hline $20101 / 00$ & 63,2 & 53,1 & 60,1 & 55,9 & 57,8 & 46,0 & 53,7 & 54,4 & 44,0 & 44,2 & 40,7 & 41,3 & 41,0 & 41,3 & 54,4 & 60,9 & 61,5 & 77,0 \\
\hline 22101100 & 63,2 & 54,4 & 63,2 & 57,8 & 57,8 & 46,3 & 55,9 & 55.9 & 44,1 & 44,2 & 40,6 & 41,2 & 41,0 & 41,3 & 54,4 & 60,8 & 61,9 & 77,0 \\
\hline $26 / 01 / 00$ & 63,2 & 52,5 & 60,1 & 54,4 & 56,8 & 47,0 & 52,0 & 53,1 & 44,1 & 44,2 & 40,6 & 41,1 & 41,1 & 41,3 & 54,4 & 60,8 & 62,7 & 78,6 \\
\hline $28 / 01 / 00$ & 67,3 & 54,4 & 61,5 & 56,8 & 60,1 & 47,4 & 52,0 & 57.8 & 44,1 & 44,2 & 40,6 & 41,1 & 41,1 & 41,3 & 54,4 & 60,8 & 63,2 & 78,6 \\
\hline $29 / 01 / 00$ & 73,0 & 57,8 & 63,2 & 60.1 & 63,2 & 48,0 & 52,0 & 55,9 & 44,1 & 44,2 & 40,5 & 41,1 & 41,1 & 41,3 & 54,4 & 60,8 & 63,2 & 78,6 \\
\hline $31 / 01 / 00$ & 73,0 & 55,9 & 63,2 & 60,1 & 63,2 & 49,0 & 55,9 & 56,8 & 44,1 & 44,2 & 40,5 & 41,1 & 41,2 & 41,3 & 54,3 & 60,8 & 63,2 & 78,6 \\
\hline 02102100 & 76.7 & 60.1 & 68,5 & 63,2 & 68,5 & 52,0 & 58.9 & 57,8 & 44,2 & 44.2 & 40,5 & 41.1 & 41,2 & 41.2 & 54,3 & 60.8 & 63,2 & 78,6 \\
\hline $03 / 02 / 00$ & 76,7 & 60,1 & 68,5 & 63,2 & 68,5 & 53,7 & 58,9 & 57,8 & 44,6 & 44,2 & 40,5 & 41,1 & 41,2 & 41,2 & 54,3 & 60,8 & 63,2 & 78.6 \\
\hline $04 / 02 / 00$ & 730 & 58,9 & 67,3 & 61,5 & 67,3 & 56,8 & 58,9 & 57,8 & 48,5 & 44,2 & 40.5 & 41,1 & 41,2 & 41,2 & 54,3 & 60,8 & 63,2 & 78,6 \\
\hline $05 / 02 / 00$ & 69,9 & 57,8 & 63,2 & 60,1 & 63,2 & 61,5 & 57.8 & 56,8 & 57,8 & 44,2 & 40,5 & 41,1 & 41,2 & 41,1 & 54,3 & 60,8 & 63,2 & 78,6 \\
\hline $09 / 02100$ & 68,5 & 55,9 & 63,2 & 58,9 & 60,1 & 67,3 & 56,8 & 55,9 & 56,8 & 44,2 & 40,5 & 41,1 & 41,2 & 41,1 & 54,3 & 60,7 & 63,2 & 78,6 \\
\hline $11 / 02100$ & 76,7 & 55,9 & 63,2 & 58,9 & 60,1 & 63,2 & 55,9 & 55,9 & 55,9 & 44,3 & 40,5 & 41,1 & 41,3 & 41,2 & 54,3 & 60,7 & 63,2 & 78,6 \\
\hline $13 / 02 / 00$ & 76,7 & 60,1 & 68,5 & 63,2 & 68,5 & 76,7 & 60.1 & 58,9 & 60,1 & 44.5 & 40,5 & 41,1 & 41,3 & 41,2 & 54,3 & 60,7 & 63,2 & 78,6 \\
\hline $14 / 02 / 100$ & 73,0 & 57,8 & 63,2 & 60,1 & 63,2 & 76.7 & 57.8 & 56,8 & 57,8 & 44,8 & 40,6 & 41.1 & 41,3 & 41,2 & 54,3 & 60,7 & 63,2 & 78,6 \\
\hline $15 / 02 / 00$ & 69,9 & 57,8 & 63,2 & 60,1 & 63,2 & 76,7 & 57,8 & 56,8 & 57,8 & 45,3 & 41,0 & 41,2 & 41,3 & 41,1 & 54,3 & 60,7 & 63,2 & 78,6 \\
\hline $16 / 02 / 00$ & 76,7 & 57,8 & 76,7 & 00,1 & 73,0 & 76,7 & 55,9 & 55,1 & 57.8 & 46,5 & 42,4 & 41,2 & 41,3 & 41,1 & 54,3 & 60,7 & 63,2 & 78,6 \\
\hline $17 / 02 / 00$ & 76.7 & 58,9 & 68,5 & 61,5 & 68,5 & 76,7 & 60,1 & 57,8 & 57,8 & 48,3 & 55,8 & 41,3 & 41,4 & 41,1 & 54,4 & 60.7 & 63,2 & 78,6 \\
\hline $18 / 02 / 00$ & 73,0 & 57,8 & 68,5 & 60,1 & 63,2 & 76,7 & 57,8 & 56,8 & 57,8 & 52,3 & 58,4 & 41,6 & 41,4 & 41,1 & 54,4 & 60,7 & 63,2 & 78,6 \\
\hline $19 / 02 / 00$ & 68,5 & 55,1 & 63,2 & 60,1 & 63,2 & 76,7 & 55,9 & 55,9 & 56,8 & 57,2 & 58,4 & 42,0 & 41,4 & 41,1 & 54,4 & 60,7 & 63,2 & 78,6 \\
\hline $23 / 02 / 00$ & 68,5 & 55,9 & 63,2 & 58,9 & 61,5 & 68,5 & 55,9 & 55,9 & 55,9 & 59,3 & 57,0 & 53,7 & 41,4 & 41,1 & 54,5 & 60,7 & 63,2 & 78,6 \\
\hline 24102100 & 67,3 & 53,1 & 60,1 & 57,8 & 60,1 & 68,5 & 54,4 & 544 & 55,8 & 59,3 & 57,0 & 54,7 & 41,4 & 41,1 & 54,5 & 60,7 & 63,2 & 78,6 \\
\hline $25 / 02100$ & 76,7 & 56,8 & 61,5 & 57.8 & 60,1 & 69,5 & 54,4 & 54,4 & 55.9 & 59,3 & 55,8 & 54,7 & 41,4 & 41.1 & 54,5 & 60,7 & 63,2 & 78,6 \\
\hline 26102100 & 73,0 & 55,9 & 61,5 & 58,9 & 63,2 & 68,5 & 54,4 & 54,4 & 55,1 & 59,3 & 55,8 & 54,7 & 41,4 & 41,1 & 54,5 & 60,7 & 63,2 & 78,6 \\
\hline $27 / 02100$ & 73,0 & 55,9 & 63,2 & 58,9 & 63,2 & 68,5 & 54,4 & 54,4 & 55,1 & 59,3 & 56,8 & 55,8 & 41,5 & 41,1 & 54,5 & 60,7 & 63,2 & 78,6 \\
\hline $28102 / 00$ & 76,7 & 58,9 & 67,3 & 63,2 & 68,5 & 68,5 & 57,8 & 56,8 & 58,9 & 59,3 & 55,8 & 55,8 & 41,5 & 41,1 & 54,5 & 60,7 & 63,2 & 78,6 \\
\hline $29 / 02 / 00$ & 76,7 & 58,9 & 68,5 & 61,5 & 632 & 76.7 & 57,8 & 56,8 & 58,9 & 63,6 & 58,4 & 55,8 & 41,5 & 41,1 & 54,5 & 60,7 & 63,2 & 78,6 \\
\hline $01 / 03 / 00$ & 76,7 & 57,8 & 68,5 & 61,5 & 63,2 & 76,7 & 57,8 & 56,8 & 57,8 & 63,6 & 61,7 & 55,8 & 41,6 & 41,1 & 54,5 & 60,7 & 64,2 & 78,6 \\
\hline $02 / 03100$ & 76.7 & 60,1 & 68,5 & 63,2 & 68,5 & 76.7 & 57,8 & 56,8 & 60,1 & 63,6 & 61,7 & 55,8 & 41,8 & 41,1 & 54,5 & 60,7 & 64,2 & 78.6 \\
\hline $03 / 03 / 00$ & 73,0 & 57,8 & 68,5 & 60,1 & 63,2 & 76,7 & 56,8 & 55,9 & 57,8 & 63,6 & 61,7 & 57,0 & 42,3 & 41,1 & 54,5 & 60,7 & 64,2 & 78,6 \\
\hline $04 / 03100$ & 76,7 & 60,1 & 76,7 & 63,2 & 63,2 & 76,7 & 57,8 & 57.8 & 57.8 & 63,6 & 59,9 & 57,0 & 44,3 & 41,1 & 54,5 & 60,7 & 64,2 & 78,6 \\
\hline $06 / 03 / 00$ & 76,7 & 58,9 & 68,5 & 61,5 & 63,2 & 76.7 & 57.8 & 55,9 & 58,9 & 63,6 & 58,4 & 58,4 & 62,5 & 41,2 & 54,5 & 60,7 & 64,2 & 78,6 \\
\hline $07 / 03 / 00$ & 76,7 & 58,9 & 68,5 & 61,5 & 63,2 & 76,7 & 57,8 & 55,9 & 58,9 & 63,6 & 58,4 & 58,4 & 62,5 & 41,3 & 54,5 & 60,7 & 64,2 & 81,1 \\
\hline $08 / 03 / 00$ & 73,0 & 57,8 & 67,3 & 60,1 & 63,2 & 73,0 & 56,8 & 55,9 & 57,8 & 62,0 & 59,9 & 58,4 & 62,5 & 41,3 & 54,5 & 60,7 & 64,8 & 81,1 \\
\hline $09 / 03 / 00$ & 68,5 & 56,8 & 63,2 & 60,1 & 632 & 76.7 & 55,9 & 55,9 & 57,8 & 62,0 & 58,4 & 58,4 & 62,5 & 41,4 & 54,6 & 60,7 & 64,8 & 81,1 \\
\hline
\end{tabular}




\begin{tabular}{|c|c|c|c|c|c|c|c|c|c|c|c|c|c|c|c|c|c|c|}
\hline \multicolumn{19}{|c|}{ UMIDADE DE SATURACAO (\%) } \\
\hline & $T 50$ & T50C & T50D & T5OE & $T 1$ & T1B & TiC & $T 10$ & T1E & $\sqrt{2}$ & $T 3$ & T3B & 14 & T5 & $T 6$ & 77 & 78 & T9 \\
\hline $10 / 03 / 00$ & 68,5 & 57,8 & 63,2 & 60,1 & 63,2 & 68,5 & 55,9 & 55,9 & 57,8 & 60,6 & 58,4 & 58,4 & 62,5 & 41,4 & 54,6 & 60,7 & 65,4 & 83,2 \\
\hline $11 / 03 / 00$ & 68,5 & 57,8 & 63,2 & 60,1 & 63,2 & 68,5 & 55,9 & 55,9 & 57,8 & 62,0 & 58,4 & 58,4 & 62,5 & 41,5 & 54,6 & 607 & 65,4 & 83,2 \\
\hline $12 / 03 / 00$ & 68,5 & 57,8 & 63,2 & 60,1 & 61,5 & 68,5 & 55,1 & 55,1 & 56,8 & 60,6 & 57,0 & 57,0 & 62.5 & 41,7 & 54,6 & 60.7 & 65,4 & 84,8 \\
\hline $13 / 03 / 00$ & 68,5 & 55,9 & 63,2 & 58,9 & 61,5 & 68,5 & 55,1 & 54,4 & 55,9 & 60,6 & 55,8 & 57,0 & 62,5 & 41,9 & 54,6 & 60,7 & 65,4 & 84,8 \\
\hline $14 / 03 / 00$ & 68,5 & 56,8 & 63,2 & 56,9 & 60,1 & 68,5 & 55,1 & 55,1 & 55,9 & 59,3 & 55,8 & 57,0 & 60,7 & 42,1 & 54,6 & 60,7 & 65,4 & 84,8 \\
\hline $15 / 03 / 00$ & 68,5 & 55,9 & 63,2 & 58,9 & 601 & 68,5 & 55,1 & 54,4 & 55,9 & 59,3 & 55,8 & 57,0 & 60,7 & 42,5 & 54,6 & 60,7 & 65,4 & 84,8 \\
\hline $16 / 03 / 00$ & 68,5 & 55,9 & 601 & 58,9 & 60,1 & 68,5 & 55,9 & 54,4 & 55,1 & 59,3 & 55,8 & 55,8 & 60,7 & 42,9 & 54,8 & 60,7 & 66,1 & 84,8 \\
\hline $17 / 103 / 00$ & 68,5 & 55,9 & 60,1 & 57.8 & 60,1 & 68,5 & 54,4 & 54,4 & 55,1 & 58,2 & 54,7 & 55,8 & 59,1 & 43,5 & 55,0 & 60.7 & 66,1 & 84,8 \\
\hline $18 / 03 / 00$ & 68,5 & 55,9 & 63,2 & 58,9 & 60,1 & 68,5 & 54,4 & 54,4 & 55,9 & 58,2 & 54.7 & 55,8 & 59,1 & 44,9 & 56,0 & 60,7 & 66,8 & 89,3 \\
\hline $20 / 03 / 00$ & 76,7 & 57,8 & 68,5 & 81,5 & 63,2 & 68,5 & 56,8 & 56,8 & 58,9 & 58,2 & 53,7 & 55,8 & 59,1 & 48,4 & 68,5 & 60,7 & 66,8 & 89,3 \\
\hline $21 / 03 / 00$ & 76.7 & 56.8 & 67,3 & 61,5 & 63,2 & 68,5 & 55.9 & 55,9 & 58,9 & 58,2 & 53.7 & 55,8 & 59.1 & 52,4 & 69,7 & 60,7 & 66,8 & 89,3 \\
\hline $22 / 03 / 00$ & 73,0 & 55,9 & 63,2 & 60,1 & 63,2 & 73,0 & 55,1 & 55,1 & 57,8 & 59,3 & 54,7 & 54,7 & 59,1 & 56,0 & 71,1 & 60,7 & 66,8 & 89,3 \\
\hline $23 / 03 / 00$ & 73,0 & 55,9 & 63,2 & 60,1 & 63,2 & 73,0 & 55,1 & 54,4 & 57,8 & 59,3 & 54,7 & 54,7 & 59,1 & 57,1 & 71,1 & 60,7 & 66,8 & 89,3 \\
\hline $24 / 03 / 00$ & 68.5 & 55,1 & 61.5 & 58,9 & 61,5 & 68,5 & 54,4 & 54,4 & 56,8 & 59,3 & 55,8 & 54,7 & 57.6 & 59,8 & 71,1 & 60,8 & 67,6 & 90.8 \\
\hline $25 / 03 / 00$ & 68,5 & 54,4 & 60,1 & 58,9 & 61,5 & 73,0 & 54,4 & 54,4 & 55,9 & 59,3 & 55,8 & 55,8 & 57,6 & 59,8 & 71,1 & 61,0 & 67,6 & 90,8 \\
\hline $26 / 03 / 00$ & 68,5 & 54,4 & 61,5 & 58,9 & 61,5 & 73,0 & 54,4 & 54,4 & 55,9 & 59,3 & 55,8 & 54,7 & 57,6 & 59,8 & 71,1 & 61,6 & 67,6 & 90,8 \\
\hline $27 / 03 / 00$ & 81,2 & 61,5 & 76,7 & 63,2 & 61,5 & 68,5 & 55,1 & 54,4 & 55,9 & 58,2 & 55,8 & 54,7 & 57.6 & 59,8 & 71,1 & 62,7 & 68,5 & 90,8 \\
\hline 28103100 & 76,7 & 60,1 & 68,5 & 63,2 & 67,3 & 68,5 & 56,8 & 57,8 & 60,1 & 58,2 & 55,8 & 54,7 & 57,6 & 59,8 & 71,1 & 62,5 & 68,5 & 90,8 \\
\hline $29 / 03 / 00$ & 76,7 & 58,9 & 67,3 & 63,2 & 67,3 & 73,0 & 56,8 & 57,8 & 60,1 & 58,2 & 55,8 & 54,7 & 57,6 & 59,8 & 71,1 & 63,4 & 69,5 & 90,8 \\
\hline $30103 / 00$ & 73.0 & 57,8 & 63,2 & 61,5 & 63,2 & 73,0 & 56,8 & 56.8 & 58,9 & 59,3 & 55,8 & 54,7 & 57,6 & 59,8 & 71,1 & 68,0 & 70,7 & 90,8 \\
\hline $31 / 03 / 00$ & 73,0 & 56,8 & 63,2 & 61,5 & 63,2 & 73,0 & 56,8 & 56,8 & 58,9 & 59,3 & 55,8 & 54,7 & 57,6 & 59,8 & 71,1 & 69,7 & 73,4 & 92,5 \\
\hline $01 / 04 / 00$ & 68,5 & 55,9 & 63,2 & 60,1 & 63,2 & 73,0 & 559 & 55,9 & 57,8 & 60,6 & 55,8 & 54,7 & 57,6 & 59,8 & 71,1 & 72,2 & 74,3 & 96,3 \\
\hline $02 / 04100$ & 68,5 & 55,9 & 63,2 & 60,1 & 63,2 & 73,0 & 55,9 & 55,9 & 57,8 & 60,6 & 55,8 & 55,8 & 57.6 & 59,8 & 71,1 & 73,2 & $\pi, 2$ & 96,3 \\
\hline $03 / 04 / 00$ & 69,5 & 55,9 & 63,2 & 60.1 & 61,5 & 68,5 & 55,9 & 55,9 & 56.8 & 59,3 & 55,8 & 55,8 & 57,6 & 59,8 & 71,1 & 73,2 & 79,6 & 96,3 \\
\hline $05104 / 00$ & 68,5 & 54,4 & 601 & 58,9 & 60,1 & 68,5 & 54,4 & 54,4 & 55,9 & 59,3 & 558 & 55,8 & 57,6 & 59,8 & 71,1 & 73,2 & 86,2 & 96,3 \\
\hline $08 / 04 / 00$ & 67,3 & 53,1 & 58,9 & 56,8 & 60,1 & 68,5 & 53,7 & 54,4 & 54,4 & 58,2 & 53,7 & 55,8 & 57,6 & 59,8 & 71.1 & 73,2 & 86,2 & 96,3 \\
\hline $11 / 04 / 00$ & 63,2 & 520 & 57,8 & 55,9 & 58,3 & 63,2 & 54,4 & 53,7 & 53,7 & 572 & 53,7 & 54,2 & 57,6 & 59,8 & 71,1 & 73.7 & 88,3 & 100,0 \\
\hline $13 / 04 / 00$ & 63,2 & 52,0 & 57,8 & 55,1 & 56,9 & 63,2 & 53,1 & 53,1 & 53,7 & 57,2 & 53,7 & 53,7 & 57,0 & 59,8 & 71,1 & 73,7 & 88,3 & 100,0 \\
\hline $19 / 04 / 00$ & 63,2 & 52,0 & 57,8 & 53,1 & 57,8 & 63,2 & 52,0 & 53,1 & 51,5 & 55,5 & 52,0 & 52,8 & 56,4 & 57,1 & 71,1 & 73,2 & 88,3 & 100,0 \\
\hline $22 / 04 / 00$ & 61,5 & 51.1 & 54,4 & 52,0 & 56,8 & 61,5 & 51,5 & 52,5 & 51,5 & 55,5 & 52,0 & 52,8 & 55,3 & 57,1 & 69,7 & 73,2 & 88,3 & 100,0 \\
\hline 26104100 & 61,5 & 49,6 & 51,1 & 50,3 & 56.8 & 60,1 & 50,7 & 52.0 & 51,1 & 54,7 & 51,3 & 52,0 & 55,3 & 571 & 69,7 & 73,2 & 88,3 & 100,0 \\
\hline $29 / 04 / 00$ & 61,5 & 48,5 & 49.0 & 48,7 & 55,9 & 58,9 & 50,0 & 51,1 & 50,3 & 54,1 & 50,6 & 51,3 & 54.3 & 56,0 & 68,5 & 72,2 & 88,3 & 100,0 \\
\hline $03 / 05 / 00$ & 60,1 & 47,2 & 47,2 & 47,6 & 55,9 & 58,9 & 49,0 & 50,3 & 49,3 & 54,1 & 50,6 & 50,6 & 54,3 & 56,0 & 68,5 & 72,2 & $B 2,5$ & 100,0 \\
\hline $06 / 05 / 00$ & 60,1 & 46,2 & 46,2 & 46,5 & 55,1 & 57,8 & 48,5 & 49,6 & 48,5 & 534 & 50,6 & 50,6 & 53,3 & 54,9 & 68,5 & 72,2 & 79,6 & 100,0 \\
\hline $10 / 05 / 00$ & 58,9 & 45,8 & 45,6 & 45,9 & 54,4 & 57,8 & 48,0 & 49,0 & 47,6 & 53,4 & 50,0 & 50,6 & 53,3 & 54,9 & 68,5 & 71,3 & 79,6 & 100,0 \\
\hline $13 / 05 / 00$ & 57,8 & 45,1 & 45,0 & 45,4 & 53,7 & 56,8 & 47,2 & 48,0 & 46,6 & 53,4 & 49.5 & 50,6 & 52,5 & 54,9 & 67,4 & 71,3 & 79,6 & 100,0 \\
\hline $17 / 05 / 00$ & 57,8 & 45,0 & 44,9 & 45,2 & 53,7 & 56,8 & 470 & 47,8 & 46,3 & 53,4 & 49,5 & 50,6 & 52,5 & 54,9 & 67,4 & 71,3 & 79.6 & 100,0 \\
\hline $20 / 05 / 00$ & 57,8 & 44,8 & 44,8 & 45,0 & 53,1 & 55,9 & 46,6 & 47,6 & 45,9 & 52,9 & 48,9 & 50,0 & 52,5 & 54,0 & 67,4 & 71,3 & 79,6 & 100,0 \\
\hline $24 / 05 / 00$ & 56,8 & 44,6 & 44,6 & 44,8 & 53,1 & 55,9 & 46,3 & 47,2 & 45,4 & 52,3 & 48,4 & 49,5 & 51,8 & 54,0 & 66,4 & 71,3 & 79,6 & 100,0 \\
\hline $22 / 05 / 00$ & 57,8 & 44,4 & 44,4 & 44,5 & 53,1 & 54,4 & 45,9 & 46,6 & 44,9 & 51,8 & 48,4 & 49,5 & 51,1 & 53,2 & 66,4 & 70,5 & 79,6 & 100,0 \\
\hline $31 / 05 / 00$ & 57,8 & 44,4 & 44,4 & 44,4 & 52,5 & 54,4 & 45,8 & 46,6 & 44,9 & 51,8 & 48,4 & 49,5 & 51,1 & 53,2 & 66,4 & 70,5 & 79,6 & 100,0 \\
\hline $03 / 06 / 00$ & 56,8 & 44,3 & 44,4 & 44,4 & 52,0 & 53,7 & 45,6 & 46,5 & 44,8 & 51,4 & 48,0 & 48,9 & 51,1 & 53,2 & 66,4 & 70,5 & 77,2 & 100,0 \\
\hline $07 / 06 / 00$ & 55,9 & 44,3 & 44,4 & 44,4 & 52,0 & 53,1 & 45,4 & 46,2 & 44,6 & 51,4 & 47,6 & 48,4 & 51,1 & 53,2 & 65,5 & 70.5 & 77,2 & 100,0 \\
\hline $10 / 06 / 00$ & 55,9 & 44,3 & 44,4 & 44,3 & 51,5 & 53,1 & 45,3 & 46,2 & 44,4 & 51,4 & 47,2 & 48,4 & 50,5 & 52,4 & 65,5 & 70,5 & 77,2 & 100,0 \\
\hline $14 / 06 / 00$ & 55,9 & 44,3 & 44,4 & 44,3 & 51,5 & 52,5 & 45,3 & 46,0 & 44,3 & 51,0 & 47,2 & 48,0 & 50,5 & 51,7 & 65,5 & 70.5 & 77,2 & 98,4 \\
\hline $17 / 06 / 00$ & 559 & 44,2 & & 44,2 & 51,5 & 52,0 & 45,2 & 45,9 & 44,2 & 50,6 & 46,8 & 47,6 & 49,9 & 51,7 & 65,5 & 69,7 & 77,2 & 98,4 \\
\hline $21 / 06 / 00$ & 55,1 & 44,2 & & 44,2 & 51,1 & 51,5 & 45,1 & 45.8 & 44,2 & 50,6 & 46,4 & 47.2 & 49,9 & 51,7 & 65.5 & 69.7 & 77,2 & 96,3 \\
\hline $24 / 06 / 00$ & 54,4 & 44,1 & & 44,1 & 50,3 & 51,1 & 45,0 & 45,6 & 44,1 & 50,2 & 46,1 & 46,8 & 49,3 & 51,7 & 64,7 & 69,7 & 75,2 & 96,3 \\
\hline $28 / 06 / 00$ & 53.7 & 44,1 & & & 50,0 & 50,7 & 44,9 & 45,6 & 44,0 & 49,8 & 46,1 & 46,8 & 49,3 & 51,7 & 64,7 & 69,7 & 74,3 & 96,3 \\
\hline $01 / 07 / 00$ & 53,7 & 44,1 & & & 49,6 & 50,3 & 44,9 & 45,6 & 43,9 & 49,8 & 45,8 & 46,4 & 48,8 & 51,7 & 64,7 & 6,1 & 74,3 & 94,3 \\
\hline $05 / 07 / 00$ & 53,7 & 44,1 & 44,3 & & 49,3 & 50,0 & 44,8 & 45,5 & 43,9 & 49,5 & 45,5 & 46,4 & 48,8 & 51,7 & 64,7 & 69,1 & 74,3 & 94,3 \\
\hline $08 / 07 / 100$ & 53,1 & 44,0 & 44,3 & & 49,0 & 49,6 & 44,7 & 45,3 & 43,9 & 492 & 45,2 & 46,1 & 48,4 & 51,0 & 64,0 & 69,1 & 74,3 & 92,5 \\
\hline $12 / 07 / 100$ & 52,0 & 43,9 & 44,2 & 44,2 & 48,5 & 49,0 & 44,4 & 45,0 & & 48,6 & 45,0 & 45,5 & 47,9 & 50,4 & 64,0 & 69,1 & 73,4 & 92,5 \\
\hline $15 / 07 / 100$ & 52,0 & 43,9 & 44,2 & 44,2 & 48,5 & 49,0 & 44,4 & 45,0 & & 48,6 & 45,0 & 45,5 & 47,9 & 50,4 & 64,0 & 69,1 & 73,4 & 92,5 \\
\hline $19 / 07 / 00$ & 51,5 & 43,9 & 44,2 & 44,1 & 48,5 & 48,7 & 44,4 & 44,9 & & 48,6 & 44,7 & 45,2 & 47,9 & 50,4 & 64,0 & 69,1 & 73,4 & 92,5 \\
\hline $22107 / 100$ & 51,1 & 43,8 & 44,1 & 44,0 & 48,2 & 48,5 & 44,4 & 44,9 & 44,1 & 48,3 & 44,5 & 45,0 & 47,5 & 49,9 & 63,4 & 68,5 & 73,4 & 92,5 \\
\hline $26 / 07 / 00$ & 51,1 & 43,9 & 442 & 44,0 & 48,2 & 48,5 & 44,4 & 44,8 & 44,1 & 48,3 & 44,5 & 45,0 & 47,5 & 49.9 & 63,4 & 68,5 & 72,7 & 92,5 \\
\hline $29 / 07 / 100$ & 51,1 & 43,9 & 44.2 & 44,1 & 48,0 & 48,5 & 44,4 & 44,8 & 44,1 & 48,3 & 44.5 & 45,0 & 47,5 & 49,9 & 63,4 & 68,5 & 72,7 & 92,5 \\
\hline $02108 / 00$ & 50,7 & & & 44,1 & 47,6 & 48,2 & 44,4 & 44,8 & 44,0 & 48,1 & 44,0 & 44,2 & 47,1 & 49,4 & 63,4 & 68,5 & 70,7 & 92,5 \\
\hline $05 / 08 / 00$ & 50,3 & & & 44,1 & 47,6 & 48,0 & 44,2 & 44,7 & 43,9 & 48,1 & 44,0 & 44,2 & 47,1 & 49,4 & 63,4 & 68,5 & 70,7 & 92,5 \\
\hline $09 / 08 / 00$ & 50,0 & & & 44,1 & 47,2 & 46,0 & 44,2 & 44,7 & 43,9 & 47,9 & 43,6 & 44,0 & 47,1 & 49,4 & 62,8 & 68,5 & 70,7 & 89,3 \\
\hline $12 / 08 / 00$ & 50,0 & & & & 47,0 & 47,8 & & 44,6 & 43,9 & 47,6 & 43,6 & 43,8 & 46,8 & 48,9 & 62,8 & 68,0 & 70,7 & $8 \mathrm{~B}, 0$ \\
\hline $16 / 08 / 00$ & 50,0 & 45,4 & 45,3 & 45,3 & 46,8 & 47,6 & 44,2 & 44,6 & 43,9 & 47,6 & 43,4 & 43,6 & 46,4 & $4 \mathrm{~B}, 9$ & 62,8 & 68,0 & 70.7 & 86,9 \\
\hline $19 / 08 / 00$ & 49,6 & 45,3 & 45,2 & 45,0 & 46,8 & 47,6 & 44,2 & 44,6 & 439 & 47,6 & 43,2 & 43,6 & 46,4 & 48,9 & 62,8 & 68,0 & 70.7 & 85,8 \\
\hline $23 / 08 / 00$ & 49,6 & 45,3 & 45,2 & 44,8 & 46,6 & 47,6 & 44,2 & 44,6 & 43,9 & 47,6 & 43,2 & 43,6 & 46,4 & 48,9 & 62,8 & 68,0 & 70.7 & 85,8 \\
\hline $26 / 08 / 00$ & 49,6 & 45,3 & 45,2 & 44,6 & 46,5 & 47,6 & 44,2 & 44,6 & & 47,4 & 43,1 & 43,4 & 46,4 & 48,9 & 62,2 & 68,0 & 70,7 & 84,8 \\
\hline $30 / 08 / 00$ & 49,6 & 45,2 & 44,8 & 44,2 & 46,2 & 47,2 & 44,2 & 44,3 & & 47,2 & 42,9 & 43,1 & 46,1 & 48,4 & 62,2 & 68,0 & 70,7 & 84,8 \\
\hline $01 / 09 / 00$ & 50,3 & 45,2 & 44,8 & 44,2 & 46,2 & 47,0 & 44,2 & 44,5 & 44,2 & 47,2 & 42,9 & 43,1 & 46,1 & 48,4 & 62,2 & 68,0 & 70.7 & 84,8 \\
\hline $04 / 09 / 100$ & 50,7 & 45,2 & 44,7 & 44,2 & 46,2 & 46,8 & 44,2 & 44,4 & 44,1 & 47,0 & 42,7 & 431 & 45,8 & 48,4 & 62,2 & 68,0 & 69,5 & 84,8 \\
\hline $06 / 09 / 00$ & 61,5 & 45,2 & 44,7 & & 46,2 & 46,8 & 44,1 & 44,4 & & 47,0 & 42,7 & 43,1 & 46,1 & 48,4 & 62,2 & 68,0 & 69,5 & 84,8 \\
\hline $08 / 09 / 00$ & 67,3 & 45,4 & 44,9 & & 46,2 & 46,8 & 44,1 & 44,4 & & 46,8 & 42,7 & 43,1 & 46,1 & 48,4 & 62,2 & 68,0 & 69,5 & 84,8 \\
\hline $10 / 09 / 00$ & 76,7 & 45,8 & 45,3 & & 46,2 & 46,8 & 44,2 & 44,5 & & 46,8 & 42,7 & 43,1 & 45,8 & 48,0 & 62,2 & 67,5 & 69,5 & 84,8 \\
\hline $12 / 09 / 00$ & 68,5 & 47,4 & 50,3 & & 55,9 & 46,8 & 44,2 & 44,5 & & 46,8 & 42,7 & 43,1 & 45,8 & 48,0 & 62,2 & 67,5 & 69,5 & 84,8 \\
\hline $14 / 09 / 00$ & 73,0 & 559 & 63,2 & & 68,5 & 46,8 & 44,2 & 44,5 & & 46,8 & 426 & 42,9 & 45,8 & 48,0 & 62,2 & 67,5 & 69,5 & 84,8 \\
\hline
\end{tabular}




\begin{tabular}{|c|c|c|c|c|c|c|c|c|c|c|c|c|c|c|c|c|c|c|}
\hline \multicolumn{19}{|c|}{ UMIDADE DE SATURACAO (\%) } \\
\hline & $T 50$ & $\mathrm{~T} 50 \mathrm{C}$ & T50D & $\mathrm{T} 50 \mathrm{E}$ & T1 & $\mathrm{T} 1 \mathrm{~B}$ & T1C & $\mathrm{T1D}$ & T1E & 12 & T3 & $T 3 B$ & $T 4$ & T5 & 16 & 77 & 18 & $\mathrm{Tg}$ \\
\hline $16 / 09 / 00$ & 73,0 & 55,1 & 61,5 & & 66,1 & 47,6 & 44,3 & 44,5 & & 46,8 & 42,6 & 42,9 & 45,8 & 48,0 & 62,2 & 67,5 & 69,5 & 84,8 \\
\hline $18 / 09 / 00$ & 68,5 & 54,4 & 60,1 & & 63,2 & 49,0 & 44,4 & 44,6 & & 46,8 & 42,6 & 42,9 & 45.8 & 48,0 & 62,2 & 67,5 & 69,5 & 84,8 \\
\hline $20 / 09 / 00$ & 67,3 & 53,1 & 57,8 & & 61,5 & 51,5 & 45,2 & 44,7 & & 47,6 & 42,6 & 42,9 & 45,8 & 48,0 & 62,2 & 67,5 & 69.5 & 84,8 \\
\hline $22 / 09 / 00$ & 66,1 & 53,1 & 57,8 & & 61,5 & 54,4 & 47,8 & 45,3 & & 48,3 & 42,6 & 42,9 & 45,8 & 48,0 & 62,2 & 67,5 & 69.5 & 84,8 \\
\hline $24 / 09 / 00$ & 63,2 & 53,1 & 56,8 & & 60,1 & 56,8 & 50,7 & 45,9 & & 49,8 & 42,6 & 42,9 & 45,8 & 48,0 & 62,2 & 67.5 & 69,5 & 84,8 \\
\hline $26 / 09100$ & 63,2 & 54,4 & 57,8 & & 58,9 & 60,1 & 54,4 & 49,3 & & 52,3 & 42,6 & 43,1 & 45,8 & 48,0 & 62,2 & 67,5 & 68,5 & 83,2 \\
\hline $28 / 09 / 00$ & 63,2 & 55,1 & 58.9 & & 58,9 & 61,5 & 55,1 & 51,5 & & 53,4 & 42.9 & 43,2 & 45,8 & 48,0 & 62,2 & 67,5 & 68,5 & 83,2 \\
\hline $30 / 09 / 00$ & 68,5 & 56,8 & 60,1 & & 60,1 & 63,2 & 55.9 & 55,1 & & 54,7 & 43,2 & 43,4 & 45,8 & 48,0 & 61.7 & 67,1 & 68,5 & 83,2 \\
\hline $02 / 10 / 00$ & 63,2 & 53,1 & 55,9 & & 58,9 & 63,2 & 53,1 & 53,1 & & 55,5 & 44,0 & 43,6 & 45.8 & 48,0 & 61,7 & 67,1 & 68,5 & 83,2 \\
\hline $04 / 10 / 00$ & 63,2 & 53,1 & 55,9 & & 57,8 & 61,5 & 53,1 & 53,1 & & 54,7 & 45,0 & 43,8 & 45,8 & 47,6 & 61,7 & 67,1 & 68,5 & 83,2 \\
\hline $06 / 10 / 00$ & 63.2 & 53,1 & 55,9 & & 57.8 & 61,5 & 53,7 & 53.1 & & 54,7 & 46,1 & 44,0 & 45.8 & 47,6 & 61.7 & 67,1 & 68.5 & 83,2 \\
\hline $08 / 10 / 00$ & 63,2 & 53,1 & 55,1 & & 57,8 & 61,5 & 53,7 & 53,1 & & 54,7 & 47,2 & 44,2 & 45,8 & 47,6 & 61,7 & 67,1 & 68,5 & 83,2 \\
\hline $11 / 10 / 00$ & 63,2 & 53,1 & 53,1 & & 57,8 & 61,5 & 53,1 & 53,1 & & 54,7 & 47,6 & 44,5 & 45,8 & 47,6 & 61,7 & 67,1 & 68,5 & 82,4 \\
\hline $14 / 10 / 00$ & 63,2 & 53,1 & 52,5 & & 57.8 & 61,5 & 53,1 & 53,1 & & 54,7 & 48,0 & 44.7 & 45,8 & 47,6 & 61,7 & 67,1 & 68,5 & 81,1 \\
\hline $18 / 10 / 00$ & 60,1 & 49,6 & 49,3 & & 56,8 & 61,5 & 51,1 & 51,5 & & 54,7 & 48,4 & 45,2 & 45,8 & 47,3 & 61,7 & 67,1 & 68,5 & 81,1 \\
\hline $21 / 10 / 00$ & 60,1 & 48,2 & 48,2 & & 55,9 & 60,1 & 50,3 & 51,5 & & 54,1 & 48,0 & 45,2 & 45,8 & 47,3 & 61,7 & 67,1 & 68.5 & 81.1 \\
\hline $25 / 10 / 00$ & 60,1 & 46,8 & 46,5 & & 55,1 & 60,1 & 48,5 & 50,0 & & 53,4 & 47,6 & 45,2 & 46,1 & 47,3 & 62,2 & 67,1 & 68,5 & 81,1 \\
\hline $28 / 10 / 00$ & 63,2 & 50,3 & 46,8 & & 56,8 & 57,8 & 47,6 & 48,0 & & 529 & 47,6 & 45,2 & 46,1 & 47,3 & 62,2 & 67,1 & 67,6 & 80,5 \\
\hline $01 / 11 / 00$ & 67,3 & 51,1 & 46,8 & & 56,8 & 57,8 & 47,4 & 48,7 & & 52,9 & 47,2 & 45,2 & 46,1 & 47,3 & 62,2 & 67,1 & 67,6 & 80,5 \\
\hline $04 / 11 / 00$ & 68,5 & 53,1 & 46,8 & & 57,8 & 57,8 & 47,2 & 48,2 & & 52,3 & 46,8 & 45,2 & 46,1 & 47,3 & 62,2 & 67,1 & 67,6 & 80.5 \\
\hline $08 / 11 / 00$ & 63,2 & 54,4 & 47,2 & & 57,8 & 56,8 & 47,0 & 47,8 & & 51,8 & 46,1 & 45,2 & 46,1 & 47,3 & 61.7 & 67,1 & 67,6 & 80,5 \\
\hline $11 / 11 / 00$ & 63,2 & 54,4 & 47,2 & & 57,8 & 56,8 & 46,6 & 47,4 & & 51,4 & 45.5 & 45,0 & 45,8 & 46,9 & 61,3 & 66,7 & 67,6 & 80,0 \\
\hline $13 / 11 / 00$ & 68,5 & 53,1 & 47,4 & & 57,8 & 55,9 & 46.2 & 46,6 & & 51,0 & 45,2 & 45,0 & 45,8 & 46,9 & 61,3 & 66,7 & 67,6 & 79,5 \\
\hline $15 / 11 / 00$ & 73,0 & 55,9 & 50,3 & & 63,2 & 55,9 & 46,0 & 46,5 & & 50,6 & 45,0 & 44,7 & 45,5 & 46,6 & 60,9 & 66,7 & 66,8 & 78,6 \\
\hline $18 / 11 / 00$ & 76,7 & 57,8 & 63,2 & & 67,3 & 55,9 & 45,8 & 46,3 & & 49,8 & 44,7 & 44,7 & 45,5 & 46,3 & 60,9 & 66,7 & 66,8 & 78,6 \\
\hline $22 / 11 / 00$ & 76,7 & 57,8 & 63,2 & & 67,3 & 63,2 & 47,8 & 46,2 & & 51,0 & 44,7 & 44,7 & 45,3 & 46,3 & 60,9 & 66,7 & 66,8 & 78,6 \\
\hline $25 / 11 / 100$ & 73,0 & 55,9 & 60,1 & & 63,2 & 68,5 & 51,1 & 45,9 & & 51,4 & 44,7 & 44,5 & 45,0 & 46,0 & 60,9 & 66,3 & 66,8 & 78,6 \\
\hline $29 / 11 / 00$ & 71,4 & 55.9 & 60,1 & & 63,2 & 68,5 & 53,1 & 45,9 & & 52,3 & 45,0 & 44.5 & 44,8 & 46,0 & 60.5 & 66,3 & 66,8 & 78,6 \\
\hline $04 / 12 / 00$ & 71,4 & 55,9 & 60,1 & & 63,2 & 68,5 & 54,4 & 46,2 & & 55,5 & 47,2 & 44,5 & 44,6 & 45.7 & 60,5 & 66,3 & 66,8 & 78,6 \\
\hline $06 / 12 / 00$ & 68,5 & 55,1 & 58.8 & & 61,5 & 68,5 & 55,1 & 47,0 & & 56,3 & 48,4 & 44.7 & 44,5 & 45,7 & 60,5 & 66,3 & 66,8 & 78,6 \\
\hline $09 / 12100$ & 67,3 & 53,7 & 57,8 & & 60,1 & 68,5 & 53,1 & 48,5 & & 56,3 & 49,5 & 45,0 & 44,3 & 45,7 & 60,5 & 66,3 & 66,1 & 78,6 \\
\hline $13 / 12 / 00$ & 68,5 & 57,8 & 68,5 & & 60,1 & 63,2 & 57.8 & 55,9 & & 55,5 & 49,5 & 45,5 & 44,1 & 45,4 & 60,5 & 66,0 & 66,1 & 78,6 \\
\hline $16 / 12100$ & 76,7 & 57,8 & 67,3 & & 68,5 & 63,2 & 57,8 & 57,8 & & 56,3 & 50,0 & 46.1 & 44,1 & 45,4 & 60,5 & 66,0 & 66,1 & 78,6 \\
\hline $20 / 12 / 00$ & 73,0 & 57,8 & 67,3 & & 63,2 & 76,7 & 57,8 & 57,8 & & 60,6 & 53,7 & 47,6 & 44,3 & 45,2 & 60,1 & 66,0 & 66,1 & 78,6 \\
\hline $23 / 12 / 00$ & 73,0 & 56,8 & 65,1 & & 63,2 & 76,7 & 56,8 & 56,8 & & 60,6 & 55,8 & 49,5 & 44,8 & 45,2 & 60,1 & 66,0 & 66,1 & 78,6 \\
\hline $27 / 12 / 00$ & 68,5 & 55,9 & 63,2 & & 61,5 & 73,0 & 55,9 & 55,9 & & 60,6 & 55,8 & 51,3 & 45,3 & 44,9 & 60,1 & 66,0 & 66,1 & 78,6 \\
\hline $30 / 12 / 00$ & 66,1 & 55,1 & 60,1 & & 60,1 & 68.5 & 54,4 & 54,4 & & 59,3 & 55,8 & 53,7 & 52,5 & 44,9 & 60.1 & 65,7 & 66,1 & 78,6 \\
\hline $03 / 01 / 01$ & 66,1 & 55,9 & 61,5 & & 60,1 & 68,5 & 54,4 & 54,4 & & 59,3 & 54,7 & 53,7 & 53,3 & 44,9 & 60,1 & 65,7 & 65.4 & 78,6 \\
\hline $06 / 01 / 01$ & 68,5 & 57,8 & 63,2 & & 60,1 & 67,3 & 55,9 & 54,4 & & 58,2 & 53,7 & 53,7 & 54,3 & 44,9 & 60,1 & 65,7 & 65,4 & 78,6 \\
\hline $11 / 01 / 01$ & 68,5 & 55,9 & 61,5 & & 60,1 & 63,2 & 55,1 & 55,1 & & 56,3 & 52,8 & 53,7 & 55,3 & 45,4 & 60,1 & 65,7 & 65,4 & 78,6 \\
\hline $14 / 01 / 01$ & 68,5 & 55,9 & 60,1 & & 60.1 & 63,2 & 55,1 & 55,1 & & 56,3 & 52,0 & 53,7 & 55,3 & 46,3 & 60,1 & 65,7 & 65,4 & 78,6 \\
\hline $17 / 01 / 01$ & 68,5 & 55,1 & 60.1 & & 60,1 & 63,2 & 55,1 & 55,1 & & 56,3 & 52,0 & 53,7 & 55,3 & 47,6 & 60,1 & 65,7 & 65,4 & 78,6 \\
\hline $20 / 01 / 01$ & 63,2 & 54,4 & 60,1 & & 60,1 & 63,2 & 55,1 & 54,4 & & 55.5 & 51,3 & 52,8 & 55,3 & 49,4 & 60,5 & 65,7 & 65,4 & 78,6 \\
\hline $24 / 01 / 01$ & 68,5 & 54,4 & 57,8 & & 58,9 & 63,2 & 53,1 & 53,1 & & 54,7 & 51,3 & 52,0 & 54,3 & 51.0 & 61,3 & 65,7 & 65,4 & 78,6 \\
\hline $27 / 01 / 01$ & 68,5 & 55,9 & 58,9 & & 60,1 & 63,2 & 53,1 & 53,1 & & 54,7 & 50,6 & 52.0 & 54,3 & 51,7 & 62,2 & 65,4 & 65,4 & 78,6 \\
\hline $31 / 01 / 01$ & 68.5 & 55,9 & 56,8 & & 61,5 & 63,2 & 53,1 & 53,1 & & 54,1 & 50,6 & 52,0 & 54,3 & 51,7 & 62,8 & 65,4 & 65,4 & 777 \\
\hline $03 / 02 / 01$ & 67,3 & 55.9 & 56,8 & & 61,5 & 63.2 & 53.1 & 53.1 & & 54,1 & 50.0 & 51,3 & 54,3 & 51.7 & 62,8 & 65,4 & 65.4 & 77,7 \\
\hline $06102 / 01$ & 67,3 & 55,1 & 55,9 & & 60,1 & 63,2 & 52.5 & 52,5 & & 54,1 & 50,0 & 51,3 & 53,3 & 51,7 & 64,0 & 65,4 & 65,4 & 77,7 \\
\hline $10 / 02 / 01$ & 68,5 & 55,1 & 55,9 & & 60,1 & 63,2 & 52,0 & 51,5 & & 53,4 & 49,5 & 50,6 & 52,5 & 51,7 & 64,0 & 65,4 & 65,4 & 77,7 \\
\hline $14 / 02 / 01$ & 67,3 & 53,7 & 55,1 & & 58,9 & 63,2 & 51,1 & 51,1 & & 53,4 & 49.5 & 50,6 & 52,5 & 51,7 & 64,7 & 65.7 & 66,1 & 77,7 \\
\hline $19 / 02 / 01$ & 67,3 & 54,4 & 60,1 & & 61,5 & 63,2 & 51,1 & 50,7 & & 53,4 & 48,9 & 50,6 & 52,5 & 51,7 & 64,7 & 65,7 & 66,1 & 77.7 \\
\hline $21 / 02 / 01$ & 73,0 & 55,9 & 63,2 & & 63,2 & 63,2 & 52,0 & 52,0 & & 53,4 & 49,5 & 50,6 & 51,8 & 51,7 & 64,7 & 65.7 & 66,1 & 77,7 \\
\hline $24 / 02 / 01$ & 68,5 & 53,7 & 58,9 & & 61,5 & 68,5 & 54,4 & 54,4 & & 53,4 & 49,5 & 50,6 & 51,1 & 51,7 & 64,7 & 65,7 & 66,1 & 77,7 \\
\hline $28102 / 01$ & 67,3 & 54,4 & 60,1 & & 63,2 & 68,5 & 55,9 & 55,1 & & 54,7 & 48,9 & 50,0 & 51,1 & 51,7 & 64,7 & 65,7 & 66,1 & 77.7 \\
\hline $03 / 03 / 01$ & 67,3 & 54,4 & 60,1 & & 63,2 & 68,5 & 55,9 & 55,1 & & 54,7 & 48,9 & 50,0 & 51,1 & 51,7 & 64,7 & 66,0 & 66,1 & 77,7 \\
\hline $07 / 03 / 01$ & 73,0 & 54,4 & 54,4 & & 63,2 & 71,4 & 55.9 & 55,9 & & 55,5 & 49,5 & 50,0 & 51.1 & 51,7 & 64.7 & 66,0 & 66,1 & 77,7 \\
\hline $10 / 03 / 01$ & 76,7 & 58,9 & 58,9 & & 63,2 & 73,0 & 57,8 & 57,8 & & 55,5 & 50,6 & 50,6 & 51,1 & 51,0 & 64,7 & 66,0 & 66,1 & 77.7 \\
\hline $14 / 03 / 01$ & 76,7 & 61,5 & 61,5 & & 63,2 & 76,7 & 58,9 & 58,9 & & 56,3 & 50,6 & 50,6 & 51,1 & 51,0 & 64,7 & 66,0 & 66,1 & 77,7 \\
\hline $17 / 03 / 01$ & 76,7 & 57,8 & 57,8 & & 61,5 & 73,0 & 58,9 & 58.9 & & 57,2 & 51,3 & 51,3 & 51,1 & 51,0 & 64,0 & 66,0 & 66,1 & 77,7 \\
\hline $21 / 03 / 01$ & 73,0 & 55,9 & 56,8 & & 61,5 & 71,4 & 57,8 & 58,9 & & 59,3 & 52,8 & 52,0 & 52,5 & 51,0 & 64,0 & 66,0 & 66,1 & 77,0 \\
\hline $24 / 03 / 01$ & 68,5 & 54,4 & 53.7 & & 61,5 & 69,9 & 56,8 & 55,9 & & 59,3 & 55,8 & 52,8 & 54,3 & 51,0 & 64,0 & 66,0 & 66,1 & 77,0 \\
\hline $28 / 03 / 01$ & 66,1 & 54,4 & 57,8 & & 60,1 & 66,1 & 55,1 & 54,4 & & 59,3 & 54,7 & 53,7 & 55,3 & 51,7 & 64,0 & 66,0 & 66,1 & 77,0 \\
\hline $31 / 03 / 01$ & 632 & 54,4 & 57,8 & & 57,8 & 63,2 & 53,1 & 531 & & 582 & 53,7 & 53,7 & 56,4 & 53,2 & 64,0 & 66,3 & 66,1 & 770 \\
\hline
\end{tabular}




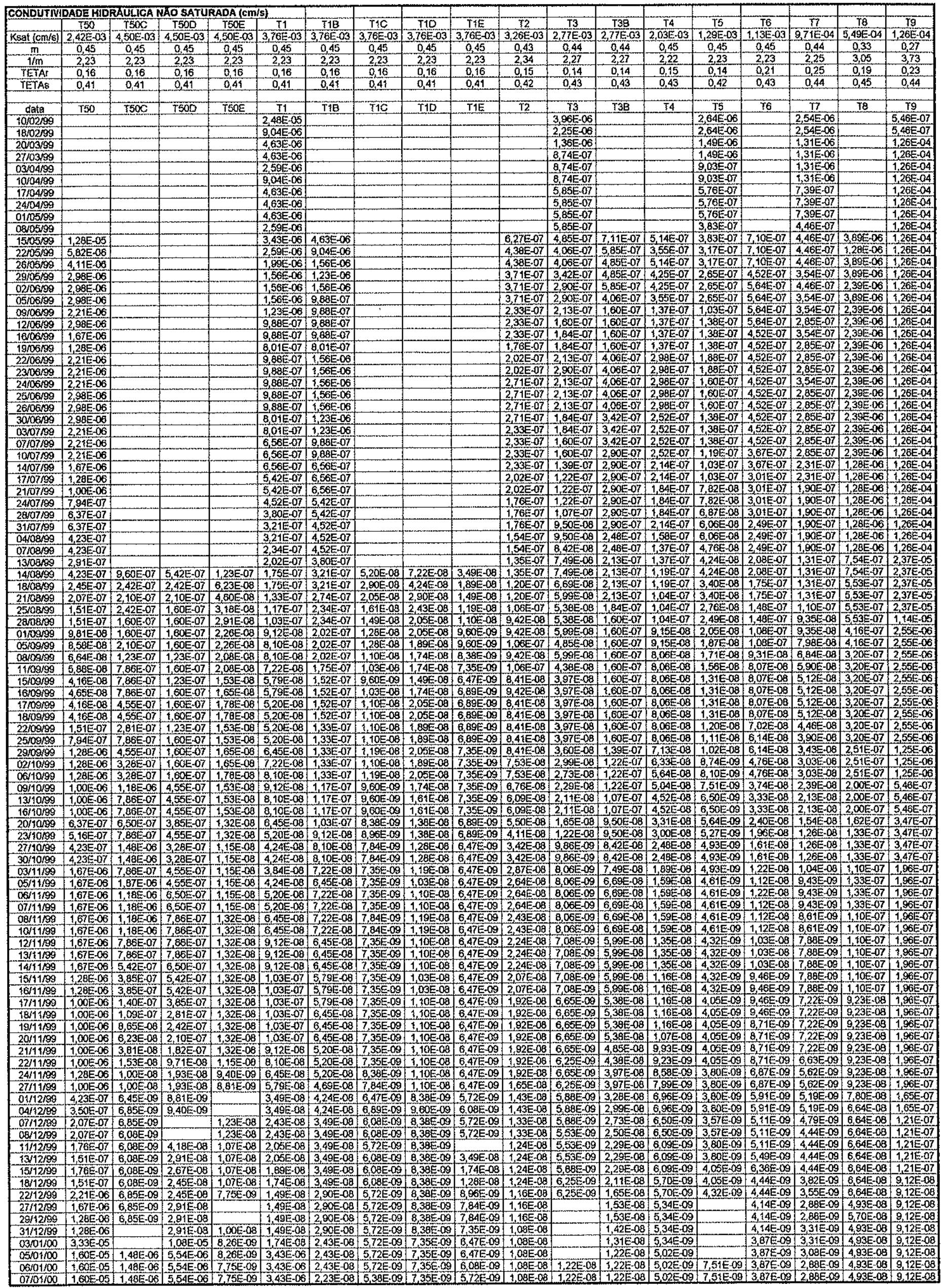

BERTOLO, R.A. - Tese de Doutoramento - 2001 


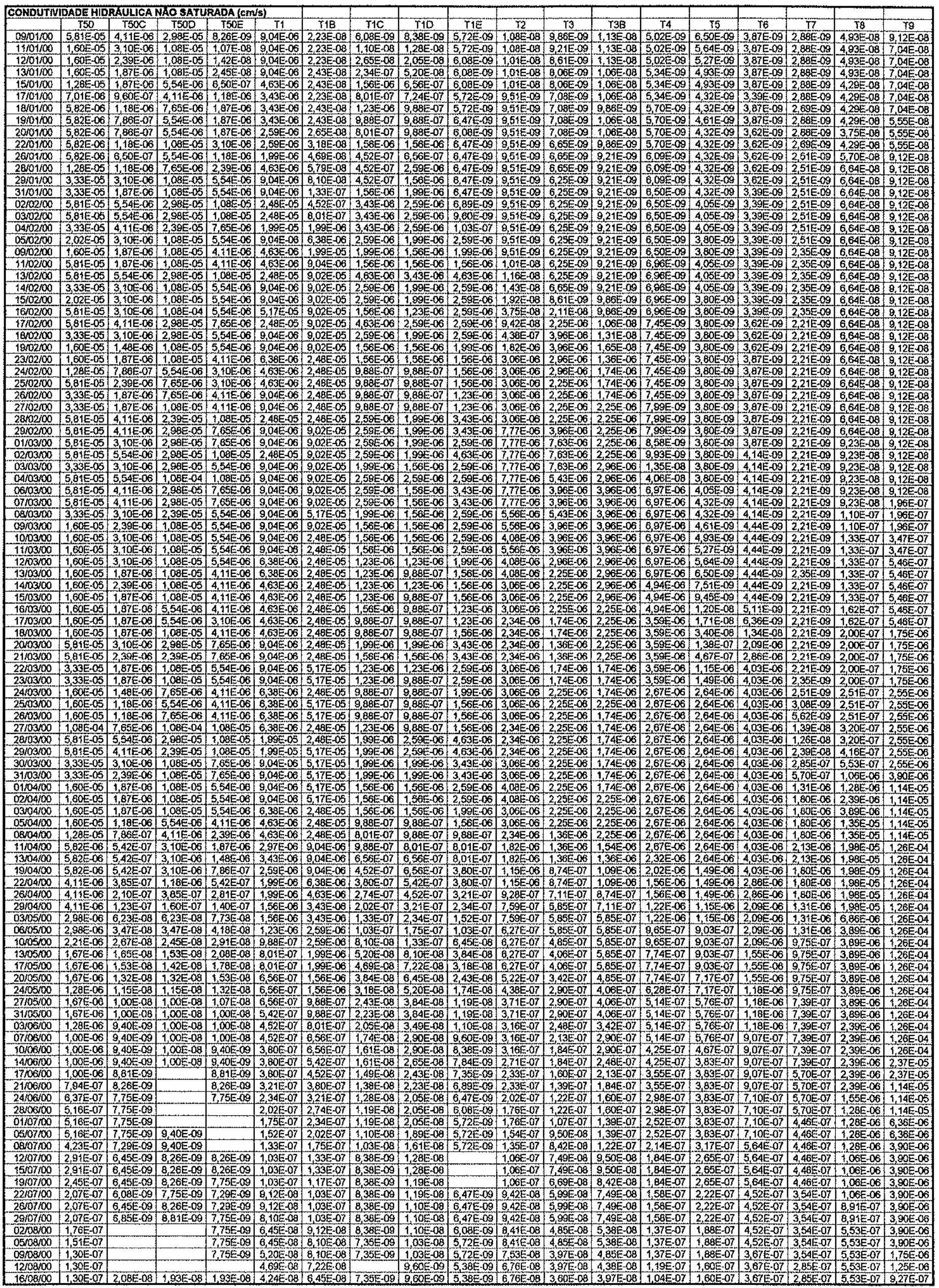




\begin{tabular}{|c|c|c|c|c|c|c|c|c|c|c|c|c|c|c|c|c|c|c|}
\hline \multicolumn{19}{|c|}{ CONDUTIVOADE HIOR } \\
\hline & 150 & T5OC & 7500 & T50E & T1 & T1B & $\mathrm{T1C}$ & T10 & T1E & T2 & $T 3$ & $\mathrm{~T} 3 \mathrm{~B}$ & 34 & T5 & T6 & 77 & 18 & T9 \\
\hline $19 / 08 / 00$ & $-1,13 \mathrm{E} \cdot 07$ & $1,93 E-08$ & $1,78 E-08$ & $1.53 \mathrm{E}-08$ & $4,24 E-08$ & $6,45 E-08$ & $6,89 E+09$ & $9,80 \mathrm{E}-09$ & $5,385.09$ & $6.76 E-68$ & $3,28 E-08$ & $3,97 E-08$ & $1,04 E=07$ & $3,60 E-07$ & $3,67 \mathrm{E}-07$ & $2,85 E-07$ & $5,53 E$ & $7,03 E-07$ \\
\hline $23 / 08 / 00$ & $1,13 E-07$ & $1,93 \mathrm{E}-08$ & $178 \mathrm{E}-08$ & $1,32 \mathrm{E}-08$ & $3,84 E-08$ & $6,45 \mathrm{E} .08$ & $6,89 E-09$ & $360 \mathrm{E}-09$ & $5,386-09$ & $6,76 E-08$ & $3,28 \mathrm{E}-0 \mathrm{~B}$ & $397 E-08$ & $1,04 E-07$ & $\frac{1,60 E-07}{7,6}$ & $3,675-07$ & $2,85 E-07$ & $5,53 E-07$ & $7,03 E-07$ \\
\hline $26,08 / 00$ & $1,13 E-07$ & $1,93 \mathrm{E}+08$ & $1,78 \mathrm{E}-08$ & $1,15 \mathrm{E}-08$ & $3,49 E-08$ & $6,45 E-08$ & $7,35 E-09$ & $9,60 E-09$ & & $6,09 \mathrm{E}-0 \mathrm{~B}$ & $2,99 E-08$ & $3,60 \mathrm{E}-08$ & $1,04 \mathrm{E} .07$ & $1,60 \mathrm{E}-07$ & $3,01 E-07$ & $2,85 E-07$ & $5,53 E-07$ & \\
\hline 30108100 & $1,13 \mathrm{E}-07$ & $4,78 E-08$ & $1,32 E \times 08$ & & $290 \mathrm{E}-0 \mathrm{OB}$ & $5,20 \mathrm{E}+08$ & $6,80 E-09$ & $7,84 \mathrm{E}-09$ & & $5,50 \mathrm{E}-08$ & $2,73 \mathrm{E}-08$ & $2,90 \mathrm{E}-08$ & $9,15 E-08$ & $1,386.07$ & $3,01 \mathrm{E}-07$ & $2,85 E-07$ & $5,53 E-07$ & $5,46 E-0 ?$ \\
\hline $0109 \% 00$ & $1,5 \mathrm{E}-07$ & $1,78 \mathrm{E}-08$ & $1,32 E-08$ & $8,81 E-09$ & $2,90 \mathrm{E}-08$ & $4,69 E-08$ & $7,35 E-09$ & $8,96 \mathrm{E}-09$ & $7,35 E-09$ & $5,50 E-08$ & $2,73 E-08$ & $2,99 E-68$ & $9,15 E-08$ & $1,38 E-07$ & $3,01 E-07$ & $2,85 E-07$ & $5,53 \mathrm{E}-07$ & $5,46 E-07$ \\
\hline 0400100 & $1,76 \mathrm{E}-07$ & $1,78 \mathrm{E}-08$ & $1,23 E-08$ & $8,81 E \cdot 09$ & $2,90 \mathrm{E}+08$ & $4,24 E \cdot 08$ & $6,89 E-09$ & $8,38 E-09$ & $647 E-09$ & $4,98 \mathrm{E}-08$ & $2,50 \mathrm{E}-08$ & $2,996-08$ & $8,06 E-08$ & $1,38 E-07$ & $3,01 \mathrm{E}-07$ & $2,85 E-07$ & $4,16 E-07$ & $5,46 E-07$ \\
\hline $06 / 09100$ & $4,11 \mathrm{E}-06$ & $1,76 \mathrm{E}-0 \mathrm{~B}$ & $1,23 \mathrm{E}-08$ & & $2,90 \mathrm{E} \cdot 08$ & $4,24 E-08$ & $6,476-09$ & $8,38 E-09$ & & $4,98 \mathrm{E}-08$ & $250 E-08$ & $2,996-08$ & $9,15 E-08$ & $1,38 E-0 ?$ & $3,01 \mathrm{E}-07$ & $2,85 E-07$ & $4,16 \mathrm{E}-07$ & $5,46 E-07$ \\
\hline $0 \mathrm{a} / 09 / 00$ & $1,28 \mathrm{E}-\mathrm{OS}$ & $2,08 E-0 B$ & $1,42 E-08$ & & $2,90 \mathrm{E}-09$ & $4.24 E-08$ & $6,47 \overline{0}-09$ & $8,36 \mathrm{E}-09$ & & $4,52 \mathrm{E}-08$ & $250 E-08$ & $2,596-08$ & $9,15<0 B$ & $1,38 E-07$ & $3,01 E-07$ & $2,85 \mathrm{E}-07$ & $4,16 E-07$ & $5,46 \mathrm{E}-07$ \\
\hline $10 / 09100$ & $5,81 \mathrm{E} 05$ & $2,67 E-08$ & $1,93 \mathrm{E}-08$ & & $2,90 \mathrm{E}-08$ & $4,24 E-08$ & $6,89 E-09$ & $8,96 \mathrm{E}+09$ & & 4,52 E.08 & $2,50=.08$ & 2,99508 & $8,06 E-08$ & $1,19 E-07$ & $3,01 E-07$ & $2,31 \mathrm{E}-07$ & $4,16 E-07$ & $5,46 \mathrm{E}-07$ \\
\hline $12 / 09 / 00$ & $1,60 \mathrm{E}-05$ & $6,93 E-08$ & $2,81 \mathrm{E}-07$ & & $1,56 \mathrm{E}-06$ & $4,24 E-08$ & $6,89 E-09$ & $8,966-09$ & & $4,52 \mathrm{E}-0 \mathrm{a}$ & $2,500-08$ & $2,99 E-08$ & $B, 06000$ & $1,19 E-07$ & $3,01 E-07$ & $2,31 E-07$ & $4,16 E-07$ & $5,46 E-07$ \\
\hline $14 / 08 / 00$ & $3,33 \mathrm{E}-05$ & $1,87 \mathrm{E}-06$ & $1,08 \mathrm{E}-05$ & & $2,48 \mathrm{E}-05$ & $4,24 \mathrm{E}-08$ & $6,89 E-09$ & $8,96 E-09$ & & $4,52 \mathrm{E}-08$ & $2,29 E-08$ & $2,73 E-08$ & $8,06 \in-08$ & $1,19 \varepsilon-0 ?$ & $3,01 \mathrm{E}-07$ & $2,31 \mathrm{E} 07$ & $4,16 \in-07$ & $5,46 E-07$ \\
\hline $1609 \%$ & $3,33 E-05$ & $1,48 \mathrm{E}-06$ & $7,65 \mathrm{E}-06$ & & $1,61 \mathrm{E}-05$ & $6,45 E-08$ & $7,84 E-09$ & $8,96 E-09$ & & $4,52 E-08$ & $2,29 \mathrm{E}-08$ & $2,73 E-08$ & $2,06 E .08$ & $1,19 E-07$ & $3,01 E-07$ & $2,31 E-07$ & $4,16 \mathrm{E}-07$ & $5,46 E-07$ \\
\hline $1209 / 00$ & $1,60 \mathrm{E}-05$ & $1,18 E-06$ & $5.54 \mathrm{E}-06$ & & $9,04 E-06$ & $1,33 E-07$ & $8,38 \mathrm{E}-09$ & $9,60 \mathrm{E}-09$ & & $4,52 E-08$ & $2,29 E-08$ & $2,73 \mathrm{E}-08$ & $8,065-08$ & $1,19 E-07$ & 3,01607 & $2,31 E-07$ & $4,16 \mathrm{E}-07$ & $5,46 \mathrm{E}-07$ \\
\hline 20109100 & $1,2 B E-05$ & $7,86 E-07$ & $3,10 E-06$ & & $6,3 \mathrm{BE}-06$ & $3,80 E-07$ & $1,496.08$ & $1,03 \mathrm{E}-08$ & & $6,76 E-08$ & $2,29 \mathrm{E}-08$ & $2,73 E 08$ & $8,06 \mathrm{E}-08$ & $1,19 \mathrm{E}-07$ & $3,01 E-07$ & $2,31 \mathrm{E}-07$ & $4,16 \mathrm{E}-07$ & $5,46 \mathrm{E}-07$ \\
\hline $22 / 09 / 00$ & $1,04 E-05$ & $7,86 \mathrm{E}-07$ & $3,20 \mathrm{E}-06$ & & $6,38 E-06$ & $9,88 E-07$ & $7,22 E-O B$ & $1,61 \mathrm{E}-08$ & & $9,42 \mathrm{E}-08$ & $2,29 \mathrm{E}-08$ & $2,73 \mathrm{E}-08$ & $8,06 E-08$ & $119 \mathrm{E} O 7$ & $3,01 \mathrm{E}-07$ & $2,31 E-07$ & $4,16 \mathrm{E}-07$ & $5,46 \mathrm{E} \cdot 07$ \\
\hline 2409,00 & $5,82 E \cdot 06$ & $786 \mathrm{E} \cdot 07$ & $2,39 E-06$ & & $4,63 E-06$ & $1,996-06$ & $2.74 E-07$ & $2,43 E-08$ & & $1,76 E-07$ & $220 E-08$ & $2,73 \mathrm{E}-08$ & $8,06 E-08$ & $1,19 \mathrm{E}-07$ & $3,01 \mathrm{E}-07$ & $2,31 E-07$ & $4,16 \mathrm{E}-07$ & $5,48 \approx-07$ \\
\hline $26109 / 00$ & $5,62 E-06$ & $1,18 \mathrm{E}-06$ & $3,10 \mathrm{E}-06$ & & $3,43 E-06$ & $4,63 \mathrm{E}-06$ & $9,88 \mathrm{E}-07$ & $1,52 \mathrm{E} 07$ & & $4,38 E-07$ & $2,29 E-08$ & $2,99 E-08$ & $8,06 E-08$ & $1,19 E-07$ & $3,01 \mathrm{E}-07$ & $2,31 E-07$ & $3,20 \mathrm{E}-07$ & $3,47 \mathrm{E}-07$ \\
\hline $28109 / 00$ & $5,82 E \cdot 06$ & $1,48 E-06$ & $4,11 E-06$ & & $3,43=06$ & $6,38 E-06$ & $1,23 E-06$ & $3,80 E-07$ & & $6,27 \epsilon=07$ & $2,73 E-08$ & $3,28 \mathrm{E}-0 \mathrm{~B}$ & $8,06 E-08$ & $1,10 \mathrm{E}-07$ & $301 \mathrm{E}-07$ & $2,31 E-07$ & $3,20 E-07$ & $3,47 E-07$ \\
\hline $30 / 09 / 00$ & $1,60 E-05$ & $2,39 E .06$ & $5,54 E-06$ & & $4,63 E-06$ & $9,04 E-06$ & $1.56 \mathrm{E}-06$ & $1.23 E-06$ & & $9.28 E-07$ & $3,2 \mathrm{BE}-0 \mathrm{OB}$ & $3,60 E-08$ & $8,06 E-08$ & $1.19 E-07$ & $2,49 E-07$ & 190 & $3.20 \mathrm{E}-07$ & $3.47 E-07$ \\
\hline $02 / 1000$ & $5,82 E-06$ & $7,86 \mathrm{E}-07$ & $1,87 \mathrm{E}-06$ & & $3,43 E-06$ & $9,04 E .06$ & $6,56 \mathrm{E} \cdot 07$ & $6,56 \mathrm{E}-07$ & & $1,15 E-06$ & $4,85 E-08$ & $3,97 \mathrm{E}-08$ & $8,06 E-08$ & $1,19 E-07$ & $2,495-07$ & $1,906-07$ & $3,20 E-07$ & $3,47 \mathrm{E}-07$ \\
\hline $0 / / 10 / 00$ & $5,82 E=06$ & $7,86 \mathrm{E}-07$ & $1.87 \leq-06$ & & $2,59 E-06$ & $6,38 \mathrm{E}-06$ & $6,58 \mathrm{E}-07$ & $6,56 \mathrm{E}-07$ & & $9,28 E-07$ & $7,49 E-08$ & $4,38 \mathrm{E}-08$ & $B, 06 E-0 B$ & $3,03 \mathrm{E}-07$ & $2,49 \mathrm{E}-07$ & $1,90 \mathrm{E}-07$ & $320 E-07$ & $3,47 \mathrm{E}-07$ \\
\hline $06 / 10 / 00$ & $5,62 \mathrm{E}-06$ & $7, \mathrm{~B} 6 \mathrm{E}-07$ & $1,87 \mathrm{E}-06$ & & $2,59 \mathrm{EE}-06$ & $6,38 \mathrm{E}-06$ & $B, 01 E-07$ & $6,56 E-07$ & & $9,28 E-07$ & $122 E-07$ & $4,85 E-08$ & $8,06 E-08$ & $1,03 E-07$ & $2,49 E-07$ & $1,90 E-07$ & $3,205-07$ & $3,47 E-07$ \\
\hline $08 / 10 / 100$ & $5,82 \mathrm{E}-06$ & $7, B 6 E .07$ & $1,48 E-06$ & & $2,59 E-06$ & $6,38 E-06$ & $B, 01 E .07$ & $6,56 E-07$ & & $9,28 E-07$ & $1,846.07$ & $5,38 E-08$ & $B, 06 E-08$ & $1,03 \mathrm{E}-07$ & $2,49 E-07$ & $1,90 \mathrm{E}-07$ & $3,20 E-07$ & $3,47 \mathrm{E}-07$ \\
\hline $11 / 10 / 00$ & $5,82 E-06$ & $7,86 \mathrm{E}-07$ & $3,86 \mathrm{E}-0 ?$ & & $2,59 \mathrm{E}-06$ & $6,38 \mathrm{E}-06$ & $6,56 E-07$ & $6,56 \mathrm{E} .07$ & & $9,28 E-07$ & $2,+3 E-07$ & $5,99 E-08$ & 8,0508 & $1,03 E-07$ & $2,49 E-07$ & $1,90 \mathrm{E}-07$ & $3,20 E-07$ & $2,83 E-07$ \\
\hline $14 / 10 / 00$ & $5,82 \mathrm{E}-06$ & $7,06 \mathrm{E}-07$ & $6,50 \mathrm{E}-07$ & & $2,59 \mathrm{E}-06$ & $8,38 E-06$ & $6,56 E-07$ & $6,56 E-07$ & & $9,28 E-07$ & $2,48 E-07$ & $6,69 E-08$ & $8,06 \mathrm{E}-0 \mathrm{~B}$ & $1,03 E-07$ & $2,40 E-07$ & $1,00 E-07$ & $320=-07$ & $196 \mathrm{E}-07$ \\
\hline $381+0100$ & $2,98 E-06$ & 2 toE-07 & $3,82 E-07$ & & $1,99 E-06$ & $6,38 \mathrm{k}-06$ & $3,21 \mathrm{E}-\mathrm{a} ?$ & $3.50 E-07$ & & $928 E-07$ & $2,90 \mathrm{E}-07$ & $8,42 E-08$ & $B, 0, E-0 B$ & $8,96 E-08$ & $249 E-07$ & $1,906-07$ & $3,20 E-07$ & $1,96 \mathrm{E}-07$ \\
\hline $21 / 10000$ & $2,98 \mathrm{E}-06$ & $1,09 E-07$ & $1,09 \mathrm{E}-07$ & & $1,56 \mathrm{E} 06$ & $4,63 E-06$ & $2,34 \mathrm{E}-07$ & $3,80 E-07$ & & $7,59 E-07$ & $2,48 E-07$ & $6,42 E-08$ & $8,06 E 0 B$ & $8,94 E-08$ & $2,49 E-07$ & $1,90 E-07$ & $3,205-07$ & $1,96 \mathrm{E}-07$ \\
\hline $25 / 10 / 00$ & $298 \mathrm{E}-06$ & $5,08 E-08$ & $4,19 \mathrm{E}, 08$ & & $1,23 E-06$ & $4,63 E-06$ & $1,03 E-07$ & $2,02 E-07$ & & $6,27 \mathrm{E}-07$ & $2,13 E-07$ & $8,42 E-03$ & $9,15 E-08$ & $8,94 \mathrm{E}-08$ & $3,0\} E-97$ & $1,90 \mathrm{E}-07$ & $3,20 E-07$ & $1,96 E-07$ \\
\hline $28 / 10 / 00$ & $5,82 \mathrm{E}-06$ & $2,81 \mathrm{E}-07$ & $5,08 E .08$ & & $1,99 \mathrm{E}-06$ & $2,59 E-06$ & $6,45 \mathrm{E}-08$ & $1,33 \mathrm{E}-07$ & & $5,22 E-07$ & $2,13 E-07$ & $8,42 E-08$ & $9,15 E-08$ & $8,94 \mathrm{E}-09$ & $3,01 E-07$ & 1,90507 & $2,51 E-07$ & $3,65 \varepsilon 07$ \\
\hline $01 / 11 / 00$ & $1,28 \mathrm{E}-\mathrm{CS}$ & $3,85 \mathrm{E}-07$ & $5,00 \mathrm{E}-0.0$ & & $1,99 \mathrm{E} \cdot 06$ & $2,59 E-06$ & $5,79 E-08$ & $1,17 \mathrm{E}-07$ & & $5,22 E-07$ & $1,84 E-07$ & $8,42 E-08$ & $\theta, 15 E-O B$ & $B, 94 E-08$ & $3,01 \mathrm{E}-07$ & $1,90 E-07$ & $2,51 E-07$ & $1,65 E-07$ \\
\hline $04 / 11100$ & $1,60 \mathrm{E}-05$ & $7,86 E-07$ & $5,08 \mathrm{E}-08$ & & $2,59 E-06$ & 259E-O6 & $5,20 E-08$ & $9,12 E-0 B$ & & $4,38 E-07$ & $1.60 \mathrm{E}-07$ & $B, 42 E-0 B$ & $9,15 E-08$ & $8,94 E-08$ & $301 \mathrm{E}-07$ & $1,90 E-07$ & $2,54 \mathrm{E} \times 07$ & $1,65 \mathrm{E}-07$ \\
\hline $08 / 17100$ & $5,82 \mathrm{E} .06$ & $1,10 \mathrm{E}-06$ & $6,23 \mathrm{E}-08$ & & $2,59 \xi-06$ & $199 \mathrm{E}-06$ & $4,69 E-08$ & $7,22 \mathrm{E}-08$ & & $3,71 E-07$ & $1,22 \mathrm{E} .07$ & $8,42 \mathrm{E}-0 \mathrm{~B}$ & $9,15 E-08$ & 6.94E-08 & $2,49 \mathrm{E}-07$ & $t 90 \mathrm{E} .07$ & $2,51 E-07$ & $1,65 \mathrm{E}-07$ \\
\hline $11 / 11 / 100$ & $5,82 \mathrm{E}-06$ & $1,12 \mathrm{E}-06$ & $6,23 \mathrm{E}-08$ & & $2,590.06$ & $1,99 E-06$ & $3,84 E-O B$ & $5,79 E-09$ & & $3,16 E-07$ & $9,50 \mathrm{E}-08$ & $7,49 \mathrm{E}-08$ & $8,08 E-08$ & $7,82 E-08$ & $2,0 B E-07$ & $57 \varepsilon-07$ & $2,51 E-07$ & $1,44 \in=07$ \\
\hline $13 / 11 / 00$ & $1,60 E-05$ & $7,86 \mathrm{E}-07$ & $6,93 \mathrm{E}-0 \mathrm{~s}$ & & $2,59 E-06$ & $1,56 \mathrm{E}-06$ & $2,90 E-00$ & $3,84 \mathrm{E}-08$ & & $277 \mathrm{E}-07$ & $8,42 E-08$ & $7,49 \mathrm{E}-08$ & $8,06 \mathrm{E}-08$ & $3,82 E-08$ & $2,08 E-07$ & $1,57 E-07$ & $2,51 E-07$ & $1,24 \mathrm{E} 07$ \\
\hline $15 / 11100$ & $3,33 \mathrm{E} .05$ & $1,87 E-06$ & $2, B+E-07$ & & $9,04 E-06$ & $1,56 \mathrm{E}-06$ & $2,65 E-08$ & $3,49 E-08$ & & $2,33 E-07$ & $7,496.08$ & $6,696.08$ & $7,13 E-08$ & $6,87 \mathrm{E}-08$ & $1,75 E-07$ & $4,57 E-07$ & $2,00 E-07$ & $9,12 \mathrm{E}-08$ \\
\hline $18 / 13 / 00$ & $5,81 \mathrm{E}-05$ & $3,10 \mathrm{E}-06$ & $1,08 \mathrm{E}-05$ & & $1,99 \mathrm{E} .05$ & $1,56 \mathrm{E} .06$ & $2,236-08$ & $3,88-08$ & & $1,76 E-07$ & $6,69 \mathrm{E}-0 \mathrm{~B}$ & $6,69 \mathrm{E}-0 \mathrm{~B}$ & $7,13 E-08$ & $B, 06 E-08$ & $1,75 E-07$ & $1,57 E-07$ & $2,00 E-07$ & $9,12 E-08$ \\
\hline $22 / 1 / 100$ & $5.81 \mathrm{E}-05$ & $3,10 E-06$ & $1,08 \mathrm{E} \cdot 05$ & & $1,990-05$ & $9,04 E-06$ & $7,22 \mathrm{E}-0 \mathrm{~B}$ & $2,900-08$ & & $2,71 \mathrm{E}-07$ & 6,69508 & $0,69 E-08$ & $6,33 E-09$ & $6,06 E-08$ & $1,75 E-07$ & $1,57 E-07$ & $2,00 \leqslant 07$ & $9,12 \mathrm{E}-\mathrm{CB}$ \\
\hline $25 / 1 / 1 / 00$ & $3,33 E-05$ & $1,878-06$ & $5,54 E-06$ & & $9,04 \mathrm{E}-06$ & $2,48 E-05$ & $3,21 E-07$ & $2,43 E-08$ & & $3,16 E-07$ & $6,69 \mathrm{E}-03$ & $5,99 E-08$ & $5,64 E-09$ & $5,36 E-09$ & $1,75 E-07$ & $1,31 \mathrm{E}-07$ & $2,00 E-07$ & $9,12 E-08$ \\
\hline $29 / 11 / 00$ & $258 \mathrm{E}-05$ & $1,87 \mathrm{E} \cdot 06$ & $5,54 E-06$ & & $9,00 \mathrm{E}-06$ & $2,48 \mathrm{E}-05$ & $6,56 \mathrm{E}-07$ & $2,43 E-08$ & & $4,38 E-07$ & $749 \mathrm{E} \cdot 08$ & $5,99 k-08$ & $5,04 E-08$ & $5,36 \mathrm{E}-08$ & $1,48 E-07$ & $1,31 \mathrm{E}-07$ & $2,00 \mathrm{E}-07$ & $9,12 E-08$ \\
\hline $04 / 12 / 00$ & $2,56 E-05$ & $1,87 \mathrm{E}-06$ & $5,54 \mathrm{E}-06$ & & $9,04 \mathrm{E}-06$ & $2,48 E-05$ & $9, B 8 E-07$ & $2,90 E-08$ & & $1,15 \mathrm{E}-06$ & $1,84 E-0 ?$ & $5,39 E-08$ & 5,04 E. 08 & $4,76 E-08$ & $1,48 \mathrm{E}-07$ & $1,31 \mathrm{E} \cdot 07$ & $2,00 E-07$ & $9,12 E-08$ \\
\hline $0 / 12 / 00$ & $7,60 \mathrm{E}-05$ & $1,48 E-06$ & 4,11E-06 & & $6,39 E-06$ & $2,4 B E-05$ & $1,23 E-06$ & $4,69 E-08$ & & $1,44 E-06$ & $2,90 \in-07$ & 6,695008 & $4,52 E-00$ & $4,76 E-08$ & $1,48 E-07$ & -07 & $2,00 \mathrm{E}+07$ & $9,12 E-08$ \\
\hline $09 / 12 / 00$ & $1,28 E .05$ & $9,60 \mathrm{E}-07$ & $3,10 E-06$ & & $4,63 E-06$ & $2,48 E-05$ & $6,56 \mathrm{E}-07$ & $1,03 \mathrm{E}-07$ & & $1,44 E-06$ & $4,06 E 07$ & $7,49 E-08$ & $4,06 E-00$ & $4,76 E-O B$ & $1,48 E-07$ & $1,31 \mathrm{E}-07$ & $1,62 \mathrm{E} 07$ & $9,12 E-08$ \\
\hline $13 / 12 / 200$ & $1,60 \mathrm{E}-05$ & $3,10 E-06$ & $2,98 E 005$ & & $4,63 E-06$ & $9,04 \mathrm{E}-06$ & $2,59 E-06$ & $1,56 \mathrm{E}, 06$ & & $1,15 \mathrm{E}-06$ & 4,06007 & $9,50 \mathrm{f}-08$ & $3,66 E .08$ & $4,24 E-08$ & $1,4 \mathrm{BE}-07$ & $1,105-07$ & $1,62 \mathrm{E}-07$ & $9,12 E-08$ \\
\hline $16 / 12 / 00$ & $5,81 E-05$ & $3,10 \mathrm{E}-06$ & $2,39 E-05$ & & $2,48 E-05$ & $9,04 E-06$ & $2,59 \mathrm{E}-06$ & $2,59 E 06$ & & $1,44 E-06$ & $4,85 \mathrm{E}-07$ & $1,22 E-07$ & $3,66 E 09$ & $4,24 \xi .08$ & $1,4 \mathrm{BE}-07$ & $1,10 E-07$ & $1,62 \mathrm{E}-07$ & $912 \mathrm{E}-0 \mathrm{~B}$ \\
\hline $20 / 12 / 00$ & $3,33 E-05$ & $3,10 \mathrm{E}-06$ & $2,39 \mathrm{E}=05$ & & $904 \mathrm{E}-06$ & $9,02 \mathrm{E}-05$ & $2,59 E-06$ & $2,59 \mathrm{E}-06$ & & $4,086-06$ & $1,36 \in-06$ & $2,13 E-07$ & $4,06 E-08$ & $3,79 \mathrm{E}-20$ & 0.07 & $1,10 E-07$ & $162 \mathrm{E}-07$ & $9,12 \mathrm{E}-\mathrm{aB}$ \\
\hline $23 / 12100$ & $3,33 E \cdot 05$ & $2,39 \mathrm{E}-06$ & $\{, 58 E-05$ & & $9,04 \mathrm{E}-06$ & $9,02 E-05$ & 1,99E-06 & $1,99 E-06$ & & 06 & $2,25 E-06$ & $4,06 \mathrm{E}-07$ & $5,04 E-08$ & $3,79 \mathrm{E} \cdot 08$ & $1,26 E-07$ & $1,10 E-07$ & $1,62 \mathrm{E}-07$ & $9,12 \mathrm{E}-08$ \\
\hline $27 / 12 / 00$ & $1,60 E-05$ & $1,87 E-06$ & $1,08 E-05$ & & $6,38 E-06$ & $5,17 E-05$ & $1,56 E-06$ & $1,56 \mathrm{E}-06$ & & 06 & $2,25 E-06$ & $7,11 \mathrm{E}-07$ & $6,33 \mathrm{E}-08$ & $3,40 E 08$ & $1,26 \mathrm{E}-07$ & $1,10 E-07$ & $1,62 \mathrm{E}-07$ & $9,12 E-08$ \\
\hline $30 / 12 / 00$ & 104 & $1,46 \mathrm{E}-06$ & -06 & & -06 & $2,48 E \cdot 05$ & $9,8 B E-07$ & $988 \mathrm{~B}-07$ & & 0.06 & $2,25 E 06$ & $1,36 \mathrm{E}-06$ & $7,74 \mathrm{E}-07$ & $3,40 E-08$ & $1,26 \subseteq-07$ & $9,35 E-08$ & $1,62 \mathrm{E}-07$ & $0,12 \mathrm{E}-0 \mathrm{~B}$ \\
\hline $03 / 01 / 01$ & $1,04 \mathrm{E}-05$ & $1,87 \mathrm{E}-06$ & $7,65 E-06$ & & $4,63 E-06$ & $2,48 E-05$ & $3,88 E-07$ & $3,8 B E-07$ & & $3,065.06$ & $1,74 E-06$ & $1,36 \mathrm{E}-06$ & $9,65 E-07$ & 08 & $3,26 \mathrm{E}-07$ & $9,35 \mathrm{E}-08$ & 07 & $9,12 E-08$ \\
\hline 060 & 1,60 & $3,50 E-06$ & $1,08 \mathrm{~B}-05$ & & 06 & 1,99 & $1,56 E-06$ & $9,88 \mathrm{E}-07$ & & $2,34 \mathrm{E}-06$ & $1,36 \mathrm{E}-06$ & $1,36 \mathrm{E}-06$ & $1,226-06$ & $3,40 E-08$ & $1,26 \mathrm{c}-07$ & $9355-08$ & $1,33 E-07$ & $9,12 E \cdot 08$ \\
\hline 1110 & $1,00 E-05$ & $1,87 E-06$ & $7,65 \mathrm{E}-06$ & & $4,63 \mathrm{E}-06$ & $8,04 E-06$ & 1,23506 & $1,23 \mathrm{E}=06$ & & $1,44 \mathrm{E}-06$ & $1,09 \mathrm{E}-06$ & $1,36 \mathrm{E} .06$ & $1,56 E-06$ & $-4,2$ & -07 & 08 & $1,33 E-07$ & $9,12 E-08$ \\
\hline & 1,60 & $1.87 \mathrm{E} 06$ & 5,5 & & 06 & $9,04 E-06$ & $1,236-06$ & $1,23 E-06$ & & $1,44 E-06$ & $8,74 \mathrm{E}-07$ & $1,36 E-06$ & $1,56 E-06$ & $6,06 E-08$ & $1,26 E-07$ & $935 \mathrm{E}-08$ & $1,33 E-07$ & $9,12 \mathrm{E}-0 \mathrm{O}$ \\
\hline 101 & $1,60 E-05$ & $1,4 \mathrm{EE}-06$ & $5,54 E-06$ & & 4,6, & $9,04 E-06$ & $1,23 \mathrm{E}-06$ & $1,23 E-06$ & & $144 E-06$ & & 3,3 & $15 x$ & & 07 & 08 & -07 & 508 \\
\hline & $5,82 E-06$ & $1,18 E-06$ & 5,5 & & $4,63=-06$ & $9,04 E-06$ & $1,23 E, 06$ & $9,88 E-07$ & & $1,15 E-06$ & $7,1\} E-07$ & $1,09 \mathrm{E}-06$ & $1,56 \in-06$ & $1,88 \mathrm{E}-07$ & $1,49 E-07$ & $9,35 E-08$ & $1,335-07$ & $9,12 \mathrm{E}-08$ \\
\hline 101 & $1,60 E-05$ & $1,18 E-06$ & $3,10 \mathrm{E}-06$ & & $3,43 E 06$ & $9,04 E .06$ & $6.56 \mathrm{E}-07$ & $6,56 E-07$ & & 9,22 & & 8,7 & 3,2 & 07 & $2,08 E-07$ & 00 & $1,33 \mathrm{E}-07$ & $9,12 E-08$ \\
\hline 2710 & 1,60 & 1,87 ㄷ.06 & 4,1 & & $4,63 \mathrm{E}-06$ & $9,04 E-06$ & $6,56 \mathrm{E}-07$ & $6,56 \mathrm{E}-07$ & & $9,28 \mathrm{E}-07$ & $5,856,07$ & $874 \mathrm{E}-07$ & $1,22 E-06$ & $3,83 E-07$ & $3,01 E-07$ & $7,98 \mathrm{E}-08$ & $5,33 E-07$ & $9,12 \mathrm{E}-08$ \\
\hline $31 / 01 / 01$ & $1,60 \mathrm{E}-05$ & $187 \mathrm{E}-06$ & $2,39 E-06$ & & $6,38 \mathrm{E}-06$ & $9,04 E-06$ & $6,56 \mathrm{E}-07$ & .07 & & -07 & & 07 & 3,2 & 8.07 & $3,67 \mathrm{E}-07$ & $7,98 \mathrm{E}-08$ & 1,33E- 07 & $7,04 E-08$ \\
\hline $03 / 0$ & $128 E-05$ & $1,87 \mathrm{E}-06$ & $2,39 E-06$ & & $6,30 \mathrm{E}-08$ & $9,04 E-06$ & $6,56 \mathrm{E}-07$ & $6,56 E-07$ & & 07 & 4,8 & $7,11 E-07$ & $1,22 \mathrm{E}-06$ & $3.33 \mathrm{E}-07$ & $3,67 \mathrm{E}-07$ & $7,080.08$ & $1,33 \mathrm{E}-07$ & $7,04 E-08$ \\
\hline $06 / 02 / 01$ & $1,2 \mathrm{BE}-05$ & $1,48 \mathrm{E}-06$ & $1,87 E-06$ & & $4,63 \mathrm{E}-06$ & $904 E-06$ & $5,42 E-07$ & 5,42 & & 75 & 4,8 & 7,1 & 9,6 & $3,23 \mathrm{E}-07$ & $5,54 \mathrm{E}-07$ & $7,98 E-08$ & $33 E-07$ & $2,04 E-08$ \\
\hline $10 / 02 / 03$ & $1,60 \mathrm{E}-05$ & $1,48 \mathrm{E} 06$ & $1,87=06$ & & $4,63 E-06$ & $9,04 E-06$ & $4,52 \mathrm{E}-07$ & $3,60 \mathrm{E}-07$ & & $6,27 E-07$ & $4,06 E-07$ & -07 & $7,74 \mathrm{E}-07$ & $3,83-07$ & $5,64 E-07$ & $7,98 E 00$ & $1,33 \mathrm{E}-07$ & $7,04 E-08$ \\
\hline $14 / 0201$ & $1,28 E-05$ & $9,60 \mathrm{E}-07$ & $1,48 \mathrm{E}-06$ & & $3,43 E .06$ & $9,04 E-06$ & $3,21 \mathrm{E}-07$ & 3,2 & & 6.2 & $4,06 E-07$ & 5,85 & $7,74 \mathrm{E}-07$ & & $7,90 E-07$ & $9,35 E-08$ & $1,62 E-07$ & $7,04 \mathrm{E}-08$ \\
\hline $19 / 02 / 01$ & $1,28 E-05$ & $1,1 \mathrm{EE}-06$ & $5,54 E-06$ & & $6,38 E-06$ & $9,04 E-06$ & $3,21 \mathrm{E}, 07$ & $2,74 \mathrm{E}-07$ & & $6,27 E-07$ & $3,42 \mathrm{E}-07$ & $5,85 \mathrm{E}-07$ & $7,74 \mathrm{E}-07$ & $3,83 \mathrm{E}-07$ & $7,10 E-07$ & & $1,62 \mathrm{E}$ & 09 \\
\hline $21 / 02 / 01$ & $3,33 E-05$ & $1,87 \mathrm{E}-06$ & $1,08 \mathrm{E}-05$ & & $9,04 E-06$ & 9,04E.06 & 4,5 & & & 6.27 & 4,0 & $5,85 \in-07$ & $6,28 \mathrm{E}-07$ & $300 \pi$ & $7,10 \mathrm{E}-07$ & $9,35 \mathrm{E}-08$ & $1,62 \mathrm{E}-07$ & $04 E .08$ \\
\hline $2402 / 01$ & $1,60 E-05$ & $9,00 \mathrm{E}-07$ & $4,11 E-06$ & & $6,38 \mathrm{E}-06$ & $2,48 E-O S$ & $9,88 \mathrm{E}-07$ & -07 & & $6,27 \mathrm{E}-07$ & $4,06 E-07$ & $5,25 \leq-07$ & $5,14 \mathrm{E}-07$ & $3,83 \mathrm{E} \cdot 07$ & & $9,35 \mathrm{E}-08$ & $1,62 \mathrm{E}-07$ & $04 E-08$ \\
\hline 2802001 & $1,28 E-05$ & $118 E 06$ & $554 \mathrm{E}-06$ & & $9,04 E-06$ & $2,48 E-05$ & $1,56 E-06$ & $1,23 E-06$ & & $9,28 \mathrm{E}-07$ & $3,425-0 ?$ & $4,85 \mathrm{E}-07$ & $5,14 E-07$ & & $7,10 E-07$ & $9,35 \mathrm{E}-09$ & $62 E-07$ & $04 E-08$ \\
\hline $03 / 03 / 01$ & $1,28 \mathrm{E}-05$ & $1,18 E-06$ & $5,54 \mathrm{E}-08$ & & $9,04 \mathrm{E}-06$ & $2,48 E .05$ & $1,56 \mathrm{E}-06$ & $1,23 E-06$ & & $9,28 \mathrm{E}-07$ & 3.425 .07 & $4,85 \mathrm{E}-07$ & $5,14 E-07$ & $3, \mathrm{B3E}-07$ & $7,10 E-07$ & 1,10 & 1,52 & $7,04 E-08$ \\
\hline $07 / 03 / 01$ & $3,33 E-05$ & $1,18 E-66$ & $1,18 \mathrm{~B}-06$ & & $904 E-06$ & $4,00 E-05$ & $1,56 \mathrm{E}-06$ & $1,56 E-06$ & & 1, 15E-06 & $4,06 E-07$ & $4,85 E, 07$ & $5,14 E-07$ & & $7100-07$ & $t, 10 \mathrm{E}-07$ & $1,62 \mathrm{E}-07$ & $7,04 E .08$ \\
\hline $10 / 03 / 01$ & $5,81 E-05$ & $4,11 E-06$ & $4,11 E-06$ & & $9,04 E-06$ & $5,17 \mathrm{E}-05$ & $2,59 \mathrm{E}-06$ & $2,59 \mathrm{E}-06$ & & $1,15 E-06$ & $5,85 E, 07$ & $5,85 E-07$ & $5,14 \mathrm{E}-07$ & 3,37 & & 1,10 & $62 E-07$ & $704 E-08$ \\
\hline 14103101 & $5,81 \mathrm{E}-05$ & $7,65 E-06$ & $7,65 E-06$ & & $9,04 E-06$ & $902 E-05$ & $3,436-06$ & $3,43 E-06$ & & $1,44 \mathrm{E}-06$ & 5.8507 & $5,65 E .07$ & $5,14 E, 07$ & 3,17 & $10 \mathrm{E}-07$ & $1,10 \mathrm{E}-\mathrm{al}$ & $1,62 \mathrm{E}-07$ & $04 E-08$ \\
\hline $17103 / 01$ & $5,81 E-05$ & $3,10=06$ & $3,10 E-06$ & & $6,38 \mathrm{E}-06$ & $5,17 \varepsilon-05$ & $3,43 E-06$ & $3,43 E .06$ & & $1,82 E-06$ & $7,1\}=07$ & $7,11 \mathrm{E}-07$ & $5,14 E-07$ & 3,17607 & & & & \\
\hline $21 / 03 / 01$ & $3,33 E-05$ & $1,87 E-06$ & $2,39 E-06$ & & $6,38 E-06$ & $4,000.05$ & $2,59 E-06$ & $3,43 E-06$ & & 3,06006 & $1,09 \mathrm{E}-06$ & $8,74 E-07$ & $7,74 \mathrm{E}-07$ & $3,17 E-07$ & $5,64 E-07$ & $10=07$ & $1,62 E-07$ & $555 E-O B$ \\
\hline $24 / 03 / 03$ & $1,60 \mathrm{E}-05$ & $1,18 E-06$ & 9,00007 & & $B, 3 B E-06$ & $3,13 E-05$ & $3,99 E-06$ & $156 E-06$ & & $3,06 E-06$ & $2,25 E-06$ & $1,09 E-08$ & $1,22 E-06$ & $3,17 \mathrm{E}-07$ & $5,64 E-07$ & $10 \mathrm{E}-07$ & $1,62 E-07$ & 5,55 \\
\hline $28 / 03 / 01$ & $1,04 E-05$ & $1,18 E-06$ & $3.10 E-06$ & & $4,63 E-06$ & $1,64 E=05$ & $1,23 E-06$ & $9,08 E-07$ & & 3,06006 & $1,74 \mathrm{E}-06$ & $1,36 \mathrm{E}=06$ & $1,56 \mathrm{E}-06$ & $3,83 \mathrm{E}-07$ & $5,64 \mathrm{E}-07$ & $1,10 \mathrm{E}-07$ & $1,62 \in-07$ & $5,55 E-08$ \\
\hline & & $88 E-06$ & $3,10 E-06$ & & 2,59506 & $904 E-06$ & $6,56 \mathrm{E}-07$ & $6,56 \mathrm{E}-07$ & & $2,34 \mathrm{EE}-06$ & $1,36 E=06$ & $1,36 E+\infty 6$ & $202 E .06$ & $5,76 \mathrm{E}-07$ & $5,64 \mathrm{E}-07$ & $1,31 \mathrm{E}-07$ & $1,62 E-07$ & $55 E-08$ \\
\hline
\end{tabular}


9.6. ANEXO 6 - RESULTADOS DE ANÁLISES QUÍMICAS E MINERALÓGICAS DO MATERIAL DO SOLO

Análises Mineralógicas por Difração de Raios X - Difratogramas Selecionados PC-3,0-T
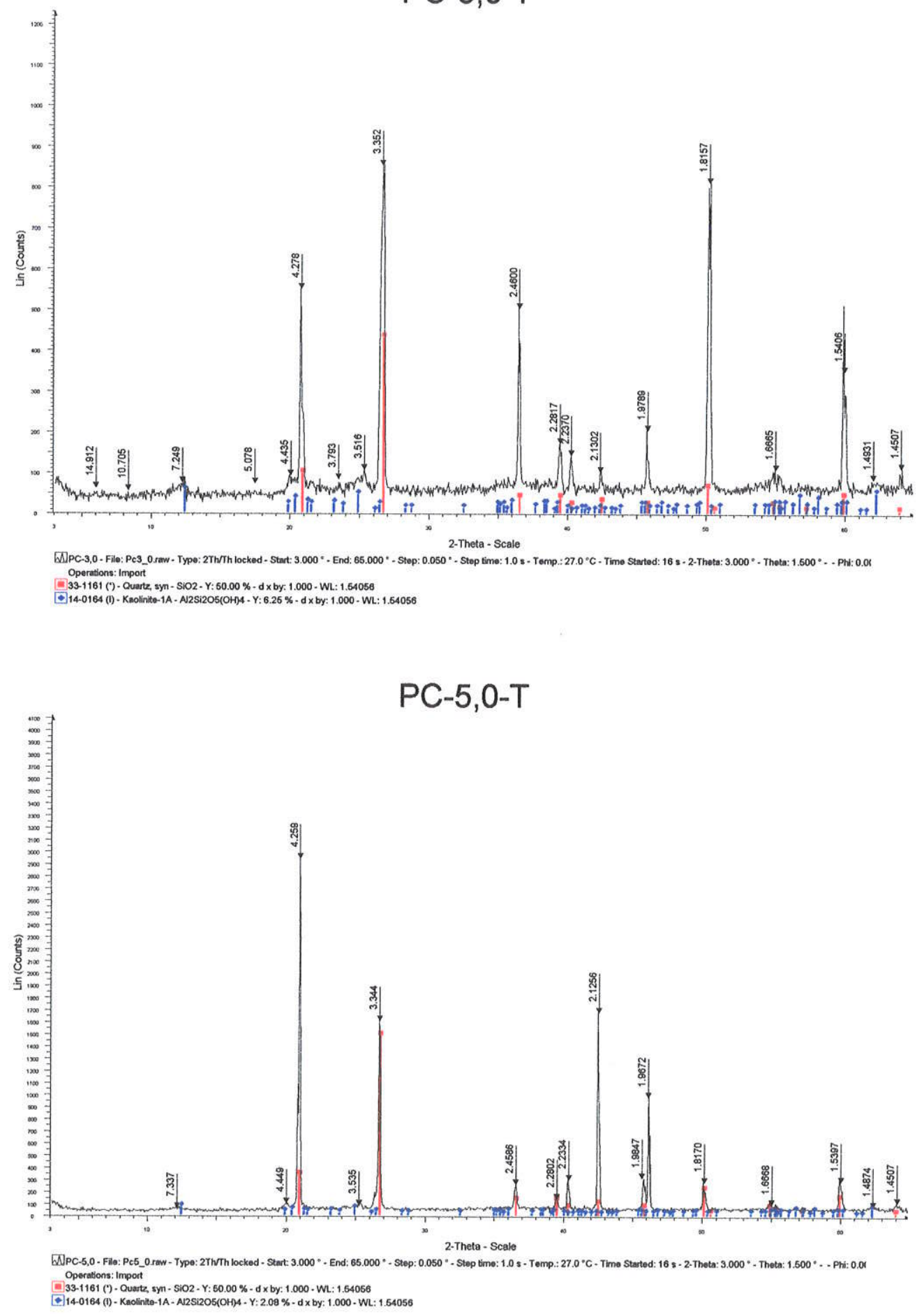
PC-11,5-T

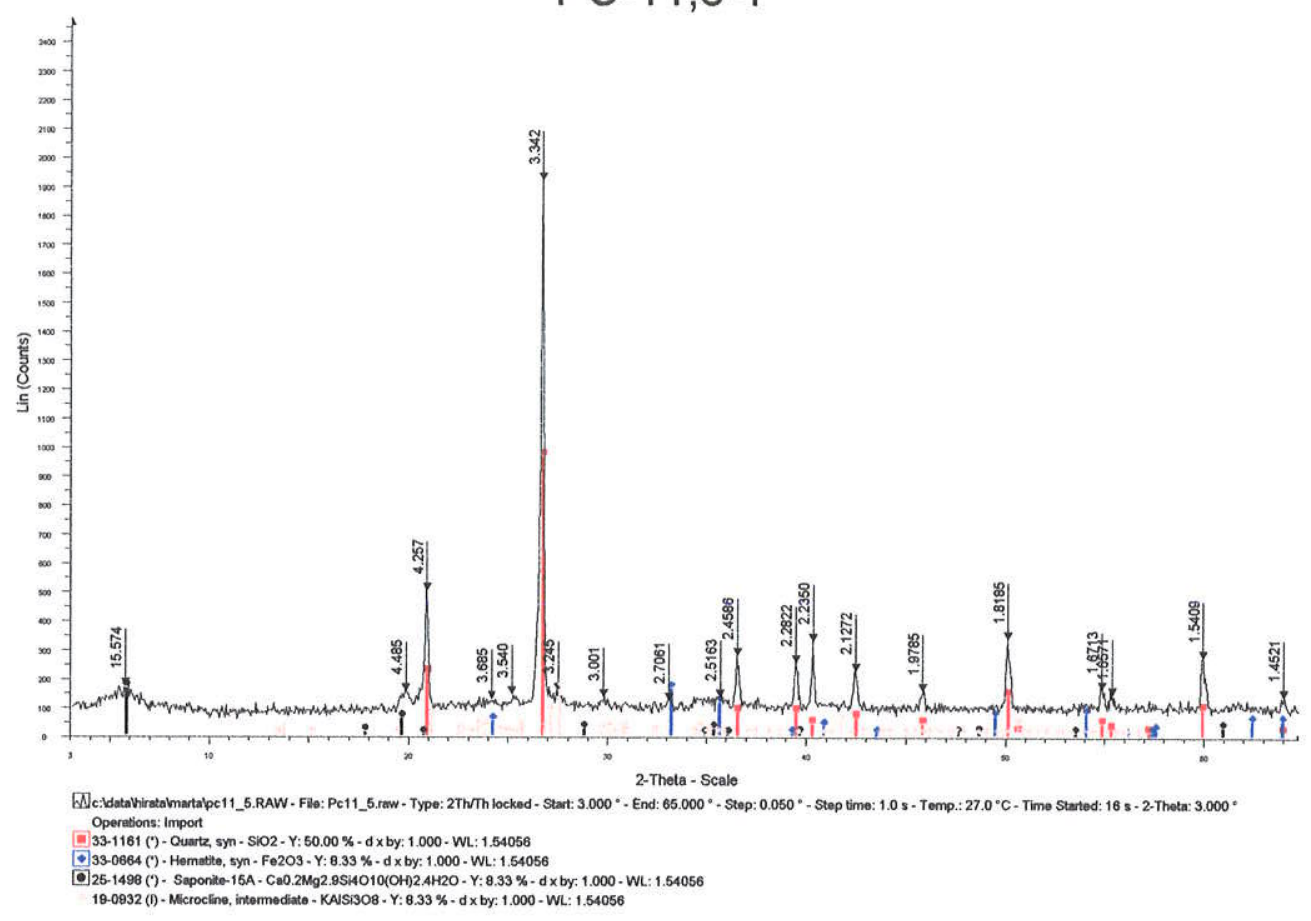

PC-1,0-F

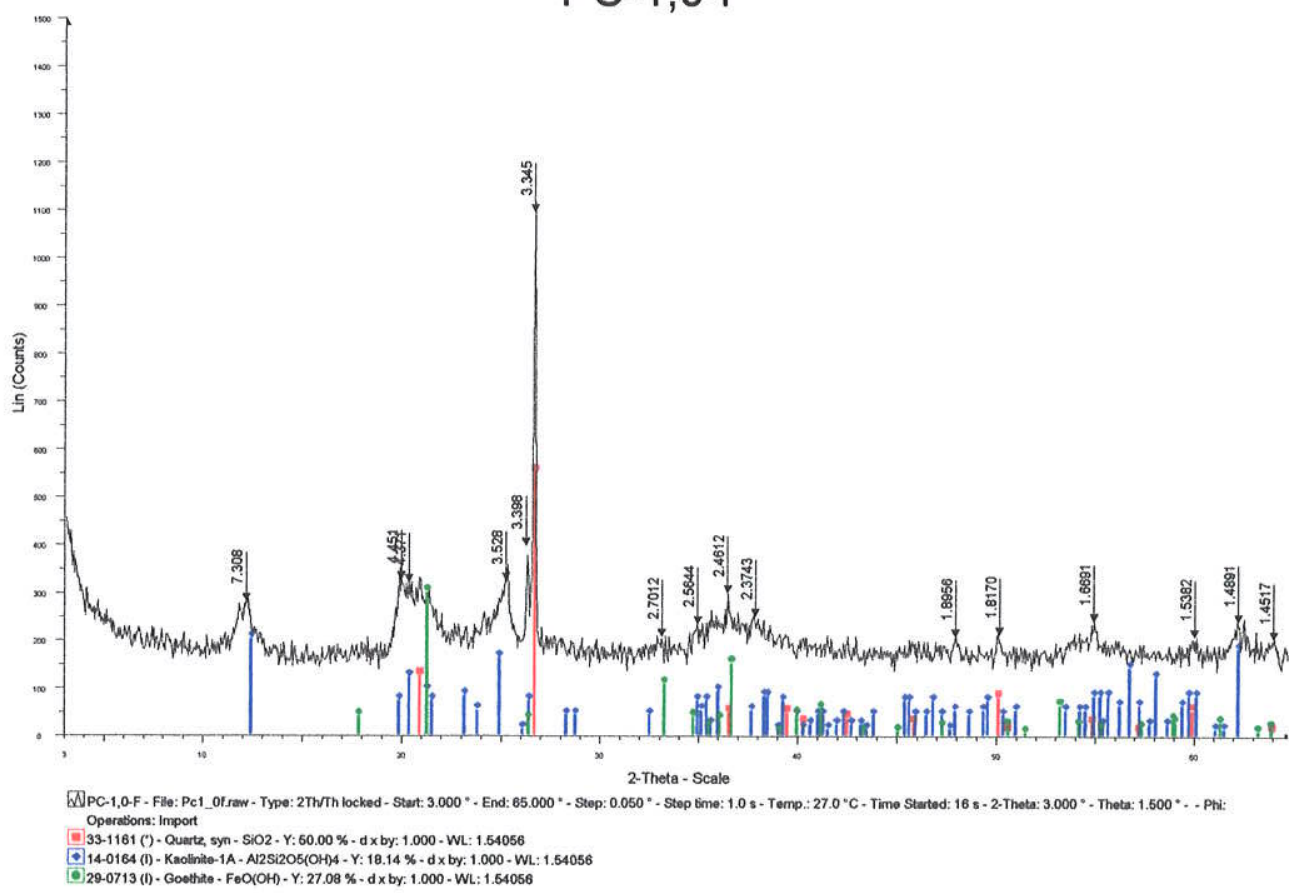




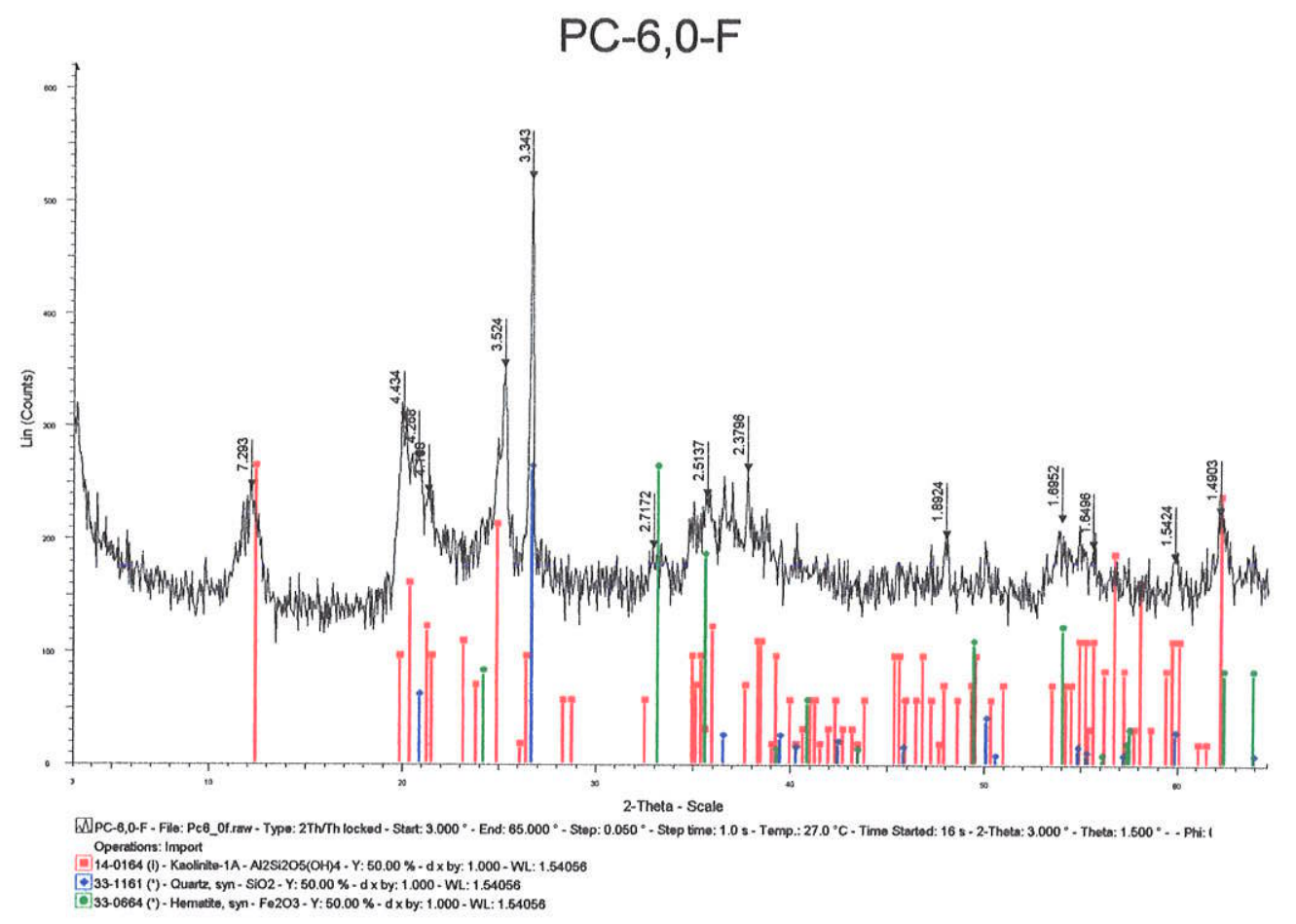

PC-6,0-FL

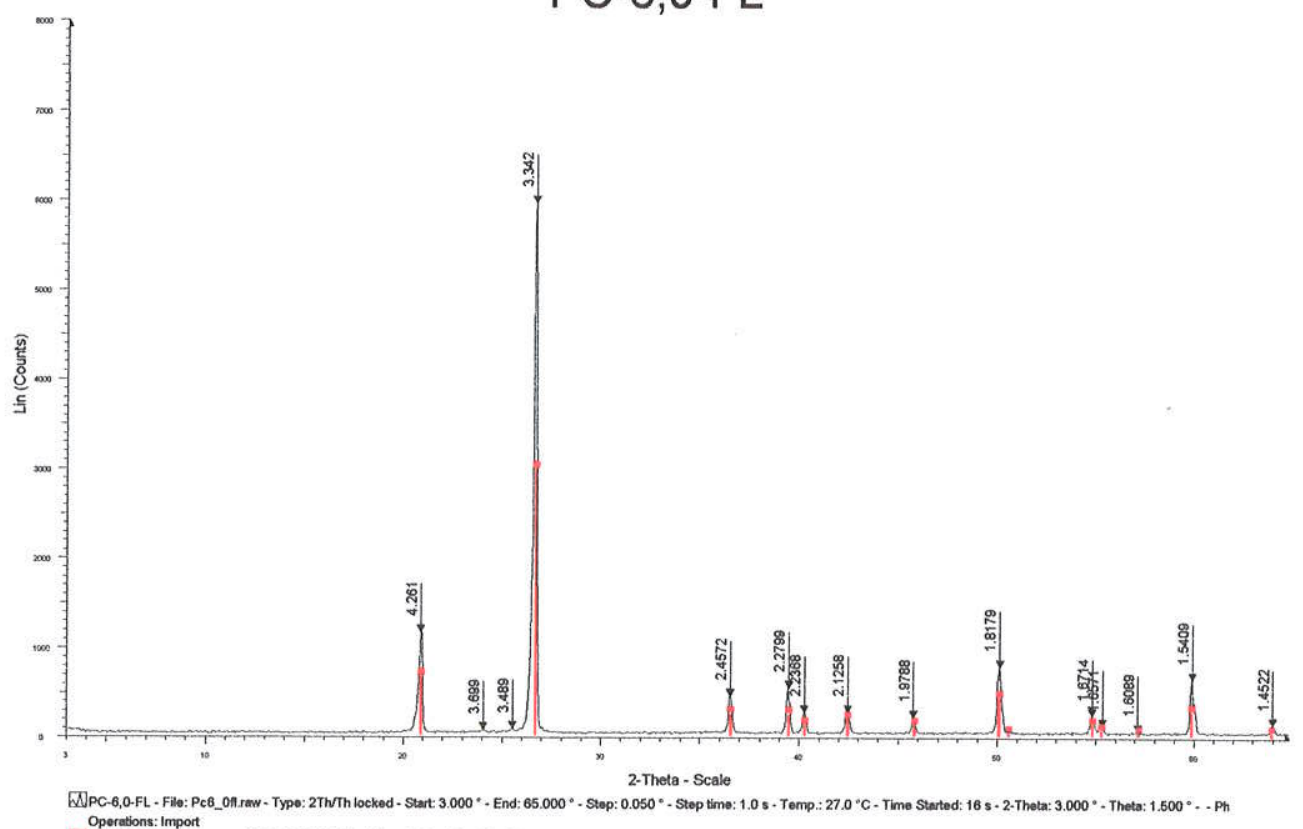

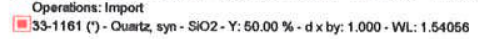



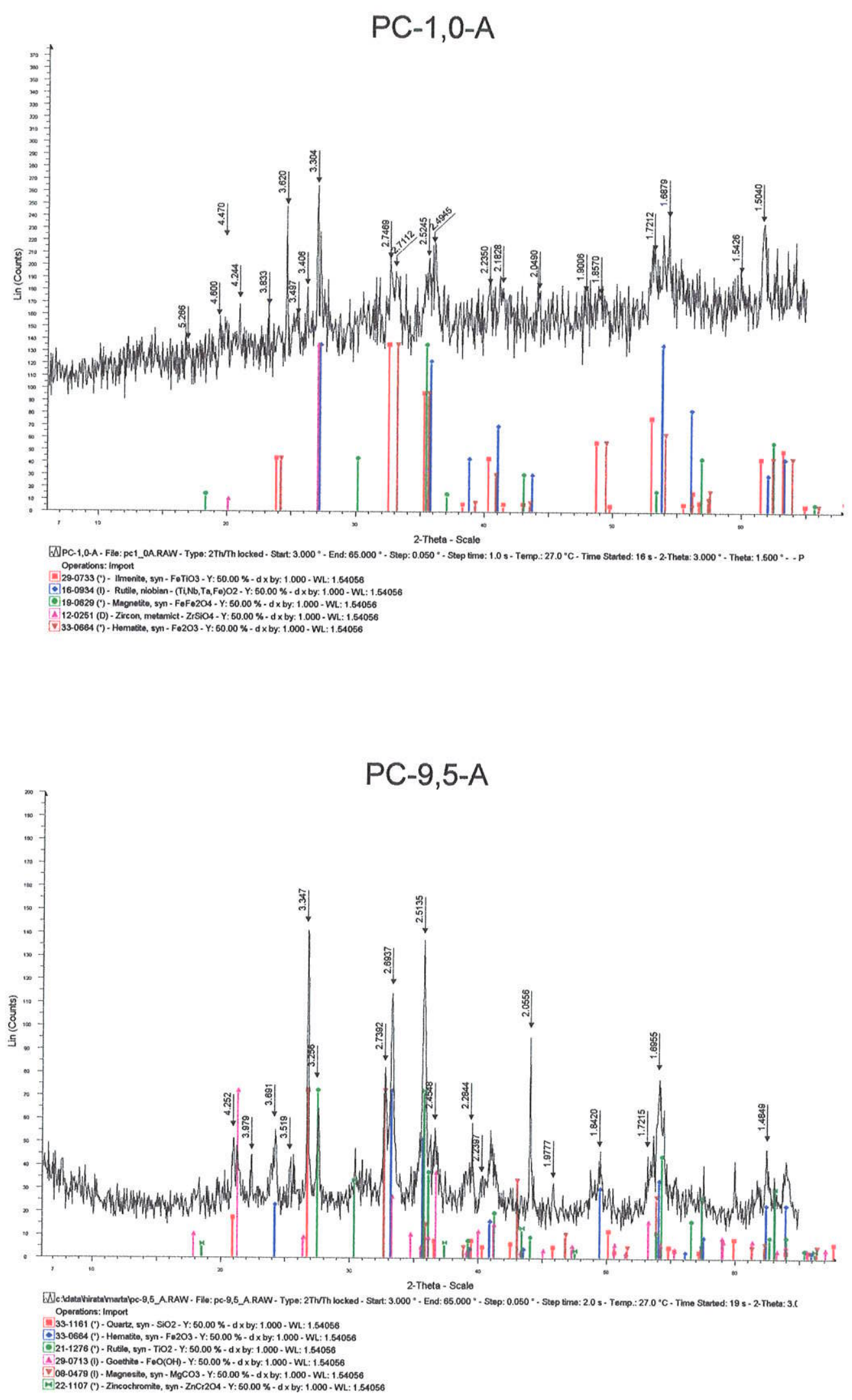


\section{RESULTADOS DE ANÁLISES QUIMICAS DE SOLO TOTAL DO POÇO E DOS LISÍMETROS EXTERNOS POR ICPIAES}

\begin{tabular}{|c|c|c|c|c|c|c|c|c|c|c|c|c|c|c|c|c|c|c|c|c|c|c|c|c|c|c|}
\hline Prof. & 0,4 & 1 & $2 a$ & $2 b$ & 3 & 4 & 5 & $6 a$ & $6 b$ & 7 & 7,2 & 8 & $9 a$ & $9 \mathbf{b}$ & 9,5 & 10,5 & 11,5 & Aterro & L50C & L1C & L50D & L1Da & L1Db & L50E & L1E & Bent* \\
\hline $\mathrm{SiO} 2$ & 88,23 & 81,42 & 84,47 & 85,29 & 83,84 & 82,22 & 83,67 & 83,35 & 83,53 & 81,12 & 93,54 & 80,23 & 77,1 & 77,25 & 94,94 & 67,4 & 82,11 & 82,54 & 87,2 & 83,05 & 87,87 & 83,3 & 82,77 & 88,65 & 81,53 & 81,88 \\
\hline A1203 & 4,58 & 7,81 & 6,95 & 6,89 & 6,95 & 7,61 & 7,18 & 7,55 & 7,61 & 8,14 & 1,79 & 7,86 & 7,06 & 7,14 & 2,32 & 11,28 & 5,47 & 7,46 & 4,62 & 7,81 & 4,75 & 7,64 & 7,76 & 4,34 & 7,91 & 5,81 \\
\hline $\mathrm{Fe} 2 \mathrm{O} 3$ & 2,25 & 3,07 & 2,97 & 3 & 3,01 & 3,15 & 3,33 & 3,04 & 3,15 & 4,08 & 2,64 & 4,85 & 7,44 & 7,08 & 2,62 & 8,62 & 4,69 & 3,33 & 2,32 & 3,16 & 2,38 & 3,12 & 3,15 & 2,16 & 3,14 & 5,1 \\
\hline $\mathrm{MgO}$ & 0,11 & 0,15 & 0,12 & 0,12 & 0,12 & 0,14 & 0,14 & 0,16 & 0,17 & 0,24 & 0,06 & 0,61 & 0,97 & 0,97 & 0,39 & 2,56 & 1,15 & 0,25 & 0,11 & 0,16 & 0,12 & 0,16 & 0,16 & 0,11 & 0,16 & 0,75 \\
\hline $\mathrm{CaO}$ & 0,08 & 0,08 & 0,06 & 0,06 & 0,05 & 0,03 & 0,04 & 0,06 & 0,07 & 0,05 & 0,02 & 0,1 & 0,15 & 0,15 & 0,09 & 0,59 & 0,27 & 0,14 & $\overline{0,1}$ & 0,08 & 0,09 & 0,09 & 0,09 & 0,1 & 0,1 & 0,23 \\
\hline $\mathrm{Na2O}$ & 0,01 & 0,02 & 0,01 & 0,01 & 0,01 & 0,01 & 0,01 & 0,01 & 0,02 & 0,02 & 0,01 & 0,04 & 0,05 & 0,06 & 0,04 & 0,1 & 0,08 & 0,03 & $<0,01$ & $<0,01$ & $<0,01$ & $<0,01$ & $<0,01$ & 0,01 & 0,01 & 0,15 \\
\hline $\mathrm{K} 2 \mathrm{O}$ & 0,12 & 0,13 & 0,11 & 0,12 & 0,08 & 0,1 & 0,12 & 0,17 & 0,17 & 0,3 & 0,1 & 0,87 & 1,35 & 1,37 & 0,6 & 2,46 & 1,45 & 0,43 & 0,09 & 0,12 & $<0,11$ & 0,13 & 0,11 & 0,09 & 0,14 & 0,79 \\
\hline $\mathrm{P} 205$ & 0,01 & 0,01 & $<0,01$ & 0,01 & $<0,01$ & $<0,01$ & $<0,01$ & 0,01 & $<0,01$ & 0,01 & 0,01 & 0,01 & 0,01 & 0,01 & $<0,01$ & 0,01 & $<0,01$ & 0,03 & 0,04 & 0,03 & 0,03 & 0,03 & 0,04 & 0,03 & 0,03 & \\
\hline $\mathrm{MnO}$ & 0,04 & 0,04 & 0,03 & 0,03 & 0,03 & 0,03 & 0,03 & 0,03 & 0,03 & 0,04 & 0,04 & 0,04 & 0,06 & 0,06 & 0,03 & 0,12 & 0,06 & 0,04 & 0,04 & 0,03 & 0,04 & 0,03 & 0,03 & 0,04 & 0,03 & \\
\hline $\mathrm{TiO} 2$ & 1,51 & 1,78 & 1,8 & 1,8 & 1,82 & 2 & 2,01 & 2,17 & 2,11 & 2,25 & 0,26 & 2,29 & 2,5 & 2,46 & 0,87 & 1,94 & 1,5 & 2 & 1,47 & 1,75 & 1,45 & 1,71 & 1,71 & 1,43 & 1,77 & \\
\hline P.F. & 2,92 & 4,1 & 3,29 & 3,29 & 3,23 & 3,42 & 3,29 & 3,44 & 3,61 & 3,85 & 1,29 & 3,69 & 3,09 & 3,09 & 1,15 & 5,16 & 2,75 & 3,79 & 3,09 & 4,01 & 3,4 & 4,19 & 4,19 & 2,88 & 4,35 & \\
\hline Total & 99,87 & 98,61 & 99,8 & 100,62 & 99,13 & 98,72 & 99,81 & 99,99 & 100,48 & 100,08 & 99,75 & 100,58 & 99,79 & 99,64 & 100,04 & 100,24 & 99,54 & 100,14 & 99,08 & 100,2 & 100,24 & 100,4 & 100,2 & 99,84 & 99,17 & \\
\hline $\mathrm{H} 2 \mathrm{O}$ & 0,63 & 1,23 & 0,88 & 0,88 & 0,78 & 0,81 & 0,81 & 1,04 & 1,04 & 1,2 & 0,23 & 1,59 & 2,05 & 2,05 & 1,39 & 8,84 & 4,28 & 0,92 & 0,61 & 0,76 & 0,61 & 0,63 & 0,63 & 0,6 & 0,6 & \\
\hline & & & & & & & & & & & & & & & & & & & & & & & & & & \\
\hline $\mathrm{Ba}$ & 48 & 50 & 39 & 39 & 33 & 37 & 38 & 50 & 49 & 80 & 91 & 186 & 288 & 288 & 157 & 473 & 325 & 121 & 43 & 45 & 51 & 42 & 50 & 46 & 46 & \\
\hline $\mathrm{Cr}$ & 180 & 202 & 214 & 207 & 197 & 271 & 312 & 296 & 297 & 594 & 409 & 322 & 355 & 362 & 61 & 195 & 161 & 239 & 142 & 168 & 155 & 184 & 192 & 165 & 185 & \\
\hline $\mathrm{Ni}$ & 52 & 32 & 33 & 22 & 26 & 31 & 22 & 27 & 23 & 28 & $<15$ & 28 & 36 & 32 & 17 & 86 & 37 & 38 & 33 & 51 & 10 & 34 & 28 & 24 & 24 & \\
\hline Sr & 8 & 8 & 6 & 6 & 6 & 6 & 7 & 8 & 8 & 11 & 10 & 23 & 35 & 36 & 20 & 63 & 45 & 16 & $<5$ & $<5$ & 6 & $<5$ & 6 & 6 & 6 & \\
\hline V & 76 & 96 & 100 & 98 & 96 & 117 & 120 & 112 & 108 & 152 & 54 & 115 & 148 & 145 & 55 & 106 & 83 & 113 & 78 & 100 & 77 & 99 & 108 & 88 & 103 & \\
\hline $\mathrm{Zr}$ & 274 & 292 & 309 & 305 & 296 & 319 & 369 & 408 & 415 & 398 & 81 & 357 & 384 & 377 & 134 & 320 & 244 & 327 & 261 & 273 & 266 & 302 & 265 & 290 & 275 & \\
\hline
\end{tabular}

a e b: análises feitas em duplicata.

Resultados expressos em \% de massa, a não ser para $\mathrm{Ba}, \mathrm{Cr}, \mathrm{Ni}, \mathrm{Sr}, \mathrm{V} \mathrm{e} \mathrm{Zr}$, expressos em mg/kg

* Bent: Amostra de mistura de solo e bentonita. 


\begin{tabular}{|c|c|c|c|c|c|c|c|c|c|c|}
\hline \multicolumn{11}{|c|}{$\begin{array}{l}\text { RESULTADOS DE ANÁLISES QUIMICAS DE SOLO DO POÇO DAS FRAÇŌES FINA, FLUTUADO E } \\
\text { AFUNDADO POR ICPIAES }\end{array}$} \\
\hline & 1F & $6 \mathrm{Fa}$ & $6 \mathrm{Fb}$ & $9,5 F$ & $1 \mathrm{~A}$ & $6 A$ & $9,5 \mathrm{~A}$ & $1 F L$ & $6 \mathrm{FL}$ & $9,5 \mathrm{FL}$ \\
\hline $\mathrm{SiO} 2$ & 43,8 & 43,98 & 43,89 & 62,78 & 15,38 & 12,21 & 9,85 & 97,99 & 97,38 & 96,4 \\
\hline $\mathrm{Al} 2 \mathrm{O} 3$ & 27,58 & 27,86 & 28,24 & 12,56 & 4,29 & 4,98 & 2,89 & 0,91 & 1,28 & 1,27 \\
\hline $\mathrm{F} e 203$ & 8,8 & 8,39 & 8,31 & 10,01 & 32,51 & 32,85 & 44,91 & 0,64 & 0,7 & 1,24 \\
\hline $\mathrm{MgO}$ & 0,44 & 0,5 & 0,49 & 2,16 & 1,13 & 1,14 & 1,15 & 0,02 & 0,02 & 0,23 \\
\hline $\mathrm{CaO}$ & 0,05 & 0,06 & 0,06 & 0,67 & 0,09 & 0,08 & 0,16 & 0,01 & 0,01 & 0,05 \\
\hline $\mathrm{Na} 2 \mathrm{O}$ & 0,02 & 0,02 & 0,02 & 0,04 & 0,1 & 0,1 & 0,08 & 0,01 & 0,01 & 0,03 \\
\hline $\mathrm{K} 20$ & 0,31 & 0,4 & 0,42 & 1,18 & 0,06 & 0,08 & 0,34 & 0,04 & 0,05 & 0,39 \\
\hline P205 & 0,09 & 0,02 & 0,03 & 0,09 & 0,04 & 0,03 & 0,04 & $<0,01$ & $<0,01$ & $<0,01$ \\
\hline Mno & 0,04 & 0,05 & 0,05 & 0,08 & 1,34 & 1,35 & 1,02 & 0,01 & 0,01 & 0,01 \\
\hline $\mathrm{TiO} 2$ & 4,6 & 5,51 & 5,57 & 2,47 & 41,78 & 42,9 & 32,22 & 0,23 & 0,37 & 0,19 \\
\hline P.F. & 14,43 & 12,8 & 12,8 & 7,59 & 1,56 & 2,23 & 2,56 & 0,66 & 0,66 & 0,89 \\
\hline Total & 100,16 & 99,6 & 99,88 & 99,65 & 101,19 & 101,09 & 96,17 & 100,51 & 100,49 & 100,71 \\
\hline $\mathrm{H} 2 \mathrm{O}-$ & 3,85 & 3,92 & 3,92 & 7,53 & 0,51 & 0,85 & 1,12 & 0,12 & 0,17 & 0,44 \\
\hline $\mathrm{Ba}$ & 98 & 105 & 105 & 335 & 97 & 101 & 229 & 20 & 25 & 104 \\
\hline $\mathrm{Cr}$ & 490 & 578 & 598 & 301 & 7229 & 7704 & 1475 & 81 & 76 & 30 \\
\hline $\mathrm{Ni}$ & 145 & 135 & 142 & 109 & 112 & 110 & 122 & 34 & 26 & 25 \\
\hline $\mathrm{Sr}$ & 13 & 16 & 15 & 83 & 22 & 23 & 34 & $<5$ & $<5$ & 13 \\
\hline $\mathrm{V}$ & 248 & 268 & 279 & 166 & 1715 & 1759 & 2059 & $<15$ & 25 & 17 \\
\hline $\mathrm{Zr}$ & 410 & 537 & 542 & 295 & 21593 & 23392 & 7104 & 43 & 64 & 30 \\
\hline$\% \mathrm{ZrO} 2$ & & & & & 2,92 & 3,16 & 0,96 & & & \\
\hline
\end{tabular}

a e b: análises feitas em duplicata.

F: análise da fração fina

A: análise da fração afundada

FL: análise da fração flutuada

Resultados expressos em \% de massa, a não ser para $\mathrm{Ba}, \mathrm{Cr}, \mathrm{Ni}, \mathrm{Sr}, \mathrm{V}$ e $\mathrm{Zr}$, expressos em $\mathrm{mg} / \mathrm{kg}$. 


\begin{tabular}{|c|c|c|c|c|c|c|c|c|c|c|c|c|}
\hline \multicolumn{13}{|c|}{$\begin{array}{c}\text { RESULTADOS DE CONTROLE DE QUALIDADE DAS ANÁLISES DE ICPIAES SOLO - BRANCO, SOLUÇŌES } \\
\text { PADRÃO OBTIDAS E CERTIFICADAS E REPRODUTIBILIDADE DAS ANÁLISES DUPLICATAS E } \\
\text { DAS SOLUÇÕES PADRÃO }\end{array}$} \\
\hline & \multirow[t]{2}{*}{ BRANCO } & \multirow{2}{*}{\begin{tabular}{|c|} 
Nist 2709 \\
Obtido
\end{tabular}} & \multirow{2}{*}{\begin{tabular}{l|} 
Nist 2709 \\
Certificado
\end{tabular}} & \multirow{2}{*}{\begin{tabular}{|c|} 
Nist 2711 \\
Obtido
\end{tabular}} & \multirow{2}{*}{$\begin{array}{l}\text { Nist } 2711 \\
\text { Certificado }\end{array}$} & \multicolumn{7}{|c|}{ REPRODUTIBILIDADE (\%) } \\
\hline & & & & & & 2 & 6 & 9 & $L 1 D$ & $6 \mathrm{~F}$ & Nist 2709 & Nist 2711 \\
\hline $\mathrm{SiO} 2$ & $<0,01$ & 62,81 & 63,45 & 64,06 & 65,11 & $-0,48$ & $-0,11$ & $-0,10$ & 0,32 & 0,10 & $-0,50$ & $-0,81$ \\
\hline $\mathrm{Al} 2 \mathrm{O} 3$ & 0.01 & 14,19 & 14,17 & 12,29 & 12,34 & 0,43 & $-0,40$ & $-0,56$ & $-0,78$ & $-0,68$ & 7 & $-0,20$ \\
\hline $\mathrm{Fe} 2 \mathrm{O} 3$ & $<0,01$ & 5,14 & 5 & 4,1 & 4,13 & $-0,50$ & $-1,78$ & 2,48 & $-0,48$ & 0,48 & 1,38 & $-0,36$ \\
\hline $\mathrm{MgO}$ & $<0,01$ & 2,6 & 2,5 & 1,73 & 1,74 & 0,00 & $-3,03$ & 0,00 & 0,00 & 1,01 & 1,96 & $-0,28$ \\
\hline $\mathrm{CaO}$ & $<0,01$ & 2,71 & 2,64 & 3,92 & 4,03 & 0,00 & -7.69 & 0,00 & 0,00 & 0,00 & 1,30 & $-1,38$ \\
\hline $\mathrm{Na2O}$ & 0,01 & 1,58 & 1,56 & 1,61 & 1,54 & 0,00 & $-33,33$ & $-9,09$ & - & 0,00 & 3 & 2,22 \\
\hline $\mathrm{K} 2 \mathrm{O}$ & $<0,01$ & 2,37 & 2,45 & 2,9 & 2,95 & $-4,35$ & 0,00 & $-0,74$ & 8.33 & -2 & -1 & $-0,85$ \\
\hline $\mathrm{P} 205$ & $<0,01$ & 0,13 & 0,143 & 0,17 & 0,197 & - & - & 0,00 & $-14,29$ & $-20,00$ & -4 & $-7,35$ \\
\hline $\mathrm{MnO}$ & $<0,01$ & 0,08 & 0,069 & 0,09 & 0,082 & 0,00 & 0,00 & 0,00 & 000 & 0,00 & 7.38 & 4,65 \\
\hline $\mathrm{TiO} 2$ & 0,01 & 0,59 & 0,57 & 0,54 & 0,51 & 0,00 & 1,40 & 0,81 & 0,0 & $-0,54$ & 1,72 & 2,85 \\
\hline P.F. & & & & & & 0,00 & $-2,41$ & 0,00 & 0,00 & 0,00 & - & - \\
\hline Total & & 92,2 & 92,55 & 91,4 & 92,63 & $-0,41$ & $-0,24$ & 0,08 & 0,10 & $-0,14$ & $-0,19$ & $-0,66$ \\
\hline $\mathrm{H} 2 \mathrm{O}-$ & & & & & & 0,00 & 0,00 & 0,00 & 0,00 & 0 & - & - \\
\hline $\mathrm{Ba}$ & $<10$ & 946 & 968 & 718 & 726 & 0,00 & 1,01 & 0,00 & $-8,70$ & 0,00 & $-1,15$ & $-0,55$ \\
\hline $\mathrm{Cr}$ & $<15$ & 135 & 130 & 44 & 47 & 1,66 & $-0,17$ & $-0,98$ & $-2,13$ & $-1,70$ & 1,89 & $-3,29$ \\
\hline $\mathrm{Ni}$ & $<15$ & 93 & 88 & 17 & 20,6 & 20,00 & 8,00 & 5,88 & 9,68 & $-2,53$ & 2,76 & $-9,57$ \\
\hline $\mathrm{Sr}$ & $<5$ & 233 & 231 & 247 & 245,3 & 0,00 & 0,00 & $-1,41$ & - & 3,23 & 0,43 & 0,345 \\
\hline V & $<15$ & 117 & 112 & 75 & 81,6 & 1,01 & 1,82 & 1,02 & $-4,35$ & $-2,01$ & 2,18 & $-4,21$ \\
\hline $\mathrm{Zr}$ & $<25$ & 159 & 160 & 304 & 230 & 0,65 & $-0,85$ & 0,92 & 6,53 & $-0,46$ & $-0,31$ & 13,85 \\
\hline
\end{tabular}

Obs.: A reprodutibilidade da análise é dada pela medida do desvio dos resultados e expressa em porcentagem: (diferença)/(soma) $\times 100$.

Valores em negrito representam resultados acima do limite estabelecido em $10 \%$. Valores sublinhados encontram-se próximo do limite estabelecido. 


\begin{tabular}{|c|c|c|c|c|c|c|c|c|c|}
\hline \multicolumn{7}{|c|}{ Resultado das Análises de Capacidade de Troca de Cátions } \\
\hline & $\begin{array}{c}\mathrm{M} . \mathrm{O} . \\
(\mathrm{g} / \mathrm{kg})\end{array}$ & $\begin{array}{c}\mathrm{pH} \\
\mathrm{CaCl} 2\end{array}$ & $\begin{array}{c}\mathrm{Na} \\
\text { meq/100g }\end{array}$ & $\begin{array}{c}\mathrm{K} \\
\text { meq/100g }\end{array}$ & $\begin{array}{c}\mathrm{Ca} \\
\text { meq/100g }\end{array}$ & $\begin{array}{c}\mathrm{Mg} \\
\text { meq/100g }\end{array}$ & $\begin{array}{c}\mathrm{Al} \\
\text { meq/100g }\end{array}$ & $\begin{array}{c}\mathrm{H} \\
\text { meq/100g }\end{array}$ & $\begin{array}{c}\text { CTC } \\
\text { meq/100g }\end{array}$ \\
\hline Aterro & 2 & 5,7 & $2,87 ?$ & 0,06 & 2,10 & 1,00 & 0,08 & 1,02 & $7,13 ?$ \\
\hline PC. 0,4 & 10 & 5,1 & 0,18 & 0,06 & 2,50 & 0,40 & 0,05 & 1,55 & 4,74 \\
\hline PC. 1,0 & 8 & 5,5 & 0,34 & 0,14 & 2,20 & 0,50 & 0,05 & 1,45 & 4,68 \\
\hline PC. 2,0 & 4 & 5,8 & 0,20 & 0,11 & 1,70 & 0,40 & 0,05 & 1,25 & 3,71 \\
\hline PC. 3,0 & 2 & 5,8 & 0,18 & 0,06 & 1,50 & 0,50 & 0,06 & 1,24 & 3,54 \\
\hline PC. 4,0 & 2 & 6,1 & 0,20 & 0,11 & 1,20 & 0,80 & 0,04 & 1,16 & 3,51 \\
\hline PC. 5,0 & 2 & 5,7 & 0,35 & 0,15 & 1,40 & 0,50 & 0,04 & 1,06 & 3,50 \\
\hline PC. 6,0 & 1 & 5,7 & 0,29 & 0,12 & 1,50 & 0,50 & 0,05 & 1,05 & 3,51 \\
\hline PC. 7,0 & 2 & 4,2 & 0,33 & 0,10 & 1,40 & 1,00 & 0,30 & 1,40 & 4,53 \\
\hline PC. 8,0 & 1 & 4,4 & 0,38 & 0,16 & 3,00 & 2,70 & 0,25 & 1,55 & 8,04 \\
\hline PC. 9,0 & 1 & 4,0 & 0,55 & 0,20 & 4,70 & 3,30 & 0,85 & 1,75 & 11,35 \\
\hline PC. 9,5 & 1 & 4,4 & 0,52 & 0,14 & 2,60 & 1,60 & 0,48 & 1,02 & 6,36 \\
\hline PC. 10,0 & 1 & 4,0 & 0,58 & 0,17 & 3,50 & 2,40 & 1,10 & 1,20 & 8,95 \\
\hline PC. 10,5 & 1 & 4,2 & 1,53 & 0,40 & $21,00 ?$ & 8,40 & 1,12 & 2,08 & $34,53 ?$ \\
\hline PC. 11,5 & 1 & 4,3 & 1,80 & 0,31 & 13,00 & 4,9 & 0,6 & 1,5 & 22,11 \\
\hline
\end{tabular}

\begin{tabular}{|c|c|c|c|c|c|c|}
\hline \multicolumn{7}{|c|}{$\begin{array}{l}\text { Resultado das Análises Químicas em } \\
\text { Microscópio Eletrônico de Varredura (MEV) (em \% atômica) }\end{array}$} \\
\hline Lâmina & $\mathrm{PC}-10,0 \mathrm{~m}$ & $\mathrm{PC}-10,0 \mathrm{~m}$ & $\mathrm{PC}-10,0 \mathrm{~m}$ & $\mathrm{PC}-10,0 \mathrm{~m}$ & PC-10,0m & PC-7m \\
\hline Ponto & 1.1 & 6.1 & 6.2 & 6.3 & 6.4 & 1 \\
\hline Mineral & K-feldspato & K-feldspato & Biotita? & $\begin{array}{l}\text { Caulinita + } \\
\text { quartzo (?) }\end{array}$ & $\begin{array}{l}\text { Caulinita + } \\
\text { quartzo (?) }\end{array}$ & $\begin{array}{l}\text { Caulinita + } \\
\text { quartzo (?) }\end{array}$ \\
\hline Fórmula & $\mathrm{K}\left(\mathrm{AlSi}_{3} \mathrm{O}_{8}\right)$ & $\mathrm{K}\left(\mathrm{AlSi} \mathrm{i}_{3} \mathrm{O}_{8}\right)$ & $\begin{array}{c}\mathrm{K}(\mathrm{Mg}, \mathrm{Fe})_{3} \\
\left(\mathrm{AlSi}_{3} \mathrm{O}_{10}\right)(\mathrm{OH})_{2}\end{array}$ & $\begin{array}{c}\mathrm{Al}_{4}\left(\mathrm{Si}_{4} \mathrm{O}_{10}\right)(\mathrm{OH})_{8} \\
+\mathrm{SiO}_{2}\end{array}$ & $\begin{array}{c}\mathrm{Al}_{4}\left(\mathrm{Si}_{4} \mathrm{O}_{10}\right)(\mathrm{OH})_{8} \\
+\mathrm{SiO}_{2}\end{array}$ & $\begin{array}{c}\mathrm{Al}_{4}\left(\mathrm{Si}_{4} \mathrm{O}_{10}\right)(\mathrm{OH})_{8} \\
+\mathrm{SiO}_{2}\end{array}$ \\
\hline $\mathrm{O}(\%)$ & 57,18 & 59,14 & 49,27 & 38,72 & 61,90 & 62,50 \\
\hline $\mathrm{Al}(\%)$ & 8,36 & 7,99 & 9,54 & 21,28 & 12,55 & 12,52 \\
\hline $\mathrm{Si}(\%)$ & 25,67 & 24,29 & 28,24 & 33,14 & 21,43 & 19,99 \\
\hline$K(\%)$ & 8,64 & 7,87 & 2,57 & 1,01 & 0,71 & 0,52 \\
\hline $\mathrm{Na}(\%)$ & - & 0,37 & 0,25 & - & 0,13 & 0,54 \\
\hline $\mathrm{Mg}(\%)$ & - & - & 2,53 & 0,90 & 1,52 & 0,29 \\
\hline $\mathrm{Ca}(\%)$ & - & - & 0,24 & 0,32 & 0,13 & 0,25 \\
\hline $\mathrm{Fe}(\%)$ & 0,09 & 0,25 & 5,85 & 2,47 & 1,15 & 1,68 \\
\hline $\mathrm{Ba}(\%)$ & 0,06 & - & - & - & - & - \\
\hline $\mathrm{Cl}(\%)$ & - & 0,10 & - & - & - & 0,25 \\
\hline $\mathrm{Ti}(\%)$ & - & - & 1,51 & 2,16 & 0,47 & 1,47 \\
\hline
\end{tabular}




\section{Laboratório IG-USP}

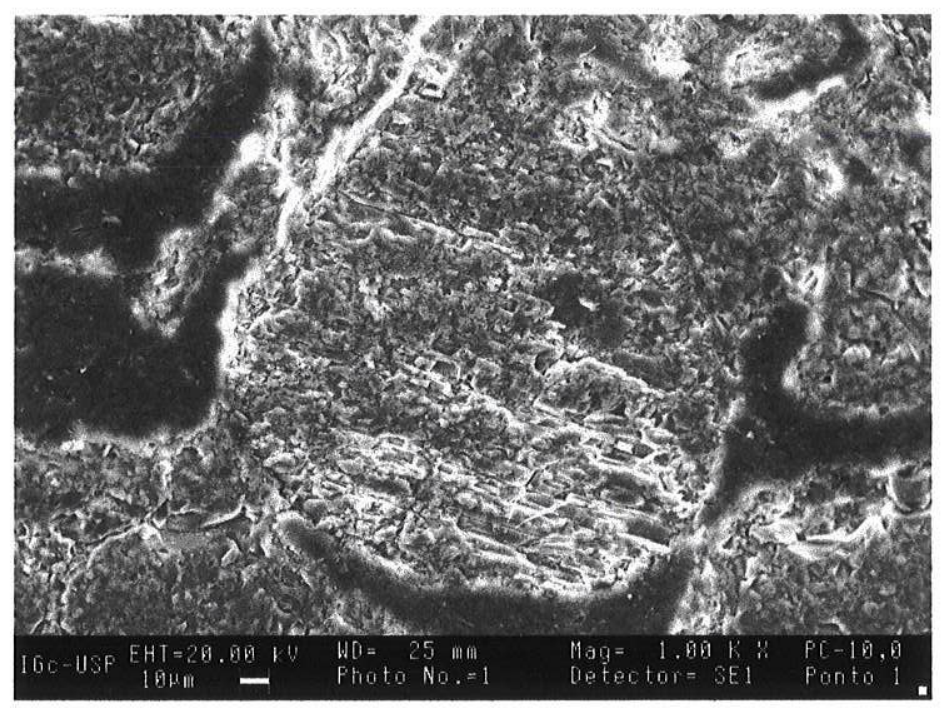

Ponto 1.1 - Lâmina $10 \mathrm{~m}$

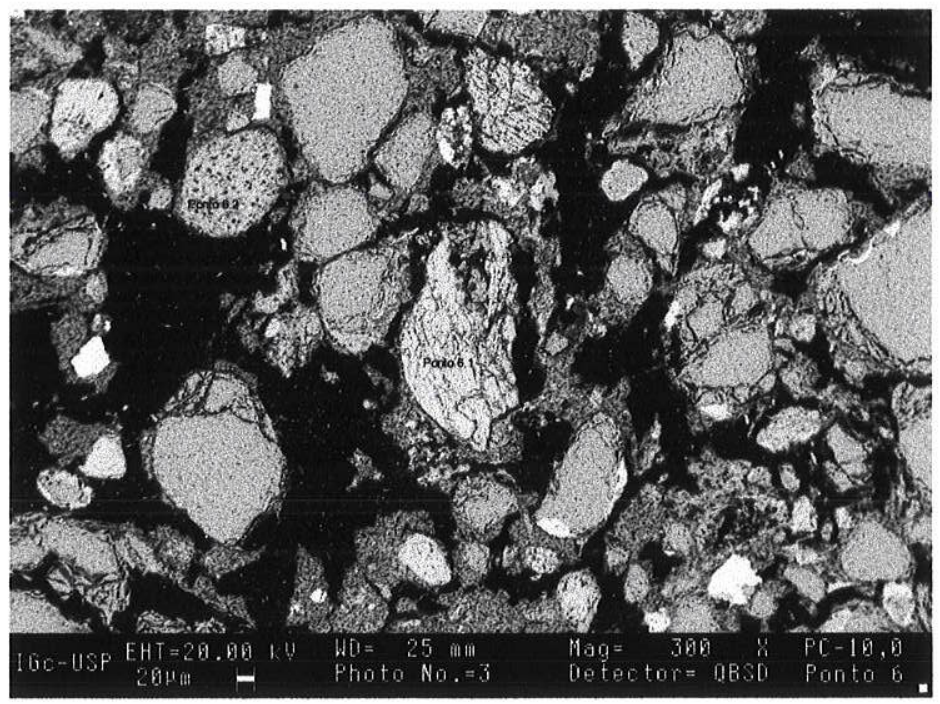

Pontos 6.1 e 6.2 - Lâmina 10 m

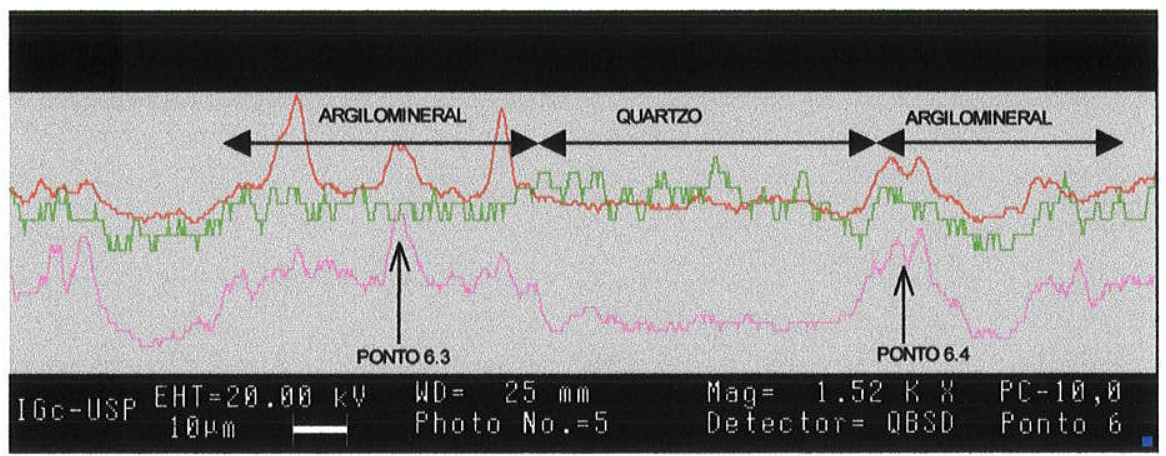

Verde $=$ Cálcio; Vermelho $=$ Potássio; Violeta $=$ Ferro .

Pontos 6.3 e 6.4 - Lâmina 10 m. Técnica "Line Scan". 


\section{Imagens Obtidas com as Análises por Microscópio Eletrônico de Varredura por "Dot Map" - LCT- POLI Minas - USP}

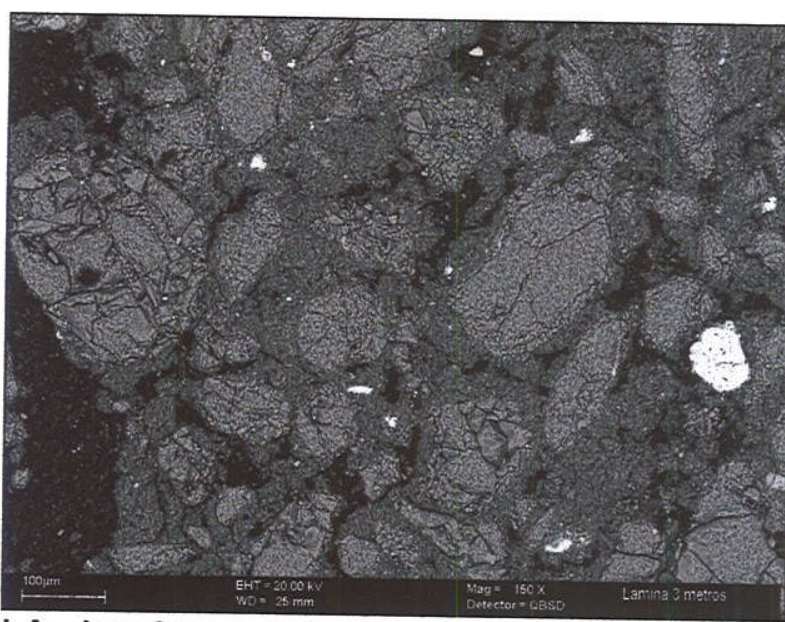

Lâmina 3m alumínio

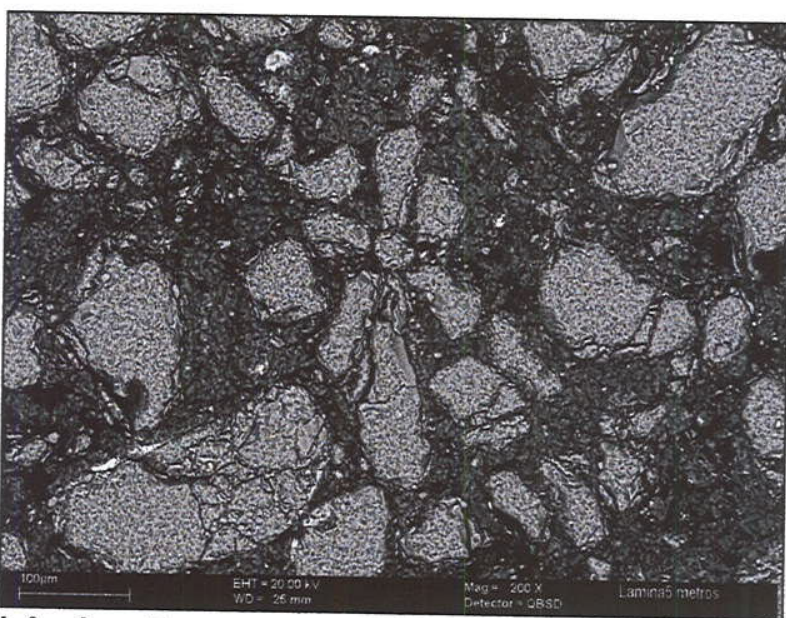

Lâmina $5 \mathrm{~m}$

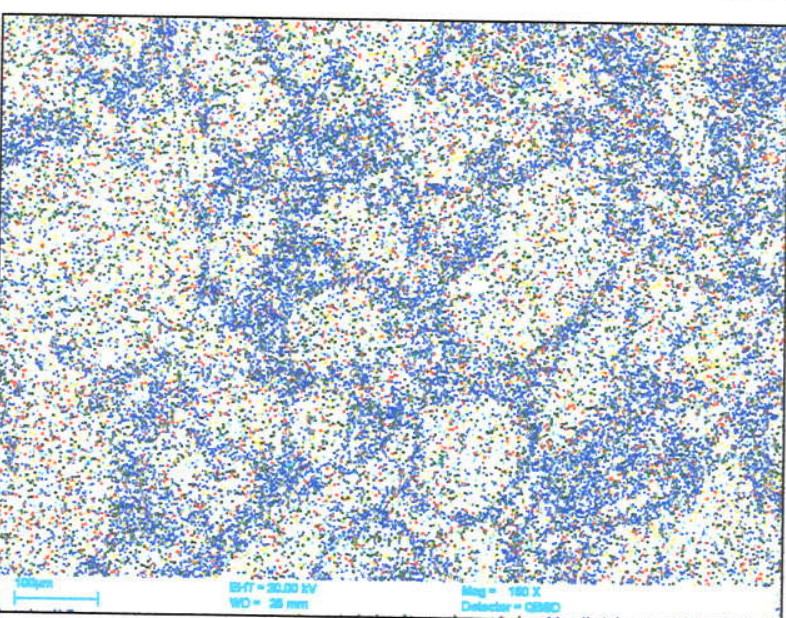

dot map lâmina $3 \mathrm{~m}$ com alumínio

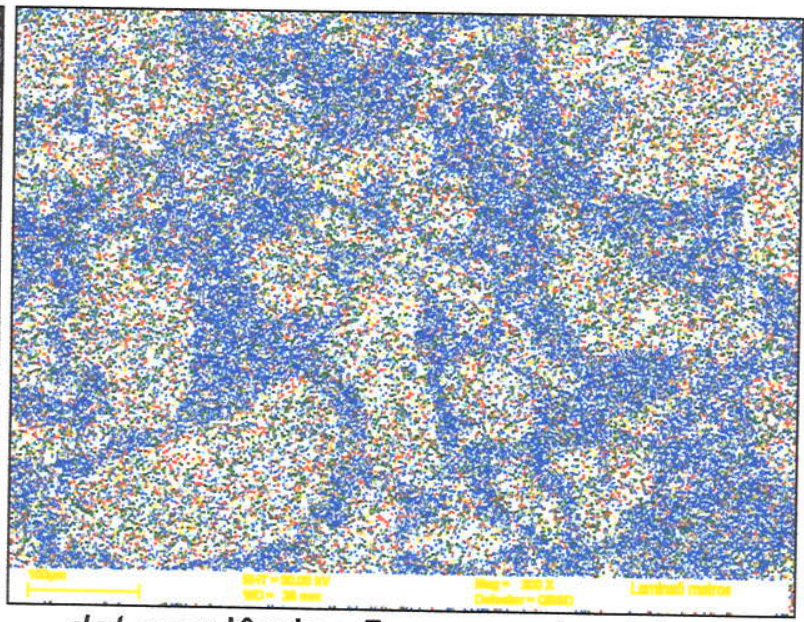

dot map lâmina $5 \mathrm{~m}$ com alumínio

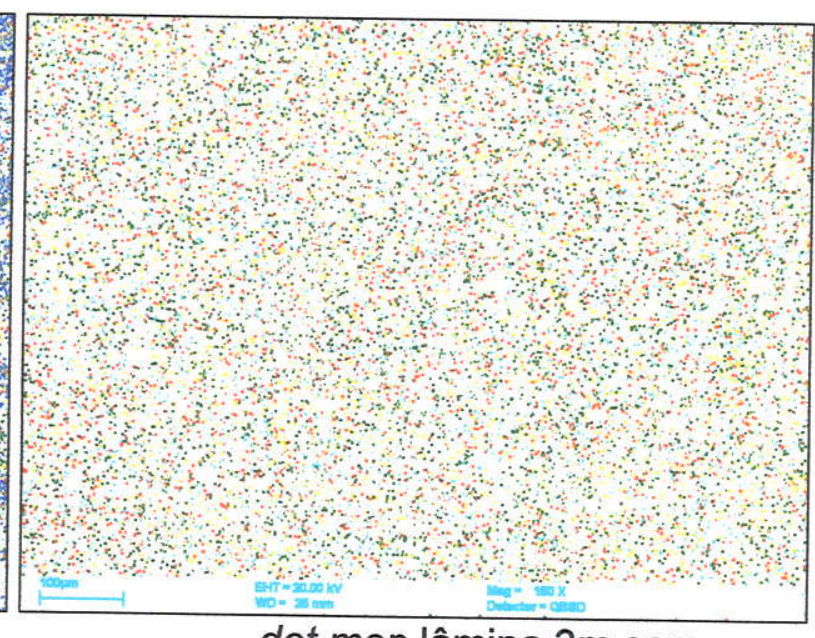

dot map lâmina $3 \mathrm{~m}$ sem

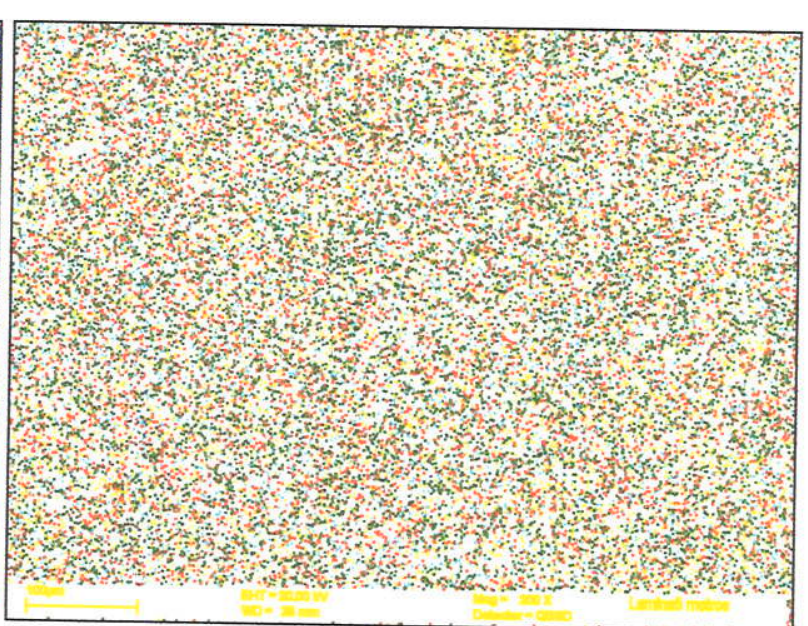

dot map lâmina $5 \mathrm{~m}$ sem alumínio

Obs: Azul escuro = alumínio; Amarelo = potássio; Verde = magnésio; Vermelho = cálcio; Azul claro = sódio As imagens originais dos "dot maps" foram tratadas em Corel Draw, através da ampliação dos pontos.

BERTOLO, R.A. - Tese de Doutoramento - 2001 


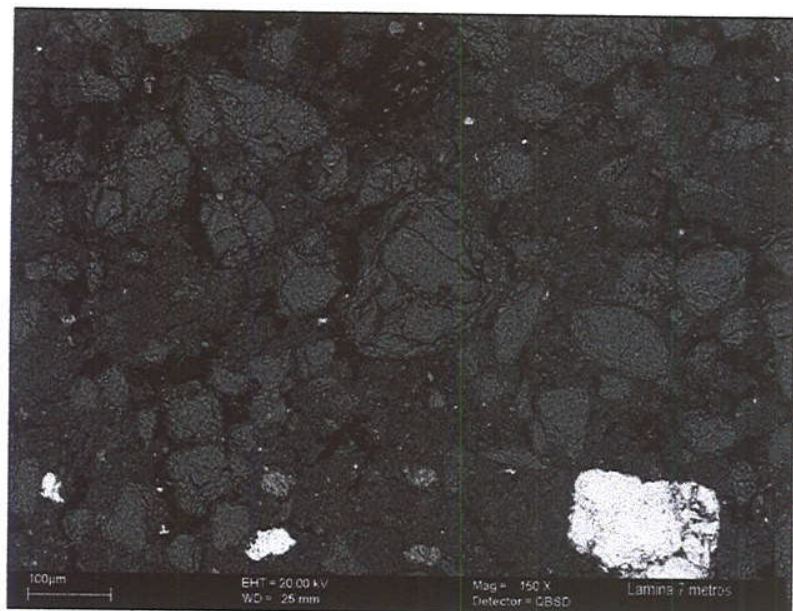

Lâmina $7 \mathrm{~m}-\mathrm{A}$

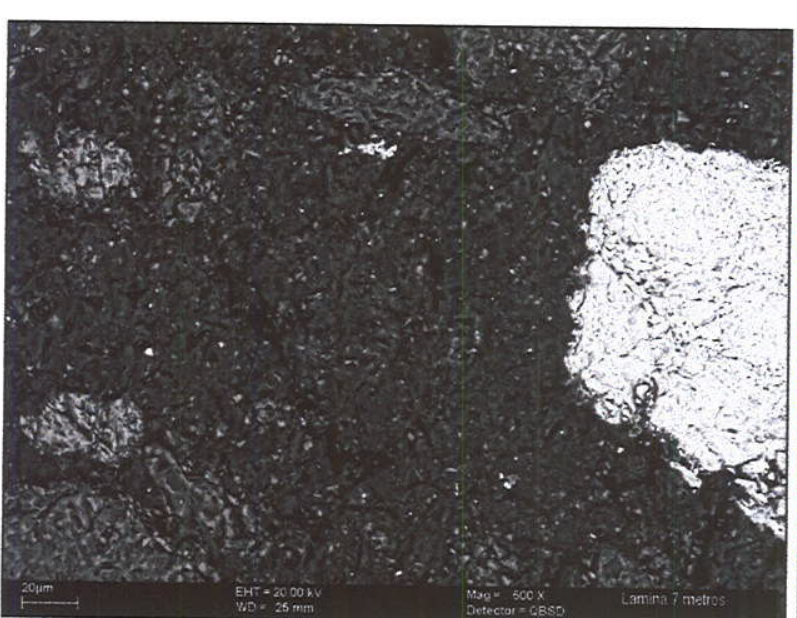

Lâmina $7 \mathrm{~m}-\mathrm{B}$ (destaque da $7 \mathrm{~m}-\mathrm{A}$ )

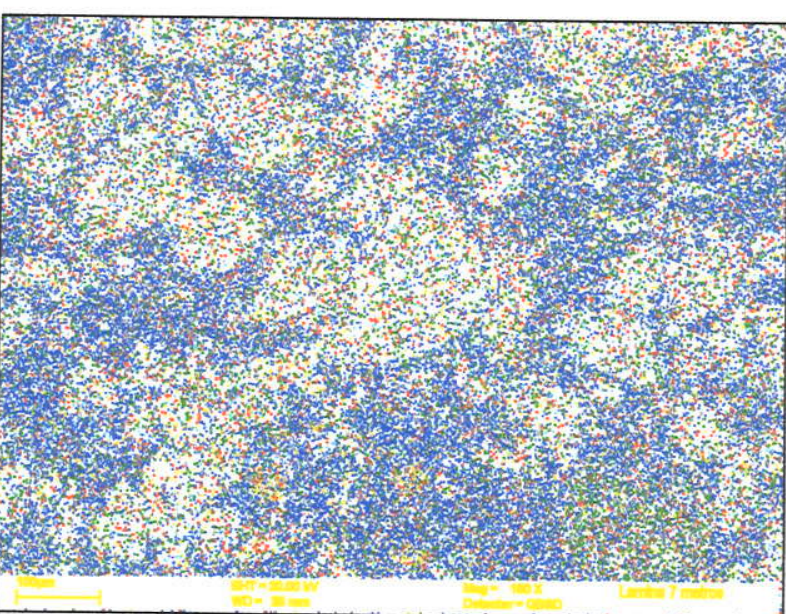

dot map lâmina $7 \mathrm{~m}-\mathrm{A}$ com alumínio

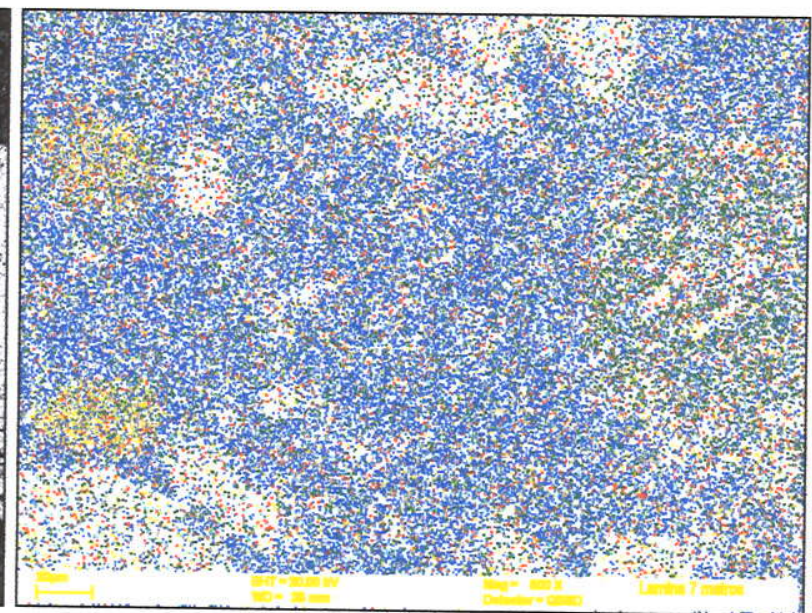

dot map lâmina $7 m-B$ com alumínio

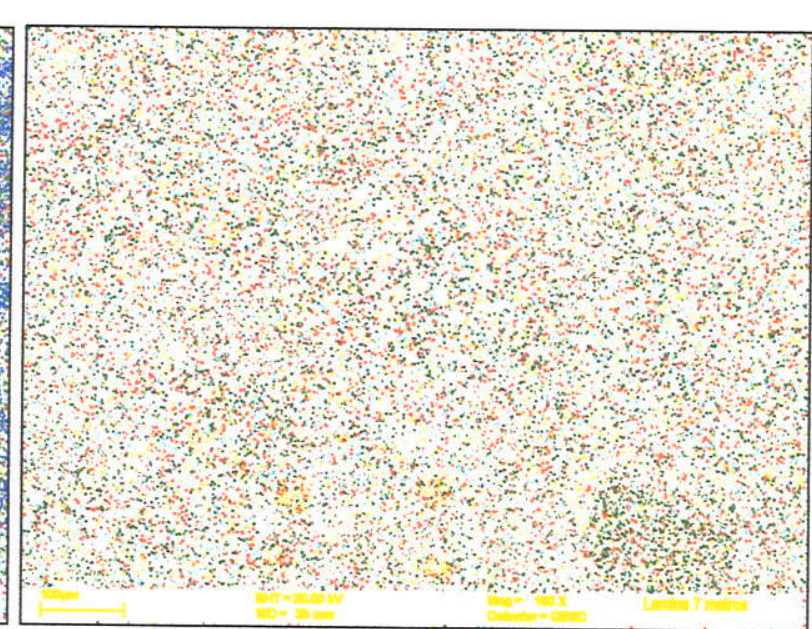

dot map lâmina $7 \mathrm{~m}-\mathrm{A}$ sem alumínio

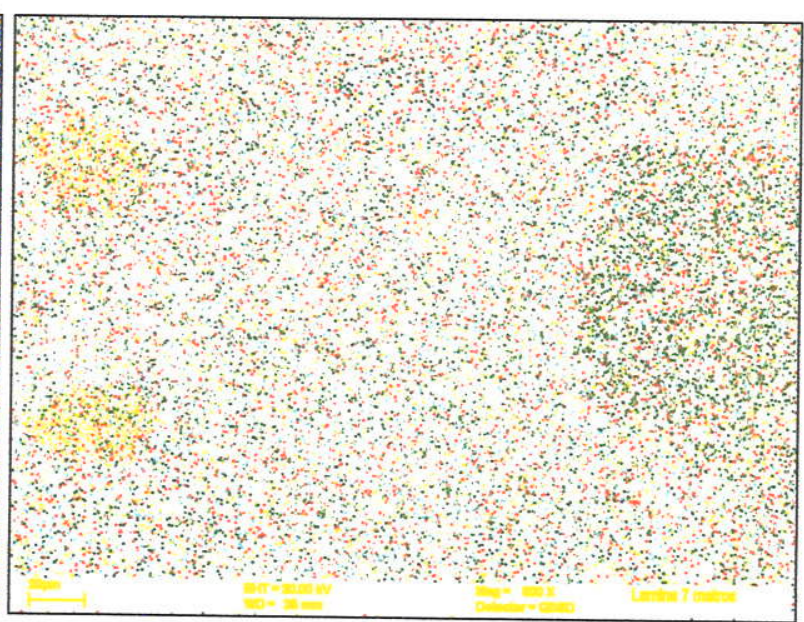

dot map lâmina 7m-B sem alumínio

Obs: Azul escuro = alumínio; Amarelo = potássio; Verde = magnésio; Vermelho = cálcio; Azul claro = sódio As imagens originais dos "dot maps" foram tratadas em Corel Draw, através da ampliação dos pontos. 


\subsection{ANEXO 7-RESULTADOS DE ANÁLISES QUIMICAS DA ÁGUA}

\begin{tabular}{|c|c|c|c|c|c|c|c|c|c|c|c|c|c|}
\hline & $\frac{\mathrm{LS0}}{12 \text {-ago-99 }}$ & $\frac{\mathrm{L} 50}{\mathrm{~L}}$ & $\mathrm{~L} 50$ & $\mathbf{L} 50$ & $\mathrm{L1}$ & $L 1$ & $L 1$ & L1 & $\mathrm{L1}$ & L1B & L1B & L1B & L1B \\
\hline 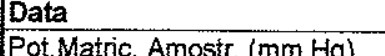 & $\frac{12 \text {-ago-99 }}{-200}$ & $\frac{20-j a n-\infty 0}{-100}$ & $12-a b r-00$ & 04 -set-00 & 12-abr-99 & 12-ago-99 & 20-jan-00 & $12-a b r-00$ & $04-$ set-00 & 12 -ago-99 & 20.jan-00 & $12-a b r-00$ & $04-$ set-00 \\
\hline Pot.Matric. Amostr. $(\mathrm{mm} \mathrm{Hg})$ & -200 & -100 & -100 & -280 & -100 & -260 & -130 & -135 & -390 & -260 & -130 & -135 & -390 \\
\hline Passagem ultima frente (dias) & $>89$ & 11 & 16 & 161 & $>61$ & $>183$ & 15 & 15 & 160 & $>183$ & 15 & 15 & 160 \\
\hline Tempo de sucçăo (hs) & 67 & 50 & 45 & 113 & 40 & 70 & 45 & 47 & 113 & 72 & 45 & 45 & 112 \\
\hline Volume amostra $(\mathrm{mL})$ & 70 & 119 & 79 & 2 & 70 & 40 & 99 & 180 & 11,6 & 55 & 31 & 99 & 6 \\
\hline Fator de diluição & $1: 1$ & $1: 1$ & $1: 2$ & na & na & $1: 2$ & $1: 1$ & na & na & $1: 2$ & $1: 3$ & $1: 1$ e $1: 2$ & na \\
\hline & & & & & & & & & & & & & \\
\hline Temp. & 22,2 & 28,9 & 29 & 22,3 & 25,2 & 27,2 & 25,3 & 30,3 & 22,6 & 29 & 23,9 & 26,3 & 19,5 \\
\hline $\mathrm{pH}$ & 6,32 & 7,31 & 7,66 & 7 & 6,35 & 6,11 & 7 & 7,05 & 6,79 & & & & \\
\hline Eh $(\mathrm{mV})$ & & 465 & 439 & - & 512 & - & 457 & 439 & - & $=$ & 333 & 448 & - \\
\hline Cond.El. (micros) & 483 & 271 & 138,1 & 282 & 340 & 169 & 228 & 118,9 & 104 & 444 & 384 & 477 & 353 \\
\hline & & & & & & & & & & & & & \\
\hline $\mathrm{HCO}-$ & 31,73 & 41,00 & 45,12 & $\because$ & 24,39 & 19,04 & 22,26 & 41,17 & 25,00 & 174,19 & 132,38 & 188,34 & 139,00 \\
\hline Sulfato & 8,30 & 9,94 & 2,55 & - & $\therefore$ & 2,94 & 2,06 & 5,77 & 5,89 & 4,53 & 4,92 & 17,98 & 23,02 \\
\hline Cloreto & 3,26 & 1,82 & 1,8 & - & - & 2,88 & 2,98 & 0,37 & 1,71 & 11,16 & 3,92 & 0,92 & 3,40 \\
\hline Nitrato & 219,90 & 90,76 & 28,23 & - & - & 58,17 & 87,66 & 15,7 & 17,41 & 85,53 & 84,88 & 90,64 & 54,56 \\
\hline Nitrito & $<0.01$ & $<0.01$ & $<0.015$ & - & - & $<0.015$ & $<0.01$ & 0,05 & $<0.005$ & $<0.015$ & $<0.02$ & $<0.01$ & $<0.005$ \\
\hline Fluoreto & 0,18 & 0,1 & 0,27 & - & $\pi$ & 0,12 & 0,08 & 0,31 & 4,69 & 0,90 & 0,68 & 0,86 & 6,61 \\
\hline Fosfato total & 1,30 & 0,014 & 0,21 & $=$ & - & 0,39 & 0,1 & 0,13 & 0,15 & 0,24 & 0,12 & 0,04 & 0,21 \\
\hline Brometo & $<0.01$ & $<0.01$ & 0,006 & - & - & $<0.015$ & 0,04 & 0,011 & $<0.005$ & $<0.015$ & 0,028 & $<0.01$ & $<0.005$ \\
\hline Sódio & 4,80 & 4,4 & 3 & $=$ & - & 4,50 & 4,2 & 5 & 9,00 & 3,30 & 4,4 & 3,2 & 8,00 \\
\hline Potássio & 1,60 & 1 & 0,6 & - & - & 1,80 & 3 & 1,4 & 1,75 & 1,50 & 4 & 1,4 & 2,00 \\
\hline Cálcio & 58,58 & 36,5 & 19,14 & - & - & 18,42 & 28,2 & 13,55 & 10,60 & 75,00 & 57,8 & 70 & 50,40 \\
\hline Magnésio & 10,10 & 6,3 & 3,24 & $=$ & - & 3,78 & 5,3 & 2,8 & 1,60 & 14,82 & 14,4 & 17,76 & 14,20 \\
\hline Estróncio & 0,40 & 0,2 & 0,9 & $\approx$ & - & 0,09 & 0,12 & 0,08 & 0,06 & 0,30 & 0,36 & 0,46 & 0,31 \\
\hline Bário & 0,28 & $<0.36$ & $<0.54$ & $=$ & - & 0,12 & $<0.36$ & 0,05 & 0,09 & 0,15 & $<0.72$ & 0,1 & $<0.18$ \\
\hline Ferro total & $<0.1$ & $<0.1$ & $<0.15$ & $\therefore$ & - & $<0.15$ & $<0.1$ & $<0.05$ & $<0.05$ & $<0.15$ & $<0.2$ & $<0.1$ & $<0.05$ \\
\hline Manganês & $<0.04$ & $<0.04$ & $<0.06$ & - & - & $<0.06$ & $<0.04$ & $<0.02$ & 0,01 & $<0.06$ & $<0.08$ & $<0.04$ & $<0.02$ \\
\hline Aluminio & $<1.1$ & 0,12 & $<1.65$ & - & - & $<1.65$ & $<1.1$ & $<0.55$ & 0,14 & $<1.65$ & $<2.2$ & $<1.1$ & $<0.55$ \\
\hline Cromo total & $<0.04$ & $<0.04$ & $<0.06$ & - & - & $<0.06$ & $<0.04$ & $<0.02$ & $<0.02$ & $<0.06$ & $<0.08$ & $<0.04$ & $<0.02$ \\
\hline Chumbo & $<0.1$ & $<0.1$ & $<0.15$ & - & - & $<0.15$ & $<0.1$ & $<0.05$ & $<0.05$ & $<0.15$ & $<0.2$ & $<0.1$ & $<0.05$ \\
\hline Cobre & $<0.05$ & 0,02 & $<0.075$ & - & $=$ & $<0.075$ & $<0.05$ & $<0.025$ & $<0.025$ & $<0.075$ & $<0.1$ & $<0.05$ & $<0.025$ \\
\hline Zinco & $<0.016$ & 0,04 & 0,03 & - & - & $<0.024$ & 0,02 & 0,02 & 0,02 & $<0.024$ & $<0.032$ & 0,02 & 0,02 \\
\hline Cadmio & $<0.018$ & $<0.018$ & $<0.027$ & - & - & $<0.027$ & $<0.018$ & $<0.009$ & $<0.009$ & $<0.027$ & $<0.036$ & $<0.018$ & $<0.009$ \\
\hline Niquel & $<0.08$ & $<0.08$ & $<0.12$ & - & - & $<0.12$ & $<0.08$ & $<0.04$ & $<0.04$ & $<0.12$ & $<0.16$ & $<0.08$ & $<0.04$ \\
\hline Prata & $<0.06$ & $<0.06$ & $<0.09$ & - & - & $<0.09$ & $<0.06$ & $<0.03$ & $<0.03$ & $<0.09$ & $<0.12$ & $<0.06$ & $<0.03$ \\
\hline Slíca & 20,80 & 46 & 33 & - & - & 12,40 & 30,4 & 21,7 & & 15,00 & & 17,1 & \\
\hline$C O D$ & - & & 60,6 & - & - & - & & 15,7 & & - & & 57 & \\
\hline $\mathrm{CO} 2$ & 21,27 & 3,25 & 1,63 & & 17,52 & 23,94 & 3,44 & 6,25 & 6,11 & 34,49 & 1.85 & 2,83 & 6,34 \\
\hline Amônio & & & 0,50 & & & & & 0,50 & & & & 0,50 & \\
\hline & & & & & & & & & & & & & \\
\hline ERRO $(\%)$ & $-4,34$ & 3,55 & 3.55 & - & & 2,24 & 4,79 & 4,87 & $?$ & 4,62 & 7,10 & 1,72 & $?$ \\
\hline
\end{tabular}

BERTOLO, R.A. - Tese de Doutoramento - 2001 


\begin{tabular}{|c|c|c|c|c|c|c|c|c|c|c|c|c|c|}
\hline & $\frac{\mathrm{L} 2}{12}$ & $L 2$ & $\mathrm{L2}$ & L3 & $\mathrm{L3}$ & $A D-L 3$ & $L 3 a$ & $\mathrm{L3b}$ & L3 & L4 & $\mathrm{L4}$ & $\mathrm{L4}$ & L5 \\
\hline Data & 12-ago-99 & 12 -abr-00 & 04 -ago-00 & $11-a b r-99$ & 11 ago-99 & 09 -ago-99 & 12 -abr-00 & $13-a b r-00$ & 02 -set-00 & 12-ago-99 & $12-a b r-00$ & $03-$ set -00 & 11-abr-99 \\
\hline Pot.Matric. Amostr. $(\mathrm{mm} \mathrm{Hg})$ & -290 & -150 & -380 & -180 & -330 & -330 & -160 & -160 & -440 & -280 & -130 & -310 & -160 \\
\hline Passagem última frente (dias) & $>183$ & 11 & 125 & $>60$ & $>183$ & $>183$ & 19 & 20 & 162 & $>183$ & -24 & 120 & $>69$ \\
\hline Tempo de sucçăo (hs) & 74 & 50 & 112 & 24 & 51 & 52 & 20 & 14,5 & 28 irreg & 75 & 50 & 91 & 32 \\
\hline Volume amostra $(\mathrm{mL})$ & 46 & 175 & 11 & 325 & 160 & 210 & 56 & 157 & 23 & 45 & 275 & 45 & 30 \\
\hline \multirow[t]{2}{*}{ Fator de dilujçăo } & $1: 2$ & na e $1: 1$ & na & na & na & na & $1: 2$ e $1: 4$ & na e 1:1 & na & $1: 2$ & na & na & na \\
\hline & & & & & & & & & & & & & \\
\hline Temp. & 27,9 & 31,2 & 20,2 & 27,8 & 25 & 25,3 & 26,8 & 25,7 & 26,2 & 28 & 29,9 & 22,2 & 22,4 \\
\hline $\mathrm{pH}$ & 6,12 & 7,03 & 6,53 & 6,48 & 6,55 & 7,05 & 6,8 & 6,81 & 6,61 & 6,28 & 7,05 & 6,54 & 6,33 \\
\hline $\mathrm{Eh}(\mathrm{mV})$ & - & 531 & - & 502 & $=$ & - & 333 & 453 & - & - & 459 & 550 & 523 \\
\hline \multirow{2}{*}{ Cond El. (micros) } & 93 & 102,3 & 81 & 259 & 60 & 63 & 139,7 & 138,9 & 134 & 105 & 116 & 95,4 & 339 \\
\hline & & & & & & & & & & & & & \\
\hline $\mathrm{HCO} 3$ & 37,12 & 39,30 & 29,00 & 41,47 & 27,60 & 29,35 & 27,79 & 22,23 & 13,57 & 52,35 & 59,79 & 37,64 & - \\
\hline Sulfato & 1,80 & 1,78 & 2,06 & 0,07 & 0,05 & 0,10 & 0,54 & 0,14 & 0,21 & 0,39 & 0,16 & 0,31 & - \\
\hline Cloreto & 1,38 & 0,28 & 5,29 & 1,11 & 1,44 & 1,37 & 1,56 & 0,55 & 1,06 & 2,64 & 0,45 & 1,98 & - \\
\hline Nitrato & 10,80 & 10,61 & 6,05 & 4,96 & 3,90 & 3,01 & 40,32 & 49,24 & 48,23 & 6,18 & 8,57 & 10,74 & - \\
\hline Nitrito & $<0.015$ & 0,16 & $<0.005$ & 0,016 & $<0.005$ & $<0.005$ & $<0.015$ & $<0.005$ & $<0.005$ & $<0.015$ & $<0.005$ & $<0.005$ & - \\
\hline Fluoreto & 0,06 & 0,15 & 3,78 & 0,03 & 0,02 & 0,03 & 0,72 & 0,35 & 2,51 & 0,08 & 0,11 & 2,05 & - \\
\hline Fosfato total & 0,36 & 0,18 & 0,03 & 0,22 & 0,11 & 0,24 & 0,05 & $<0.01$ & 0,01 & 0,42 & 0,38 & 0,012 & - \\
\hline Brometo & $<0.015$ & 0,01 & 0,01 & 0,02 & $<0.005$ & 0,01 & 0,04 & $<0.005$ & $<0.005$ & $<0.015$ & 0,01 & $<0.005$ & - \\
\hline Sódio & 3,90 & 3,40 & 6,25 & 2,3 & 1,80 & 2,30 & 4,80 & 3 & 6,00 & 3,60 & 3,10 & 3,8 & - \\
\hline Potássio & 1,50 & 1,50 & 5,25 & 0,8 & 1,00 & 1,00 & 1,50 & 1.1 & 1,00 & 1,50 & 1,10 & 0,9 & - \\
\hline Cálcio & 10,98 & 12,10 & 9,00 & 5,65 & 5,05 & 5,35 & 13,38 & 13,15 & 10,80 & 9,72 & 10,40 & 8,55 & - \\
\hline Magnésio & 2,40 & 2,80 & 1,00 & 2,85 & 2,75 & 2,90 & 5,94 & 6,3 & 5,30 & 5,16 & 6,80 & 4,6 & - \\
\hline Estrôncio & 0,03 & 0,10 & 0,10 & 0,05 & 0,04 & 0,03 & 0,12 & 0,1 & 0,10 & 0,03 & 0,09 & 0,06 & - \\
\hline Bário & $<0.54$ & $<0.18$ & 0,10 & $<0.18$ & 0,08 & 0.05 & 0,09 & 0,05 & 0,08 & $<0.54$ & 0,01 & $<0.18$ & - \\
\hline Ferro total & $<0.15$ & $<0.05$ & $<0.05$ & $<0.05$ & $<0.05$ & $<0.05$ & $<0.15$ & $<0.05$ & $<0.05$ & $<0.15$ & $<0.05$ & $<0.05$ & - \\
\hline Manganês & $<0.06$ & $<0.02$ & 0,01 & $<0.02$ & $<0.02$ & $<0.02$ & $<0.06$ & $<0.02$ & $<0.02$ & $<0.06$ & $<0.02$ & $<0.02$ & - \\
\hline Aluminio & $<1.65$ & $<0.55$ & 0,25 & 0,08 & $<0.55$ & $<0.55$ & $<1.65$ & $<0.55$ & $<0.55$ & $<1.65$ & $<0.55$ & $<0.55$ & - \\
\hline Cromo total & $<0.06$ & $<0.02$ & $<0.02$ & $<0.02$ & $<0.02$ & $<0.02$ & $<0.06$ & $<0.02$ & $<0.02$ & $<0.06$ & $<0.02$ & $<0.02$ & - \\
\hline Chumbo & $<0.15$ & $<0.05$ & $<0.05$ & $<0.05$ & $<0.05$ & $<0.05$ & $<0.15$ & $<0.05$ & $<0.05$ & $<0.15$ & $<0.05$ & $<0.05$ & - \\
\hline Cobre & $<0.075$ & $<0.025$ & $<0.025$ & $<0.025$ & $<0.025$ & $<0.025$ & $<0.075$ & $<0.025$ & $<0.025$ & $<0.075$ & $<0.025$ & $<0.025$ & - \\
\hline Zinco & $<0.024$ & $<0.008$ & 0,02 & $<0.008$ & $<0.008$ & $<0.008$ & 0,03 & $<0.008$ & 0,01 & $<0.024$ & 0,01 & 0,01 & - \\
\hline Cadmio & $<0.027$ & $<0.009$ & $<0.009$ & $<0.009$ & $<0.009$ & $<0.009$ & $<0.027$ & $<0.009$ & $<0.009$ & $<0.027$ & $<0.009$ & $<0.009$ & - \\
\hline Niquel & $<0.12$ & $<0.04$ & $<0.04$ & $<0.04$ & $<0.04$ & $<0.04$ & $<0.12$ & $<0.04$ & $<0.04$ & $<0.12$ & $<0.04$ & $<0.04$ & - \\
\hline Prata & $<0.09$ & $<0.03$ & $<0.03$ & $<0.03$ & $<0.03$ & $<0.03$ & $<0.09$ & $<0.03$ & $<0.03$ & $<0.09$ & $<0.03$ & $<0.03$ & - \\
\hline Silica & 22,20 & 23,60 & & - & 8,60 & 8,60 & 13,50 & 14,4 & & 16,80 & 20,10 & & - \\
\hline$C O D$ & - & 18,40 & & - & - & - & & 19,6 & & - & 10,70 & & - \\
\hline $\mathrm{CO} 2$ & 46,65 & 6,36 & 12,38 & 22,83 & 12,39 & & & 5,44 & 5,33 & 45,36 & 9,01 & 16,26 & \\
\hline Amónio & & 0,50 & & $<0,1$ & 0,30 & & & 0,70 & & & 0,40 & & \\
\hline & & & & & & & & & & & & & \\
\hline ERRO (\%) & 4,41 & 8,99 & $?$ & 10,20 & 2,00 & 4,39 & 9,30 & 5,57 & 4,04 & 2,21 & 4,72 & 1,76 & \\
\hline
\end{tabular}

BERTOLO, R.A. - Tese de Doutoramento - 2001 


\begin{tabular}{|c|c|c|c|c|c|c|c|c|c|c|c|c|c|}
\hline & L5 & DL5 & $L 5$ & L5 & DL5 & $\mathrm{LEB}$ & L5B & L58 & L5B & L6 & L6 & L6 & $L 7$ \\
\hline Data & 11-ago-99 & 11-ago-99 & $12-a b r-00$ & $02-$ set-00 & $02-$ set-00 & 11-ago-99 & $20-j a n-00$ & 12 -abr-00 & $02-\operatorname{set}-00$ & 12 -ago-99 & $11-a b r-00$ & $03-5 e t-00$ & $11-a b r .99$ \\
\hline Pot.Matric. Amostr. $(\mathrm{mm} \mathrm{Hg})$ & -340 & -340 & -120 & -260 & -260 & -340 & -520 & -120 & -260 & -210 & -100 & -200 & -120 \\
\hline Passagem última frente (dias) & $>183$ & $>183$ & 19 & 162 & 162 & $>183$ & -353 & 19 & 162 & $>183$ & 22 & 167 & $>69$ \\
\hline Tempo de sucçẫo (hs) & 46 & - & 50 & 64 & 64 & 47 & 45 & 45 & 64 & 73 & 26 & 91 & 32 \\
\hline Volume amostra (mL) & 180 & - & 500 & 230 & 231 & 200 & 28 & 500 & 140 & 41 & 70 & 52 & 130 \\
\hline Fator de diluiçăo. & na & na & na & na & na & na & $1: 3$ & na & na. & $1: 2$ & $1: 1$ & na & na \\
\hline & & & & & & & & & & & & & \\
\hline Temp. & 27,1 & - & 28,9 & 21,8 & 21,8 & 25,2 & 23,8 & 27,1 & 21,4 & 27,2 & 28,9 & 22 & 25 \\
\hline $\mathrm{pH}$ & 6,62 & - & 6,71 & 6,56 & 6,56 & 7.26 & 6,45 & 6,41 & 6,58 & 6,61 & 7,31 & 7 & 6,6 \\
\hline$E h(m V)$ & - & - & 511 & 595 & 595 & - & 444 & 452 & 590 & - & 350 & 520 & 450 \\
\hline Cond.El (micros) & 77 & - & 69,3 & 49 & 49 & 102 & 96,1 & 85 & 71 & 161 & 174 & 100,8 & 346 \\
\hline & & & & & & & & & & & & & \\
\hline $\mathrm{HCO} 3-$ & 28,56 & - & 29,15 & 18,35 & 18,35 & 14,60 & 13,02 & 11,14 & 6,01 & 80,91 & 64,81 & 48,10 & 21,95 \\
\hline Sulfato & 0,08 & $=$ & 0,11 & 0,04 & 0,08 & 0,11 & 0,56 & 0,14 & 0,07 & 3,93 & 0,90 & 3,55 & 0,19 \\
\hline Cloreto & 0,63 & - & 0,22 & 0,29 & 0,33 & 1,96 & 3,76 & 0,68 & 0,78 & 4,98 & 1,28 & 1,35 & 6,84 \\
\hline Nitrato & 15,66 & - & 9,29 & 6,58 & 6,58 & 37,64 & 28,88 & 32,22 & 28,53 & 3,66 & 7,60 & 2,63 & 60,92 \\
\hline Nitrito & $<0.005$ & - & $<0.005$ & $<0.005$ & 0,08 & $<0.005$ & $<0.02$ & $<0.005$ & 0,06 & $<0.015$ & $<0.01$ & $<0.005$ & 0,08 \\
\hline Fluoreto & 0,03 & - & 0,01 & 0,55 & 0,53 & 0,01 & 0,16 & 0,07 & 0,46 & 0,15 & 0,18 & 1,66 & 0,17 \\
\hline Fosfato total & 0,04 & $<0.02$ & 0,01 & 0,02 & 0,03 & 0,07 & 0,16 & 0,06 & 0,06 & 0,15 & 0,03 & 0,23 & 0,04 \\
\hline Brometo & $<0.005$ & - & $<0.005$ & 0,008 & $<0.005$ & $<0.005$ & $<0.02$ & $<0.005$ & $<0.005$ & $<0.015$ & $<0.01$ & $<0.005$ & 0,05 \\
\hline Sódio & 2,10 & 1,85 & 2,50 & 1,9 & 1,9 & 18,00 & 17,2 & 13,4 & 12,80 & 8,10 & 8,40 & 6,80 & 5,1 \\
\hline Potássio & 1,50 & 1,61 & 1,50 & 1,1 & 1,1 & 1,30 & 2 & 1,2 & 1,00 & 4,50 & 4,60 & 3,50 & 28 \\
\hline Cálcio & 7,25 & 5,94 & 6,15 & 4,4 & 5,6 & 1,95 & 2 & 1,75 & 2,00 & 13,68 & 9,40 & 7,35 & 8,15 \\
\hline Magnésio & 3,45 & 3,32 & 2,75 & 2,2 & 1,8 & 0,45 & 0,4 & 0,5 & $<0.003$ & 6,36 & 5,50 & 4,20 & 5,95 \\
\hline Estrôncio & 0,05 & 0,058 & 0,06 & 0,05 & 0,05 & $<0,05$ & 0,04 & 0,01 & 0,01 & 0,09 & 0,10 & 0,09 & 0,09 \\
\hline Bário & 0,08 & 0,046 & 0,03 & 0,04 & $<0.18$ & 0,04 & 0,16 & $<0.18$ & $<0.18$ & 0,12 & 0,06 & 0,06 & 0,1 \\
\hline Ferro total & $<0.05$ & 0,011 & $<0.05$ & $<0.05$ & $<0.05$ & $<0.05$ & $<0.2$ & $<0.05$ & $<0.05$ & $<0.15$ & $<0.1$ & $<0.05$ & $<0.05$ \\
\hline Manganês & $<0.02$ & $<0.01$ & $<0.02$ & $<0.02$ & $<0.02$ & $<0.02$ & $<0.08$ & $<0.02$ & $<0.02$ & $<0.06$ & $<0.04$ & $<0.02$ & 0,01 \\
\hline Aluminio & $<0.55$ & $<0.1$ & $<0.55$ & 0,1 & $<0.55$ & $<0.55$ & $<2.2$ & $<0.55$ & 0,03 & $<1.65$ & $<1.1$ & 0,05 & 0,06 \\
\hline Cromo total & $<0.02$ & $<0.002$ & $<0.02$ & $<0.02$ & $<0.02$ & 0,01 & $<0.08$ & $<0.02$ & $<0.02$ & 0,03 & $<0.04$ & $<0.02$ & $<0.02$ \\
\hline Chumbo & $<0.05$ & - & $<0.05$ & $<0.05$ & $<0.05$ & $<0.05$ & $<0.2$ & $<0.05$ & $<0.05$ & $<0.15$ & $<0.1$ & $<0.05$ & $<0.05$ \\
\hline Cobre & $<0.025$ & $<0.001$ & $<0.025$ & $<0.025$ & $<0.025$ & $<0.025$ & $<0.1$ & $<0.025$ & $<0.025$ & $<0.075$ & $<0.05$ & $<0.025$ & $<0.025$ \\
\hline Zinco & $<0.008$ & 0,008 & 0,01 & $<0.008$ & $<0.008$ & $<0.008$ & 0,08 & $<0.008$ & $<0.008$ & $<0.024$ & 0,04 & 0,01 & $<0.008$ \\
\hline Cádmio & $<0.009$ & - & $<0.008$ & $<0.009$ & $<0.009$ & $<0.009$ & $<0.036$ & $<0.009$ & $<0.009$ & 0,027 & $<0.018$ & $<0.009$ & $<0.009$ \\
\hline Níquel & $<0.04$ & $<0.001$ & $<0.04$ & $<0.04$ & $<0.04$ & $<0.04$ & $<0.16$ & $<0.04$ & $<0.04$ & $<0.12$ & $<0.08$ & $<0.04$ & $<0.04$ \\
\hline Prata & $<0.03$ & - & $<0.03$ & $<0.03$ & $<0.03$ & $<0.03$ & $<0.12$ & $<0.03$ & $<0.03$ & $<0.09$ & $<0.06$ & $<0.03$ & $<0.03$ \\
\hline Sílica & 7,90 & $=$ & 11,80 & 10,8 & & 9,40 & & 17,1 & 16,24 & - & 21,00 & & - \\
\hline $\mathrm{COD}$ & 16.70 & - & 3,30 & 14,9 & & 11,20 & & 8,4 & & - & 12,00 & & - \\
\hline $\mathrm{CO} 2$ & 11,23 & & 9,61 & 7,62 & & 1,28 & 7,20 & 7,17 & 2,37 & 32,02 & 5,28 & 7,16 & 0,86 \\
\hline Amónio & & & 0,50 & $<0,1$ & & $<0,1$ & & 0,50 & 0,10 & & 0.70 & & $<0,1$ \\
\hline & & & & & & & & & & & & & \\
\hline ERRO (\%) & 2,30 & $-3,38$ & 5,43 & 8,12 & 9,23 & 2,42 & 7,29 & 2,68 & 5,89 & 1,79 & 7,34 & 3,22 & $-12,60$ \\
\hline
\end{tabular}

BERTOLO, R.A. - Tese de Doutoramento - 2001 


\begin{tabular}{|c|c|c|c|c|c|c|c|c|c|c|c|c|c|}
\hline & $\frac{L 7}{12}$ & $\mathrm{L7a}$ & $\mathrm{L} 7 \mathrm{~b}$ & 17 & $L 8$ & L8SF & L8 & $L 8$ & DL8 & L9 & DL9 & $\mathrm{Lg}$ & DL9A \\
\hline Data & 12-ago-99 & $11-a b r-00$ & 13-abr-00 & 02 -set 00 & 11-aga-99 & 01 -ago-99 & 19-jan-00 & 03 -set-00 & $03-\operatorname{set}-00$ & 10 -abr-99 & 10-abr-99 & 11-ago-99 & 11 -ago- 99 \\
\hline Pot. Matric. Amostr. (mm Hg) & -200 & -105 & -105 & -180 & -80 & -80 & -230 & -100 & -100 & 0 & 0 & 0 & 0 \\
\hline Passagem ultima frente (dias) & $>183$ & 10 & 12 & 154 & $>183$ & $>183$ & -352 & 169 & 169 & $>68$ & -68 & $>183$ & $>183$ \\
\hline Tempo de sucção (hs) & irregular & 20 & 14,5 & 28 itreg & 28 & 28 & 45 & 73 & 73 & 32 & 32 & 24 & 24 \\
\hline Volume amostra $(\mathrm{mL})$ & 107 & 45 & 80 & 106 & 800 & 800 & 120 & 560 & 560 & $>1000$ & $>1000$ & 2000 & 2000 \\
\hline \multirow[t]{2}{*}{ Fator de difuição } & $1: 1$ & $1: 3$ e $1: 4$ & $1: 1$ e $1: 3$ & $n a$ & na & na & $1: 1$ & na & na & na & na & na & $\mathrm{na}$ \\
\hline & & & & & & & & & & & & & \\
\hline Temp. & 27,5 & 27,7 & 26 & 24,5 & 25,3 & 25,3 & 26,2 & 21,9 & 21,9 & 28,6 & 28,6 & 24,9 & 24,9 \\
\hline $\mathrm{pH}$ & 6,78 & 6,46 & 6,71 & 6,8 & 5,49 & 5,49 & 6 & 6,49 & 6,49 & 5,29 & 5,29 & 5,11 & 5,11 \\
\hline Eh $(\mathrm{mV})$ & $=$ & 370 & 350 & 514 & - & - & 472 & 550 & 550 & 524 & 524 & - & - \\
\hline \multirow[t]{2}{*}{ Cond.Et. (micros) } & 120 & 118,2 & 96 & 47 & 66 & 66 & 58,6 & 110 & 110 & 281 & 281 & 105 & 105 \\
\hline & & & & & & & & & & & & & \\
\hline $\mathrm{HCO} 3-$ & 17,13 & 13,06 & 9,38 & 9,68 & 2,86 & 2,86 & 5,86 & 12,30 & 12,30 & 2,44 & 2,44 & 6,66 & 6,66 \\
\hline Sulfato & 0,28 & 0,28 & 0,10 & 0,13 & 0,03 & 0,06 & 0,56 & 0,08 & 0,08 & 0,07 & 0,09 & 0.12 & 0,10 \\
\hline Cloreto & 1,08 & 2,16 & 1,32 & 0,37 & 1,64 & 1,54 & 1,68 & 2,2 & 2,65 & 0,76 & 0,83 & 0,88 & 0,89 \\
\hline Nitrato & 49,90 & 40,80 & 37,32 & 11,93 & 28,14 & 27,65 & 16,9 & 40,15 & 41,29 & 37,29 & 36,62 & 48,91 & 48,69 \\
\hline Nitrito & 0,10 & 0,04 & $<0.01$ & $<0.005$ & $<0.005$ & $<0.005$ & $<0.01$ & $<0.005$ & $<0.005$ & $<0.005$ & $<0.005$ & $<0.005$ & $<0.005$ \\
\hline Fluoreto & 0,02 & 0,28 & 0,12 & 0,73 & 0,01 & 0,01 & 0,018 & 0,03 & 0,06 & 0,08 & 0,06 & 0,01 & 0,01 \\
\hline Fosfato total & 0,12 & 0,08 & 0,02 & 0,11 & 0,04 & 0,04 & 0,68 & $0, \overline{04}$ & 0,07 & 0,02 & 0,03 & 0,08 & 0,06 \\
\hline Brometo & $<0.01$ & 0,02 & 0,01 & $<0.005$ & $<0.005$ & $<0.005$ & $<0.01$ & $<0.005$ & $<0.005$ & 0,006 & 0,005 & $<0.005$ & 0,01 \\
\hline Sódio & 3,80 & 6,00 & 2,80 & 2,70 & 0,60 & 0,60 & 1,2 & 1 & 1,00 & 0,9 & 0,9 & 0,90 & 0,90 \\
\hline Potássio & 2,60 & 3,20 & 2,00 & 1,30 & 1,30 & 1,30 & 1 & 1,9 & 1,90 & 1,4 & 1,3 & 1,50 & 1,60 \\
\hline Cálcio & 10,10 & 7,60 & 6,70 & 3,70 & 4,60 & 4,70 & 3,6 & 10,4 & 10,25 & 5,65 & 5,8 & 7,80 & 7,60 \\
\hline Magnésio & 7,00 & 4,48 & 4,68 & 1,95 & 3,10 & 3,10 & 2,9 & 4,5 & 4,45 & 3,1 & 3,15 & 4,20 & 4,20 \\
\hline Eströncio & 0,06 & 0,04 & 0,06 & 0,03 & 0,03 & 0,03 & 0,06 & 0,08 & 0,08 & 0,04 & 0,04 & 0,05 & 0,05 \\
\hline Bário & 0,16 & 0,16 & 0,06 & 0,09 & 0,13 & 0,13 & 0,08 & 0,08 & 0,08 & 0,05 & 0,05 & 0,14 & 0,19 \\
\hline Ferro total & $<0.1$ & $<0.2$ & $<0.1$ & $<0.05$ & $<0.05$ & $<0.05$ & $<0.1$ & $<0.05$ & $<0.05$ & $<0.05$ & 0,01 & $<0.05$ & $<0,05$ \\
\hline Manganês & $<0.04$ & $<0.08$ & $<0.04$ & $<0.02$ & $<0.02$ & $<0.02$ & $<0.04$ & 0,02 & 0,02 & 0,01 & 0,01 & $<0,02$ & $<0.02$ \\
\hline Aluminio & $<1.1$ & $<2.2$ & $<1.1$ & $<0.55$ & $<0.55$ & $<0.55$ & $<1.1$ & $<0.55$ & $<0.55$ & 0,08 & 0,05 & $<0.55$ & $<0.55$ \\
\hline Cromo total & $<0.04$ & $<0.08$ & $<0.04$ & $<0.02$ & $<0.02$ & 0,01 & 0,02 & $<0.02$ & 0,01 & $<0.02$ & $<0.02$ & 0,02 & 0,01 \\
\hline Chumbo & $<0.1$ & $<0.2$ & $<0.1$ & $<0.05$ & $<0.05$ & $<0.05$ & $<0.1$ & $<0.05$ & $<0.05$ & $<0.05$ & $<0.05$ & $<0.05$ & $<0.05$ \\
\hline Cobre & $<0.5$ & $<0.1$ & $<0.05$ & $<0.025$ & $<0.025$ & $<0.025$ & 0,02 & $<0.025$ & $<0.025$ & $<0.025$ & $<0.025$ & $<0.025$ & $<0.025$ \\
\hline Zinco & $<0.016$ & 0,08 & 0,06 & $<0.008$ & $<0.008$ & $<0.008$ & 0,02 & 0,03 & 0,03 & 0,03 & 0,04 & $<0.008$ & $<0.008$ \\
\hline Cadmio & $<0.018$ & $<0.036$ & $<0.018$ & $<0.009$ & $<0.009$ & $<0.009$ & $<0.018$ & $<0.009$ & $<0.009$ & $<0.008$ & $<0.009$ & $<0.009$ & $<0.009$ \\
\hline Niquel & $<0.08$ & $<0.16$ & $<0.08$ & $<0.04$ & $<0.04$ & $<0.04$ & $<0.08$ & $<0.04$ & $<0.04$ & 0,01 & $<0.04$ & $<0.04$ & $<0.04$ \\
\hline Prata & $<0.06$ & $<0.12$ & $<0.06$ & $<0.03$ & $<0.03$ & $<0.03$ & $<0.06$ & $<0.03$ & $<0.03$ & $<0.0 \overline{3}$ & $<0.03$ & $<0.03$ & $<0.03$ \\
\hline Sílica & 8,60 & 13,50 & 10,80 & 14,12 & 10,40 & - & 32,8 & 17,2 & & 15,8 & 14,8 & 12,90 & 13,80 \\
\hline COD & - & & 24,00 & & 11,20 & $=$ & & 10,6 & & $<2,0$ & $<2,0$ & 7.80 & 9,50 \\
\hline $\mathrm{CO} 2$ & 4,64 & & 2,94 & 2,43 & 15,84 & & 9,62 & 5,93 & & 44,93 & 44,93 & 87,42 & 87,43 \\
\hline Amônio & & & 0,70 & 0,20 & $<0,1$ & & & 0,20 & & $<0,1$ & & $<0,1$ & \\
\hline & & & & & & & & & & & & & \\
\hline ERRO (\%) & 7,63 & 8,52 & 5,56 & 10,14 & $-0,25$ & 1,18 & 5,35 & 3,69 & 1,33 & 3,50 & 2,30 & $-6,41$ & $-6,62$ \\
\hline
\end{tabular}

BERTOLO, R.A. - Tese de Doutoramento - 2001 


\begin{tabular}{|c|c|c|c|c|c|c|c|c|c|c|c|c|c|}
\hline & DL9B & $\frac{19}{10}$ & DL9 & 19 & DL9 & 19 & $P M$ & DPM & PM & $P M$ & PM1 & PM2 & CHUVA 1 \\
\hline Data & 11-ago-99 & 19-jan-00 & 19-jan-00 & $11-a b r-00$ & $11-a b r-00$ & $01-$ set-00 & 10 -ago-99 & 10 -ago-99 & 17-jan-00 & $10-a b r-00$ & $01-$ set -00 & 01 -set -00 & 17-jan-00 \\
\hline Pot.Matric. Amostr. $(\mathrm{mm} \mathrm{Hg})$ & 0 & -110 & -110 & 0 & 0 & -50 & - & - & - & - & - & - & - \\
\hline Passagem última frente (dias) & $>183$ & -352 & -352 & 76 & 76 & 219 & & & & & & & \\
\hline Tempo de sucçăo (hs) & 24 & 45 & 45 & 24 & 24 & 41 & - & - & - & - & - & $\div$ & - \\
\hline Volume amostra $(\mathrm{mL})$ & 2000 & 550 & 550 & 550 & 550 & 700 & - & - & - & - & - & $=$ & 240 \\
\hline Fator de diluiçăo & na & na & na & na & na & na & na & na & $n a$ & na & na & na & na \\
\hline & & & & & & & & & & & & & \\
\hline Temp. & 24,9 & 26 & 26 & 27,2 & 27,2 & 23,9 & 26 & - & 28,1 & 27,6 & 26,4 & 26,4 & 30,3 \\
\hline$p+4$ & 5,11 & 5,94 & 5,94 & 5,59 & 5,59 & 5,41 & 7,23 & - & 6,31 & 6,39 & 7 & 7 & \\
\hline En (mV) & - & 482 & 482 & 409 & 409 & 543 & $=$ & - & 406 & 506 & 396 & 396 & 673 \\
\hline Cond El (micros) & 105 & 76,6 & 76,6 & 79,6 & 79,6 & 69 & 280 & - & 226 & 240 & 225 & 225 & \\
\hline & & & & & & & & & & & & & \\
\hline $\mathrm{HCO} 3-$ & $=$ & 5,86 & 4,69 & 1,73 & 1,73 & 1,11 & 100,74 & $=$ & 80,84 & 72,49 & 82,30 & 82,30 & 3,00 \\
\hline Sulfato & - & 0,14 & 0,13 & 0,1 & 0,11 & 0,11 & 1,70 & - & 0,44 & 1,69 & 0,86 & 0,87 & 0,53 \\
\hline Cloreto & - & 0,96 & 0,99 & 0,91 & 0,77 & 1,30 & 1,42 & - & 1,48 & 1,75 & 1,53 & 1,76 & 0,68 \\
\hline Nitrato & - & 33,01 & 33,16 & 36,24 & 36,13 & 29,35 & 45,96 & $=$ & 47,54 & 55,32 & 44,13 & 44,18 & 1,31 \\
\hline Nitrito & - & $<0.005$ & $<0.005$ & $<0.005$ & $<0.005$ & $<0.005$ & 0,13 & - & 0,24 & $<0.005$ & $<0.005$ & $<0.005$ & $<0.005$ \\
\hline Flisoreto & - & 0,03 & 0,025 & 0,1 & 0,05 & 0,11 & 0,15 & - & 0,014 & 0,012 & 0,05 & 0,05 & 0,95 \\
\hline Fosfato total & $<0.02$ & 0,016 & 0,04 & 0,008 & 0,015 & 0,02 & 0,07 & 0,04 & 0,04 & 0,04 & 0,26 & 0,02 & 0,05 \\
\hline Brometo & $=$ & $<0.005$ & $<0.005$ & 0,007 & 0,002 & $<0.005$ & $<0.005$ & - & $<0.005$ & 0,002 & $<0.005$ & $<0.005$ & $<0.005$ \\
\hline Sódio & 0,78 & 1,7 & 1,7 & 1,1 & 1,1 & 1,00 & 7,20 & 6,76 & 1,7 & 5 & 2,00 & 2,10 & 0,3 \\
\hline Potássio & 1,64 & 1,7 & 1,7 & 1,4 & 1,4 & 1,40 & 3,10 & 3,16 & 4,8 & 3,9 & 3,00 & 3,00 & 0,2 \\
\hline Cálcio & 7,36 & 5,35 & 3,15 & 6,05 & 5,65 & 4,90 & 35,38 & 35,38 & 39,9 & 38,38 & 41,70 & 42,20 & 0,85 \\
\hline Magnésio & 4,22 & 3,05 & 5,25 & 3,4 & 3,4 & 2,95 & 4,65 & 4,9 & 5,65 & 5,55 & 5,48 & 5,48 & 0,1 \\
\hline Estrôncio & 0,07 & 0,05 & 0,06 & 0,06 & 0,06 & 0,04 & 0,66 & 0,642 & 0,48 & 0,45 & 0,49 & 0,50 & $<0.05$ \\
\hline Bário & 0,17 & 0,13 & 0,05 & 0,09 & 0,06 & 0,11 & 0,13 & 0,111 & 0,11 & 0,16 & 0,06 & 0,10 & $<0.18$ \\
\hline Ferro total & $<0.002$ & $<0.05$ & $<0.05$ & $<0.05$ & $<0.05$ & $<0.05$ & $<0.05$ & 0,004 & $<0.05$ & $<0.05$ & $<0.05$ & $<0.05$ & $<0.05$ \\
\hline Manganés & $<0.01$ & $<0.02$ & $<0.02$ & $<0.02$ & $<0.02$ & 0,01 & 0,03 & 0,04 & 0,19 & 0,08 & $<0.02$ & $<0.02$ & $<0.02$ \\
\hline Alumínio & 0,05 & 0,06 & 0,11 & $<0.55$ & $<0.55$ & $<0.55$ & $<0.55$ & $<0.1$ & $<0.55$ & $<0.55$ & $<0.55$ & 0,04 & $<0.55$ \\
\hline Cromo total & $<0.002$ & $<0.02$ & $<0.02$ & $<0.02$ & $<0.02$ & $<0.02$ & 0,02 & $<0.002$ & $<0.02$ & $<0.02$ & $<0.02$ & $<0.02$ & $<0.02$ \\
\hline Chumbo & - & $<0.05$ & $<0.05$ & $<0.05$ & $<0.05$ & $<0.05$ & $<0.05$ & - & $<0.05$ & $<0.05$ & $<0.05$ & $<0.05$ & $<0.05$ \\
\hline Cobre & $<0.025$ & $<0.025$ & $<0.025$ & $<0.025$ & $<0.025$ & $<0.025$ & $<0.025$ & $<0.001$ & $<0.025$ & $<0.025$ & $<0.025$ & $<0.025$ & 0,01 \\
\hline Zinco & 0,01 & 0,03 & 0,03 & 0,02 & 0,02 & $<0.008$ & $<0.008$ & $<0.005$ & 0,03 & 0,03 & $<0,008$ & $<0.008$ & 0,02 \\
\hline Cádmio & - & $<0.009$ & $<0.009$ & $<0.009$ & $<0.009$ & $<0.009$ & $<0.009$ & - & $<0.009$ & $<0.009$ & $<0.009$ & $<0.009$ & $<0.009$ \\
\hline Niquel & 0,01 & $<0.04$ & $<0.04$ & $<0.04$ & $<0.04$ & $<0.04$ & $<0.04$ & $<0.001$ & $<0.04$ & $<0.04$ & $<0.04$ & $<0.04$ & $<0.04$ \\
\hline Prata & - & $<0.03$ & $<0.03$ & $<0.03$ & $<0.03$ & $<0.03$ & $<0.03$ & $=$ & $<0.03$ & $<0.03$ & $<0.03$ & $<0.03$ & $<0.03$ \\
\hline Silica & - & 33 & 33 & 26,2 & 27 & 20,90 & 12,00 & - & 46 & 26,2 & 21,70 & 22,2 & \\
\hline $\mathrm{COD}$ & - & 185 & 185 & 9,2 & 6,6 & 15,9 & 10,10 & - & 8,9 & 9,5 & 12,9 & 13,3 & \\
\hline $\mathrm{CO} 2$ & & & 8,83 & 8,02 & & 8,23 & 9,13 & & 59,96 & 47,03 & 12,79 & & \\
\hline \multirow[t]{2}{*}{ Amônio } & & 0,10 & & 0,40 & & 0,20 & $<0,1$ & & 0,10 & 0,40 & 0,20 & & \\
\hline & & & & & & & & & & & & & \\
\hline ERRO $(\%)$ & $-7,16$ & 0,37 & 4,17 & 3,34 & 2.47 & 2,93 & 1,57 & 1,61 & 10,96 & 11,46 & 11,88 & 13,85 & $-19,22$ \\
\hline
\end{tabular}

BERTOLO, R.A. - Tese de Doutoramento - 2001 


\begin{tabular}{|c|c|c|c|c|c|c|c|c|c|c|c|c|}
\hline & CHUVA 2 & CHUVA & L50C & LSOC & L50D & L50D & $\mathrm{L} 50 \mathrm{E}$ & L1C & L1C & L1D & LID & LIE \\
\hline Data & 20-jan -00 & $03-$ set-00 & 19-jan-00 & $13 \mathrm{ab}-00$ & 19-jan-00 & $13-a b r+00$ & 13 -abr-00 & 19-jan-00 & $13-a b r-00$ & 19-jan-00 & $13-a b r-00$ & 13 -abr-00 \\
\hline Pot.Matric. Amostr. (mm Hg) & - & $=$ & -200 & -220 & -120 & -140 & -170 & -180 & -200 & -180 & -200 & -190 \\
\hline Passagem última frente (dias) & & & 10 & 17 & 10 & 17 & 17 & 1 & 16 & 4 & 16 & 16 \\
\hline Tempo de sucçăo (hs) & - & - & 49 & 48 & 52 & 48 & 48 & 52 & 46 & 54 & 46 & 46 \\
\hline Volume amostra $(\mathrm{mL})$ & 650 & 750 & 175 & 52 & 125 & 52 & 57 & 125 & 61 & 50 & 67 & 95 \\
\hline \multirow[t]{2}{*}{ Fator de diluiçãa } & na & na & na & $1: 2$ & $1: 1$ & $1: 2$ & $1: 2$ & $1: 1$ & $1: 1,5$ & $1: 2$ & $1: 2$ & $1: 1 \mathrm{e} 1: 2$ \\
\hline & & & & & & & & & & & & \\
\hline Temp. & 24,5 & 19,6 & 29,5 & 29,6 & 28,9 & 28,3 & 28 & 29,2 & 30,5 & 29,7 & 29,1 & 28,5 \\
\hline $\mathrm{pH}$ & & & 6,56 & 6,8 & 6.51 & 6.75 & 7,09 & 6,71 & 6,79 & 6,41 & 7,04 & 6,82 \\
\hline$E$ En (m) & 590 & 673 & 445 & 466 & 477 & 482 & 472 & 474 & 490 & 497 & 477 & 475 \\
\hline \multirow[t]{2}{*}{ Cond.El. (micros) } & & & 227 & 54,5 & 323 & 63,1 & 90,2 & 181,6 & 52 & 225 & 72 & 54,7 \\
\hline & & & & & & & & & & & & \\
\hline $\mathrm{HCO}-$ & 1,00 & 0,00 & 26,36 & 26,42 & 21,67 & 16,98 & 47,22 & 13,91 & 22,48 & 14,94 & 34,37 & 24,47 \\
\hline Sulfato & 0,33 & 0,55 & 26,4 & 1,41 & 17,96 & 8,67 & 0,42 & 3,14 & 2,25 & 8,37 & 2,13 & 1,42 \\
\hline Cioreto & 0,22 & 0,14 & 4,5 & 1,29 & 5,1 & 1,68 & 1,38 & 4,64 & 0,95 & 14,79 & 0,87 & 1,56 \\
\hline Nitrato & 1,25 & 0,5 & 49,21 & 0.45 & 124,08 & 0,39 & 0,06 & 66,16 & 0,85 & 64,08 & 0,24 & 0,24 \\
\hline Nitrito & $<0.005$ & $<0.005$ & 1,12 & $<0.015$ & 0,66 & $<0.015$ & $<0.015$ & $<0.01$ & $<0.0125$ & $<0.015$ & $<0.015$ & $<0.01$ \\
\hline Fluoreto & 0,33 & 0,28 & 0,04 & 0,27 & 0,12 & 0,15 & 0,18 & 0,04 & 0,275 & 0,24 & 0,12 & 0,06 \\
\hline Fosfato total & 0,019 & 0,013 & 0,45 & 0,06 & 0,32 & 0,021 & 0,12 & 0,28 & 0,0275 & 0,009 & 0,02 & 0,12 \\
\hline Brometo & $<0.005$ & $<0.005$ & $<0.005$ & 0,003 & $<0.01$ & 0,003 & 0,036 & $<0.01$ & 0,005 & $<0.015$ & 0,02 & 0,02 \\
\hline Sódio & 0,1 & $<0,01$ & 1,7 & 1,5 & 2,2 & 2,4 & 1,5 & 1,8 & 2,25 & 4,5 & 1,63 & 0,80 \\
\hline Potássio & 0,1 & $<0.01$ & 2,1 & 0,7 & 6 & 1,2 & 0,6 & 1,2 & 0,5 & 3,9 & 1,80 & 1,60 \\
\hline Cálicio & 0,35 & 0,95 & 32,9 & 6,2 & 41,7 & 6,72 & 11,04 & 21 & 5,75 & 25,5 & 7,96 & 6,16 \\
\hline Magnésio & 0.05 & $<0,003$ & 6,95 & 1,2 & 8,8 & 1,5 & 1,86 & 6 & 1,5 & 5,55 & 2,08 & 1,60 \\
\hline Estrôncio & $<0.05$ & $<0.05$ & 0,14 & $<0.15$ & 0,2 & 0,03 & 0,03 & 0,1 & 0,025 & 0,54 & 0,09 & 0,02 \\
\hline Bário & $<0.18$ & $<0.18$ & 0,05 & $<0.54$ & 0,18 & $<0.54$ & $<0.54$ & 0,1 & $<0.45$ & 0,33 & 0,09 & $<0.36$ \\
\hline Ferro total & $<0.05$ & $<0.05$ & $<0.05$ & $<0.15$ & $<0.1$ & $<0.15$ & $<0.15$ & $<0.1$ & $<0.125$ & $<0.15$ & $<0.15$ & $<0.1$ \\
\hline Manganês & $<0.02$ & $<0.02$ & $<0.02$ & $<0.06$ & $<0.04$ & $<0.06$ & $<0.06$ & $<0.04$ & $<0.05$ & $<0.06$ & $<0.06$ & $<0.04$ \\
\hline Aluminio & 0,11 & $<0.55$ & $<0.55$ & $<1.65$ & $<1.1$ & $<1.65$ & $<1.65$ & 0,08 & $<1.375$ & 0,3 & $<1.65$ & $<1.1$ \\
\hline Cromo total & $<0.02$ & $<0.02$ & $<0.02$ & $<0.06$ & $<0.04$ & $<0.06$ & $<0.06$ & $<0.04$ & $<0.5$ & 0,03 & $<0.06$ & $<0.04$ \\
\hline Chumbo & $<0.05$ & $<0.05$ & $<0.05$ & $<0.15$ & $<0.1$ & $<0.15$ & $<0.15$ & $<0.1$ & $<0.125$ & $<0.15$ & $<0.15$ & $<0.1$ \\
\hline Cobre & $<0.025$ & $<0.025$ & 0,01 & $<0.075$ & $<0.05$ & $<0.075$ & $<0.075$ & $<0.05$ & $<0.0625$ & 0,06 & $<0.075$ & $<0.05$ \\
\hline Zinco & 0.01 & $<0.008$ & 0,06 & 0,15 & 0,08 & 0,18 & 0,06 & 0,12 & 0,05 & 0,3 & 0,09 & 0,08 \\
\hline Cádmio & $<0.009$ & $<0.009$ & $<0.009$ & $<0.027$ & $<0.018$ & $<0.027$ & $<0.027$ & $<0.018$ & $<0.0225$ & $<0.027$ & $<0.027$ & $<0.018$ \\
\hline Niquel & $<0.04$ & $<0.04$ & $<0.04$ & $<0.12$ & $<0.08$ & $<0.12$ & $<0.12$ & $<0.08$ & $<0.1$ & $<0.12$ & $<0.12$ & $<0.08$ \\
\hline Prata & $<0.03$ & $<0.03$ & $<0.03$ & $<0.09$ & $<0.06$ & $<0.09$ & $<0.09$ & $<0.06$ & $<0.075$ & $<0.09$ & $<0.09$ & $<0.06$ \\
\hline Sílica & & & 52 & & 52 & & & 40 & & & & 26,40 \\
\hline $\mathrm{COD}$ & & & & & & & & & & & & 25,20 \\
\hline $\mathrm{CO} 2$ & & & 11,66 & 7,14 & 10,82 & 5,07 & 6,37 & 4,50 & 6,35 & 9,67 & 5,25 & 6,24 \\
\hline \multirow[t]{2}{*}{ Amônio } & & & & 0,60 & & 0,20 & 0,50 & & 0,70 & & 0,90 & 0,80 \\
\hline & & & & & & & & & & & & \\
\hline ERRO (\%) & $-11,05$ & 10,22 & 9,45 & 0,61 & 2,67 & 7,95 & $-1,30$ & 5,20 & 8,79 & 5,17 & 7.08 & 3,19 \\
\hline
\end{tabular}

BERTOLO, R.A. - Tese de Doutoramento - 2001 


\subsection{ANEXO 8 - ESTATISTIICAS DOS RESULTADOS DE ANÁLISES QUIMICAS DE ÁGUA}
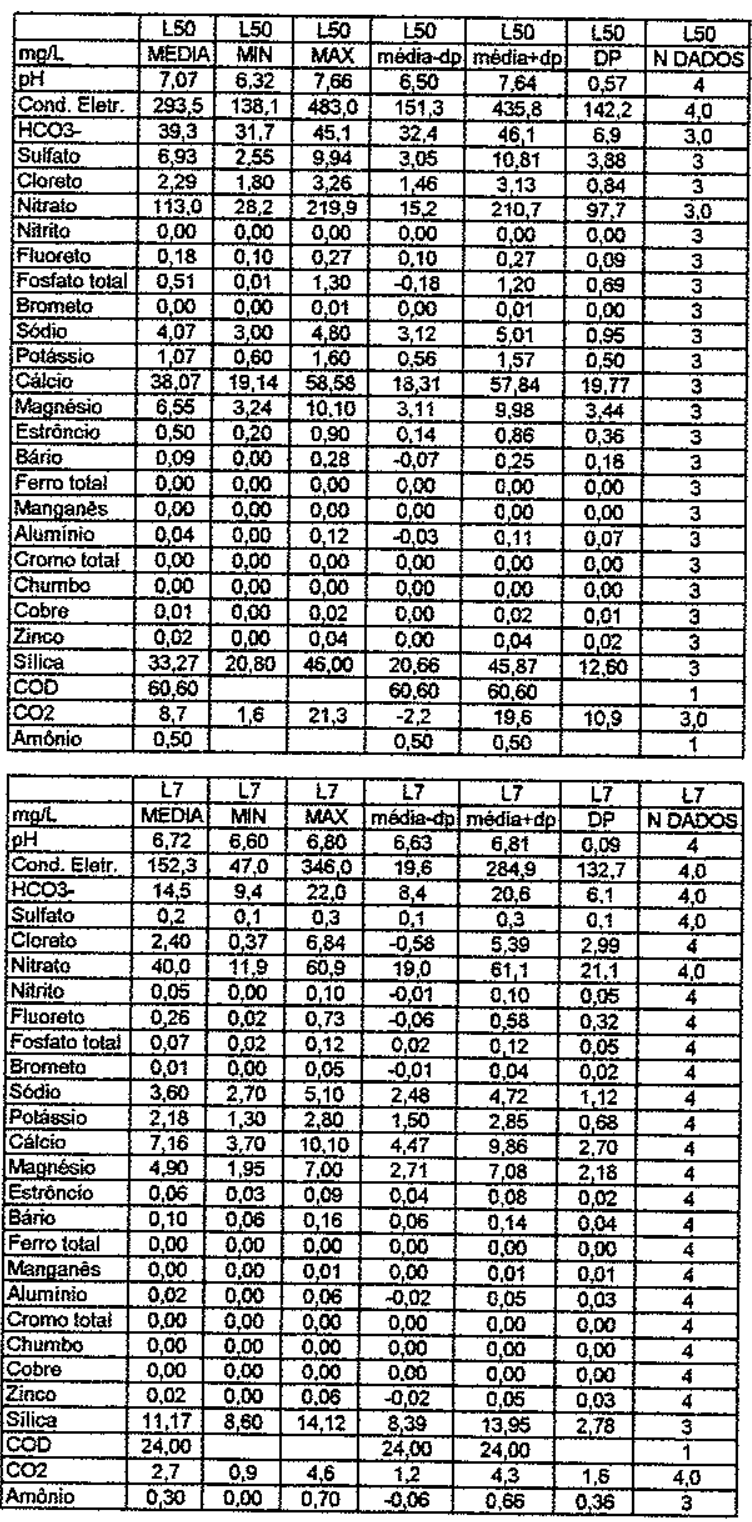

BERTOLO, R.A. - Tese de Doutoramento - 2001
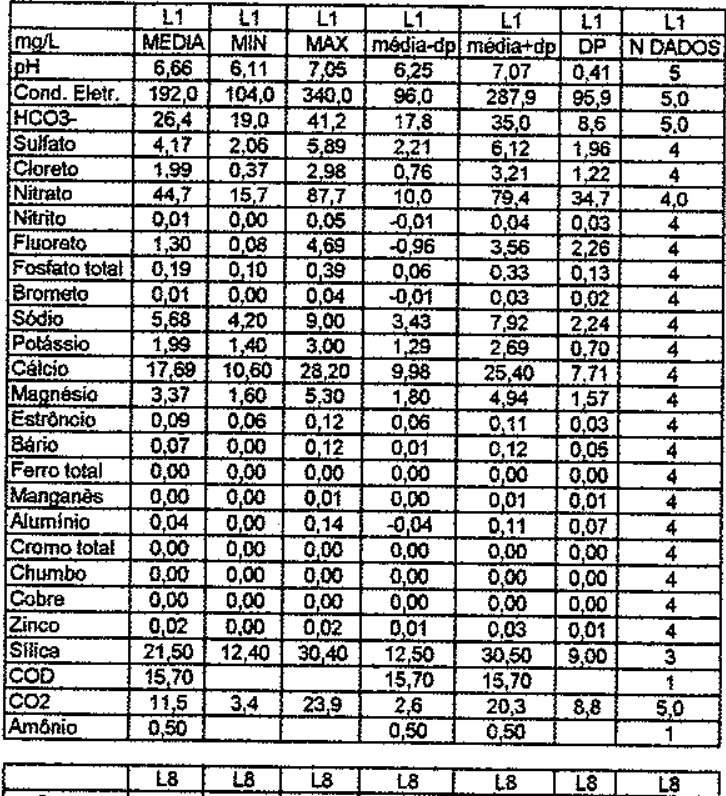

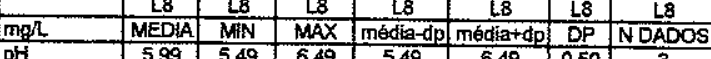
\begin{tabular}{|l|c|c|c|c|c|c|c|}
\hline pHi & 5,99 & 5,49 & 5,49 & 5,49 & 6,49 & 0,50 & 3 \\
\hline Cond. Elatt. & 78,2 & 58,6 & 110,0 & 50,4 & 106,0 & 27.8 & 3.0 \\
\hline HCO3- & 70 & 2,9 & 123 & 2, & 11, & 3,0 & 30 \\
\hline
\end{tabular} \begin{tabular}{|l|c|c|c|c|c|c|c|}
\hline Sulfato & 0,2 & 0,0 & 0,6 & $-0,1$ & 0,5 & 4,8 & 3,0 \\
\hline
\end{tabular} \begin{tabular}{|l|l|l|l|l|l|l|l|}
\hline cloreto & 1,84 & 1,64 & 2,20 & 1,53 & 2,15 & 0,31 & 3,0 \\
\hline
\end{tabular} \begin{tabular}{|l|c|c|c|c|c|c|c|}
\hline Nitrato & 28,4 & 16,9 & 40,2 & 16.8 & 40,0 & 11,6 & 3,0 \\
\hline Nitrito & 0,00 & 0,00 & 0,00 & 0,00 & 0,00 & 0,00 & 3 \\
\hline
\end{tabular} \begin{tabular}{|l|c|c|c|c|c|c|c|}
\hline Fluoreto & 0,02 & 0,03 & 0,03 & 0,01 & 0,03 & 0,01 & 3 \\
\hline Fostabo lotal & 0,25 & 0.04 & 0,68 & $-0,12$ & 0,62 & 0,37 & 3 \\
\hline
\end{tabular} \begin{tabular}{ll|l|l|l|l|l|l|l|} 
Brometo & 0,00 & 0,00 & 0,00 & 0,00 & 0,00 & 0,00 & 3 \\
\hline
\end{tabular} \begin{tabular}{|l|c|c|c|c|c|c|c|}
\hline Sódio & 0,93 & 0,60 & 1,20 & 0,63 & 1,24 & 0,31 & 3 \\
\hline
\end{tabular} \begin{tabular}{|l|c|c|c|c|c|c|c|}
\hline Pot́ssio & 1,40 & 1,00 & 1,90 & 0,94 & 1,86 & 0,46 & 3 \\
\hline Cálcio & 6,20 & 3,60 & 10,40 & 2,53 & 9.87 & 3,67 & 3 \\
\hline
\end{tabular} \begin{tabular}{|l|c|c|c|c|c|c|c|}
\hline Cálcio & 6,20 & 3,60 & 10,40 & 2,53 & 9,87 & 3,67 & 3 \\
\hline Magnnésio & 3,50 & 2,50 & 4,50 & 2,63 & 4,37 & 0,87 & 3 \\
\hline
\end{tabular} \begin{tabular}{|l|c|c|c|c|c|c|c|}
\hline EEstróncio & 0,06 & 0,03 & 0,08 & 0,03 & 0.08 & 0,87 & 3 \\
\hline Bàrio & 0.10 & 0.08 & 0.13 & 0.07 & 0.13 & 0.03 & 3 \\
\hline
\end{tabular} \begin{tabular}{|l|c|c|c|c|c|c|c|}
\hline Fetro tofal & 0,00 & 0,00 & 0,00 & 0,00 & 0,00 & 0,00 & 3 \\
\hline
\end{tabular} \begin{tabular}{|l|l|l|l|l|l|l|l|}
\hline Manganés & 0,01 & 0,00 & 0,02 & 0,00 & 0,02 & 0,01 & 3 \\
\hline
\end{tabular} \begin{tabular}{|l|c|c|c|c|c|c|c|}
\hline Aluminio & 0,00 & 0,00 & 0,00 & 0,00 & 0,00 & 0,00 & 3 \\
\hline
\end{tabular}

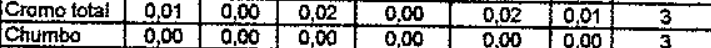
\begin{tabular}{|l|l|l|l|l|l|l|l|}
\hline Culumbo & 0,00 & 0,00 & 0,00 & 0,00 & 0,00 & 0,00 & 3 \\
\hline Cabre & 0,03 & 0,00 & 0,02 & 0,00 & 0,02 & 0,01 & 3 \\
\hline
\end{tabular} \begin{tabular}{|l|l|l|l|l|l|l|l|}
\hline Zinco & 0,02 & 0,00 & 0,03 & 0,00 & 0,02 & 0,01 & 3 \\
\hline Silo & 20,13 & 1000 & 0,02 & 3 \\
\hline
\end{tabular} \begin{tabular}{|l|c|c|c|c|c|c|c|c|}
\hline Silica & 20,13 & 10,40 & 32,80 & 8,65 & 31,62 & 11,5 & 3 \\
\hline $\mathrm{COD}$ & 10,90 & 10,60 & 11,20 & 10,48 & 11,32 & 0,42 & 2 \\
\hline $\mathrm{CO}$ & 10,5 & 5,9 & 15,8 & 5,5 & 15,5 & 5,0 & 3,0 \\
\hline
\end{tabular} \begin{tabular}{|l|c|c|c|c|c|c|c|}
\hline $\mathrm{CO} 2$ & 10,5 & 5,9 & 15,8 & 5,5 & 1,5 & $\frac{5,0}{5}$ & 3,0 \\
\hline Ambranio & 0,10 & 0,00 & 0,20 & $-0,04$ & 0,24 & 0,14 & 2 \\
\hline
\end{tabular}

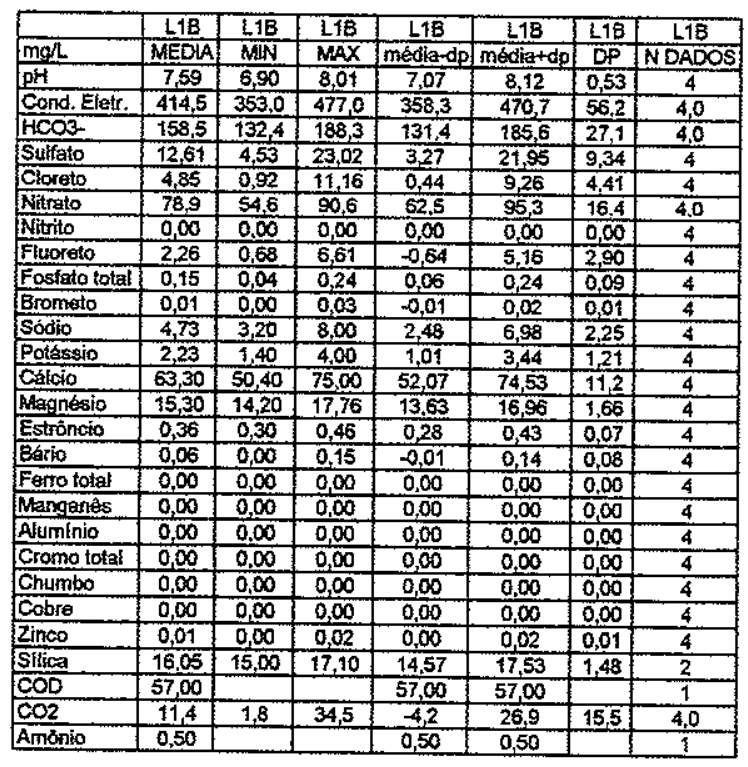

\begin{tabular}{|l|l|l|l|l|l|l|l|}
\hline & LS & LS & ig & L9 & LS & L9 & L9 \\
\hline
\end{tabular}

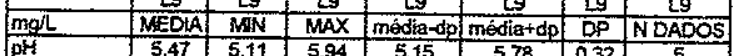

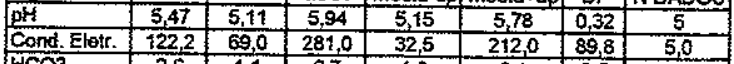
\begin{tabular}{l|l|l|l|l|l|l|l|}
\hline Sulfiat & 3,6 & 1,1 & 6,7 & 1,0 & 6,1 & 2,5 & 5,0 \\
\hline
\end{tabular}

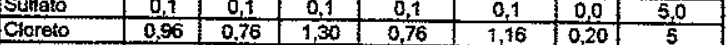
\begin{tabular}{|l|c|c|c|c|c|c|c|}
\hline Nitato & 37,0 & 29,4 & 48,9 & 29,6 & 44,3 & 7,4 & 5,0 \\
\hline Nintio & 0,0 & 000 & 0,00 & 0.0 & 0,00 & 000 & 5 \\
\hline
\end{tabular} \begin{tabular}{|l|l|l|l|l|l|l|l|}
\hline Nitrito & 0,00 & 0,00 & 0,00 & 0,00 & 0,00 & 0,00 & 5 \\
\hline Furoreto & 0,07 & 0,01 & 0.11 & 0,02 & 011 & 0,04 & 5 \\
\hline
\end{tabular} \begin{tabular}{|l|l|l|l|l|l|l|l|}
\hline Furotio & 0,07 & 0,01 & 0,11 & 0,02 & 0,11 & 0,04 & 5 \\
\hline Fosfato tobal & 0,03 & 0,01 & 0,08 & 0,00 & 0,06 & 0,03 & 5 \\
\hline
\end{tabular} \begin{tabular}{|l|l|l|l|l|l|l|l|}
\hline Brometo & 0,00 & 0,00 & 0,01 & 0,00 & 0,01 & 0,03 & 5 \\
\hline
\end{tabular} \begin{tabular}{|l|c|c|c|c|c|c|c|}
\hline Sódio & 1,12 & 0,90 & 1,70 & 0,79 & 1,45 & 0,33 & 5 \\
\hline Potíssio & 1,8 & 140 & 170 & 135 & 151 & 0,13 & 5 \\
\hline
\end{tabular} \begin{tabular}{|l|c|c|c|c|c|c|c|}
\hline Cálíi & 5,95 & 4,90 & 7,80 & 4,83 & 7,07 & 1,12 & 5 \\
\hline Mán
\end{tabular} \begin{tabular}{|l|c|c|c|c|c|c|c|}
\hline Magnésio & $\mathbf{3 , 3 4}$ & $\mathbf{2 , 9 5}$ & 4,20 & 2,83 & 3,85 & 0,51 & $\mathbf{5}$ \\
\hline Estronncio & 0,05 & 0,04 & 0,06 & 0,04 & 0,06 & 0,01 & 5 \\
\hline
\end{tabular}

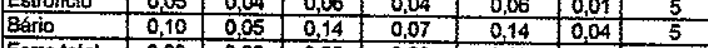

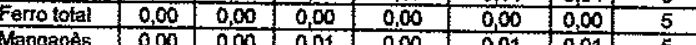
\begin{tabular}{l|l|l|l|l|l|l|l|l|l}
\hline Áumínio & 0,03 & 0,00 & 0,08 & $-0,01$ & 0,01 & 0,01 & 5 \\
\hline
\end{tabular} \begin{tabular}{l|l|l|l|l|l|l|l|} 
Cromo total & 0,00 & 0,00 & 0,02 & 0,00 & 0,01 & 0,01 & 5 \\
\hline
\end{tabular} \begin{tabular}{|l|c|c|c|c|c|c|c|}
\hline Chumbo & 0,00 & 0,00 & 0,00 & 0,00 & 0,00 & 0,00 & 5 \\
\hline Cobre & 0,00 & 0,00 & 0,00 & 0,00 & 0,00 & 0,00 & 5 \\
\hline
\end{tabular} \begin{tabular}{|l|l|l|l|l|l|l|l|}
\hline Cobre & 0,00 & 0,00 & 0,00 & 0,00 & 0,00 & 0,00 & 5 \\
\hline Zinco & 0,02 & 0,00 & 0,03 & 0,00 & 0,03 & 0,02 & 5 \\
\hline
\end{tabular} \begin{tabular}{|l|c|c|c|c|c|c|c|}
\hline Slica & 21,76 & 12,50 & 33,00 & 13,69 & 29,83 & 8,07 & 5 \\
\hline COD & 8,48 & 1,00 & 15,90 & 2,37 & 14,58 & 6,11 & 4 \\
\hline
\end{tabular} \begin{tabular}{|l|c|c|c|c|c|c|c|}
\hline $\mathrm{CO} 2$ & 31,5 & 8,0 & 87,4 & $-3,6$ & 66,5 & $3,5,1$ & 5,0 \\
\hline Amónio & 0,14 & 0,00 & 0,40 & $-0,03$ & 0,31 & 0,17 & 5 \\
\hline
\end{tabular} 


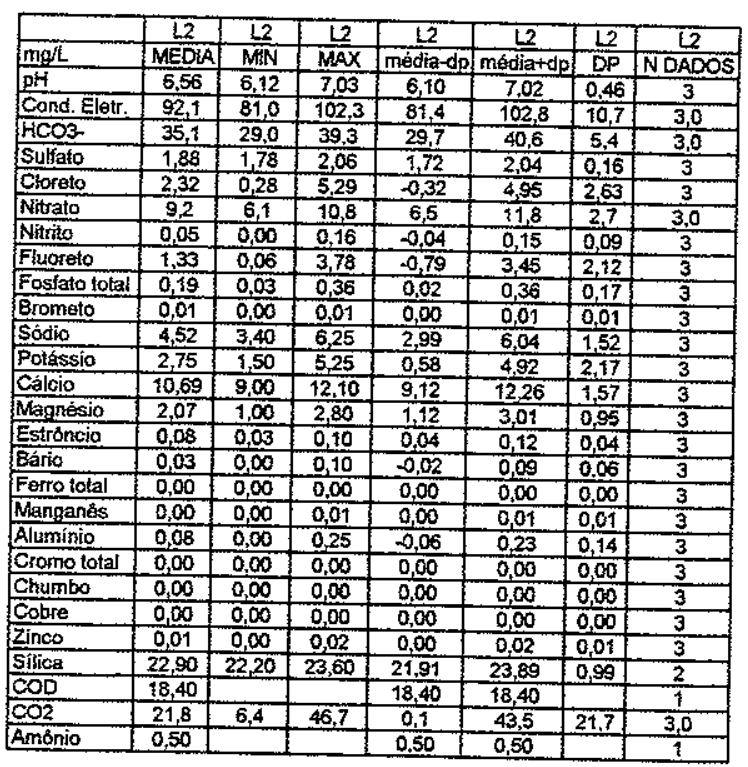

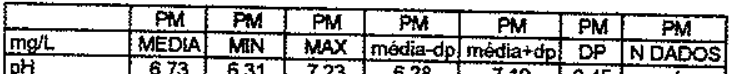

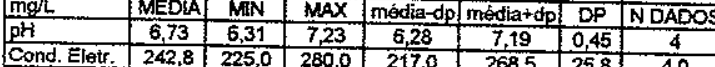
\begin{tabular}{|l|c|c|c|c|c|c|c|}
\hline BCO3 & 84,4 & 72,5 & 100,7 & 72,2 & 20,5 & 25,0 & 4,0 \\
\hline Sulfato & 1,2 & 0,4 & 1,7 & 0,5 & 1,9 & 4,0 \\
\hline
\end{tabular} \begin{tabular}{|l|c|c|c|c|c|c|c|}
\hline Sulfato & 1,2 & 0,4 & 1,7 & 0,5 & 1,8 & 0,6 & 4,0 \\
\hline Cloreto & 1,55 & 1,42 & 1,75 & 1,40 & 1,69 & 0,14 & 4 \\
\hline
\end{tabular}

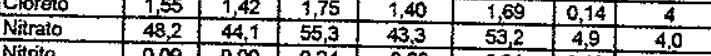
\begin{tabular}{|l|l|l|l|l|l|l|l|}
\hline Nitrito & 0,09 & 0,00 & 0,24 & $-0,02$ & 53,21 & 0,92 & 4,0 \\
\hline
\end{tabular} \begin{tabular}{|l|l|l|l|l|l|l|l|}
\hline Fluoseto & 0,06 & 0,01 & 0,15 & $-0,01$ & 0,12 & 0,06 & 4 \\
\hline Fosfoto total & 0.10 & 0,04 & 0,26 & 0.00 & 0,21 & 0,1 & 4 \\
\hline
\end{tabular} \begin{tabular}{|l|l|l|l|l|l|l|l|}
\hline Fosfato total & 0,10 & 0.04 & 0,26 & 0.00 & 0,21 & 0,11 & 4 \\
\hline Brometo & 0,00 & 0.00 & 0.00 & 0.00 & 0,00 & 0,00 & 4 \\
\hline
\end{tabular} \begin{tabular}{|l|c|c|c|c|c|c|c|}
\hline Somelo & 0,00 & 0,00 & 0,00 & 0,00 & 0,00 & 0,00 & 4 \\
\hline Sódio & 3,98 & 1,70 & 7,20 & 1,36 & 6,59 & 2,62 & 4 \\
\hline
\end{tabular}

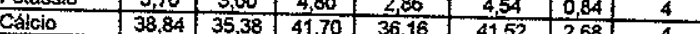
\begin{tabular}{|l|l|l|l|l|l|l|l|l|}
\hline Magnósio & 5,33 & 4,65 & 5,65 & 4,87 & 5,79 & 0,66 & 4 \\
\hline
\end{tabular} \begin{tabular}{|l|l|l|l|l|l|l|l|}
\hline Estrôncio & 0.52 & 0.45 & 0,66 & 0.43 & 0,61 & 0.09 & 4 \\
\hline
\end{tabular} \begin{tabular}{|l|l|l|l|l|l|l|l|}
\hline Bário & 0,12 & 0,06 & 0,36 & 0,07 & 0,16 & 0,06 & 4 \\
\hline Farro total & 0,00 & 0,00 & 0,00 & 0,00 & 0,00 & 0,00 & 4 \\
\hline
\end{tabular}

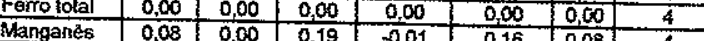

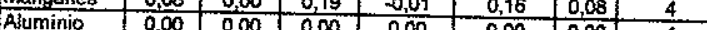
\begin{tabular}{|l|l|l|l|l|l|l|l|l|}
\hline Cromo total & 0,01 & 0,00 & 0,02 & 0,01 & 0,02 & 0,01 & 4 \\
\hline
\end{tabular} \begin{tabular}{|l|l|l|l|l|l|l|l|}
\hline Chumbo & 0,00 & 0,00 & 0,00 & 0,00 & 0,00 & 0,00 & 4 \\
\hline
\end{tabular} \begin{tabular}{lllll|l|l|l|l|l}
\hline Cobre & 0,00 & 0,00 & 0,00 & 0,00 & 0,00 & 0,00 & 4 \\
\hline
\end{tabular} \begin{tabular}{|l|l|l|l|l|l|l|l|}
\hline Sinco & 0,02 & 0,00 & 0,03 & 0,00 & 0,03 & 0,02 & 4 \\
\hline
\end{tabular} \begin{tabular}{|l|l|l|l|l|l|l|l|l|l|}
\hline COD & 10,35 & 890 & 1200 & 8,17 & 40,78 & 14,30 & 4 \\
\hline
\end{tabular} \begin{tabular}{|l|c|c|c|c|c|c|c|}
\hline $\mathrm{CO} 2$ & 32,2 & 9,1 & 60.0 & 7,58 & 12,32 & 1,77 & 4 \\
\hline
\end{tabular} BERTOLO, R.A. - Tese de Doutoramento - 2001
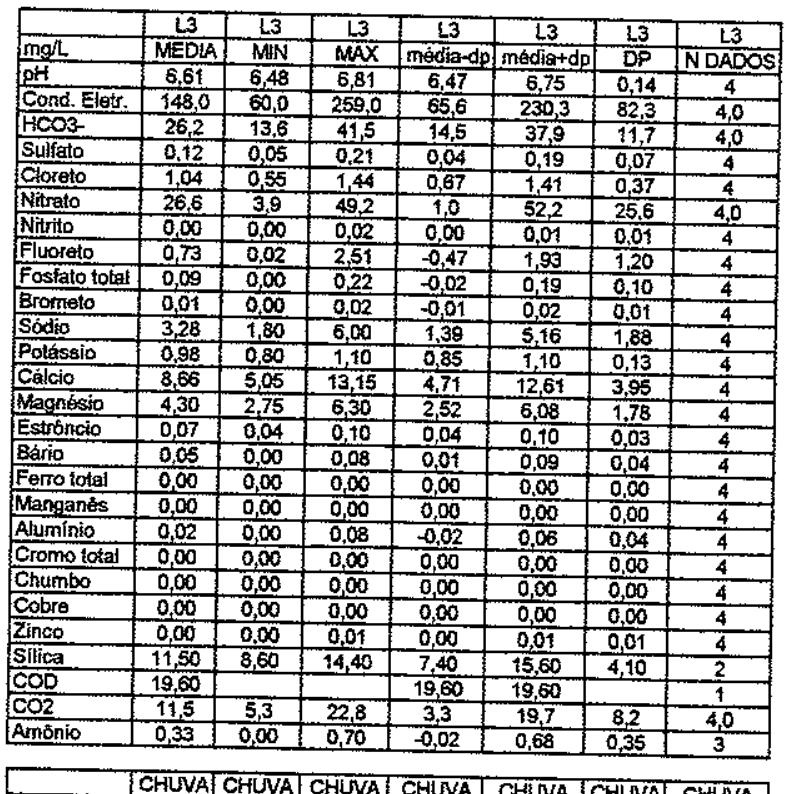

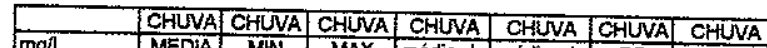

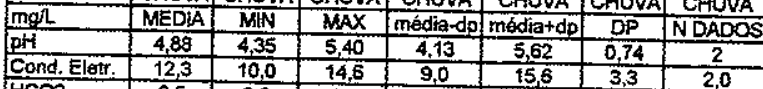

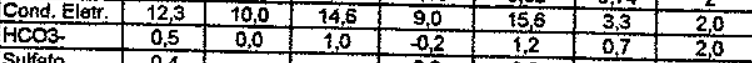

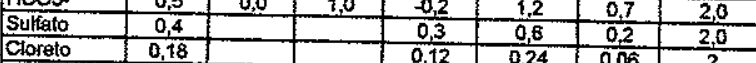

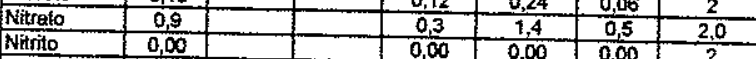

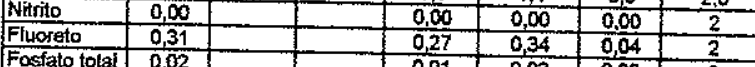

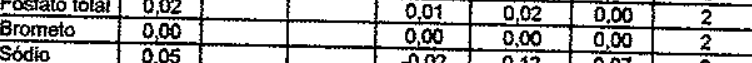
\begin{tabular}{|l|l|l|l|l|l|l|l|}
\hline Sodia & 0,05 & & & $-0,02$ & 0,12 & 0,07 & 2 \\
\hline Potássio & 0,05 & & & $-0,02$ & 0,12 & 0,07 & 2 \\
\hline
\end{tabular}

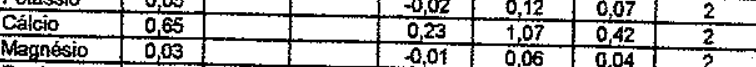

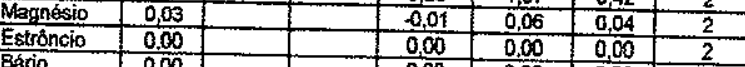

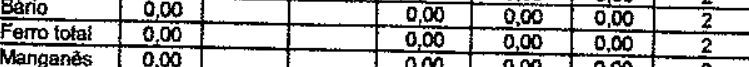

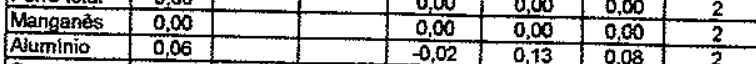

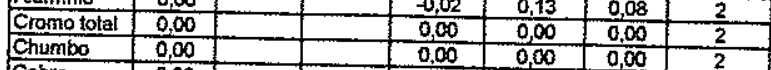

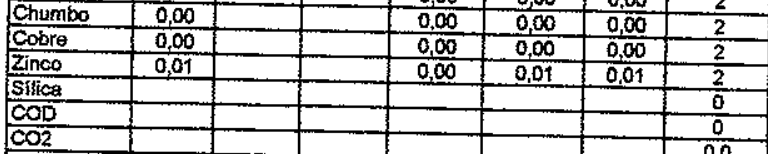

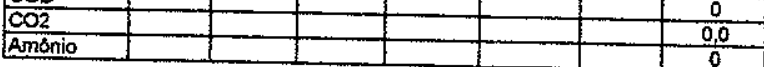

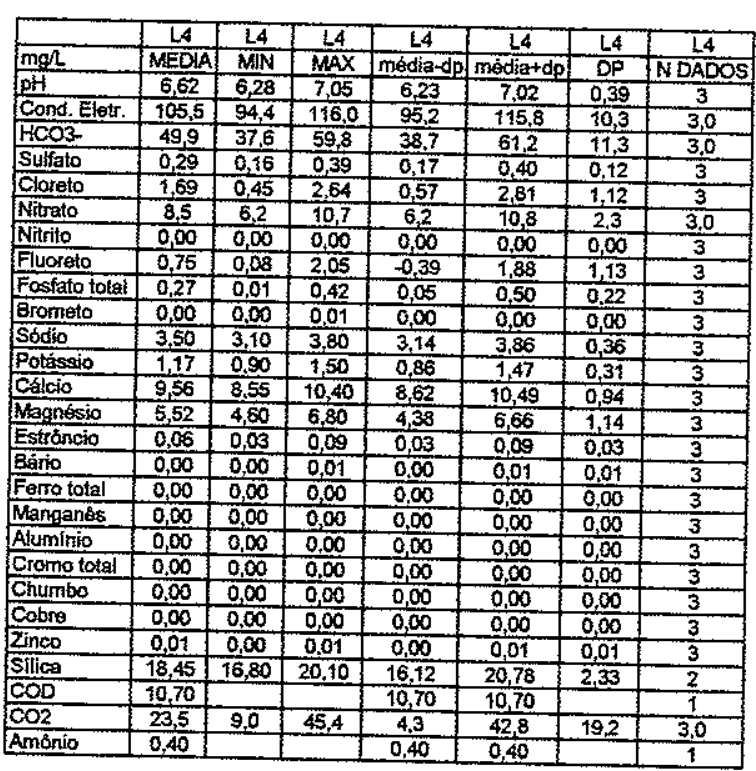

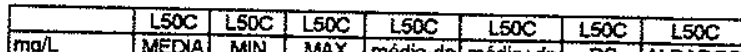

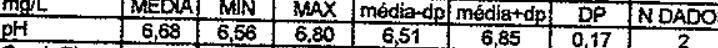
\begin{tabular}{|l|l|l|l|l|l|l|l|}
\hline Cond. Eletr. & 140,8 & 54,5 & 227,0 & 6,51 & 6,85 & 0,17 & 2 \\
\hline HCO3 & 26.8 & 26,4 & 262,7 & 122,0 & 2,0 \\
\hline
\end{tabular} \begin{tabular}{|l|c|c|c|c|c|c|c|}
\hline BCO3 & 26,4 & 26,4 & 26,4 & 26,3 & 26,4 & 0,0 & 2,0 \\
\hline Sulfato & 13,9 & 1,4 & 26,4 & $-3,8$ & 31,6 & 17,7 & 2,0 \\
\hline
\end{tabular} \begin{tabular}{|l|l|l|l|l|l|l|l|}
\hline Sulfato & 13,9 & 1,4 & 26,4 & $-3,8$ & 31,6 & 17,7 & 2,0 \\
\hline Closeto & 2,90 & 1,29 & 4,50 & 0,63 & 5,16 & 2,27 & 2 \\
\hline
\end{tabular} \begin{tabular}{|l|c|c|c|c|c|c|c|}
\hline Nitrato & 24,8 & 0,5 & 49,2 & $-9,6$ & 59,3 & 34,5 & 2,0 \\
\hline Nitrito & 0,56 & 0,00 & 1,12 & $-0,23$ & 1,35 & 0,79 & 2 \\
\hline
\end{tabular} \begin{tabular}{|l|l|l|l|l|l|l|}
\hline Fluoretio & 0,16 & 0,04 & 0,127 & $-0,23$ & 1,35 & 0,79 \\
\hline
\end{tabular} \begin{tabular}{l|l|l|l|l|l|l|l|}
\hline rosfato tolal & 0,26 & 0,06 & 0,45 & $-0,02$ & 0,32 & 0,16 \\
\hline
\end{tabular} \begin{tabular}{|l|l|l|l|l|l|l|l|}
\hline & 0.00 & 0,00 & 0,00 & 0,28 & 2 \\
\hline
\end{tabular} \begin{tabular}{|l|l|l|l|l|l|l|l|}
\hline & 1,39 & 1,48 & 1,70 & 1,44 & 1,75 & 0,15 & 2 \\
\hline
\end{tabular} \begin{tabular}{|l|c|c|c|c|c|c|c|}
\hline Potássio & 1,40 & 0,70 & 2,10 & 0,41 & 2,39 & 0,59 & 2 \\
\hline Ć́lcio & 19,55 & 6,20 & 32,90 & 0,67 & 38,43 & 18,88 & 2 \\
\hline
\end{tabular} \begin{tabular}{|l|c|c|c|c|c|c|c|}
\hline Magnósic & 4,08 & 1,20 & 6,95 & 0,01 & 8,14 & 4,06 & 2 \\
\hline
\end{tabular} \begin{tabular}{|l|l|l|l|l|l|l|l|}
\hline Estróncio & 0,07 & 0,00 & 0,14 & $-0,03$ & 0,14 & 4,06 \\
\hline
\end{tabular} \begin{tabular}{|l|l|l|l|l|l|l|l|l|}
\hline Bario & 0,03 & 0,00 & 0,05 & $-0,01$ & 0,06 & 0,04 & 2 \\
\hline Eerrot & 0.00 & \\
\hline
\end{tabular} \begin{tabular}{|l|l|l|l|l|l|l|l|}
\hline Ferro tolar & 0,00 & 0,00 & 0,00 & 0,00 & 0,00 & 0,00 & 2 \\
\hline
\end{tabular} \begin{tabular}{|l|l|l|l|l|l|l|l|}
\hline Manganiss & 0,00 & 0,00 & 0,00 & 0,00 & 0,00 & 0,00 & 2 \\
\hline Aluminio & 0,00 & 0,00 & 0,00 & 0,00 & 0,00 & 0,00 & 2 \\
\hline
\end{tabular}

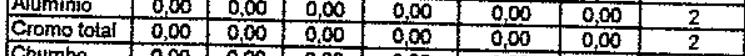
\begin{tabular}{|l|l|l|l|l|l|l|l|}
\hline Chumbo & 0,00 & 0,00 & 0,00 & 0,00 & 0,00 & 0,00 & 2 \\
\hline Comber & 0,00 & 2 \\
\hline
\end{tabular} \begin{tabular}{|l|c|c|c|c|c|c|c|}
\hline Cobre & 0,01 & 0,00 & 0,05 & 0,00 & 0,01 & 0,01 & 2 \\
\hline Zinco & 0.11 & 0,06 & 0,15 & 0,04 & 0.17 & 0,06 & 2 \\
\hline
\end{tabular} \begin{tabular}{|l|l|l|l|l|l|l|l|}
\hline Silica & 52,00 & & & 0,04 & 0,17 & 0,06 & 2 \\
\hline$C O D$ & & & & & & & 1 \\
\hline
\end{tabular} \begin{tabular}{|l|c|c|c|c|c|c|c|}
\hline $\mathrm{COD}$ & & & & & \\
\hline $\mathrm{CO2}$ & 9,4 & 7.1 & 11,7 & 6,2 & 12,6 & 3,2 & 2.0 \\
\hline Ámónio & 0,60 & & & 0,60 & 0,60 & & 1 \\
\hline
\end{tabular} 


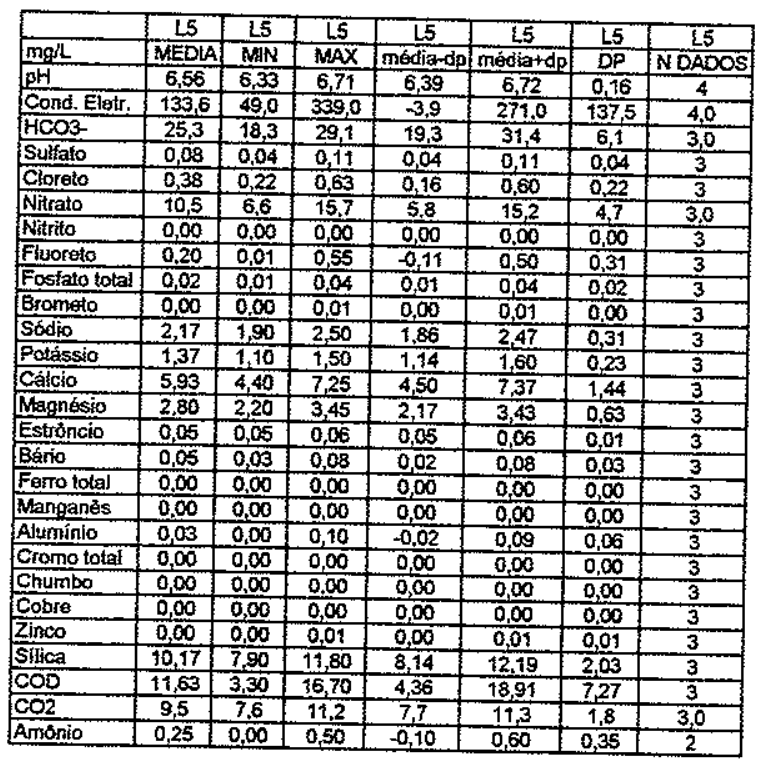

15001500 Ti50

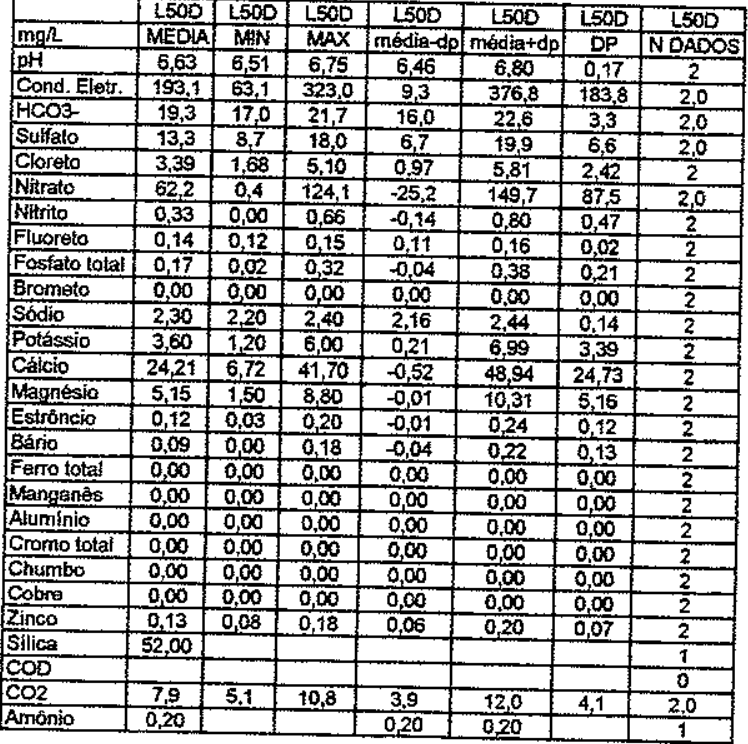

BERTOLO, R.A. - Tese de Doutoramento - 2001
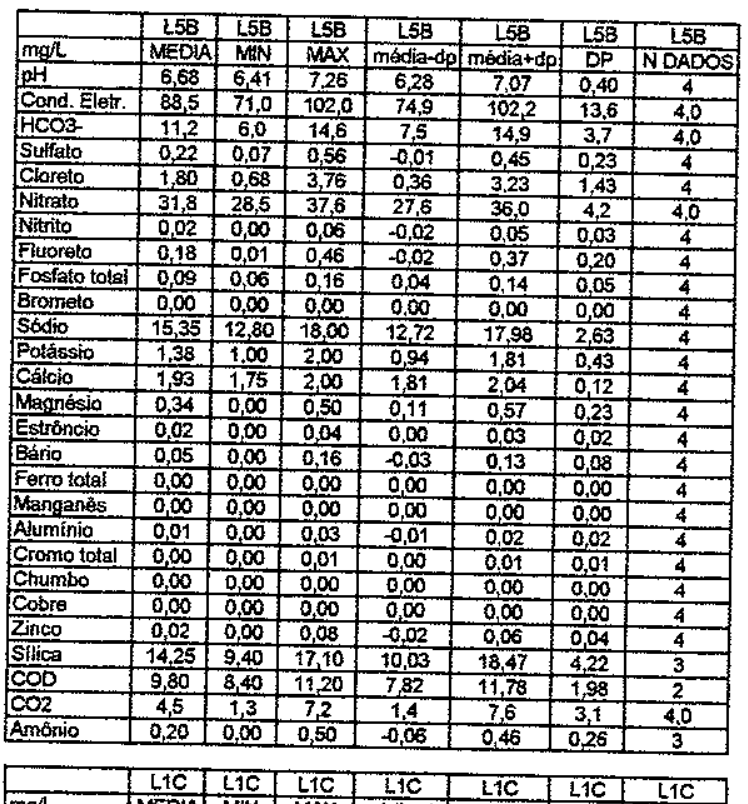

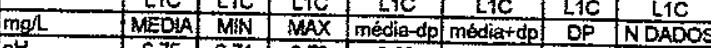
\begin{tabular}{|l|c|c|c|c|c|c|c|}
\hline pH & 6,75 & 6,71 & 6,79 & 6,69 & 6,81 & 0,06 & 2 \\
\hline Cond.Elets. & 116,8 & 52,0 & 181,6 & 25,2 & 208,4 & 31,6 & 2,0 \\
\hline
\end{tabular} \begin{tabular}{|l|c|c|c|c|c|c|c|}
\hline HCO3- & 18,2 & 13,9 & 22,5 & 12,1 & 24,3 & 6,1 & 2,0 \\
\hline Sulfato & 27 & 23 & 3, & 2,0 & 3, & 0.0 \\
\hline
\end{tabular} \begin{tabular}{|l|c|c|c|c|c|c|c|}
\hline Sulfato & 2,7 & 2,3 & 3,4 & 2,3 & 3,3 & 0,6 & 2,0 \\
\hline Cioreto & 2,80 & 0,95 & 4,64 & 0,19 & 5,40 & 2,61 & 2 \\
\hline Nitrato & 33,5 & 0 &, 52 & 127 & 7,7 & 46 & 20 \\
\hline
\end{tabular} \begin{tabular}{|l|c|c|c|c|c|c|c|}
\hline Nitrato & 33,5 & 0,9 & 66,2 & $-12,7$ & 79,7 & 46,2 & 2,0 \\
\hline Nitrito & 0,00 & 0,00 & 0,00 & 0,00 & 0,00 & 0,00 & 2 \\
\hline
\end{tabular}

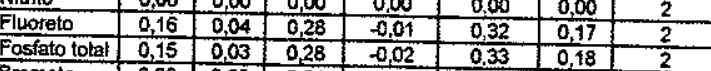
\begin{tabular}{|l|l|l|l|l|l|l|l|}
\hline Brometo & $0,0,00$ & 0,00 & 0,01 & 0.00 & 0,01 & 0,18 & 2 \\
\hline Sontio & 2,03 & 0,00 & 2 \\
\hline
\end{tabular} \begin{tabular}{l|c|c|c|c|c|c|c|}
\hline Sodio & 2,03 & 1,80 & 2,25 & 1,71 & 2,34 & 0,32 & 2 \\
\hline Potássio & 0,85 & 0,50 & 1,20 & 0,36 & 1,34 & 0,49 & 2 \\
\hline
\end{tabular} \begin{tabular}{|l|l|l|l|l|l|l|l|}
\hline Cálcio & 13,38 & 5,75 & 21,00 & 2,59 & 24,16 & 10,78 & 2 \\
\hline
\end{tabular} \begin{tabular}{|l|l|l|l|l|l|l|l|}
\hline Magnesio & 3,75 & 1,50 & 6,00 & 0,57 & 6,93 & 3,18 & 2 \\
\hline Estronncio & 0,06 & 0.03 & 0,10 & 0.01 & 0.12 & 0,05 & 2 \\
\hline
\end{tabular} \begin{tabular}{|l|l|l|l|l|l|l|l|}
\hline Eśrionio & 0,06 & 0,03 & 0,10 & 0.01 & 0.12 & 0,05 & 2 \\
\hline & 0,05 & 0,00 & 0,10 & $-0,02$ & 0,12 & 0,07 & 2 \\
\hline
\end{tabular} \begin{tabular}{|l|l|l|l|l|l|l|l|}
\hline Fama lotal & 0,00 & 0,00 & 0,00 & 0,00 & 0,00 & 0,00 & 2 \\
\hline
\end{tabular}

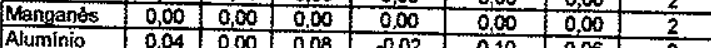
\begin{tabular}{|l|l|l|l|l|l|l|l|}
\hline Aluminio & 0,04 & 0,00 & 0,08 & $-0,02$ & 0,10 & 0,06 & 2 \\
\hline Cromo total & 0,00 & 0,00 & 0,00 & 0,00 & 0,00 & 0,00 & 2 \\
\hline
\end{tabular} \begin{tabular}{|l|c|c|c|c|c|c|c|}
\hline Cromo total & 0,00 & 0,00 & 0,00 & 0,00 & 0,00 & 0,00 & 2 \\
\hline Chumbo & 0,00 & 0,00 & 0,00 & 0,00 & 0,00 & 0,00 & 2 \\
\hline
\end{tabular} \begin{tabular}{l|l|l|l|l|l|l|l|l|}
\hline Cobre & 0,00 & 0,00 & 0,00 & 0,00 & 0,00 & 0,00 & 2 \\
\hline
\end{tabular}

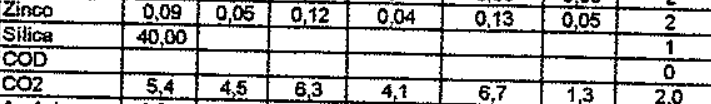
\begin{tabular}{|l|c|c|c|c|c|c|c|}
\hline $\mathrm{CO}$ & 5,4 & 4,5 & 6,3 & 4,1 & 6,7 & 1,3 & 0 \\
\hline Annónio & 0,70 & & & 0,70 & 0,70 & & 1 \\
\hline
\end{tabular}

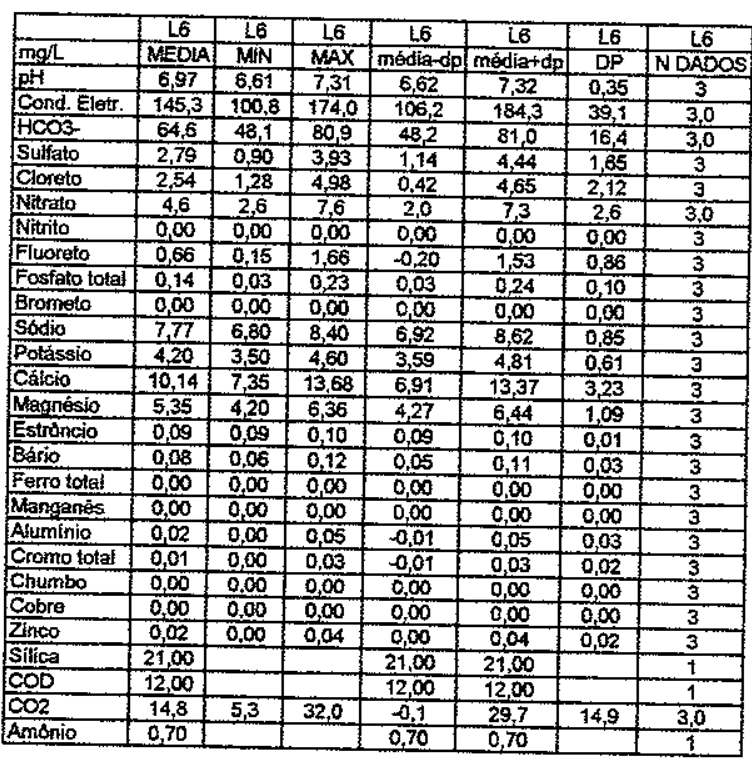

\begin{tabular}{|l|l|l|l|l|l|l|l|}
\hline & L1D & L1D & LID & L1D & L1D & L1D & LID \\
\hline
\end{tabular}

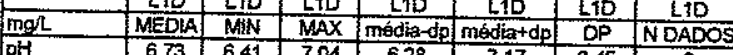
\begin{tabular}{l|c|c|c|c|c|c|c|}
\hline $\mathrm{PH}$ & 6,73 & 6,41 & 7,04 & 6,28 & 7,17 & 0,45 & 2 \\
\hline Cond. Elet. & 148,5 & 72,0 & 2250 & 403 & 2,5 & 1032 & 20 \\
\hline
\end{tabular} \begin{tabular}{l|c|c|c|c|c|c|c|}
\hline Sulfato & 24,7 & 14,9 & 34,4 & 10,9 & 38,4 & 13,7 & 2,0 \\
\hline
\end{tabular} \begin{tabular}{l|l} 
Sulfato & 5,3 \\
\hline Cloreto & 7,33 \\
\hline
\end{tabular} \begin{tabular}{|l|c|c|c|c|c|c|c|}
\hline Citoreto & 7,83 & 0,87 & 14,79 & $-2,01$ & 17,67 & 9,84 & 2 \\
\hline Nitrato & 32,2 & 0,2 & 64,1 & $-13,0$ & 77,3 & 45,1 & 2,0 \\
\hline
\end{tabular} \begin{tabular}{|l|l|l|l|l|l|l|l|}
\hline Nitrito & 0,00 & 0,00 & 0,00 & 0,00 & 0,00 & 0,00 & 2,0 \\
\hline
\end{tabular} \begin{tabular}{ll|l|l|l|l|l|l|l} 
Fluoreto & 0,18 & 0,12 & 0,24 & 0,10 & 0,26 & 0,00 \\
\hline
\end{tabular}

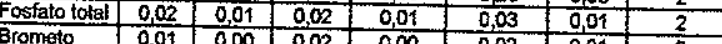
\begin{tabular}{l|l|l|l|l|l|l}
\hline Brometo & 0,01 & 0,00 & 0,02 & 0,00 & 0,02 & 0,01 \\
\hline Sodio & 307 & 1,3 & 150 & 104 & 5,09 & 2,03 \\
\hline
\end{tabular} \begin{tabular}{|l|l|l|l|l|l|l}
\hline Podiós & 3.07 & 1,63 & 4,50 & 1,04 & 5,09 & 2,03 \\
\hline
\end{tabular} \begin{tabular}{|c|c|c|c|}
\hline$, 3,33$ & 1,48 & 2 \\
\hline
\end{tabular}

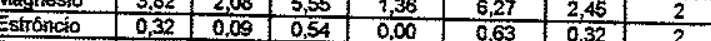
\begin{tabular}{l|l|l|l|l|l|l|l}
\hline Basio & 0,21 & 0,09 & 0,33 & 0,04 & 0,38 & 0,17 & 2 \\
\hline
\end{tabular} \begin{tabular}{|l|l|l|l|l|l|l|l|}
\hline Eerro total & 0.00 & 0,00 & 0,00 & 0,00 & 0,00 & 0,00 & 2 \\
\hline Manganés & 0,00 & 0.00 & 0,00 & 0,00 & 0,00 & 0,00 & 2 \\
\hline
\end{tabular} \begin{tabular}{l|l|l|l|l|l|l} 
Mangands & 0,00 & 0,00 & $0, \infty$ & 0,00 & 0,00 & 0,00 \\
\hline Aluminio & 0,15 & 0,00 & 0,30 & 0,06 & 0,36 & 0,0
\end{tabular} \begin{tabular}{|l|l|l|l|l|l|l|l|}
\hline Cromo total & 0,02 & 0,00 & 0,03 & $-0,06$ & 0,36 & 0,21 & 2 \\
\hline
\end{tabular} \begin{tabular}{|l|l|l|l|l|l|l|l|}
\hline Chumbo & 0,00 & 0,00 & 0,00 & 0,00 & 0,00 & 0,00 & 2 \\
\hline Co
\end{tabular} \begin{tabular}{|l|c|c|c|c|c|c|c|}
\hline Cobre & 0,03 & 0,00 & 0,06 & $-0,09$ & 0,00 & 0,00 & 2 \\
\hline Zinco & 0,20 & 0,09 & 0,30 & 0,05 & 0,07 & 0,04 & 2 \\
\hline
\end{tabular}

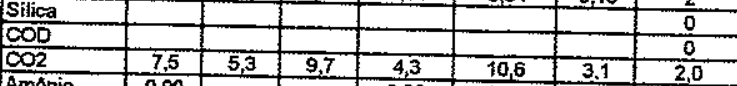
\begin{tabular}{|l|c|c|c|c|c|c|c|}
\hline $\operatorname{CO}^{2}$ & 7,5 & 5,3 & 9,7 & 4,3 & 10,6 & 3.1 & 2,0 \\
\hline Amónio & 0,90 & & & 0,90 & 0,90 & & 1 \\
\hline
\end{tabular} 


\subsection{ANEXO 9-RESULTADOS DE MODELAGENS HIDROQUIMICAS}

\begin{tabular}{|c|c|c|c|c|c|c|c|c|c|c|c|c|c|c|c|c|c|c|c|c|}
\hline \multicolumn{21}{|c|}{$\begin{array}{l}\text { ÍNDICES DE SATURAÇÃO DE MINERAIS } \\
\text { Dolomita }\end{array}$} \\
\hline & \multicolumn{5}{|c|}{ Calcita } & \multicolumn{5}{|c|}{ Dolomita } & \multicolumn{5}{|c|}{ Gipso } & \multicolumn{5}{|c|}{ Anidrita } \\
\hline & abr/99 & ago/99 & $\mathrm{jan} / 00$ & abr/oo & ago/00 & $a b r / 99$ & ago/99 & $\mathrm{jan} / 00$ & abrioo & ago/00 & $a b r / 99$ & ago/99 & jan/00 & abrio0 & ago/00 & $a b r / 99$ & ago/99 & jan/00 & abr/00 & ago/00 \\
\hline L50 & & $-1,69$ & $-0,86$ & $-0,71$ & & & $-4,12$ & $-2,19$ & $-1,89$ & & & $-2,26$ & $-2,48$ & $-3,27$ & & & $-2,50$ & $-2,65$ & $-3,44$ & \\
\hline $\mathrm{L1}$ & & $-2,67$ & $-1,58$ & $-1,48$ & $-2,17$ & & $-5,75$ & $-3,61$ & $-3,33$ & $-4,91$ & & $-3,22$ & $-3,23$ & $-3,04$ & $-3,12$ & & $-3,41$ & $-3,44$ & $-3,20$ & $-3,35$ \\
\hline L2 & & $-2,56$ & & $-1,54$ & $-2,46$ & & $-5,50$ & & $-3,41$ & $-5,65$ & & $-3,61$ & & $-3,59$ & $-3,62$ & & $-3,79$ & & $-3,74$ & $-3,88$ \\
\hline L.3 & $-2,43$ & $-2,62$ & & $-2,07$ & $-2,55$ & $-4,88$ & $-5,24$ & & $-4,18$ & $-5,14$ & $-5,29$ & $-5,47$ & & $-4,68$ & $-4,57$ & $-5,47$ & $-5,68$ & & $-4,88$ & $-4,77$ \\
\hline$L 4$ & & $-2,31$ & & $-1,44$ & $-2,33$ & & $-4,61$ & & $-2,76$ & $-4,69$ & & $-4,34$ & & $-4,72$ & $-4,48$ & & $-4,53$ & & $-4,88$ & $-4,72$ \\
\hline L5 & & $-2,36$ & & $-2,30$ & $-2,89$ & & $-4,76$ & & $-4,66$ & $-5,84$ & & $-5,13$ & & $-5,05$ & $-5,61$ & & $-5,32$ & & $-5,22$ & $-5,85$ \\
\hline L6 & & $-1,68$ & & $-1,20$ & $-1,84$ & & $-3,41$ & & $-2,34$ & $-3,68$ & & $-3,23$ & & $-4,01$ & $-3,49$ & & $-3,42$ & & $-4,18$ & $-3,73$ \\
\hline$L 7$ & $-2,50$ & $-2,29$ & & $-2,81$ & $-2,96$ & $-4,87$ & $-4,46$ & & $-5,50$ & $-5,94$ & $-4,74$ & $-4,48$ & & $-5,08$ & $-5,17$ & $-4,95$ & $-4,67$ & & $-5,28$ & $-5,38$ \\
\hline L8 & & $-4,67$ & $-3,97$ & & $-2,79$ & & $-9,25$ & $-7,76$ & & $-5,70$ & & $-5,73$ & $-4,56$ & & $-4,99$ & & $-5,93$ & $-4,76$ & & $-5,23$ \\
\hline 19 & $-4,50$ & $-4, \overline{48}$ & $-3,96$ & $-4,64$ & $-5,10$ & $-8,97$ & $-8,96$ & $-7,89$ & $-9,25$ & $-10,16$ & $-5,16$ & $-4,93$ & $-5,00$ & $-5,10$ & $-5,13$ & $-5,34$ & $-5,14$ & $-5,20$ & $-5,29$ & $-5,36$ \\
\hline PM & & $-0,48$ & $-1,56$ & $-1,50$ & $-0,85$ & & $-1,70$ & $-3,67$ & $-3,58$ & $-2,07$ & & $-3,14$ & $-3,79$ & $-3,24$ & $-3,49$ & & $-3,34$ & $-3,97$ & $-3,42$ & $-3,69$ \\
\hline L50C & & & $-1,79$ & $-2,10$ & & & & $-4,02$ & $-4,50$ & & & & $-2,04$ & $-3,80$ & & & & $-2,21$ & $-3,97$ & \\
\hline L50D & & & $-1,89$ & $-2,47$ & & & & $-4,16$ & $-5,30$ & & & & $-2,19$ & $-3,11$ & & & & $-2,36$ & $-3,29$ & \\
\hline L50E & & & & $-1,48$ & & & & & $-3,45$ & & & & & $-4,23$ & & & & & $-4,42$ & \\
\hline L1B & & $-0,39$ & 0,42 & 0,65 & $-0,21$ & & $-1,18$ & 0,50 & 0,97 & $-0,77$ & & $-2,63$ & $-2,66$ & $-2,07$ & $-2,04$ & & $-2,80$ & $-2,88$ & $-2,26$ & $-2,31$ \\
\hline L1C & & & $-2,13$ & $-2,33$ & & & & $-4,51$ & $-4,94$ & & & & $-3,15$ & $-3,76$ & & & & $|-3,32|$ & $-3,91$ & \\
\hline L1D & & & $-2,32$ & $-1,53$ & & & & $-4,99$ & $-3,44$ & & & & $-2,67$ & $-3,43$ & & & & $-2,84$ & $-3,60$ & \\
\hline L1E & & & & $-2,27$ & & & & & $-4,83$ & & & & & $-3,93$ & & & & & $-4,11$ & \\
\hline L5B & & $-2,61$ & $-3,47$ & $-3,58$ & $-3,70$ & & $-5,58$ & $-7,39$ & $-7,43$ & & & $-5,54$ & $-4,82$ & $-5,47$ & $-5,70$ & & $-5,75$ & $-5,04$ & $-5,66$ & $-5,95$ \\
\hline
\end{tabular}

BERTOLO, R.A. - Tese de Doutoramento - 2001 


\begin{tabular}{|c|c|c|c|c|c|c|c|c|c|c|c|c|c|c|c|c|c|c|c|c|}
\hline & & & lagnesita & & & INDICE & ES DE & $\begin{array}{l}\text { SATU } \\
\text { Fluorita }\end{array}$ & $\mathrm{RAC} \overline{\mathbf{A}}$ & ODE & MINER & $\underbrace{\text { AIS - }}_{\text {Sillic }}$ & contin & mucáo & & & & alcedóni & & \\
\hline & $a b r / 99$ & ago/99 & jan/00 & $\mathrm{abr} / 00$ & ago/00 & abr/99 & ago/99 & jan/oo & $a b r / 00$ & ago/00 & $\mathrm{abr} / 99$ & ago/99 & jan/00 & $\mathrm{abr} / 00$ & ago/00 & \begin{tabular}{|l|}
$\mathrm{abr} / 99$ \\
\end{tabular} & ago/99 & jan $/ 00$ & abr/0o & ago/00 \\
\hline$L 50$ & & $-2,93$ & $-1,82$ & $-1,67$ & & & $-1,99$ & $-2,89$ & $-2,26$ & & & $-0,41$ & $-0,14$ & $-0,29$ & & & 0,10 & 0,36 & 0,22 & \\
\hline $\mathrm{L1}$ & & $-3,57$ & $-2,53$ & $-2,35$ & $-3,24$ & & $-3,06$ & $-3,13$ & $-2,29$ & 0,01 & & $-0,69$ & $-0,28$ & $-0,48$ & & & $-0,19$ & 0,22 & 0,02 & \\
\hline$L 2$ & & $-3,43$ & & $-2,36$ & $-3,69$ & & $-3,84$ & & $-2,97$ & $-0,28$ & & $-0,45$ & & $-0,46$ & & & 0,06 & & 0,05 & \\
\hline L3 & $-2,94$ & $-3,12$ & & $-2,61$ & $-3,08$ & $-4,66$ & $-5,00$ & & $-2,15$ & $-0,53$ & & $-0,83$ & & $-0,61$ & & & $-0,32$ & 0,25 & $-0,11$ & \\
\hline$L 4$ & & $-2,79$ & & $-1,81$ & $-2,86$ & & $-3,62$ & & $-3,31$ & $-0,74$ & & $-0,57$ & & $-0,51$ & & & $-0,06$ & 0,25 & $-0,01$ & \\
\hline L5 & & $-2,89$ & & $-2,85$ & $-3,45$ & & $-4,53$ & & $-5,57$ & $-2,24$ & & $-0,89$ & & $-0,73$ & $-0,69$ & & $-0,38$ & 0,37 & $-0,23$ & $-0,19$ \\
\hline L6 & & $-2,22$ & & $-1,63$ & $-2,34$ & & $-2,92$ & & $-2,92$ & $-0,99$ & & & & $-0,48$ & & & & & 0,02 & \\
\hline$L 7$ & $-2,86$ & $-2,66$ & & $-3,18$ & $-3,47$ & $-3,00$ & $-4,77$ & & $-3,35$ & $-1,99$ & & $-0,85$ & & $-0,74$ & $-0,61$ & & $-0,35$ & & $-0,23$ & $-0,10$ \\
\hline L8 & & $-5,07$ & $-4,28$ & & $-3,41$ & & $-6,10$ & $-5,16$ & & $-4,32$ & & $-0,75$ & $-0,26$ & & $-0,49$ & & $-0,24$ & & & 0,02 \\
\hline$\angle 9$ & $-4,96$ & $-4,98$ & $-4,42$ & $-5,10$ & $-5,56$ & $-4,91$ & $-6,33$ & $-4,89$ & $-3,56$ & $-3,52$ & $-0,63$ & $-0,65$ & $-0,25$ & $-0,37$ & $-0,43$ & $-0,13$ & $-0,14$ & & 0,14 & 0,08 \\
\hline $\mathrm{PM}$ & & $-1,72$ & $-2,61$ & $-2,57$ & $-1,72$ & & $-2,39$ & $-4,84$ & $-4,82$ & $-3,42$ & & $-0,69$ & $-0,13$ & $-0,37$ & $-0,44$ & & $-0,19$ & & 0,13 & 0,07 \\
\hline $50 \mathrm{C}$ & & & $-2,72$ & $-2,90$ & & & & $-3,69$ & $-2,56$ & & & & $-0,09$ & & & & & $0, \overline{41}$ & & \\
\hline$\angle 50 D$ & & & $-2,76$ & $-3,32$ & & & & $-2,70$ & $-3,17$ & & & & $-0,09$ & & & & & 0,42 & & \\
\hline$\angle 50 E$ & & & & $-2,46$ & & & & & $-2,80$ & & & & & & & & & & & \\
\hline $1 \mathrm{~B}$ & & $-1,29$ & $-0,42$ & $-0,17$ & $-1,05$ & & $-0,76$ & $-1,03$ & $-0,81$ & 0,94 & & $-0,63$ & & $-0,55$ & & & $-0,12$ & & $-0,04$ & \\
\hline-10 & & & $-2,87$ & $-3,10$ & & & & $-3,90$ & $-2,71$ & & & & $-0,20$ & & & & & 0,30 & & \\
\hline-10 & & & $-3,16$ & $-2,39$ & & & & $-2,59$ & $-3,05$ & & & & $-0,21$ & & & & & 0,29 & & \\
\hline$-1 E$ & & & & $-3,05$ & & & & & $-4,00$ & & & & & $-0,38$ & & & & & 0,13 & \\
\hline L5B & & $-3,47$ & $-4,41$ & $-4,34$ & & & $-6,02$ & $-3,58$ & $-4,39$ & $-2,62$ & & $-0,79$ & & $-0,55$ & $-0,51$ & & $-0,29$ & & $-0,05$ & 0,00 \\
\hline
\end{tabular}

BERTOLO, RA. - Tese de Doutoramento - 2001 


\section{DADOS DE ENTRADA DO MODELO INVERSO L3-L5 (AGOSTO/99)}

\section{PARTE I DO RELATÓRIO: DADOS DE ENTRADA DO MODELO L3-L5 - AGOSTO/99}

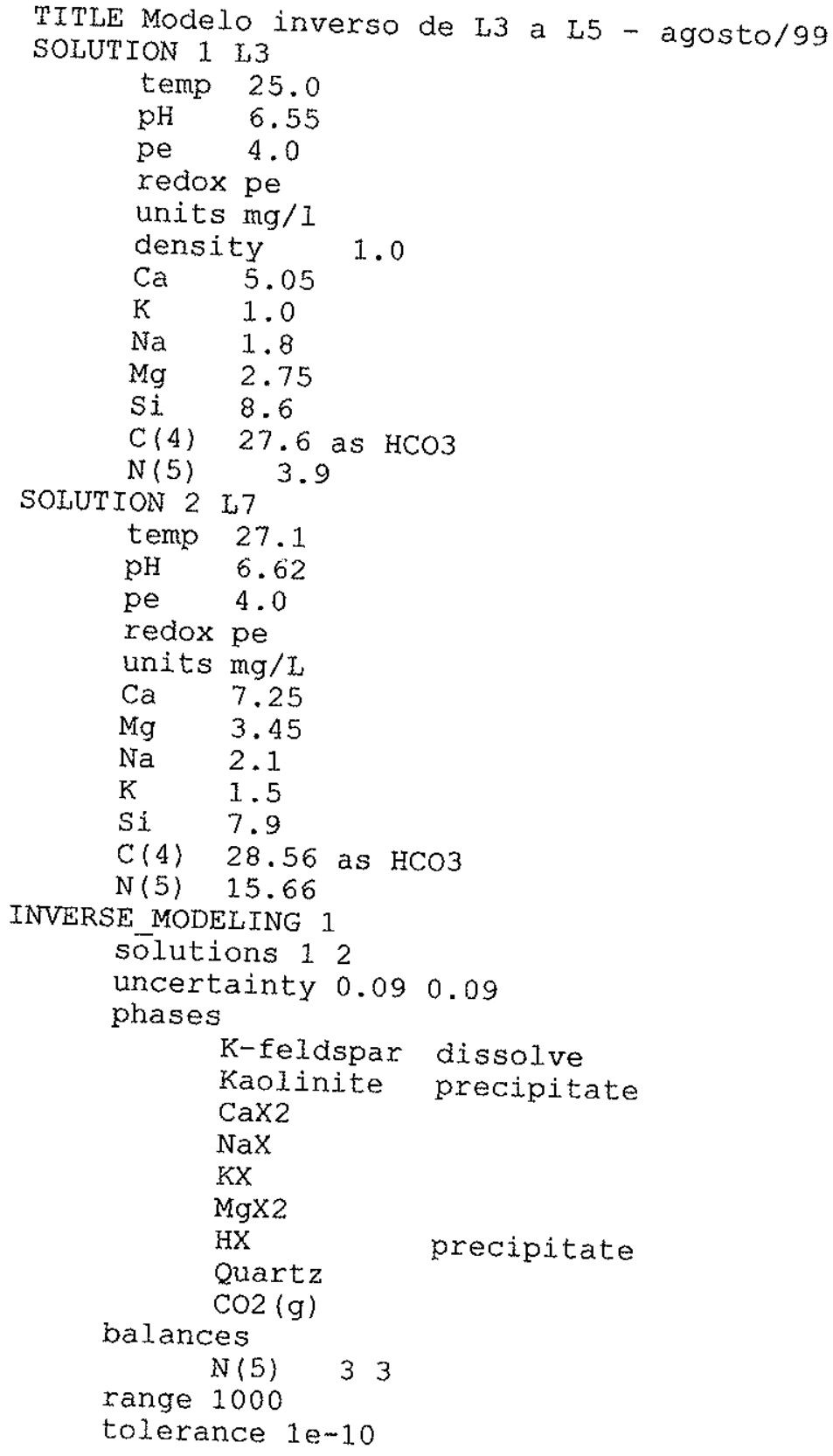




\section{DADOS DE ENTRADA DO MODELO INVERSO L5-L7 (AGOSTO/2000)}

PARTE I DO RELATÓRIO: DADOS DE ENTRADA DO MODELO L5-L7 - AGOSTO/2000

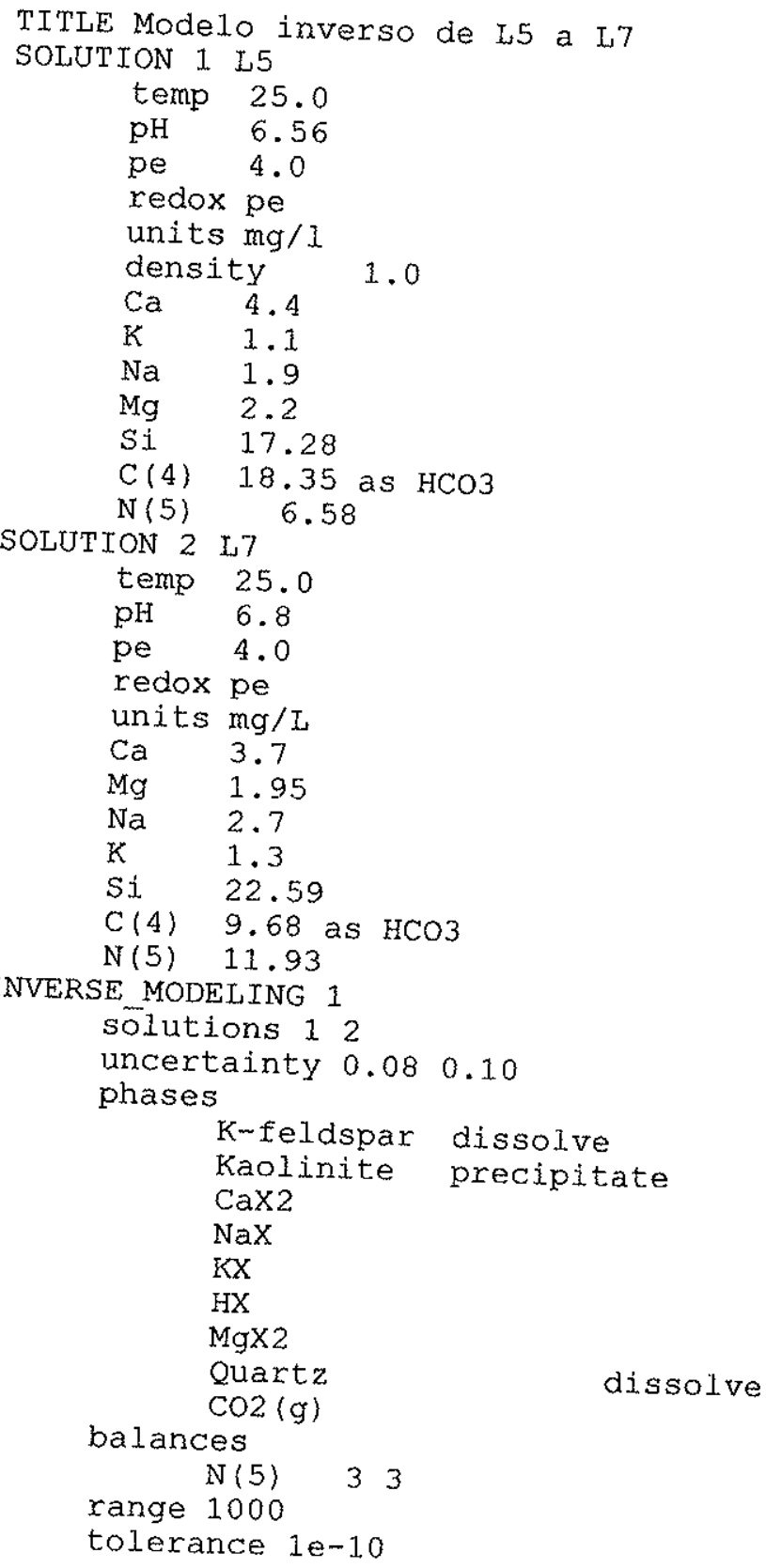


EXEMPLO DE RELATÓRIO COM RESULTADO DE MODELAGEM INVERSA

PARTE III DO RELATÓRIO - RESULTADO DE UMA POSSIBILIDADE DE MODELAGEM INVERSA

Beginning of inverse modeling calculations.

Solution 1: L3

$\begin{array}{rr}\mathrm{pH} & 6.550 \mathrm{e}+00 \\ \mathrm{Al} & 0.000 \mathrm{e}+00 \\ \text { Alkalinity } & 2.805 \mathrm{e}-04 \\ \mathrm{C}(-4) & 0.000 \mathrm{e}+00 \\ \mathrm{C}(4) & 4.523 \mathrm{e}-04 \\ \mathrm{Ca} & 1.260 \mathrm{e}-04 \\ \mathrm{H}(0) & 0.000 \mathrm{e}+00 \\ \mathrm{~K} & 2.558 \mathrm{e}-05 \\ \mathrm{Mg} & 1.131 \mathrm{e}-04 \\ \mathrm{~N}(-3) & 0.000 \mathrm{e}+00 \\ \mathrm{~N}(0) & 0.000 \mathrm{e}+00 \\ \mathrm{~N}(3) & 0.000 \mathrm{e}+00 \\ \mathrm{~N}(5) & 2.785 \mathrm{e}-04 \\ \mathrm{Na} & 7.830 \mathrm{e}-05+ \\ \mathrm{O}(0) & 0.000 \mathrm{e}+00+ \\ \mathrm{Si} & 1.431 \mathrm{e}-04 \\ \mathrm{X} & 0.000 \mathrm{e}+00+\end{array}$

$+\quad 0.000 \mathrm{e}+00$

$+\quad 0.000 \mathrm{e}+00$

$-1.870 \mathrm{e}-05$

$0.000 e+00$

$-3.010 e-05$

1. $260 \mathrm{e}-05$

$0.000 e+00$

$0.000 e+00$

$1.131 \mathrm{e}-05$

$0.000 \mathrm{e}+00$

$0.000 e+00$

$0.000 \mathrm{e}+00$

$8.969 e-05$

$0.000 e+00$

$0.000 e+00$

$0.000 e+00$

$0.000 e+00$

Solution 2: L5

$\begin{array}{rr}\text { pH } & 6.620 e+00+ \\ \text { A.l } & 0.000 e+00+ \\ \text { Alkalinity } & 3.115 e-04+ \\ \text { C }(-4) & 0.000 e+00+ \\ \mathrm{C}(4) & 4.681 e-04+ \\ \mathrm{Ca} & 1.809 \mathrm{e}-04+ \\ \mathrm{H}(0) & 0.000 \mathrm{e}+00+ \\ \mathrm{K} & 3.836 \mathrm{e}-05+ \\ \mathrm{Mg} & 1.419 \mathrm{e}-04+ \\ \mathrm{N}(-3) & 0.000 \mathrm{e}+00+ \\ \mathrm{N}(0) & 0.000 \mathrm{e}+00+ \\ \mathrm{N}(3) & 0.000 \mathrm{e}+00+ \\ \mathrm{N}(5) & 1.118 \mathrm{e}-03+ \\ \mathrm{Na} & 9.135 \mathrm{e}-05+ \\ \mathrm{O}(0) & 0.000 \mathrm{e}+00+ \\ \mathrm{Si} & 1.315 \mathrm{e}-04+ \\ \mathrm{X} & 0.000 \mathrm{e}+00+\end{array}$

Phase mole transfers:

$\begin{array}{rr}\text { K-feldspar } & 8.083 e-05 \\ \text { Kaolinite } & -4.042 e-05 \\ \text { CaX2 } & 2.421 e-05 \\ \text { NaX } & 1.305 e-05 \\ \text { KX } & -6.805 e-05 \\ \text { MgX2 } & 3.292 e-06 \\ \text { Quartz } & -1.733 e-04 \\ \text { Co2 }(g) & 9.260 e-05\end{array}$

$0.000 e+00$

$0.000 e+00$

3. $115 e-05$

$0.000 e+00$

$4.676 \mathrm{e}-05$

$-1.809 e-05$

$0.000 e+00$

$0.000 e+00$

$-1.419 \mathrm{e}-05$

$0.000 e+00$

$0.000 e+00$

$0.000 e+00$

$-7.500 e-04$

$0.000 e+00$

$0.000 e+00$

$0.000 e+00$

$0.000 e+00$

$$
\begin{array}{r}
\text { Minimum } \\
6.139 e-05 \\
-4.509 e-05 \\
2.420 e-05 \\
0.000 e+00 \\
-8.379 e-05 \\
3.292 e-06 \\
-2.195 e-04 \\
2.323 e-05
\end{array}
$$

$=$

. 000 et00

2. $618 e-04$

$=0.000 \mathrm{e}+00$

$=4.222 \mathrm{e}-04$

$=1.386 \mathrm{e}-04$

$=0.000 \mathrm{e}+00$

$=2.558 \mathrm{e}-05$

$=1.244 \mathrm{e}-04$

$=0.000 \mathrm{e}+00$

$=0.000 e+00$

$=0.000 e+00$

$=3.681 \mathrm{e}-04$

$=7.830 \mathrm{e}-05$

$=0.000 \mathrm{e}+00$

$=1.431 \mathrm{e}-04$

$=0.000 e+00$

End of simulation.

$$
\begin{aligned}
& =\quad 6.620 \mathrm{e}+00 \\
& =\quad 0.000 \mathrm{e}+00 \\
& =\quad 3.426 \mathrm{e}-04 \\
& =\quad 0.000 \mathrm{e}+00 \\
& =\quad 5.148 \mathrm{e}-04 \\
& =1.628 \mathrm{e}-04 \\
& =\quad 0.000 \mathrm{e}+00 \\
& =\quad 3.836 \mathrm{e}-05 \\
& =\quad 1.277 \mathrm{e}-04 \\
& =\quad 0.000 \mathrm{e}+00 \\
& =0.000 \mathrm{e}+00 \\
& =\quad 0.000 \mathrm{e}+00 \\
& =\quad 3.681 \mathrm{e}-04 \\
& =\quad 9.135 \mathrm{e}-05 \\
& =\quad 0.000 \mathrm{e}+00 \\
& =1.315 \mathrm{e}-04 \\
& =\quad 0.000 \mathrm{e}+00
\end{aligned}
$$

$\begin{aligned} \text { Maximum } & \\ 9.019 e-05 & \text { KAlsi308 } \\ -3.069 e-05 & \text { Al2Si205(OH) } 4 \\ 3.860 e-05 & \text { CaX2 } \\ 2.880 e-05 & \text { NaX } \\ -5.499 e-05 & \text { KX } \\ 1.769 e-05 & \text { MgX2 } \\ -1.070 e-04 & \text { SiO2 } \\ 1.078 e-04 & \text { CO2 }\end{aligned}$




\subsection{ANEXO 10 - DADOS DE ENTRADA DAS MODELAGENS DE TRANSPORTE}

SIMULAÇÃO DE CONTAMINANTES EM FOSSA

Modelo simulando área de infiltração de fossa, com a determinação da taxa de infiltração necessária para tempo de transito do contaminante igual a 50 dias. Dados hidrodinâmicos idênticos ao modelo Urânia $A$.

\section{Profile. VS2D/T profile1 \\ Model Settings}

[VS2DT] Case Settings

\begin{tabular}{|l|c|c|}
\hline \multicolumn{1}{|c|}{ Parameter } & Value & Units \\
\hline Initial Conditions: Water & Uniform Pressure Head & $(-)$ \\
Initial Conditions: Chemical & Uniform Concentration & $(-)$ \\
Max. Simulation Time & 365 & $($ days $)$ \\
Evapotranspiration & No evapotranspiration & $(-)$ \\
Transport Simulation & No adsorption or ion exchange & $(-)$ \\
Soil Hydraulic Function & van Genuchten & $(-)$ \\
\hline
\end{tabular}

[VS2DT] Solver Settings

\begin{tabular}{|l|c|c|}
\hline \multicolumn{1}{|c|}{ Parameter } & Value & Units \\
\hline Flow Closure Criteria & 0.00100 & $(\mathrm{~m})$ \\
Relaxation & 0.900 & $(-)$ \\
Weighting Hydr. Cond. & 0.5 & $(-)$ \\
Transport Closure Criteria & 0.10 & $(\mathrm{mg} / \mathrm{l})$ \\
Min. Herations & 2 & $(-)$ \\
Max. Herations & 50 & $(-)$ \\
Space Differencing & Center-in-Space & $(-)$ \\
Time Differencing & Center-in-Time & $(-)$ \\
Maximum Number of Time Steps & 5000 & $(-)$ \\
Display Balance Every Time Step & no & $(-)$ \\
\hline
\end{tabular}

VS2DT] Flow Upper Boundary
\begin{tabular}{|c|c|c|c|c|c|}
\hline$\#$ & Start Time & End Time & Type & Value & Allowed Ponding (m) \\
\hline 1 & 0 & 365 & Flux (m/day) & 0.022 & 1 \\
\hline
\end{tabular}

VS2DTJ Flow Lower Boundary
\begin{tabular}{|c|c|c|c|c|}
\hline$\#$ & Start Time & End Time & Type & Value \\
\hline 1 & 0 & 50 & Pressure Head $(\mathrm{m})$ & -1 \\
2 & $\mathbf{5 0}$ & $\mathbf{3 6 5}$ & Pressure Head $(\mathrm{m})$ & 0 \\
\hline
\end{tabular}

[VS2DT] Transport Upper Boundary

\begin{tabular}{|c|c|c|c|c|c|}
\hline$\#$ & Start Time & End Time & Type & Value & $\begin{array}{c}\text { Inflow Concentration } \\
\text { (mo/l) }\end{array}$ \\
\hline 1 & 0 & 365 & $\begin{array}{c}\text { No Specified Boundary } \\
(-)\end{array}$ & No Specified Boundary & 50 \\
\hline
\end{tabular}

VS2DTI Transport Lower Boundary

\begin{tabular}{|c|c|c|c|c|c|}
\hline$\#$ & Start Time & End Time & Type & Value & $\begin{array}{c}\text { Inflow Concentration } \\
\text { (mg/l) }\end{array}$ \\
\hline 1 & 0 & $\mathbf{3 6 5}$ & $\begin{array}{c}\text { No Specified Boundary } \\
(-)\end{array}$ & No Specified Boundary & 0 \\
\hline
\end{tabular}

[VS2DT] Profile Initial Conditions

\begin{tabular}{|l|c|c|}
\hline \multicolumn{1}{|c|}{ Parameter } & Value & Units \\
\hline $\begin{array}{l}\text { Pressure Head } \\
\text { Initial Concentration }\end{array}$ & -1.00000 & $(\mathrm{~m})$ \\
& $(\mathrm{mg} / \mathrm{l})$
\end{tabular}


[VS2DT] Stress Period Defaults

\begin{tabular}{|l|c|c|}
\hline \multicolumn{1}{|c|}{ Parameter } & Value & Units \\
\hline Initial Time Step & 0.1 & (days) \\
Time Step Multiplier & 2 & $(-)$ \\
Maximum Time Step & 10.0000000 & (days) \\
Minimum Time Step & 0.0100000 & (days) \\
Reduction Factor & 0.40 & $(-)$ \\
Maximum Head Change & 1.00000 & $(\mathrm{~m})$ \\
Head Criterion & 0.00100 & $(\mathrm{~m})$ \\
\hline
\end{tabular}

Profile Structure

\begin{tabular}{|c|c|c|c|}
\hline Layer & $\operatorname{Top}(m)$ & Bottom (m) & Thickness (m) \\
\hline [01] ARE 0,0-1,5 & 0.0000 & -1.5000 & 1.5000 \\
\hline [02] ARE 1,5-2,5 & -1.5000 & -2.5000 & 1.0000 \\
\hline 103] ARESILT 2,5-3,5 & -2.5000 & -3.5000 & 1.0000 \\
\hline$\frac{C A}{204}[0$ ARESHLT 3,5-4,5 & -3.5000 & -4.5000 & 1.0000 \\
\hline [OD] ARESILT 4,5-5,5 & -4.5000 & -5.5000 & 1.0000 \\
\hline [06] ARESILT 5,5-6,5 & -5.5000 & -6.5000 & 1.0000 \\
\hline 207 ARESILT $6,5-7,5$ & -6.5000 & -7.0000 & 0.5000 \\
\hline
\end{tabular}

Soil Parameters

IGUAL AO MODELO URÂNIA A

Transport Parameters

(IGUAL PARA TODAS AS PROFUNDIDADES)

\begin{tabular}{|l|c|c|}
\hline \multicolumn{1}{|c|}{ Parameter } & Value & Units \\
\hline Alpha L & 0.30000 & (m) \\
Dm (Molecular Diffusion) & 0 & (cm2/day) \\
Decay Constant & 0 & (hr) \\
Bulk density & 1.400 & $(\mathrm{~g} / \mathrm{cu} . \mathrm{cm})$ \\
\hline
\end{tabular}



de $1000 \mathrm{mg} / \mathrm{L}$. Dados hidrodinâmicos idênticos ao modelo Urânia A.

\section{Profile. VS2D/T profile1}

Model Settings

[VS2DT] Case Settings

\begin{tabular}{|l|c|c|}
\multicolumn{1}{|c|}{ Parameter } & Value & Units \\
\hline Evapotranspiration & No evapotranspiration & $(-)$ \\
Transport Simulation & No adsorption or ion exchange & $(-)$ \\
Soil Hydraulic Function & van Genuchten & $(-)$ \\
Initial Conditions: Water & Nonuniform Pressure Head & $(-)$ \\
Initial Conditions: Chemical & Uniform Concentration & $(-)$ \\
Max. Simulation Time & 730 & (days) \\
\hline
\end{tabular}

VS2DT] Solver Settings

\begin{tabular}{|l|c|c|}
\hline \multicolumn{1}{|c|}{ Parameter } & Value & Units \\
\hline Weighting Hydr. Cond. & 0.5 & $(-)$ \\
Transport Closure Criteria & 1 & $(-)$ \\
Min. Iterations & 2 & $(-)$ \\
Max. Iterations & 500 & $(-)$ \\
Space Differencing & Center-in-Space & $(-)$ \\
Time Differencing & Center-in-Time & $(-)$ \\
Maximum Number of Time Steps & 50000 & $(-)$ \\
Display Balance Every Time Step & no \\
Flow Closure Criteria & 0.00100 & $(\mathrm{~m})$ \\
Relaxation & 0.900 & $(-)$ \\
\hline
\end{tabular}

VS2DTI Flow Upper Boundary

\begin{tabular}{|c|c|c|c|c|c|}
\hline$\#$ & Start Time & End Time & Type & Value & Allowed Ponding (m) \\
\hline 1 & $\mathbf{0}$ & 99 & Pressure Head (m) & -1.34 & 0.01000 \\
\hline 2 & 99 & 110 & Pressure Head (m) & -1.9 & 0.01000 \\
\hline 3 & 110 & 113 & Pressure Head (m) & -2.44 & 0.01000 \\
\hline 4 & 113 & 117 & Pressure Head (m) & -3.26 & 0.01000 \\
\hline $\mathbf{5}$ & 117 & 120 & Pressure Head (m) & -4.07 & 0.01000 \\
\hline 6 & 120 & 124 & Pressure Head (m) & -5.16 & 0.01000 \\
\hline 7 & 124 & 131 & Pressure Head (m) & -5.97 & 0.01000 \\
\hline 8 & 131 & 145 & Pressure Head (m) & -7.33 & 0.01000 \\
\hline 9 & 145 & 250 & Pressure Head (m) & -8.14 & 0.01000 \\
\hline 10 & 250 & 254 & Pressure Head (m) & -6.92 & 0.01000 \\
\hline 11 & 254 & 268 & Pressure Head (m) & -3.53 & 0.01000 \\
\hline 12 & 258 & 260 & Pressure Head (m) & -1.4 & 0.01000 \\
\hline 13 & 260 & 266 & Pressure Head (m) & -1.7 & 0.01000 \\
\hline 14 & 266 & 270 & Pressure Head (m) & -2.04 & 0.01000 \\
\hline 15 & 270 & 274 & Pressure Head (m) & -1.7 & 0.01000 \\
\hline 16 & 274 & 282 & Pressure Head (m) & -2.25 & 0.01000 \\
\hline 17 & 282 & 288 & Pressure Head (m) & -2.77 & 0.01000 \\
\hline 18 & 288 & 295 & Pressure Head (m) & -4.25 & 0.01000 \\
\hline 19 & 295 & 318 & Pressure Head (m) & -5.32 & 0.01000 \\
\hline 20 & 318 & 320 & Pressure Head (m) & -3.53 & 0.01000 \\
\hline 21 & 320 & 341 & Pressure Head (m) & -1.58 & 0.01000 \\
\hline 22 & 341 & 344 & Pressure Head (m) & -1.9 & 0.01000 \\
\hline 23 & 344 & 365 & Pressure Head (m) & -1.37 & 0.01000 \\
\hline 24 & 365 & 464 & Pressure Head (m) & -1.34 & 0.01000 \\
\hline 25 & 464 & 475 & Pressure Head (m) & -1.9 & 0.01000 \\
\hline 26 & 475 & 478 & Pressure Head (m) & -2.44 & 0.01000 \\
\hline 27 & 478 & 482 & Pressure Head (m) & -3.26 & 0.01000 \\
\hline 28 & 482 & 485 & Pressure Head (m) & -4.07 & 0.01000 \\
\hline 29 & 485 & 489 & Pressure Head (m) & -5.16 & 0.01000 \\
\hline 30 & 489 & 496 & Pressure Head (m) & -5.97 & 0.01000 \\
\hline 31 & 496 & 510 & Pressure Head (m) & -7.33 & 0.01000 \\
\hline 32 & 510 & 615 & Pressure Head (m) & -8.14 & 0.01000 \\
\hline 33 & 615 & 619 & Pressure Head (m) & -6.92 & 0.01000 \\
\hline 34 & 619 & 623 & Pressure Head (m) & -3.53 & 0.01000 \\
\hline 35 & 623 & 625 & Pressure Head (m) & -1.4 & 0.01000 \\
\hline 36 & 625 & 631 & Pressure Head (m) & -1.7 & 0.01000 \\
\hline 37 & 631 & 634 & Pressure Head (m) & -2.04 & 0.01000 \\
\hline 38 & 634 & 638 & Pressure Head (m) & -1.7 & 0.01000 \\
\hline 39 & 638 & 647 & Pressure Head (m) & -2.25 & 0.01000 \\
\hline
\end{tabular}




\begin{tabular}{|c|c|c|c|c|c|}
\hline$\#$ & Start Time & End Time & Type & Value & Allowed Ponding (m) \\
\hline 40 & $\mathbf{6 4 7}$ & $\mathbf{6 6 3}$ & Pressure Head $(\mathrm{m})$ & -2.77 & 0.01000 \\
$\mathbf{4 1}$ & $\mathbf{6 5 3}$ & $\mathbf{6 6 0}$ & Pressure Head $(\mathrm{m})$ & -4.25 & 0.01000 \\
$\mathbf{4 2}$ & $\mathbf{6 6 0}$ & $\mathbf{6 8 3}$ & Pressure Head $(\mathrm{m})$ & -5.32 & 0.01000 \\
$\mathbf{4 3}$ & $\mathbf{6 8 3}$ & $\mathbf{6 8 5}$ & Pressure Head $(\mathrm{m})$ & -3.53 & 0.01000 \\
$\mathbf{4 4}$ & $\mathbf{6 8 5}$ & $\mathbf{7 0 6}$ & Pressure Head $(\mathrm{m})$ & -1.58 & 0.01000 \\
$\mathbf{4 5}$ & $\mathbf{7 0 6}$ & $\mathbf{7 0 9}$ & Pressure Head $(\mathrm{m})$ & -1.9 & 0.01000 \\
$\mathbf{4 6}$ & $\mathbf{7 0 9}$ & $\mathbf{7 3 0}$ & Pressure Head $(\mathrm{m})$ & -1.37 & 0.01000 \\
\hline
\end{tabular}

VS2DT] Flow Lower Boundary

\begin{tabular}{|c|c|c|c|c|}
\hline$\#$ & Start Time & End Time & Type & Value \\
\hline 1 & 0 & 20 & Pressure Head (m) & -7.87 \\
\hline 2 & 20 & 84 & Pressure Head (m) & -8.14 \\
\hline 3 & 84 & 86 & Pressure Head (m) & -7.73 \\
\hline 4 & 86 & 89 & Pressure Head (m) & -4.61 \\
\hline 5 & 89 & 117 & Pressure Head (m) & -2.04 \\
\hline 6 & 117 & 127 & Pressture Head (m) & -1.63 \\
\hline 7 & 127 & 166 & Pressure Head (m) & -1.76 \\
\hline 8 & 166 & 201 & Pressure Head (m) & -2.04 \\
\hline 9 & 201 & 222 & Pressure Head (m) & -2.31 \\
\hline 10 & 222 & 272 & Pressure Head (m) & -2.44 \\
\hline 11 & 272 & 327 & Pressure Head (m) & -2.71 \\
\hline 12 & 327 & 362 & Pressure Head (m) & -2.99 \\
\hline 13 & 362 & 365 & Pressure Head (m) & -3.26 \\
\hline 14 & 365 & 385 & Pressure Head (m) & -3.26 \\
\hline 15 & 385 & 449 & Pressure Head (m) & -3 \\
\hline 16 & 449 & 451 & Pressure Head (m) & -2.5 \\
\hline 17 & 461 & 454 & Pressure Head (m) & -2.25 \\
\hline 18 & 454 & 482 & Pressure Head (m) & -2.04 \\
\hline 19 & 482 & 492 & Pressure Head (m) & -1.63 \\
\hline 20 & 492 & 531 & Pressure Head (m) & -1.76 \\
\hline 21 & 531 & 566 & Pressure Head (m) & -2.04 \\
\hline 22 & 566 & 587 & Pressure Head (m) & -2.31 \\
\hline 23 & 587 & 637 & Pressure Head (m) & -2.44 \\
\hline 24 & 637 & 692 & Pressure Head (m) & -2.71 \\
\hline 25 & 692 & 727 & Pressure Head (m) & -2.99 \\
\hline 26 & 727 & 730 & Pressure Head (m) & -3.26 \\
\hline
\end{tabular}

\begin{tabular}{|c|c|c|c|c|c|}
\hline$\#$ & $\begin{array}{l}\text { Start } \\
\text { Time }\end{array}$ & End Time & Type & $\begin{array}{l}\text { Inflow Concentration } \\
\text { (mg/l) }\left(1^{\mathrm{a}}, \text { simulaçå) }\right.\end{array}$ & $\begin{array}{c}\text { Inflow Concentration ( } \mathrm{mg} / \mathrm{l}) \\
\left(2^{\mathrm{a}} \text {. simulação) }\right.\end{array}$ \\
\hline 1 & 0 & 7 & No Specified Boundary (-) & 200 & 1000 \\
\hline 2 & 7 & 22 & No Specified Boundary (-) & 146 & 730 \\
\hline 3 & 22 & 38 & No Specified Boundary (-) & 93 & 465 \\
\hline 4 & 38 & 52 & No Specified Boundary (-) & 58 & 290 \\
\hline 5 & 52 & 67 & No Specified Boundary (-) & 29 & 145 \\
\hline 6 & 67 & 82 & No Specified Boundary ( $)$ & 11 & 55 \\
\hline 7 & 82 & 98 & No Specified Boundary (-) & 1,5 & 7.5 \\
\hline 8 & 98 & 730 & No Specified Boundary (-) & 0 & 0 \\
\hline
\end{tabular}

[VS2DT] Transport Lower Boundary

\begin{tabular}{|c|c|c|c|c|}
\hline$\#$ & Start Time & End Time & Type & Inflow Concentration (mg/l) \\
\hline 1 & 0 & 730 & No Specified Botundary $(-)$ & 0.000000000000000 \\
\hline
\end{tabular}

[VS2DT] Profile Initial Conditions

\begin{tabular}{|c|c|c|}
\hline \multicolumn{1}{|c|}{ Parameter } & Value & Units \\
\hline Initial Concentration & 0.000000000000000 & (mg/l) \\
\hline
\end{tabular}

[VS2DT] Stress Period Defaults

\begin{tabular}{|l|c|c|}
\hline \multicolumn{1}{|c|}{ Parameter } & Value & Units \\
\hline Minimum Time Step & 1.2 & $($ days \\
Reduction Factor & 0.40 & $(-)$ \\
Maximum Head Change & 1.00000 & $(\mathrm{~m})$ \\
Head Criterion & 0.00100 & (m) \\
Initial Time Step & 0.1 & (days) \\
Time Step Multiplier & 1.2 & $(-)$ \\
Maximum Time Step & 10.0000000 & (days) \\
\hline
\end{tabular}


Profile Structure

IGUAL AO MODELO URÂNIA A

Soil Parameters

IGUAL AO MODELO URÂNIA A

\section{Transport Parameters}

(IGUAL PARA TODAS AS PROFUNDIDADES)

\begin{tabular}{|l|c|c|}
\hline \multicolumn{1}{|c|}{ Parameter } & Value & Units \\
\hline Alpha L & 0.30000 & $(\mathrm{~m})$ \\
Dm (Molecular Diffusion) & 0 & $(\mathrm{~cm} /$ day) \\
Decay Constant & 0 & $(\mathrm{hr})$ \\
Bulk density & 1.400 & $(\mathrm{~g} / \mathrm{cu} . \mathrm{cm})$ \\
\hline
\end{tabular}

Initial Conditions

\begin{tabular}{|l|l|c|c|}
\hline Layer & Parameter & Value & Units \\
\hline $\mathbf{0 , 5}-\mathbf{1 , 5} \mathrm{m}$ & Pressure Head & -8.14 & $(\mathrm{~m})$ \\
\hline $\mathbf{1 , 5}-\mathbf{2 , 5 \mathrm { m }}$ & Pressure Head & $-7,87$ & $(\mathrm{~m})$ \\
\hline $\mathbf{2 , 5}-\mathbf{3 , 5 \mathrm { m }}$ & Pressure Head & $-8,68$ & $(\mathrm{~m})$ \\
\hline $\mathbf{3 , 5}-\mathbf{4 , 5 \mathrm { m }}$ & Pressure Head & $-8,55$ & $(\mathrm{~m})$ \\
\hline $4,5-5,5 \mathrm{~m}$ & Pressure Head & $-8,41$ & $(\mathrm{~m})$ \\
\hline $\mathbf{5 , 5 - 6 , 5 \mathrm { m }}$ & Pressure Head & $-8,01$ & $(\mathrm{~m})$ \\
\hline $\mathbf{6 , 5 - 7 , 0 \mathrm { m }}$ & Pressure Head & $-7,60$ & $(\mathrm{~m})$ \\
\hline
\end{tabular}

